\title{
Universiteit tussen vorming en opleiding : de modernisering van de Nederlandse universiteiten in de negentiende eeuw
}

Citation for published version (APA):

Wachelder, J. C. M. (1992). Universiteit tussen vorming en opleiding : de modernisering van de Nederlandse universiteiten in de negentiende eeuw. [Doctoral Thesis, Maastricht University]. Uitgeverij Verloren. https://doi.org/10.26481/dis.19920312jw

Document status and date:

Published: 01/01/1992

DOI:

10.26481/dis.19920312jw

Document Version:

Publisher's PDF, also known as Version of record

Please check the document version of this publication:

- A submitted manuscript is the version of the article upon submission and before peer-review. There can be important differences between the submitted version and the official published version of record.

People interested in the research are advised to contact the author for the final version of the publication, or visit the DOI to the publisher's website.

- The final author version and the galley proof are versions of the publication after peer review.

- The final published version features the final layout of the paper including the volume, issue and page numbers.

Link to publication

\footnotetext{
General rights rights.

- You may freely distribute the URL identifying the publication in the public portal. please follow below link for the End User Agreement:

www.umlib.nl/taverne-license

Take down policy

If you believe that this document breaches copyright please contact us at:

repository@maastrichtuniversity.nl

providing details and we will investigate your claim.
}

Copyright and moral rights for the publications made accessible in the public portal are retained by the authors and/or other copyright owners and it is a condition of accessing publications that users recognise and abide by the legal requirements associated with these

- Users may download and print one copy of any publication from the public portal for the purpose of private study or research.

- You may not further distribute the material or use it for any profit-making activity or commercial gain

If the publication is distributed under the terms of Article $25 \mathrm{fa}$ of the Dutch Copyright Act, indicated by the "Taverne" license above, 
Universiteit tussen vorming en opleiding 
$\quad \therefore \quad a$ 


\section{UNIVERSITEIT TUSSEN VORMING EN OPLEIDING}

De modernisering van de Nederlandse universiteiten in de negentiende eeuw

\section{Proefschrift}

ter verkrijging van de graad van doctor aan de Rijksuniversiteit Limburg te Maastricht, op gezag van de Rector Magnificus, Prof.Mr. M.J. Cohen, volgens het besluit van het College van Dekanen, in het openbaar te verdedigen op donderdag, 12 maart 1992 om 16.00 uur

door

JOSEPH CASPAR MARIE WACHELDER

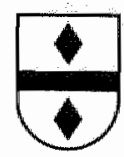

Hilversum

Verloren

1992 
Promotores:

Prof.Dr. A.J.C. Boon

Prof.Dr. J.J.H. Dekker (RU Groningen)

Beoordelingscommissie:

Prof.Dr. H. Philipsen (voorzitter)

Prof.Mr. G.C.J.J. van den Bergh (RU Utrecht)

Prof.Dr. H.A.M.J. ten Have (KU Nijmegen)

Prof.Dr. M.J. van Lieburg (EU Rotterdam/VU Amsterdam)

Prof.Mr. N.H.M. Roos

ISBN $90-6550-352-8$

Afbeelding omslag: Kapel (kleine bibliotheekzaal) van het voormalige palleis van koning Lodewijk Napoleon in gebruik bij de Universiteitsbibliotheek Utrecht. Op de achtergrond de lange gang door de balzaal (grote bibliotheekzaal). Situatie na 1858. Uit: J.J.F. Wap, De stad Utrecht; Album bevattende afbeeldingen ..., Utrecht 1859-1860.

Q1992 Uitgeverij Verloren, Alexanderlaan 14, 1213 XS Hilversum

typografie: Rombus, Hilversum

drukwerk: Wilco, Amersfoort

brochage: Meeuwis, Amsterdam

No part of this book may be reproduced in any form without written permission from the publisher and a thor 


\section{Inhoud}

Voorwoord

1. Modernisering van de Nederlandse universiteiten 9

Inleiding 9

Een theoriegeleid perspectief 13

Madernisering $\quad 19$

$\begin{array}{ll}\text { De }{ }^{x} \text { Duitse Universiteit' } & 27\end{array}$

Kritiek en programma 33

2. De maatschappelijke organisatie van het hoger onderwijs 40

Inleiding $\quad 40$

Lager Onderwijs $\quad 42$

Middelbaar Onderwijs $\quad 46$

Hoger Onderwijs $\quad 62$

Conclusie $\quad 79$

3. Het onderwijs in de Faculteit der Geneeskunde 81

Inleiding $\quad 81$

Een ander ordeningsprincipe voor het medisch beroep 83

Het onderwijs aan de hogescholen 95

De opvatting van ziekte 111 .

Theorie en praktijk $\quad 124$

Eenheid van stand $\quad 132$

$\begin{array}{ll}\text { Conclusie } & 139\end{array}$

4. Het onderwijs in de Faculteit der Rechtsgeleerdheid 144

Inleiding $\quad 1.44$

$\begin{array}{ll}\text { Op zoek naar zekerheid } & 147\end{array}$

Codificatie, continuiteit en verandering $\quad 154$

Wet en rechter, logica en ontwikkeling 166

Recht als onderdeel van een maatschappelijk proces $\quad 179$

$\begin{array}{ll}\text { Conclusie } & 198\end{array}$

5. Geleerdheid en Wetenschap 204

Inleiding 204 
Materiele en formele vorming 205

Modernisering en de disciplinaire organisatievorm van wetenschap 212

Verzamelen en classificeren; kabinet en bibliotheek 220

6. Voorheen en Thans 231

Inleiding 231

Een universitaire missie $\quad 233$

De 'Basisfilosofie' van de Rijksuniversiteit Limburg 239

$\begin{array}{ll}\text { Het Maastrichtse systeem } & 249\end{array}$

Individualisering en internationalisering 255

Samenvatting $\quad 260$

Summary 265

Bibliografie $\quad 270$

$\begin{array}{ll}\text { Curriculum vitae } & 313\end{array}$ 


\section{Voorwoord}

Het vertrekpunt voor deze studie werd gevormd door een interesse in de ontwikkeling van idleeën over hoger onderwijs. Een interesse met een ambivalent karakter. Aan de ene kant was er de belangstelling voor het debat over het hoger onderwijs, zoals dat in tijdschriften, in kranten, in besturen en raden gevoerd werd. Aan de andere kant leefde het gevoelen dat deze debatten met de ontwikkeling van de onderwijs- en onderzoekspraktijk binnen de muren van de universiteiten weinig of slechts zijdelings van doen hadden. Die gemengde gevoelens houden ook verband met de directe aanleiding tot deze studie. Het hier gepresenteerde onderzoek vond plaats in het kader van een heroverweging van de 'Basisfilosofie' van de Rijksuniversiteit Limburg te Maastricht. In 1972 nodigden de plannen tot oprichting van de Rijksuniversiteit Limburg uit tot het schrijven van een "Basisfilosofie", een notitie met uitgangspunten en wensen aangaande de (toekomstige) universitaire organisatie. $\mathrm{Nu}$, bijna twintig jaar later, valt te constateren dat aan een aantal van die oorspronkelijke verlangens is vorm gegegeven, aan een aantal andere ook weer niet; dat sommige idealen zijn gebleven, terwijl andere zijn verworpen en plaats hebben moeten maken voor nieuwe slogans die het universitaire beleid in de jaren negentig zouden moeten oriënteren. De vraag hoe verschuivingen in (onderwijs)ideologie, veranderingen in de inrichting van het onderwijs in de faculteiten en ontwikkelingen in de maatschappelijke ongeving van de universiteiten met elkaar samenhangen is de inspiratiebron geweest tot dit boek.

In dit onderzoek is er voor gekozen de complexiteit van die vraagstelling te behouden. Om inzicht in veranderingsprocessen binnen het hoger onderwijs te verkrijgen is een markante periode in de ontwikkeling van de Nederlandse universiteiten onder de loep genomen. In het algemeen wordt aangenomen dat gedurende de periode tussen de eerste (1815) en de tweede nationale hoger onderwijswet (1876) in de inrichting van, en het denken over, het hoger onderwijs cruciale verschuivingen zijn opgetreden. De fundamenten voor de moderne universiteit zijn toen gelegd. De problemen en controversen die daarbij in publieke discussies over de inrichting van het academisch onderwijs in zijn algemeenheid, en over de inrichting van het onderwijs in de geneeskunde en de rechtsgeleerdheid in het bijzonder naar voren kwamen, worden in dit boek voor het voetlicht gebracht. Daarbij stond een drieledig doel voor ogen. Ten 
eerste een samenhangende interpretatie te geven van de veranderingen die zich gedurende deze periode in de universiteiten hebben afgespeeld. Ten tweede inzicht te verschaffen in de verstrengeling van de problemen die zich in de aangegeven drie domeinen aandienden. Ten derde de zo verkregen inzichten toe te passen op discussies die op dit moment in de universiteiten spelen. In hoeverre ik deze doelstellingen heb weten waar te maken, is ter beoordeling aan de lezer.

Ik wil van deze gelegenheid gebruik maken om al diegenen die mij tijdens het tot stand komen van dit boek gesteund hebben te bedanken. Mijn promotor, Prof.Dr. L. Boon, vooral om de intellectuele vrijheid die hij mij gegund heeft, zonder daarbij de hoofdlijnen uit het oog te verliezen. De tweede promotor, Prof.Dr. J.J.H. Dekker, heeft een bewonderenswaardig geduld aan de dag gelegd in zijn nauwkeurige commentaar op ieder deel van de tekst. Wanneer ik mij de eerdere versies van deze tekst voor de geest haal, is het vertrouwen dat hij in mij gesteld heeft niet anders dan grootmoedig te noemen. Hij heeft mij steeds gewezen op de eisen van de historische kritiek. Als dit boek daarin in gebreke blijft, hem treft geen verwijt.

Ik ben blij verrast door de bereidwilligheid en de nauwgezetheid waarmee een aantal specialisten op deelgebieden deze studie van commentaar hebben voorzien. Met name wil ik noemen Prof.Mr. G.C.J.J. van den Bergh, Mr. C.J.J. Jansen en Prof.Dr. M.J. van Lieburg. Van mijn collega's wil ik in het bijzonder Drs. T. Blom, Prof.Dr. W. Callebaut, Drs. T. Nijhuis en Prof.Mr. N. Roos memoreren. Zonder hen zou dit boek niet geschreven zijn. In laatste instantie wil ik diegenen noemen die tijdens het schrijwen van dit boek ook al geen prioriteit kregen: mijn ouders, Peter en Rita. Bedankt. 


\section{I \\ Modernisering van de Nederlandse universiteiten}

\section{Inleiding}

Door de eeuwen heen heeft het hoger onderwijs steeds een bron van discussies gevormd. De kwaliteit van het hoger onderwijs is altijd omstreden geweest. Tussen het geleerde op de universiteit en de eisen van de praktijk heeft nooit een mooie liefde mogen groeien. De verzuchting dat de universitaire studies niet aan de eisen der tijd voldoen, is niet eens meer een cliché te noemen. Van de kant van de universiteiten zijn de "broodstudiën" altijd all zwartgemaakt; "die pest der academiën" zo werden ze in de vorige eeuw genoemd. Het beeld van de wereldvreemde geleerde, Professor Zonnebloem, werkt nog steeds aanstekelijk. Jammerklachten over een gebrekkige vooropleiding, de geringe inzet en het losbandige leven van studenten zijn eveneens van alle tijden (Veen 1991:572). Een historisch onderzoek naar het verloop van debatten over het universitaire onderwijs lijkt dan ook weinig nieuws aan het licht te kunnen brengen. Wie ooit voor-en tegenstanders van een wetenschappelijk georiënteerde dan wel een beroeps- en praktijkgerichte academische studie aan het woord heeft gehoord, zal best willen geloven dat ook honderd, driehonderd of vijfhonderd jaar eerder soortgelijke controverses hebben gespeeld. De belangrijkste functie die het nimmer aflatende debat over de inrichting van het hoger onderwijs lijkt te vervullen, is de institutionalisering van een generatieconflict. Het gekanker op de inzet en de kwaliteiten van studenten schept een behaaglijke band tussen gezeten intellectuelen, terwijl het studenten de mogelijkheid biedt te hoop te lopen tegen gevestigde posities.

Met de kreten van twintig jaar geleden, toen studenten getuigden de voorhoede van een radicale democratiseringsbeweging uit te willen maken (Regtien 1969), nog vers in het geheugen proberen universitaire bestuurders ons op dit moment van de bedrijfsmatige opzet van hun instellingen te overtuigen. Universiteiten profileren zich thans als ondernemend en innovatief. Hier lijkt de conclusie vooral te moeten luiden dat de ideeën over de doelstellingen en de inrichting van het hoger onderwijs op de golven van een ongrijpbare 'Zeitgeist' meedeinen. Dergelijke algemene beschouwingen lijken meer als windvaan voor de politieke overtuiging te dienen dan iets te vertellen over de 
praktijk van het universitaire onderwijs en onderzoek. Dat alles neemt niet weg dat voor iedereen die bij het universitair onderwijs betrokken is, als student, docent, beleidsambtenaar, bestuurder of politicus, zich onvermijdelijk de vraag aandient hoe het onderwijs of zijn studies in te richten. Moet in het curriculum de nadruk liggen op het aanleren van een wetenschappelijke attitude of op beroepsgerichte vaardigheden? Is een meer generalistische opleiding te verkiezen boven een specialistische? In hoeverre dienen opleidingen disciplinaire kaders te volgen? Is studievrijheid voor studenten een groot goed of is een meer schoolse aanpak te verkiezen? Moeten bestuurders van universiteiten proberen algemene lijnen voor hun onderwijs aan te geven of juist niet? Kenmerkend voor dit soort vragen is dat ze verwijzen naar een uitgebreid conglomeraat van probleemstellingen. Zonder te schromen worden in een vloeiende beweging uiteenlopende zaken als de bestuurbaarheid van de universitaire organisatie, veranderende maatschappelijke verhoudingen en de samenhang tussen cognitieve structuren en de inhoud en methode van het onderwijs in een vakgebied aan de orde gesteld. Pogingen om dit kluwen te ontwarren, door bijvoorbeeld de effecten na te gaan van een beperkt aantal maatregelen, zoals het invoeren van het stelsel van voorwaardelijke financiering voor een gedeelte van het wetenschappelijk onderzoek in Nederland (Spaapen et al. 1988), zijn niet bijster succesvol geweest.

Dat valt niet de onderzoekers te verwijten. In opvattingen over het doel, de functie en de inrichting van het hoger onderwijs vallen nu eenmaal politieke, juridische, sociaal-economische, wetenschapsinhoudelijke, pedagogischeen didactische overwegingen te traceren. In de universitaire organisatie kruisen wetenschap en politiek met de eisen van uiteenlopende (beroeps)praktijken. De universiteit leidt niet enkel jonge mensen op voor functies in de gezondheidszorg, de administratie en de rechtspraak, ze beïnvloedt ook de gang van zaken in die praktijken. Die beïnvloeding kan trouwens ook in omgekeerde richting verlopen. De aanstaande gemeenschappelijke binnenmarkt in Europa heeft een felle discussie over de inrichting van de juridische opleiding aangezwengeld. De kritiek van twintig jaar geleden op de 'medicalisering' van de gezondheidszorg heeft radicale voorstellen voor een hervorming van de medische opleidingen voortgebracht.

Deze studie heeft discussies over de inrichting van het hoger onderwijs in Nederland tot onderwerp. In dit boek worden de veranderingen die, gedurendle een bepaalde periode, in de ideeën over de organisatie van het hoger onderwijs zijn opgetreden geanalyseerd. Daarbij worden drie domeinen onderscheiden: de maatschappelijke organisatie van het hoger onderwijs als zodanig, waar onder andere de idee en het ideaal van hoger onderwijs ter discussie staan, en de inrichting van het onderwijs in de geneeskunde en het recht. De confrontatie tussen deze domeinen kan inzicht geven in hun onderlinge condi- 
tioneringsverhoudingen. De bedoeling daarachter is uitdrukkelijk niet een gedetermineerdheid van het ene handelingsbereik door het andere op het spoor te komen. Waar het om gaat is om de samenhang te laten zien tussen de handelingsmogelijkheden in die verschillende bereiken en de geleidelijke verschuivingen daarin gedurende een bepaalde periode te volgen.

Hoewel ogenschijnlijk in het debat over het hoger onderwijs steeds dezelfde thema's terugkeren - de verhouding tussen theorie en praktijk, het dilemma tussen studievrijheid en een vaste studievolgorde, de voor- en nadelen van examens - verandert geleidelijk de betekenis van termen als vorming, ervaring of wetenschap die in deze debatten een prominente rol spelen. Dergelijke betekenisverschuivingen zeggen iets over maatschappelijke veranderingen die over een langere termijn in de breedte zijn opgetreden. De resultaten die een overzicht van discussies over de organisatie van het hoger onderwijs kan opleveren, hoeven daardoor niet beperkt te blijven tot het documenteren van een aantal stereotype discussiepatronen. Ze kunnen ook de (verborgen) grondpatronen van de maatschappelijke orde aan het licht brengen.

De hier bestudeerde periode is dan ook niet willekeurig gekozen. De negentiende eeuw vormt de bakermat van de moderne maatschappij. De negentiende eeuw vormt tevens het tijd perk waarin een tweede wetenschappelijke revolutie plaatsgrijpt. Algemeen wordt aangenomen dat in de periode die ligt ingesloten tussen de eerste nationale Hoger Onderwijswet, het zogenaamde Organiek Besluit', uit 1815 en de navolgende Hoger Onderwijswet die uit 1876 stamt, de fundamenten zijn gelegd voor de moderne universiteit. De wet op het Hoger Onderwijs van 1876 werd pas in zijn geheel vervangen - of beter gezegd met behoud van geest gemoderniseerd - door de Wet op het Wetenschappelijk onderwijs van 1960 (WWO van 22 december 1960, Stb. 559; Van den Bergh 1988a: 43; Foppen 1989: 52). Kennis van het veranderingsproces dat zich tussen 1815 en 1876 aan de Nederlandse universiteiten voltrok, geeft niet alleen inzicht in de wisselwerkingen tussen de drie boven onderscheiden domeinen, het legt ook de fundamenten van het huidige stelsel van hoger onderwijs bloot. Kennis daarvan kan de beoordeling van de talloze voorstellen tot rigoureuze reorganisatie van het stelsel van hoger onderwijs in onze tijd ondersteunen.

De veranderende ideeën over de aard en de functie van het hoger onderwijs zoals die uit negentiende eeuwse debatten naar voren komen, getuigen van een moderniserende maatschappij. De debatten over de vraag of de medische faculteit een 'kunstbeoefenaar' danwel een 'geneeskundige' opleidt, en meningsverschillen over de plaats van het Romeinse recht in de vorming tot

1 Koninklijk Besluit nopens de organisatie van het hooger onderwij). Nederlavdsche Stan tscourawt ni. 242 (12-10-1815) en nr. 243 (13-10-1815) (Wingelaar 1989: 99). 
rechtsgeleerdle vallen eveneens in die context te begrijpen. In dit eerste hoofdstuk wordt uiteengezet wat die modernisering inhoudt, en binnen welk maatschappijtheoretisch kader die wordt begrepen. In de verdere loop van het boek zal de hier gepresenteerde visie op modernisering verder worden uitgewerkt en zal worden getoond hoe in een wisselwerking tussen wetenschapsinhoudelijke, pedagogische en organisatorische veranderingen geleidelijk aan het beeld van de universiteit verandert. Daarmee geeft deze interpretatie een alternatief voor de visie dat Nederland een 'Duits' model zou hebben overgenomen, waarbij het primaat voor de veranderingen binnen de universiteiten bij de wettelijke implementatie van een organisatorisch kader wordt gelegd.

Van de wet van 1876 wordt immers veelal gezegd dat deze geënt was op het 'Duitse model' ${ }^{2}$. Daarmee wordt het type universiteit aangeduid dat in het begin van de vorige eeuw in Duitsland gestalte zou hebben gekregen, met als karakteristieken het ontstaan van een onderzoekstaak voor de hoogleraar ('Forschungsimperativ'), het samenbrengen van onderwijs en onderzoek op het niveau van de leerstoel binnen de muren van de universiteit ('Einheit von Forschung und Lehre'), de vrijheid van de hoogleraar om naar eigen inzichten het onderwijs in te richten ("Lehrfreiheit") en de vrijheid van de student om zelf de inrichting van zijn studies te bepalen ('Lernfreiheit'). Tot ver voorbij de Tweede Wereldoorlog vormde de 'Duitse Universiteit' hèt referentiekader voor het hoger onderwijsbeleid. Minister K. Posthumus, de grote pionier van de vernieuwing van het Nederlandse hoger onderwijs, begon de eerste nota met voorstellen om het hoger onderwijs te herstructureren aldus: "Universitair onderzoek en universitair onderwijs zijn schering en inslag van hetzelfde weefsel. Hun draden kunnen worden onderscheiden: zij kunnen niet worden gescheiden zonder vernietiging van de structuur" (Ministerie van Onderwijs en Wetenschappen 1968). Alhoewel discussies over het hoger onderwijs anno 1991 vooral studierendementen, de beperking van de studieduur, kwaliteitsbewaking, financieringssystemen of technieken om efficiëntie en effectiviteit van onderwijs te meten betreffen (Wiegersma 1989: 15-26; Foppen 1989), blijft op de achtergrond de 'Duitse Universiteit' figureren (Boon et al. 1989: 60-69). De eenheid van onderwijs en onderzoek binnen de universiteiten, de gewenste mate van overlappingen tussen indelingen in faculteiten, disciplines en studierichtingen, de 'academische vrijheid', de verhouding tussen 'sturing' en 'zelforganisatie", de voor-en nadelen verbonden aan het voorschrijven van een vaste

2 "Hoewel de wet van 1876 in niet gernge nate het resultat is geweest van compromissen tussen verschillende partijen, is duidelijk dat de Duitse universiteil model heeft gestan voor de inrichting van de Nederlandse universiteit" (Van Berkel 1985: 132). Zie ook Noordam (1979: 89) of Foppen (1989:44-45). Willink (1988: 136) toont zich terughoudender" "Toch heeft het Duitse model in de wet mies diepgaand doorgewerkt." 
studievolgorde aan studenten, zijn kwesties waarbij met graagte een beroep op de academische traditie wordt gedaan (Chapman ed. 1983).

\section{Een theoriegeleid perspectief}

Onderwijs en opvoeding hebben zich altijd in een grote belangstelling van de kant van de sociologie - en niet alleen specifiek de onderwijssociologie - mogen verheugen'. Gedurende lange tijd zijn dit soort studies echter volledig aan de onderwijsinhoud of onderwijsmethode voorbij gegaan". De in de laatste jaren enorm toegenomen interesse voor het grensgebied tussen kenuissociologie en maatschappijgeschiedenis heeft de ernst van dat hiat duidelijk aan het licht gebracht (Wachelder $1991 \mathrm{~b}$ ). Ook op methodologisch niveau heeft de onderwijssociologie de afgelopen decennia averij opgelopen. Vooral de van oudsher in de onderwijssociologie populaires systeemtheorie heeft het wat dat betreft moeten ontgelden. In een trendrapport uit 1958 benadrukken J. Floud en A. Halsey het belang van het bestuderen van de relatie tussen onderwijssysteem en sociale verandering, maar ze tonen zich daarbij tegelijkertijd reeds sceptisch over de structuralistisch-functionalistische systeemtheorie omdat die uitgaat van evenwichtstoestanden en maatschappelijke stabiliteit terwijl juist verandering en conflict karakteristiek voor samenlevingen zijn. Dergelijke kritiek heeft de afgelopen decemia binnen de onderwijssociologie aanleiding gegeven tot het zoeken naar alternatieven: "[I] nstead of seeing higher educational systems and institutions as, tending to maintain a relatively stable equilibrium by way of continuous processes which neutralize endogenous and exogenous sources of variability that would change the structure (...), we see them not only as structure-maintaining but also as structure-elaborating systems. We must conceptualize an inherently instable system bringing out dynamic, processual, and potential - maintaining properties" (Jobling 1973: 213). Meer in het algemeen zijn de laatste jaren als reactie op de in beginsel ahistorische*

3 Geen van de peetwaders van de sociologie - Marx, Weber, Durkhejm - is aan opvoeding en onderwijs voorbijgegaan. T. Parsons en G. Platt geven het hoger onderwijs hoge prioriteit in een analyse van de maderne samenleving: "[H]igher education, including the research complex, thad become the most critical single feature of the developing structure of modern societies" (Parsons and Platt 1973: vij). De bekendste onderwijssocioloog van dit moment is P. Bourdiew.

4 "In placing curricular developments in their historical context William" [1961] approach is oryginal and insightful. (...) It is only regrettable that in the eleven intervening years no sociologist has followed then up" (Young 1973: 347).

5 Dat ligt enigszins voor de hand, want zelfs in het alledaggse taalgebruilk wordt als wanzelfisprekend over onderwijssystemen en onderwijsstelsels gesproken.

6 "The magical elimination of conflict, and the wondrous achevement of harmony, remove from this "systematic' and 'general" theory the possibilities of dealing with social change, with thistory" (Mills 1959: 42), 
structuralistisch-functionalistische systeemtheorie tal van aanzetten tot historisch-sociologische theorieën geformuleerd (Eisenstadt 1974; Zapf 1979). Maar geen van die programma's heeft tot dusverre tot een overtuigende theorie van sociale verandering geleid (Abrams 1982; Skocpol ed. 1984). Historisch-sociologen geven in het algemeen duidelijk aan waar ze zich tegen afzetten, maar zijn veelal nog niet in staat een consistent, samenhangend alternatief aan te bieden (Rüschemeyer 1984: 138).

In deze studie wordt gebruik gemaakt van een deel van het door Niklas Luhmann ontwikkelde conceptuele kader? . R. Stichweh $(1984)^{8}$ bleek in staat om op basis van Luhmanns theorie van zelforganiserende systemen een niet triviale interpretatie te formuleren van het ontstaan van het moderne systeem van wetenschappelijke disciplines in de periode tussen 1740 en 1890 (Turner 1989: 299-300; Wachelder 1990a). Belangrijker is echter dat Luhmann op een fundamentele manier tegemoet lijkt te komen aan de kritiek die het ahistorische en acontextuele karakter van de functionalistisch-structuralistische traditie uitgelokt heeft. Daardoor biedt Luhmanns maatschappijtheorie de mogelijkheid recht te doen aan de specifieke intellectuele en maatschappelijke context waarin maatschappelijke veranderingen zich afspelen, terwijl ze daarnaast in staat stelt tot het formuleren van een globaler perspectief, dat de samenhang van maatschappelijke veranderingen kan duiden.

Luhmann (1984) verankert de historiciteit en het besef van contingentie in zijn sociale theorie door sociale systemen op te vatten als sociale processen, die op het meest basale niveau zijn opgebouwd uit communicaties. Communicaties vormen de in de tijd opeenvolgende elementen van een sociaal systeem. Afzonderlijke communicaties hebben zelf geen duurzaamheid. Met hun ontstaan lossen ze al weer op, om plaats te maken voor nieuwe communicaties. Om een element te zijn heeft een communicatie een andere communicatie nodig. Pas door de uitingscomponenten van de volgende communicatie kan duidelijk worden of de voorafgaande begrepen is. Communicaties zijn daarom voor Luhmann zelfreferentiële elementen (Blom 1988: 239). Sociale systemen krijgen daarmee het karakter van zelfreferentiële, door en door getemporaliseerde systemen. Daarmee is het historisch karakter van sociale systemen op het meest basale niveau in Luhmanns sociale theorie verdisconteerd.

Door sociale systemen in eerste instantie als processen te beschouwen ver$\mathrm{dwijnt}$ het structuurbegrip - lange tijd de focus binnen de systeem theoretische traditie - naar het tweede plan. Tevens kunnen structuren niet langer, zoals in de systeemtheoretische traditie gebruikelijk, opgevat worden als min of

7 Luhumnns matschappijtheorie heeft het karakter van een voortidurend "work in progress". Zie woor een overzicht van de ontwikkeling in Luhmanns oeuvre Kiss (1990).

8 Herop wordt uilgebreider teruggekomen in hoofdstuk 5. 
meer stabiele relaties tussen een aantal elementen van het geheel". In plaats daarvan worden structuren als complementair aan het proceskarakter opgevat en krijgen ze de vorm van verwachtingsstructuren, die bemiddelen tussen in de tijd opeenvolgende communicaties. "Der Strukturbegriff präzisiert mit anderen Worten, die Relationierung der Elemente über Zeitdistanzen hinweg" (Luhmann 1984: 383). Communicaties worden bijeengehouden en eerst begrijpelijk door de verwachtingsverwachtingen die de communicatoren delen. Verwachtingsstructuren selecteren door het systeem toegelaten aansluitmogelijkheden; verwachtingsstructuren bieden zinvolle, mogelijke aansluitingen op een communicatieve act aan, terwijl andene worden witgesloten. Ze houden een bepaald domein van selecties gereed waarmee systemen de complexiteit van hun omgeving tegemoet treden. Door structuren als verwachtingsverwachtingen op te vatten, verliezen deze hun statische karakter. De aansluitmogelijkheden die in een systeem of communicatief proces worden toegelaten en aangeboden, kunnen - en moeten - veranderen ${ }^{10}$.

Belangrijk is op te merken dat verwachtingsstructuren aansluitmogelijkheden selecteren. "Die Struktur hält, weil (! - nicht nur: obwohl) sie selbst durch Selektion zustande kommt, einen Möglichkeitsspielraum bereit" (Luhmann 1984. 388). Verwachtingsstructuren maken daarbij gebruik van 'zin'" , waarbij de differentie tussen het actueel gegevene en het mogelijke constitutief is (Lulmann 1984: 111). "Festzuhalten ist, daß Sinn sich hier durch einen Verweisungszusammenhang auf andere Möglichkeiten des Erlebens und Handelns auszeichnet, der faktisch eine Umweltkomplexität reduzierende Strategie selektiven Verhaltens so erzwingt, daß trotz der Ausblendung anderer Möglichkeiten, die Latenz dieser anderen Möglichkeiten erhalten bleibt; sie hängt von der "Aktualität des Erlebens' $\mathrm{ab}^{\prime \prime}$ (Kiss 1990: 14). In het structuurbegrip is het contingente karakter van sociale systemen verankerd ${ }^{12}$. De voortzetting, de wijze van voortzetting en de afloop van alle sociale processen zijn te allen tijde onzeker ${ }^{13}$. Die

9 Zie voor een kritische bespreking van Luhmanns structuurbegrip Berrger (1987).

10 "Kommunikative Systeme unterstellen sich auf diese Weise im Verlauf und zur Aufrechterhaltungs ithres "Sich-selbst-prozessierens' ainem fortgesezten "Selbstweränderungszwang" (Schmid 1987: 29).

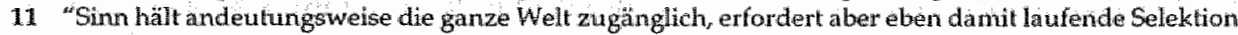
des nächsten Schritts in eimem mehr oder weniger konkret apperzipierten Kontext anderer Möglichkeiten.

(4..) Aller Sinn präsentiert deshalb Wirkliches durchsetzt mit anderen Mögliehkeiten und setzi das Verhalten damit unter Selektionsdruck, weil von diesem appräsentierten Möglichkeitsuberschu\& nur die eine oder die andere Eventualität aktuell realisiert, thematisch intendiert, handlungsmäBig nachwollzogen werden karnn" (Luhmann 1981a. 35, 17).

12 "Zin" "macht also die Selektwität jeder faktischen Selektion und damit Kontingenz bewuBt erfahrbar" (Küzzler 1989: 82).

13 Onzekerheid is zelfs een bestaansvoorwatrde voor structuren: "Insofern ist und bleibt auch Unsicherheit Strukturbedingung. Mit der Ausmerzung jeder Unsicherheit würde auch die Struktwr sich selibst aufheben, derun ihre Funktion liegt gerade darin, die autopoietische Reproduktion trotz Unworhersehbarkeit zu ermöglichen" (Luhmann 1984: 390-391). 
onzekerheid en onvoorspelbaarheid is produktief - zonder deze zou communicatie en socialiteit ondenkbaar zijn. Anderzijds is het noodzakelijk die onzekerheid in te dammen en te beheersen; anders kan van zinvolle communicatie geen sprake zijn.

Het indammen van contingentie - onder een gelijktijdige regulering van de reproduktie van contingentie - vindt plaats in collectief toegankelijke verwachtingsstructuren, die hun uitdrukking vinden in semantieken, intersubjectief beschikbare betekenisstelsels ${ }^{14}$. Semantiekanalyse wordt dan de methodische ingang om maatschappelijke veranderingen in hun context te bestuderen ${ }^{15}$. Immers de veranderingen die zich op het niveau van de semantiek afspelen, zijn niet alleen vanuit ideehistorisch perspectief interessant maar weerspiegelen veranderingen in de maatschappelijke orde. "Theoretische Auffassungen (...) fungieren - sofern sie kommunikativ erfolgreich sind und von hinreichend vielen Teilnehmern an gelehrter Kommunikation geteilt werden - als Prämissen, d.h. als derzeit unproblematische Voraussetzungen weiterer Kommunikation. (...). Soziologische Differenzierungstheorie zielt aber begrifflich eine Ebene an, die den Untersehied von semantisch und Sozialstruktur übergreift" (Stichweh 1984: 21).

De keuze voor semantiekanalyse als methode brengt specifieke beperkingen met zich mee. Wanneer het er om te doen is verschuivende aansluitmogelijkheden in een aantal domeinen te traceren en aan elkaar te relateren, wordt geen causale ${ }^{16}$ verklaring nagestreefd. Bovendien blijven economische factoren op de achtergrond. De politiek komt in beeld als onderdeel van een maatschappelijke en ideehistorische ontwikkeling die zich over een langere periode voltrekt. Voorts staat bij semantiekanalyse niet de vraag voorop wie, wat, in welke context en met welk doel gezegd heeft en welke concrete beslissingen dat tot gevolg heeft gehad. Dat behoort immers tot het domein van de pragmatiek. De vooronderstellingen die proponenten of antagonisten in een discussie delen en de geleidelijke verschuivingen daarin, zijn belangrijker dan de uitkomst van een specifieke controverse. Het gelijk van één van de discussianten is minder interessant dan de ontwikkeling van de thema's waarin zij gezamenlijk een probleem erkennen. Overigens is van een sluiting van een controverse in debatten over de inrichting van het hoger onderwijs zelden sprake. Veeleer is er sprake van het verschuiven van het gewicht dat aan verschillende argumenten ten opzichte van elkaar wordt toegekend, dlan aan het formuleren van

14 "Unter Semantik verstehen wir demnach einen höherstufiggeneralisierten, relativ siluationsunabhämgig verfügtaren Sinn" (Luhmann 1981a: 19; zie ook Luhmann 1990: 107-108).

15 "Wenr jedes Soziale Systen gleichzusetzen ist mit geschlossen operierender Kommunikation, dann muis sich in logischer" Weise jeder Wandel als Veränderung der betreffenden Kommunikationsmodi oder: Kommunikationsthemen erfassen lassen" (Haferkamp \& Schmid 1987b: 13).

16 In de zin van Elster (1989) dat het mechanisme dat handelingen verbindt, wordt blootgelegd. 
geheel nieuwe inzichten.

Het primaire bronnenmateriaal voor deze studie wordt gevormd door publicke ideeën- en gedachtenwisselingen over de inrichting van het academisch onderwijs zoals die via tijdschriften, oraties, of met betrekking tot de maatschappelijke organisatie van het onderwijs in debatten in de Tweede Kamer via de Handelingen aan ons overgeleverd zijn. Een systematisch onderzoek van andere mogelijk interessante en relevante bronnen is daardoor onmogelijk. Wegens de duur van de bestudeerde periode en de breedte van het onderzoek zou dat ook praktisch onhaalbaar zijn. Voor het opsporen van de belangrijkste controversen in de verschillende domeinen is in eerste instantie gebruik gemaakt van secundaire literatuur van specialisten in de verschillende deelgebieden ${ }^{17}$ en catalogi van de Koninklijke Bibliotheek, de Universiteit van Amsterdam en de Rijksuniversiteit Utrecht. In de zo opgespoorde debatten wordt weer verwezen naar anderen die zich over de inrichting van het onderwijs uitlaten. Zo is allengs een beeld ontstaan van de belangrijkste controversen die in het publieke debat over de inrichting van het onderwijs spelen. Op die manier kan geen volledigheid ${ }^{18}$ worden gegarandeerd; maar dat is in de gevolgde methode, semantiekanalyse, ook geen eis. Het gaat er primair om zicht te krijgen op de ontwikkeling van de thema's die in het publieke debat aan de orde zijn. OF om het traceren van een betekenisverandering van bepaalde termen, bijvoorbeeld 'waarneming', 'ervaring' of 'praktijk'. Wel zijn in het onderzoek steeds vooren tegenstanders van een bepaalde stellingname opgezocht.

De benadering van het onderzoek en de keuze van het primaire bronnenmateriaal - publieke controverses over de inrichting van het academisch onderwijs - sluiten de pretentie uit een historisch verantwoord overzicht te kunnen geven van de ontwikkeling wan de Nederlandse universiteiten in de negentiende eeuw. Aan de taak tot het schrijven van een overzichtsgeschiedenis van één universiteit durft in Nederland zich al nawwelijks meer een historicus te wagen $^{19}$. Op de gebieden die in dit boek aan de orde komen, het onderwijs, de geneeskunde en het recht, zijn specialisten actief, die zich afhankelijk van hun invalshoek als historici, filosofen of sociologen doen kennen. Een coherent beeld van de ontwikkeling van de Nederlandse universiteit in de negentiende

17 Voor de medische geschiedenis met mame publicaties van Prof.Dr. H. Beukers en Prof.Dr. M.J. van Lieburg; voor het domein van de rechtsgeleend heid heb ik mij kunnen orienteren op Prof.Mr. G.C.J.J. van den Bergh, Mr. C.J,H. Jansen, Prof.Dr. A.Ph. Jaspers, Mr. P.C. Kop, en Mr. Th.J. Veen.

18 De tijdschriften De Gids, De Algeneene Konst-en Letterbode en de Nederiandsche Bijdragen voor Rog $15-$ gelectheid en Netgeving zijn voor de bestudeerde periode wel integraal gevolgd.

19 Over het maar niet tot stand willen komen van een overzichtsgeschiedenis van de Leidse universiteit schinft het Leidse universiteitsblad Mare (27 februari 1986: 9): "Verschillende mensen zijn daurvoor informeel benaderd, maar niemand waagde zich aan datt werk" 
eeuw ontbreekt $\mathrm{t}^{20}$, uitgezonderd Huizinga's (1951b) geschiedenis van de Universiteit van Groningen. Voor die verregaande specialisatie en inperking van historische wraagstellingen zijn goede argumenten te geven: we weten inderdaad nog weinig, er moet nog zoveel onderzoek gedaan worden etc. Maar anderzijds zal een proliferatie van detailstudies alléén geen integraal beeld opleveren (Davids, Lucassen en Luiten van Zanden 1988: 24). Wegens de gevolgde methode, semantiekanalyse, kent dit onderzoek evenmin een strakke periodisering. De periode die deze studie bestrijkt, begint met (het tot stand komen van) het Organiek Besluit (1815). Het eindpunt is moeilijker te fixeren: omstreeks de tweede hoger onderwijswet (1876). In de medische faculteit kondigen zich vanaf de jaren veertig belangrijke veranderingen aan, binnen de rechtenfaculteit treden soortgelijke veranderingen later op. Daarom concentreert het onderzoek wat betreft de geneeskundige faculteit zich op de periode tot 1870 terwiil de rechtenfaculteit tot medio tachtig gevolgd wordt.

De publieke debatten die worden gevolgd, betreffen de maatschappelijke organisatie van het hoger onderwijs als zodanig en de inrichting van het onderwijs in de geneeskunde en het recht. De keuze voor de faculteit der geneeskunde vindt haar grond in de directe aanleiding tot deze studie - de 'Basisfilosofie' van de RL was eveneens toegespitst op de medische opleiding. Tevens biedt de geneeskundige faculteit een ingang om de effecten van de opmars van de natuurwetenschappen in de negentiende eeuw te volgen. Een vergelijking met de rechtsgeleerdheid, ook een praktische wetenschap, ligt dan voor de hand. Het onderwijs in de theologie of godgeleerdheid, van oudsher de derde hogere faculteit, wordt niet behandeld. Het feit dat ged urende de negentiende en de twintigste eeuw de maatschappelijke betekenis van het recht als maar toeneemt, en die van het geloofsleven geleidelijk aan vermindert, kan die keuze ondersteunen. Van de andere kant is het buiten beschouwing blijven van de theologische faculteit jammer omdat religieuze overwegingen voor een belangrijk deel het gezicht van de 'schoolstrijd' bepalen (De Bruin 1985). Tevens wordt het thema van de 'moderniteit', dat in deze studie bij de interpretatie van de geconstateerde veranderingen in de universiteiten een prominente rol vervult, binnen de theologische faculteit expliciet aan de orde gesteld ${ }^{21}$.

20 "Zelfs de imposante gedenkboeken van de Gemeente Universiteit van Amwsterdam en van de Universiteith van Utrecht ("..) bleven steken in de veeheid van disparaat materiaal dat het universitair verleden samenstelt: De verneuwing die deze twee gedenkboeken brachten, is het feit dat de ontwikkeling van de diverse disciplines apart beschreven werd door een veelheid van deskundigen. Dat was een idee dat al gebruikt: was bij het halve eeuwleest van 1925 te Leiden en dit zou ook tat op heden de gebruikelijke vom zijn wantin een jubilerende academie omziet" (Otterspeer 1984: 2).

21 Via de 'moderne richting'; zie Herderschee (1904); Brouwer (1912), Roessingh (1922) en Hoenderdaal (1984). 


\section{Modernisering}

In dit boek worden de veranderingen die zich gedurende de negentiende eeuw aan de Nederlandse universiteiten voltrekken geplaatst in de context van een moderniserende maatschappij. De thema's die in de debatten over de organisatie van het onderwijs naar voren komen, getuigen in alle drie onderscheiden domeinen van een transformatie die als 'modernisering' kan worden geduid. 'Modernisering' is in de afgelopen decennia ontdaan van zijn aanvankelijke theoretische en politieke $e^{22}$ pretenties en heeft meer en meer de lading gekregen van een overkoepelende term om uiteenlopende processen als industrialisering, vervreemding, bureaucratisering, rationalisering, verwetenschappelijking, civilisering, individualisering, statenvorming, secularisering en functionele differentiatie, die in het Westen hebben plaatsgehad mee aan te duiden (Van Bottenburg 1990: 114). Kort gezegd, het 'moderniseringsparadigma' is in de maalstroom van de kritiek op het structuralistisch-functionalisme, onder wiens gesternte het ook was geboren, als theoretisch programma ten onder ge$\operatorname{gaan}^{23}$. Wie desondanks wil vasthouden aan een maatschappijtheoretisch perspectief op modernisering heeft de taak een hernieuwde theoretische precisering aan te geven.

In scherp contrast met de traditionele sociologische optiek, waarin het probleem van de (dubbele) contingentie $e^{24}$ vanaf Parsons ${ }^{25}$ steeds vanuit een negatief gezichtspunt is benaderd (Blom 1988: 237), wordt door Luhmann ${ }^{25}$ aan

22 De interesse voor 'modernisering' is ontstaan in de sociologie direet ma cle Tweede Wereldoorlog: (Lermer 1972: 386) en kwam onder andere voont uit het streven om op grond wan comparatieve macrom sociologische analyses van het ontstaan van de "moderniteit" in het Westen, ower theorieën te beschikken die de ontwikkeling van. Derde Wereld (toen nog onderontwikkeld geheten) landen zouden kunnen modelleren en stimuleren.

23 * The results of almost two decades of modemization theory do not justify a third. The time has come to begin working toward an alternatwe paradigm" (Tipps 1973: 224).

24 Iedere communicatieve bijdrage stelt een selectie voor wambij voor de communicatoren dudelijk is dat ook een andere selectie gemaakt had kinnen worden. lin leder sociatll contact beschikken de betrok kenen over een scala wan mogelijkheden, en weten van elkar dot ze over ten veelhelid wan mogelijkhedeit beschikken: "Nur unter dieser Voraussetzung kanu man sinnwoll von Kommunikation sprechen: denth Kommunikation ist immer Ubermittlung von Selektionen, die als Selektionen erkennbar sind. In solehen Beziehumgen können Kommunikationen welchen Inhalis inumer nur als Selektionsofferten gemeint sein, die abgelehnt werden können. Alle Betexligten haben die Möglichkleit, nein zu segen oder sich anders zu verhalten, als ihnen nahegelegt wird. Auch dies ist eine universell präisente stets mitpräsentierte Mög* lichkeit, der man in der Wahl seiner Kommuniktationen Rechnung trägt" (Luhmaru 1975: 68).

$25{ }^{2}$ [A]ls Thalcott Parsons 1937 eine gewisse Konvergenz in dem soziologischen Theorien won Alfred Marshall, Emile Durkheim, Vilfredo Pareto und Max Weber feststellte (...) schwebte [ihm] der Versuch vor, mit einem Organon zusammenhängender Kattegorien das Problem der Integration sogenamner "sozialer Systeme" zu bewältigen. Die neue Frage hieß" "Was hält Gesellschalten zusammen?' * nicht mehr: 'Was treibt sie voran?' Der EinfuB dei' Parsonsschen Fragestellung auf die neuere (und keineswegs nur die amerikanische) Soziologie läß3t sich schwerlich uberschätzen" (Dahrendorf 1958: 76).

26 En bijvoorberd Giesen (preprint: 4; 9): "Diese Theorie (...) behandelt soztalen Wandel nicht mehr 
contingentie een produktieve rol in thet sociale proces toebedacht. Van oudsher werd met het orde-probleem in de sociologie geproblematiseerd hoe matschappijen erin slagen de met dubbele contingentie samenhangende onzekerheid zo te reduceren dat sociale orde überhaupt mogelijk is ${ }^{27}$. Door het dubbele contingentievraagstuk te verbinden met het orde-probleem en primair te betrekken op de mogelijkheid van stabiliteit en evenwicht van maatschappijen wordt echter aan het produktieve aspect van het contingente met betrekking tot het sociale voorbijgegaan. Zelfs in de conflicts- en machtstheorieën die als kritiek op Parsons zijn geformuleerd, vindt men die negatieve benadering van het historisch contingente terug: "Absicht einer soziologischen Theorie des Konflikts ist es, die prinzipielle Zufälligkeit unerklärtes historisches Geschehens durch dessen Reduktion auf soziale Strukturelemente zu überwinden; anders ausgedrückt: bestimmte Prozesse mit prognostischer Verbindlichkeit zu erklären" (Dahrendorf 1958: 78).

In het door Luhmann ontworpen categoriale kader stelt de contingentie van socialle systemen niet alleen een probleem dat opgelost moet worden, maar worden juist de produktieve aspecten in het sociale en communicatieve proces daarvan onderkend. Meer in het algemeen wordt in de systeemtheorie de laatste tijd erkend dat de onzekerheid ${ }^{28}$ die in de modelmatige beschrijving van systeemprocessen opduikt, niet eenvoudigweg als onvolkomenheid van het model kan worden afgedaan ${ }^{29}$. Het is nu mogelijk 'modernisering' te herinter-

als vorübergehende Störung sozialer Ordmung oder als Turbulenz auf dem Wege zu den Strukturen einer idealen Gesellschaft, sondern als selbstverständlichen Normalfall der Analyse: Ordnung und Wandel tauschen damit die Plätze (...) [D]ie Handlungssituation bieibt letztlich "dämanisch" kontingent."

27 "Expectations then, in combination with the "double contingency" of the process of interaction as it has been called, create a crucially imperative problem of order. (...) The problem of order, and thus of the nature of the integration of stable systems of social interaction, that is, of social structure, thus locusses on the integration of the motivation of actors with the normative cultural standards which integrate the action system, in our context interpersonally. These standards are (...) patterns of valueorientation, and as such are a particularly crucial part of the cultural tradition of the social system." (Parsons 1951: 36-37).

28 G. Klir (1989) onderscheidl twee typen van onzekerheid: "fuzziness" (of "vagueness") en 'ambiguity". 'Fuzziness' is het gevolg van het ontbreken van duidelijke grenzen. 'Ambiguity' houdt verband met het bestaan van meet uidigheid; hierin is weer een onderwerdeling aan te brengen. Het ene type ambiguiteit refereent nat situaties warin twee of meer situaties ongespecificeerd bijiven ("nonspecificity"; possibilisme). Het andere type kenmerkt conflicten waar tussen meerdere alternatieven gekozen moet worden ("dissonarice"). De onzekerheid waarmee sociale processen op het meest basale niveau omgeven zijn, vallen onder de noemer 'non specificiteit" te rangschikken.

29 Onder andere in Langman (1986: 41) en in Klix (1989: 9): "The relationship among complexity, credibility, and uncertainty of systems models (..) is not as yel well understion. In general, we try to achieve a high credibility of models that are simple and, if possible, we want to avoid uncertainty. Unfortunately, these objectives conflict with each other in a ther complicated way. Although uncertainly is undesirable when considered alone, it becomes very valuable when considered un connection with complexity and credibility. (...) Its role is particularly important when we attempt to model phenomena that are very complex or pheriomena for which data are scarce" 
preteren als een kwalitatieve omslag in de wijze waarop in de verwachtingsstructuren de onzekerheid die ten aanzien van de voortzetting van sociale processen bestaat, wordt gereproduceerd en ingeperkt (Wachelder 1989b).

Gedurende de laatste anderhalve eeuw hebben tal van denkers gepoogd onder woorden te brengen wat het 'modernisme' is. Ch. Baudelaire schrijft "La modernité, $c^{\prime}$ est le transitoire, le fugitif, la contingence" (Baudelaire 1954 [1859']: 892, in Van Bottenburg 1990: 108). B. Verschaffel weet de 'moderniteit" zelfs aan te wijzen en te dateren: "Het is een ketterij, die veroordeeld werd door het decreet Lamentabili sane exitu van het Heilig Officie van 3 juli 1907, en definitief door Pius $\mathrm{X}$ in de encycliek Pascendi Dominici Gregis van 8 september 1907. En het modernisme is niet zo maar een ketterij, het is 'de verzameling van alle ketterijen'. (...) Kernpunt van het modernistische stelsel, waar al het andere uit voortvloeit, is 'het principe van ontwikkeling'. De Moderne Wereld - de Moderniteit - begint met het 'principe der ontwikkeling', of de overtuiging dat alles op elk moment verandert, en dat alle veranderingen passen in één grote ontwikkeling. De moderne wereld begint, wanneer men vanuit dat 'besef van ontwikkeling' gaat denken en handelen. Het ontwikkelingsprincipe kan in organische of vitalistische termen gedacht of beleefd worden, en heet dan: 'evolutie'. De ontwikkeling kan ook in historische termen gedacht en beleefd worden, en heet dan: 'geschiedenis': 'Alles is historisch'. De Moderne Wereld begint wanneer de 'Anschauung des Universums als Natur' geruild wordt voor de 'Anschauung des Universums als Geschichte" (Schelling)" (Verschaffel 1988/89: 44).

Verschaffel wijst op het belang van 'historisering', 'vooruitgangsidenken' en 'ontwikkeling' als karakteristiek van 'modernisering'. Bij het hier uiteen te zetten perspectief op modernisering zal die 'historisering' eveneens als leidraad fungeren. In de geschiedwetenschap heeft R. Koselleck de afgelopen decennia de zich wijzigende tijds- en geschiedsbeleving in de achttiende eeuw tot onderwerp van fascinerende studies gemaakt. Het proces van 'Verzeitlichung' dat in diverse wetenschapsgebieden in de late achttiende en vroege negentiende eeuw optreedt is onder andere door $M$. Foucault en later door $W$. Lepenies gedocumenteerd. Een systematische verwerking van dergelijke ideeën in de maatschappijtheorie heeft echter nog niet plaatsgevonden. P. Virilio (1989) drijft weliswaar in zijn 'bewegingsleer' - waarin snelheid de centrale parameter vormt voor de analyse en beschrijving van maatschappijen - een aantal correcte intuities op de spits, een systematische maatschappijtheorie valt zijn 'dromologie' niet te noemen.

'Modernisering' wordt hier gehanteerd ter aanduiding van een kwalitatieve omslag in de organisatie van verwachtingsstructuren, die om te beginnen samenhangt met een schaalvergroting in de ruimtelijke dimensie, met een vergroting van de schaal waarbinnen sociale processen zich afspelen en op elkaar afge- 
stemd worden, iets dat we als globalisering ${ }^{30}$ betitelen. Daarin speelt de ontwikkeling van het verkeer een grote rol. Alhoewel Nederland reeds ten tijde van de Republiek (1579-1795) een florerend stelsel van trekschuiten bezat (De Jong 1986: 11), krijgen pas in de loop van de negentiende eeuw afstanden een andere betekenis ${ }^{31}$. In 1823 werd de eerste houten stoomboot op de Nederlandse binnenwateren gesignaleerd. In 1824 voer de Batavier naar Londen. In 1825 werd de Amsterdamse Stoomboot Maatschappij opgericht. In 1839 werd de spoorweg Amsterdam-Haarlem in bedrijf genomen, oorspronkelijk alleen voor personenvervoer (Valkhoff 1938: 11). Het spoorwegnet zou vanaf 1860 in rap tempo worden uitgebreid. In Nederland valt die periode van schaalvergroting grotendeels samen met de implementatie van de statelijke eénwording (Van Holthoon red. 1985 ) en het ontstaan van een centrale staatsbureaucratie (Van IJsselmuiden 1988). In 1795 bezegelde de Bataafse Revolutie de ondergang van de federatieve staatsinrichting van de Republiek der Verenigde Nederlanden, die gebouwd was op particularistische (voor)rechten (Spoormans 1988: 89). Nauwelijks twee decennia later, in 1813, lieten de Fransen bij hun vertrek de fundamenten van een moderne eenheidsstaat achter, die vanaf 1815 het Koninkrijk der Nederlanden heette (Heederik 1973; Knippenberg en De Pater 1988: 13-18), en die in de loop van de negentiende eeuw zou worden opgebouwd.

Globalisering betreft veranderingen van schaal en betekenis in de ruimtelijke dimensie, wat verdergaande en meer complexe eisen stelt aan (centraal geleide) afstemming tussen een aantal maatschappelijke domeinen. Dat roept rechtstreeks een aantal veranderingen in de omgang met de tijdsdimensie op (Prigogine \& Stengers 1988: 33). Het trein- en telegraafverkeer vereist dat de regionale tijdrekening vervangen wordt door een nationale (Knippenberg en Nauta 1989) en liefst zelfs internationale tijdrekening (Van Zanten 1887; Draaisma 1990). Het leven in de negentiende eeuw wordt steeds meer rondom een centraal geregelde en gemeenschappelijk beleefde tijd georganiseerd (Van der Poel 1988: 10; O'Malley 1990). Aan de opmars van het horloge zou dat duidelijk te maken $z^{i j n^{32}}{ }^{32}$ Precieze gegevens omtrent het horlogebezit in Nederland zijn

30 H. Nowotny (1988; 21) noent dit 'mobility'. Globalisering impliceert trouwens geen uniformisering. Wanneer op het platteland de invioed van de stad groter wordt, kan dat platteland zich op onderdelen als bijvoorbed kleding en sieraden bewust afwijkend gan profileren (Schumman 1989: 172).

31 "Mar nu is wethasist alle afstand tusschen steden en Janden, van maanden en dagen to uren en minuten verminderd" (Müller 1864: 468). "Op het einde der vorige en in het begin dezer eeuw werd er nog in de kerken gebeden, als iemand de moeilijke en gevaarlijke reis van Leeuwarden naar's Graverihage of van Groninger naar Amsterdam moest ondernemen. Thans zijn er geen afstanden meer" (Van der Wijck 1898: 85). De gemiddelde snelheid van een trekschuit bedroeg zes killometer per uur (Van der Woud 1987: 114).

32 "Where world watch output at the end of the eighteenth century was around 350. - 400,000 pieces a year, it wasi up almost tenfold, to 2.5 million pieces, three quarters of a century later" (Landes 1983 ; 287) Uiterand wordt deze periode ook gekenmerkt door een enorme demografische expansie. 
echter niet bekend (Wijsenbeek-Olthuis 1987; Schuurman 1989: 171 en 272).

Maar in de tijdsdimensie is meer aan de hand. Geleidelijk aan vindt een heroriëntatie in de verwachtingsstructuren plaats waarbij segmentaire of hiërarchische indelingen hun primaire ordeningsfunctie verliezen terwijl die wordt overgenomen door concepten die verwijzen naar processen ${ }^{33}$. Segmentaire ordeningen zijn opdelingen in gelijke of vergelijkbare delen, bijvoorbeeld van een taart in punten. Hiërarchische indelingen worden ten eerste gekenmerkt door het aangeven van een preferentie in de opdeling: "hoog' is bijvoorbeeld verkieslijker dan 'laag' (Schwartz 1981). Maar nog kenmerkender voor hiërarchische indelingen is de verhouding tot ontwikkeling en het verloop van tijd. Een hiërarchische indeling veronderstelt dat de loop van de geschiedenis niet van invloed is op de ordenende kracht van de ordeningsparameter ${ }^{34}$. Hiërarchische indelingen worden gekenmerkt door het aanbrengen van een gelaagdheid op basis van criteria waarin de ontwikkeling in de tijd ofwel in het geheel geen rol speelt, òfwel gefixeerd is in één tijdsmoment, ofwel naar een traditie verwijst die wordt geacht in stand te blijven. Een hiërarchische en segmentaire inrichting van de verwachtingsstructuren brengt daardoor een specifiek patroon van indamming en reproduktie van contingentie met zich mee. Wanneer in de verwachtingsstructuren de aansluitmogelijkheden in het communicatief proces primair worden georganiseerd door een samenhangend stelsel van segmentaties en hiërarchieën, is de communicatieve omgang met het nieuwe en onbekende, waarin zowel zakelijke als sociale componenten een rol kunnen spelen, georiënteerd op het herleiden van het onverwachte binnen een bekende, hiërarchisch samenhangende orde. Niet alleen het indammen van contingentie maar ook de reproduktie van contingentie vindt in verwachtingsstructuren die door hiërarchische en segmentaire indelingen gereguleerd worden op een kenmerkende wijze plaats. Verfijndere indelingen kunnen vernieuwingen introduceren. Daarmee is ook de vorm van het conflict voorgestructureerd. Namelijk als een strijd om een hergroepering binnen of een herinterpretatie van de bestaande hiërarchieën ${ }^{35}$.

33 "Wue keine andere Neuzeit erscheint die Moderne, markiert durch. Französische und industrielle Revolution, durch ein neues Verhältnis zur Zeit gekennzeichnet: nach den Thesen Reinhart Kogellecks sind für sie Prozessualisierungs- und Beschleunigungsvorgainge ebenso charakterisch wie die De-Naturalisierung überlieferter Zeitvorstellungen und die Herausarbeitung des Fortschrittsbegriffe" (Lupenies 1976: 9).

34 Met behulp van het evolutionaire gedachtengoed kan uiteindelijk ook het hiéranchiembegrip getempo raliseerd worden, wat het mogelijk makkt tussen exclusieve en inclusieve hièranchieen te onderscheiden. "The scala maturae, which so strongly dominated thinking from the sixteenth to the eighteenth cantury is another good illustration of an exchuse hierarchy. Each level of perfection was considered as an advance (or degradationy from the next lower (or higher) lewel in the hierarchy, but did not inchude ill. (...) The modern hierarchy of taxonomic categoties is a typical example of an inclusive hierarchy" (Mayr 1982: 206). Herop wordt uitwoerig teruggekomen in hoof dstuk vijf.

35 "DaB alle Wirklichkeit von Vielfalt und Konflikt bestimmt ist, ist trivial" das Besondere am enropäi* 
Door niet langer segmentaties en hiërarchieën primair de aansluitmogelijkheden in de verwachtingsstructuren te laten reguleren maar procestermen, die gekenmerkt worden door een principiële openheid en onzekerheid ten aanzien van de toekomst, die rol te laten vervullen, wordt in het sociale systeem de nadruk verlegd van het reduceren van het nieuwe tot een bekende orde, naar een verhoogde sensibiliteit voor het onverwachte. Wanneer in de verwachtingsstructuren processen de centrale notie vormen die communicatieve aansluitmogelijkheden voorstructureren dan kan het onverwachte niet meer primair worden gereduceerd door te verwijzen naar een bestaande tijdsonafhankelijke hiërarchie, of naar aangeboren of essentiële eigenschappen. In plaats daarvan wordt de nadruk verlegd naar een voortdurende aanpassing aan een veranderende omgeving. Daardoor kunnen moderne maatschappijen een grotere complexiteit, begrepen als een groter aantal open mogelijkheden (Luhmann 1987b: 31), hanteren.

Koselleck (1979) heeft het veranderende geschiedbeeld en de zich wijzigende tijdservaring vanaf de zestiende tot de vroege negentiende eeuw tot het centrale onderwerp van zijn boek 'Vergangene Zukunft' gemaakt. In de zestiende en zeventiende eeuw vallen ervarings- en verwachtingshorizonten nog verregaand samen: "Es war eine bis in das achtzehnte Jahrhundert fast unwidersprochenen weitergereichte Lehre, daß man aus der Historie der Vergangenheit für die Zukunft lernen könne. Die Erkenntnis des Gewesenen und die Voraussicht des Kommenden blieben zusammengehalten durch eine quasi-naturalen Erfahrungshorizont, innerhalb dessen sich nichts prinzipiell Neues ereignen konnte" (Koselleck 1979: 88). Kenmerkend voor het moderne idee van 'geschichtliche Zeit' is allereerst de beleving van een differentie tussen verleden en toekomst, tussen ervaring en verwachting (Koselleck 1979: 12; Dux 1989: 312-348), die er voorheen niet was $^{36}$. Aan de hand van documenten met betrekking tot de religieuze beleving laat Koselleck zien dat de Christelijke wereld tot in de 16de eeuw beheerst wordt door de verwachting van het einde der tijden, dat maar niet wil komen. Het einde der dagen werd enerzijds tijdens de Reformatie en de godsd iensttwisten steeds vaker op zeer korte termijn aangekondigd, anderzijds vanaf de 15 de eeuw alsmaar vooruitgeschoven. Met de twijfel en het ongeloof aan de Dies Irae groeit het besef van een lineaire tijdsopvatting met een duidelijke differentie tussen ervaring en verwachting (Doorman 1989b).

Vervolgens is met het moderniseringsproces een verandering in de verhou-

schen Mittelalter ist, daß die Vielfalt legitimiert ist und die Konflikte eingehegt sind. Das ist darum so, weil alle Vielfalt auf den einen transzendenten Ursprung aller Ordnung bezogen ist, die vielen ungleichen Freiheiten auf die eine gleiche und allgemeine Freiheit des Erlösten" (Nipperdey 1990: 35).

36 Het uiteenvallen van de ervarings" en verwachtingshorizont schept pas de mogelijkheid om te spreken van een "anachronisme" in een geschiedverhaal (Blaas 1988: ix). 
ding tussen ervaring en verwachting in het geding. Zo lang men dacht dat men in afwachting van het Laatste Oordeel verkeerde, kon iets werkelijk nieuws pas op de Jongste Dag plaatsvinden. In het onder zijn medeverantwoordelijkheid uitgegeven 'Geschichtliche Grundbegriffe' laat Koselleck zien hoe het idee van een 'geschichtliche Zeit', met een duidelijk onderscheid tussen ervaring en verwachting en uiteindelijk zelfs een geloof in de maakbaarheid van de toekomst, geleidelijk aan in een groot aantal concepten en maatschappelijke domeinen verschijnt. In het Duitse taalgebied krijgen vanaf 1770 , met als belangrijkste periode van omslag - de 'Sattelzeit' - de tijdsspanne tussen 1789 en 1799, een groot aantal woorden een andere betekenis en creëren een nieuwe verwachtingshorizon. "Begriffe dienen nicht mehr nur, Vorgegebenheiten so oder so zu erfassen, sie greifen aus in die Zukunft. Zunehmend wurden Zukunftsbegriffe geprägt, erst künftig zu erringende Positionen mußten sprachlich vorformuliert werden" (Koselleck 1979: 113).

Die heroriëntatie waarbij de verhouding tussen ervaring en verwachting een andere inhoud krijgt, is een uiterst complex proces (Blaas 1988). Voor een historicus in het midden van de achttiende eeuw was er nog een vanzelfsprekende, door de continuïteit van ruimte en tijd gegarandeerde orde, de continua series (Roelevink 1986: 189). Deze stelde de polyhistor in staat alle feiten in een natuurlijke orde van handelingen te plaatsen ${ }^{37}$. De ordo rerum gestarum maakte het historisch proces als zodanig aanschouwelijk door beschrijving van afzonderlijke daden van mensen (Roelevink 1986: 280-285). De menselijke natuur werd immers als een constante beschouwd waardoor menselijke handelingen op een bijna mechanistische manier met elkaar verbonden konden worden (Roelevink 1986: 310). Het verleden fungeerde daardoor tevens als leidraad voor het inpassen van nieuwe historische feiten. Het nieuwe feit moest in de bestaande series passen, wilde het betrouwbaar worden geacht (Roelevink 1986: 287). Daaruit volgde dat kennis van het verleden direct toepasbaar was op het heden. De kritische polyhistor "wildle niet alleen verzamelen en ordenen, maar ook integreren in wetenschappelijke zin en bruikbaar maken voor het heden. Eruditie en nut voor het heden waren onverbrekelijk met elkaar verbonden" (Roelevink 1986: 222) ${ }^{38}$.

37 "[H]et kwam er slechts op aan deze bronnen zo goed mogelijk aan elkaar te hechten. Op dit gesloten, lineaire beeld van het werleden dat bij Adam begon, is in ce zeventiende eeuw slechts in een incidenteel geval inbreuk gemaakt" (Van der Woud 1990: 16).

38 Van der Woud (1990: 13) illustreert dit type van geschiedschrijving aan de hand van de "Bataafse mythe'. Wetenschappelijke weetgierigheid richtte zich op de opsporing van nieuwe schuiftelijke bronnen en de uitleg daarvan waarbij het er vooral om ging de voorgeschiedenis van. Holland zo te vertellen dat de betekenis en de legitima tie van Hollands machl als een vanzelfsprekendheid naar woren kwamen. "Zo ontstond de langdurige en ingewikkelde verhouding van Holland met zijin Bataafse verleden, een verhouding waarin niet alleen pollitiek en wetenschap maar ook het heden en verleden zich vermengden" (Van der Woud 1990: 13). 
In de loop van de achttiende en het begin van de negentiende eeuw werd de overmaat aan detailkennis steeds minder belangrijk, ten gunste van de grote lijn ${ }^{39}$, de ontwikkeling in de geschiedenis (Roelevink 1986: 313; Blaas 1988: 34). De vanzelfsprekendheid van de ordening van historische feiten, singularia, viel weg. Er was vraag naar een nieuw selectiecriterium. De gestage ontwikkeling van de mensheid, een volk of een staat kon dat leveren (Van der Woud 1990: 24). Maar nog steeds stond de geschiedschrijving in het teken van een ontwikkelingsdenken, een soort van universele geschiedenis, die een beroep deed op essentiële eigenschappen die aan de bron van die ontwikkeling lagen. Pas in de loop van de negentiende eeuw krijgt, met als afzetpunt het ontwikkelingsdenken dat de geschiedfilosofieën kenmerkt, het contingente van het historisch proces steeds meer nadruk ${ }^{40}$. Hoewel de natie of het volk nog tot het begin van de twintigste eeuw het vanzelfsprekende uitgangspunt van historische studies zal blijven. Dan pas begint het probleem van de geschiedschrijving in de moderne tijd, namelijk welk selectiecriterium te hanteren om historische feiten met elkaar in verband te brengen, zich af te tekenen.

Wanneer het historisch proces geleidelijk zijn natuurlijke orde verliest, $\mathrm{d}$ ringt het besef van zowel de onvoorspelbaarheid als de maakbaarheid van de toekomst zich op. "Die Zukunft wurde zu einem Bereich endlicher Möglichkeiten, der in sich nach Graden größerer oder minderer Wahrscheinlichkeit abgestuft war (...). Die zweite Folge eines solchen Verhaltens war die Einstellung auf mögliche Ueberrasschungen, da meist nicht die eine oder andere, sondern eine dritte, vierte oder sonstwievielte Möglichkeit sich realisierte" (Koselleck 1979: 29). Er ontstaat met andere woorden een verrassingsbewustzijn. Dat brengt een omslag te weeg in de omgang met het besef dat verwachtingen over de werkelijkheid ook niet gerealiseerd kunnen worden. In veel sterkere mate dan voorheen kan dan de bereidheid, verwachtingen bij te stellen wanneer deze teleurgesteld worden, getolereerd en zelfs gestimuleerd worden. Wanneer maatschappelijke verhoudingen worden georganiseerd rondom tijdsonafhankelijke criteria zijn zowel de noodzaak als de mogelijkheden daartoe veel kleiner. Wanneer principes en tradities de maatschappelijke omgang reguleren, zal in het geval van het niet overeenstemmen van de verwachtingen met de concrete

39 Roelevink (1986: 275) wijst op de toenemende complexiteit" "Alleen mensen met een frenomenal geheugen en een geweldige werkkracht konden de aanzwellende stroom van beschikbare feiten de baas." Blaas (1988: 35-36) hecht groot belang aan de ontrlekking van de Nieuwe Wereld: "Wat niet eigen was, heette naar Grieks recept vreend dat wil zeggen 'barbaars" of "wild'. Als tegenpool tungeerde het eigen cultuurgoed dat in de humanistische denktrant met civilite, beschaving werd aangeduid. (n. Deze classificierende begrippen dwongen meer en meer tot een differentiërend vergelijken en het was juist deze procedure die op de lange duur een nieuw hisitorisch perspectief oplewerde."

40 Zie Brands (1965:53-100). Volgens E. Kessel is het wezen van het historisme gelegen in "die Anm erkennung und positive Würdigung des Unerklärbaren und Unberechenbaren im menschlichen Leben" (Brands 1965: 80). 
ervaring, veel eerder een beroep worden gedaan op de externe omstandigheden en uiteindelijk zelfs op het ingrijpen door Gods hand ${ }^{41}$. Door in de verwachtingsstructuren aan processen, waarvan de uitkomst principieel onzeker is, de ordenende plaats te geven die voorheen hiërarchische en segmentaire indelingen vervulden, wordt - in de terminologie van Luhmann - de mogelijkheid geopend tot het domineren van cognitieve over normatieve verwachtingsstructuren. Waarbij 'cognitief' betekent dat indien verwachtingen teleurgesteld worden, dat tot een aanpassing van de verwachtingsverwachtingen leidt, terwijl 'normatief' betekent dat in het geval van teleurgestelde verwachtingen er geen verandering in de verwachtingsstructuren optreedt. Deze cognitieve dominantie brengt een steeds sterker wordende oriëntatie op de toekomst met zich mee, waarbij bronnen uit het verleden hun zeggingskracht verliezen. "Der Fortschritt öffnet nunmehr eine Zukunft, die den überkommenen prognostizierbaren, naturalen Zeit- und Erfahrungsraum überschreitet und der dadurch - im Zug seiner Dynamik - neue, transnaturale und langfristige Prognosen provoziert" (Koselleck 1979: 34). Maar dat vereist weer een andere omgang en (empirische) studie van de werkelijkheid. Niet langer staat de kennis van principes, de samenhang en de verhouding tussen bekende bronnen voorop, maar de confrontatie van een verwachte uitkomst van een proces en de realiteit. Deze studie wil onderzoeken of dat perspectief op modernisering licht kan werpen op en samenhang kan aanbrengen in concrete discussies over de inrichting van het hoger onderwijs in de vorige eeuw.

\section{De 'Duitse Universiteit'}

Debatten over de inrichting van het hoger onderwijs markeren verschuivingen in wetenschappelijke, pedagogische en politieke inzichten. De inrichting van het medisch onderwijs bij voorbeeld is afhankelijk van de organisatie van de zorg en een afgeleide van bepaalde opvattingen van ziekte. Maar daarnaast is ook de verhouding tussen statusgroepen of de betekenis die men aan examens toe wil kennen van belang. In de navolgende hoofdstukken wordt nagegaan in hoeverre bovengeschetst perspectief op modernisering het bestaan van en de verschuiving in dergelijke afhankelijkheden kan verhelderen. Deze benade-

41 "Erwartungen, die über alle bisherige Erfahrung hinauswiesen, waren nicht auf diese Welt bezogen. Sie richteten sich atuf das sogenannte Jenseits, apokalyptisch angereichert auf das Einde dieser Welit insgesammt. Dagegen konnten auch alle Enttäuschungen nichts verschlagen , die hochtauchten, wenn sich wieder einmall herausstellte, da\& eine Prophezeiung vom Ende dieser Welt nücht eingetroffen war" Eine nicht erfülte Prophetie war stets reproduzierbar. Mehr noch, der Irrtum, den die Nichterfullung einer solchen Erwartung bloßstellte, wurde zum Beweis dafür, daß die apokalyptische Voraussiage vom Weltende beim nächsten Mal mit um so größerer Wahrscheinlichkeit eintreffen werde" (Koselleck 1979: 362). 
ring van het veranderingsproces van de Nederlandse universiteiten vormt een alternatief voor de opvatting dat Nederland in de negentiende eeuw een "Duits model' zou hebben overgenomen (Van Berkel 1985: 132). In die visie worden de veranderingen die zich in de Duitse universiteiten in de loop van de negentiende eeuw hebben voltrokken, beschreven in termen die primair en vrijwel uitsluitend de wetenschapsbeoefening en de interne organisatie van de universiteiten betroffen (Rudy 1984). Dat organisatorisch model zou vervolgens door de wet van 1876 in Nederland zijn geintroduceerd.

$\mathrm{Nu}$ is het niet de bedoeling te suggereren dat er aan de Duitse universiteiten in de negentiende eeuw niet zoiets als een onderzoeksethos zou zijn ontstaan of dat er geen professionalisering van het wetenschappelijk beroep, gevolgd door een verregaande specialisering van het onderzoek, zou hebben plaatsgevonden (Turner 1975; Wittrock and Elzinga 1983; Ben-David 1984; Van Berkel 1985). Deze studie verzet zich wel tegen het idee dat de 'Duitse universiteit' opgevat kan worden als een complex van organisatorische maatregelen die de organisatie van het wetenschappelijk onderzoek betreffen en die veelal als een implementatie van het neo-humanistische ideeëngoed worden gezien. Het idee dat wetenschappelijke veranderingen zich in een maatschappelijk vacuüm voltrekken, wordt in deze studie expliciet losgelaten. De traditionele visie heeft vrijwel uitsluitend aandacht voor de veranderingen die in de universiteiten hebben plaatsgevonden met betrekking tot de organisatie van het wetenschappelijk onderzoek. De negentiende eeuwse universiteit was echter in eerste instantie een onderwijsinstelling. Niet voor niets werd deze meestal met de term "hoogeschool" aangeduid. En juist ook op het gebied van het onderwijs vinden in de loop van de negentiende eeuw tal van veranderingen plaats. Selectie en examens krijgen in het hoger onderwijs een voorheen ongekende rol. Het ons zo vertrouwde idee van een curriculum en een vaste studievolgorde is in het begin van de vorige eeuw allerminst vanzelfsprekend. In uiteenlopende vakgebieden worden praktische oefeningen geïntroduceerd terwijl dictaatcolleges naar de achtergrond worden gedrongen. In tegenstelling tot een eeuwenlange traditie is in 1876 de opleiding tot arts een uitsluitend universitaire aangelegenheid geworden. Het curriculum van de rechtsgeleerde faculteit krijgt, onder andere als gevolg van de codificatie, een geheel ander aanzien.

Vormt in de traditionele beschrijving van het veranderingsproces aan de negentiende eeuwse universiteiten de vrijwel uitsluitende aandacht voor het aspect van het onderzoek al een ernstig manco, recent onderzoek heeft bovendien het idee van een énduidig 'Duits' model op de helling gezet. De mythische betekenis van 'Wissenschaft' is tot reële proporties teruggebracht (Turner 1989: 297). Decennia lang stond de 'Duitse universiteit' symbool voor de glorietocht van 'Wissenschaft'; Wilhelm von Humboldt (1767-1835) was haar 
schepper. In het kader van de oprichting van een nieuwe universiteit te Berlijn formuleerde Von Humboldt ${ }^{42}$ (1984c) een aantal organisatorische randvoorwaarden waaraan de universiteit zou moeten voldoen. Organisatorische randvoorwaarden die direkt afgeleid werden uit de doelen die voor een universiteit nastrevenswaardig waren. Centraal in Humboldts neohumanistische denken staat de 'Bildung" ${ }^{43}$ van het individu" senschaft ${ }^{\text {45: " }}$ Der Universität ist vorbehalten, was nur der Mensch durch und in sich selbst finden kann, die Einsicht in die reine Wissenschaft. Zu diesem SelbstActus im eigentlichsten Verstand ist notwendig Freiheit, und hülfereich Einsamkeit, und aus diesen beiden Punkten fließt zugleich die ganze äußere Organisation der Universitäten. Das Kollegienhören ist nur Nebensache, das Wesentliche, daB man in enger Gemeinschaft mit Gleichgestimmten und Gleichaltigen und dem BewuBtsein, daß es am gleichen Ort eine Zahl von schon vollendet Gebildeter gebe, die sich nur der Erhöhung und Verbreitung der Wissenschaft widmen" (Humboldt 1984b: 79).

Het lot van vele mythen is de terugreis naar het land der fabelen ${ }^{46}$. "Wissenschaft' en 'Forschung' hebben bij Humboldt een andere betekenis dan wij daarmee verbinden. 'Wissenschaft' staat uitsluitend ten dienste van de persoonlijkheidsvorming: "Denn nur die Wissenschaft die aus dem Innern stammt und ins Innere gepflanzt werden kann, billet auch den Charakter um, und dem Staat ist es ebensowenig als der Menschheit um Wissen und Reden, sondern um Charakter und Handeln zu tun" (Humboldt 1984b: 84). 'Wissenschaft' heeft niets met de veelheid van natuurwetenschappelijke specialismen zoals wij die kennen van doen ${ }^{47}$. Voor Humboldt is 'Wissenschaft' een strikt indivi-

42 Naast Von Humboldt werden ook voorstellen geformuleerd door F.W.I. Schelling 'Vorlesungen über' die Methode des akademischen Studiums" (1802), J.O. Fichte, "Deduzierter Plan einer zu Berlin zu errichtenden höheren Lehranstalk' (1807), F. Schleiermacher, 'Gelegentlichen Gedanken über Universiltä ten im deutschen Sinn' (1808) en H. Steffens (1808/9), "Ueber die lidee der Universitäten' (1808/9), Deze ztjin gebundeld in Antich (1956). Zie voor een kritische bespreking en vergelijking Menze (1975: 280-31.8).

43 Zie voor een ideehistorische beschrijwing van het concept "Bildung' Labrie (1986).

44 In Humbolds humanisme is individuele 'Bildung' overigens niet het einddoel. De taal bemiddelt tussen de mens en de wereld. 'Bildung' is daarom altijd "sprachliche Bildung' . Vielmehr sei jede Bildung unauthebbar an die nationale Sprache gebunden, und der durch Studium vertiefende Einblick in die Muttersprache schaffe jene nationale Kultur, die es der Individualitảt ermögliche, in dem durch die gemeinsame Sprathe bestimmten gesellschallichen Verbände in Freiheil zu leben" (Menze 1975: 475). 45 "Es ist ferner eine Eigentümlichkeilt der höheren wissenschaftlichen Anstalten, da:Bs sie die Wissenschaft immer als ein noch nicht ganz aufgelöstes Problem behandeln und daher immer im Forschen. bleiben. Das Verhältnis zwischen Leluer und Schüler wird daher durchaus ein anderes (...), beide sind fiür die Wissenschaft da" (Humboldt 1984c" 82-83).

46 "For fifteen years contemporary historians of science, education and ideas have been remor'selessly unmasking the myth of Wissemschaft" (Turner 1989: 298).

47 "Wissenschaft, so sei wiederholt, war im Zeitalter der Auflärung zwar an Suche nach der Wa hrheit, an Wissensgewinn orientiert, stellte sich aber in erster Linie als Billdungswissenschaft, als Zusammenschau dar" (Ellwein 1985: 124). "Zunächst liegt in dem Begriff der 'reinen" Wissenschaft die Ablehrung der auf 
duele aangelegenheid, die "aus der Tiefe des Geistes heraus" (Humboldt 1984b: 84) moet komen. Met empirie wil zij niets te maken hebben (Nipperdey 1986: 144 ff.). De kunst en meer nog de filosofie - omdat deze betrekking heeft op taal - benaderen de 'Wissenschaft' die Humboldt nastreeft nog het meest (Menze 1975: 30-40). De moderne ideeën over hoger onderwijs lijken meer op het Philantropijnse ${ }^{48}$ ideaal dan op Humboldts neohumanistische. Ook de gelijkschakeling van academische vrijheid - in de zin van autonomie van universiteiten ten opzichte van de staat - met de principes van Lehr- en Lernfreiheit is overhaast (Stichweh 1987b). 'Lehrfreiheit', libertas philosophandi, werd trouwens al in de achttiende eeuw in de universiteit van Göttingen geïntroduceerd, enerzijds passend in de idealen van de verlichting, zoals verwoord door Christian Thomasius (1655-1728) ${ }^{49}$, anderzijds als strategie om de universiteit van Göttingen meer aanlokkelijk te maken voor buitenlandse hoogleraren ${ }^{50}$ (Boehm 1983: 94; Brookman 1979).

Historisch onderzoek heeft het belang van de persoon en de ideeën van Wilhelm von Humboldt naar de marge gedrukt (Olesko 1988b: 297). De universiteiten van Halle en Göttingen hebben wellicht al in de achttiende eeuw meer bijgedragen aan de institutionalisering van het natuurwetenschappelijk onderzoek aan de Duitse universiteiten dan de oprichting van de universiteit van Berlijn (Ellwein 1985: 112; Schelsky 1971: 25-32). Het apolitieke karakter van Humboldts 'Bildungsphilosophie' is ontmaskerd door deze in zijn politieke en sociale context te bezien, onder andere ${ }^{51}$ door A. Labrie (1986). Het uitgangs-

das praktische Leben bexogenen, angetwandten und damit spexialisierten Wissenschaft" (Schelsky 1971: 66).

48 Neohumanistische Billdungsidealen ontstonden in direct verzet tegen een progressief onderwijsprogramma ontworpen aan J.B. Basedows Philanthropinium. De onderwijsidealen daar behelsden het ontwikkelen van de natuurlijke eigenschappen van de leerling en het ontwikkelen van praktische vaardigheden. Onder verwijzing naar de Philanthropijnse denkbeelden bepleitte minister J.E. von Massow de afschaffing van de universiteiten en de oprichting van gespecialiseerde vakscholen (Niethammer 1808; König 1970; Schelsky 1971; Menze 1975; Rủegg 1983).

49 "Das Recht zur Freiheit der Lehre und damit zur Freiheit des Irrtums ist unteilbar, den Wissenschaf" ten weserisnotwendig. (...) War es bisher üblich, sich hinter fremden, autorisierten Meinungen zu verschanzen, die Waltheil einer Sache durch die Anführung einer anerkannten, aber meist nicht selbst geprüftten Autorität zu beweisen, muß jetzt das eigene und gegründete Urteil, die überzeugende und vernünftige Aussage beweiskräftig sein" (Hammerstein 1972: 56)

50 "Zij [het bestuur van de universiteit van Göttingen] beriepen de eerste mannen van Duitsland om datar te komen, en vonden zij in Duitsland niet, wat zij zochten, dan zochten ze in ans vaderland en elders. Eenurial die hebbende, bemoeiden zij er zich nu verder niet mede, hoe die moesten handelen, hoe onderwijzen, hoe de studiën voortzetten. (..) Dat Göttingen in korte tijd onder de oudste en beroemdste akkademiën van Duitschland eene plaats kreeg en tot nu toe behield ${ }_{p}$ en het licht van kennis en wetenschap zich zoo van hier door de geheele geleerde weneld verspreidde, als uit geene Duitsche akademie in de voorgaande eeus $w^{\prime \prime}$ (Van Heusde 1829: 178).

51 Zie ook Ellwein (1985: 125): "Die erneuerte Uniwersität erlang sich nach 1800 große Freiheit und Autonomie: Sie sicherte diese Autonomie durch ein sie stärkendes Bündnis mit dem Bildungsbürgertum ab. Das Bündnis würde vor allem von den der 'allgemeinen' Bildung zugewandten Wissenschaftem gepflegt. Geschichte, Archäologie oder Germanistik erlebten einen ungeheuren Aufschwung." 
punt van Labries beschouwingen wordt gevormd door de opkomst van een nieuwe intelligentsia en een daarmee verbonden individualistische instelling in de late achttiende eeuw. Dat liet zich moeilijk verenigen met het waardenpatroon van de traditionele standenmaatschappij": "De schrijver, die zich als genie opvat en zich zo verheft boven de beperkingen van de bestaande maatschappij, neemt bij implicatie ook afstand van relaties en waarden, die met deze samenleving zijn verbonden. (...) Het ontstaan van de moderne "Bildungsidee' hangt nauw samen met dit individualisme en kan (...) onder meer worden opgevat als een mogelijke oplossing voor het gesignaleerde verlies aan sociale geborgenheid. (...) Bildung dient te worden gezien als het antwoord van de intellectueel , die streeft naar sociale integratie" (Labrie 1986: 20, 28). F. Ringer had in 1969 reeds een vergelijkbare onderneming opgezet, maar bij hem lag de nadruk op de periode $1890-1933^{53}$. Ringer koppelt de opkomst en de kracht van het 'Bildungsbürgertum' aan de overgang van een feodale agrarische samenleving, waar sociale status verbonden is met (land)bezit en geboorte, naar een geindustrialiseerde samenleving. In de overgangstase speelt de geleerde elite - de mandarijnen zoals Ringer ze noemt - een belangrijke rol. Deze ontleent haar status aan "Bildung' en bepleit in het verlengde hiervan te haar faveure een bureaucratische monarchie als bestuursvorm voor de staat (Ringer 1969: 34). Ringer heeft vervolgens laten zien in welke mate dat de ontwikkeling van het geesteswetenschappelijke en sociaal-wetenschappelijke denken in Duitsland heeft beinvloed ${ }^{54}$.

Het onderzoek van de laatste decennia heeft nog scherpere krassen aangebracht in het standaardbeeld van de 'Duitse universiteit'. De interpretaties die R.S. Turner (1971) en J. Ben-David (1984 [1971ㄱ) twee decennia geleden nog gaven over de ontwikkeling van de Duitse universiteit zijn inmiddels al weer achterhaald. Turner legde het zwaartepunt bij het ontstaan van instituten en seminaries, die oorspronkelijk de opleiding tot het leraarsberoep ten doel hadden. Het seminarie fungeerde als een elite-instituut, waar de beste studenten werden aangemoedigd door middel van zelfstandig onderzoek aan de 'Wis-

52 Die opvatting is trouwens al te vinden bij W. Windelband (1909b: 7). "Damit brach and in Detutschland die Zeit herein, in der das Individuum wesentlich mit sich selbst und seinen geistigen Interessen beschäftigt war, die Zeit der Briefe und der Tagebuicher, der Gentimentalen Selbstbespiegelung und der geistigen Lebensgemeinschaft in Liebe und Freundschaft."

53. In tegenstelling tot Labrie werkt Ringer echter birnen een vastomlijnd maatschappijtheoretisch kader (M. Weber). Maar in hun conclusies stemmen zij overeen: "Particularly social history did not fit into the mandarins scheme of reality, since it would have challenged the rather one-sided identification of the national "whole" with the cultural mission of its intellectual leaders" (Ringer 1969: 117). Thans positioneert Ringer zich overigens als geestverwant van P. Bourdieu (Ringer 1990).

54 Zie voor een verdere uitwerking van dit thema (Rülegg 1983: 119): "[T] he nineteenth-century crissis in the humanities was caused by the displacement of the program of studia hwmiona by the German invention of the Geisteswissenschaften." Ook Schelsky (1971: 91 fo). 
senschaft' bij te dragen en zo aan hun verdere 'Bildung' te werken. Daarmee was de band met het neohumanistische 'Bildungsideal' gelegd. Het instituut dat zijn oorsprong kende in het domein van de klassieke filologie $\mathrm{e}^{55}$, zou vervolgens door de natuurwetenschappen zijn overgenomen, en aldus de "Forschungsimperati $v^{\prime}$ in de natuurwetenschappen geïntroduceerd hebben. Archiefonderzoek en een nauwkeurigere bestudering van de lokale context die de laatste jaren hebben plaatsgevonden, hebben dat beeld van de ontwikkeling van de Duitse universiteiten alweer ondermijnd. Of de feitelijke situatie in de seminaries correspondeerde met het neo-humanistisch ideaalbeeld wordt ernstig betwijfeld (Olesko 1988b: 306). Een direct verband tussen het humanistische seminarie en de instituten waar natuurwetenschappelijk onderzoek een plaats in het universitaire onderwijs verwierf lijkt niet te bestaan ${ }^{56}$. In plaats van de voorbeeldfunctie van het filologisch instituut, worden thans andere aspecten benadrukt: de rol van persoonlijke ideeën, onderzoeksprogramma's, onderwijsstijlen, het studentenaanbod, onderwijsideologieën, materiële en economische randvoorwaarden, ministerieel beleid of het staatsbelang (Olesko 1988b: 298). Met name de wens tot pedagogische vernieuwingen, onder andere geïnspireerd door Pestalozzi, krijgt een belangrijke rol toegedicht (Coleman 1988; Tuchman 1988; Olesko 1988a). De innige relaties tussen vakinhoudelijke, pedagogische en politieke invloedssferen komen daarbij steeds meer naar voren (Olesko ed. 1989) $)^{57}$. W. Coleman en F. Holmes (1988: 3) stellen in de inleiding van hun gezaghebbende bundel "The Investigative Enterprise': "[W] emphasize that the distinction so easily drawn between, for example, research and pedagogy, professional and state interests, and scientific activity and institutional frameworks should be recognized as only heuristically useful categories. In the investigative enterprise these boundaries are commonly indistinct and frequently unreal."

Door zo sterk lokale en contextafhankelijke aspecten te benadrukken is het ooil zo gave "Duitse model' aan scherven geslagen. Voor een verklaring van

55 Met name de Seminaries van J.M. Gesner en C.G. Meyre te Göttingen en datt van C.H. Wollf te Halle zijin vermaard.

56. "Although n final assessment of this issue must await detalled studies of the origins of more senwinars and institutes than now exist, it seems unlikely that any strong causal connection between seminars and institutes will surface" (Olesko 1988b. 309).

57. Het uitgangspunt van Ben-Davids studies wordt daarmee uitgehold. Ben-David ([1971] 1964: 14) begint "The scientist's role in society' waarin hij de invloed nagaat die faculteitsindelingen, financieringsstructuren en carriëremogelijkheden hadden op de ontwikkeling van onder andere de Duitse wetenschap in de vorige eeuw aldus: "We have seen that although there is a possibility for an interactional sociology" of scientific activity, the possibility for either an interactional or institutional sociology of the conceptual and theoretical contents of science are extremely limited. The remaining approach, an institutional sociology of scientific activity, is the one that will be followed in this book. We shall examine the conditions that determined the level of scientific activity and shaped the roles and careers of scientists and the organization of science in different countries at different times." 
de globale, lange termijn ontwikkeling van de Duitse universiteiten wordt meer en meer een beroep gedaan op de politieke en economische context van een moderniserende maatschappij (Tuchman 1988: 91-92; Schubring en Hültenschmidt 1991$)^{58}$. Waarbij wel uitdrukkelijk als voorwaarde wordt gesteld dat de gehanteerde sociale theorie ruimte moet laten voor de gesignaleerde contextafhankelijkheid ${ }^{59}$.

\section{Kritiek en programma}

Een van de belangrijkste bezwaren die door historici tegen het "moderniseringsparadigma" is ingebracht, geldt de nadruk die alle theorieèn leggen op een vermeende discontinuiteit in de geschiedenis, op een niet vol te houden dichotomie tussen 'traditie' en 'moderniteit' (Wehler 1975). Ook de hier gepresenteerde interpretatie van modernisering lijkt zich aan die kriliek niet te kunnen onttrekken. Het is echter van belang de verschillende functies die dichotomisering kan vervullen te onderscheiden. In de structuralistischfunctionalistische benadering is er sprake van een driedeling: twee stabiele maatschappelijke ordes, de traditionele aan de ene, de moderne aan de andere kant die gescheiden worden door een reëel aanwijsbare overgangsfase. Hier fungeert de discontinuiteit tussen traditie en moderniteit daarentegen slechts als hulpmiddel om de effecten van een geleidelijk en continu verlopend veranderingsproces aan te geven. Natumrlijk is het in een historische ontwikkeling steeds mogelijk continuiteiten aan te geven, echter zo' $n$ analyse zal niet makkelijk bijdragen aan een verruiming van het handelingsperspectief (Boon 1989). Wie, zoals de meeste macrosociologen ${ }^{60}$, daarop is gericht, is eerder geneigd veranderingen - die uiteraard geleidelijk en gradueel optreden - te omlijnen, over een langere periode met elkaar te contrasteren om vervolgens

58 "The intraduction into the German universities of innovative means of instruction, including especially participation in the research process and the creation of university institutes, led some authors to search for reasons in the economic and politic contexts of the German states. To a greater or lesser extent they have suggested that state efforts at modernization created an environment that was either conducive to or necessary for these innovations" (Olesko 1988b: 322).

59 "Tuchman and Lenoir have argued most strongly that the context of economic and political modemization was essential for the educational innovations in physiology that took place at Heidelberg in Baden and Leipzig in Saxony. Though suggestive, the connections that they have drawn between modernization and educational change are also not universal, so dependent are they upon a thorough understanding of sharply defined llocal contexts" (Olesko 1988b: 323).

60 "A few years ago, the demise of modernization theory was widely celebrated. (...) Now, however, modernization theory appears alive and well (...) I would argue that such a commitment is inescapable for all social theonists. Consequently it would be better to acknowledge this explicitly and accept that we are all modernization theorists. We all work with some notion of a transition from premodern to moderv society" (Roxborough 1988: 753; 755). 
de discontinuiteit en de geconstateerde verschillen in handelingsmogelijkheden te beklemtonen.

De functie van dichotomisering is ten opzichte van de structuralistisch-functionalistische invalshoek veranderd. Tevens wordt een van de vooronderstellingen die hoorde bij de driedeling, namelijk dat de beweging tussen de twee polen traditionaliteit en moderniteit irreversibel, gericht en unilineair verloopt (Coleman 1971: 396), expliciet verworpen. Het idee was dat wanneer eenmaal de basale grondstructuren van de moderne maatschappij geïnstitutionaliseerd zijn, de verdere ontwikkeling vanzelf op gang zou komen (Eisenstadt 1974: 233-234) ${ }^{61}$. Alle maatschappijen en maatschappelijke deelgebieden zoudlen een zelfde reeks van fasen doorlopen, die convergeren naar een moderne samenleving. Unilineaire ontwikkeling die een fasekarakter draagt, werd daarbij gelijkgeschakeld aan evolutie ${ }^{62}$. Iets dat in de sociologie tot weinige jaren geleden gemeengoed was $^{63}$. Wanneer Parsons (1964) in de jaren zestig pogingen onderneemt om het structuralistisch-functionalistische ideeëngoed te 'dynamiseren', gaat hij op zoek naar 'evolutionary universals', nood zakelijke organisatorische condities in een ontwikkelingsproces die verdergaande evolutie, opgevat als de aanpassingscapaciteit van een organisme of systeem aan zijn omgeving, bevorderen en eerst mogelijk maken (Schmid 1982: 169-176). Wie echter, zoals Luhmann, kiest voor een model van de sociale werkelijkheid dat recht doet aan de contingentie van het historisch proces, is niet meer primair geinteresseerd in het aanwijzen van stadia in een groeiproces (van een individu dat tot een soort behoort). In een evolutionair model wordt de aandacht verlegd van het individu naar de populatie, waarin mechanismen van variatie en selectie werkzaam zijn. Zonder pluriformiteit en lokale variatie is een evolutionair model niet eens denkbaar. Micro-sociologische analyse zal uiteindelijk de variatie- en selectiemechanismen die in communicatieve processen werkzaam zijn, bloot moeten leggen. De invloed van de zelfbeschrijving van sociale systemen op de toegelaten variaties is daarbij een van de eerste punten die onderzoek verdienen.

Deze studie beperkt zich tot een herinterpretatie van het moderniseringsperspectief in een getemporaliseerd systeemmodel. Functionele differentiatie

61. Dat leidde onder andere tot pogingen het punt van economische "take-off en de condities daarvoor te bepalen (Rostow 1956; 1960).

$62{ }^{\circ}$ Older evolutionary theory was based on classification of mone or less complex social structures and on the assumption that all societies have passed or will pass through a determinate sequence of steps and stages" (Rüschemeyer 1984: 135\%. Smith (1973: 28-29) omschrift dat klassieke 'evolutionisme' als volgt: "The much-sought 'laws of stuccession' are uniform, and the fundamental "logic of change' is everywhere the same. The lask of the sociologist is to uncover this logic and these laws."

63 "I shall use devolop and development as synonymous with evolve and evolution. There may be differences in the context of modern biology, and even of the social sciences, that are significant for certain purposes, but not here" (Nisbet 1986: 34). 
wordt niet meer opgevat als een noodzakelijk kenmerk van een moderne maatschappij waarin een aantal a priori afleidbare functies vervuld moeten worden. Functionele differentiatie is een effect van de overheersende invloed van procestermen en een cognitieve dominantie in de verwachtingsstructuren. Dan kan in de verwachtingsverwachtingen de aanpassingsbereidheid aan wisselende omstandigheden zo'n vlucht nemen dat de hiërarchische en segmentaire samenhang tussen maatschappelijke domeinen meer en meer verloren gaat en ondergeschikt wordt aan een interne dynamiek ${ }^{64}$. "In functionally differentiated societies, subsystems develop as a consequence of the selective focusing of interactive and communicative processes on special societal functions" (Schriewer and Harney 1987: 207). Welke functies dat zijn of worden, is - in scherp contrast met Parsons' structuralistisch-functionalistische theorie - echter niet a priori vast te stellen, maar is een gevolg van variatie- en selectieprocessen. Evenmin is de koppeling tussen functionele differentiatie en modernisering dwingend. Zowel reïntegratie als verdergaande differentiatie zijn denkbaar.

Wanneer we ons echter tot Nederland in de negentiende eeuw beperken dan valt te constateren dat het standsbesef, dat een typisch hiërarchisch indelingscriterium verschafte ${ }^{65}$ en waar in de Republiek een belangrijke voorstructurerende werking van uitging, geleidelijk aan die werking verliest. Het besef dat mensen door geboorte en opvoeding tot een bepaalde stand behoorden, reguleerde in de Republiek in belangrijke mate iemands maatschappelijke en persoonlijke leven ${ }^{66}$ (Knippenberg en De Pater 1988: 32). De statusgroep ${ }^{67}$ bepaalde vriendschapsbanden en huwelijksbetrekkingen (Weber 1972: 179) die maatschappelijk aanvaardbaar waren, zoals de statusgroep ook beroepsmogelijkheden en de mogelijkheden tot politieke invloed selecteerde. Geboorte, milieu en afkomst bepaalden niet alleen de facto de plaats van het individu in de samenleving, maar er leefde ook de overtuiging dat dit zo hoorde of op

64 "Das Risiko der eigengesetzlichen zinkulären Geschlossenheit wird kombiniert mit dem Risiko funktionaler Spezifikation unter Abbau multifunktionaler Institutionen und Moralen (...) Der Verzicht auf Sicherheit durch Redundanz muss dann durch eine höhere Ëgendynamik und Sensibilität der Funktionssysteme ausgeglichen werden, zum Beispiel durch das, was die Metapher 'Markl' für die Wirtschaft oder die Metapher "Demokratie" für die Politik ausidrückt" (Luhmann 1986a: 13).

65 "Die Naturgeschichte klassifiziert statisch: das Reich der Pflanzen und Tiere kann mit den Ständen verglichen werden, da bei diesen zwar auch Zwischenstufen sich finden, ohne daß doch ein Uelbergang von einem Stand zum anderen angenommen werden könulte" (Lepenies 1976; 47).

66 "[W] meel juridiseh, maar in de praktijk en in de opvattingen. men worct in een bepaalde stand geboren, volgens de normen en behoeften daarvan grootgebracht, en blijt in beginsel zijn leven lang in die stand" (Van Tijn 1977: 132 133).

67 Status die tot uitdrukking komt in de welstand die getoond kon worden in onder andere kleding, wonìg. woningimichting, rijtuigen en paarden, huishoudeljk personeel en opleiding (Van Tijn 1977: $132)$. 
zijn minst natuurlijk was en ook zo zou blijven. In ieder geval vanaf 1800 valt er kritiek op de verstarring en stilstand van de standenorganisatie te bespeuren (Mathijssen 1987: 1), waarbij vooral de beslotenheid van de oude gildenstructuur, met haar monopolie over produktietechnieken, marktgebieden en beroepsuitoefening het moest ontgelden (Lenders 1988: 10; Spoormans 1988: 109).

De polemiek ${ }^{6.5}$ die rond 1975 over de sociale stratificatie van Nederland en de veranderingen daarvan rond 1850 is gevoerd, maakt duidelijk dat rond die tijd het standsbesef zijn voorstructurerende werking definitief verliest. Waar het in de polemiek om ging was ò en zo ja welke objectieve criteria zijn aan te voeren voor een standenindeling van de Nederlandse bevolking (Giele en Van Oenen 1976: 167). J. Lucassen en Th. van Tijn (1976a) hebben helder aangegeven dat in deze polemiek twee fundamenteel verschillende visies met elkaar concurreerden. Men kan er ofwel van uitgaan dat "een sociale geleding bestaat bij de gratie van het bewustzijn der betrokkenen, [en dan] zal men dienen te onderzoeken hoe de tijdgenoten-betrokkenen zelf de sociale structuur zien" (Lucassen en Van Tijn 1976a: 75) ); $^{6}$ òfwel men baseert een stratificatie bij voorbeeld op een marxistische klassentheorie en bepaalt de stratificatie aan de hand van de verhouding tot de arbeidskracht, "d.w.z. als klassen die, gezien de produktieverhoudingen, objectief bestaan, los van de vraag of ze door de betrokkenen al of niet als zodanig ervaren worden" (Lucassen en Van Tijn 1976a: 75). Wanneer men afziet van de specifiek marxistische invulling van deze tweede benaderingswijze dan klinkt daarin ook de opvatting door dat het vraagstuk van de veranderende sociale stratificatie rond 1850 niet meer primair benaderd kan worden als een geleidelijke verschuiving tussen en binnen statusgraepen, maar bestudeerd moet worden vanuit het inzicht dat de leidende betekenis van de statusgroep als zodanig voor de organisatie van maatschappelijke verhoudingen op zijn retour is (zie ook Van Tijn 1974 en Diederiks 1974). Omdat een ander organisatieprincipe - in een marxistisch perspectief klassentegenstellingen afgeleid uit de produktieverhoudingen - die rol overneemt ${ }^{30}$. Vanuit het hier gepresenteerde gezichts-

68 Zie Giele en Van Oenen (1974); Van Tijn (1974); Diederiks (1974); Giele en van Oenen (1975); Giele en Van Oenen (1976); Lucassen en Van Tijn (1976a en b).

69 Ook wanneer men deze weg bewandelt kan men tot verschillende resultaten komen. 1. Brugmans (1960) onderscheidde, afgaand op het standsbewustzijn slechts twee standen: de 'gegoede stand' - 15 tot 20 procent wan de bevolking - en het 'gewone volk'. Een afzonderlijke middenstand zou ontbreken terwijl wirkeliers en ambachtslieden in psychusch, cultureel, saciaal en economisch opzicht deel uit zouden maken van het volk. Sommige negentiende eeuwse waarnemers van sociale stratificatie komen tot een vierdeling: de grote burgerij (regenten, hoge staatsfunctionarissen, bankiers, âcademici), de kleine burgerij (winkeliers, zelfstandige ambachtslieden, onderwijzers), werklieden (in landbouw, ambachten en fabrieken) en arbeiders/paupers (waaronder tijdelijk of permanent bedeelden, bedeliaars) (Knippenberg en De Pater 1988: 32). W. Ultee (1983) behandelt uitstekend de problemen die stratificatieondlerzoek oproept.

70 "Degenen die de arbeidskracht bezitten vormen een klasse, nl. de arbeidsklasse, terwijl de kapita- 
punt ligt het 'moderne' van het klassebewustzijn in het feit dat klassen gekenmerkt worden door belangentegenstellingen ${ }^{71}$ die afgeleid worden uit een betrokkenheid op een specifiek proces, het arbeids- en produktiepro$\mathrm{ces}^{72}$. E. Thompson (1967) heeft laten zien hoe industrialisering een geleidelijke verschuiving van taak- naar tijdoriëntatie met zich meebrengt. Door het produktieproces centraal te stellen worden collectieve belangen zichtbaar die aangevallen of verdedigd moeten worden en waarbij de afloop van de confrontatie onzeker is. In het accepteren van die onzekerheid ligt een kwalitatief verschil tussen traditionele en moderne samenlevingen, tussen 'standen' en 'klassen', besloten".

De maatschappelijke transformatie die daarin tot uitdrukking komt, valt niet in termen van een emancipatie van een burgerlijke stand (Boogman 1978: 30; Mooy 1987b: 90) te beschrijven (Luhmann 1981a: 7). Evenmin als het negentiende-eeuwse liberalisme als een 'zuil' te midden van andere politieke en religieuze zuilen kan worden begrepen ${ }^{74}$. De opkomst van het liberalisme, dat Thorbecke nog beschouwde als synoniem voor 'constitutionalisme' (Poortinga

ten en de grondeigenaren een klasse vormen omdal zij zich de arbeidskracht (van anderen) toëige nen" (Giele en Van Oenen 1974: 12). "De door Giele en Van Oenen genoemde fundamentale klassekenmerken (...) leiden ons inziens vanzelfsprekend tot het theoretische onderscheid in drie sociale klassen, niet neer en niet minder, namelijk: 1. zij die andermans arbeidskracht exploitenen; zij die dat niet doen maar wier arbeidskracht ook niet door anderen geexploiteend wordt; 3 , zajj wier arbeidskracht door anderen (nl. de mensen van groep 1) geëxploiteerd wordt" (Lucassen en Van Tijn 1976a: 75-76). 71 Vergelijkbaar met M. Weber die klassen identificeerde met verschillen in rijkdom en cconomische macht, terwijl de indeling in standen op statusverschillen, op aanzien en prestige zouden berusten. "Klassenlage und Klasse bezeichnet an sich nur Tatbestande gleicher (oder áhnlicher) typischer" Interessenlagen, in denen der Einzelne sich ebenso wie zahlreiche andere befindet. (...) Ständische Lage soll heißen eine typisch wirksam in Anspruch genommene positive oder negative Priviligierung in der sozialen Schärung (Weber 1972: 177-180).

72 "In diesem Zusammenhang muB etwa die physiokratische "Tradition berücksichtigt werden, inher" halb derer die alten Stände erstmalig nach ökonomisch funktionalen Kritterien umdefiniert wurten (...). Die Verwendung won "Klasse' zeigt, daß hier ein soziales Modkll ins Spiel gebracht wird, das in die Zukunft weist, während der Begriff des Standes an eine jahrhundert alte Tradition ankrupft, an Strukturen wie sie in Landrectut gerade noch eirmal legalisilert worden sind" (Koselleck 1979" 111). Dat neemt uiteraard niet weg dat de begrippen "standen' en 'klassen' in het: dagelijkse taalgebruik door elkaar heen gebruikt worden en werden.

73. In 1869 manifesteert zich de 'modeme' arbeidersbeweging met aarvallende stakingen wan de van oudsher" gezagsgetrouwe, orangistische scheepstimmerlieden, de "bijlies", en van de typografen. "Waarschuwingen tegen de schone woorden en beloften van de Internationale vindt men bijna dagelijks in de krant en zijn op de hoek van de straat te horen: "Werklieden, geeft toch geen gehoor aan hen, die u gouden droomen voorspiegelen. De mensch is nu eermaal zoo, dat er steeds rijken en armen, bevelenden en gehoorzamen zullen zijn" (Jaspers 1980: 117-118).

74 "De kracht van het liberalisme ligt in de "vanzelfsprekende algemeenheid" ervan: het presenteert zich nu juist niet als een afgebakend blok met liberale opschriften. (...) De $19 \mathrm{e}$-eeuwse liberale hegemonie was niet zomar de machtspositie van een partijpolitiek blok als jeder ander. De dominante positie van het liberalisme was verankerd in bepaalde algemene structumelementen van het moderne kapitalisme en de moderne staat (...) Meer dan welke andere politieke stroming is het liberalisme de onganishe drager. van het project van de moderniteil geweest" (Stuuranan 1987; 267-269). 
1987: 68), en dat in de loop van de negentiende eeuw zou leiden tot een parlementair democratisch stelsel ${ }^{\text {ss }}$ valt op zichzelf te begrijpen als uitingsvorm van een herorganisatie van het politieke domein. Terwijl voorheen een hiërarchische standenindeling de mogelijkheden tot politieke inmenging vaststelde en beperkte, komt in het domein van de politiek geleidelijk de centrale idee naar voren dat politiek een besluitvormingsproces is, waarbij niemand ooit absolute zeggingskracht zal verkrijgen, en waarin het de moeite loont die onzekerheid te institutionaliseren.

Het kiesstelsel dat na de Franse tijd was ingevoerd en dat tot 1848 zou gelden, berustte in onderdelen op de situatie voor 1795, maar bevatte ook een aantal nieuwe elementen. De Eerste Kamer werd door de Koning benoemd; de 110 leden van de Tweede Kamer werden door de Provinciale Staten uit haar midden aangewezen. Op hun beurt werden de Provinciale Staten gekozen door de drie (politieke) standen: de edelen of ridderschappen, de landelijke stand en de steden. De getalsverhoudingen tussen de standen lagen daarbij vast en verschilden per provincie. Doordat het kiesstelsel meermaals getrapt was en met een census werkte, leek het nog het meest op een stelsel van coöptatie: "De Tweede Kamer, die bestond uit 58 'Edel Mogende Heeren', droeg nog in hoge mate het karakter van een deftige notabelen-sociëteit" (Boogman 1978: 28).

Pas in de jaren veertig krijgt in Nederland het doctrinaire liberalisme vorm (Poortinga 1987: 67-68). In 1844 verkondigt Thorbecke in zijn rede 'Over het hedendaagsche Staatsburgerschap' dat algemeen kiesrecht een principe is, dat logisch uit de historische $e^{76}$ ontwikkeling van de staat volgt. De staat is een gemeenschap van allen, en aan allen komen dus politieke rechten toe. Wegens. de geringe ontwikkeling en het geringe bezit van een deel van de bevolking is het echter te verkiezen dat algemeen kiesrecht stapsgewijs in te voeren (De Wit 1980b: 44; Kossmann 1984: 134). In 1848 wordt met Thorbecke's grond wet een principiële verandering aangebracht in de staatsinrichting ${ }^{7}$. Thorbecke's argumentatie voor democratie berust niet op een streven naar volkssoevereiniteit ('meerderheidsalmacht') maar vindt haar grondslag in de vestiging van het staatsburgerschap. "Omdat de Staat voorgesteld wordt als "Gesamtpersönlichkeit", als samengestelde persoon, en Thorbecke de Staat identificeert met het uichtbare volk, kunnen volgens hem de burgers als (organisch in de Staat

75 Spoormans 1988; De Wit 1978; Boogman; 1978; De Wit 1980a; Kossmann 1984.

76. Zhe voor Thorbecke's band mat de Historische school Poortinga (1987) en De Wit (1978: 77-112; $1980)$.

77 "[Z]oads Boogman $(1978 ; 61)$ stelt, een mijlpaal in de staatkundige geschiedenis van Nederland, omdat in dat jaar de latste resten varn de oude standenstaat worden opgeruind" (Spoormans 1988" 127). De macht wan de koning wordt ingeperk. De Tweede Kamer wordt in het vervolg direct gekozen, terwij] de Prowinciale Staten de Eerste Kamer kiezen. Bovendien wordt een districten-stelsel ingevoerd. 
gebonden) leden aan de Staat deel hebben en zodoende een bijdrage leveren aan de ontwikkeling van de Staat. Zij vertolken in deze hoedanigheid het algemeen belang, niet de individuele eigen belangen" (Poortinga 1987: 66). Bovendien houdt een censuskiesrecht het aantal kiesgerechtigden in eerste instantie beperkt tot een klein deel van de mannelijke bevolking. De geleidelijke uitbreiding van het kiesrecht (Knippenberg en De Pater 1988: 148-149; Spoormans 1988: 89) gaat hand in hand met het groeiende besef dat belangentegenstellingen een onvermijdelijk onderdeel van de politiek vormen en dat democratie een geschikte institutie is om die belangentegenstellingen te reguleren. In de jaren zestig verkondigen neo-liberalen de opvatting van het algemeen belang als een compromis van deelbelangen, gekoppeld aan een pluriforme maatschappijopvatting (Poortinga 1987: 143).

Unger (1976), Przeworski (1979) en Spoormans (1988) vatten democratie op als een specifieke vorm om conflicten tussen (belangen)groepen te hanteren en te beëindigen"s. In een democratisch politiek bestel wordt de maatschappij niet langer beschouwd vanuit het gezichtspunt van een geordend, gestratificeerd en liefst harmonieus en stabiel geheel waar weinigen de dienst uitmaken voor allen, maar wordt erkend dat belangentegenstellingen een onlosmakelijk onderdeel uitmaken van de politiek. Democratie behelst de erkenning van die onzekerheid van het politieke besluitvormingsproces en het institutionaliseren van de regels waarmee politieke conflicten afgehandeld dienen te worden: "The process of establishing a democracy is a process of institutionalizing uncertainty, of subjecting all interests to uncertainty. (...) Democracy means that all groups must subject their interests to uncertainty" (Przeworski 1979: 14). Een democratisch compromis kan geen blijvend compromis vormen; het zal steeds de vorm hebben van een overgaand, institutioneel compromis, onderwerp van verandering en onderhandeling tijdens de volgende verkiezingen. Kenmerkend voor het stelsel van parlementaire democratie is immers het herhaald terugkeren van verkiezingen. Vanuit dit gezichtspunt verschijnt de introductie van een democratisch politiek bestel als een manifestatie van een moderniseringsproces dat zich met de steekwoorden globalisering en temporalisering laat typeren. Deze studie wil nagaan in hoeverre een dergelijk perspectief op modernisering licht kan werpen op de veranderingen aan de Nederlandse universiteiten in de negentiende eeuw.

78. Uiteraard is dat éen van de vele opvattingen die ten anazien van democratie bestaan. Trouwens oak gedurende het democratiseringsproces zèlf veranderen de ideeèn daaromtrent: "Om te beginnen kan de vlag "democratie" meerdere en uiteenlopende ladingen dekken. Wanneer Van der Capellen in 1783 spreekt over 'democratie' dan staat hem iets anders voor ogen dan de voorstanders wan kiesrechtuitbreiding rond 1900 . (...) De scheidslijnen lopen niet alleen tussen voor- en tegenstanders van 'de democratie, want de voorstanders zijn onderling verdeeld over de vrag wat democratie eigenlijik betekent" (Spoormans 1988: 88). 


\section{II \\ De maatschappelijke organisatie van het hoger onderwijs}

\section{Inleiding}

Wie ooit te maken heeft gehad met een Ministerie van Onderwijs en Wetenschappen dat grossiert in planningscycli, visitatiecommissies en financieringsstelsels, moet het als een sprookje in de oren klinken. Twee eeuwen geleden is er van een centraal geleide organisatie van het onderwijs nog in het geheel geen sprake. Ten tijde van de Republiek der Verenigde Nederlanden (15791795) is de organisatie van het onderwijs een zaak van gewestelijke en stedelijke autonomie. Het beheer van de scholen ligt in handen van lokale instituties van kerk en magistraat en wordt geregeld door gewestelijke en plaatselijke schoolverordeningen die onderling niet hoeven te corresponderen (Boekholt en De Booy 1987: 294; Lenders: 1988: 35). Eerst met de Franse Revolutie wordt onderwijs een zaak van de staat (Dodde 1983). Voor ons land leidt dat in 1798 tot het instellen van een 'Agent voor Nationaale Opvoeding', waaronder begrepen is 'de Geneeskundige Staatsregeling, de vorming der Nationale Zeden, en de bevordering van het openbaar onderwijs, en van de Konsten en Wetenschappen'. Bij besluit van 12 januari 1807 trekt Koning Lodewijk Napoleon het opperbestuur van alle Nederlandse universiteiten aan zich. De Napoleontische heerschappij drijft vervolgens - in ieder geval wat het hoger onderwijs betreft - de centralisatie op de spits. Het rapport van F. Noël en G. Cuvier ${ }^{1}$ vormt de aanleiding om bij keizerlijk decreet van 22 october 1811 het hele onderwijs te organiseren naar Frans model (Van Berkel 1886; Duyvendijk 1955: 16). De hogescholen van Leiden en Groningen worden ingelijfd bij de keizerlijke universiteit te Parijs; de hogescholen van Franeker en Harderwijk opgeheven terwijl de hogeschool van Utrecht en het Athenaeum ${ }^{2}$ van Amsterdam degraderen tot écoles sécondaires - iets dat voor de de praktijk van het onderwijs overi-

1 Rapport sur les établissements dinstruction publique en Hollande, et sur les moyens de les réunir ¿ l'université imperial, fait en exécution de larticle 50 du décret imperrial du 18 Octobre 1810.

2 Athenea fungeerden als universiteiten van de tweede mang, die de eerste jaren van de universiteitsstudie overnmen. Ze bezaten geen academische examenbevoegdheid en geen promotierecht. Studenten in de theologie en de geneeskunde moesten na een atheneum doorlopen te hebben nog twee, de overige studenten nog eén jaar op een universiteit doorbreryen. 
gens geen noemenswaardige consequenties met zich meebracht (Roelevink 1986: 67).

De Franse overheersing brengt echter niet alleen een centralisatie van de organisatie van het onderwijs teweeg. Bij de Fransen leven ook andere ideeën over onderwijs. Zo kende de Republiek alleen het onderscheid tussen hoge en lage scholen. De jaren van Frans bestuur introduceren een driedeling in de organisatie van het onderwijs. De discussie over de aard van het middelbaar onderwijs die vervolgens ontstaat leert dat achter deze ogenschijnlijk simpele ordeningskwestie een wereld van verschil schuilt. Ook op andere fronten, zoals de wenselijkheid of onwenselijkheid van een voorgeschreven studievolgorde, wordt in negentiende eeuwse onderwijsdebatten de Franse aanpak dikwijls met de vroeger bestaande of de Duitse geconfronteerd. Het is echter niet de bedoeling om de Franse wijze van organiseren van het onderwijs systematisch met de Duitse te vergelijken. In dit hoofdstuk wordlen de discussies over de organisatie en inrichting van het Nederlandse onderwijs - waar de confrontatie van het Franse met het Duitse onderwijsbestel één element van vormt - geplaatst tegen de achtergrond van een kwalitatieve verandering in de maatschappelijke orde als zodanig, zoals die in het voorafgaande hoofdstuk aan de orde is gesteld.

In de centralisatie van de organisatie van het onderwijsbestel die de Fransen introduceren en die nadien zal worden gehandhaafd, valt het aspect van globalisering te herkennen. Ingrijpender echter dan deze centralisatie is de omwenteling die in de loop van de negentiende eeuw plaatsvindt van een primair standsgewijze - of in de terminologie van Ringer gesegmenteerde ${ }^{3}$ - organisatie van het onderwijs naar een onderwijsorganisatie die het individuele leerproces tot uitgangspunt neemt ${ }^{4}$ (Boekholt en De Booy 1987: 93-94). In dit hoofdstuk worden vooral de gevolgen die deze verandering voor de organisatie van het hoger onderwijs met zich meebrengt belicht. Het lager en het middelbaar onderwijs worden beschreven in zoverre de (effecten van de) invoering van de driedeling tussen lager, middelbaar en hoger onderwijs bijdragen aan een beter begrip van de ontwikkelingen in het hoger onderwijs. De verdere indeling van dit hoofdstuk volgt daarmee het hedendaagse onderscheid tus-

3 Ringer (1979; 1982) onderscheidt drie (externe) criteria om onderwijsstelsels te beschrijven: Indusie, het relatieve antal opgeleiden per onderwijstype per leeftjidscategorie, progressie, het relatieve aantal hoger opgeleiden dat wordt gerecruteerd uit de lagere en de lage midden klasse, en segmentatie, de malte watrin parallelle opleidingen onderscheiden worden op basis van sociale herkomst (vertika al) of vakkenpakket (horizontaal). Horizontale en verticale segmentatie treden meestal in conjunctie op (Ringer 1987: $7)$

4 "Het zoude niet moeijelijk zijn, het onderwijs voor iederen stand in de matschappij op de doelmatigste wijze in te rigten, wanneer men voor iederen stand een afzonderlijke school daarstelde, geheel naar zijne behoefte ingerigt, mar war zoude dit heen? Zoo veel verschillende standen, 200 weel verschillende scholen!" (Houck 1840: 27). 
sen lager, middelbaar en hoger onderwijs. Zoals hierboven is aangeduid staat in de negentiende eeuw echter juist dat indelingscriterium ter discussie. Dat thema zal daarom in de drie paragrafen, achtereenvolgens gewijd aan het lager, middelbaar en hoger onderwijs, telkens weer terugkeren. Maar de transformatie die in de organisatie van het onderwijs plaatsvindt, treft ook de inhoud en methode van het onderwijs. Die aspecten komen eveneens aan bod.

\section{Lager Onderwijs}

Het is verwarrend en enigzins misleidend om in de achttiende eeuw in algemene zin over lager onderwijs te spreken. Het suggereer: een eenheid die schijn is. De scholen waarop de kwalificatie lager onderwijs van toepassing zou kunnen zijn, verschilden onderling nogal: dorpsscholen, stadsscholen, armenscholen, semi-particuliere en particuliere scholen. Voorts gingen zelfs achter deze verzamelnamen sterk uiteenlopende leerprogramma's schuil (Lenders 1988: 35). Zoals gezegd bestond tot in de laatste dagen van de Republiek geen andere indeling van scholen dan die in hoge en lage. De verzamelnaam 'lager' suggereerde allerminst een eenheid van (kennis)niveau, die in het hedendaags gebruik van het woord 'lager' in de context van onderwijs wel te vinden is. 'Lage' scholen vormde de verzamelnaam voor een groot aantal uiteenlopende onderwijstypen, voor wier onderlinge onderscheiding drie categorieën van belang waren: sekse, religie en maatschappelijke status (Frijhoff 1983b: 10). De armsten gingen naar een armenschool of vaak in het geheel niet naar school (Mathijssen 1987: 7; Lenders 1988: 43). De particuliere scholen, gedreven door onderwijzers en gefinancierd uit de opbrengst van de schoolgelden, waren bedoeld voor de betere (burger)standen. Het waren veelal eenmansscholen waar leerlingen van alle niveaus en leeftijden door elkaar in één, vaak slecht geoutilleerd, lokaal zaten, stonden en liepen (Boekholt en De Booy 1987; 28-29). Kinderen van nog beter gestelden kregen huisonderwijs van een gouverneur of gouvernante of bezochten een goede kostschool. Omdat de ouders zichzelf beschouwden als, zoniet per definitie de beste, dan toch de eerstaangewezen opvoeders, bestond de neiging om zowel opvoeding als onderwijs binnenshuis te houden'.

De Wet op het Lager Onderwijs van 1806 sloot aan op de situatie in de Re-

5 Een warm pleitbezorger van dergelijke denkbeeden was de Haags-Utrechtse gedeputeerde W.E. de Perponcher. De strekking van diens 'Instructions d'un père à san fils' (1774) is dat apvoeding in het ouderlijk huis de regel moet zijn en de school slechts bij uitzondering die taak over mag nemen. Immers opvoeding door de ouders zelf, mits deze zich van hun taak bewust zijn, geeft de beste waatborgen voor het morele peil van de kinderen (Frijhoff 1983b: 13). 
publiek. Ze maakte een onderscheid tussen bijzondere, door particulieren of liefdadige instellingen onderhouden, en openbare, geheel of gedeeltelijk van overheidswege gefinancierde, scholen (De Groot 1898: 123; Boekholt en De Booy 1987: 99-100). De bijzondere scholen werden wederom in twee klassen onderscheiden. Scholen van de tweede klasse waren voor de hogere standen bedoeld. Deze werden geacht gefinancierd te worden uit schoolgelden op te brengen door de ouders van de leerlingen. Scholen van de eerste klasse daarentegen werden onderhouden door particuliere instellingen zoals de Maatschappij tot Nut van 't Algemeen ${ }^{6}$ en waren bestemd voor de volksklasse. Leden van de Maatschappij tot Nut van't Algemeen hadden sedert de oprichting daarvan in 1784 in allerlei toonaarden verkondigd dat alle mensen, ongeacht hun stand of geloofsbelijdenis, door onderricht hun plichten moesten leren kennen en dat daarom nationaal openbaar onderwijs een eerste vereiste voor een christelijke maatschappij was?. Doelstelling was volksverheffing, het bijbrengen van christelijke en maatschappelijke deugden en het tegengaan van pauperisme $^{B}$ (Kruithof 1990: 61). Al was het openbaar onderwijs bedoeld voor alle standen in de maatschappij, dat wil niet zeggen dat het bevorderen van de sociale mobiliteit tot de doelstellingen behoorde (Noordman 1981: 525-526). In 1791 had een lid van het Nut zelf zich al bezorgd afgevraagd of er niet "voor het geheel, of voor eenige gedeelten der burgerlijke Maatschappij eenige nadeelen te vreezen [waren], uit de poogingen om het verstand en den smaak van de laagere rangen der Burgers, vooral ook in de jeugd, te beschaaven en te verbeteren?" (in Van der Ploeg \& Zinkstok 1986: 35). Het 'Verslag van den staat der Hooge, Middelbare en Lagere Scholen in den jare $1817^{\prime}$ meldt dat in het lager onderwijs alle gelegenheden te baat genomen worden "om bij hen te ontwikkelen tevredenheid met hunnen stand" (Algemeene Konst en Letterbode 1818: 377 ). In 1839 zou het Nut nog een prijsvraag uitschrijven waarin werd gevraagd de juistheid te onderzoeken, van het door sommigen tegen de Nutsscholen ingebrachte bezwaar, dat ze het onderwijs "bij de kinderen van den burgerstand te hoog [opvoeren] (...), zoodat het schijnt, alsof men, door al te

6 Zie over het Nut Mijnhardt en Wichers (red.) (1984) en Gedenkboek (1934).

7 Zie onder andere Schama (1970: 601): "This was perhape the most distinctive feature of educational reform in the Netherlands: the conjunction of moral evangelism with organizational efficiency." "Dasrom moet Onderwijs voor jedereen open zijn. De Maatschappili is verpligt om die middelen daar te stellen waardoor het opkomend geslagt de pligten en kundigheden kan werkrilgen, welke de Maatschappij wan hen zal vorderen: zij ligt derhalve onder de onwermijdelijke verpligting, om te zorgen voor de Opvoeding en Onderwijs der jeugd", schreef ến van de leden wan het Nut in een ontwerp van een plan voor openbaar nationaal onderwijs in 1796, geciteerd in Van der Ploeg \& Zinkstok (1986: 34).

8 "De tijd na 1770 wordt wel aangeduid als het "Zeitalter des Pauperismus". Deze aanduiding is toepasselijk voor een deel van Europa, maar het zou zeker te ver gaan te beweren, dat in Nederland als geheel grote delen van de bevolking in een extreme noodsituatie verkeerden. (....) Echte armoede kwam in deze tijd dus vooral in de steden voor" (Boekholt en De Booy 1987: 90). 
groote verlichting, of het aanbrengen van al te uitgebreide of min zakelijke kundigheden, hun den lust beneemt, om in den stand hunner ouders te blijven" (in Duyvendijk 1955: 249). Een van de vragen, waarop in verband met deze kwestie tevens een antwoord wordt verlangd, luidt: "En hoe prent men voorts den jongen lieden van beiderlei geslacht het gelukkige van den nederigen middelstand in (...)?" (in Duyvendijk 1955: 249)". Overwegend was men van mening dat onderwijs in overeenstemming moest zijn met de stand van de leerling (Boekholt en De Booy 1987: 94-95; 109). Vooral van het heemkundig onderwijs verwachtte men veel om de standenmobiliteit tegen te gaan.

Toch valt er, in ieder geval sinds 1800 , ook kritiek op de verstarring en stilstand van de standenorganisatie te bespeuren ${ }^{10}$. In de jaren veertig en vijftig gaan steeds meer stemmen op om het lager onderwijs in te zetten als middel tot verticale sociale mobiliteit (Dasberg en Jansing 1977:218). Onderwijshervormers bepleiten dan een nieuwe lagere school om zowel de bestaande lessituatie - of eigenlijk het ontbreken daarvan ${ }^{11}$ - als de op een standenindeling gebaseerde organisatie te doorbreken ${ }^{12}$. Het leerproces dient het uitgangspunt van het lager onderwijs te vormen. "Onder de omstandigheden van hoofdelijk onderwijs werd 'geene geregelde orde, noch een geregeld plan van onderwijs' mogelijk geacht. (...) volgens de kritiek [kon daar] geen sprake (...) zijn van een doelgerichte ontwikkeling van leerprocessen" (Lenders 1988: 80). De hoofdelijke leerwijze kende geen stilte als gevolg van strikte en gezamenlijke concentratie op de leerstof. Tegenover de wanorde, de verbrokkeling en het lawaai van de oude school plaatsen de hervormers het concept van de welingerichte school: een ordelijke en stille school die functioneerde volgens een weloverwogen leerplan en waar aan leerlingen van ongeveer dezelfde leeftijd en hetzelfde niveau les wordt gegeven (Lenders 1988: 80-81). Dat deze hervormingen een verandering van de selectieprocedures met zich meebrengen, wordt onder-

9 Ben wam de inzendingen was Howck (1840) (Buddingh 1842: 110).

10 "Het hièrarchisch denken iss voor het eerst in die tijd massaal doorbroken" (Mathjussen 1987: 1).

11 "Van deze openbare scholen heb iker gekend (en niet slechts in mijne jeugd, maar nog lang daama) die, in den spiegel van onzen tijd gezien, eene schrille tegenstelling vormen met de zorg der overheid in onze dagen. Bạna alle van die scholen bestonden uit éen lokaal en bevatten tot 200, 300 kinderen en soms nog weel meer (...) Dat het onderwijs op zulke scholen niet veel kon beduiden, al bestond het alleen miat in lezen, schrijven en rekenen, is licht te begrijpen" (De Groot 1898: 120-121).

12 In zijn pleidooi voor een uibreiding wan het lager onderwijs en een verhoging van het aanzien van het onderwijs voor de lagere standen poogt A.J. Houck (1840: 18) aan te tonen dat daarmee het standsbesei als zodanig niet ondergraven wordt: "[D]at men door eenen stand in aanzien te verhoogen, niet moet verstaan, ctat men het anzien van alle standen in de maatschappij gelijk moet maken, noch ook, dat in denzelfden stand alle opklimmende graden een gelijk aanzien behooren te genieten; maar het is noodig, dat iecler, in welken stand hij ook geplaatst zij, door in graden op te klimmen, tevens in het oog zijner medeburgers in aanzien wint, en dat er in iederen stand in de maatschappij ten minste Gén graad zij, welke zooveel aanzien geniel, dat de hoop om tot dien een maal te kumnen opklimmen, in stat is om de keus van een aantall jongelieden op dien stand te vestigen." 
kend: een rechtvaardige selectie dient plaats te vinden op basis van talent en prestatie. De invoering van het gelijktijdig of klassikaal onderwijs zou een gelijke behandeling van de leerlingen en daarmee een rechtvaardige selectie garanderen. Verdeel de leerlingen in groepen, zo luidt het advies, en behandel de leerstof per groep. De leerlingen worden in dat geval gelijktijdig aangesproken en ontvangen in principe een gelijke behandeling. Om de lessen te kunnen. volgen zullen de leerlingen stil moeten zijn. Door de groepen samen te stellen naar het niveau van de leerlingen - in overeenstemming met hun ontwikkelingsfase - zou er bovendien een ontwikkelingsperspectief worden geboden in de richting van een vastgesteld leerdoel als eindniveau (Lenders 1988: 80-81). Het gelijktijdig of klassikaal onderwijs was geen uitvinding van de negentiende eeuw. In de grotere Latijnse Scholen werd het al langer toegepast (Boekholt en De Booy 1987: 79) ${ }^{13}$. Maar de invoering ervan in het lager onderwijs was nieuw en werd ervaren als een radicale verandering ${ }^{14}$.

De wet van 1806 bleef tot 1 januari 1858 gehandhaafd. De situatie aan de lagere scholen is dan inmiddels zowel wat de inrichting van de scholen als de onderwijsmethodes betreft fors aan het veranderen (Boekholt en De Booy 1987) ${ }^{15}$. Dat komt ook tot uiting in de zich wijzigende definities die in de loop der tijd aan het lager onderwijs gegeven worden. In de 'Handleiding Staatsbestuur' uit 1865 omschrijft J. de Bosch Kemper het lager onderwijs niet langer uitsluitend als eindonderwijs voor de laagste standen, het is expressis verbis ook de eerste fase van het leerproces van iedereen: "het lager onderwijs omvat niet alleen de cerste opleiding tot het middelbaar en hooger onderwijs, maar ook het geheele maatschappelijke onderwijs van die talrijke klasse van ingezetenen, die van het middelbaar en hooger onderwijs geen gebruik maken" (De Bosch Kemper 1865: 911).

Verdere aampassingen en wijzigingen van zowel bestuurlijke als pedagogische aard leidden uiteindelijk in 1878 tot een nieuwe wet op het lager onderwijs, die op 1 November 1880 in werking trad. Naast het verder doorvoeren van het prestatiebeginsel en het centraal stellen van het leerproces was de

13 Althans in de grotere stedlen. In 1831 schetst $T$. Fliedner (1831: 169-170) nog het volgende beeld: "In kleineren Städten haben die lateinische Schulen nur einen Lehrer, Rector genannt, in grö́sseren vier, einen Rector, einen Conrector, und 2 Praeceptores."

14 "Het prestatiebeginsel moest dan oak voortdurend verdedigd worden tegenover behoudende delen der natie, die in de nieuwe school wel degelijk het gevaar van ongecontrolleerde standsverheffing bespeurclen" (Lenders 1988: 55).

15 Uiteraard worden ook hier veranderingen uiterst geleidelijk geintroduceerd: "Voor" een goed deel was en bleef het onderwijs hoofdelijk, in weerwil van thet desbetreffende voorschrift in de Algemeene Schoolorde van 1821, dat de school moest verdeeld worden in drie klassen, die ieder binnen elken schooltujd onderwijs moesten ontwangen" (De Groot 1898: 121). Het moment var verandering was meestal de komst van een nieuwe, geèxamineerde leerkracht (Boekholt en De Booy 1987: 106). Eerst met de schoolwet van 1806 waren onderwijzersaktes ingevoerd. 
maatschappelijke inrichting van het lager onderwijs in de negentiende eeuw vooral het strijdtoneel van verschillende godsdienstige overtuigingen. De discussie over het lager onderwijs wordt gekleurd door de schoolstrijd, waarin door uiteenlopende religieuze groeperingen om godsdienstvrijheid, dit is het recht geen onderwijs te hoeven ontvangen in inrichtingen waar iets geleerd wordt strijdig met de eigen geloofsovertuiging (De Bosch Kemper 1865: 911; Boekholt en De Booy 1987: 132-145; Kruithof 1990), wordt gevochten. Dat aspect blijft geheel buiten deze studie.

\section{Middelbaar Onderwijs}

Valt het al moeilijk om in het tijdvak van de Republiek in globale zin over lager onderwijs te spreken, wat het middelbaar onderwijs betreft is dat onmogelijk. Tot in de laatste dagen van de Republiek bestond geen andere indeling van scholen dan die in hoge en lage. Het rapport ${ }^{17}$ van de door Koning Lodewijk Napoleon in 1808 ingestelde Commissie (Van Swinden c.s.) maakt voor het eerst een onderscheid in drieën: te weten "het lager of eerste onderwijs, het middelbaar of tweede onderwijs, het eindelijk onderwijs; die te zamen het volledig stelsel van openbaar onderwijs uitmaken" (in Bolkestein 1914: 56). Met dat tweede openbaar onderwijs wilde de Commissie voorzien in een onderwijs "geschikt ter verkrijging van kundigheden van een hoger aard, die wezenlijk naauw verbonden zijn met het geen men een goede opvoeding noemt, en die voor hen, welken boven de laagste kringen der maatschappij verheven zijn, volstrekt noodzakelijk zijn, en wel te meer onmisbaar, naarmate zij zich in eenen hogeren rang bevinden, tot eenen verhevener stand geraken, of ruimere middelen van bestaan hebben" (Rapport van de Commissie van Swinden c.s., geciteerd in Bolkestein 1914: 57). Een revolutionaire breuk met het verleden in dit plan is de intentie de scholen voor het tweede of middelbaar onderwijs te bestemmen voor "alle standen van burgers". Alleen de laagste stand in de stad en de boerenbevolking op het platteland konden het ontberen (Bolkestein 1914: 58; Van Wieringen 1975: 6; Boekholt en De Booy 1987: 122). Anders dan voorheen wordt het onderwijs niet langer ingedeeld op basis van eindonderwijs voor de diverse standen, maar op grond van niveau en leeftijdsonder-

16 In de grondwet wan 1848 was opgenomen: "L'instruction publique est organisée par la loi, de manière A ne blesser les comwictions religieuses de personne" (Steyn Parwe 1878: 18), Vertaling van Steyn Parvế. 17 "Vertoog over de Universiteiten, met betrekking tot het stelsel van openbaar onderwijs, en tot alle de inrigtingen die tot hetzelve, middellijk of onmiddellijk behooren; aangeboden aar. Zijne Majesteit den Koning van Folland, doon eene daartoe opzettelijk benoemde Commissie", op 22 April 1809 aan Koning Lodewijk aangeboden door de daartoe benoende Comissie bestaande uit de de Heeren wan Swinden, Valckenaer, Bennet, Van Beeck Calkoen. 
scheid.

Niet alleen op organisatorisch gebied, ook inhoudelijk drong de Commissie van Swinden op drastische veranderingen aan. Het rapport vroeg meer aandacht voor Frans, Engels en Duits in het onderwijs op de middelbare scholen. De vrijwel uitsluitende aandacht voor de klassieken op de Latijnse Scholen - die tijdens de Republiek tot het hoger onderwijs gerekend werden werd veroordeeld ${ }^{18}$. De Commissie wees er op, dat de inrichting van de Latijnse Scholen berustte op een traditie: die van de Renaissance met haar afgesloten klasse van geleerden, wier kenmerk de beheersing van de oude talen was (in Duyvendijk 1955: 16). "[H]et geen men in de latijnsche scholen leert, de woorden, de spreekmanieren, de declinatiën, de conjugatiën, de regels der grammatica, alles in eén woord dient slechts om het geheugen te oefenen: niets dat strekke tot ontwikkeling van het vermogen, om juist te redeneren, of om zich de gelukkige gewoonte eigen te maken, om ongevoelig de eene waarheid met de andere, de gevolgen met de grondbeginselen te verbinden, niets dat den geest oefene in eenig beredeneerd onderzoek." Ook voor het onderwijs in het Latijn zelf werd een andere methode gesuggereerd ${ }^{19}$. Maar het Vertoog van de Commissie van Swinden, zo schreef A. van den Ende in 1846, "had geen ander gevolg, dan dat wegens hetzelve, in December van gezegd jaar, door de eerste Sectie van den Staatsraad een rapport werd uitgebragt" (Van den Ende 1846: 16).

Tijdens de inlijving van Nederland bij Frankrijk werd in officiële stukken de indeling en benaming van de scholen zoals die door de Commissie van Swinden was voorgesteld, namelijk in primaires, secondaires en definitives gevolgd (Bolkestein 1914: 90): "de primaire voor elk en een iegelijk; de secondaire ter voorbereiding tot het hoogste onderwijs, in welk vak dan ook; en dit hoogste of eindelijk onderwijs in de daarom alzoo genoemde, definitive scholen" (Van den Ende 1846: 16). Na de inlijving bleef de driedeling in officiële stukken behouden, en "zoo ging èn de drieledige indeeling èn de Fransche benaming van eerste, tweede en eindelijke, of Lage, Middelbare en Hooge scholen, in de

18 Er wordt onder andere een witbreiding van de leervakken aan de Latijnse scholen met wis-en naturikunde bepleit. De Commissie Vat Swinden volgde damrmee het rapport wan de keizerlijke Rapporteurs G. Cuvier en F. Noel, dat de directe aanleiding had gevornd voor hel instellen van de Com. missie. Het oordeel van Cuvier en Noel over de toestand van hel Nederlandse onderwijs was vernietigend. Wat de Latingse Scholen betreft zagen zij alls enige positieve uitzondering de Latijnse School van Haarlem waar niet uitsluitend de klassieken maar ook moderne talen en wiskunde werder gedoceerd. 19 "De jonge liedien moesten niet meer volgens den vervelenden en omslagtigen weg die tot hier toe gebruikelijk is geweest, in het grammaticale onderwezen worden, maar steeds moest het gramumaticale van begin af aan met het lezen van stukken uit de beste oude schrijveren worden verbonden, zoo dat deze stukken niet alleen, wat den zin en de constructie der woorden, maar ook wat den zakelijken inhoud, en den geest des schrijvers betreft, begrepen worden" (Rapport Commissie van Swinden, in Bolkestein 1914: 62-63). 
grondwet van [29 Maart] 1814 over" $^{\prime \prime}$ (Van den Ende 1846: 16) ${ }^{20}$.

Bij besluit van 18 januari 1814 benoemde de Souvereine vorst, Koning Willem I, een Commissie ${ }^{21}$ tot het ontwerpen van een organisatie van het hoger onderwijs. Daarbij diende deze Commissie in het oog te houden "eensdeels wat de geest van den Nederlandschen landaard en deszelfs gehechtheid aan alle oude instellingen vorderen, maar ook ten anderen, welk voordeel in de gedeeltelijke navolging der maatregelen van lateren tijd zoude gelegen zijn" (Bijvoegsel bij het Staatsblad 1813-1814 I: 58, in Huizinga 1951b; 49). De Commissie Kemper ging in haar rapport uitvoerig in op de verdeling tussen het lager, middelbaar en hoger onderwijs en met name op de relatie van de Latijnse Scholen tot het middelbaar onderwijs. De Latijnse Scholen kunnen ofwel tot het middelbare ofwel tot het hogere onderwijs gerekend worden en de Commissie Kemper erkent dat voor beide standpunten argumenten aan te voeren zijn. Maar"daar in allen gevalle algemeene beschaafdheid ook zonder kennen der Latijnsche taal verkrijgbaar was, maar geen grondige geleerdheid zonder grondige kennis der oude talen, en de vermenging van ongelijksoortig onderwijs altijd tot verwaarloozing van het een of het ander met zich voert" kiest de Commissie Kemper om de Latijnse scholen weer, in navolging van de situatie tijdens de Republiek, "als de 'eerste" trap van het hoger onderwijs aan te merken". Naar het oordeel van de Commissie moet het lager en het middelbaar onderwijs dat van de Latijnse Scholen weliswaar voorafgaan, maar dat laatste mag in ieder geval niet met het middelbaar onderwijs gemengd worden. Daarvoor verschillen de geleerde talen te veel in karakter van de moderne (Rapport van de Commissie Kemper 1814, in Bolkestein 1914: 98-99). De Raad van State schaarde zich vrijwel geheel achter het advies van de Commissie Kemper. De aard van het te volgen onderwijs moet worden afgeleid van de bestemming die aan de student aan de aanvang van zijn studies wordt toegekend. Het Organiek Besluit van 2 Aug 1815 nam vervolgens de indeling van de Commissie Kemper over: "Onder den naam van hooger onderwijs wordt verstaan zoodanig onderwijs, als ten doel heeft den leerling, na afloop van het lager en middelbaar onderwijs, tot eenen geleerden stand in de maatschappij voor te bereiden (A.rt. 1). (...) De Latijnsche scholen moeten beschouwd worden als de eerste trap van het hooger onderwijs, en als

20 Art. 140 van de Grondwet van 29 maxt 1814 vermeldde: "Ter bevordening van Godsdienst, als een vaste steun van den stat en ter uitbreiding van kernis is het openbaar onderwijs op de hooge, middelbare en lage scholen een aanhoudend voorwerp van zorg der Regering. De Souvereine vorst doet van den stat dier scholen jaarlijks aan de Staten-Generaal een uitvoerig verslag" (Bolkestein 1914: 97). 21 De Commissie stond onter voorzitterschap van A.F.J.A. Van der Duyn van Maasdarn, met als overige leden J.M. Kemper, F. W. Boers, D.J. van Lennep, M. van Marum, H. Tollius, H. Collot d'Escury van Feinenoord. Secretaris was J.L.W. de Geer, en tijdelijke leder J.F.W. van Spaen var Biljoen, A.G. Camper, en H. Muntinghe (Groen 1985c: 1547). 
inzonderheid bestemd voor diegene, welke, na aanvankelijk door het lager en middelbaar onderwijs te zijn beschaafd geworden, nu verder tot eenen of anderen geleerden stand in de maatschappij zullen worden opgeleid" (Art. 4).

Het hoofddoel van de Latijnse Scholen bleef "het onderwijs, in de Taalen van die twee beroemde Volken der Oudheid, de Grieken en de Romeinen, wier schriften de egte bronnen en grondslagen der waare geleerdheid zijn, en ook de beste hulpmiddelen bevatten, ter vorming van den geest, ter ontwikkeling van deszelfs denkingskragt en ter regeling en beschaaving van den smaak" (De Perponcher 1816:6). Het Organiek Besluit behelsde voor een groot gedeelte een terugkeer naar de oude orde van voor de Franse overheersing (Krul 1985: 38). Wel werd het lesrooster van de Latijnse Scholen uitgebreid met "bijvakken", die "zoveel mogelijk" gegeven moesten worden, echter "pas na afloop van het dagelijks onderwijs in de oude talen" (Boekholt en De Booy 1987: 125). Onder die bijvakken hoorden de beginselen der wiskunde, de nieuwe en oude aardrijkskunde, de nieuwe en oude geschiedenis en de Griekse en Latijnse fabelkunde $^{22}$; onderwijs in de moderne talen en in de meeste exacte vakken bleef ontbreken (Organiek Besluit 1815: art. 10). Ten aanzien van de docenten op de Latijnse Scholen werden in het Organiek Besluit een aantal eisen geformuleerd; alle docenten moesten over een kandidaatschap in de letteren beschikken, in de grotere steden was voor de rector een promotie verplicht en in de allergrootste steden werd die eis ook aan de conrector gesteld (Fliedner 1831: 169179). Maar ook dit sloot aan bij de reeds in de achttiende eeuw bestaande gewoonte van schoolbesturen om van aanstaande leraren enige academische vorming te eisen (Roelevink 1986: 21-23; Wingelaar 1989:5). Bovendien bevatte het Organiek Besluit meer richtlijnen dan strakke voorschriften. De inrichting van de Latijnse School werd grotendeels aan de stadsbesturen overgelaten, die van de voorschriften konden afwijken dan wel dispensatie vragen (Boekholt en De Booy 1987: 124). Door de Latijnse Scholen tot het hoger onderwijs te rekenen herstelde het Organiek Besluit de situatie van voor de Franse overheersing weer in ere. Aan de andere kant schafte het Organiek Besluit de door de Fransen ingestelde driedeling niet af. Het gevolg van het Organiek Besluit was dat er, afgezien van een wettelijke omschrijving, feitelijk geen middelbaar onderwijs meer bestond (Van Wieringen 1975: 7) ${ }^{23}$. Een uitzondering vormden de Franse scholen waaraan vooral de hogere burgers hun kinderen toevertrouwden, maar die formeel gezien ook tot het lager onderwijs behoorden.

22 "[D]e fabelkunde, die wel enkel verdichte en hersenschimmige voorwerpen behandelt; maar log, tot verstand der oude schriften en oirkonden, volstrekt noodzakelijk is" (De Perponcher 1816: 5).

23 "De opsteller wan het ontwerp dat ons bezig houdt, moge in art. 95 verzekeren: "Bestaande voorschriften betreffende middelbaar onderwijs vervallen"; aangezien er niets bestaat, kan ook niets vervallen" (Van der Heim 1862: 2). 
Het 'middelbaar onderwijs' was daarmee niet uit het zicht verdwenen. In de eerste helft van de 19de eeuw was het zelfs herhaaldelijk onderwerp van gesprek. Maar het ging dan vooral om het karakter en de status van dat middelbaar onderwijs, of om de verhouding tussen de Latijnse Schoolit en dat middelbaar onderwijs. Van den Ende verklaarde in 1817 het hele begrip middelbaar onderwijs als gevolg van de wettelijke bepalingen tot "non-sens". (Idenburg 1960: 201; Van den Ende 1846: 74 en Bolkestein 1914: 107). De verhouding tussen het gymnasium en de hogeschool en de verhouding tussen het gymnasium en het middelbare onderwijs vormde een van de belangrijkste aandachtspunten voor de Commissie voor het hoger onderwijs van $1828^{25}$.

De meerderheid in die Commissie was van mening dat de Gymnasia speciale scholen behoorden te blijven voor hen die zich voorbereidden op de academische lessen. Zij waren met name ervoor beducht dat de klassieke talen in het gedrang zouden komen. Uitbreiding van het vakkenpakket was niet aan de orde. Een vermenging van leerlingen die zich op een geleerde stand voorbereidden met anderen die dat niet deden, werd afgewezen ${ }^{26}$ : "Beider bestemming acht zij te zeer uiteenloopende, dan dat men, de zaak uit paedagogische beginselen beschouwende, zich zou kunnen voorstellen, dat dezelfde opleiding voor beiden geschikt zoude zijn. De meeste onderwerpen van onderwijs zullen, naar deze meening, voor die verschillende kweekelingen geheel onderscheiden zijn. Die, welke zij met elkander gemeen hebben, behooren grootendeels voor de eene en andere soort van kweekelingen op eene verschillende wijze te worden onderwezen." Voor leerlingen aan de Gymnasia moest de aardrijkskunde in verband worden gebracht met de klassieke schrijvers; voor de leerlingen der middelbare school zou de aardrijkskunde vooral nuttig zijn, "wanneer zij de natuurlijke gesteldheid der landen, derzelver voortbrengselen, enz. doet kennen." Voor de behandeling van de geschiedenis en de wiskunde werden gelijksoortige verschillen aangewezen (Rapport van de Commissie van 1828, in Bolkestein 1914: 115-118). De Aka-

24 De Latijnste Seholen op zich waren voor de landelijke overheid aen voortdurende bron van zorg. onder andere door de grote verschillen in kwaliteit (Boekholt en De Booy 1987: 125). Al wrordt un de loop wan de nugentiende eenw het oordeel over de Latijnse Scholen geleidelijk aan gunstiger (Rector 1834: 133; Terpsttra 1838; Van Duyvendijk 1955: 238).

25 Irgesteld bij K.B. van 13 April 1828, leden: Roell, voorzitter, J Ackersdijck, C. de Brouckère, O. le Cler, H. Collot d'Escury van Heinenoord, Van Wickevaort Crommelin, Donker Curtius van Tienhoven, Dotrenge .L.L.W. de Geer, K.B. van Keverberg, van Pabst tot Bingerden, A. Quetelet, J.F.L. Schröder, A.G.A van Rappard, secretaris. Zie Bolkestein (1914: 113).

26 "Eveneens, dit is een andere grond, welke de meerdertheid heeft aargevoerd, zoude gebrek ath overeentemming tusschen de leerlingen nadeelige gevolgen hebben. Een getijksoortig streven bij jonge lieden, welke aan hetzelfde onderwijs deel nemen, is een van de beste middelen tot opwekking en aansponing, Het bijeenbrengen daarentegen van leerlingen, welke een geheel verschillend doel beoogen, zoude hen aftrekken en verwarren, zoo het zells geene aanleiding gaf tot botsingen en onaangenatamheden" (Rapport van de Commissie van 1828 in Bolkestein 1914: 115-118). 
demische Senaat van de hogeschool te Utrecht was desgevraagd van mening dat "het eenige doel van een gymnasium is te zijn eene voorbereidende school voor de Akademie, bij uitsluiting een school voor den geleerden stand (...) Aanstaande geleerden moeten eene geheel andere opleiding hebben als aanstaande Kooplieden, grondbezitters of krijgslieden" (Inlichtingen 1828: 3). H.W. Tydeman (1828) huldigde vergelijkbare opvattingen, zij het dat hij de (Noordelijke) Athenea wel geschikt achtte voor diegenen die een beschaafde opvoeding wilden ontvangen, maar niet de universiteit wilden bezoeken.

Een minderheid in de Commissie vond echter dat de Latijnse Scholen op de trap van het middelbaar onderwijs dienden te staan. Zij zagen het juist als een voordeel wanneer de leerlingen langere tijd hetzelfde onderwijs volgden alvorens zich te gaan richten op hun uiteindelijke bestemming. Tevens zagen zij niet in waarom een verschillende leerwijze of didactiek moest worden gehanteerd voor leerlingen wier uiteindelijke bestemming uiteenliep. Bovendien signaleerden zij het probleem dat bij de zogenaamde beschaafde klassen in de eerste jaren der jeugd nog niet duidelijk is welk beroep men uiteindelijk zal beoefenen.

Uit de omschrijving die de Commissie uiteindelijk van het lager en middelbaar onderwijs gaf, wordt duidelijk dat zij daarbij met name eindonderwijs voor ogen heeft, bedoeld voor uiteenlopende standen: "Er zijn kundigheden, welke niet slechts in elk beschaafd man, maar in elk burger eener beschaafde maatschappij, worden vereischt; zoo als b.v. de kennis van de moedertaal, het lezen, schrijven, cijferen, de kennis van de munten, maten en gewigten des Rijks. De mededeeling dezer kundigheden behoort tot den kring van het lager onderwijs: Boven dit lager onderwijs verheft zich het middelbare. Het moet zich niet enkel bepalen tot de voortzetting en volmaking van hetgeen men zich door het lagere heeft eigen gemaakt, maar het moet ook zoodanig ingerigt zijn, dat het tot eene meer algemeene beschaving leidt, en tot het verkrijgen van kundigheden, welke schier onmisbaar zijn voor hen, die, door hunne omstandigheden, aan de aangenaamheden des gezelligen levens kunnen deelnemen, en voor hen, die zich op zulke bedrijven wenschen toe te leggen, welke eenige wetenschappelijke kennis, doch geen eigenlijk gezegd geleerd onderwijs, vorderen" (Rapport van de Commissie van 1828, in Steyn Parvé 1863: 9-10). Uiteraard lag het in het verlengde van die visie dat bij de verdere inrichting van het hoger onderwijs op de gymnasia en hogescholen "elk, die in een zoogenaamden geleerden stand komt, niet alleen de kundigheden moet bezitten, welke tot dien stand behooren, maar ook door zedelijke hoedanigheden tot eer van denzelven moet verstrekken" (Rapport van de Commissie 1828, in Bolkestein 1914: 127).

Nog voor de in 1828 ingestelde Commissie haar rapport had ingediend (dit zou op 30 mei 1829 gebeuren), was bij Koninklijk Besluit van 19 Februari al- 
weer een Commissie voor het middelbaar onderwijs ${ }^{27}$ in het leven geroepen. In het verslag van deze Commissie, eveneens gedagtekend 30 mei 1829, geeft zij te kennen een bredere opvatting van middelbaar onderwijs voor te staan: " $L$ 'instruction moyenne comprend toute l'instruction intermédiaire entre $l^{\prime}$ instruction primaire et $l^{\prime \prime}$ instruction académique ou universitaire. L'instruction moyenne a un triple but: celui de préparer les jeunes gens aux études académiques; celui de fournir aux exigences d'une éducation soignée en faveur de ceux qui ne se destinent pas aux grades académiques; enfin celui de procurer des connaissances utiles à ceux qui se destinent au commerce, aux arts industriels et mécaniques ou à d'autres états utiles à la societé civile" (Verslag van de Commissie voor het Middelbaar Onderwijs van 30 Mei 1829, in Steyn Parvé: 1863). Een circulaire van het Ministerie van Binnenlandse Zaken van 5 juli 1830 laat zich in dezelfde zin over middelbaar onderwijs uit: "Door middelbaar onderwijs, daarentegen, heeft men verstaan datgene, hetwelk gegeven wordt aan jeugdige personen, die reeds het lager onderwijs, volgens bovenstaande omschrijving, genoten hebben en zich wenschen voor te bereiden, hetzij voor het hooger of universiteits-onderwijs, hetzij voor een' bijzonderen stand of beroep, of die ook blootelijk verlangen eene beschaafde opvoeding te voltooijen" (in Steyn Parvé 1863: 17).

Voor Ph.W. van Heusde, éen van de prominenten die zich in de discussie rond de Staatscommissie van 1828 mengden, hingen de wezenlijke verschillen tussen het lager, het middelbaar en het hoger onderwijs samen met de ontwikkelingsfase $e^{23}$ waarin de student verkeerde. Volgens Van Heusde was de aard van de mens in de diverse leeftijdsfasen verschillend. Hij onderscheidde in de ontwikkeling van de mens de fasen kind, knaap, jongeling, man en grijsaard. Een onderscheid dat hij terugvond in de geschiedenis van het menselijke geslacht (Star Numan 1839: 32). "[H]et kind moet als kind, de knaap als knaap, de jongeling als jongeling, worden behandeld, en niet, gelijk helaas! meestal gebeurt, kinderen als knapen, knapen als jongelingen, jongelingen als mannen: waardoor in alle zedelijke en maatschappelijke betrekkingen eene schromelijke verwarring is ontstaan" (Van Heusde, in Star Numan 1839:33). Het lager onderwijs moest het kind tot mens en het middelbaar de knaap tot beschaafd mens vormen. Aan de universiteiten zou de vorming van jongeling tot zedelijk en verstandelijk zelfstandig mens moeten worden voltrokken ${ }^{2}$.

27 Leden: de hertog wan Ursel, voorzitter, C. le Hon, L.G. Luzac, M.G. Metelerkamp, W.F.L. baron Rengers, I.H. wan Reenen, F.J.M.U. baron de Secus, J, van Toers, A. L. Dugniolle, secretaris. Zie Bolkestein (1914: 135).

28 Voor teen algemene karakterisering wan het type ontwikkelingsdenken dat Van Heusde uitdraagt, zie het eerste hooldstuk. In hoofdstuk 3 en 4 komt het ontwikkelingsdenken in de specifieke contexten varn geneeskuncle en rechit terug.

29 Schleiermacher (1808: 281) had ooit vergelijkbare ideeën geuit: "Die Universität steht an der Stufe, 
Uit de discussies over een mogelijke invulling van het middelbare onderwijs kwamen drie opties naar voren (Bolkestein 1914; Matthijssen 1982: 94-95). Als eerste werd de stichting van een tweede schoolsoort geopperd, zonder klassieke talen maar met moderne vakken, naast de Latijnse Scholen. Als tweede de invoering van een algemene middelbare school als tussenschool na de lagere school. Deze zou twee à drie jaar moeten duren. Daarna zou men naar het gymnasium kunnen overgaan. En als derde de opbouw van een soort lyceum, waarin alle leerlingen zonder onderscheid moderne vakken zouden leren doch daarenboven, desgewenst 'geleerde talen' (Idenburg 1960: 201). Maar geleidelijk aan was op de Latijnse Scholen ook een aantal veranderingen doorgevoerd. De meeste Latijnse Scholen kenden nog het systeem van klasseleraren, aan wie alle vakken - wiskunde meestal uitgezonderd - waren opgedragen. Enerzijds poogde de overheid aan de roep om uitbreiding en verbetering aan de Latijnse Scholen vorm te geven. Zo formuleerde het K.B. van 9 september 1826 minimumeisen voor wat betreft de kennis van de wiskunde waaraan de student bij het verlaten van de Latijnse School moest voldoen. Belangrijker was echter dat vanaf 1836 buiten de wettelijke kaders om, in navolging van de Latijnse School van 's Gravenhage, op een groeiend aantal Latijnse Scholen - die dan veelal Gymnasia genoemd gaan worden - zogenaamde tweede afdelingen werden ingericht, waar met name wiskunde, moderne talen, Nederlandse geschiedenis, schei- en natuurkunde, staathuishoudkunde en boekhouden werden onderwezen. Deze afdelingen waren onder andere bedoeld voor toekomstige zakenmensen, ambtenaren en officieren (Van Duyvendijk 1955: 19; Boekholt en De Booy 1987: 126).

Voorstanders van zelfstandige Latijnse Scholen, die met name te vinden waren onder leden van het op 6 Augustus 1830 opgerichte 'Genootschap van leraren aan de Nederlandse Gymnasia', bekritiseerden deze ontwikkeling op inhoudelijke en didactische gronden (Boekholt en De Booy 1987: 127). Omdat de inrichting en verdere uitbreiding van de tweede afdelingen aan de gymnasia zich voltrok buiten een formeel wettelijk kader om, kon ook kritiek daarop niet uitblijven. In een Kamercommissie van 1848 werd naar aanleiding van de 'Verslagen nopens den staat der hooge, middelbare en lagere scholen in het Koninkrijk der Nederlanden, over de jaren 1845 en 1846' geconstateerd dat "verscheidene latijnsche scholen, uitgebreid en vervormd onder den daaraan bijzonder toegeëigenden naam van gymnasien, eene tweeledige bestemming

die im Lebenslauf des Einzelnen den Eintritt in das Erwachsenenalter darstellt. Sie leistet im Giesamtprozefs der Bildung den Uebergang zwischen der Schule, wo durch eine Grundlage von Kenntrissen, durch eigentliches Lernen die Jugend ernst bearbeitet wird für die Wissenschaft' (s. 238) (...) Die Erziehung an der Universität setzt eine Zeit der Abhängigkeit und Unmundigkeit voraus und konstitudiert den Beginn von Selbständigkeit" (Rosenbrock 1979: 909) 
hebben bekomen". Dat had twee gevolgen: "[V]ooreerst dat deze gymnasien niet meer uitsluitend kunnen worden beschouwd te zijn, hetgeen ze volgens art. 4 der organieke bepalingen van 2 A ugustus 1815 behooren te zijn, 'de eerste trap van het hooger onderwijs, en inzonderheid bestemd voor diegenen, welke, na aanvankelijk door het lager en middelbaar onderwijs te zijn beschaafd geworden, nu verder tot eenen geleerden stand zullen worden opgeleid', en ten andere, dat het middelbaar onderwijs, hetwelk ontegenzeggelijk aan die hoogere se[c] holen wordt gegeven, daardoor met der daad is onttrokken aan het gebied der wet van 3 April 1806 waartoe het, op zich zelf beschouwd, nog altijd behoort" (Commentaar in de Kamercommissie 1848, in Steyn Parvé 1863: 23-24).

De grondwet van 1848 sprak wederom van middelbaar onderwijs. Op de vraag van de Tweede Kamer wat daaronder begrepen moest worden, kwam als antwoord: "wat door middelbaar onderwijs wordt verstaan, zal door de wet op dit onderwerp te maken worden bepaald. De aard der zaak en de reeds bestaande industriescholen toonen genoegzaam, wat onder het middelbaar onderwijs zal moeten worden gerangschikt" (in Bolkestein 1914: 155156). Het Koninklijk Besluit van 15 Januari 1849 stelde opnieuw een Commissie voor het hoger onderwijs in. Op 31 Augustus 1849 verscheen haar rapport waarin ook zij constateerde dat "tegenwoordig gymnasia tweeslachtige instellingen zijn, die, door tweeërlei rigting te bedoelen, een eigen bepaald karakter hebben verloren" (Rapport van de Commissie 1849 in Bolkestein 1914: 2627). Maar in de ogen van de Commissie hoefde dat niet tot onoverkomelijke problemen te leiden. Zij kwam met het voorstel om "het onderwijs op de Latijnsche scholen niet langer tot het hooger onderwijs te brengen, maar te beschouwen als middelbaar onderrigt, dat voor het hooger voorbereidt, daarvan verschilt in strekking en methode, en aan den anderen kant zich boven het lager verheft, niet alleen door de onderwerpen, die het behandelt, maar ook door den vorm van het onderwijs en de wijze waarop het den geest ontwikkelt en het oordeel scherpt" (Rapport van de Commissie 1849, in Bolkestein 1914: 25-26). Art. 1 van de door de Commissie ontworpen wet omschreef het hoger onderwijs als dat onderwijs "hetwelk onmiddellijk vormt en voorbereidt tot die maatschappelijke betrekkingen, waarvoor grondige studie noodig is, en de kweekelingen opleidt tot een eigen helder inzigt in de wetenschap, en tot hare toepassing in het praktische leven"; "wat tot hetzelfde doel slechts middellijk voorbereidt, zij onder het middelbaar onderwijs begrepen". "[N]iet alleen de aard en de strekking van het hooger onderwijs onderscheidt het kenmerkend van het middelbare; ook in vorm en methode is het daarvan verschillend" (Rapport van de Commissie 1849, in Steyn Parvé 1863: 26-27).

De Memorie van Toelichting van het door minister Van Reenen op 22 september 1854 aan de Tweede Kamer aangeboden wetsontwerp tot regeling van 
het lager en middelbaar onderwijs ging wederom uitvoerig in op de verhouding tussen het lager, middelbaar en het hoger onderwijs. In het wetsontwerp werden de Latijnse Scholen tot het middlelbare onderwijs gerekend: "Het lager onderwijs, moet strekken tot die ontwikkeling en vorming, welke voor een ieder onmisbaar is; het middelbaar onderwijs, voortzetting van het lager, moet behalve tot verdere ontwikkeling en beschaving, tot opleiding dienen niet alleen voor handel, land bouw en nijverheid (in industrie-scholen), maar ook voor de universiteit (in gymnasiën ${ }^{30}$; het hooger onderwijs moet strekken tot hoogere beoefening der wetenschap om haar zelve en tot vorming voor betrekkingen in den Staat, waartoe eene wetenschappelijke voorbereiding wordt vereischt" (Memorie van Toelichting bij het wetsontwerp van 22 sept. 1854, in Bolkestein 1914: 157; in Steyn-Parvé 1863: 29-30). Er was echter én belangrijk praktisch bezwaar tegen deze regeling. Art. 194 van de grondwet van 1848 voorzag in een onderzoek naar de bekwaamheid en zedelijkheid voor leraren aan het lager en middelbaar onderwijs. Leraren in het hoger onderwijs, en dus ook voor de Latijnse Scholen en gymnasia, waren van een dergelijke proeve vrijgesteld. De praktische problemen die zouden ontstaan wanneer de gymnasia tot het middelbaar onderwijs gerekend zouden worden, waren dermate groot dat de regering "van eene indeeling die haar overigens de meest natuurlijke toescheen, heeft willen afzien" (Minister Van Reenen, in Bolkestein 1914: 158).

Het wetsontwerp dat uiteindelijk op 2 Mei 1863 tot wet wordt verheven, stamt van J.R. Thorbecke. Ook bij het tot stand komen van deze wet ontstaat weer discussie over het karakter van de middelbare scholen ${ }^{31}$. Maar in tegenstelling tot eerdere wetsontwerpen speelt in Thorbecke's plan voor de organisatie van het middelbaar onderwijs de opvatting dat de maatschappij een hiërarchische standenopbouw kent weer een centrale rol. Middelbaar onderwijs moet dienen ter "vorming van die talrijke burgerij, welke het lager onderwijs te boven, naar algemene kennis, beschaving en voorbereiding voor de onderscheidende bedrijven der nijvere maatschappij tracht" (Memorie van Toelichting, in Idenburg 1963: 4). Middelbaar onderwijs is onderwijs bestemd voor de middengroep - de kern - van de maatschappij. Het hoger onderwijs, gymnasium en universiteit, is bestemd voor de geleerde stand. De arbeidersklasse en het gemeen kan met lager onderwijs volstaan. Thorbecke verklaart bij de be-

30 Vitringa (1860:6) hanteert een vergelijkbare definitie. Middelbaar onderwijs heeft een tweeledig doel: enerzijds "eindonderwijs voor den beschaafden stand", anderzijds "voorbereidend onderwijs voor inrigtingen die toegewijd zijn aan de wetenschappelijke beschouwing van sommige beroepen".

31 "Dikwerf is de vraag gedaan, wat is in Nederland middelbaar onderwijs? Wat zijn middelbare scholen? Doch wie heeft ze kunnen vinden, al spreekt de grondwet van dit onderwijןs, all wijst de wet op het lager onderwijs, van 13 Aug 1857, (Stbl. no 103), op de toekomstige regeling, en al waagt zij ook (art. 72) een flauwe poging om het te omschrijwen, als bevaltende het verder voortgezet onderwijs in de levende talen en in de wis- en natuurkunde" (Van der Heim: 1862: 1). Zie ook Naber (1868). 
handeling van de wet op het middelbaar onderwijs: "Vergelijkt men de bestemming van het hooger onderwijs met die hetgeen onze wet middelbaar onderwijs noemt, dan heeft het laatste voor de maatschappij een algemene practische vaardigheid te bekwamen; het andere tot eigen studie der wetenschap onafhankelijk in staat te stellen". Of anders gezegd: "[H]et onderwijs in de hoogere burgerschool en polytechnische school is gerigt op onmiddellijk gebruik voor het leven en de bedrijvige maatschappij. Het hooger onderwijs strekt tot ontwikkeling van zelfstandige studie, van wetenschap en om haar selve" (Van Wieringen 1975: 8).

Uiteraard wordt deze stap terug van Thorbecke ten aanzien van de aard van middelbarar onderwijs niet voetstoots aanvaard (zie ook Vitringa 1860; Riedel 1860). H.J. van de Heim (1862: 3-5) is in zijn kritiek heel expliciet: "[W]anneer men, gelijk de M.v.T. [Memorie van Toelichting] "lager onderwijs volksonderwijs noemt in den zin, dat het, als eerste aanvang van ontwikkeling, gelijkelijk bestemd is voor allen; dan zal het middelbaar onderwijs niet 'de vorming van die talrijke burgerij' op het oog houden, maar de vorming en verdere ontwikkeling van allen, welke het lager onderwijs te boven, naar algemeene kennis, beschaving en voorbereiding voor de onderscheiden bedrijven (en betrekkingen) der nijvere maatschappij trachten. (...) In de dagelijksche wereld bestaat die sterke afscheiding niet tusschen den stand der geleerden en der 'rijveren', welke sommige aannemen, en de klove, zoo zij er is, moet gedempt, niet verwijd worden." Van der Heim wil het gymnasium eveneens tot het middelbaar onderwijs rekenen. In de kamerdebatten rondom de invoering van de Middelbaar Onderwijswet klinken vergelijkbare geluiden: "Is deze onderscheiding der standen wel in de geest dezer eeuw? En is dit geen terugtred op de weg die men vóór 1848 heeft ingeslagen?" (Van Goltstein in de Tweede Kamer, 3 Maart 1863, in Idenburg 1963:7). De afgevaardigde Creemers verzet zich tegen "de scherpe afscheiding van de groote massa der burgerij, van burgerstanden en den geleerden stand" (Creemers 1863, in Idenburg 1960: 157). "Het is beter dat jongelieden van de hogere stand en van de burgerij, van de praktische en van de geleerde stand, zo lang mogelijk samen blijven en aan elkander gewennen, opdat zij later de maatschappij beter kennen en zich daarin herkennen", aldus Creemers (1863, 1 Mei 1863 in de Eerste Kamer, in Idenburg 1963: 7).

Een aantal parlementariërs trekken de door Thorbecke voorgestelde scheiding tussen hoger, middelbaar en lager onderwijs in twijfel. Zij vragen of het niet juister zou zijn ook de Latijnse scholen tot het middelbaar onderwijs te rekenen? De leeftijd van de leerlingen en de methoden van onderwijs zijn immers gelijk. Waarom zou de plaats in het schoolbestel dan verschillend wezen? Indien men onder middellbaar onderwijs alle onderwijs tussen lagere school en universiteit zou verstaan, ware ook de anomalie vermeden, dat aan leraren van gymnasia geen eisen van bekwaamheid en zedelijkheid gesteld worden 
- omdat de Grondwet die voor het hoger onderwijs niet kent - terwijl de leraren van de burgerscholen en hogere burgerscholen, evenals de onderwijzers bij het lager onderwijs, wèl aan zulke criteria zijn onderworpen, ondat de grondwet dit daar uitdrukkelijk eist (Idenburg 1963: 7). Weer anderen zien het onderscheid tussen lager en middelbaar onderwijs daarin gelegen dat het eerste in het belang van de maatschappij, het laatste voornamelijk in het belang van enkele personen wordt gegeven (Steyn Parvé 1863: 47). Ook de leeftijd, de onderwijsmethode of de te doceren vakken ${ }^{32}$ worden als indelingscriterium genoemd (Steyn Parvé 1863: 55). In het amendement-Van Hemstra dat in stemming wordt gebracht, word het middelbaar onderwijs gekenschetst als de "voortzetting van het lager en de voorbereiding voor het hoger onderwijs".

Door de pleiters voor een opvatting van middelbaar onderwijs die ook het gymnasium omvat, wordt verwezen naar het standpunt van de in 1849 ingestelde Commissie voor het hoger onderwijs (zie Ontwerp van Wet op het Hooger Onderwijs 1849). Maar Thorbecke wraakte deze Commissie, omdat zij bestaan had uit curatoren en professoren, die de benaming hoger onderwijs uitsluitend in beslag namen voor het universiteitsonderwijs, in strijd met hetgeen tot dusver hier te lande gegolden had (Handelingen Tweede Kamer 1862/1863 p. 548.1, in Janssen 1963: 36). Hij handhaafde zijn reeds vroeger uitgesproken mening, dat de grondwet de wetgever vrij liet bij de bepaling van de inhoud van het middelbaar onderwijs en verklaarde, dat in zijn ontwerp van die vrijheid op de juiste wijze gebruik was gemaakt door de gymnasia en Latijnse Scholen niet als middelbaar onderwijs te beschouwen. Deze "behooren tot een ander stelsel, tot een ander gebied dan hetgeen hier behandeld wordt. Wie ziet niet in dat de latijnsche scholen niet anders kunnen geregeld worden dan in verband met het universiteitsonderwijs? De voorwaarden, de eischen, de examina, de bevoegdheidseischen voor de leeraren der Latijnsche scholen, zijn gansch anders dan die gesteld moeten worden voor hen die onderwijs hebben te geven aan inrigtingen, als dit ontwerp bedoelt" (Handelingen Tweede Kamer 1862/1863 p. 548.3, in Janssen 1963: 37). Een ander argument dat Thorbecke voor de Tweede Kamer aanvoert, verwijst direct naar een aan de historische school ${ }^{33}$ ontleend ontwikkelingsdenken: "Het hooger onderwijs heeft ook zijn eerste beginselen, zijn abcboek en, van het eerste oogenblik dat de leerling in de oudheid wordt ingewijd, behoort het onderwijs, dat hij ontvangt, tot het hooger onderwijs" (in Steyn Parvé 1863). Hiet idee dat de maatschappelijke bestemming van de leerling al vast ligt bij de toetreding tot een bepaalde vorm van onderwijs, keert terug in Thorbeckes reactie op kritiek

32 "Die fout bestat eenvoudig hierin, dat men hel onderscheidende kenmerk van lager, middelbaar en hooger ondlerwijs in de onderwezen vakken heeft gezocht" (Opzoomer 1873. 43).

33 Zhe de paragraaf "kritiek en programmat' van thet eerste hoofdstuk en hoofistuk wier. 
geuit in de Eerste Kamer: "Het onderscheid van de beide soorten van opleiding ligt niet zoozeer daarin, dat de eene zich tot de oudere talen uitstrekt, de andere niet, maar dat de beoefening dier talen in den regel het kriterium uitmaakt, waardoor aangewezen wordt, welke de rigting is, die de leerling later volgen zal. Het is eene geheele andere zaak of de oude talen, zoo als voor de aanstaande studenten der hoogeschool het geval is, het hoofdbestanddeel der opleiding uitmaken, dan well of eenige kennis dier talen voor een bijzonder praktisch doel verkregen wordt ${ }^{2 \prime}$ (in Steyn Parvé 1863: 127).

Het ontwerp van Thorbecke dat tot wet wordt verheven, onderscheidt onder de openbare middelbare scholen land bouwscholen, dag- en avondscholen voor de eenvoudige burgerstand, 3 en 5 -jarige Hogere Burgerscholen bestemd voor de gezeten burgerstand en de grote burgerij, en ten slotte de polytechnische school, bestemd voor de opleiding van aanstaande industriëlen en technologen. De HBS-en zouden de tweede afdelingen aan de gymnasia, waar Nederlands, 2 of 3 moderne talen, geschiedenis, aardrijkskunde en wiskunde (en soms wat natuur- en scheikunde) werden gedoceerd, moeten gaan vervangen. Via het K.B. van 20 juni 1864 wordt in het kader van de M.O.-wet ook een polytechnische school ingesteld. De Koninklijke Akademie voor Industrie en Handel, die in 1843 te Delft was opgericht ${ }^{34}$ (Buddingh 1842), gaat daarin op. In 1828 had de senaat van de hogeschool te Utrecht nog uitgesproken niet te verwachten "dat de nijvere klassen, uit de verschillende oorden des Rijks, die [polytechnische] instellingen zullen komen bezoeken en zich de moeiten, den tijd en de kosten getroosten, om er zich behoorlijk te laten onderwijzen" (Inlichtingen 1828: 7). De faculteit der Wis- en Natuurwetenschappen te Leiden had in dat verband laten weten dat "de zoogenaamde Polytechnische Scholen te veel verwijderd zijn van de inrigting onzer Akademien, om ze daarmede in verband te brengen" (Senaat 1828: 3). In 1865 wordt de mogelijkheid van onderbrenging van de polytechnische school bij het hoger onderwijs echter al uitvoerig besproken. Een 'Oud-student' van de Delftsche Akademie bepleit in 1860, in reactie op een vlugschrift van Dr. Pijnappel die de Delftsche Akademie had ingedeeld bij het middelbaar onderwijs, opname bij het hoger onderwijs: "Moeijelijk is het voorzeker naauwkeurig te bepalen, wat men onder hooger, middelbaar of lager onderwijs verstaat; nog moeijelijker is het, de grenzen tusschen elk dezer takken van onderwijs aan te toonen. (...) Jhr. Mr. J. de Bosch Kemper, zegt in zijn Handlei-

34. Bij de oprichting wan de Akademie van ingenieurs in 1843 werd het Koninklijk Besiluit van 13 mei 1825 ingetrokken (K.B. van 25 Febr. 1843 no. 67, art. 8). In de korte periode tussen 1825 en 1830 is ex sprake wan enig technisch onderwijs aan de hogescholen. In het kader van een industrialisatiepolitiek had koning Willem I via het K.B. van 13 mei 1825 aan elk der universiteiten onderwijs over de toepassing van scheikunde en werktuigkunde op de muttige kumsten werplicht gesteld. Dat onderwijs is nooit een succes geworden. 
ding tot de kennis van het Ned. Staatsregt en Staatsbestuur: 'Onder den naam van Hooger onderwijs wordt verstaan, zoodanig onderwijs als ten doel heeft, na afloop van het lager en middelbaar onderwijs, den jongeling tot een geleerden stand in de maatschappij voor te bereiden' en verder "onder middelbaar onderwijs behoort het onderwiijs, dat dient tot opleiding voor het hooger onderwijs, en dat onderwijs, dat voor maatschappelijke betrekkingen voorbereidt, in welke, hoogere wetenschappelijke vorming geen vereischte is.' Nu zal toch niemand kunnen aantoonen, dat een hoogere wetenschappelijke vorming voor den Ingenieur dezer eeuw geen voornaam vereischte is, tenzij men b.v. de wis- en natuurkundige wetenschappen, waarvan in Delft zoo vél werk wordt gemaakt, daar niet onder mogt willen rekenen" (Oudstudent 1860: 10-11). Thorbecke bleef echter vasthouden aan het strikte onderscheid tussen een vorming "geheel en al voor behoeften van den tegenwoordigen tijd, voor diensten, aan de tegenwoordige maatschappij te bewijzen in technische of oeconomische vakken" en de "opleiding tot zelfstandige beoefening van de wetenschap, onafhankelijk daarvan, of men later zijn leven enkel daaraan wijde" (in Idenburg 1960: 211). "[W]anneer men zich dan aan de eene zijde iemand voorstelt, die in de volle kracht des woords zijne studien aan de hogeschool volbragt heeft, en aan de andere zijde een geoefend polytechnicus, dan is het onderscheid tusschen beiden in het oog vallend, en wat de algemeene kennis en beschaving betreft ten voordeele van den eerste. De reden wordt door velen voor een deel gezocht in de vormende kracht van de studie der klassieke oudheid, die, tot hiertoe althans, den grondslag uitmaakt van het hooger onderwijs" (Memorie van Toelichting van het gewijzigd ontwerp van wet, October 1862, in Steyn Parvé 1863: 52).

Van Thorbecke's plannen komt weinig terecht (De Loos 1898). De Wet op het M.O. van 2 mei 1863 had studievrijheid voor de studenten voorzien. Op de Rijks HBS-en zouden de leerlingen kunnen plaatsnemen in de klassen die ze zelf verkozen. Er zouden geen verplichte toelatings- of overgangsexamens worden gehouden. Wel werd een eindexamen af te nemen door externe examencommissies ingesteld. Onder druk van het eindexamen verdwijnt echter de studievrijheid. Al in 1868 worden de eindexamens tot op zekere hoogte gecoördineerd. Uiteindelijk komt er een uniform schriftelijk examen voor het hele land. In 1872 verklaarde Thorbecke in de kamer: "Hetgeen ik niet wilde is ingeslopen; in de jongste jaren is de heerschappij wederom gekomen aan schoolsch begrip van dwang, waardoor het onderwijs, met name het middelbaar onderwijs, waarmede wij nu te doen hebben, een soort van fabriek zou worden. Mijne verklaarde mening was steeds, dat het genot van het onderwijs aan de hoogere burgerscholen vrij moet zijn gelijk aan de universiteiten" (Thorbecke, in Idenburg 1960: 40-41). J. Karsemeyer, die in 1963 terugblikt op een eeuw Middelbaar Onderwijswet, constateert dat er "eigenlijk gedurende 
die hele tijd een strijd gevoerd is (...) tegen de grote vrijheid die de wet op het middelbaar onderwijs liet" (Karsemeyer 1963: 23). Volgens Karsemeyer is de geschiedenis van de HBS vooral een geschiedenis van een opeenvolging van steeds strengere eisen en examens (Karsemeyer 1963: 25; Boekholt en De Booy 1987: 186-187).

Thorbecke's verwachtingen worden op een geheel ander punt eveneens teleurgesteld. In plaats van eindonderwijs te verzorgen en voor te bereiden op de "nijvere maatschappij' ontwikkelen de HBS-en zich al gauw tot een vooropleidingsinstituut voor verdere vormen van onderwijs (Van Wieringen 1975: 9). Reeds in 1871 gaan er stemmen op, onder andere van hoogleraren in de geneeskunde (Rosenstein 1871), die het recht op universitaire studie bepleiten voor gediplomeerden van een HBS $^{35}$ (Bartels 1963: 132 e.v.; Willink 1988: 231). Aanvankelijk moeten HBS-ers - net als alle anderen die geen gymnasiale opleiding afgerond hebben - toelatingsexamen ${ }^{36}$ doen. Na 1865 begint de minister echter dispensatie te verlenen, met name voor toekomstige geneeskundigen (Boekholt en De Booy 1987: 189). Verzoeken om dispensatie worden, naar de willekeur van de minister afgewezen dan wel ingewilligd. De strijd om de gelijkschakeling van toelatingsrechten tot de universteit voor de HBSen en de gymnasia bereikt een voorlopig hoogtepunt in 1876 bij de behandeling van de aanstaande wet op het Hoger Onderwijs. Amendementen van die strekking, ingediend door de Kamerleden Rombach en Stieltjes, worden door minister Heemskerk afgewezen en door de Tweede Kamer verworpen (Bartels 1963: 135). Het amendement-Van Houten weet wel voldoende voorstanders te vinden; gediplomeerden van de HBS behoeven voortaan enkel een aanvullend examen in Latijn en Grieks af te leggen om tot de universiteit te worden toegelaten; voor de overige vakken biedt het HBS-diploma vrijstelling. De artsenwet van 1878 staat vervolgens toe dat HBS-ers, na het afleggen van het eerste natuurkundig examen van de universiteit, de universitaire artsenstudie volgen ${ }^{37} . \mathrm{Zij}$ het dat voor hen in speciale examens, parallel aan

35 Het zal niet verbazen dat Rosensteins indeling van scholen in Hagere en hogere gebeutrt op basis van niveau en niet op basis van leervakken "Iedere school heeft ten doel, aan den eenen kant, den intellectueelen en zedelihken aanleg van het kind in het algemeen te ontwikkelen, en aan den anderen kant den leerling in staat te stellen, later aan alle belangen der matischappij zelfstandig deel te nemen en daatoe mede te werken. Narmate de school zulk eene ontwikkeling tot stand brengt, en naar den grand van positieve kennis, welke op de school bereikt wordt, verdeelt men de scholen in lagere en hogere" (Rosenstein 1871: 10).

36 Zie de paragraaf'eentheid van stand' van hoofdstuk 4.

37 "Er waren wel 'eentige leden', die er volgens het Voorlopig Verslag over dit wetsontwerp uitgebracht, op wezen, dat het wetsontwerp breekt met het beginsel, dat de klassieke vorming noodzakelijk is voor wettenschappelinke opleiding', maar volgens hen zou de regeling het voordeel opleveren 'dat eene vergelijkende proef zal kunnen worden genomen omitrent de gevolgen en vruchten van klassieke en niet-klassieke opleiding." (Bartels 1963: 136). 
de academische examens, is voorzien. Binnen de medische opleiding stond de nadruk op de klassieken echter reeds enige decennia onder druk (Roelants 1842; Karsemeyer 1963: 29; Bartels 1963: 136-137).

De Hoger Onderwijs Wet van 1876 rekent opnieuw de gymnasia tot het hoger onderwijs, nu als instellingen voorbereidend tot wetenschappelijk onderwijs. Het hoger onderwijs dient nu tot "vorming en voorbereiding tot zelfstandige beoefening der wetenschappen en tot het bekleeden van maatschappelijke betrekkingen, waarvoor eene wetenschappelijke opleiding vereischt wordt" ${ }^{\prime \prime}$. Maar terwijl tot dusverre curatoren en gemeentebesturen autonoom over de inrichting van de gymnasia konden beslissen, worden dan alle gymnasia gelijkgeschakeld en wordt een uniforme zes-jarige leergang vastgesteld waarbij voor ieder vak het aantal te doceren uren precies is vastgelegd (Hubrecht 1880). Het eindexamen wordt voortaan afgenomen door rijks-gecommitteerden, terwijl de docenten over een academische graad of een M.O.-akte moeten beschikken (Boekholt en De Booy 1987: 197). Tevens wordt de 'vakleraar' geintroduceerd. Ook daar was fel oppositie tegen gevoerd (Van Heusde 1829; Ekker 1854; Naber 1863: 11-13; Naber 1867), met als belangrijk argument dat door de vakleraar het vormende - lees in een statusgroep introducerende - aspect van het gymnasium verloren gaat: "Vele stemmen verklaren thans: met het vakstelsel dient te worden gebroken; de klasseleeraars alleen kunnen het gymnasium redden (...) De kolossale fout der hedendaagsche opvoeding is dat men te zeer den nadruk legt op wat iemand weet, niet op wat hij is" (Van der Wijck 1898: 97; 100).

De precieze verhouding tussen het middelbaar en het hoger onderwijs blijft nog geruime tijd een omstreden kwestie. Zou het gymnasium, in zijn vernieuwde vorm, in staat zijn "ieder het zijne te geven" (Van Duyvendijk 1955: 277)? Nog in 1898 stelt $B$. van der Wijck dat het verschil tussen hoger en middelbaar onderwijs geen verschil van rangorde is maar wel degelijk van karak$\operatorname{ter}^{38}$. Voor de reorganisatie van het lager, middelbaar en hoger onderwijs wordt in 1903 door Minister Kuyper een Staatscommissie ingesteld - de zogenaamde Ineenschakelingscommissie - met als opdracht voorstellen voor te bereiden "tot betere ineenschakeling van de onderscheidene deelen van het onderwijs". De keuzes en de dilemma"s waarvoor die commissie staat - als die tussen algemeen vormend onderwijs en beroepsonderwijs, en tussen algemeen onderwijs en standsonderwijs - zijn vandaag de dag nog onderwerp van gesprek (bijvoorbeeld in de discussie rondom de middenschool). Pas met de Wet van 22 mei 1905 (Stb. 141) ${ }^{39}$ wordt de Polytechnische school ${ }^{*}$, die vanaf dat

38 "De namen: "hooger en middelbaar onderwijs' doen denken aan een verschil van rangorde. Toch is dat niet de bedoeling. Welk verstandig man zou meenen, dat het onderwijs der polytechuische school lager statat dan dat der eerste klasse van een gymasium? Het is een verschil in karakter, dat door die misleidende termen wordt aangeduid" (Van der Wijck 1898: 83).

39 In deze wet werd ook het instituut van bijzondere leerstoel geschapen (Van den Bergh 1988a: 43). 
moment Technische Hogeschool zou gaan heten, gerekend tot het hoger onderwijs. Eerst in 1909, bij de oprichting van 'Het Nederlandsch Lyceum' verschijnt het middelbaar onderwijs definitief in de vorm zoals wij dat kennen, namelijk als onderwijs voor een bepaalde leeftijdsgroep, uitgesplitst naar niveau (Boekholt en De Booy 1987: 272). Met het aannemen van de Wet Limburg (1917) worden de laatste verschillen in toelatingsbevoegdheid tot de universiteit tussen de HBS en het gymnasium geslecht $t^{4_{1}}$, in die zin dat ook de studenten die via de HBS tot de universitaire studie worden toegelaten, het recht verkrijgen tot een academische promotie. Maar ook dan wordt het onheil dat deze beslissing voort zou brengen, nog luidkeels ${ }^{42}$ en uitgebreid ${ }^{43}$ bezongen (Bartels 1963: 141).

\section{Hoger Onderwijs}

Alhoewel in het Organiek Besluit van 1815 een groot aantal van de door de Fransen in de organisatie van het hoger onderwijs geintroduceerde veranderingen gehandhaafd blijven, valt dit Besluit toch vooral te kenschetsen als een poging om op een aantal beslissende punten terug te keren naar de oude orde $e^{\text {t4 }}$. Het Organiek Besluit volgde de Fransen onder andere in hun indeling van faculteiten. De door hen aangebrachte splitsing van de oude artesfaculteit in een faculteit der natuurwetenschappen en wiskunde en een faculteit der bespiegelende wijsbegeerte en letteren bleef. De Fransen werden eveneens gevolgd in hun besluit de verantwoordelijkheid voor het beheer van de hogescholen te

40 Evenals het van Rijkswege te geven hoger landbouw- en handelsonderwijs.

41 Al blijwen Lakijn er Crieks woor enkele academische studies (0.a. theologie) verplicht.

42 "Velen willen verder gaan en den leerlingen der Hoogere Burgerschool het recht zien geschonken in medicingen an natumrwetenschappen doctor te worden. Het onmiddellijk gevolg ware, datt het gymnasium een groot deel zijnen discipelen verloor, want jeder toekonstig geneesheer en natumkundige zou voontan den mexr "practischen weg' kiezen, welke doon de Hoogere Burgerschool ontsloten word: En wanneer voor deze belangrijke groep aanstaande leden van den geleerden stand Latijn en Grieksch beiden eens overtollig waren verklaard, zou men er, door de kracht van het beginsel voortgeslept, spoedig toe komen voor de toekornstige juristen althans het Grieksch te laten vallen, Daarmede zou aan de tegenwoondige gymnasia de doodsteek zijn gegeven. Voortganande in dezelfde lijn zou men de universiteiten moeten opheffen, de medici naat de hospitalen eener wereldstad zenden, de naturuonderzoekers nar een polytechnicum, juristen en theologen naar voor hen ingerichte seminaria en de literatoren, die men niet meer zou kunnen gebruiken, adn hun eigen lot overlaten. Dat alles ware zeer practisch, matr verderfelijk. Intusschen, de eerste schrede in die richting is reeds gezet, toen ondarks de enheid van stand, de classieke opleiding voor de artsen overtollig werd verklaard!" (Van der Wijck 1898: 100), Zie ook de hoofdstukken drie en zes.

43 Zie bijwoorbeeld de jaargang 1917 van het NTVG.

44 "Het Organiek Beshut laat zich lezen als een gentlemen's agreement ter bestendiging van de vroegere toestand, maar met vermijding van de ergste misbruiken en met een gepast respect voor de hoogleraar als docent en gelleerde" (Roelevink 1986: 69). 
verplaatsen van de gemeentebesturen naar het rijk. De drastische reductie van het aantal hogescholen die de Fransen hadden doorgevoerd, wrerd daarentegen grotendeels teniet gedaan. De Commissie Kemper, die het Organiek Besluit had voorbereid, had zich eveneens uitgebreid gebogen over het aantal hogescholen dat in Nederland zou moeten worden gevestigd"s. De door Lodewijk Napoleon bij keizerlijk decreet van 22 october 1811 tot "école sécondaire" gedesavoueerde hogeschool van Utrecht kreeg met ingang van het Organiek Besluit haar universitaire waardigheid terug. Harderwijk en Franeker werden Rijks-Athenea ${ }^{46}$; aan Amsterdam, Middelburg, Deventer en Breda" werd toegestaan gemeentelijke Athenea in te richten (zie ook Fliedner 1831: 88-89). Athenea dienden, zo bepaalde het Organiek Besluit, een tweeledig doel: "algemeene verspreiding van smaak, beschaving, geleerdheid enz." en het "gedeeltelijk vervangen van de hooge scholen en het akademisch onderrigt" (Organiek Besluit art. 36 lid 1 en 2, in Wingelaar 1989: 6) ${ }^{\star 8}$. Dat betekende dat athenea geen academische graden mochten verlenen. Daarvoor moesten de atheneumstudenten op het eind van hun studie naar één van de drie hogescholen.

Het Organiek Besluit was de eerste regeling van het (hoger) onderwijs op nationale schaal. Tijdens de Republiek ontbraken studie- en examenbepalingen voor de hogescholen in het geheel. In de achttiende eeuw hadden academische examens bijzonder weinig om het lijf. Aan toelating tot de universiteit werden in het geheel geen eisen gesteld; hetgeen in de loop van de eeuw steeds vaker een bron van kritiek ging vormen (Roelevink 1986). Afsluitende examens hadden ook niet primair een selecterende functie. De opleiding diende meer ter introductie in een statusgroep - de geleerde stand - dan tot het aanleren van specifieke kennis en vaardigheden (Frijhoff 1981: 289-292). Frijhoff heeft aangetoond dat de feitelijke beroepen die de academici in de achttiende eeuw uitoefenden, tot op zekere hoogte onderling uitwisselbaar waren (Frijhoff 1981: 241, 278). Het Organiek Besluit eiste dat om als student tot de hogeschool te worden toegelaten, men voortaan moest beschikken over een diploma van een Latijnse School. Daarnaast werd echter de mogelijkheid open gelaten om via een toelatingsexamen aan de faculteit der letteren en een proeve van bekwaamheid in de wiskunde - dit alles te beoordelen door individuele hoogleraren - toegang te krijgen tot één der universiteiten. De eisen die hieraan gesteld werden waren dermate laag dat velen deze weg kozen en de laat-

45 Zie voor een uitvoerige documentatie van de discussies in en rond de Commissie Kemper, De Geer (1869); voor dit punt pagina 218.

46 Het Atheneum van Harderwijk zou in 1818 worden opgehewen; dat in Franeker in 1843.

47 In Middelburg en Breda zou nooit een Akheneum van de grond komen.

48 De jeugdige leeftujd (13 of 14 jaar) waarop de zonen van de burgerij van school kwamen (De Baar 1982: 7-9) en het drukken van de studiekosten (Fliedner 1831: 88), worden als belangrijkste redenen genoend voor het functioneren van athenea nasit de universiteiten. 
ste jaren van de Latijnse School doodeenvoudig oversloegen (Roelevink 1986: 71-74; Wingelaar 1989: 25). Van strenge selectie bij de toelating tot de universiteit was nog steeds geen sprake (Boekholt en De Booy 1987: 127). Dat mag ook niet verwonderen. In de standsgeoriẻnteerde onderwijsorganisatie die Kemper in zijn ontwerp voor het Organiek Besluit voor ogen stond ${ }^{49}$, paste selectie op basis van leerprestaties niet.

Kempers ontwerp probeerde aan te sluiten op de situatie tijdens de Republiek. In tegenstelling tot de middeleeuwse universiteiten ${ }^{50}$ die zonen uit lagere standen kansen op emancipatie boden, hadden de universiteiten sedert de zestiende eeuw een steeds meer aristocratisch aanzien verworven. In de Republiek waren universiteiten instellingen voor de elite $e^{51}$. Het percentage adellijke studenten was groot. Zij kregen speciale privileges - bijvoorbeeld aparte banken vóor in de collegezaal - en de universitaire voorzieningen werden meer en meer op hun behoetten afgestemd, onder meer door de aanstelling van dans- en schermmeesters ${ }^{52}$ (Van den Bergh, Spruit en Van de Vrugt (red.) 1986: 17). De aristocraat leerde er in gelijkgestemd gezelschap paardrijden, biljarten, schermen, converseren, en last but not least drinken (Roelevink 1987: 22; Veen 1991: 572). Studenten genoten trouwens als groep

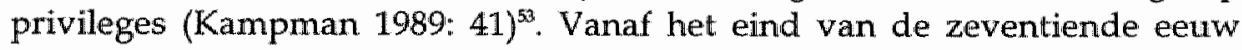
waren studenten zich ook in hun kleding gaan onderscheiden " met name door de zogenaamde 'japanse rock' of 'sjamberloek', een soort van satijnen

49 J. Huizinga (1951b: 56-57) omschrijft de intenties die Kemper, de geest achter het Organiek Besiluit leidden als volgt: "De geleerde stand opnieuw verheven tot het oude wanzien dat hij in Nederland steeds genoten hadl, en thans ook wit stoffelijk oogpunt woor een iecter begeerlijker dan voorheen, zoo wilde het Kemper."

50 "Höchst ungewöhnlich und doch meist zu wenig beachtet ist schon die Tatsache, daß die Universitäten von Anfang an und gerade in ihren mittelalterlichen Anfängen Gemeinschaften sind, an denen alle soziale Schichten, Stände, Klassen aus allen europäischen Ländern und Völkern gleicherweise und gleichberechtigt beteiligh sind ohne Rücksicht auf ihre Herkunft, sogar weniger noch auf die soziale als auf die nationale Herkunft der Magister und Studenten" (Grundman 1964: 17).

51 Dit geldt voon de mees te Europese universiteiten in de achthiende eeuw. Over Oxford merkt Stone op" "During the late 17 th and the 18th centuries this system of social and economic symbiosis between rich and poor broke down, and the llatter were progressively squeezed out of the university" (Stone 1975c: 73).

52 De wet van 1815 herstelde de academische schermmeester, dansmeester, pikeur, muziekmeester en tekenmeester weer in ere. Bij besluit van de minister van Publiek Onderwijs, Nationale Nijwerheid en Koloniën van 10 Januari 1821 werd aangekondigd dat openwallende vacatures van deze posten niet meer ingevuld zouden worden (Huizinga 1951 b: 65).

53. Tot die privileges behoorden onder andere de vrijstelling van tol, weggelden en schoorsteengeld, wrijstelling wan de accijns op wịn, bier en tabak, vrije zitplaatsen in de academiekerk en het feit dat studenten niek onderworpen waren aan de gewone burgerlijke rechtspraak, maar hun daden zo nodig moesten verantwoorden voor een eigen rechtbank

54 "Omstreeks 1840 herkende men hier den student nog aan 'onmiskenbare teekenen': een groen buis met gladde knoopen, een rood vest, een blauwe pet met in zilveren lettertjes civis academicus" (Huizinga 1951b: 190). 
kamerjas die echter ook buitenshuis gedragen werd (Kampman 1989: 45-46; Peeze 1986: 85). Het ontwerp van de Commissie Kemper werd weer gekenmerkt door een op stand en hiërarchie gebaseerde visie op hoger onderwijs. Vanuit dat gezichtspunt lag het voor de hand de gymnasia weer tot het hoger onderwijs te rekenen. Het gymnasium was immers de eerste trap in de ontwikkeling van een persoon tot volwaardig lid van de geleerde stand. Rondom 1800 had die standsgewijze onderwijsorganisatie korte tijd ter discussie gestaan (Fortgens 1958: 131-136; Vos 1973-4; Noordman 1981). G.C.C. Vatebender, rector van de Latijnse School te Gouda, bepleitte toen al radicale hervormingen (Boekholt en De Booy 1987: 93). Hij betitelde het als een onbegrijpelijke dwaasheid "om door het instellen van erfelijke Voorrechten, Ordens en Adelstand ook reeds wezens te vereeren die nog niet geboren zijn." Hij sprak er zijn verwondering over uit "hoe deze uitgebeelde en erfelijke waardigheden zich ergens staande houden, waar gezond verstand, Staatkunde, Wijsbegeert en kennis van het waar belang eenes Volks plaats vinden". Dit selectieprincipe, of liever gezegd de afwezigheid van selectie, bevorderde naar zijn mening luiheid en uilspatting onder de rijken. Terwijl het de eenvoudige burger aan motivatie ontbrak om hogerop te komen, "daar hij vooraf weet dat hij tot zulke post nimmer geroepen zal worden; dat de weg voor hem geslooten is, en alléen openstaat voor hun die, door de geboorte en de verdervene Staatkunde, daartoe verordend zijn. (...) Vernietigd zij (...) alle voorrecht op geboorte, vermogen of bezitting gegrond. Als burgers van eene maatschappij behoort aan ieder, zonder onderscheid, dezelfde aanspraak op achting, aanzien, ambten, bevordering. Alleen verdienste moet beslissen" (Vatebender 1802b, in Lenders 1988: 53-54; Vos 1973-4).

De Commissie Kemper koos voor een indeling van het onderwijs op basis van hiërarchie en segmentering. Ze volgde ook de traditionele hiërarchie van faculteiten. De Commissaris voor de Binnenlandse Zaken kwam daartegen in verzet in zijn ten behoeve van de vorst opgestelde commentaar op het Rapport: "Art. $53(56,57)$. Men heeft in dit artikel, ten aanzien der faculteiten, de volgorde behouden, waarin dezelve voorheen gerangschikt werden, en voor zooveel het volgen van dien rang bij dit artikel betreft, heb ik daartegen geene bedenkingen. Dan ter wegneming van die onaangename distinctie, welke daaruit voorheen ontstond, vinde ik mij verpligt (...) [vast te stellen] om jaarlijks den rang der faculteiten te verwisselen en die faculteit als de praesidiale te beschouwen, waartoe de tijdelijke rector behoort" (in De Geer 1869: 255). Naast een hiërarchie van faculteiten kende het ontwerp van de Commissie Kemper eveneens een hiërarchie van universiteiten: De Leidse universiteit: die als troost voor de geleden verliezen als gevolg van een buskruitramp op 12 januari 1807 al tot Koninklijke Hoogeschool verheven was - stond aan de top; wat in het Organiek Besluit onder meer tot uitdrukking kwam in het 
aantal leerstoelen dat Leiden kreeg toegeweżen.

Een ander punt waar in het ontwerp van de Commissie Kemper de standsmatige opvatting van hoger onderwijs tot uitdrukking $\mathrm{kwam}$, was de herinvoering van de volledige studievrijheid voor de student. "Waaromtrent der geleerden gevoelens verschillen"; zo reageerde de Raad van State op het rapport van de Commissie Kemper, "betreft de vraag, of het al dan niet nuttig zij aan de leerlingen een orde in de loop der studiën voor te stellen. Bij de Fransche universiteiten is zulks gedaan: dan het heeft in ons land weinig bijval gevonden. De commissie van den jare 1809 heeft over deze vraag zeer belangrijke en verstandige aanmerkingen medegedeeld, welke der lezing overwaardig zijn; zij vermeende, dat tot zekere hoogte toe een orde van studiën kon ontworpen worden, welke niet als eene in alle hare uitgebreidheid, ten strengste verbindende regelmaat zou moeten beschouwd worden, maar nogthans als een voorschrift, 't welk het te wenschen zou zijn, dat alle studenten konden volgen, en hetwelk derhalven alleenlijk naar de omstandigheden moest vatbaar zijn voor uitzonderingen en wijzigingen, door professoren om wijze en gewigtige redenen toe te laten, wanneer het nut der leerlingen zulks zou schijnen te wereischen". Volledige studievrijheid paste in een onderwijssysteem dat de introductie in een bepaalde stand nastreefde. Het was een traditionele verworvenheid van het student zijn, en het stelde studenten in staat het met hun studie niet te nauw te nemen ${ }^{35}$. Studenten die zich in hun gedragingen te buiten gingen waren in de achttiende eeuw $w^{56}$ een bekend fenomeen: "De luiheid en het losbandige gedrag van de student was al eeuwen lang een gemeenplaats. Maar in de achttiende eeuw zwollen de klachten over misstanden aan de universiteiten aan tot een doordringende klaagzang" (Roelevink 1987: 21). In het begin van de negentiende eeuw was dat beeld zeker niet verdwenen ${ }^{57}$. Wanneer in de organisatie van het onderwijs in plaats van de introductie in een

55 "Evenmin als een toelatingsexamen kende de achttiende eeuwse Nederlandse universiteit cen vast, in jaren ingedeeld curriculum dat de studenten met goed gevolg moesten doorloper. Niet de academie of de docenten bepalden hoe de studenten hun studie moesten opbouwen, maar de leerlingen zelf (Roelevink 1986: 17).

56 Overigens niet alleen in Nederland. Schelsky laat zich in gelijkluidende termen uit over de situatie atan de Duritse universiteiten in de achttende eeuw: "[D] He Studenten hatten sich von der eigentlichuen Sinnverpflichtung der Universität, dem Studium, ün ihrer Lebensweise gelöst, ihre studentische Freiheit zu einer selbständigen Existenzform ausgebaut, die parasitär war" (Schelsky 1971: 23).

57 Het Verslag van den Staat der Hooge, Middelbare en Lagere Scholen over het jaar 1818 (Algemeene Konst en Lutterbode 1819:484) spreekt over het wangedrag van de studenten in de volgende termen: "Zal men, in dit latste opxigt, niets meer te wenschen overig houden, dan moeten de studenten en de Hoogleeraren zelwe die begrippen üt hun geheugen bannen, volgens welke Akademieburgers zich als een bewoorregten stand willen beschouwd hebben." "[H]et opschift eener Hoogeschool moest overal zijn: "School van wijsheid" het is bij ons, "School van losbandigheid"s (Iets 1845: 25). Opzoomer (1849: 11) omschrijft het hoofdgebrek van de hogescholen kort en bondig als "Er wordt slecht gestudeerd en ex word" slecht geleefd." 
statusgroep het individuele leerproces en de leerprestaties voorop komen te staan, dan is het natuurlijk met die studievrijheid gedaan ${ }^{58}$. Dat leerproces is immers gebaat bij een bepaalde, voorgeschreven volgorde. De relatie tussen studievrijheid en een standsgeoriënteerde onderwijsorganisatie is overigens al te vinden bij W.P. Metzger (1955: 113): "The German's pride in these two freedoms [Lehr- en Lernfreiheit] can be attributed in part to the status they conferred and to their significance as patriotic symbols. To the university student, coming from the strict and formal Gymnasium, Lemfreiheit was a precious privilege, a recognition of his arrival at man's estate. To the university professor, extremely sensitive to considerations of social esteem, Lehrfreiheit was a dispensation that set him apart from the ordinary civil servant. In a nation still aristocratic and feudalistic in its mores, caste considerations thus underlay the loyalty to academic freedom."

Het Organiek Besluit nam in deze kwesties een middenpositie in (Kemper 1816: 9; 21; 33). Vergeleken met de situatie gedurende de achttiende eeuw, stelde het Besluit regelgeving voor. Tegelijkertijd werd een aantal traditionele verworvenheden verbonden met het hoogleraar- of studentschap in ere hersteld. Het Organiek Besluit werd ook als zo'n compromis ervaren. Tydeman (1828) omschreef de organisatie van de academische studies in het Organiek Besluit als het "gecomposeerde stelsel", "eene soort van transactie tusschen het voormalige en het Fransche stelsel". Kenmerkend voor het "oude-of oribepaalde stelsel" waren de volledige vrijheid van de student, de sterk variërende studieduur en het nagenoeg ontbreken van examina. Daarnaast onderscheidde hij het "Fransche stelsel", waar de "ouderdom der leerlingen, hun bevoegdheid de studiën te beginnen, de gang en de duur der studie zelf, de stof der lessen, allles was bepaald, terwijl verplichte certificaten van trouw collegebezoek en precies voorgeschreven talrijke examens de nauwkeurige uitvoering der bepalingen moesten waarborgen" (Huizinga 1951b: 52).

De discussie over het hoger onderwijs van 1828 en 1848 concentreerde zich met name op het behoud, de afschaffing of de herinvoering van de privileges die van oudsher met het hoger onderwijs verbonden waren: de lengte van de academische vakantie ${ }^{59}$, de studievrijheid van de studenten ${ }^{60}$, de zin van exa-

58 "En wilt gij nu weten, waarom ons Hooger Onderwijs niet goed is? (...) Om de eenvoudige reder: dat wij eigenlijk geen Hooger Onderwijs hebben (...) Men gaat naar eene Academie om eenige jaren van zijn leven wrolijk en onbezorgd door te brengen, en als Doctor ergens in, weer thuis te komen. De studie is en noodzakelijk kwaad en daaraan doet men zo min mogelijk. Waarom zou men? Met ijver talent en geleerdheid krijgt gij geen ander voorregt, dan de doctorstitel aan jeder geeft, ook all werd hij op zijne examina doorgelaten, omdat hij er toch nooit iets van leeren zou" (Student 1849: 12).

59 "Nogeen ander misbruik is langzamerhand ingeslopen. Vier wijt matanden, het is geen overdrijving, worden er gewoonlijk geen collegies gegeven, om niet te spreken van de dagen dai men buten dew wakantietijd, om allerlei, soms beuzelachtige redenen, met wederzijdsch goed winden vakantie neemtt" (Kam 1865,12 , Zie ook Siegenbeek (1828). 
meneisen $^{61}$, het verloren aanzien van de geleerde stand ${ }^{62}$ etc. Van Heusde nam in zijn 'Brieven over de aard en de strekking van Hooger Onderwijs' (1829) in de kwestie van de studievrijheid een middenpositie in. Vanuit zijn affectie met het ontwikkelingsdenken van de historische school baseerde hij zijn onderwijsfilosofie op de diverse ontwikkelingsstadia van het kind, maar hij hield daarbij tegelijkertijd vast aan een standsgeoriënteerde onderwijsorganisatie ${ }^{\text {ti }}$. Daardoor was van Heusde (1829: 186) in deze tot enig geschipper gedwongen: "Maar ook dat bepaald voorschrijven van alles, zoodat er niets aan eigene keus, aan eigene werkzaamheden overgelaten word $t$, dat strijdt met de natuur des jongelings, die daarom het gymnasium verlaten heeft, omdat hij nu in staat was geworden, om zich zelven in zelfstandigheid te oefenen. Waarmede ik niet bedoele, dat men de studiën geheel vrij moet laten, gelijk sommigen bij ons, als +++ , willen en het inderdaad te Munchen ingevoerd is: verre vandaar! Onze universiteiten, ik herhaal het, moeten Hoogescholen blijven en hoe hoog, hoe vrij, hoe liberaal het onderwijs daar zij, scholen moeten zij zijn en blijven, en geene scholen zijn denkbaar zonder orde en wel geregeld onderwijs. (...) Maar alles voor te schrijven, bijvakken zoo wel, als hoofdvakken, neemt men zoo ligt alle lust en denkbeeld van eigen studie weg."

Misschien wel het belangrijkste punt van de discussie in 1828 vormde de vraag of de cursussen zich over een half jaar, zoals in Duitsland ingevoerd was $^{\text {(it }}$ (B.L.G. 1824: 21), dan wel over een jaar, zoals in Nederland in de wet van 1815 was vastgelegd ${ }^{65}$, zouden moeten uitstrekken. Het belang van deze vraag is terug te voeren op het feit dat zij tot een keuze dwingt tussen studie-

60 "[H] studeren zal ex, geloof $\mathrm{ik}$, niet slechter om gaan als er zoo iets van het heilige moeten bij kom t" (B.L.G. 1824: 370). “ [A]lle verpligting en aamwjizing wan bijzondere vakken van studie uitdrukkelijk op te heffen, zou hier al die lessen destruenen die niet of tol de broodstudie geacht werden te behooren, of althans van ouds aan de Academiën ew tram waren" (Tydeman 1828: 20).

61 "V]erander slechts de wet op de examens, en de Doctoren 'zonder eenige kennis." zijn weldra niet meer the winden. De examens moeten anders worden afgenomen dan thans geschiedt, nu elke afwijzing eene zeldzamheid, een wonder is" (lets 1842: 8).

62 "[D|atar de verlichting thans in volle stroomen over geheel het volk is uilgestort, daar ieder in het openbatar op hoogen toon schrift, en spreekt, al wat hij verkiest (...) zoo is er volstrekt niets bijzonders meer in eene betrekking, wartoe ieder een de bekwaamheden heeft; ja men kan even zedig zeggen: $\mathrm{k}$ wil professor worden als Baardschraper, Doodgraver, Kousewever" (B.L.G. 1824: 3). Hoogleraren waren soms gedwongen ter aanwulling van hun inkomem voor studenten kostschool aan huis te houden (Tydenan. 1828).

63 "[I] eder moet voor zijne bestenming eene bijzondene opleiding ontvangen, en de laatstgenoemde, de anstainde studenten, hebben gewis eene veel hoogere beschaving, dan de overige, nodig. Zoo will de natuur dat $^{2 i j}$ zich afscheiden" (Van Heusde 1829: 143).

64 "Het is bekend, dat de kunst, on twee Academische jaren in ển te hebben, eene vroege Duilsche bezuiniging is" (Tydeman 1828: 9).

65 "De wet van 1815 schueef uitdrukkelijk voor, dat het geheele systeen eener wetenschap in een bepaalden tijk, gewoonlijk een jaar moest worden afgehandeld. Dit was een bescherming van den student tegen den professior, die hem zou willen noodzaken, jaren achtereen de colleges te volgen" (Huizinga $1951 b: 169)$. 
vrijheid aan de ene kant - gekoppeld aan een standsgewijze organisatie - of het invoeren van een verplichte volgorde in de academische studies, een academisch curriculum - waarbij het leerproces centraal staat. Achter de halfjarige cursusduur schuilt (aanvankelijk) het idee dat elk half jaar alle cursussen gegeven worden, waaruit de student een keuze maakt. Daardoor is afstuderen niet meer aan een heel studiejaar gebonden, maar wordt dat ieder half jaar mogelijk. Dat zou tijdwinst voor studenten en dus besparingen op kunnen leveren. Als tegenwerping worden legio problemen opgeworpen. Wanneer men vasthoudt aan het idee dat studenten gedurende een cursus een overzicht over het gehele vakgebied aangeboden wordt - zonder dat men een bepaalde vaststaande voorkennis kan veronderstellen - moet dat noodzakelijkerwijs tot oppervlakkigheid leiden (Inlichtingen 1828: 8; B.L.G. 1824: 12). Bovendien moeten de cursussen opgedeeld worden", met het nadeel dat "de beide helften nu even groot moeten worden, naar de verdeeling van het jaar; terwijl bij onze inrigting, men in de afscheiding en behandeling der hoofddoelen van zijn onderwerp niet behoeft te zien op die uitwendige omstandigheid" (Tydeman 1828: 9). De series lectionum van de zuidelijke universiteiten kenden wel een halfjaarlijks rooster. Maar dat is in de ogen van Tydeman slechts schijn: "Men zie art. 1 en 2 van 't Luiksch Statuut van 1827; en de series lectionum dier universiteiten van ' $t$ tweede halfjaar, alwaar men telkens vinden zal: lectiones continuabit" (Tydeman 1828: 43). Wanneer men echter afstand doet van het idee dat iedere cursus een volledig overzicht van een vak moet geven, maar de cursussen plaatst binnen een curriculum, waarbij iedere cursus voorkennis mag veronderstellen, verdwijnt het merendeel van de bezwaren ingebracht tegen de halfjarige cursus. Het misverstand dat Tydeman (1828 Bijlage B) naar aanleiding van de vraag van de Commissie 1828 naar de wenselijkheid van het invoeren van een halfjarige cursusduur signaleert, brengt die omslag in beeld: "Onder de vraagpunten welke aan de overweging der Commissie voor het hooger onderwijs zijn onderworpen geworden, bevindt er zich een betrekkelijk de halfjarige cursus. Deze vraag is tot nog toe steeds behandeld in de veronderstelling, dat dezelfde cursus tweemaal in een jaar zouden gegeven worden en dat de tijd der studiën zoude worden verkort. Hiertegen is met regt aangevoerd, dat de werkzaamheden der Hoogleeraren boven mate zouden worden vermeerderd en de lessen te oppervlakkig zouden worden. Maar bij de Commissie is, volgens de considerratiën van eenige leden de vraag ontstaan, of de cursus niet op eene andere wijze halfjarig zouden kunnen gemaakt worden, namelijk door de cursus, welke nu gelijktijdig door denzelfden Hoogleeraar

66 Bijvoorbeeld Medicina forensis in Medicina legalis en politica; Economigue politique in Valks-en Statswirthschaft; Statis tiek in Theorie der Statistiek en Nationaal- en Statskunde; Encyclopaedia juridica zou gescheiden worden van Encyclopaedia politica (Tydeman 1828: 9). 
elk in twee of drie of vier lessen wekelijks, gedurende het geheele jaar gegeven worden, zóo op elkander te laten volgen, dat sommig in het eerste, de andere in het tweede halfjaar werden afgehandeld" (Tydeman 1828: 42). Onder de voordelen van een dergelijke interpretatie van de halfjarige cursus rekent Tydeman de concentratie van gelijksoortige leerstof en de specifieke volgorde van de cursussen die zou ontstaan.

Geleidelijk zou in het verdere verloop van de eeuw het leerproces het standsbesef opvolgen als spil waaromheen het (hoger) onderwijs georganiseerd dient te worden. Verbonden met de notie van individueel leerproces is het invoeren van examens om de vorderingen te toetsen. Kenmerkend voor het achttiende eeuwse onderwijs was het ontbreken van een serieuze toetsing van de resultater ${ }^{67}$. Hoe hoger het onderwijs, des te geringer de zwaarte van de toetsen: "Zware examens stonden haaks op een standenmaatschappij die uiteraard meer waarde hechtte aan hoge geboorte dan aan geestelijke begaafdheid" (Roelevink 1987: 25-26). Uiteraard stuitte het invoeren van examens bij diegenen die de hogescholen in de oude staat wilden handhaven op bezwaren (Alberti 1847): "Van de Akademiën maakt men instituten: het zullen in het groot lyceën en gymnasiën worden: ja, het scholastieke der middeleeuwen wordt meer en meer ingevoerd, ten voorbeelde, die graden van cum laude en summis cum laudibus bij de examens, even als bij de lagere scholen. Men zoekt daardoor te bewerken, dat er beter gestudeerd zal worden, maar alle eigen ontwikkeling gaat weg door alles voor te schrijven, en wat moet er van de professoren worden? Welk groot man buiten 'slands zal hier willen komen om bloot praeceptor en paedagoog te worden? Om den broode zal men professor worden, uit noodzakelijkheid zal men de lessen bijwonen en wat moet daarvan het gevolg zijn? Nachtelijke duisternis" (Van Heusde, omstreeks 1828, in De Geer 1869: 272). In de loop van de negentiende eeuw werd het losbandige studentengedrag geleidelijk beteugeld (Van Heusde 1829: 207; Tydeman 1828; Huizinga 1951b: 187; Roelevink 1986: 108). De studievrijheid werd meer ingeperkt terwijl er een voortdurend trekken en duwen ontstond om een verzwaring van de exameneisen". "Zoekt men het voorname kenmerk van het hooger onderwijs juist in de vrijheid om naar keuze lessen te volgen of oefeningen bij te wonen, dan geeft de wet slechts teleurstelling; want, zoo als wij

67 "Aan de universiteiten zelf ontbrak iedere werkelijke toetsing" (Roelevink 1987; 26).

68 "H]et onderwijs [wordt] gansch en al (...) ingericht on den discipel bekwam te maken voor het eximen: vandaar alle wrijheid aam den leermeester benomen ü de keuze en de mate en de wijze van mededeeling der wetenschappelijke stof: de meester is slaaf geworden van een bijdoel, en de leerling verliest onder dien dwang allen hust in de studje, alle liefde en vatbaarheid voor wetenschap: hij wordt eer stomper dan bevattelijker" (Brill 1864: 21). "Niet oneigenaardig wordt de eeuw, in wellke wij lewen, die der standbeelden en genootschappen genoemd" voor ons Nederlanders zoude zij met evenveel regt met den natm kunnen worden bestempeld van eeuw der examina" (Staatcommissie 1852: 2). Zie ook Kan (1865). 
zagen, is de vrijheid thans tot het uiterste beperkt - het vakonderwijs heeft haar verdrongen", aldus constateert J.L. van Geer (1887a: 96).

Het doel, de aard en de concrete invulling van examens was één belangrijk discussieonderwerp in het hoger onderwijs. Een ander belangrijk thema werd gevormd door de verhouding tussen gymnasium en universiteit. Het Organiek Besluit had de gymnasia weer tot het hoger onderwijs gerekend. De kwaliteit van de Latijnse Scholen werd echter algemeen te laag geacht (Terpstra 1838; Van Heusde 1829; Vitringa 1860; Fortgens 1958: 126-127; 202; Krul 1985: 40). De commissie voor het hoger onderwijs, ingesteld bij Koninklijk Besluit van 13 april 1828, was expliciet gevraagd zich te beraden over maatregelen tot verbetering van de Latijnse Scholen. Het gymnasium kwam in een complex krachtenveld te staan. Er was een grote groep die vast wilde houden aan de klassieke Latijnse School, die het gymnasium vooral wenste te zien als eerste trap van hoger onderwijs, als voorportaal tot de geleerde stand ${ }^{69}$. Dat was de mening van de meerderheid van de Commissie van 1828 evenals die van Van Heusde die zich hevig verzette tegen het verdwijnen van het Latijn als academische voertaal; een proces dat zich met name in Duitsland al gedurende geruime tijd (in Halle al sinds 1711 ) aan het voltrekken was: "Ik heb altijd al het goede en voortreffelijke, dat ik op Duitsche akademiën aangetroffen heb, hoog gewaardeerd; maar dezen overgang van het gymnasium tot het hooger onderwijs, en deze voorbereiding tot de hoofdvakken van hetzelve, miste ik overal: (...) Hoe groote vorderingen iemand in de oude literatuur gemaakt hebbe, komt hij daar op de universiteit, zoo is het hem moeijelijk te doorzien, waartoe dat alles hem dienen moet. De lessen worden in de moedertaal gegeven: waartoe dus zijne vorderingen in het Latijn? Al terstond gaat hij aan zijn hoofdvak: op een ogenblik is hij theoloog of jurist of medicus geworden. (...). Met beroemde geleerden in Duitsland, die ook onze academiën kenden, en het goede, waar het ook te vinden is, opmerkten en waardeerden, heb ik meermalen hierover gesproken (...). Zoo er een middel is, zeiden zij, om de broodstudie voor te komen, die pest der akademiën, is het de klassieke literatuur, en hetgene daar mede in verband moet staan, het behoud der Latijnsche taal" (Van Heusde 1829: 194-195). Vanuit de hogeschool kwamen echter ook geluiden die scherpere en ten dele ook andere (toelatings)eisen bepleitten en in het verlengde hiervan de vrijwel exclusieve aandacht voor Latijn en Grieks op het gymnasium afwezen. Geleidelijk werd de roep vanuit de hogescholen om meer natuurwetenschappen en moderne talen in het curriculum van het gymnasium sterker. C.W. Opzoomer (1849: 21) bijvoorbeeld vond het geheel misplaatst, dat sommige geleerden in het vaak jammerlijk misvormde Latijn het behoud wilden zien

69 "Laat men de Latijnsche scholen blifven hetgeen ze zijn, speciale inrigtingen ter" voorbereiding tot het Academisch Onderwij"s" (Over het onderwijs 1840: 166). 
van de ware wetenschap $\mathrm{p}^{70}$. Hij wilde aan het Nederlands een prominente rol geven; het academisch jaar zou met een toespraak in die taal geopend dienen te worden en ook de examens zouden in de moedertaal afgenomen moeten worden. Zoals reeds gesignaleerd waren inmiddels aan de Latijnse Scholen zelf tweede afdelingen ingericht waar ook Nederlands, Frans, Duits, Engels en vakken als natuurkunde, scheikunde, natuurlijke historie, staathuishoudkunde, kosmografie, boekhouden en werktuigkunde gedoceerd werden (Dasberg en Jansing 1977: 213; Fortgens 1958: 214).

De poging van de regering om in 1845 paal en perk te stellen aan het lage eindniveau van sommige Latijnse Scholen door van overheidswege een toelatingsexamen $^{71}$ - en nu een staatsexamen - voor de universitaire studie in te stellen, liep op een mislukking uit. Onder andere ${ }^{72}$ wegens de drastische daling van de studenteninstroom werd bij Koninklijk Besluit van 1850 reeds vastgesteld het toelatingsexamen nog uitsluitend als controle op de Latijnse Scholen te handhaven. In juni 1852 werd besloten dat er in dat jaar geen staatsexamen zou plaatsvinden. In augustus 1852 ging men over tot volledige afschaffing van het examen; aan de toelating tot de hogeschool werd nu zelfs geen enkele eis meer gesteld. Een jaar later besloot men weer terug te keren naar de situatie van voor 1845 (Wingelaar 1989: 9). Curatoren of scholarchen van de Latijnse Scholen kregen weer het recht van bevordering tot de universiteit (het zogenaamde jus promovendi); daarnaast was het aspirant-studenten weer mogelijk een academisch toelatingsexamen af te leggen (Dasberg en Jansing 1977: 213-214).

Stond enerzijds de aansluiting tussen Latijnse School en universiteit ter discussie $^{\text {i3 }}$, anderzijds noopte de discussie rondom de wettelijke organisatie

70 Opzoomers afkeer van het Latijn is verbonden met het afwijzen van een centrale plaats wan het Romeinse recht in de rechtsgeleerde opleiding: "Het Romeinsch regt is noodug woor den regigeleerde, en dezen zjjm zeer zeldzarm, het is geheel onnoodig voor den advokaat, den regter, veel meer nog den stabtsman" (Opzoomer 1849:21). Zie ook hoofdstuk vier.

71 Het Staatsexamen geeft een indruk van wat men in het midden van de vorige eeuw meende te kunhen verlangen van de a.s. academieburger en hoe ver de Latijnse scholen met hun onderwijs kwamen. In de volgendle groepen wan vakken wetd geẻxamineerd: 1. Grieks, 2. Latiyn, 3. Oude geschieden aardrijkskunde, Griekse en Romeinse oudheden en letterkundige geschiedenis, Griekse en Romeinse fabelleet, 4. Middel-, nieuwe en vaderlandse geschiedenis, nieuwe aardrijkskundie, 5. Nederlandlse taal en stỉl, 6. 'Wiskunat'. (Fortgens 1958: 216-217).

72 Boekholt en De Booy (1987: 127) wijzen op de principiele bezwaren die van doctrinair-liberale zijde op de instelling van statsexamens woor de toelating tot de universiteit werden geuit.

73 "Wij weten wel, dat het veler verlangen is, de Gymmasia te vervormen tot kleine Hoogescholen, watr de anstande geneesheer reeds physische kennis bil xitstek, en de aanstaande regtsgeleerde reeds juridische wetenschap komt opdoen, ten einde de Hoogescholen te veranderen in Seminaria voor geneesheeren, advokaten en gadgeleerden; doch wij hopen, dat in Nederland hel begrip eener. Universiteit-Inhighing zal blijven zegevieren, en daarmede ook de Gymnasia bljven aanbieden, wat de middelbare school volgens de Regering leveren moet "verdere ontwikkeling van zien, denken en kernen" en oefening in die kundigheden "welke teder behoeft, die zich tot eenige zedelijke en stoffelijke zelfstandig. 
wan het middelbaar onderwijs tot het opnieuw preciseren van de eigen aard en functie van het hoger onderwijs. Het tot standkomen van de middelbaar onderwijswet van 1863 werd als een bedreiging voor het hoger onderwijs ervaren. " [Z]ouden er niet zijn, die oordeelen, dat het al duidelijker en duidelijker wordt, hoe de Hoogeschool haren tijd gehad heeft? De oprichting van zoo vele middelbare scholen in deze dagen brengt voorzeker menigeen de vraag op de lippen: waartoe is daarnevens het hooger onderwijs nog noodig?" (Brill 1864: 3). Volgens W.G. Brill hadden de geneeskundige faculteiten het grootste gevaar te duchten, nu de regering te kennen had gegeven dat om de volledigste bevoegdheid tot de uitoefening der geneeskunst te verkrijgen, niet langer academisch onderwijs vereist was.

De geneeskundige faculteit zou vervolgens de natuurkundige in haar val meeslepen. De letterkundige faculteit liep eveneens gevaar door de propaedeutische studies naar het gymnasium over te brengen. Van de twee resterende faculteiten dreigde de godgeleerdheid te worden opgeheven omdat het Rijk niet aan éên enkel kerkgenootschap privileges mocht toekennen. Resteerde de faculteit der Rechtsgeleerdheid. Maar een universiteit kan niet uit slechts één faculteit bestaan ${ }^{74}$. De argumenten die Brill van stal haalde om het voortbestaan van de universiteiten te bepleiten, berustten op het verheven karakter dat het hoger onderwijs traditioneel toegemeten werd. De middelbare school moest dienen "om de jeugd voor eenig beroep, voor de eene of ander nijvere betrekking bekwaam te maken. (...) Nuttige kennis brengt zij aan; praktische menschen vormt zij, geen denkers, die zich van het leven terugtrekken, om zich in bespiegelingen toe te geven". De denkende mens mocht zich niet verliezen in de praktijk: hij was bestemd tot theorie. "Deswegens nu is het noodzakelijk, dat nevens het zoogenaamde Middelbare Onderwijs (...) eene andere leer, die het waarlijk menschelijke te midden van het stoffelijke, het eeuwige te midden van het eindige tot haar voorwerp heeft, in eene instelling van onderwijs vertegenwoordigd $z \mathrm{ij} .(\ldots)[\mathrm{E}] \mathrm{r}$ is eene behandeling der wetenschap zelve noodig, waarbij deze de waarheid openbare, die immers op alle gebied één is, dezelfde waarheid, welke den inhoud der godsdienst uitmaakt. De wetenschap nu, zoo onderwezen, ziedaar het voorwerp van het Hooger Onderwijs." Het grootste gevaar dat de hogescholen bedreigde, kwam volgens Brill voort uit het feit dat aan de overgeleverde schat uit de klassieke oudheid geen onvoorwaardelijk gezag meer werd toegekend, maar dat de kritiek zich boven alles plaatste. "Wat moet van die kritische, niets als absoluut erkennen-

heid verheffen wil" (Van der Heim 1862:4).

74 "En buitendien, wanneer het zoo ver gekomen ware, zou het niet aan redenen ontbreken, om ook nog deze ééne Faculteit op te heffen: of zou ten haatste het onderwijs in nog meer deelen der rechtswetenschap niet mede aan de Hoagere Burgerschool opgedragen kunuen worden?" (Brill 1864: 5). 
de methode het gevolg zijn?" (Brill 1864: 6-13).

Toch was de opvatting van hoger onderwijs, zoals die in 1864 nog hartstochtelijk door Brill verdedigd werd, op zijn retour. In 1860 signaleert De Bosch Kemper veranderingen in de ideeën over het hoger onderwijs: "Het ideaal van het akademisch onderwijs is lang daarin gezocht, dat men door het hooger onderwijs zou gevormd worden tot een zelfstandig denker, terwijl men op andere inrigtingen van onderwijs alleen zou worden onderwezen. Een edeler opvatting van de zamenleving moet dat onderscheid doen verwerpen. De inspanning der zelfvorming, onder leiding van vrijzinnige voorgangers, bij het akademieleven, als het kostbaarste kleinood van een beschaafd volk boven alles te handhaven, moet bij alle klassen der maatschappij aangemoedigd worden. Het hooger onderwijs moet niet van het lagere onderscheiden zijn in wezen, dat het lagere niet behoeft op te wekken tot zelfstandigheid, maar slechts in omvang. Alle menschen zijn tot een zelfstandig leven bestemd, maar ieder heeft voor een onderscheiden kring zijn zelfstandig oordeel te vormen: Terwijl de handwerksman in den kring zijner levenservaring tot zelfstandigheid zich vormen moet, moet de staatsman een zelfstandig oordeel uitspreken over den toestand van Europa. (...) De geschiedenis van de verdeeling van het onderwijs in hooger, lager en middelbaar enz., toont duidelijk aan een streven om allen zoveel mogelijk te vormen tot een zelfstandig geestelijk leven. De onderscheidene instellingen van onderwijs leiden, bij de tegenwoordige levensbeschouwing, slechts op tot onderscheidene levensbetrekkingen" (De Bosch Kemper 1860: 296-297). Enkele jaren later, in de Handleiding Staatsbestuur, is De Bosch Kemper (1865: 915) nog explicieter: dat de Latijnse Scholen niet tot het middelbaar onderwijs worden gerekend, noemt hij kortweg een gebrek der wet (De Bosch kemper 1865: 918). Dat Kemper de Latijnse Scholen ooit tot het hoger onderwijs rekende wijt hij aan de druk der toenmalige omstandigheden: "Door den nood gedrongen nam men, in afwachting van de geheele regeling van het middelbaar onderwijs, de organisatie van de latijnsche scholen in het besluit omtrent het hooger onderwijs zelf op, ofschoon de gymnasia niet tot het eigentlijk hooger onderwijs behoorden. (...) Het hooger onderwijs kan van het middelbaar onderwijs niet zoo scherp onderscheiden worden, dat niet eenig hooger onderwijs gegeven wordt op de middelbare scholen, terwijl aan de andere zijde niet alle middelbaar onderwijs van de hoogescholen behoeft te worden uitgesloten; zoo is het genees- en heelkundig onderwijs voor een gedeelte middelbaar onderwijs, evenzeer als het aanleeren van de eerste beginselen van de Oostersche talen en van de eerste beginselen van het stellige regt. De scherpe afscheiding is niet mogelijk" (De Bosch Kemper 1865: 921-923).

Die veranderde opvattingen over het doel van alle onderwijs, namelijk dat in eerste instantie de vorming van zelfstandig denkende mensen moest worden nagestreefd, ziet De Bosch Kemper (1860: 297) weerspiegeld worden in de 
geschiedenis van de onderwijsmethode. Aan het begin van de negentiende eeuw vormde het dictaatcollege nog steeds de belangrijkste onderwijsvorm ${ }^{75}$. Volgens J.A.C. Rovers (1875: 35) kwam daar tijdens de onderwijsloopbaan van Van Heusde een kentering in: "[N]iet lang beviel hem dat aanhoudend dicteren, waardoor jonge menschen meer aan een werktuig deden denken, dan aan een' tot het opnemen van goed zaad wel bereiden grond. Voortgaande met zijne voordragten in duidelijke en zuivere taal op te schrijven, waagde hij het eerst er van af te wijken bij de exegetische colleges, waar het zelfwerkzaam zijn der hoorders van zelf leidde tot een woord van opheldering en verbetering en soms de eene vraag de andere uitlokte. Van daar ging hijj verder en waagde zich eindelijk aan eene vrije voordragt, nooit even wel zonder zich op het te behandelen onderwerp degelijk voorbereid te hebben, en altijd enkele hoofdpunten in de pen gevende, waaraan men het gesprokene gemakkelijk kon vastknopen." Van Heusde was een echte overgangsfiguur. Vanuit het perspectief van de achttiende eeuw valt vooral op dat Van Heusde in zijn onderwijs niet uitsluitend het aankweken van eruditie nastreefde maar zich het opleiden van zelfstandig denkende mensen ten doel stelde ${ }^{\%}$. Van Heusde bleef echter de lezing van klassieke teksten daarvoor de enig aangewezen weg vinden. Daardoor ontpopte Van Heusde zich rond 1828 tot wellicht de meest prominente vaderlandse verdediger van de idee van de 'klassieke geleerde vorming": "Opleiding, vorming van den geheelen Mensch, met volledige bewustheid van hetgeen de Mensch is, en worden kan en moet: hiernaar streefde hij, voor zich zelven en anderen (...) Daarom vergenoegde hij zich niet, om den Mensch in de geschiedenis en rondom zich waar te neemen: deze waarnemingen waren hem slechts een middel tot gestadige navorschingen aangaande's Menschen aanleg en bestemming; den aard, het doel en het verband van kunsten en wetenschappen, die Goddelijke uitvloeisels van den menschelijken geest. De studie der Oudheid, de methode der Socratische philosophie, wees hem hierbij den regten weg en lichtte hem bestendig voor" (Star Numan 1839: 35; zie ook Cousin 1838).

Bij Van Heusde stond waarneming van de werkelijkheid op het tweede plan. Voor hem, wiens denken werd beheerst door ontwikkelingsideeën, ging het in onderwijs om de ontwikkeling van het wezen dat in aanleg aanwezig is",

75 "De regel was echter, dat op het college zell des professors eigen compendium werd voorgedragen en wel woordelijk gedicteerd. Het was volkomen rationeel gewrest in den tijd toen er nog geen handboeken bestonden. Omstreeks 1830 was deze gewoonte in Nederland nog zeer verbreid" (Hiluizinga 1951b: 169).

76. "Van Heusde sprak zijn leerling niet aan als aanstaand erudiet of uitverkoren 'uomo uniwersale', maar als redelijk mens. De student moest zijn eigen mens-zijn leren verstaan en ontwikkelen. Niet geheugen of ervaring, maar het analytische vermogen stond centraal" (Roelevink 1986: 312).

77 Als onderwijs methode stond Van Heusde de natwunulg voor: "[D]e methode om niets in den 
en in wetenschap om het doorgronden van het wezen dat zich in de werkelijkheid ontwouwde. In de hoofdstukken gewijd aan het onderwijs in geneeskunde en recht wordt getoond, hoe een zelfstandige waarneming van de werkelijkheid gedurende de negentiende eeuw een steeds belangrijkere rol in het onderwijs krijgt toebedeeld. Die ontwikkeling sluit aan bij het verleggen van de nadruk in het onderwijs op reproductie van bestaande kennis ${ }^{78}$ naar een orièntatie op een open toekomst. De universitaire studie kan niet meer alleen uit een kennisname van oude, vaststaande en klassieke bronnen bestaan, maar wordt de eerste fase van een kennisverwervingsproces dat zich over de gehele verdere carriere uitstrekt. Dan wordt het belangrijk zelfstandig kennis te kunnen vergaren ${ }^{79}$. Klikspaan roept de hoogleraren op de studenten zelfstandiger aan de slag te laten gaan: "Gij hebt hen altijd aan daadzaken, aan vaste beginselen, aan waarheden gekluisterd, gij hebt hen altijd de wetenschap naar uw model geknipt, door uwe bril laten zien (...) laat hen vrij, laat hen struikelen, opstaan, zich redden zoo als zij kunnen" (Klikspaan 1839-1841: 155). De dictaatcolleges verdwenen geleidelijk van het toneel ${ }^{\text {(D) }}$, evenals het instituut der prijsvragen. De wet van 1876 voorzag wel nog in een formele regeling ${ }^{\mathrm{Bl}}$, maar het instituut was toen al merkbaar op zijn retour (Van den Bergh 1988a: 43). De universitaire prijswraag was bedoeld ter aanmoediging ${ }^{82}$ van de studen$\operatorname{ten}^{\text {i3 }}$. Maar de prijsvraag leed aan dezelfde euvels als het dictaatcollege en de dissertatie: "Van Heusde zegt: 'onze wet van het jaar vijftien biedt eerepenningen aan allen die eene prijsvraag niet te diep, niet te nieuw, niet boven het bereik van jongelingen gaande, maar toch eene prijsvraag, volledig beantwoor-

Mensch te brengen, waarvan de kiemen niet reeds in zijne ziel of in zijn gemoed aanwezigg zijn, maar al de beginselen, van het goede in hem te ontwikkelen, en daardoor vooral het kwade te onderdrukken" (Star Numan 1839: 36). Van Heusde propageerde de socratische methode in het onderwijs orndat die aansloot bij de natumijke bestemming van de mens. Dat die visie naadloos paste in een standsgeorianteerde onderwijsopvatting behoeft geen verder betoog.

78 "Dissertatie, Compilatie. Voor geen greintje eigen oordeel of verstand; het is altijd al den duivel aanhaling wan " $t$ begin tot het einde" (Klikspaan 1839-1841: 168).

79. Dat idee kont onder andere natr voren in de context van de technische opleidingen: "De $C$. [iviel] Ingenieur is gedwongen, van de Akademie gekomen zijnde, altijd door te blyjen studeren; dit is bepaald een eigenaurdig kenmerk zijner betrekking. De uitvindingen, de nieuwe elkander opvolgende systemen, de vorderingen op wetenschappelijk of technisch gebied, zijn zoo talloos, zoo belangrijk, dat zijn geheele betrekking voortdurend een bron wan studie moet zijn. Daartoe moet hij geleerd hebben zelf studeren" (Oud-Student 1860: 20).

80 "In vele vakken is thet onontbeerlith, maar in Regten, Theologie, Philologie kunnen de boeken vrit getuakkelijk de collegiën vervangen. Nu geven deze omtrent hetzelfde als een boek, althans niet meer ${ }^{2 i}$ (lets 1842: 15-16)

81 leder janr moest een van de drie Rijksunversiteitten tien prijsvragen uitschrijven, twee in elke faculteilt. 82. "Zur Ermunterung in den Studien werden jährlich von der Universität zu Leiden 10, von der $2 u$ Utrecht 6, und von der zu Groningen 6 lateinische Preisfragen ausgeschrieben, deren beste Beantwortung eine goldene Medaille von 50 th. werth, oder diese Summe selbst erwirbt" (Fliedner 1831: 180).

83 "Waarvoor prijsvragen? Ten behoeve des jongutu" of ten behoeve der wetenschap? Volstrekt niet ten behoeve der" wetenschap; de academie is geen geleerd genootscha p" (Klikspaan 1839-1841: 112). 
den'. Van Heusde zat er met zijne bepaling kennelijk in. Niet te diep, niet boven het bereik van jongelingen gaande, is reeds eene bloote herhaling; niet te nieww, eene volslagen veroordeeling. Niet te nielww! een oud versleten, verjaard, opgewarmd, uitgezogen onderwerp dus. (...) Alleen zullen zij scherp toezien of het wolledig, zoo als van Heusde zegt, is behandeld, want daarop komt het altijd in de eerste plaats" (Klikspaan 1839-1841: 112).

De Wet op het Hoger Onderwijs van 1876 bracht op zich geen grote veranderingen. In 1872 had L.W.E. Rauwenhoff het rectoraat in Leiden neergelegd met een rede, tegen de voorschriften in uitgesproken in het Nederlands, over de verhouding tussen hogeschool en maatschappij. Daarin evalueerde hij de status die het Organiek Besluit van 1815 op dat moment nog bezat: "Wij zijn aan het Besluit van 1815 ontgroeid. (...) Sinds lang is het een erkende zaak, hoe groote waarde de nieuwere classieken hebben, als hulpmiddelen der beschaving. Die literatuur, vroeger als een zaak van liefhebberij beschouwd, is in het buitenland en ook bij ons het voorwerp geworden van ernstige studie en hier ook reeds opgenomen onder de leerstof van het middelbaar onderwijs. Maar onze wet dagteekent uit een tijd, toen men nog uitsluitend de classieken der oude wereld beschouwde als de ware leermeesters van den goeden smaak, en ons academisch onderwijs is in dit opzicht gebleven op de hoogte van 1815 . De beschaving is het hooger onderwijs voorbijgesneld, en de heroën van den nieuwen tijd, een Shakespeare en Göthe, zoeken nog te vergeefs een plaats in onzen tempel der wetenschap" (Rauwenhoff 1872: 26; 29).

In de wet van 1876 werd het lot van het Latijn als academische voertaal definitief bezegeld. De literaire en wiskundige propaedeuse werd van de hogeschool naar het gymnasium overgebracht. Voor G.J. Mulder vormde de wet van 1876 aanleiding om een geschrift van $E$. Brücke over de noodzakelijkheid van een gymnasiale opleiding voor geneeskunst-beoefenaren uit het Duits te vertalen, en van een voorrede te voorzien om nogmaals het belang van een brede, klassieke opleiding voor de geneeskundige te bepleiten. Mulder bestreed de opinie dat, nu Latijn en Grieks niet meer van direct belang waren voor de geneeskunde, ze in het geheel gemist zouden kunnen worden. De wet op de gymnasia (1876) was in zijn ogen een regelrechte ramp: "Zoo doende (...) werd aan de geneeskundigen op de gymnasiën minder van de oudheid geleerd en bedierf men de gymnasiën nog eenmaal, door, ten nadleele van goede studie der geneeskundigen, hier natuurwetenschappen in te halen, die slechts als opvoedende schets op een gymnasium behooren" (Mulder 1880: 16). De klassieken, en met name de klassieke vooropleiding op het gymnasium zijn belangrijk omdat zij de mens sieren, de ontwikkelingsgeschiedenis van de mens uit de barbarij tonen en bijdragen tot de ethische ontwikkeling, die vooral voor geneeskundigen zo belangrijk is. " $[\mathrm{H}]$ et komt er op aan, dat hij die vormende baan afgelegd hebbe, die de staat voor de eerste in rang ver- 
klaart, die hij voor zijne Geestelijken, voor zijne Regters en Pleitbezorgers en voor den hoogen Leeraars- en Ambtenarenstand voorschrijft" (Brüicke, in Brücke/Mulder 1880: 11).

Hoewel de H.O.-wet van 1876 grotendeels een bevestiging vormde van de aan de Nederlandse universiteiten gegroeide situatie, werden er ook veranderingen ingevoerd en bestuurlijke knopen doorgehakt. De instituten van privaatdocent $^{84}$ en buitengewoon hoogleraar ${ }^{\text {s5 }}$ werden ingevoerd; het aantal leerstoelen drastisch uitgebreid. Welke vakken het academisch examen moest omvatten werd niet meer in de wet geregeld, maar "aan een licht te wijzigen academisch statuut" (Van der Wijck 1898: 94) overgelaten. De bevoegdheid verbonden aan de academische examens werd gesplitst in een maatschappelijk en een wetenschappelijk domein. Voorts mocht Amsterdam haar Athenaeum omzetten in een gemeentelijke universiteit ${ }^{36}$. Dat maakte een - voorlopig $^{\mathrm{B7}}$ - einde aan het debat over het aantal hogescholen waaraan Nederland behoefte had ${ }^{\text {ss }}$.

84 "Er werden in 1876 in de Kamer dan ook wel stemmen gehoord, die op de voortreffelijke resulta. ten van het Duitsche stelsel wezen (...). Een der weinige stappen die men in de Duitsche richting deed, was de toelating van privaatdlocenten" (Huizinga 1951b: 291). Wegens de gelijktijdige verandering in het collegegeldstelsel - geen betaling meer per gelopen college maar per jaar - was het instituut van de privaatdocent een doodgeboren kindje (Van Geer 1887a).

85 "[H]et instituut der professores extraordinarïi, dat had kunnen dienen am uitnemende krachten voor de wetenschap te behouden, werd misbruikt on voor een deel het tractement van een gewoon hoogleeraar uit te sparen. Zoo verkeerde wat een zegen voor de universiteit had kumnen zijn in een wloek" (Van der Wijck 1898: 88).

86. In de kamerclebatten voorafgaand aan de wet van 1876 hadden de voorstanders van het behoud van de Groningse universiteit en de pleitbezorgers van het behoud wan het Amsterdamse Athenaeum de handen ineengeslagen (Van der Wijck 1898: 91). Op 21 maart 1876 werd het amendement-Kappeyne van de Copello, Tak wan Poortwliet, Mackay, de Vries en Godefroì - waarin het aan Amsterdam werd toegestaan hatai Athenatum on te zetten in een Gemeentelijke Universiteit - met 41 tegen 32 stemmen - llegen de zin van Minister van Heemskerk - aangenomen (Van Geer 1887b; Van de Woestigne 1982: 47-48).

87 "Toch werd reeds in 1879 door Afdeelingen der Tweede Kamer" opnieuw overwogen 'of, vooral ook met het $00 \mathrm{~g}$ op onze financiër, de drie Rijksuniversiteiten kondlen behouden blijven" (Van der Wijck 1898: 101).

88 Vooral in tijden van economische recessie en achteruitgang in studentenaantallen deed dat onderwerp van zich horen. In de gemeenteraad van Amsterdam was vanaf de jaren veertig herhaaldelijk aangedrongen op het opheffen van het Athenaeum (Van de Woestijne 1982* 44). Onder andere onder verwijzing naar de toename van de verkeersmiddelen die de universiteitssteden makkelijker bereikbaar hadden gemaakt. Het Athenaeum verkeerde in financiële nood, terwijl de hoge onderwijsbelasting van de hoogleraren regelmatig tot conflicten en zelfs tot vrijwillig ontslag had geleid. Ook de universiteit van Groningen werd al lange tijd, in verband met geringe studentenaantallen, met siuiting bedreigd. De Staatscommissie van 1848 had gesuggereerd de hogeschool van Groningen op te heffen. In 1873 werd over het sluiten van de hogeschool wan Utrecht gedacht (Willink 1988: 135). 


\section{Conclusie}

Hoewel de achttiende eeuw dikwijls de eeuw van de pedagogiek wordt genoemd $^{89}$ (De Swaan 1989: 62-65), waarin een herwaardering van de kindfa$\mathrm{se}^{\mathrm{s}}$ optreedt, is en blijft de organisatie en inrichting van het onderwijs in ons land op standenonderscheid gebaseerd". Dat komt al naar voren in de lage scholen: "De hoogte van het schoolgeld bepaalde er [in de steden] in belangrijke mate het niveau van het onderwijs. Wie het zich maar enigszins permitteren kon, vermeed een armenschool, waar geen schoolgeld betaald hoefde te worden en stuurde zijn kinderen naar de stads-lagere school of naar een bijzondere onderwijzer. Zo werd binnen het geheel van lagere scholen de plaats op de maatschappelijke ladder van de ouders duidelijk zichtbaar. (...) Op het platteland was geen plaats voor afzonderlijke scholen voor de verschillende standen. Hier kwam het standsverschil binnen de ene school tot uiting: de kinderen van de dorpsnotabelen kregen eenvoudig een betere behandeling, én schrijf-en rekenonderwijs, waarvoor hun ouders apart betaalden" (Boekholt en De Booy 1987: 109). En uiteraard op de hogeschool: "Die noch kapitaal noch inkomen hebben, behoorden, (met weinige uitzonderingen, nopens blijkbaar - en niet door inbeelding - buitengewone verstanden) hunne kinderen niet in de geleerde studiën te stoten; maar ze in hun eigen of eenig ander burgerlijk bedrijf te houden. Die uitzonderingen vinden dan ook wel hunne begunstigers, die de studiekosten voor hen verzorgen. - En is dan het geluk altijd zeker te vinden door de geleerde studiën en in de hoogere standen?!" (Tydeman 1828: 23).

Aan het einde van de negentiende eeuw is het onderwijssysteem zoals wij dat heden ten dage kennen - althans in zijn contouren - een feit. De grote lokale autonomie die gedurende de Republiek de organisatie van het onderwijs gekenmerkt had, heeft dan plaats gemaakt voor een centraal afgestemde organisatie. Maar nog belangrijker: de organisatie van dat onderwijs kent niet langer een standsmatige opbouw, maar is afgeleid van de idee van een leerproces. Terwijl een standsgewijze onderwijsorganisatie onderwijstypen primair differentieert in termen van eindonderwijs behorend bij een stand, staat in een onderwijsstelsel dat zich op het individuele leerproces oriënteert het doorstroomkarakter voorop. Daarbij zijn twee modellen te onderscheiden ${ }^{\text {g/ }}$.

89 "In der zweiten Măfte des achtzehnten Jahrhunderts erscheirnen in Deutschland mekr Schriften und Aufsätze über Erzielzung und Unterricht als in den 300 Jahren vorther" (Menze 1975: 11).

90 Zie voor een evaluerende bespreking van de "geboorte" van het kind o.a. Dekker (1981) en Dekker en Groenendijk (1991).

91 "De herwardering van het kind en zijn individualiteit gaat echter niet zover dat de opvoeding van de eigen waarde en de eigen natum van het kind vertrekt (...), of dat de interne normen van de leeftijdskllasse tolt uitgangspunt worden genomen" (Frijhoff 1983b; 12).

92 In hedendaagse onderwijssystemen worden veelal prestatie- en leeftijd-downstroommodellen op exen 
In het leeftij-doorstroommodel, dat tot op zekere hoogte in Noord Amerika gehanteerd wordt, gaat men uit van het principe dat iedere leerling onderwijs moet ontvangen overeenkomstig de eigen geaardheid en situatie. In zijn meest extreme vorm houdt dat in dat differentiatie in schoolvormen alleen op grond van leeftijdskenmerken wordt gemaakt. In het prestatie-doorstroommodel, dat thans in Europa overwegend gangbaar is, vindt doorstroming plaats als de student of de leerling voldaan heeft aan specifieke prestatieeisen die groepsgewijs worden gesteld. In tegenstelling tot het leeftijd-doorstroommodel is het onderwijs niet afgestemd op de individuele leerling, maar gericht op het gemiddelde kind in de groep. Klasseindelingen duiden hier verschillen in prestatieniveau aan (Wiegersma 1989: 30-32).

Een standsgeoriënteerde organisatie van het onderwijs verschilt van de beide doorstroommodellen met name in de selectiecriteria die worden gehanteerd. In een standsgewijze onderwijsorganisatie zijn de primaire differenties tussen onderwijstypen geformuleerd in termen van eindonderwijs voor de diverse standen. De maatschappelijke bestemming ligt vooraf, bij de toegang tot het onderwijs, grotendeels reeds door afkomst en geboorte vast. Onderwijs behelst dan primair de introductie in een statusgroep (Frijholf 1987b: 7; 12). Komt daarentegen in de organisatie van het onderwijs de notie van leerproces centraal te staan, dan worden de individuele prestaties van de leerling of student doorslaggevend. Daarmee hangt zowel een 'pedagogisering' van het onderwijs als de centrale rol van examens - selectie op basis van individuele leerprestaties - samen. De zekerheid die het standsbesef bood, wordt geëlimineerd; de mogelijkheden ${ }^{93}$ tot verticale mobiliteit worden vergroo ${ }^{2 i}$. Daarmee wordt - in moderne termen gesproken - de weg geopend tot een democratisering van het onderwijs. Selectie op basis van individuele prestaties vergroot de onzekerheid van de uitkomst van het leerproces op het niveau van het individu.

subtiele wijze gecombineerd.

93 Dat betekent niet dat daandoor de opwaartse sociale mobiliteit noodzakelijk vergroot wordt. De invoering van het prestatiebeginsel kan wat dat betreft (in eerste instantie) zelfs negatief werken. Stone in zijn studie over Oxford: "The institution of neritocracy merely made it more difficult rather than less for a boy to compete on equal terms who because of poverty lacked access to grammar-school education. The main benificiaries of these reforms were the midale classes (Stone 1975c: 73).

94 Wameer in de jaren tachtig de toeloop tot de nuversiteiten toeneemt, wordt dat aan een toegenomen verticale mobiliteit geweten: "Menig kleinhandelaar en winkelier die een goede zaak heeft, acht zijn zoon te goed voor dien nederigen werkkring en zend hem vol ilhusien omtrent eene schitterende toekomst naar de universiteit. Anderen doen dit door nood gedrongen, omclat zij geen betere bestemming wool hun zonen weten. Zoo wordt het hooger onderwijs overvoerd evenals de polytechnische school en de opleidingsscholen voor het lager onderwijs" (Van Geer 1887b: 220). 


\section{III \\ Het onderwijs in de Faculteit der Geneeskunde}

\section{Inleiding}

In het begin van de vorige eeuw werd het gezicht van de medische zorg nog in belangrijke mate getekend door een onderlinge hiërarchie van kunstbeoefenaars. De wet op het geneeskundig staatstoezicht ${ }^{1}$ van 1818 noemde dertien verschillende typen; naast academisch opgeleide Medicinae Doctores werden verschillende soorten kunstbeoefenaars van een lagere stand onderscheiden. De wet van 1865 voerde een uniformering van bevoegdheden en examenvereisten door. Vanaf 1876 was het enkel nog mogelijk tot de praktijk te worden toegelaten via een academische studie. In de literatuur wordt het monopolie van de academisch opgeleide arts $^{2}$ veelal verbonden met de professionalisering van het medisch beroep, waarbij de niet-academische beroepsbeoefenaars in een concurrentiestrijd met de universitair opgeleiden definitief het onderspit delven. Die interpretatie gaat echter gemakkelijk voorbij aan het gegeven dat ook de academische opleiding tot arts in deze periode, met name door de introductie van de natuurwetenschappen in het curriculum, radicaal verandert. Hier wordt betoogd dat de hervormers die een geneeskunde op natuurwetenschappelijke grondslag bepleitten, niet zozeer een academische elite ${ }^{3}$ verdedigden, maar veeleer, door een opvatting van ziekte als een verstoord individueel (levens)proces te proclameren, een alternatief organisatiecriterium aanreikten, zowel voor de maatschappelijke organisatie van de zorgverlening als voor de opleiding van de aanstaande arts en voor de beoefening van de geneeskundige wetenschap als zodanig. In dit hoofdstuk komt vooral de verwevenheid aan de orde tussen opvattingen over de organisatie van zorg, over wat 'ziekte" is

1 De officiële titel wan deze wet luidt" "Wet, ter regeling van hetgeen betrekkelijk is tot de uitoefening van de verschillende takken der geneeskunde" (Staatsbind' no. 16, 12 maart 1818).

2 De litel 'arts' is in deze context feitelijk een anachronisme. Pas in 1865 werd deze titel ingevoerd. ter aanduiding van de leden van een medische beroepsgroep, waarin de traditionele onderscheidingen. weggevallen waren (Nijhoff 1923).

3 Cr. Schepers (1989: 213): "De diepgaande werschillen binnen de bercepselite in overweging nemend, rijst de vraag of men niet beter zou gewagen wan beleidsdeelname van enkele vooraanstaande geneesheren zonder hilermee enige belangempresentatie van de elite als geheel te suggereren." 
en over de wijze waarop het medisch onderwijs moet worden ingericht ${ }^{4}$. Het in het eerste hoofdstuk geïntroduceerde perspectief op madernisering levert de invalshoek daartoe.

Het aspect globalisering komt naar voren in het streven naar een geneeskundige staatsregeling die als leidraad voor de inrichting van de geneeskundige zorg in het gehele Koninkrijk kon dienen. Doordat de bevoegdheden van de verschillende kunstbeoefenaars daarbij in het geding waren, raakte de discussie over de geneeskundige staatsregeling direct de medische opleiding. In deze discussie manifesteerde zich een groep hervormers, die geen genoegen meer nam met de overgeleverce kennis maar het hoe, het waarom en het waardoor wilde weten ( $D e$ Gids 1838: 323). Deze groep wilde de medische opleiding en in feite het gehele medisch domein op de natururwetenschappen baseren. Die natuurwetenschappen - en meer bepaald de fysiologie - stelden een aantal traditionele en hiërarchische indelingen in het medisch domein ter discussie en gaven een alternatief, dat samenhing met de nadruk die de fysiologie legde op het proceskarakter van ziekte.

In de eerste paragraaf van dit hoofdstuk, ${ }^{~}$ Een ander ordeningsprincipe voor het medisch beroep', wordt de discussie over de inrichting van het medisch onderwijs geplaatst tegen de achtergrond van het debat over de organisatie van het medisch beroep. In de paragraaf 'Het onderwijs aan de hogescholen' komen veranderingen in het medisch onderwijs aan de hogescholen aan bod, en vooral de argumenten waarmee deze worden ingevoerd en bestreden. Een centrale plaats in die discussie over het academisch onderwijs wordt ingenomen door pleidooien om de opleiding op de natuurwetenschappen te oriënteren. Paragraaf drie, 'De opvatting van ziekte', gaat nader in op de relatie tussen de verandering van ziekteopvatting en de reorganisatie van het medisch beroep.

Alle hierbovengenoemde elementen - het verdwijnen van de rangen en standen in de medische beroepsgroep, de integratie van opleidingstradities, de opkomst van de natuurwetenschappen, de verschillende opvattingen over de oorzaken van ziekten - komen tot uitdrukking in een zich radicaal wijzigende verhouding tussen theorie en praktijk. In het begin van de negentiende eeuw definieerde het verschil tussen geneeskunst en geneeskunde nog twee principieel verschillende domeinen van menselijke activiteit: "Er zijn er, - en vooral:

4 M. Foucault (1986) brengt in zijn studie naar het ontstaan van de 'medische blik' in Frankrijk tussen 1770 en 1825 een vergelijkbare samenhang an tusser veranderingen in de opleiding, het medisch kennen en de orgarvisalie van de medische zorg. Zie voor een kritische evaluatie Gelfand (1980) en Mer" quiritior (1988).

5 "Heeft de natuurkunde in het algemeen en de physiologie in het bijzonder het verband tusschen oorzak en werking nog niet angetoond, zoo moet de gaping worden alangewezen, in plaats van ze met hoogdravende doch zümissende woorden te bedekken" (Gobee 1844a: viii). 
er waren er, - die uitsluitend zich op het zoogenoemd praktische gebied bewegen, en onder het woord 'wetenschap" schijnen te begrijpen iets, dat met de 'praktijk' zich kwalijk verdraagt, zoo dat de eene de andere als 't ware uitsluit" (Ali Cohen 1852: 2). Na een fase van overgang, die gekenmerkt wordt door betekenisverschuiving en begripsverwarring - "wat praktisch is, is in het ontwerp niet bepaald; er wordt verwezen naar Art. 5., waarin wel het oude onderscheid tusschen theoretisch en praktisch voorkomt, maar waarvan niet wordt aangegeven, wat men eronder verstaat" (Mulder 1865: 7) -, wordt op basis van een aan de fysiologie ontleend ziektebegrip de eenheid van theorie en praktijk geproclameerd: "Physiologisch eine Unkenntnis, pathologisch ein Irrtum, therapeutisch ein Mord" (De Gids 1848: 318). Wetenschap en niet langer routine en ervaring dienen de basis te vormen voor de praktijk: "Wetenschap moet de grondslag van al ons werken, van al ons pogen zijn. Ook gij [studenten], - ik ben er zeker van, - gij wilt geen routiniers ${ }^{6}$ worden, maar degelijke, wetenschappelijk gevormde practische mannen" (Polano 1869: 46). In de vierde paragraaf getiteld 'Theorie en Praktijk' wordt door betekenisveranderingen van begrippen als 'praktijk' en 'ervaring' te volgen, nogmaals de verwevenheid van opleidingskwesties, de reorganisatie van het beroep en de opvatting van ziekte aan de orde gesteld. De paragraaf 'Eenheid van stand' gaat ten slotte kort in op de periode tussen het tot stand komen van de artsenwetten van 1865 en de navolgende artsenwet van 1878. In de afsluitende paragraaf wordt de hier gepresenteerde visie op professionalisering vergeleken met andere theorieën.

\section{Een ander ordeningsprincipe voor het medisch beroep}

Werd de organisatie van het onderwijs ten tijde van de Republiek in zijn algemeenheid gekenmerkt door segmentatie en lokale autonomie, voor de opleiding tot en de inrichting van het medisch beroep gold dat eens te meer. De hogescholen verzorgden de opleiding van Medicinae Doctores, geleerde artsen. De chirurgijnsgilden examineerden voor het chirurgisch examen; aan hen was ook de toelating van vroedmeesters en reizende meesters toevertrouwd. Stadsbesturen behartigden strikt lokale belangen. Met de komst van het Bataafs bewind werd de gezondheidszorg, zowel binnen de steden als op het platteland, mede een taak van de centrale overheid. Aan de 'Agent van Nationale Opvoeding' waarin de Nederlandse staatsregeling van 1798 voorzagr was ook de

6 Routiniers "door Luther reeds genoemd Herrgottsflicker, en volgens Kieser, practici currentes, wier studeerkamer de straat is, en die woor elken bijzanderen nam van ziekte een bijzonder recept in den zak hebben" (Baart de la Faille 1842:48). 
zorg voor 'de Geneeskundige Staatsregeling, de vorming der Nationale Zeden, de bevordering van het Openbaar Onderwijs en van Konsten en Wetenschappen' toebedeeld (Idenburg 1960: 26). Net zoals in de periode tussen 1795 en 1815 voor de maatschappelijke organisatie van het (hoger) onderwijs verstrekkende en rigoureuze hervormingsvoorstellen circuleerden, was dat ook het geval ten aanzien van de "Geneeskundige Staatsregeling". De staatsregeling van 1798 maakte formeel een einde aan de opleidingen en examens in gildeverband. Dat maakte de vraag naar een geneeskundige staatsregeling nijpend. In januari 1801 werden 'Departementale Commissies van Geneeskundig Bestuur' ingesteld die er onder andere op zouden moeten toezien dat niemand enige vorm van de geneeskunst onbevoegd zou uitoefenen. Deze commissies zouden de Agent echter ook dienen te adviseren over en op de hoogte te houden van al die onderwerpen, die betrekking hadden op 'verbetering van den staat der Geneeskundige Wetenschappen in dit Gemeenebest, tot het openbaar Geneeskundig onderwys, of tot eenig gedeelte der Geneeskundige Staatsregeling" (Cannegieter 1954: 25; Heederik 1973: 67-68). Daarnaast zouden in de steden, ter opvolging van Collegia Medica en Chirurgijnsgilden, plaatselijke Commissies van Geneeskundig Toevoorzicht moeten worden ingericht onder wier verantwoordelijkheid het lokale geneeskundige onderwijs zou komen. De taakstelling, bevoegdheden en verantwoordelijkheden van de Departementale Commissies werden vervolgens een speelbal van de politieke machtswisselingen in de Bataafse Republiek. De politieke strijd om nationale eenheid versus verregaande provinciale autonomie had zijn directe weerslag op de inrichting en bevoegdheden van de commissies. In de op 20 maart 1804 afgekondigde 'Verordeningen omtrent het Geneeskundig Onderzoek en Toevoorzigt binnen de Bataafsche Republiek' werd aan de departementale besturen een grote autonomie toegedicht. Eén van de uitdrukkelijke opdrachten aan de Departementale Commissies was te zorgen voor een verbetering van de geneeskundige zorg op het platteland en aan boord van de koopvaardijschepen (Van Lieburg 1978: 58). Tevens zouden in de toekomst alle niet academische examens door de Departementale (later Provinciale) Commissies van Geneeskundig Onderzoek en Toevoorzicht worden afgenomen. Het examineren van heelmeesters, vroedmeesters, vroedvrouwen en apothekers en het waarmerken van de bullen van de Doctores Medicinae die zich in het departement wilden vestigen, groeide uit tot de belangrijkste taak van de Departementale Commissies. Verder werden zij geacht toezicht te houden op apothekers- en chirurgijnswin-

7 L. Bicker hield op 15 mei 1795 een "Vertoog over de noodzakelijkheid van een Committé van algemeene gezondheid of Geneeskundige Staatsregeling'. D. Heilbron lanceerde in 1797 een plan van een vergelijkbare strekking. Een overzicht over de periode 1795-1815 geven Cannegieter (1954: 11-42), Heederik (1973: 31-80), Van der Korst (1988: 179-191) en Schepers (1989: 43-49). 
kels. Het bewind van Koning Lodewijk Napoleon zou in de op 7 maart 1806 vastgestelde 'Additionele Artikelen' de Departementale Commissies weer onder het toezicht van 'Binnenlandse Zaken' plaatsen. De daarmee nagestreefde centralisatie werd echter slechts zeer ten dele gerealiseerd. Tot enige coördinatie tussen de verschillende Departementale Commissies is het nooit gekomen; de exameneisen in de verschillende departementen bleven sterk uiteen lopen, mede omdat deze waren afgestemd op de bestaande opleidingsmogelijkheden (Van der Korst 1988: 187).

Nadat het Koninkrijk Holland in 1810 was ingelijfd bij het Franse Keizerrijk, werd de geneeskundige staatsregeling in overeenstemming gebracht met de in Frankrijk geldende en aangepast aan de op instigatie van Napoleon doorgevoerde hervormingen van het hoger onderwijs. De rijke schakering aan medische kunstbeoefenaars die de Bataafse Republiek en het Koninkrijk Holland hadden gekend, zou moeten worden vervangen door een tweedeling tussen 'docteurs en médecine ou en chirurgie' en 'officiers de santé. Echter zoals de Franse hervormingen in het hoger onderwijs nauwelijks sporen achter zouden laten, zo zouden na de proclamatie van het Koninkrijk der Nederlanden (1813) bij Koninklijk Besluit van 29 januari 1814 ook de Franse geneeskundige regelingen die "allezins onvoldoende" werden geacht, worden afgeschaft (Van der Korst 1988: 189).

Ter regeling van de geneeskundige verzorging greep de nieuwe eenheidsstaat, het Koninkrijk der Verenigde Nederlanden, vervolgens terug op de wetten van vóór 1810. Provinciale Commissies van Geneeskundig Onderzoek en Toevoorzicht werden belast met de taken hun in 1804 opgedragen, terwijl de 'Additionele Artikelen' van 1806 en de in 1805 gepubliceerde 'Pharmacopaea Batava' in ere werden hersteld. Met het Organiek Besluit van 2 augustus 1815, dat refereerde aan een standsgebonden opvatting van hoger onderwijs, werd het universitaire onderwijs in de geneeskunde aan een aantal regels ${ }^{8}$ gebonden. Er werden voor het eerst wettelijke bepalingen vastgesteld ter verkrijging van de graad van Doctor in de heel-, verlos- en artsenijmengkunde. De wet van 12 maart 1818 "ter regeling van hetgeen betrekkelijk is tot de uitoefening van de verschillende takken der geneeskunde" nam een groot aantal traditionele onderscheidingen over, zoals de differentie tussen stad en platteland ${ }^{\text {in }}$, tussen geleerde en niet-geleerde artsen en de indeling tussen genees-, heel- en verloskunde (Cannegieter 1954: 42; Van Lieburg 1983a: 433). Daarmee institu-

8 Voor de formele eisen, werplichte leervakken en examenregelingen, zie Groen (1985b).

9 "Hierdoon werden an deze zoo lang veronachtzaamde takken der" geneeskunde eerst, als het ware den haar toekomenden wetenschappelijken rang, op eene officiête wijs toegekend, en met de inwendige Geneeskunde gelijk gesteld d' (Salomon 1842: 13).

10 Daarnaast werd de geneeskundige werzorging op de schepen onderscheiden. 
tionaliseerde de wet van 1818 een hiërarchie van bevoegdheden en het onderscheid tussen 13 verschillende beroepsbeoefenaars. De heel- en verloskunde waren de enige vakken die volgens de wet gecombineerd mochten worden uitgeoefend. Medicinae Doctores die tevens Chirurgiae en/of Obstetriciae Doctor waren, dan wel een graad als stedelijk heelmeester of vroedmeester verkregen hadden, mochten hun extra bevoegdheden slechts bij consultatie uitoefenen (NMG 1924: 22, Van Lieburg 1983a: 436). In 1845 kwam D. Arntzenius (1845: 54-57) nog tot 25 verschillende typen van geneeskundige beroepsbeoefenaren ${ }^{11}$.

Die indeling was gebaseerd op criteria waarin de tijdsfactor geen rol speelde: het onderscheid tussen stad en platteland, de traditionele $e^{12}$ verdeling in vakgebieden of het mogen hanteren van bepaalde instrumenten ${ }^{13}$. Deze classificaties werden in stand gehouden door de opleidingen, die zich van elkaar onderscheidden door fundamentele verschillen van inhoud en vorm van de over te dragen kennis. Twee opleidingstradities vallen principieel te onderscheiden. Eén traditie had van oudsher plaats in gildeverband; daar werd ervaring van meester op leerling overgegeven en zo mogelijk uitgebreid. In eerste instantie bleef die opleiding strikt beperkt tot praktijkvorming bij een meester-chirurgijn aan huis (Groshans 1853). Vanaf het einde van de $16 \mathrm{de}$ eeuw werd deze vorming steeds vaker aangevuld met systematisch ontleed-en heelkundig onderwijs door (of onder supervisie van) een daartoe van hogerhand aangesteld theoretisch geschoold geneesheer (Boesman 1942; Van Eeghen 1974) 14. Anno $^{14}$. 1818 waren alle heel- en vroedmeesters gevormd in het systeem van het meester-gezel onderwijs (Houtzager 1979: 44; Van Lieburg 1983a: 437). Voor de an-

11 Medicinae Doctores, Medicinae et Art. Obstetr. Doctores, Medicinae Chirurgat Doctores, Medicinae Chirurgae et Art. Obstetr. Doctores; Stedelijke Heelmeesters, Stedelijke Vroedmeesters, Stedelijke Heelen Vroedmeesters, Plattelands. Heelmeesters, Plattelands Heel-en Vroedmeesters, Scheeps-Heelmeesters, Militure artsen met verschillende graden, Vroedvrouwen. Apothekers, drogisten, Pharmaciae Doctores, Oogm en Thumeesters en anderen (Arntzenus 1845: 27).

12 Het onderscheid tussen de geneeg- en heelkuinde gaat onder andere tertig op het concilie van Tours (1215\%, waar de kerk universiteiten verbiedt de chururgie te beoefienen onder het motto "ecclesia a sanguine abhorret" (de kerk schuwt bloed") (Van Lieburg 1978: 11). De ankeer van bloed is ingebed in een hiërarchisch wardenschema waarin het direct contact met God (de monnik, de priester) bovenaan, en het contact met bloed (de beul, de chirurginn) onderaan stat (Mortier 1985/6: v). De Medicinae Doctor nemt een positie daartussen in. In de achttiende eeuw dringt geleidelijk het besef door dat de heelkunde te laag gewardeerd wordt (Beukers 1989a: 46).

13 Bujvoorbeeld in de afpaling van bevoegdheden en exameneisen tussen vroedwrouwen en vroedmeesters in de achttiende eeuw: "Karakteristiek voor beide beroepsvelden is het al dan niet mogen hanteren van bepallde verloskundige instrumenten. Met uitzondering van de klisteerspuit en de blaascatheter mochten vroedvrouwen geen enkel instrument gebruiken. In het bijzonder moet men daarbij denken aan de verschillende verloskundige tangen, de hevel (ook bekend als het Roontrujsianse geheim) en her instrumentariun voor de schaambeensnede en de keizersnede" (Van Lieburg en Marland 1989a. 184). 14 De "anatomische les" vormt de symbolische uitdrukking van de verhouding tussen geneesheer en heelmeester (Groshans 1853: 8; Frijhoff 1983a: 398). 
dere, geleerde traditie, garandeerde niet ervaring maar de kennis van het Latijn, de klassieke boeken en de systematische orde van de ziekten de continuiteit. Interferentie tussen deze opleidingstradities was er in de achttiende eeuw $w^{75}$ - in Nederland - nog nagenoeg niet ${ }^{16}$ : "Zoo ooit de vroegere scheiding der verschillende, in de wet bedoelde, takken der geneeskunde, gegrondvest was op de meening des volks en zelfs der geleerden, was het ten onzent. Teder dier takken werd door beide als van elkander bijna onafhankelijke gedeelten der geneeskunde beschouwd; de geneesheer - exceptis excipiendis - lag, na het volbrengen zijner Academische loopbaan, de heel- en verloskundige dictaten in een 'hoek van zijne boekenkast (...) De chirurg, de Accoucheur, hielden den kring hunner traditionele kennis zoo eng mogelijk gesloten" (Wenken en Menirgen 1838: 103).

Het Organiek Besluit bestendigde het onderscheid tussen geleerde en nietgelleerde artsen. Maar als gevolg van het afschaffen van de gilden in 1798 was officiee ${ }^{17}$ niet meer in een opleiding voor de niet-geleerde artsen voorzien. Een decreet van Raadspensionaris R.J. Schimmelpenninck uit 1806 had de oprichting van klinische scholen in de heel-en verloskunde (De Moulin 1978: 30) gesuggereerd. Het zou evenwel tot 6 januari 1823 duren tot een Koninklijk Besluit "scholen ter aankweking van Heelmeesters en Vroedvrouwen" zou invoeren. Vanaf die datum werden tot de provinciale examens nog uitsluitend diegenen toegelaten die hun opleiding aan een klinische school hadden genoten, vrijstellingen uitgezonderd (art. 2). De oprichting van zo' $n$ school was voorbehouden aan steden waar daartoe geschikte gasthuizen werden aangetroffen. In de jaren na 1823 werd een aantal klinische scholen opgericht (Alkmaar, 1824; Haarlem, 1825; Middelburg, 1826; Hoorn, 1827; Amsterdam, 1828; Rotterdam 1828$)^{18}$.

De klinische scholen vormden van aanvang af een hybride construct. Enerzijds leunden ze sterk op de meester-leerling traditie ${ }^{19}$, vooral in de kleinere

15 In hoeverre er in de zeventiende eeuw wel sprake is van een combinatie van 'geleerd' en 'ervaren' onderricht aan de hogescholen (zie Beukers 1989b) blijtt hier buiten beschouwing.

16 In hoeverre da geldt voor de praktikuntoefening van het medisch beroep is een vraag die verder onderzoek vereist. Zo malkt de praktijk van consultatie opgang. Van Lieburg (1983c; 19896: 128) wijkt op een vervaging wan de grenzen tussen genees- en heelkunde op het einde vari de achttiende veuw. Het betreft hier echter net als bij de oprichting (1790) van hel "Genootschap ter Bevorclering der" Heelkunde" door Andneas Bonn (1738-1818) meer "de chirurgische elite, dic ook al in de landelijke geleerde genootschappen zitting had, dan (...) de lagere geledingen van de heelkundige stand ${ }^{\text {wr }}$

17 Volgens Heederik (1973: 45; 60 en 67) hadden de gilden door het besluit van 1798 weinig an feitelijke macht en invloed ingeboet (zie ook Schepers 1989: 47).

18 Er is ook sprake van een geneeskundige school te Maastricht (De Man 1902), Deze provinciale school verzorgde de opleiding tot apotheker en vroedvrouw (Cormips 1953).

19 "H]et mut eener instelling [klinische school], waar de voorbereidende en gevorderde kumdigheden. niet alleen kunnen worden verzameld, maar de zoo hier als elders verkregene kunnen toegepast, en aun den toetssteen der ondervinding beproefd worden, van waar men, niet slechts toegerust met de noodige 
steden $^{\text {s. }}$. De verordeningen schreven voor dat het onderwijs gegeven zou worden door practici in de gasthuizen, terwijl men zo mogelijk gepromoveerden voor dat doel moest uitkiezen (De Man 1902:4) ${ }^{21}$. Bij gelegenheid van de opening van de Geneeskundige School te Rotterdam getuigde lector C.A.R. Sander, hoewel noch het 'Clinicum' noch de verloskundige zaal gereed was, van "het niet genoeg te waarderen nut (...) van de leerlingen gelegen in het volgen zijner leeraren naar het ziekbed, of naar de zaal der zwangeren" (Van Lieburg 1978) ${ }^{22}$. Colleges werden op zeer vroege of late tijdstippen gehouden, om de docenten in staat te stellen tijdens de normale werkuren de praktijk uit te oefenen. Soms namen de buitenschoolse verplichtingen van de lectoren dusdanige vormen aan dat het lesgeven er volledig bij inschoot: "[E]en drukke praktijk, zoodat in het beruchte koortsjaar 1826, hij 120 visites per dag had af te rijden, en gedurende een maand lang daardoor verhinderd was in zijn gezin te dineeren; hij moest dit terloops bij zijn lijders doen. Er was dus, ondanks veel goeden wil, slechts weinig tijd voor hem over om zich aan de school te wijden, die hem zoo dierbaar was" (De Man 1902: 54). Leerlingen waren genoodzaakt "in hun levensonderhoud te voorzien door dienst te nemen bij een apotheker of heelmeester" (Van Lieburg 1978: 66-67). De toelatingseisen tot de klinische scholen waren minimaal. Deze betroffen een minimumleeftijd van 16 jaar, een goede gezondheid, onbesproken gedrag, het kunnen lezen en "daarenboven, voor de leerlingen in de heelkunde, de gedachten geregeld in schrift te kunnen uitdrukken" (Salomon 1842: 17).

Anderzijds zou het onjuist zijn de klinische scholen volledig te associëren met een opleidingstraditie op basis van een meester-leerling verhouding. In openingsredes van diverse klinische scholen werd een beeld van de klinische school geschetst als een mengvorm tussen de oude meester-leerling traditie en

geschiktheid om te ondervinden, matr zelfs reeds met eene uitgelezene en welgeordende ondervinding voorzien, den gewigtigen post van geneesheer met mindere huivering kan aamvaarden" (Thijjsen 1828 : $12-13)$

20 "De op te richten scholen moesten geen kweekscholen zijn var hoogere wetenschap, doch slechts hulpmiddelen on in de bestaande behoeften te voorzien. (...) Met gebrekkige of liever geen hulp middelen deden intusschen - men mag dit niet ontkennen - lectoren wat zij konden. Het waren mannen, zóó op eens genomen niet uil de kringen der wekenschap, maar uil die der praktijk. Geen enkele hunner had ter ooil op gewkend zulk een post op zich te zullen nemen en bij de drukke bezigheden van den geneesheer, was men matar al te zeer gewoon spoedig de boeken voor de ondervinding prijs te geven" (De Man 1902: 44).

21 Nahurlijk spelen hier ook financiele overwegingen een belangrijke rol. Zonder de mogelijkheid tot het uitoefenen van de praktijk was het niet mogelijk geweest het jaarsalaris voor een docentschap op het lage niveau wan 500 guiden vast te stellen. Salomon (1842. 27) spreekt zelfs van jaarweddes van 200 tot 500 gulden. Hooglenaren aan de hogescholen was hel voeren van een eigen praktijk juist uitedrukkelijk verboder.

22 In Middelburg was het de lectoren toegestaan voor het onderwijs in de praktijk "driemaal "s weeks met zijn leerlingen de gasthuizen [te] bezoeken ${ }_{*}$ zelfs op de uren, waarop de stads-chürurgijns däár zijn, maar zij mogen in tegenwoordigheid der lijders de ziekten niet beoordeelen" (De Man 1902: 6). 
de geleerde universiteit, zoals door J.A. van Bemmelen bij de opening van de klinische school te Haarlem: "[Z]onder wetenschappelijke kennis [wordt] onze kunst slechts een handwerk (...), hetwelk even min door anderen wordt geacht, als het dengenen, die het verrigt, zelfsvoldoening verschaft" (Van Bemmelen 1825: 30). De drie belangrijkste voordelen van een opleiding als die bij de Rotterdamse klinische school achtte Sander gelegen in "de ontwikkeling van den wetenschappelijken zin", "de vrijmoedigheid waarmede de kweekelingen dezer school eenmaal hunne waarnemingen en ontdekkingen aan de wereld zullen schenken" en de mogelijkheid om tot een "nationale heelkunst" te komen (Van Lieburg 1978: 62). In de klinische scholen van Rotterdam en Amsterdam werd een groot aantal veranderingen in het medisch onderwijs en denken op de voet gevolgd of misschien juist daar wel geïntroduceerd (Van Lieburg 1983b).

De klinische scholen in de kleinere steden hebben een weinig florissant bestaan gekend (De Moulin 1978: 31; Van Lieburg 1983a: 439). Dat kwam met name door het Koninklijk Besluit van 27 mei 1830 dat de exclusieve positie van de klinische scholen wat betreft de toelating tot de examens van de provinciale commissie teniet deed ${ }^{23}$. De Regering - onder verwijzing naar de aantasting van de vrijheid van onderwijs en geconfronteerd met een grote vraag naar officieren van gezondheid wegens de Belgische opstand - viel met dit besluit volledig terug op de opleiding in meester-leerling verband. De inschrijvingen voor de klinische scholen liepen drastisch terug ${ }^{24}$. Alleen in Amsterdam bleef men vasthouden aan de eis dat men de klinische school bezocht moest hebben om toegelaten te worden tot het examen van de provinciale commissie. "Wat zagen wij daarentegen bij vele andere gebeuren? Heden werd er een, met gebrekkige kennis toegerust, op eene gebrekkige wijze verkregen par fas et nefas, door de provinciale geneeskundige commissie geadmitteerd, en morgen lazen wij in de Courant, dat zich bij hem de gelegenheid aanbood tot het opleiden en geven van grondig onderwijs in de genees-, heel- en verloskunde. Wie zouden hem dit verbieden? Zijne instructie immers had hem het houden van eenen, ja meerdere leerlingen toegestaan!" (Schneevogt 1842: 31)

23 "[E]en ieder, die de noodige kundigheden zal hebben opgedaan, zonder onderscheil waar of hoe hij die verkregen zal hebben, zal toegelaten worden tot het afleggen der examens en het verkrijgen der getuigscluriften of graden, welke tot het waarnemen van sommige ambten of beroepen vereischt worden" (K.B. 27 mei 1830).

24 "[W]ant zeker is het aantal van candidaten, die zich tot de examina aanmelden en die geen onderwijs aan de clinische scholen hebben ontvangen, even groot als clat van hen die daar hunne opleiding hebben gehad" (Groshans 1853: 33).

25 "[IIn eenige artikelen in de Geneeskundige Courant, die over de standen in de geneeskunst handelden, wordt in 1848 nog medegedeeld, dat 'de meeste' heel- en verloskundigen geen onderwijs aan een klinische school hebben gehad, matr bij een particulier geneesheer hebben geleerd, het liefst bij een, die tevens lid eener Provinciale commissie was, bij welke men dan examen deed" (NMG 1949: 28). 
Het functioneren van de provinciale commissies vormde een bron van kritiek (zie o.a. Ontijd 1843; Delprat 1924). Vooral omdat in hun optreden elke uniformiteit ontbrak (Bierman 1988: 30: Schepers 1989: 214). Waar de commissie streng examineerde bood zich slechts een beperkt aantal kandidaten voor het examen aan (Donders 1875: 6). Provinciale commissies werd verweten de aspirant-plattelands heelmeester te examineren naar de kennis die blijkens de instructie van hem werd verlangd, en niet naar de bepalingen van het examenreglement. De provinciale commissies konden van hun kant wijzen op het ontbreken van bevoegdheden en van medewerking van hogere overheden (Delprat 1924: 31). De commissieleden vervulden hun taak naast een normale dagtaak (Bierman 1988: 31). Bovendien vormde de wet van 1818 met de bijbehorende reglementen en instructies een bron van onduidelijkheid en tegenstrijdigheden (Van Lieburg 1983a: 447).

De geneeskundige staatsregeling groeide uit tot een publiek heftig bediscussieerde kwestie. Staatscommissies kwamen en gingen; wetsontwerpen schoven heen en weer met bevoegdheden ${ }^{26}$. Op 17 januari 1816 was bijvoorbeeld bepaald dat het gecombineerd uitoefenen van de Heel- of Verloskunde met de Geneeskunst aan de Chirurgiae en Artis Obstetriciae Doctores, in steden waar een geneeskundige commissie gevestigd was, niet geoorloofd was. Op 27 maart 1838 werd die bepaling weer buiten werking gesteld (Salomon 1842: 14). Dat voerde de discussie over de geneeskundige staatsregeling naar een hoogtepunt (Van Lieburg 1987: 5). In de jaren veertig ${ }^{27}$ liep de kwestie zo hoog op dat tijdschriften werden opgericht uitsluitend gewijd aan de problemen rond de geneeskundige staatsregeling. Omdat de regeling van bevoegdheden en verantwoordelijkheden van de verschillende kunstbeoefenaars direct verband hield met de inrichting van de opleidingen, vormde dat laatste een centraal thema in de discussie. Net als bij het hoger onderwijs in zijn algemeenheid, drong zich ook hier de vraag op wat het leidende indelingscriterium voor de regeling van opleiding en bevoegdheden zou kunnen zijn: " [Z]al eene Staatsregeling haar doel bereiken, dan moet zij naauwkeurig voor elken burger het

26. Cannegieter (1954), Goudsmit (1978), Van Lieburg (1983) en Groen (1985b) hebben de formele bestlommemingen rondom de wetgeving en de regeling van bevogdheden in het kader van die medische stutatsregeling witwoerig beschreven (zie ook Verzameling 1836).

27. In 1828 had de Konung al een Commissie, sa nengesteld uit de presidenten vart alle provinciale geneeskundige commissies in het Verenigd Koningrijk der Nederlander, bijeengeroepen;" waarwan de resultaten in het publivek geheel en al ziju onbekend gebleven" (Salomon 1842: 10). Het rapport van de op 20 november 1841 ingestelde stamtscommissie, dat in 1842 verschijn; leidt tot heftige reacties. De meerderheid van de conmissie wil het bij bijstellingen laten. Een minderheid (Van Deen. Hendriksz en Heye) bepleit een rigoureuze verandering, o.a thet concentreren van alle geneeskundig onderwijs in Amsterdam. Immers: "Niet Eene der than bestaande inrigtingen tot Geneeskundig onderwijs aan acadenien, allhenaea of clinische scholen voldoet an hetgeen de wetenschap verlangt, aan hetgeen de Staat vorderen moet" (zie minderheidsnota in Archief voor Geneeskunde" 1843; voor kritiek hierop Doctor L. 1842). 
gebied bepalen, waarop hij zich maatschappelijk te bewegen hebbe. Deszelfs natuurlijke grenzen moeten haar tot grondslag van die bepaling dienen. (...) Zullen de wetten die zij voorschrijft, billijk zijn, dan moet zij aan ieder regten toekennen, overeenkomstig de eischen, die de maatschappij aan hem doet" (Schneevogt 1842).

De reorganisatie van het medisch domein en de herverkaveling van bevoegdheden staat in rechtstreeks verband met een reorganisatie van de opleiding. Dat de inrichting van de medische zorg, vooral op het platteland ${ }^{28}$, verbetering behoeft, wordt algemeen erkend. Maar over de vraag hoe dat gerealiseerd zou moeten worden, lopen de meningen uiteen. De vraag welke rangen en standen in het domein van de geneeskunde over moeten blijven, en hoe de opleiding daartoe hoort uit te zien, leidt tot felle verschillen van mening. Bij de overdracht van het rectoraat van de universteit van Utrecht dringt B.F. Suerman (1848) aan op een verbetering van het medisch onderwijs, "den voornaamsten grond, waarop de in ons vaderland in te voeren geneeskundige wetgeving behoort te rusten". In De Gids van 1848 verschijnt een commentaar van J.C.G. Evers" (1848: 616): "Hij [Suerman] wenscht, dat het getal hoogleeraren aan onze akademiën vermeerderd worde, dat de bestaandle inrigtingen voor klinisch onderwijs aldaar uitgebreid worden. (...) Hij verlangt, dat er twee geneeskundige standen blijven bestaan, één van geleerde, één van ervarene geneesheren. De geleerden zouden in rang gelijk komen met de tegenwoordige doctoren in de genees-, heel- en verloskunde; dle ervarenen zouden op het platteland de geneeskunde in haren geheelen omvang, in de steden alleen de heelen verloskunde mogen uitoefenen. Het onderscheid in onderwijs tusschen deze beide rangen zal daarin bestaan, dat de geleerden iets langer moeten studeren en de gymnasiën moeten doorlopen hebben." Evers deelt Suermans visie niet en bepleit opheffing van de rangen en standen ${ }^{30}$ binnen het geneeskundig beroep. Zodra de geleerde doctor er zeker van kan zijn op het platteland geen concurrentie meer van de heel- en vroedmeesters te zullen ondervinden, zal diens bereidheid om zich op het platteland - met minder inkomsten ${ }^{31}$ maar

28 De verbetering van de geneeskundige zorg op het platteland vormde al de inzet bil het streven naar een geneeskundige staaksegeling ten tijde var de Bataafse Republiek, en zou ook nog gerume tijd een punt van zorg blijven: "[D]e opleiding der plattelands-geneeskundigen, en de wijze waarop zij geexamineerd werclen, zoo te laten als zij is, dat zou een misdand jegens de mantsohnppij zijn (...) Het platteland blijt vool een deel van geneeskundige hulp verstoken" (Koster 1865: 7; 12).

29 Sikkel (1899) gat uitwoerig op de persoon Evers in.

30 "[E]venmin als men de geneeskunde in in- en uitwendige scheiden kan, [zal] men geneeskundigen van dern eersten en tweeden rang (..) kunnen vormen" (Evers 1848: 631).

31 "Om de daartoe noodige kundigheden te verzamelen, is van de exste jeugd af aran een doelmatig onderwijs een hoofdvereischte voor den toekomstigen geneesheeg; dit onderwijs gat met kosten gepaard, die het genot daarvan niet aam alle standen veroorloven; de geneeskundige zal dus tot eenen stand moeten behooren, die meerdere en grootere behoeften dan de landbouwer heeft; zijne verdiensten 
ook met minder kosten - te vestigen toenemen (623). De heelkunde zou dan als een specialiteit verder ontwikkeld kunnen worden. Evers loopt in zijn reactie op Suerman diens argumenten om twee standen te blijven onderscheider na. De noodzaak van een klassieke opleiding van de geleerde doctor die Suerman bepleitte, is volgens Evers (1848: 625) weggevallen: "Op zeer weinige uitzonderingen na wordt aan de buitenlandsche hoogescholen het geneeskundig onderwijs in de landtaal gegeven; de band, die door middel van het Latijn tusschen de geleerden bestond, is verbroken, want aan velen is die taal vreemd geworden (...). Vergelijk hetgeen in de geneeskundige litteratuur in het Latijn met dat, wat in de nieuwere talen uitgegeven wordt, en gij zult zien, dat het Latijn opgehouden heeft de taal der geleerden, althans der geneeskundigen te zijn." De klassieke bronnen der geneeskundige kennis kunnen vertaald worden. Een concreet alternatief voor de opleiding - hoe met name de kloof tussen de ervaren en geleerde geneesheren te overbruggen - staat Evers echter niet voor ogen". "De keuze der woorden ervaren en geleerd zal wel niemand gelukkig noemen. De onbruikbaarheid der zoogenaamde geleerden voor het praktische leven is zoo algemeen erkend, dat wel niemand aan den naam van geleerd boven dien van ervaren de voorkeur zal geven. Ervaren zijn in eene kunst sluit al van zelfs het begrip in van al datgene geleerd te hebben, wat tot de uitoefening vereischt wordt. Geleerd te zijn bewijst nog niet dat men tot het toepassen van het geleerde geschikt is" (Evers 1848: 629-630). Maar daarmee geeft Evers tegelijkertijd de zwakte van zijn argumentatie bloot. Dat argument kan namelijk ook ingezet worden in een pleidooi voor het handhaven van de 'ervaren' richting: "Er hebben zich in ons vaderland als stedelijke heel- en vroedmeesters mannen ontwikkeld, die door de vaardigheid, bij eene lange en drukke beoefening der kunst verkregen, het algemeen vertrouwen hebben verworven. (...) Zij zijn de vraagbaken voor de jongere beoefenaren der heel- en verloskunst" (Suerman 1857: 6).

Het alternatief dat de dichotomie tussen 'geleerdheid' en 'ervaring' ter zijde zou schuiven, wordt aangereikt door de natuurwetenschappen. Geneeskunde moet in de toekomst als exacte natuurwetenschap bedreven worden (Van Geuns 1842a; Heye 1843: 44). Voorts moet de examinandus tonen dat zijn wetenschap "geene geerfde, maar verworvene eigendom is. Hij moet toonen dat het hem niet genoeg was, dictaten na te schrijven, definitiën van buiten te leeren, verdeelingen aan zijne vingers op te tellen, en ziekten te kunnen beschrijven, zoo afgerond als zij in het Handboek staan" (Heye 1843: 17). Het nauwkeurig waarnemen en registreren van het verloop van een ziekteproces moet daarvoor

zullen, wil hij, zoo als hij van jongs af gewend of verwend is geweest, blijven voortleven, betrekkelijk groot moeten zün" (Evers 1848: 622).

32 Zie ook de paragraaf 'theorie en praktijk'. 
in de plaats komen. Die nadruk op de ziektegeschiedenis ondermijnt het fundament waarop de hiërarchieën in het medisch beroep tot dusverre steunden. G.E.V. Schneevogt trekt bijvoorbeeld door het verloop van een ziekteproces te volgen, de ratio achter de afzonderlijke uitoefening van Genees- en Heelkunde in twijfel. Een Medicinae Doctor dient als er zich ten gevolge van inwendige ziekten uitwendige gebreken voordoen, de hulp in te roepen van een Chirurgiae Doctor of een gekwalificeerd stedelijk Heelmeester. De stedelijke Heelmeester op zijn beurt wordt geacht voor het toepassen van inwendige hulpmiddelen een Medicinae Doctor te raadplegen. Maar demarcatieproblemen liggen op de loer: Wie zal beider gebied bepalen? "[D]e instructie bepaalt het begrip van uitwendige gebreken ${ }^{33}$, enigszins nader als de zoodanige, die door de toepassing der handen, en de aanwending van heelkundige werktuigen of hulpmiddelen, kunnen bestreden worden" (Schneevogt 1842: 33). Wanneer Schneevogt stilzwijgend het niveau van verschijnselen verlaat en over oorzaken gaat spreken, doemen problemen op: "Welke ziekten door inwendige oorzaken ontstaan zijn, en als zoodanig tot het gebied van den Doctor, welke daarentegen door uitwendige oorzaken voortgebragt zijn, en dus tot dat van den Chirurgijn behooren" (33). Pneumonie, door inademing van scherpe koude lucht ontstaan, een uitwendige oorzaak dus, zou een chirurgisch geval zijn. Tegelijkertijd constateert hij dat bij vele zogenaamde inwendige ziekten, uitwendige gebreken ontstaan. Maar vooral: "[W]elke uitwendige gebreken vereischen niet de toediening van inwendige geneesmiddelen!" (34). Schneevogts twijfel aan de grond van het ordeningsprincipe doet hem de bestaande indeling van het medisch domein verwerpen: "[A]lles geeft ons den moed, de scheiding van Medicinae Doctoren en Heelmeesters te verwerpen, als even willekeurig en onmaatschappelijk als die van Doctoren voor rijken en armen, voor kinderen en oude lieden, voor mannen en vrouwen, voor hoofd-, borst- of buikziekten" (41).

Door in zijn redenering het ziekteproces centraal te stellen komt Schneevogt tol de conclusie dat het geneeskundig beroep als eenheid gezien moet worden. $\mathrm{H}$. Broers ${ }^{\mathrm{W}}$ (1842: 23) komt via een analoge redenering tot eenzelfde conclusie ten aanzien van de bestaande taakverdeling tussen vroedvrouw, vroedmeester en de Obstetriciae Doctor in de verloskunde: "De grondslagen, waarop deze klassificatie van eischen en regten van kennis en bevoegdheid berust, zijn onwetenschappelijk, wankelend en onzeker; de klassificatie zelve is ongerijmd;

33 Tot de heelkunde rekende de wetgewer "alle ongemakken van witwendige beleedigingen of oorzalken afhankelijk, gelijk ook dezulke, welke door inwendige oorzaken zijn voortgebracht en door de toepassing der handen en de aanwending van heelkundige werktuigen of hulpmiddelen kunen genezen worden ${ }^{\prime \prime}$ (Wan Lieburg 1983a: 434-435).

34 Inhoeverre Broers" opvathingen in bredere kring erkenning wonden is onduidelijk. 
hare gevolgen voor de maatschappij zijn hoogst nadeelig". Ook hier moet de zorg worden toevertrouwd aan iemand die in staat is het verloop van de gehele zwangerschap - zowel zwangerschap, bevalling als kraambed - kritisch te volgen. De vroedvrouw "bepaalt zich immers alleen tot het oogenblik der verlossing zelve, en dat nog wel blootelijk der natuurlijke verlossing. Noch zwangerschap, noch kraambed, die met de verlossing zoo naauw verbonden zijn, kunnen aan hare zorg worden toevertrouwd" (Broers 1842: 24). De vroedvrouw heeft onvoldoende fysiologische, pathologische en therapeutische kennis om te weten wanneer zij de hulp van een vroedmeester, die verloskundige instrumenten mag hanteren, moet inroepen. Naast algemenere diskwalifikaties die Broers aan het adres van de vroedmeester richt, geldt ook voor hem dat diens hulp "evenals die der Vroedvrouw, slechts tijdelijk te noemen [is]. Noch zwangerschap, noch kraambed, maken onderwerpen zijner behandeling uit. Ook hij kan dus niet de kunstoefenaar zijn, zoo het behoort, maar wordt blootelijk handwerksman. (...) Alleen aan den Medicus kan de behandeling van dit alles worden toevertrouwd, die zelf Obstetricator is, en het verledene met het tegenwoordige kan verbinden, om daaruit tot het toekomstige te

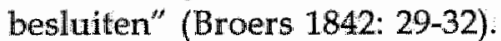

Niet alleen levert de concentratie op het individuele ziekteproces argumenten om de traditionele hiërarchieën te verwerpen, het introduceert ook een alternatief organisatieprincipe voor het medisch beroep. Dat is gelegen in het nauwkeurig registreren en bijhouden van het verloop van dat ziekteproces in de ziektegeschiedenis of het ziektejournaal. "Goede artsen, zeg ik, staan in zekeren zin onder contrôle, want zij teekenen de verschijnselen, welke zij bij hunne zieken waarnemen, nauwkeurig op, om dezelve naderhand in derzelver zamenhang onderling, en met de behandeling te kunnen overzien; zij vergelijken dezelve met vroeger waargenome en met hetgeen de wetenschap daaromtrent geboekt heeft" (Ramaer 1845: 101). Was de functie van de ziektegeschiedenis voorheen vooral gelegen in het opsporen en optekenen van essentiële symptomen van bepaalde ziekten, de ziektegeschiedenis wordt nu een referentiepunt die coöperatie tussen artsen mogelijk maakt $t^{35}$. Voor de onderlinge hiërarchie van geneeskunstbeoefenaars komt een model van coöperatie in de plaats ${ }^{36}$. J.N. Ramaer (1842) acht het voeren van een ziektejournaal een mi-

35 Gobee (1844a: xii) sigmaleert de venanderde functie en betekenis die het nauwkeurig registreren van het individuele ziekteverloop verknijgt door een nieuwe term te introduceren: "Volgens dit physiologisch gxondbeginsel zullen wij meer ziekteontwikkelingen dan ziektegeschiedenissen mededeelen en hal Klimisch standpunt steeds in het oog houdende, de therapie met de verkregene daadzaken zoo veel mogelijk in verband brengen." Zie ook de paragraaf "de opvatting van ziekte".

36 Van Lieburg (1986a: 317) vermeldt dat J.B. Molewater, de geneesheer-directeur van het in 1851 te Rolterdam geopende Coolsingelziekenthuis, aangeeft "met de Heeren Polano, Dr. Schmidt en Neumana (...) de overeenkomst [te hebhen]] gemaakt, dat alle aanteekeningen omtrent die verpleegden niet als bij- 
nimumvoorwaarde om controle mogelijk te maken. Voorts stelt een ziektejournaal de familie van een overledene in staat deskundigen te raadplegen en hun oordeel over de behandeling in te winnen. Het bijhouden van een ziektejournaal vergroot tevens de nauwkeurigheid van de behandeling. Het maakt het de patiënt mogelijk tijdens een behandeling van arts te wisselen, en het stelt de behandelend geneesheer in staat zich te weer te stellen tegen eventuele latere aantijgingen dat hij de behandeling niet volgens de regels der kunst zou hebben uitgevoerd. Het centraal stellen van de ziektegeschiedenis en het verwerpen van de onderlinge hiërarchie legt de grondslag voor de moderne professionele autonomie.

\section{Het onderwijs aan de hogescholen}

In de discussie over de geneeskundige staatsregeling komen de traditionele hiërarchieën en de verschillen in opleiding waarop deze gebaseerd zijn onder druk te staan. Deze beweging gaat vergezeld van veranderingen in het onderwijs aan de hogescholen. Uit de reacties van de universiteiten op de door de Staatscommissie van 1828 ingestelde rondvraag naar het functioneren van de hogescholen, spreekt weinig dat doet vermoeden dat binnen het geneeskundig onderwijs aan de universiteiten in de navolgende decennia belangrijke veranderingen zouden optreden. De academische senaat van de hogeschool van Utrecht (Inlichtingen 1828) merkt op dat de genees-, wis- en natuurkundige faculteiten weliswaar financiële subsidies vereisen, maar dat "die inrigtingen en verzamelingen, die overal, ook buiten de Akademiën nuttige kennis verspreiden, en waarvan het daarstellen vooral zoo kostbaar is, [reeds] bestaan (...); het voorzien in de onkosten van derzelver onderhoud is naar evenredigheid gering." Th. Fliedner die in het verslag (1831) van zijn rondreis door Europa een vergelijking tussen het Duitse, Engelse en Nederlandse onderwijsstelsel opneem $t^{37}$, is over de Nederlandse universiteiten eligenlijk heel goed te spreken: "Jede Wissenschaft, welche den Gegenstand einer besonderen Vorlesung ausmacht, muß den Regel nach in einem Jahre abgehandelt werden. Auch soll, so viel wie möglich, in allen Vorlesungen von den Professoren und von den Studenten respondirt werden. (...) Unter den Theologen, so wie unter den andern Studenten herrscht größtenteils ein ernster Eifer im Studium und

zonder eigendiom zouden beschouwd worden, maar bij het ontslag of overlijden der persionen waarop zij betrekking hadden zouden worden gevoegd bij het 'archief' der afdeeling waarin de bedoelde lijders warem verplleegd geworden."

37 Collektenreise nach Holland und England, nebst einer ausfuihrlichen Darstellung des Kirchen-, Schul-, Amen und Gefängniswesens beider Länder milt vergleichender Hinweigung auf Deutschland, vorziglich Preussen. 
ausgezeichnete Wissenschaftlichkeit. Diese wird hauptsächlich befördert durch die vielen kleinen wissenschaftlichen Vereine, welche die Studenten, sowohl die literarischen, als auch die theologischen und aus andern Fakultäten zu 8 -12 unter sich wöchentlich ein bis zweimal halten. Hier liest abwechselnd eins der Mitglieder eine über einen selbstgewählten Gegenstand verfertigte lateinische Abhandlung vor, worüber nun lateinisch disputirt, und sowohl über diese, als auch über andere Theses opponirt wird. (...) Alles geschah dabei in einer so würdigen, ernsten und wissenschaftlichen Weise, daß ich nicht umhin konnte, die Bildung solcher Vereine fủr unsere deutschen Universitäten in ähnlicher Weise zu wünschen" (Fliedner 1831: 179-188).

In 1848 waait een heel ander geluid uit Duitsland over. Wanneer J. Moleschott (1848:478) zijn ongenoegen over de benoeming van $\mathrm{H}$.J. Halbertsma tot buitengewoon hoogleraar in de anatomie en fysiologie aan de hogeschool te Utrecht de vrije loop laat, fulmineert hij tegen de onderwijssituatie aan de Nederlandse Hogescholen: "Dass es bei einer solchen Zusammensetzung der Facultäten vielfach an dem gehörigen Eifer fehlt, dass namentlich die praktische Anleitung in allen Fächern, von dem Secirtisch bis zum Krankenbett, lahm und teilweise durchaus ungenügend sein muss, ergibt sich von selbst. Bedenkt man nur, dass die Empfehlung einer kleinen, durch lauter Nebenrücksichten geleiteten Coterie hinreicht, um einen oft sehr unreifen und dazu talentlosen jungen Manne seinen Marschallstab zu verleihen, der ilhm das ganze Leben hindurch nicht genommen werden kann; bedenkt man ferner, dass der oben hervorgehobene Mangel an Concurrenz den Professoren einen übermächtigen Einfluss gibt, zumal da die ihren Händen anvertrauten Doctor-Examina zugleich Staatsexamina sind; dass sie in Folge dieses Einflusses und ihrer isolirten Stellung vom Publikum als die Einzigen, von dem Studierenden als die Mächtigen vergöttert und verhätschelt werden; dass die ganze Richtung der Wissenschaft in Niederland noch immer die Gelehrte und nicht die lebensfrische, das eigentliche Wissen erzielende ist; dass der Vortrag der gewöhnlich auf ihren Lorbeeren einschlafenden Lehrer oft noch durch die lateinische Sprache gehemmt wird: so ist nicht zu verwundern, wenn im Allgemeinen die Bildung der jüngeren Aerzte in Niederland eine - wir wollen das rechte Wort nicht scheuen - grundschlechte ist."

In 1848 stonden echter ook in Nederland zelf inhoud en vorm van de opleiding reeds geruime tijd ter discussie. In 1840 had G. Salomon in zijn 'Gedachten en wenken, rakende de geneeskundige wetten en het geneeskundig onderwijs in het koningrijk der Nederlanden' nog de loftrompet gestoken over de vaderlandse hogescholen. De boekbeoordeling in het Archief voor Geneeskunde laat geen spaan van die visie heel: In de hoogescholen "ligt toch welligt grootstendeels de fons et origo malorum (...) verscheidene kollegiën worden niet gegeven; belangrijke onderdeelen slechts ter loops aangestipt; de gelegenheid tot 
practische oefening in de Nosocomia is veel te gering" (Geschriften 1842: 108; 113). Er komt een beweging op gang die pleit voor meer praktisch onderwijs aan de hogescholen. Praktisch onderwijs dat van oudsher vanuit de universiteiten met minachting werd bekeken ${ }^{38}$. Onder de roep om meer praktisch onderwijs wordt een groot aantal inhoudelijke en methodische veranderingen in het geneeskunde onderwijs geintroduceerd. Praktisch onderwijs wordt gepresenteerd als een didactische vernieuwing. Centraal thema daarbij is de nadruk op het belang van het zelfstandig waamemen en registreren van het verloop van een proces. Dat praktisch onderwijs levert enerzijds een alternatief dat de rigide scheiding tussen theorie en praktijk doorbreekt. Anderzijds houdt dat praktisch onderwijs verband met een breuk in de geleerde traditie zelf. De invoering van praktisch onderwijs leidde in eerste instantie tot de uitbreiding van natuurwetenschappelijke kennis en natuurwetenschappelijke methodes in het onderwijs: "Zal de geest worden aangeduid, die het onderwijs in de genoemde en in bijna al de overige takken van de geneeskundige wetenschap thans bezielt, dan wijst men hoofdzakelijk op de methode der natuurkundige wetenschappen in het algemeen. De demonstratieve leerwijze, op waarneming en proefneming gevestigd, staat op den voorgrond; de eigen oefening der studerenden in alles wat tot waarneming en proefneming geschikt is, kan van haar niet worden afgescheiden. Zóó is de praktische rigting van onderwijs en studie der geneeskunst van onzen tijd te verstaan" (Geneeskund ige Staatscommissie 1850: 10). Praktisch onderwijs betekende niet het eenvoudigweg overnemen van elementen uit de meester-leerling traditie": "De schrijver [Van Geuns (1842a: 155)] zegt: 'in het clinisch onderwijs ligt de geheele toekomst der wetenschap'. Wij zouden liever zeggen: in het praktisch onderwijs, zowel voor natuurkundige als voor geneeskundige zaken, ligt de geheele toekomst der wetenschap; want als dat niet voorafgegaan is, zal het clinisch onderwijs, hetgeen een vervolg van de practische rigting zijn moet, geene vruchten dragen (...) Op die wijze zal de onderwezene geene phrases en woorden, dien

38 "Om kort te zijn kunnen wij bỷ de zoogenaamde practische vakken mek de enkele opmerking volstain dat hier aan de behandeling van specialiteiten hoegenaand niet gedacht wordt; aan de universiteiten wordt daarvoor eene ernstige minachting geprofesseerd, zonder te vragen of de geneeskundige bij zijne intrede in het werkelijke leven daardoor niet in zijne handelingen verlamd wordt en zich genoodzaakt ziet willig het veld te ruimen voor de charlatans die hel gouvernement met eene ongelooflijke liberaliteit beschermt ${ }^{* t}$ (De Gids 1845: 607).

39 "Bij dit examen, dat van praktische bekwamheid, op wetenschap gegrond, moet getuigen, worden bewijzen gevorderd van klinische oefeningen gedurende een mimimum van tijd. (...) Men heeft aan dit examen den naam wan toegepast gegeven, omdat bij hetzelve de bewijzen moeten worden geleverd, dat de wetenschap, van welke de vroegere examens hebben getuigd, met vrucht door de candidaten op de uitoefening der kunst $\mathrm{kan}$ worden aangewend. Men verlangt daarom bij dit examen het onderzoek steeds gerigt te zien op de herkenning, beoordeling en behandeling van bijzondere ziekten, vooral van die, bij welke eene rationeele toepassing van algemeene zoo wel anatomische als physiologische pathologie mogelijk is" (Geneeskundige Staatscommissie 1850: 61-62). 
ledigen vorm van wetenschap, aanwinnen, maar hij zall wetenschap en kunst gelijktijdig leeren. (..) En dat kan in denzelfden tijd geschieden, waarin thans boeken en dictaten van buiten geleerd worden, waarin men thans met woorden en definitiën zich laat afschepen; in denzelfden tijd zeg ik, maar bij veranderde methode, en bij docenten, die zelve weten, zooals Mulder het weet, wat een praktische geest is" (Boekbeoordeling van "Bijdragen tot de geneeskundige staatsregeling', De Gids 1845: 101). Voor zover het praktisch onderwijs een uitbreiding van het klinisch onderwijs inhield betekende dat vooral ook een breuk met de opvattingen en doelstellingen die daaromtrent aan de hogescholen ooit leefden.

G.J. Mulder had vanaf 1828 aan de klinische school van Rotterdam (Groshans 1853: 25; Van Lieburg 1973: 223) en vervolgens aan de universiteit van Utrecht, het onderwijslaboratorium in Nederland geïntroduceerd (Snelders 1986: 205). Wat Mulder met het praktische onderwijs in de scheikunde voor ogen stond, formuleert hij helder in de 'Toespraak bij het openen der scheikundige lessen' in 1841 aan de Hogeschool van Utrecht. Het doel van Hoger Onderwijs kan in de ogen van Mulder geen ander zijn dan de ontwikkeling van de edele vermogens, waarvan de kiem reeds in de mens besloten ligt. Wetenschapsbeoefening is de weg die dat doel het meest dichtbij brengt: "Er zijn vele wegen tot ontwikkeling maar: Ten opzigte der natuurstudie ga ik verder: ik beweer dat zij onmisbaar is voor den op beschaving prijs stellende" (Mulder 1841: 4). De zelfstandige beoefening der wetenschap vormt de geest door met alle kracht naar iets groots, iets moeilijks te streven. "Niet die kennis, die hier in eenen kleinen kring slechts bruikbaar is, maar ontwikkeling van die kiem van edeleren aard, die den mensch boven het dier onderscheidt, moet het eerst genoemd worden, als men het doel van wetenschappelijke bemoejing zal aanwijzen" (6). Langs deze lijn verder redenerend, komt Mulder tot de conclusie dat het vrij onverschillig is welk deel der wetenschap beoefend wordt: harmonische ontwikkeling van de vermogens van de geest is het eerste doel, de toename van kennis, "reine wetenschap" een afgeleide". Een jaar later formuleert hij het belang van de natuurwetenschappelijke studie aldus: "kennis, in den zin van weten, is het geenszins, wat den geneeskundigen vormt. Zijn waarnemingsvermogen moet tot eene hooge mate ontwikkeld worden, en daartoe dient eene opscherping van zijne zintuigen (...) zou niet reeds daarom alleen $u$ die natuurstudie eene even onmisbare behoefte toeschijnen voor uwe ontwikkeling als aanstaande geneeskundigen, als gij daartoe het aanleeren van

40 Mulder zou daar veertig jaar later heel anders tegen aankijken: "Er behoeft bijna niet gehandeld te worden ower de vraag, of beoefening van wetenschap al of niet het karakter vormt of helpt vormen. $Z$ ij dodt drut niat. Bij de mannen van wetenschap vindt gij de gewone menschelijke gebreken, en soms in nog grootere mate dan bij den gewonen mensch" (Mulder 1883 tweede deel: 132). 
eene taal hebt noodig gehad?" (Mulder 1842a: 327-328). De beoefening der wetenschap zal bijdragen aan een betere vervulling van de latere functie in de maatschappij: "Noch pleitbezorgers, noch receptenschrijvers, mag de Hoogeschool aankweeken; maar Rechtsgeleerden en Geneeskundigen. Die de wetenschap, om eene kostwinning te bekomen, heeft aangeleerd, mag zijne zaak als beroep drijven; maar den voormaligen Academieburger is dit onwaardig. Menschen, op eene Hoogeschool opgevoed, behooren, om hunne ontwikkeling, hunne betrekking in de maatschappij anders te vervullen" (Mulder 1841: 7).

Vertaald naar onderwijsmethode betekent dat practische lessen in een onderwijslaboratorium: "Die zelf onderzoekt kan iets van scheikunde leeren; die dit verzuimt, raakt ter naauwernood de oppervlakte der wetenschap aan" (Mulder 1841: 15). Het onderwijslaboratorium wordt uitdrukkelijk als een onderwijskundige innovatie gepresenteerd: "Ik stem toe, dat het tot nog toe onder ons vreemd klinkt, dat men laboratoria bezoeken en zelf scheikundige proeven nemen moet, als men iets van die wetenschap wil leeren; maar gij zult dan wel met mij willen erkennen, dat het oreemd klinken eenvoudig een bewijs is van het tot heden niet bestaan van die gewroonte onder ons" (Mulder 1841: 12). Wat uit de boeken aan de scheikunde te leren valt, heeft geen waarde. Wie kennis vergaren wil, moet de voorwerpen zelf zien, hun eigenschappen met de voorwerpen in de hand zelf bestuderen ${ }^{41}$. De eigen waarneming komt centraal te staan. En dat niet alleen voor diegenen onder de studenten die scheikundige willen worden. Immers dissecties van menselijke lijken dienen ook volgens Mulder niet louter om zich tot ontleedkundige ex professo te bekwamen. Mulder richtte een onderwijslaboratorium in. Volgens Homburg (1987: 55), die het criterium voor een onderzoekslaboratorium legt bij het bezit van een eigen instituutsbibliotheek, kwam de transformatie tot onderzoekslaboratorium onder Mulders bewind nog niet op gang ${ }^{42}$.

41. De nawwe relatie tussen pedagogische herworming en inhoudelijhe vernieuwing is algemeen. Oles" ko (1988a: 96-97) stell in haar analyse van de onderwijslaboratoria van Justus Liebig (chemie, omstreeks 1826, Gie(Ben), Franz Neumann (fysica, omstreeks 1838, Königsberg) en Michael Foster (fysiolo. gie, onutreeks 1867. Cambridge): "Liebig. Foster" and Neumann appear to have initially constructed their curricula largely from some ideal image of what scientific instruction should be. (...) each scientist used his introductory counse as a forum for integrating or emphasizing something wot present or dominant in the discipline beforehand."

42 Omdat universitteitsbibliotheken als primaire tak het collectioneren wan kostbare en zeldzame boeken hadden (zie hoofdstuk 5), ontbraken meer recente ütgaven. De bibliotheek van 's Rijks Kweekschool voor Militair Geneeskundigen te Utrecht is vermoedelijk de eerste bibliotheek geweest met een ander collectieprofiel: "Wie de catalogus van de bibliotheek analyseert, vindt dat daar vit de periodie 1840 '70 niet minder dan 15 binnenlandse en 23 bultenlandse wetenschappelijke tijdsclwiften vertegenwoordigd waren. Waarschijnlijk verklaart de torgankelijkheid tot deze bron van buitenlandse informatie het hoge gehalte van deze pathologischwanatomische publicaties en referaten der negentiende eeuwse militaire artsen" (Haneveld 1985: 78). Doordat hoogleraren ook over een particuliere collectie bescluikten, mogen uit de collectieprofiellen van bibliotheken overïgens geen al te verstrekkende conclusies worden getrokken. 
In Amsterdam volgt een aantal jaren later J. van Geuns Mulders voorbeeld na. Bij Van Geuns zijn onderwijs- en onderzoeksfunctie onmiddellijk verstrengeld: "Wil de docent dit onderwerp [de scheikunde] in zijn lessen met succes. behandelen en daaraan de zorg wijden welke de ontwikkeling en de voortdurende vordering der wetenschap eisen, dan moet hij zich door regelmatig onderzoek en oefening, met de toepassing der scheikunde op de ziekte- en herkenningsleer vertrouwd maken" aldus Van Geuns in 1853 in een brief aan het Bestuur van de Klinische School (Hellinga en Groen 1953: 80). In 1854 gaat een schrijven van de hoogleraren aan het Athenaeum naar $B$ en $W$ van Amsterdam. De studenten zelf, aldus het desbetreffend schrijven, "waren reeds doordrongen van de overtuiging, dat bij hunne vorming, de oefening in de experimentele methode niet zou kunnen worden gemist, zodat meerdere van hen reeds begonnen waren, zich de daartoe elders bestaande gelegenheid ten nutte te maken" (Hellinga en Groen 1953: 82). Ook in de verdere pleidooien en subsidieverzoeken van Van Geuns klinkt de verwevenheid van onderwijs en wetenschap door (Kühler 1953: 126-127; Hellinga en Groen 1953). Maar steeds is duidelijk dat het Van Geuns in eerste instantie om de inrichting van een onderwijslaboratorium gaat: "Een goed deel van hetgeen in de lessen in de physiologie geleerd wordt, berust op hetgeen de proefnemingen aan het licht gebragt hebben. De studenten zullen hetgeen zij op die lessen hooren voordragen, juister begrijpen en beter volgen, wanneer zij door eigen oefening zich in het experimenteele gedeelte gevormd hebben, wanneer zij die verschijnselen zelf gezien hebben, dan wanneer het hun enkel verhaald wordt $t^{\text {rr }}$ (Van Geuns, Memorandum 1854/5, in: Hellinga en Groen 1953: 102).

Werden via het onderwijslaboratorium de organische chemie en vervolgens de moderne fysiologie binnen de muren van de universiteit geïntroduceerd (Morrell 1972), het microscopisch laboratorium deed dat voor het nieuwe vakgebied van de op de fysiologie georiënteerde pathologische anatomie. Het anatomische kabinet ${ }^{43}$, waarvan het Organiek Besluit ${ }^{\text {th }}$ eiste dat het aan iedere hogeschool aanwezig was, zou uiteindelijk zijn centrale plaats in de beoefening en onderwijs van de anatomie voorgoed verliezen: "Het betere deel der geneeskundigen, die beseffen, dat de menschheid en de wetenschap hoogere

43 Zie ook de paragraaf 'De opvatting van ziekte" en hoofdstuk 5. Het Leidse anatomische kabinet, dat de preparaten van Rau, Albinus, Van Doeveren en Sandifort bevatite en in 1819 nog werd uitgebreid met de particuliere verzamelingen van Brugmans en Bonn, vormde de trots der hogeschool (Beukers $1984:$ $78-79$ ). Zie ook Elshout (1952).

44. Naast het anatomisch kabinet moest de faculteit beschikken over een "zoo veel mogelijk volledige verzameling van heelkundige en vroedkundige instrumenten, niet alleen voor zoo verre die thans in gebruik zijn, maar ook voor zoo verre die bij geschiedkunige vergelijkingen kunnen dienen, om de vorderingen der wetenschapen, of de manier wan anderen bij het onderwijs te doen kennen* (Beukers 1984: 78-79). 
eischen aan hen mogen doen, dan die door de chaotische kennis van casus rariones (...) kunnen voldaan worden" (Boekbeoordeling van Nieuw Practisch Tijdschrift voor de Geneeskunde in al haren omvang,... red. L. van Eldik en S.J. Galamar 1847, De Gids 1847: 718). Niet het systematisch tonen van afwijkingen ter illustratie van een bepaald ziektetype, maar het onderzoek naar de aard van de afwijking in de weefsels en bovenal het nauwkeurig volgen en registreren van de veranderingen in het verloop van een ziekteproces, was voortaan de invalshoek voor de beoefening van de (pathologische) anatomie. G.T Haneveld (1978: 261) signaleert in zijn studie naar de ontwikkeling van de pathologische anatomie aan de Rijksuniversiteit te Utrecht een noviteit die Schroeder van der Kolk introduceerde in diens pathologisch-anatomische collectie: ziekelijke afwijkingen werden in hun ontwikkeling samengebracht. Het belangrijkste deel van Schroeder van der Kolks verzameling bestond uit preparaten die bedoeld waren om opeenvolgende stadia van ziekteprocessen aanschouwelijk te maken. De plaats van het kabinet en de anatomische atlas zouden echter geleidelijk worden overgenomen door de microscoop en het microscopisch laboratorium.

Evenals het onderwijslaboratorium wordt de microscoop en het microscopisch laboratorium als een didactisch hulpmiddel geïntroduceerd, dat de waarnemingscapaciteiten van de aanstaande artsen moet verbeteren ${ }^{45}$. Bij de opening van een cursus ${ }^{46}$ in de microscopische histologie op ' $t$ Hoogt te Utrecht benadrukt $\mathbb{P}$. Harting (1844: 10-11) met name de didactische betekenis van het microscoperen. "In de eerste plaats dan zeide ik, maakt het gebruik van den mikroskoop den geneeskundigen meer geschikt voor de goede uitoefening van zijn beroep (...) [Want] wat leeren zulke nasporingen? De kunst van het waarnemen." Door oefening in het microscopisch onderzoek leert de student de kunst van het waarnemen, die van zo'n grote betekenis is voor het geneeskundig onderzoek. "Door de mikroskopische waarneming van eenig voorwerp verschaffen wij ons een beeld, bestaande uit de som van alle indrukken welke het voorwerp door den mikroskoop gezien, op ons waarnemings-vermogen maakt. Iets geheel dergelijks heeft plaats, wanneer de geneesheer zijnen lijder onderzoekt" (Harting 1844: 14). Zoals de microscopist storende elementen uit het beeld dient weg te denken om tot een helder beeld te komen, zo moet ook de arts aan het ziekbed zijn waarnemingen zuiveren.

Deze veranderingen in het onderwijs en de nadruk op het zelfstandig waar-

45 Dat geldt ook nog twee decennia later. Zie onder andere Heynsius' inaugurele rede te Leiden (1866: 36)." "Het [onderwijstaboratorium] is de oefenschool woor onze studenten in het watrnemen, in het experimenteren. Dat is het wat voor hunne worming als wetenschappelijke geneeskundigen in de eerste plaats vereischt wordt."

46 Koelliker (1899: 116) die in 1850 Nederland bezoekt, maakt melding van een tiental microscopen in Haxtings microscopisch observatorium. 
nemen van het verloop van processen hingen samen met veranderingen in de fysiologie. Arntzenius (1842b) bepleitte dat een grondige bestudering van de fysiologie de grondslag moest gaan vormen voor de geneeskundige studie. Ten einde naderhand in staat te zijn door eigen onderzoek veranderingen in het lichaam te kunnen vaststellen, dienden de studenten aan de universiteit geoefend te worden in microscopisch en chemisch onderzoek van het gezonde lichaam. De zelfstandige waarneming van de student moest worden ontwikkeld. De nadruk werd verlegd van het ordenen en indelen van ziekten naar het zelfstandig bestuderen van levens- en ziekteprocessen. In die lijn paste ook het benadrukken van het belang zelfstandig lijkopeningen te verrichter: "[P]laatwerken en kabinetten mogen tot nut van meer geoefenden verstrekken, en de belangstelling van enkelen bewijzen, zij voldoen niet, om de pathologische Anatomie bij allen ingang te verschaffen (...), moet men de veranderingen in het lijk zelve bestuderen, vele en herhaalde lijkopeningen gezien en gedaan hebben, ten einde de nuances te kennen (...) ten einde de betrekking, die er tusschen de afwijkingen van verschillende organen bestaat, te leeren inzien, en ten einde gewaarborgd te wezen voor eene al te organisch-ontologische opvatting der ziekte, die ons het ziekteproduct voor ziekteoorzaak, ja voor het essentiële daarvan zou laten houden. Lijkopeningen, zelfs vele lijkopeningen moeten er dus gedaan worden" (Boekbeoordeling van Handboek der bijzondere ziektekundige ontleedkunde van R. Rokitansky (vertaald door J. Moleschotk 1846), De Gids 1847: 315). Het benodigde materiaal voor die vele lijkopeningen ontbrak echter. De enige uitzondering daarop vormde het Binnengasthuis te Amsterdam, dat jaarlijks 600 lijken ter beschikking kon stellen. Elders, zowel aan de hogescholen als aan de klinische scholen (Van Lieburg 1978: 69; De Man 1902), was er een tekort ${ }^{47}$.

De nieuwe onderwijskundige opvattingen kwamen duidelijk naar voren in een advies over het geneeskundig onderwijs dat in 1850 uitgebracht werd. Het advies van de in 1848 ingestelde Commissie luidde dat de studie van de geneeskunde moest geschieden naar analogie van de methode der natuurkundige wetenschappen. Het onderwijs moest "demonstratief" zijn, dat wil zeggen gebaseerd op waarneming en proefneming. Daarnaast diende er voor de studenten gelegenheid te zijn tot praktische oefening. Daartoe ontbraken met name fysiologische laboratoria, uitgerust "met de noodige toestellen voor mikroskopische en andere waarnemingen". De Commissie achtte het wenselijk dat

47 "De Nosocomien in onze academiesteden leveren door hun klein getal bedden eenen te schamelen voontand van lijkopeningen. De werderfelijke afscheiding die er in eenige dier steden nog gevonden wordt thisschen de zoogenaamde stedelijke en akademische ziekeninrigting maakt, dat een relatief belangrijk materiëel, hetzij aan het onderwijs, hetzij aan de oefeming der geneeskundigen ontrokken wordt" (Boekbeoordeling van Handboek der bijzondere ziektekwndige ontleedkunde yan R. Rokitansky (vertald door J. Moleschott 1846 ), De Gids, 1847: 316). 
aan iedere universiteit de hoogleraar in de algemene pathologische anatomie een assistent zou hebben, belast met "chemische en microscopische beoefening der pathologische anatomie" (Beukers 1983: 68).

Uiteraard werden dergelijke onderwijskundige vernieuwingen niet aan alle Nederlandse hogescholen tegelijkertijd ingevoerd. Utrecht vervulde met hoogleraren als Mulder, Harting, Schroeder van der Kolk, Donders ${ }^{26}$ en Moleschott duidelijk een voortrekkersrol ${ }^{49}$. Het Athenaeum van Amsterdam (Heynsius 1856; Hellinga en Groen 1953: 105) en de hogeschool van Groningen ${ }^{50}$ volgden. Leiden fungeerde als hekkesluiter met het fysiologisch laboratorium van A. Heynsius (1866), die voorheen directeur was geweest van het laboratorium van het Athenaeum van Amsterdam (Koelliker 1899: 121). In het Leidse antwoord op de enquête van de Staatscommissie van 1848 vindt men nergens verwijzingen, zoals in het rapport van Utrecht, naar mogelijkheden tot microscopisch onderzoek ${ }^{51}$ door studenten - behalve bij de plantkunde. Noch werd de wens uitgesproken daar verandering in aan brengen (Beukers 1983: 76). De kwaliteit van de kabinetten en verzamelingen, waaronder het Kabinet van Natuurkundige Instrumenten, het Rijksherbarium en de Hortus, het Scheikundig laboratorium, het Rijksmuseum van Natuurlijke Historie en het Anatomisch Kabinet, stemde de faculteit tot tevredenheid over de materiële hulpmiddelen voor het natuur- en geneeskundig onderwijs, omdat "hier ter stede bijna alles aangetroffen wordt, wat daarvoor nodig kan gerekend worden, terwijl het ontbrekende zonder moeite zoude te verkrijgen zijn" (in Beukers 1984: 85) ) $^{52}$.

Enerzijds werd de roep om meer praktisch onderwijs ingevuld door practica in de natuurwetenschappen te introduceren. Daarnaast werd het praktisch klinisch onderwijs aan de hogescholen uitgebreid of eigenlijk geïntroduceerd. Klinisch onderwijs vond aan de hogescholen in het begin van de negentiende

48 F.C. Donders opende in 1847 eem fysiologisch onderwijslaboratorium an het Hoogt te Utrecht, naar het voorbeeld (1839) van Purkyne in Breslau (Groen 1985b; 36; Coleman 1988). Van 1842 tot 1848 was Donders verbonden aan "s Rijkskweekschool voor Militair Gervesikundigen te Utrecht. Daar beschikte hilj reeds over een (primitief) fysiologisch laboratorium mett microscoop (Groustrai 1988: 53).

49 Koelliker (1899: 116) noemt Utrecht in 1850 tjdens zijn bezoek aan Nederland "die erste medizimit sche Schule Hollands". Zeer waarschijnlijk is van de aanwexigheid van "s Rijkskweelkschool voor Militair Geneeskundigen te Utrecht een stimulerende invloed uitgegan.

50 Van Deen die in 1851 het hoogleraarschap aan de universiteit van Groningen aanvaardde, kon in: 1853 beschikkeri over een laboratorium (De Knecht-Van Eekelen 1985: 20).

51 "Ikzelf [hebl in Leiden, in 1838, bij Sandifort nooit een microscoop (...) gezien. Een bijna niet te begripen in het Latün woorgelezen en niet uitgelegd dictaat was alles wat men te Leiden over physiologie. hoorde" (De Man 1902: 47).

52 "Slechts twee vakken, die de faculteit wan belang achtte werden miet onderwezen: fysiologische scheikunde en ziektekundige ontleedkunde. Maar daar zou met geringe materièle woorzieningen in kunner worden voorzien. Men had daarbif vooral het $00 \mathrm{~g}$ op het kabinet van J.C. Broerb, een verzameling pathologische-anatomische preparaten, die inderdaad voor ruim $\mathrm{f}_{3} 300 \mathrm{o}_{f}$ werd aangeschaft. Even wenselijk was een uilbreiding wan het personeel, in het bijzonder voor de fysiologie en de gerechtelijke geneeskunde" (Benthers 1984: 85). 
eeuw slechts in zeer beperkte mate plaats: "De praktische studiën waren toen hoofdzakelijk kamerstudiën, de praktijk, het lezen en bestuderen van een systematisch compendium of uitgebreidere werken met toepassing aan het ziekbed. Eigenlijk klinisch onderwijs bestond niet ${ }^{\prime r}$ (Pruys van der Hoeven 1866. 22). Het weinige klinisch onderwijs dat gegeven werd, had een heel speciale vorm, namelijk de demonstratie van een beperkt aantal voorbeeld-patiënten. in het nosocomium: "Behalve deze [door Thomassen à Thuessink en Hendriksz in het akademisch ziekenhuis te Groningen] echter en eenige zeldzame ziektegevallen, in Akademische proefschriften bekend gemaakt, zal men vruchteloos eenig volledig berigt van een Nederlandsch Klinikum zoeken; niet omdat deze aan onze Akademiën ontbreken, maar omdat zij, van de stadsziekenhuizen afgezonderd, bij eene geringe bevolking en beperkte toelage, niet dan weinige en gelijksoortige zieken kunnen bevatten" (Thijssen 1828: 23). Het Nosocomium Academicum kon slechts een zeer beperkt aantal - zo omstreeks twintig (De Moulin 1988: 120; Van Lieburg 1989b: 129) - zieken herbergen. Doordat het klinisch onderwijs aan de hogescholen echter vooral een demonstratieve functie vervulde, vormde dat geen echte beperking. Dat soort klinisch onderwijs was ooit door Hermann Boerhaave (1668-1738) aan de hogeschool te Leiden geïntroduceerd ${ }^{53}$ en had aan vele andere universiteiten, waaronder Edinburgh (Richards 1987: 31; Jacyna 1988) en Wenen ${ }^{54}$, navolging gekregen. Uit de groep armen in het stadsgasthuis mochten de hoogleraren een klein aantal patiënten laten opnemen in het Nosocomium, ten einde deze aan de studenten te tonen ${ }^{55}$. De patiënten voor het onderwijs werden zorgvuldig geselecteerd, en twee keer per week bezocht. Boerhaave beschreef de ziektesymptomen, en liet er een diagnose, prognose en therapie (indicatio) op volgen: "He gathered the available bedside information, and with the help of analogies, placed it into a pre-established system of disease categories based

53 De vraag war en door wie klinisch onderwijs in Nederland is geintroduceerd, laten we liver buiten beschouwing (Beukers 1989b). Na Boerhave's afscheid zou het klinisch onderwijs aan de universitej wan Leichen wederom een zachte dood sterven.

54 Cfr. Billroth (1876:43): "Wie ich schon früher bemerkte, war der Unterricht am Krankenbette anfangs nur rein demonstrativ, d.h det Schüler sollte die prägnanten Krankheitssymptome am Lebendan wehen, damit er sie sich besser einprägen könne; der Kranke war für den Lehrea 'und fur den Schülei identisch mit einem vorbereiteten amatomischen Präparat, mit einem aus der Sammlung zur Denonstration hervorgeholten Mineral, mit dem aus dem Herbarium hervorgeholten Pflanzen. Die Krankheitssymptome und die dazu gehörige Therapie sollten vor allem tradirt werden; der Kranke diente nur zur lebhaften Unterstützung des Gedächtnisses der Schüler. Dies hat sich im laufe der letzten Decenuien geändert". 55 Art. 181 van het Organiek Besluit getuigt nog van dezelfde sfeer: "Om bij het meestal klein getal bedden in deze akademie-gasthuizen het clinisch onderwijs echter zoo uitgebreid als mogelijk te maken. worden de stedelijke regeringen of megenten der stads- of diakonje gasthuizen uitgenoodigd, mek cura toren der hooge scholen schikkingen te maken, ten einde zoodarige patienten uit de diakonie of stadsgasthuizen, welke voor thet dirisch onderwajs nuttig of leerzaam zouden kunnen zijn, op enene allezins. vellige wijze natr het akademie.gasthuis worden overgebragt" (Verzameling 1836: 228), 
on the contemporary iatromechanical pathogenesis"' (Risse 1989:4). De prognose was daarbij belangrijker dan het nauwkeurig volgen van het ziekteproces: "[C]linical teaching in the Boerhaavian sense was meant to support the notion that medical experience and book knowledge could be harmoniously integrated. His goal was to create more certainty in medicine instead of ambiguity, more confidence rather than doubt" (Risse 1989: 5). Nauwkeurige en onafgebroken observatie van het ziekteproces was overbodig: eens de kenmerkende symptomen zijn gesignaleerd, valt de ziekte te typeren en de prognose te geven. M. Foucaults typering van de proto-kliniek is welbekend: "[Z]e moet het georganiseerde kennisbestand van de nosologie bijeenbrengen en waarneembaar maken. De kliniek zal dus niet openstaan voor alles, zoals de dagelijkse praktijk van een arts, en evenmin gespecialiseerd zijn (...); ze grenst zich af rond de didactische kwaliteit van een ideale ervaring (...). De kliniek van Edinburg was lange tijd een voorbeeld; deze was zo opgezet, dat er die gevallen bijeengebracht waren die het meest instructief lijken" (Foucault 1986: 85).

De roep om meer praktisch, klinisch onderwijs refereerde ten dele aan de nauwe verbindingen die vanaf de eeuwwisseling onder andere in Parijs en Wenen waren gegroeid tussen de hospitalen en de medische opleidingen (Thijssen 1828: 24-25; Van Geuns 1842a). Geluiden om ook in Nederland dat type onderwijs te gaan verzorgen, kwamen vooral uit Amsterdam ${ }^{56}$. Wegens de samenwerking ${ }^{57}$ tussen klinische school en het Athenaeum was de situatie te Amsterdam afwijkend ${ }^{59}$ van steden waarin uitsluitend een hogeschool ${ }^{59}$

56 De klinische school was in het Binnengasthuis gevestigd, en beschikte daardoor over een groot aantal patiënten voor het klinisch onderwijs (Hellinga 1930:51). De gedachte om in de beide gassthuizen van Amsterdam klinisch onderwijs te organiseren stamt uit de Franse tijd (Hellinga en Groen 1953: 66).

57 Die samenwerking was wettelijk verplicht. Art. 43 (van de verzameling van de wetten en besluiten op het Hooger Onderwijs in de Noordelijke provinciën van het Koninkrijk der Nederlanden vermeerderd met de besluiten van, $2 . M$. van 13-10-1836 to: 30 juni 1840) vermeld de dat met het oog op de kostbaarheid der bijbehorende irurichtingen aan een Athenaeum slechts onderwijs ind de geneeskunde mag worden gegem ven, indien in dezelfde stad een geneeskundig provinciaal of stedelij.k onderwijs was gevestigd. Getuige het groot aantal personele ruzies tussen klinische school en Athenaeum verliep deze samenwerking niet zonder incidenten. Deze werden voor een deel in de hand gewerkt doorclat een groot analal woorzieningen miret onder het gezag van het Athenaeum welen (Hellinga 1930; Hellinga en Groen 1953).

56. Alleen al de taal waarin het onderwijs gegeven werd, week af. Athenea diw met een linische school verbonden waren, moestew wolgens het Organiek Besluit hun geneeskunde-onderwijs in het Nederlands verzorgen (Napjus en Lindeboom 1985: 13-14).

59. Tot op zekere hoogte was er in Utrecht sprake van samenwerking tussen de hogeschool en 's Rijks Kweekschool voor Militaire geneeskundigen. Het militair hospitaal stond open voor studenten van die universiteit. Op 5 maart 1835 werd de chirurgijn-majoor Alexander benoemd tot professor honorarius aan de Utrechtse hogeschool. In de series lectionum werd vanaf die tijd vermeld dat Alexander dagelijks 'Institutiones Clinices' zou verzorgen: "De lessen van Alexander zijn vermoedelijk weinig in de smank gevallen. (...) Alexanders therapie [bestond] grotendeels uit het appliceren van hirudines (bloedzuigers.) "Een heel of een half eskadron", luidde zijn commando aan de ziekenoppassers in het Hospital. De studenten beschouwden dergelijke drastische bloedontlastingen als 'vampyrisme" (Haneveld 1988: 75; zive ook Mulder 1883: 86.87). 
of klinische school gevestigd was (Kühler 1953: 14). Het propaedeutisch onderwijs aan de klinische school van Amsterdam werd gegeven door de hoogleraren in de genees-; verlos- en heelkunde, de scheikunde, de plantkunde en de artsenijbereidkunde van het Athenaeum ${ }^{60}$. Bij Raadsbesluit van 27-8-1828 was bepaald, dat de hoogleraren die aan de klinische school zouden worden aangesteld, tevens als professores honorarii aan het Athenaeum Illustre zouden zijn verbonden. Dit had tot gevolg, dat de studenten van het Athenaeum de klinische lessen in het Binnengasthuis konden volgen (Kühler 1953: 14). Voor het eigenlijke klinische onderwijs werd eerst éen, en weldra een tweede professor aan de klinische school benoemd, en zij werden als professores honorarii in de orde van het Athenaeum opgenomen (Gedenkboek 1932). Daardoor waren de studenten van het Athenaeum in de gelegenheid zeer vele zieken van dichtbij te volgen en de lijken van gestorvenen te openen.

In het debat over de uitbreiding van het klinisch onderwijs wordt de grootte van het nosocomium het cruciale discussiepunt ${ }^{61}$. Bij de opening van de Clinische School te Amsterdam voert H.F. Thijssen een aantal redenen aan om in navolging van Parijs een verbinding tussen het stadsziekenhuis en de opleiding tot stand te brengen. Hij acht het wenselijk studenten in contact te laten komen met grotere aantallen zieken. Het aantal ziekten was immers toegenomen, terwijl ziekten liefst onder verschillende omstandigheden moeten worden waargenomen. Alhoewel C. Pruys van der Hoeven (1826) aangeeft ook reserves ten aanzien van Boerhaave's model van klinisch onderwijs te bezitten ${ }^{62}$, wijst hij een uitbreiding van het klinisch onderwijs via hospitalen, zoals in Frankrijk, nadrukkelijk af. Net zoals men op markten geen mensenkennis opdoet, doet men in hospitalen geen ondervinding op: "[H]et is niet het weel zien, maar het goed zien dat ware ondervinding geeft" (Pruys van der Hoeven 1826: 269; zie ook Baart de la Faille 1842: 56-60). "Nadat groote hospitalen de leerschool der praktijk zijn geworden, waar men de ondervinding in massa opdoet, is de praktijk zelve in een proefondervindelijke natuurkunde ontaard. En is het dan wel te verwonderen, dat de kunst van het waarnemen, welke de ouden zo meesterlijk verstonden, bij zoodanige inrigtingen verloren en in vergetelheid moet raken?" (Pruys van der Hoeven 1828: 144).

Het Neo-Hippocratisme dat Pruys van der Hoeven voor ogen staat, de her-

60 De hooggeranen van het Athenaeum, die aan de klinische school onderwijs gaven, ontwingen voor hun werkzaamheid aan de school geen salaris, maar slechts een aandleel in de opbrengst der lesgelchen (Gedenkboek 1932).

61 Zie voor een overzicht van deze discussie Van Geuns (1845: 283-303).

62 "Eindelijk is ieder [van de studenten] gehouden van zijn patient eene fristorio morb" te geven, die dan aanleiding geeft, om over de ziekte zelva, de klasse, het genus, de species waartoe zij behoort te spreken, riet zoozeer, om haar eene plaats te geven in eenige systema nosologiae symptomaticne als wel, om met derzelver charactertes naturales bekend te worden" (Pruys van der Hoeven 1826: 266). 
interpretatie van Hippocrates" idealen waarbij het principe van de zorgvuldige waarneming eveneens een belangrijke rol speelt, zou echter niet de leidraad worden voor de uitbreiding van het klinisch onderwijs aan de hogescholen. Die uitbreiding wordt onderdeel van de beweging om de natuurwetenschappen en in het verlengde daarvan de bestudering van individuele levens- en ziekteprocessen een centrale plaats binnen het onderwijs te geven. "Der klinische Lehrer muss daher in jedem einzelnen Falle darauf hinweisen, dass wir Aerzte keine Krankheiten behandeln, sondern kranke Individuen" (Rosenstein 1866: 26) ${ }^{63}$. Het klinisch onderwijs dient in het verlengde te liggen van het onderwijs in de natuurwetenschappen: "De onderscheiding (...) tusschen propaedeutische, theoretisch-geneeskundige en praktische studievakken, tot hiertoe bij het akademisch onderwijs gevolgd, wordt thans algemeen afgekeurd. (...) Zoo als de theoretisch- en praktisch-geneeskundige studiën met elkander gepaard moeten gaan, (...) zoo mag er vooral geene scheiding plaats hebben tusschen de beoefening der natuur- en der geneeskundige wetenschappen" (Suringar 1855: 275; Ontwerp van Wet op de examens 1849: 146; Rosenstein 1866: 28). Hoofddoel van het klinisch onderwijs is ook nu weer het ontwikkelen van de warneming ${ }^{\text {t4 }}$. En mede daardoor vormt het ziekenluis de meest geschikte lokatie voor dat klinisch onderwijs: "Moge toch in zoodanige kleinere Clinica het beginsel verkondigd worden, dat de Geneeskunde op ervaring berust, en door waarneming, in de Natuur zelve, moet geleerd worden, - dat beginsel kan daar niet leven" (Van Cooth 1842: 81). Het ontwikkelen van de waarneming van de aanstaande arts moet plaats vinden in een omgeving die recht doet aan de opvatting dat het klinisch onderwijs in het verlengde van de natuurwetenschappelijke studie staat: "Veelzijdig kan dáár het Geneeskundig Onderwijs zijn (...) indien zoodanige grootere Clinische Inrigting niet is eene uitsluitend praktische School, waar zieken en lijken de Alpha en de Omega zijn, - maar verbonden wordt met eene in allen deele volkomene Geneeskundige School, waar de Natuurkundige en Elementaire Wetenschappen naar den geest des tijds zo geleerd worden, dat de band, die de Geneeskunde met allen vereenigt, door gestadige praktische toepassing, naauwer en naauwer, de scheiding tussen het theoretische en het praktische verbroken wordt" (Van Cooth 1842: 87). De lokatie van het ziekenhuis "is de eenige, die ons toestaat de zieken naauwkeurig gade te slaan, en is daardoor het best in staat de wetenschap te helpen bevorderen" (Von Baumhauer 1848: 9; zie ook Van Kaathoven en Van der Boon Mesch 1848: 5-7). Volgens het ideaal moet de

63 "Die Berwecksichtigung aller individuellen Verhaeltnisse in diagnostischer und prognostischer Beziehung wird auch fuer die Erforschung der Ursachen strengere Aufgaben stellen" (Rosenstein 1866: 27). 64 "Wir muessen an das kranke Individuum wie an die thachtung eines naturwissenschaftlichen $O b$ jektes mit voller Unbefangenheit ohne Schablone heramgehen, und zuerst sehen" (Rosenstein 1866: 26). 
klinische studie "zooveel mogelijk met de vroegere pathologisch-diagnostische in verband gebragt" (Koster 1864: 34).

Door het benadrukken van de band tussen klinisch onderwijs en de natuurwetenschappen en de daarbij behorende ziekteopvatting, wordt bij de inrichting van het klinisch onderwijs niet slaafs het Franse model, waarnaar Thijssen in 1828 verwijst en waarin de opening van het lijk een centrale rol inneemt. gevolgd. "Het is dus niet enkel om veel zieken te zien, dat wij groote Clinica behoeven (het punt waarop de tegenstand omtrent uitgebreide ziekenhuizen draait), maar om op iedere hoogte en bij elke onderverdeling der studiën gelegenheid te geven tot het waarnemen der afwijkingen van den physiologischen norm, tot het kiezen van de voorwerpen, die men op een bepaald oogenblik voor een bepaald deel van het onderwijs (en niet alleen voor clinisch in den engeren zin, maar ook pathologisch, physiologisch, anatomisch en chemisch onderwijs) behoeft. Het is, omdat, zoo al niet ieder studeerende, ten minste ieder Docent, door voortgezette en voortdurende waameming, op de hoogte zijner wetenschap zou kunnen blijven, en haar tot hoogere ontwikkeling zou kunnen opvoeren" (Heye 1843: 54-55). Van Geuns (1842a: 145-146) wijst de Franse praktijk van het klinisch onderwijs zelfs expliciet af wegens de onvoldoende aandacht die daar bestaat voor de fysiologie: "Noemden wij zoo even Broussais groot, zoolang hij zich bij zuivere waarneming bepaalde, haast zouden wij geneigd zijn, de hedendaagsche Fransche geneeskunde klein te noemen, omdat zij zich in tegengestelden zin, te zeer en te angstvallig binnen de grenzen der waarnemingen aan het ziekbed en in de sectiezaal beperkte. (...) Zoekt men naar de oorzaak, of althans naar de aanleidingen, ten deele zal men die welligt dáárin vinden, dat bij de Franschen de beoefening der Physiologie niet in evenredigheid staat tot den ijver, dien zij aan de Diagnostiek wijden."

Het grote belang van het zelfstandig door de student waarnemen van individuele ziekteprocessen, komt in de pleidooien voor het uitbreiden van het klinisch onderwijs steeds terug ${ }^{6}$. Het optekenen van de ziektegeschiedenis kan daarbij gezien worden als de didactische tegenhanger van de demonstratiepatiënt: " $[\mathrm{H}]$ are waarde [van de ziektegeschiedenis] ligt in de objectiviteit der voorstelling; de langdurigste praktijk en de veelvuldigste ervaring geldt minder dan het geringste, maar objectief voorgestelde feit. Het is voor de weten-

65 "Dikwerf toch is een behoorlijk onderzoek na den dood alleen in staat den slujjer te ligten, welke de oorzaak van vele kwalen zoodanig bedekt, de herkenning en voorzegging van vele ziekten zoo duister maakt" (Thijssen 1828: 29).

66. "Getrouwe waarneming der ziekteverschijnselen, aan ieder hunne zijne juiste waarde toe te kenner. onvermoeide ijver in het opsporen der oorzaken, vergelijking van individualiteiten onderling, naauwkeurige beschouwing der pathologische veranderingen in lijken, scheikundig en mikroskopisch onderzoek van al wat de ziek van zich geeft, ziet daar de zoogenaamde proefnemingen, die in goed ingerigte zièkenhuizen op zieken genomen worden" (Von Baumhauer 1848: 11). 
schap van het grootste gewigt, nauwkeurig waargenome ziektegeschiedenissen te hebben, omdat de ziekelijke toestanden zoo veelvuldig gecombineerd zijn, dat dikwijls de geringstschijnende omstandigheid de meeste waarde heeft; de echt wetenschappelijke geest weet daarin vaak den grond van een nieuw inzigt der dingen te vinden" (H. 1842a: 123) Het invoeren van het zelfstandig optekenen van ziektegeschiedenissen vereist verder historisch onderzoek ${ }^{k 7}$. Volgens Van Lieburg (1978: 81) bestond het derde jaar van de vierjarige opleiding aan de klinische school te Rotterdam grotendeels uit het opstellen van ziektegeschiedenissen en verslagen van lijkopeningen. In 1841 werden aan die klinische school voorgedrukte statusformulieren voor de beschrijving van ziektegeschiedenissen ingevoerd. Nog tot laat in de negentiende eeuw was het gebruikelijk dat academische proefschriften de vorm van een verslag van ziektegeschiedenissen van een bepaalde kliniek hadden ${ }^{6 s}$.

In de uitbreiding van het klinisch onderwijs en de associatie van ziekenhuis en opleiding komt een verandering van kennisideaal tot uitdrukking waarbij de nadruk wordt verlegd van het ordenen van ziektes in een systeem naar de nauwkeurige registratie van het verloop van een individueel ziekteproces. Die verschuiving van de aandacht van hiërarchische indelingen naar het individuele ziekteproces is op het niveau van de maatschappelijke organisatie van de zorgverlening verbonden met een herdefiniëring van de taak van het gasthuis dat dan tot ziekenhuis wordt. De discussies in de gemeenteraad van Rotterdam over het nieuw in te richten Coolsingelziekenhuis te Rotterdam, door Van Lieburg (1986a) gedocumenteerd, markeren die omslag. Terwijl het gasthuis dienst deed als sociaal-charitatieve instelling, als verzorgingstehuis voor de laagste standen, stond geneesheer-directeur Molewater met het in 1851 nieuw in te richten Coolsingelziekenhuis iets geheel nieuws voor ogen. Dat het ziekenhuis onder de directie van een geneesheer kwam, was op zich al een noviteit, en uitdrukking van het principe dat de medische functie het leidende organisatieprincipe geworden was. "Met dat doel staat alles in het gesticht in verband; de geheele inrigting van het huis, de ligging, de kleeding, de voeding, in een woord alles is aan dat doel ondergeschikt" verklaarde het raadslid J.A.M. Bichon van IJsselmonde in 1856. In een dergelijke instelling was het noodzakelijk dat de leiding in handen was van een medicus, "iemand (...) die

67 De oorsprong van de ziektegeschiedenis reikt terug tot in de zeventiende eeuw. Maar is dar ondergeschikt aan het doel een ziekte in een nosologisch systeem onder te brengen (Lepenies 1976: 84) "Scholars agree that systematic nosology, the classification of diseases into definite clinical species, begins with the efforts of Sydlenham. Instead of dealing with diseases in individual patients as Hippocrates had done, Sydentiam's natural history seeks by acute observation to delineate species of disease, akin to the method of the seventeenth century botanists" (Wolfe 1961: 205).

68 Zie bijvoorbeeld de verslagen der verloskundige kliniek en polikliniek aan de Leidsche hogeschool gedurende de jaren 1870-1871 en 1871-1872. 
op de hoogte der wetenschap is en alles kan inrigten in het belang der zieken" (in Van Lieburg 1986a: 308). In dit beeld past ook de wens van geneesheerdirecteur Molewater om in het nieuwe Coolsingelziekenhuis een verpleegprijs in te voeren ${ }^{6}$. Onmiddellijk na het bekend worden van Molewaters voornemen, rees er verzet tegen "de opheffing eener liefdadigheidsinstelling waarvoor in de plaats wordt gesteld een kosthuis voor zieken" (Aldus de N.R.C., in Van Lieburg 1986a: 299). In de gemeenteraadsvergaderingen gewijd aan het nieuwe Coolsingelziekenhuis is de onzekerheid over de functie die dat nieuwe ziekenhuis moet gaan vervullen pregnant aanwezig. Raadslid Beelaerts van Blokland stelde de functie van een ziekenhuis of gasthuis expliciet aan de orde $e^{20}$. Verschillende sprekers wezen erop dat het Coolsingelziekenhuis toch de opvolger van het oude gasthuis was, en dat om die reden gratis verpleging een vanzelfsprekende zaak behoorde te zijn. Tot oktober 1853 werd de toegang tot het ziekenhuis daadwerkelijk beperkt tot betalende patiënten, d.w.z. patiënten voor eigen rekening of voor rekening van particulieren of armbesturen. Niet iedereen kon zich echter vinden in de nieuwe taakopvatting van het ziekenhuis. Raadslid de Critter meende in oktober 1853 op te moeten merken "dat de behoeftige lijders in het nieuwe ziekenhuis te veel behandeld worden als menschen van den grooten stand" (in Van Lieburg 1986a: 307). In 1856 was de meerderheid van de gemeenteraad inmiddels de mening toegedaan dat het Coolsingelziekenhuis de ziekenverpleging en zo mogelijk de ziekengenezing tot doel moest hebben. "In vijf jaar tijd had het stedelijk ziekenhuis van Rotterdam in de publieke opinie een volledige metamorfose ondergaan", aldus Van Lieburg (1986a: 308) $)^{7 \mathrm{p}}$.

69. "Deze regelling was een ewsentieel onderdeel van Molewaters fil osofie over het moderne ziekenthuis, dat naar ajin mening geen charitatieve instelling mocht zijn, in thoofdzadk bedoeld voor on en minvermogende Rotterdammers en gefinaneierd uht liefdadigheid en publieke fondsen, mar dat een medische instelling bestemd was voor zieken ongeacht hun geografische herkomst of sociale status en gefinancierd moest worden op basis van de inkomsten uit de verpleeggelden" (Van Lieburg 1986a: 298) 70 "Wat is, ter opzigte van het in behandeling zijnde onderwerp, een ziekenhuis of gasthuis?" Het is geen loggenent, geen intichting ten behoeve van de wetenschap, noch een unrichting voor diegenen die ziekenverpleging zelf kunnen betalen. "Het is alzoo een sitadsgesticht, bestemd ter ziekenverpleging van allen, maar in de erste en voomannste plaats van onvermogenden" (Raadslid F.W.A. Beelaerts van Blokland, in Van Lieburg 1986a: 303).

$71 J_{4}$ de Bosch Kempers "Handleiding Staalsbestuur" (1865: 813) doet vermoeden dat de ambivalentie over de status van de gasthuizen in Nederland als gehevel echter langer heeft bestaan. Paragraaf 356 die over de gasthuizen handelt, laidt als wolgt: "In onderscheidene groote gemeenten bestaan gasthuizen ter ziekenverpleging; zij worden bestuurd volgens stedelijke reglementen, nuar behooren als geneeskundige instellingen aan geneeskundig toezigt ondewworpen te zijn. De gasthuizen zijn bijna alle oorspronkelijk als liefladige gestichten opgerigt. Zij behoeven dat karakter niet te verliezen, al is het ook dat de sthatszorg, bij gemis van genoegzame liefdadigheid, de zorg voor behoeftige zieken zich moet aantrekken." 


\section{De opvatting van ziekte}

Op de achtergrond van de debatten over de inrichting van het medisch domein en de medische opleiding speelde een verandering door in de opvatting van ziekte, die samenhing met een emancipatie van het fysiologisch denken. Aan het einde van de achttiende eeuw werd de geneeskundige wetenschap vooral gekenmerkt door eclecticisme: "[T]erugkijkend op de ontwikkelingen die zich ten aanzien van de algemene pathologie voordeden in de achttiende eeuw, wordt men in de eerste plaats getroffen door de aanwezigheid van vele nosologische systemen: de iatromechanische leer (Boerhaave), de tonustheorie (Hoffmann), het 'animisme' (Stahl), de leer der irritabiliteit en sensibiliteit van Von Haller, de 'neuropathologie' van Cullen, het Brownianisme en het vitalisme (Borden)" (Haneveld 1978: 47-48; zie ook De Moulin 1978: 40; Hamers van Duynen 1978: 41-47). Maar afgezien van onderlinge verschillen was in het algemeen het streven, in aansluiting op het heersende kennisideaal van de natuurlijke historie $\mathrm{e}^{72}$, ziekten te groeperen en hun onderlinge samenhang in een systeem tot uitdrukking te brengen (Tsouyopoulos 1990). Ziekten werden geclassificeerd op basis van typologieën ${ }^{73}$ of essentiële ${ }^{74}$ symptomen. Vanaf Sydenham (1624-1689) had de overtuiging post gevat dat zoals er plantesoorten bestonden ook soorten ziekten waren aan te wijzen (Lepenies 1976: 78). Ziekten werden opgevat als afzonderlijke eenheden, die systematisch konden worden gegroepeerd en geclassificeerd (Lesch 1990: 97). Dat had in de achttiende eeuw tot een groot aantal nosologische systemen geleid ${ }^{75}$. Bij de aanvaarding van het hoogleraarsambt aan de hogeschool Groningen sprak E.J.

72 "De tijd zal komen, het welk ik vooruit zie, dal aan iedere Hoogeschool van dit Rijk, even als in een middelpunt, alle voortbrengselen der Naturur, (...) zullen worden bijeengebragt: opdat eindelijk eens; doou" gemeenschappelijke arbeid, eene volkoome Natumirgeschiedenis van het Rijk der Nederilanden ten. voorschijn kome" (Driessen 1820:34). Zie verder hoofdstuk 5.

73 In de Nedexlandse medische literatuur tussen 1750 en 1875 werden volgens $P$. Kalmthout: 13 verschillende koortstypen onderscheiden (De Moulin 1978; 25), De Nijmeegse arts A. Mok onderscheidde in 1823 nog tenminste 12 polstypent klein vs. groot, zwak ws. sterk, week vis, hard, onderdrukt vs. vol; snel vs. langzazin, geregeld vs. ongeregeld enz. in allerlei combinaties (Groustra 1985: 39).

74 "Sydentham nimmt also den Krankheilsfall nicht als etwas Ganzes, er abstrahiert vielmeht davon 1. die Symptome, die Ausdruck der dahinter stehenden spezifische Krankheit sind und 2. die Symptome, die mur zufällyg, durch falsche Behandlung oder derglewchen, sich überlagern, das Büld allerdings vollig verwischen $k$ önen. (...) Sydenhams Beobachtung faBt also die Krankheiten ins Auge. Er hat Hurdwerte von Kranken gesehen, what sie genau beobachtet, aber ex will in ithnen die Species der Krankheiten schauen und deren geordnete Beschreibung geben, damit die Medizin ein System der Krankheiten erhalte. Er betrachtet in welen Kranken nicht das inmer wieder verschiedene, individuell schwankende, sondern das Konstante, das Bleibende, die Krankheitsgattung, die sich im Individuum beispielnaftatisprïgt" (Temkin 1928:344; 348).

75 "Rather than seeking new, more accurate descriptions of disease, the nosologists of the latter 18 th century took existing descriptions and tried to catallogue and group them, usually on the basisis of symptoms" (Lesch 1990: 98) 
Thomassen a Thuessink in 1794 de volgende desiderata uit: "[H]et ontwikkelen van een classificatie van ziekten naar analogie van die van Cullen" en "het aanleggen van een grote, welgeordende registratie van obductieverslagen, vergezeld van een zo volledig mogelijke anamnese naar het voorbeeld van Morgagni" $^{\prime \prime}$ (Groustra 1985: 33). De door Thomassen genoemde Morgagni (16821771) was éen van de grondleggers ${ }^{76}$ van de morfo- of solidairpathologie, de stroming binnen de geneeskunde die ziektes op basis van in post-mortem onderzoek geconstateerde anatomische structuurveranderingen ${ }^{\pi}$, classificeerde en indeelde (Verwey 1987: 16).

Door de nadruk op systeem en orde lag de beoefening van de pathologische anatomie geheel in het verlengde van de anatomie, die het basisvak voor de gehele geneeskunde vormde (Haneveld 1978). Dat vond zijn materiële uitdrukking in de presentatievorm: het pathologisch kabinet. Zelfs de fysiologie was onderworpen aan het overkoepelende perspectief van de anatomie, en gericht op het blootleggen van structuren. Bernard Siegfried Albinus (1697-1770) bijvoorbeeld, die gedurende 50 jaar als hoogleraar aan de universiteit van Leiden was verbonden, was er in zijn fysiologisch onderzoek aanvankelijk op uit, om onder gebruikmaking van de microscoop en een vaatinjectie ${ }^{78}$-techniek de kleinste functionele eenheid, het 'vas minimum', in Boerhaave's mechanistisch $^{79}$ model bloot te leggen (Punt 1983: 75). Op macroscopisch niveau werd dat gecomplementeerd door het streven de "homo perfectus" te representeren, de ideale mens in al zijn symmetrie en harmonie ${ }^{80}$ te laten zien. Pas vanaf

76. Morgagni's 'De sedibus et causis morborum' (Bologna, 1761) wordt vaak als 'Grundbuch" van hel localistisch-laesionistische denkern angehaald (Verwey 1987: 16).

77 Structuurveranderingen die bij een the paalde ziekte telkens werden aangetroffen, werden als primair aangemerkt, terwijl andlere als secundair werden beschouwd (Haneveld 1978: 28).

78. De techniek wan het injecteren van vaten was onstreeks 1720 tot grote hoogte gebracht door Frederik Ruysch, verbonden aan het Athenaeum van Amsterdam. "[F]or a time, anatomical injection was known as the "Ruyschian art" (Lawrence 1988: 196). Ruysch" "collection of human and anatomical matrial alone filled ten cabinets. A special iten consisted of two intricate groups of anatomical preparations of himan origins danked and crowmed by the skeletons of little children and meant to repregent allegories of death (Lunsingh Scheurieer 1985: 119).

79 Hermainu Boerhatuve (1668-1738), een van de grote voomannen van de iatromechanische richting bihnen de beofening van de fysiologie, vatte het licham op als een machine. Het lichaam is een systeen van buizen en buisjes waar doorheen de humeuren de "corpuscula terrestria", de structurele elementen die via het voedsel het lichaam binnenkomen, transporteren. Deze kleine deeljes klonteren samen tot vezels, die op hun beurt de membranen vormen wamuit de 'vasa minima' van het systeem bestaan. De organen staan op zich weer in een onderlinge hiërarchie. De wetmatigheid binnen het lichaam laat geen enkele autonomie toe; een ontregeld orgaan movt met een rigoureuze therapie worden tertuggedrongen (Luyendijk-Blshout 1989:32). Ziektes worden opgevat als zelfstandige entiteiten die het complexe stelsel van pijpen werstoppen (Richards 1987: 31).

80 "[T] him, symmetry symbolized ideal beatuty, strength and health. Boerthavve had earlier already claimed that a disturbance of symmetry in the smallest parts was responsible for diseases, and believed that the symmetry of the small and the large parts determined their functioning" (Punt 1983. 18). De verwevenheid varu esthetica en ana tomie is algemeen in de achttiende eeuw. "[T]o the eighteenth century 
omstreeks 1750, won de fysiologie voor Albinus aan betekenis en kreeg deze een meer zelfstandige rol $^{\text {:n }}$.

Wanneer F.C. Donders, die bij voortduring op een fysiologische benadering van de pathologie heeft aangedrongen (Haneveld 1978: 230) ${ }^{22}$, in 1872 in ronkende bewoordingen de overwinning van de fysiologie viert, doet hij dat door haar benaderingswijze af te zetten tegen de school van Albinus: "In den laatsten der Sandiforts vinden wij een waardigen vertegenwoordiger der school van Albinus. (...) over de wetenschap van het leven lag de schaduw des doods: het langzaam voorlezen van latijnsche dictaten, te recht of te onrecht als een vertaling van Richerands Nouveaux élémen[t]s uitgekreten, gold voor onderwijs in de physiologie (...). Zoo was het, en wie het anders zou hebben gewenscht ware door velen als ketter uitgeworpen. Zelfs verscheidene jaren later - in 1846 - kende de geneeskundige faculteit nog geen hooger ideaal dan de school van Albinus" (Donders 1872: 64).

De fysiologie omarmt in haar opmars alle vakken die niet gericht zijn op het blootleggen van structuur en het plaatsen in een systematische orde, maar op het registreren van het verloop van een proces. De fysiologie zet de bestaande verhouding tussen de leervakken op zijn kop en plaatst zichzelf aan de basis: "Zoo wordt dan Physiologische Anatomie, Histologie, vergelijkende Physiologie en Physiologie van den mensch de kroon der wetenschap van den menschelijken zamenstel in den gezonden toestand" (Heye 1843: 46). Coleman (1988: 43) formuleert de veranderingen in het fysiologisch denken in Duitsland in de volgende bewoordingen: "Physiologists and anatomists came to differ on methods applicable to both instruction and inquiry. The physiologist wanted direct access to vital processes and was eager to exploit physical, chemical, microscopical, and vivisectional techniques to gain that access; his institute was to be built around this proposition. The anatomist, in contrast, continued to stress skill in dissection and to offer a comparative view of function by means of preserved materials" ${ }^{\prime \prime}$. I. van Deen $(1851: 6)$ omschrijft in zijn inaugu ${ }^{-}$

eye, aesthetics were fundamental to anatomical discernment: the most natural anatomical preparations were also the most beatiful" (Lawrence 1988: 200).

81 "Albinus initially regarded anatorny as subservient to the "oeconomia animalis', as taught by Boerhave, but he failed to find sufficient evidence for this. A clear need thus arose for a new physiclogical model, which prompled further research in physiology. As a result of this research Albinus moulded his own structural elements of anatomy, together with the results of intability experiments, into a new model. In this way he succeeded in effecting a synthesis of mechamistic and vitalistic ideas, allhough it is clear that he sometimes prefened to materialise the vital force" ( $P$ un $1983: 1$ ). Hel materialuseren van de 'Lebenskraft' is een algemeen fenomeen in de emancipatie warh de fysiologie wit de classificerende geneeskunde (Tsouyopoulis 1990: 104).

82 De Nederlandse vertaling van $\mathbb{1}$. Liebigs 'Die organische Chemie in ihrer Anwendung auf Physiologie und Pathologie" (Braunschweig 1842) die reeds in 1842 verschijnt (Dierlijke scheikunde of bewarkw tuigde scheikunde toegepast op physiologie en pathologie), is van Donders' hand. 
rale rede het verschil in benaderingswijze tussen anatomie en fysiologie aldus: "Ofschoon beschrijvende ontleedkunde zeer goed zonder physiologie kan beoefend worden, zal echter de met eenige zucht tot wetenschap bezielde anatoom zich nimmer tevreden stellen met de eenvoudige beschrijving der verschillende werktuigen, maar ook in de verrigting daarvan willen doordringen."

Met name de pathologische anatomie komt dan in een spanningsveld tussen de anatomie en de fysiologie te staan. Een artikel in De Gids (1848: 322-326) schetst de ontwikkelingsgang van de geneeskunde aan de hand van de beoefening van de pathologische anatomie. Daarin worden vier verschillende ontwikkelingsstadia onderscheiden: de eerste fase wordt gekenmerkt door het speuren naar curiosa voor kabinetten; in de tweede fase staat het geven van opheldering van een ziektegeval centraal; vervolgens komt het er op aan het verband tussen de afwijking der verschillende organen aan te geven "ten einde daardoor een helderder inzigt in den oorsprong, den aard en de uitbreiding van het ziekteproces te winnen, en zijne uiterlijke verschijnselen te leeren verklaren". De vierde fase, de wetenschappelijke en zelfstandige beoefening van pathologische anatomie treedt in "wanneer zij, vrij van de zucht om rariteiten te vinden, en zich niet bekommerde om de voorafgaande ziekte-verschijnselen, de afwijkingen der organen op zich zelve beschouwt, naar de fijnere delen, waarin die afwijkingen bestaan, onderzoek doet, het microscoop om opheldering van de fijnere structuurveranderingen vraagt (...) zoo doende algemeene gezigtspunten vaststelt en de bijzonderheden tot een systeem tracht te verbinden."

De schrijver wil in dit artikel betogen dat de pathologische anatomie in ontwikkeling is. Maar wat het artikel vooral duidelijk maakt is dat de auteur nog midden in die ontwikkeling staat. Dat blijkt onder ander uit zijn analyse van de manco"s: "Aan de pathologische anatomie ontbrak nog altijd [rond 1820] die veelzijdige blik, die het geheel kon overzien, die scherpzinnige opvatting, die het bijzondere onder algemeene gezigtspunten zou brengen, en met het zittend oordeel tot een systeem zou coördineren, en zoodoende de pathologische Anatomie tot eene meer zelfstandige wetenschap moest verheffen. Want de rijkdom der kennis moge de geleerdheid uitmaken, ${ }_{s}$ - het samenvatten der empirische feiten tot een geheel, het terugvoeren van het afzonderlijke tot algemeene waarheden, en de bevestiging van deze door vaste beginselen, dit alleen maakt de wetenschap uit." Als toppunt van geleerdheid zweeft de schrijver een geordend systeem voor ogen, waar het bijzondere, het nieuw ontdekte, in overeenstemming wordt gebracht met het "zittend oordeel" en zich daarbij niet laat leiden door de voorafgaande ziekteverschijnselen.

De pathologische anatomie die in de loop van de negentiende eeuw in $\mathrm{Ne}$ - 
derland en Duitsland ${ }^{\infty}$ gestalte krijgt, is niet zozeer gericht op het blootleggen van pathologische structuren als wel op de fysiologie: "Welk patholoog is in staat, de physiologie op moeielijke tochten bij haar snelle vaart te volgen, zoo hij niet nu en dan op de wieken van zijn ambtgenoot kan drijven?" (Donders 1872: 65). De verschillende zienswijzen op de beoefening van de pathologische anatomie komen expliciet naar voren bij de splitsing van de leerstoel van Halbertsma te Leiden. Aan de ene kant staat de moderne, fysiologische richting met Heynsius, aan de andere kant de klassieke anatomische richting met Zaayer en daartussen Boogaard met de 'anatomische-physiologische' richting (Beukers 1983: 79; Donders 1872: 65). T. Zaayer (1866: 7) beschouwt de ontleedkunde "als de grondsteen, waarop het verdere gebouw der geneeskunde moet worden opgetrokken". Het anatomisch onderwijs moet inzicht geven in de (verhouding tussen de) samenstellende delen van het menselijk lichaam. Het anatomisch kabinet is het didactisch hulpmiddel daarbij. Zaayers voorkeur gaat uit, zoals die van zijn voorganger Halbertsma, naar de macroscopische anatomie, waarbij een verbetering van de ontleedkundige techniek vooruitgang moet brengen. Heynsius aanvaart in 1866 het hoogleraarsambt in de fysiologie en bepleit daarentegen het invoeren van praktisch klinisch onderwijs en experimenteel laboratoriumonderwijs. Terwijl Zaayer de microscopische vaatinjectiepreparaten van Hyrtl, die hij in 1867 verworven had, demonstreert, laat Heynsius de studenten met verse preparaten werken ${ }^{\text {si }}$ (Beukers 1983: 79).

De centrale plaats van het kabinet, dat evenals de anatomische atlas en de publieke ontleding vooral een overzicht moest geven van normale en patholo-

83 In hoeverre de ontwikkeling van de pathologische anatomie in. Frankrijk (Maulitz 1987: 95), met thet geleidelijk verleggen van dhe onderzoeksinteresse van organen via weefsels (Bichat 1771-1802) naar de aantasting van functionele systemen in zijn totaliteit (Laennec 1781-1826), hierin past (Rey 1990) of zich daar net aan onttnekt (Jacyna 1990), blift hier buiten beschouwing. "There is substantial agreement among historiars of the life sciences that between the works of Xavier Bichat (1771-1802) and those of Francois Magendie (1783-1855) there was profound transformation in French physiology, (n..) We are dealing with a specific manifestation of a very general shift in the conceptual structure of European science" (Pickstone 1981: 114). In ieder geval spelen in Frankujk ook veranderingen in de anatomie ent belangrijlke rol: "By the early nineteenth century the mutual relations of anatomy and physiology were being broken, and this separation has uswally been seen as the outcome of the work of physiologists, notably Francois Magendie: However it is equally plausible to argue that an opposite factor, on the anatomical side, was also at work. (...) the creation of surgical anatomy" (Lawrence 1988: 212). Zie ook Gelfand (1980) en Lesch $(1984,1988$ en 1990).

84 Beukers (1983: 79) citeert wit de Leidsche studentenalmanak (1869)" "Onbegrijpelijk kont het ons evenwel voor dat de hoogleraar [Zaiyer] ons ook dit jaar weer heeft toegezegd een gedeelte van deut. bij aan histologie te zullen wijden. Gewoonlijk komen deze lessen - althans zoo was het vorige jaar -. hierop neer. Eerst hebben wij een repetiltie van de gewoone anatomie - en dat is hemel nuttig maar hel kon met veel minder tijdverlies even goed geschieden - dan krijgen wij eenige teekeningen uit Kolliker te zien, en ten laatste worden ons door middelmatige microscopen, in een tamelik slecht-verlicht Jokaal, enige geluteende preparaten vertoond. En dat, terwij wij bij prof. Heynsius dezelf de onderwerpen zoo helder mogelijk hooren voordragen en een aantal preparaten die altijd met de beste zorg behandeld, en, zoo het nod.'ig 
gische structuren, werd overgenomen door de microscoop. Internationaal gezien begon de microscoop rond 1800 aan een opmerkelijke come-back. Op dat moment stond het instrument nog op hetzelfde niveau van technische ontwikkeling als anderhalve eeuw eerder. Toen werd de microscoop echter in amper 75 jaar zo ver ontwikkeld, dat de theoretisch maximaal haalbare vergroting van 1400 keer ook daadwerkelijk werd bereikt (Fournier 1983: 59; Van Wijhe 1889: 8). In Nederland beleefde het gebruik van de microscoop tussen 1830 en 1840 een doorbraak (Beukers 1983: 67). De microscoop ondersteunde de opmars van de fysiologie ${ }^{86}$. "Microscopical anatomy might be expected to have belonged to anatomy, but whenever possible it was seized by physiologists (and pathologists). As noted earlier, the microscope (...) promised a new approach not only to structure but to function and dysfunction" (Coleman 1988: 43). P. Harting, de grote voorspreker van het microscoperen in Nederland, gaf duidelijk aan dat hem bij het gebruik van de microscoop een ander kennisdoel voor ogen stond dan voorheen: "Wanneer wij dus de ontleedkunde niet tot eene eenvoudige beschrijving van het bestaande willen beperken, dan moeten wij ook trachten in de geheime werkplaatsen der natuur door te dringen, ten einde de wijze op te sporen, op welke uit het levenlooze, de voor leven vatbare organen worden voortgebragt ${ }^{\prime \prime}$ (Harting 1844: 18) ${ }^{87}$.

De microscopische anatomie moest voortaan geleid worden door de fysiologie (Lenoir 1988: 157). Wat die fysiologische benadering zo anders maakte, was dat zij geen principieel onderscheid aannam tussen het lichaam in gezonde en in zieke toestand: "Hoe meer men de geneeskunde op de regte wijze leert te beoefenen, des te levendiger wordt de overtuiging, dat de kennis van den mensch in den ziekelijken toestand, door die van de gezonden mensch moet

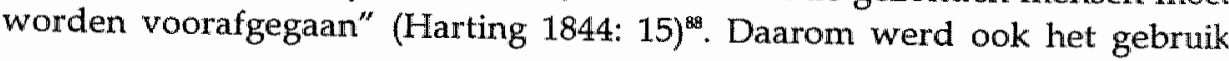

85 sthe mint problem in early nineteenth-century microscope building - reducing the chromatic abetration caused by the dispersion of light - had been largely solved by the 1830 's, and the new microscopes, inexpensive enough to be paid for out of a students allowance, permitted observation of clearly definable structures where before only halos and globules had been seen (Tuchman 1988: 74). 86 Althans in Duitsland waar de Nederlandse geneeskundigen zich sterk op richtten: Mulder - Liebig Donders - Purkyne; Ramaer - Wunderlich. Donders, Van Deen en Moleschott redigeerden gedurende de jaren 1845-1847 het tijdschwift Holländische Beiträge zu den anatomischen und physiologischen Wissenschaf ken. Zie ook Haneveld (1978: 95). "Een analyse van de catalogus van de Universiteitsbibliotheek (1835) laat zien dat men in Utrecht op het gebied der ziektekunde en ziektekundige ontleedkunde in het begin der vorige euw opmerkelijk sterk op Duitsland georiènteend was."

87 "Thans ecthter, om met de woorden van Harting te spreken, nu het mikroscoop niet meer als kaleidoskoop wordt gebruikt, maar nu men in zijn onderzoek geregeld voortgaat, niet meer vragende Thoe schoon" madr alleenlijk "hoe, thans mag zich de microskopie verheugen dien rang onder de positieve wetenschappen te bezitten, welke haar wegens haren rijkdom aan feitten en hulpmiddelen tae. kom ${ }^{2 x}$ (Boekbeoordeling van P. Harting: Het microscoop, deszelfs gebruik, geschiedenis en tegenwoordi.
ge toestand, Utrecht 1848 , De Gids, 1848: 508).

W8 Haneveld (1978: 159) citeert Harting: "Sueman vertegenwoordigde dle pathologie en de chirurgie. Wat de eersite betreft, zoo had toen der tijde het besef dat pathologie niets anders is dan physiollogie, nog 
van verse preparaten gepropageerd. "[E]indelijk zag men ook in, dat, indien men eene juiste kennis wilde verkrijgen nopens het maaksel der deelen in den levenden toestand, men dan ook het onderzoek zoodra mogelijk na den dood moet bewerkstelligen" (Harting 1844: 2; zie ook Czermak 1851: 2). De pathologische anatomie moest niet langer streven naar een overzicht van post-mortem geconstateerde afwijkingen binnen organen, maar diende bij te dragen aan het begrijpen van ziekte als een verstoord levensproces. Het ziekelijke leven verschilde slechts daarin "dat de omstandigheden, waaronder het organismus zich bevindt, gewijzigd zijn geworden" (Schrant 1862: 25-26). In een op de natuurwetenschappen en meer specifiek op de fysiologie geënte opvatting van ziekte, is er sprake van een graduele overgang tussen ziek en gezond (Lepenies 1976: 192-194; Toulmin 1975; Büttner 1990)" ${ }^{59}$ " Der Physiologie dankt die Pathologie diese fundamentale Wahrheit, dass Gesundheit und Krankheit nur Kehrseiten eines und desselben Lebensvorganges sind, welche nach gleichen Gesetzen verlaufen, verschieden nur nach den aeusseren Bedingungen, und oft so nahe an einander grenzend, dass wir von der Breite der Gesundheit sprechen müssen" (Rosenstein 1866: 10). In een kennisideaal waarin ziektes worden geclassificeerd op basis van essentiële kenmerken of op post-mortem geconstateerde afwijkingen in organen, is die continuiteit afwezig. Tegenover dergelijke 'ontologische' opvattingen van ziekte plaatsen fysiologen een opvatting van ziekte als een (verstoord) levensproces.

Kenmerkend voor de opvatting van ziekte die in de fysiologie tot ontwikkeling komt, is de afkeer van het classificeren van ziektes op basis van typologieën en symptomen, waarbij de ziektegeschiedenis geen rol speelt (Lepenies 1976: 80). Foucault $(1986: 27 ; 32)$ heeft een aantal eigenschappen van de ziekteopvatting in de classificerende geneeskunde opgesomd. "Om de waarheid van het pathologische feit te kennen moet de arts van de patiënt abstraheren: Wie een ziekte beschrijft, moet een zorgvuldig onderscheid maken tussen de symptomen die er noodzakelijk mee gepaard gaan en specifiek voor haar zijn, èn de symptomen die slechts accidenteel en toevallig zijn, zoals bijvoorbeeld de symptomen die van het temperament en de leeftijd van de patiënt afhangen (...). In deze pathologie speelt de tijd een beperkte rol. (...) Er is geen ontwikkelingsproces". Niet het individuele ziekteproces, maar het onderkennen en benoemen van de essentiële symptomen of afwijkingen staat centraal. De fysiologie profileert zich door zich af te zetten tegen een 'ontologisch' ziektebegrip, waaronder het denkbeeld verstaan wordt dat ziekte één geheel vormt, "welk

volstrekt geen ingang gevonden."

89 "Velen verklaarden de ziekte ontologisch en meenden, dat het een eigen toestand was, geheel tegenovergesteld aan dien van de gezondheid (..) nu men helder heeft leeren inzien, dat er voot ziekte en gezondheid slechts éene eenheid bestaat; 'het leven" (Van Deen 1851: 7). 
geheel zijne bestendige en eigene oorzaken, zijn regelmatig beloop en karakteristieke eigenschappen, dat is de pathognomische verschijnselen vertoont" (Van Geuns 1850: 80; zie ook H. 1842a en b; Kiehl 1852: 20). Bij zijn aanvaarding van het hoogleraarsambt te Leiden (1862) zet J.M. Schrant zijn visie op de' 'empirische ontwikkeling van het ziektebegrip' aan de hand van de ziektekunde (pathologie) uiteen. De "tijd van beeldspraak en van vrome ontologische verdichting, mijne Heeren, snelt met rassche schreden ten einde. (..) Het scherpe zwaard der kritiek hieuw menige onherstelbare opening in de oude (..) verroeste, dogmatische wapenrusting" (Schrant 1862: 8-15). Traditioneel kende de pathologie drie delen: de nosologie, de natuur en het wezen der ziekte, de aetiologie, "eene soort van beredeneerden catalogus van ziekteoorzaken" en de symptomatologie, "een hoofdstuk waarin alle mogelijke abnormale levensverschijnselen achtereenvolgens worden gerecenseerd". "De hoofdfout der oude indeling der pathologie is dat zij in tegenspraak is met de methode van het natuuronderzoek, dat zij de synthesis aan de analysis voortrekt, dat zij begint met te construeren, waar zij moest aanvangen met observatie, dat zij spreekt over den grond en het wezen van eene zaak, voor dat zij die nog historisch heeft doen kennen." Het toepassen van de natuurwetenschappelijke methode, die waarneming en proefneming vooraf laat gaan aan nadenken, heeft bressen geslagen in die oude indeling. "Wat de symptomatologie aangaat, zoo is het hier vooral dat men den invloed der nieuwere denkbeelden duidelijk waarneemt. De oude dorre catalogus der ziekteteekenen begint meer en meer plaats te maken voor eene pragmatische historie der verschijnselen van het zieke organisme. Wij danken deze verandering aan den vooruitgang der physiologie, waardoor wij in staat werden gesteld verband en zamenhang op te merken en verschijnsels te verklaren, wier kennis men vroeger alleen door middel van bespiegeling meende te kunnen verkrijgen." Op een vergelijkbare manier vallen ook de aetiologie en de nosologie ten prooi aan de nieuwe opvatting van ziekte.

Schrant waarschuwt dat de ontologie nog niet geheel en al uitgebannen is. Al is ziekte niet meer "een parasiet met een eigen lijf en leven" of een "typische kracht", ook de pathologische anatomie die aan de lijkentafel de reële en vaste stoffelijke grond van ziekte poogt te detecteren, valt, aldus Schrant, nog ten prooi aan de ontologie ${ }^{0}$. "[I] meen te moeten waarschuwen tegen overschatting, tegen eenzijdige opvatting en ook nog tegen het oude ontologische spooksel. Het was om die reden, dat ik het nuttig achtte, nogmaals aante-

90 [H] elgenlijke punt van uitgang dier ontologische dwaling, hetzij deze in een philosophisch of in een anatonisch gewaad gehuld werd, gelegen is in de aannemirig van plantselifk leven, van phaabselijke ziekten." (Schrant 1862: 28-29). Verwey (1987: 4) spreekt in dit verband van een localistisch-(laesionistische) benaderingswijze. 
toonen, dat de physische diagnostiek ons geene ziekten leert kennen, maar anatomische toestanden, en dat anatomische toestanden geene ziekten zijn, maar ziekteverschijnselen ${ }^{91}$ (...). Zoo zal men gevrijwaard blijven voor nieuwe anatomische ontologie, waarbij aan het materiële substraat van een gedeelte des zieken ligchaams, de beteekenis en de regten worden toegekend van het geheele leven van den zieken mensch" (Schrant 1862: 22). Een zelfde ontologische dreiging ziet Schrant in de opkomende cellulaire pathologie. Ook cellen zijn geen autonoom werkende wezens; het verband tussen de delen moet altijd in het oog worden gehouden. Een juist ziektebegrip vereist dat het hele organisme in zijn onderlinge samenhang en ontwikkelingsgang benaderd wordt.

De opvatting van ziekte als een verstoord levensproces ${ }^{22}$ en het bijbehorende idee dat de fysiologie van de gezonde mens aan de basis moet liggen van de beoefening van de geneeskunde ${ }^{93}$, verspreidt zich over een groot aantal domeinen van de geneeskunde. D. van Haren Noman geeft in zijn inaugaurale rede (1886) een overzicht van de ontwikkeling van het ziektebegrip in de dermatologie. Ook daar ziet hij een opeenvolging van stelsels en systemen, en strijd om het juiste ordeningsprincipe: Maar "bij alle stelsels, die slechts op één kenmerk gebaseerd zijn, [worden] de meest uiteenlopende ziekteprocessen in elkanders onmiddellijke nabijheid gevonden" (Van Haren Noman 1886: 4-5). Het ziekteproces moet het doorslaggevende indelingscriterium vormen. $\mathrm{Om}$ die reden wordt het systeem der huidziekten van de Weense patholooganatoom Hebra afgewezen: "Vergeten wij niet - dat, streng genomen, de patholoog-anatoom alleen van toestanden, niet van processen spreken kan. Wel is waar kan in enkele gevallen de pathologisch-anatomische toestand voor de een of andere ziekte bepalend zijn, in zeer vele andere gevallen komen bij zeer uiteenloopende ziekte-processen dezelfde pathologisch-anatomische toestanden voor" (Van Haren Noman 1886: 7). "Gelukkig zijn de tijden voorbij,

91 "[K] juist begrens de ziekte kan aangenomen worden, maar veeleer alleen ziekteverschijngel is" (Heye 1841: 39 .

92 "Wat mogen wij evenwel in het levensproces oorzaak, wat gexolg noemen? Slujten beiden zich niet als voortgezethe beweging aan elkander aan, zooals het gebruikelijk woord proces reeds aanduidt? (...) Wel zullen we daarbij gedwongen worden telkens dieper door te dringen op den weg van onderzoek; en soms verrast, als wij̈ - gelijk Liwingstone voor de Nijlbron, - in plaats van céne enkele een zamenge* steld net van bronnen zich aan onzen blik zien voordoen" (Huet 1872: 9-10).

93 " $\mathrm{BBj}$ zilekte] zijn geene andere chemische, physische of physiologische wetten in het spel gekoment dan die, waaraan het organisme in zijin normalen toestand ook gehoorzaamt. Hoe vreemd het ook moge klinken, juist is, dunkt müj, de bewering, dat zilek worden evenzeer een physiologische uiting is wan den gezonder mens of van een gezond orgaan als het gezond zjjn zelf" (Van Haren Noman 1886" 211) "Zonder physiologische grondslag is geene pathologie denkbaar. We mogen het dan ook dankbaar erkennen, dat de vruchten van de vooruitgang in de beschouwing en opvatting van ziekten aan ene meer algemeen verbreide en hooger ontwikkelde physiologische opwodling te danken zijn" (Huet 1872: 21). 
dat men bij den zieke zocht naar een vreemd wezen, naar een kakodaemon, die het lichaam vijandig overvallen had en het éénmaal onder zijn macht, deed gehoorzamen aan nieuwe wetten, andere dan den normalen mensch beheerschen. Thans is wel niemand meer met dergelijke ontologische begrippen behept" (Van Haren Noman 1886: 19-20).

In het domein van de geesteszieken ontstaat eveneens verzet tegen een 'ontologische' opvatting van ziekte (Kroon 1863: 147-8). J.N. Ramaer staat het ideaal voor ogen pathologie en therapie der krankzinnigheid te ontwikkelen naar het voorbeeld van Duitse natuurwetenschappers, onder andere Griesinger. De psychiatrie is zijns inziens weinig gebaat met spiritualistische en materialistische systemen. Het spiritualisme wijst hij af omdat dat was blijven steken in de fenomenologische beschrijving van de zieleverschijnselen en niet toegekomen was aan het opstellen van wetten. Het spiritualisme heeft "geenen blik geworpen in de processen des zielelevens, noch die in hunnen organische ontwikkeling doen begrijpen" (Ramaer 1851: 24). Het materialistisch gekleurde psychologisch onderzoek had weliswaar enkele belangrijke feiten opgeleverd, maar men was tegelijkertijd vervallen tot het opstellen van 'voorbarige hypothesen'. Hiermee doelt hij op pogingen tot localisatie van hogere psychische functies in bepaalde delen van de hersenen (Foville, Gall, Bergmann) en/of andere organen (Nasse). Ramaer is weliswaar voorstander van een somatische benadering van psychische stoornissen, maar acht een localiserende werkwijze in strijd met zijn natuurwetenschappelijk wetenschapsideaal. Door verschijnselen te localiseren in bepaalde organen vervalt men onvermijdelijk in "ontologie', d.w.z. "het vormen van afgetrokkene begrippen tot (denkbeeldige) wezens". Met Roser en Wunderlich houdt Ramaer het ontologisch ziektebegrip dan ook voor "den obersten und wesentlichsten Irrthum, die allen duurzamen vooruitgang in onze wetenschap teruggehouden heeft". Ziektes zijn geen entiteiten, maar "wandelbare Zustände", aldus Griesinger. Bijgevolg moet het in een wetenschappelijke geneeskunde niet in eerste instantie gaan om de anatomische veranderingen, maar om de pathologische processen die daaraan ten grondslag liggen. Griesinger drukt het als volgt uit: "Auch wir halten den Process, nicht der anatomische Veränderung, für das wesentliche in den Krankheit" (in Ter Meulen en Widdershoven-Heerding 1985: 113). Het is daarom niet de pathologische anatomie, maar de pathologische fysiologie die in een wetenschappelijke geneeskunde het primaat heeft. Immers, de fysiologie levert in de ogen van Griesinger door haar onderzoek naar de processen in het lichaam en naar de functionele samenhang van de organen pas causale verklaring (Ter Meulen 1988: 129). Zoals de pathologie in het algemeen, zo moet in

94 Het onderstaande is grotendeels gebaseerd op Ter Meulen en Widdershoven-Heerding (1985) en Ter Meuten (1988). 
de ogen van Ramaer ook de psychopathologie gebaseerd worden op het onderzoek naar stoornissen in de stofwisseling. Daarbij dient men zich niet te beperken tot datgene wat zich in de hersenen afspeelt, maar moet men ook de invloed onderzoeken die door de verschillende organen (longen, hart, zenuwstelsel, darmen) daarop wordt uitgeoefend. Het is daarom ook, dat het doel van de psychiatrie nooit gelegen kan zijn in het zoeken naar een specificum ${ }^{\circ 6}$ tegen krankzinnigheid (zie ook Ramaer 1844). Het begrip van specifieke geneesmiddelen berust op de misvatting, dat geneesmiddelen een eigen vermogen bezitten. Dit begrip leidt er tevens toe, dat afwijkingen van bepaalde organen (i.c. de hersenen) buiten het verband met het totale organisme worden geplaatst. "De rationele arts", aldus Ramaer "doet dit niet, omdat hij zowel in de pathologische veranderingen der organen als in den invloed, welke sommige geneesmiddelen hierop uitoefenen, de eindwerking der gewijzigde stofwisseling erkent, welke zich het duidelijkst in die organen openbaart, [en] wijzigt zijn geneesplan naar gelang van de verschijnselen, welke het organisme hem ook buiten het bij voorkeur aangedane deel oplevert." Gezien het feit, zo gaat Ramaer verder, "dat de verstandelijke werkingen van zeer samengestelde aard zijn, en dat het orgaan, waardoor zij in de werkelijkheid treden, niet slechts uit verschillende deelen bestaat, van welke ieder hoogstwaarschijnlijk met eigene verrigtingen bedeeld is, maar ook den invloed der meeste afwijkingen van andere organen in zijne levenswerkdadigheid ondervindt, dan besluit gij zeker met mij, dat het zoeken naar specifica nergens minder op zijn plaats is dan bij de behandeling van de stoornissen der hersenverrigtingen" (Ramaer 1857: 113).

Valt enerzijds gedurende de negentiende eeuw de opmars van een aan de fysiologie ontleende procesopvatting van ziekte te constateren, anderzijds veranderen de op typologieën en classificaties geënte (leer-)vakken van aard, of verdwijnen zelfs in het geheel, zoals bijvoorbeeld de materies medica, het overzicht en de classificatie van beschikbare geneesmiddelen, van het leerprogramma. Van oudsher ${ }^{\circ \%}$ vormde materies medica eén van de pijlers onder het medisch handelen ${ }^{\circ}$. C. Pruys van der Hoeven (1826: 274) lijkt in 1826 het ein-

95. Het specificum is het therapeutisch middel dat correspondeert met een specifieke ziekte in een nosologisch systeem: "So schlließt sich folgerichtig der Gedankenkreis: Feste species der" Krankheiten, diesen bestummt zugeordnete Heilungsmethoden, wo möglich durch spezifische Mittel" (Temkin 1928: 347). Zie ook Schmitz (1984: 8-9).

96. Galiemus bracht in zijn "de Simplicum medicamentorum temperaturis et facultatibus" reeds 540 plantaardige, 180 dierlijke en 100 delfstoffelijke artsenijmiddelen in kaart (Stoeder 1974: 3).

97 "Materies medica toch en therapie, thoezer ook nog de duisterste bladzijden uimakende van het geheele boek der geneeskunst, zij, achter wier uitspraken en leerstellingen meestal nog een groot. vraagteeken geplaatst behoorde te worden, zijin desniettemin die weterschappen, waarop het in de geneeskunst in de erste plaats aankomt, waarvan de geneesheer zijne kracht en de resultaten wan zijn werken, de hijder zijne hulp en zijne redding moet wachten" (Boekbeoordeling van De Beginselen der 
de van de materies medica al te voorzien: "Het ontbreekt onze materies medica voorzeker niet aan uitgebreidheid, maar well an grondigheid, het is een gebouw breed van gevel, maar gering van diepte. In deze laatste afmeting moet zij bearbeid worden, zal zij wezenlijk verbeterd kunnen heeten. Aan medicamenten hebben wij zoo groot geene behoefte. Ja ik zou bijna durven voorspellen, dat, hoe meerder men vordert in de kennis van den waren aard der ziekten, hoe eenvoudiger en beperkter onze materies medica worden zal.". Volgens Miquel (1842: 20) kan de materies medica alleen "eenen rang onder de wetenschappen (...) verkrijgen" als ze op de "grondslagen der Chemie, der Botanie en Physiologie" zal worden gebouwd. De materies medica moet niet langer het domein zijn van dorre kennis van classificaties (19). "Wanneer men gelooft, dat deze Wetenschap, gelijk vroeger, slechts in de kennis der namen, differentiële kermerken, enz. der in de Geneeskunde gebruikte planten bestaat, met bijvoeging van de gebruikelijke deelen en andere pharmaceutische of pharmacognostische bijzonderheden, verlaagt men de Botanica medicinalis tot een zielloos geheugenwerk" (20-21). Met de opkomst van de organische chemie en de fysiologie gaat de eenduidige koppeling tussen een geneesmiddel en een ziekte teloor: "De aprioristische beschouwing der oudere geneeskunde over den grond en het wezen der ziekten gaf, zooals van zelf spreekt, vaste regelen voor de therapie aan de hand. De vijand, die het ligchaam was binnengedrongen moest, het kostte wat het wilde, daaruit worden verdreven. (...) Gelukkig was de natuur niet schaarsch in de levering van doeltreffende middelen. Te kust en te keur kon men kiezen, en vol zelfvertrouwen werd dan ook daarvan ruimschoots gebruik gemaakt. - Maar de ontwikkeling der natuurkundige wetenschappen nam het zelfvertrouwen bij den geneeskundigen weg. (...) Zullen wij treuren over het verlies van dit zelfvertrouwen dat geen reëlen grondslag had? Zeker niet. Alleen voor de pharmaceuten is het eene zware ramp, die zij nog in onzen tijd niet te boven gekomen zijn" (Heynsius 1866: 31).

Dat in de loop van de negentiende eeuw het aan de fysiologie ontleende ziektebegrip dominant wordt, wil niet zeggen dat de opvatting van ziekte als proces een uitvinding is van de negentiende eeuw $w^{\text {st }}$. Veel eerder, in de humo-

rnateria medica en den therapie, door Jon. Pereilra, naar het engelsch bewerkt door $L$. Fock, Amersfoort, De Gids 1851, 672). Zie voor de geschiedenis van de farmacie in de negentiendle eeuw Bierman (1988). 98 "Schon durch Röschlaub, aber mehr noch und radikaler durch Conrad Joseph Kilian (1771-1811) wurde der Bruch mit clen nosologischen Traditionen des 18. phuth. vollzogen, da man nach der Ueberwindung der mechanistischen Vorstellung von der Wirkungsweise des Organismus als Maschine strebte und sie durch die Auffassung von wechselseitiger, nicht linear kausaler Verknüpfung von Ursache und Wirkung zu ersetzten suchte. Dabei waren das Prozeßhafte bei der Entstehung des kranken aus dem gesunden Zustand und seine Rückbilding in Form der Genesung betont ${ }^{\prime}$ d.h. das Geschehen wurde verzeitlicht betrachtet" (Lammel 1989: 84). 
raalpathologie (Maulitz 1987: 13) en ook in de iatrochemische traditie ${ }^{100}$ vallen aspecten van de fysiologische opvatting van ziekte als een verstoord levensproces te herkennen (Büttner 1990). Maar in de humoraalpathologie is die verbonden met de opvatting dat interne ziekten intrinsiek onobserveerbaar zijn (Gelfand 1980: 178). De fysiologische benadering leidt daarentegen tot de conclusie dat de geneeskunde als wetenschap zich moet baseren op de nauwkeurige waarneming van (verstoorde) levens-processen op alle niveaus (Heynsius 1856: 22; Cranefield 1957: 422).

Van de andere kant vallen in de fysiologische opvatting van ziekte als een verstoord levensproces aanvankelijk nog duidelijk teleologische en zelfs teleomechanische elementen aan te wijzen ${ }^{101}$. In zijn 'Pathologische Untersuchungen $^{\prime}$ trekt J. Henle (1840a) ten strijde tegen het ontologische ziektebegrip. In een rationele geneeskunde moet in zijn ogen ziekte beschouwd worden vanuit het perspectief van de interactie van een georganiseerd lichaam met zijn omgeving (Tuchman 1988: 76-77). Het argument ${ }^{102}$ waarop Henle deze moderne ziekteopvatting baseert, ontleent hij echter aan de teleomechanische traditie: "[I] $t$ was because of the dependence of the organism on the environment that disease was at all possible. As Henle explained, 'If the organism, the germ, were to carry within itself all the conditions for developing according to its idea [that is, type], then deviations would not be possible. But since these conditions are in part external and independent of it, the possibility exists that it will deviate from the idlea, and this is the most general concept of disease.' (Henle 1840b: 182). Given that disease results from the interaction of the type with the environment, there should, logically speaking, be two mechanisms whereby deviations should occur. Either the type could respond abnormally to stimuli or the external stimuli could be directly responsible for the deviations" (Tuchman 1988: 77). De eerste mogelijkheid wijst Henle af omdat een "Typus irregularis" een "contradictio in adjecto" vormt. Het type determineert bij definitie de regelmaat in iemands leven. Regelmatigheid en determinatie

99 De opvalting dat ziektes voortkomen uit een verstoring van het evenwichut tussen de vier menselijke lichaamssappen bloed, gele en zwarte gal en slijm.

100 De iatrochemische traditie gaat terug op Paracelcus (1493-154l) en werd in de Lage Landen door J.B. Wan Helmont (1577-1644) en F. dele Boë, Sylvius (1614-1672) verder voortgezet. Paracelcus en later Van Helmont zagen het stoffelijke lichaam onderworpen aan de heerschappij van de archeus $s_{r}$ die in de maag huist. De archeus reinigt en creëert en wikt en beschikt over ziekte en gezondheid (Peeters 1989: 35; Moleschott 1989 [1864']: 91).

101 "Zusammenfassend kann festgestellt werden, daß sich in den naturphilosophischen medizinischen Systemen bei allen Unterschieden eine Entsprechung von Entwicklungsgedanke, Einheit der magnetischen elektrischen und chemischen Erscheinungen, der Lebensfunkttionen und des physiologischen Aufbaus mit den Krankheitsformen nachweisen läBt" (Lammel 1989: 96).

102 Van Geuns (1850) wijst Henle's aanname van een type af, op grond wan het feit dat het type niet voor de waarneming toegankelijk is. 
vormen basisaannamen in het teleomechanistische denkschema. Enkel afwijkende condities kunnen aanleiding geven tot ziekte: "A parasitic notion of disease, wherebye the pathological symptoms would be seen as the expression of a distinct disease entity or, worse yet, as an entity itself, must be denied if one accepts the lawfulness of the type" (Tuchman 1988: 78).

\title{
Theorie en praktijk
}

\begin{abstract}
Alle elementen die tot dusverre aan de orde zijn gekomen, het verdwijnen van de rangen en standen in de medische beroepsgroep, de integratie van opleidingstradities, de opkomst van de empirische natuurwetenschappen, de verschillende opvattingen over ziekten, zorgen er samen voor dat het denken over de verhouding tussen theorie en praktij $k^{103}$ in de negentiende eeuw radicaal verander $t^{104}$. In dat veranderingsproces worden zowel de traditionele zekerheden van de geleerde artsen, als de overgeleverde traditie van de 'practici" ter discussie gesteld ${ }^{105}$. Het therapeutisch handelen van zowel de geleerde artsen als van de 'practici' berustte grotendeels op overgeleverde routines. Wat de geleerde arts van de 'practicus' deed verschillen was zijn kennis van de geleerde traditie, van de grote boeken en overzicht in de systemen ${ }^{10 \%}$. "De ge-
\end{abstract}

103 De betekenisverschuiving van het begrip 'praktijk' blijft uiteraard niet beperkt tot het domein wam de geneeskunde. Een dergelijke betekenisverandering valtook te signaleren in de context van de oprichting wan een landbouthogeschool (De Gids 1838: 55il).

104 Een aspect klaarvan dat niet aan de orde komit, betreft de kwestie of hoogleraren een eigen praktijk mogem uitoefenen. In tegenstelling tot de siltuatie aan de klinische scholen, waar - vanuit de vertbondenheid met de meester-leerling traditie - van de docenten werd geëist dat zij praktijk uitoefenden in het gasthuis, was dat aan hoogleraren van hogescholen door het Organiek Besluit juist verboden. Het mogen uitoefenen van een eigen praktijk door hoogleraren in de geneeskunde en in de rechtsgeleerdheid vormt vervolgens een punt van onderhandeling en discussie tussen hoogleraren, curatoren van de hogeschool en overheid. Zie Kühler (1953) voor de verwikkelingen rondom J. wan Geuns aan hel Atheraeum van Amsterdam; voorts Senaalt (1828: $14-16)$, Inlichtingen (1828: 19) en Tydeman (1828: 24). Uiteraird spelen in deze discussie financiele overwegingen een grote rol.

105 " $[2]$ oo moogt ge toch niet vergeten, dat de praktische geneeskunde slechts van lieverledle die hulpmiddelen opneemt; zij voegt het nieuwe aan het oude, en dwingt het een naat het andere. Reeds nu heeft hier en daar de aanwending van scheikunde en mikroskoop zoodanige resultaten opgelewerd. dat het memand in den zin zal komen, bij enkele ziekten het nut dier hulpmiddelen te ontkennen ("x) Maar wie den gang der wetenschap heeft gadegeslagen, hij zal het gevoelen, cat hare rigting hoe langer hoe meer damheen leidt, om het scheikundig en mikroskopisch onderzoek met de praktisclhe geneeskunde in naauwer en inniger verband te brengen; daamede zal het vertrouwen op de onfeilbaar heid van zekere karakteristieke en pathognomische teekenen, die tot nu toe een onbestreden gezag in de wetenschap hadden, ondermijnd worden" (Van Geuns 1849; viii).

106 Zie bijwoorbeeld H.A. Schreuders (1839: 11) karakterisering van het verschill tussen oude en jonge geneeskundigen: "Oude en jorige Geneeshenen zijn, als het ware, twee tegenover elkander geplaatste Polen; (...) zeden, karakter, denkbeelden, meeningen, theorie, praktijk: dat alles stelt sprekende contrastern daar*. De kwrekeling stelt een onbegrensd vertrouwen in zijn kennis. Voor oude geneeskundigen geldt dat "theorie (...) een woord [is], dat zij geheel en al verbannen" (27), terwijl zij de mening zijn toegedaan 
neesheer behoort door zijn beroep tot den beschaafderen stand der Maatschappij. Als zoodanig veronderstelt men in hem eene beschaafde opvoeding en ook eene liberale wetenschappelijke vorming, welke als eene hoogere, eene laatste opvoeding te beschouwen is. Die laatste wetenschappelijke opvoeding verkrijgt hij op de Hoogeschool, als de plaats zijner voorbereiding voor zijne belangrijke en hoogstgewigtige betrekking in de maatschappij der menschen (...). [O]m gewone routiniers, om geneeskundige handwerkslieden te hebben, daartoe (...) behoefde men al dien omslag niet. Men zou volstaan kurnen met een Cours d'Anatomie te houden, eene Apotheek te frequenteren en met een oud prakticus zieken te gaan zien" (Pruys van der Hoeven 1828: 128) ${ }^{100}$.

De verschuiving in de verhouding tussen theorie en praktijk is te volgen aan de betekenisverandering van begrippen als 'ervaring', 'waarneming' en 'empirie'. 'Waarneming', 'ervaring' en 'empirie' zijn termen die aanvankelijk in het domein van de praktijk thuis horen ${ }^{108}$. 'Practici' en 'empirici' zijn lieden die geen kennis hebben van de geleerde traditie, en die in hun therapie een overgeleverde handelingspraktijk voortzetten. Theorie verschilt fundamenteel van ervaringskennis, 'geleerdheid' van 'empirie': "Waarom is de jonge Geneesheer, toegestemd, dat hij geleerd, bekwaam is, nog zoo weinig bruikbaar in het practisch-geneeskundig leven? Omdat het hem hapert aan ondervinding, die de dochter van waarnemen en overwegen is" (Schreuder 1839: 31). Vanuit het standpunt van de geleerde arts wordt daarbij 'empirie' aan een dubieuze 'routine' gekoppeld (o.a. Van Geuns 1842a: 204) ${ }^{\text {nog }}$. Bij de uitgave van het

\footnotetext{
"dat men slechts oogen om te zien, een" vinger om te voelen en geduld moet hebben, om waarnemingen te maken en ziekten te doorgronden" (27). De oude geneesheer, "[d]ikwerf eene halve eeuw lang geoefend in het zien van zieken en ziekten, maakt (...) er zich geene hoofdzaak van (...) aan dit of dat stelsel vast te hechten, nog minder om dezelven te rangschikken en te groeperen. Niets is den jongen Geneesheer meer eigen, die, nog verre van zeker ảangaande zijn zaak, altijd aan zijne Schrijvers on Meesters denkt" (22)

107 De dichotomie tussen 'routiniers' en 'Medicinae Doctones' beperkt zich niet tot Nederland. In Duiltsland speelt volgens T. Broman (1989: 44) de theorie-praktijk controverse het sterkst rond 1800. "The kernel of the distinction between Routiniers and doctors of medicine lay in the doctors" possiession of Wissenschaft." Broman (1989: 45) citeert Reil (1804): De routinier handelt "as a psychological automaton, who certainly is not conscious with respect to the construction of those rules from principles (...) The Routinter (...) possesses Wissentschaft merely as an artifice and in concreto; not as his own property but through an outside transferal (durch fremde Ueberlieferung)." Zie ook Billroth (1876:43).

108 " $[\mathrm{H}]$ et verkeerde begrip van de Regering om de Leerlingen der Clinische Scholen te doen examineren door Chirurgen en Vroedmeesters en Apothekers (met eene minderheid van akademisch gegraduëerden in hun midden, die nooit eene School bezocht hadden, die wit de hoogte nederzagen op Onderwijs, en vooral op Wetenschappelijk Onderwijs, die veelal niet anders waren dan lieden van enkel empirie), kon die clinische scholen miet aan hare bestemming doen beantwoorden" (Mulder 1842c: 74) 109 Deze koppeling gaat terug op het Aristoteliaanse gedachtengoed waar 'empureia', "ervaring' een bepaalde kennisvorm aanduidde die gekenmerkt wordt door het 'vertrouwd zijn met' of het "geoefend zijn in' iets. (Aristoteles, Met. 980 b 28ff.): "Aus der Erinnerung geht bei den Menschen die Empirie hervor; erst viele Erinnerungen nämlich ein und derselben Sache ergebern die Fähigkeit (dunamis) einer Erfahrung," (Ritter Hrsg. 1972: 609). Hippocrates' aphorisme 'Ars longa, wita brevis' verwijst naar de
} 
'Nieuzi praktisch tijdschrift voor de geneeskunde in al haren omvang, .... onder redaktie van L. van Eldik en S.J. Galamar in 1847, deelt De Gids (1847: 707) die zich uiteraard meer verwant voelt met de geleerde traditie - een sneer uit in de richting van het voormalige praktisch tijdschrift dat vijfentwintig jaar onder redactie van Van Moll en Van Eldik als lijfblad ${ }^{110}$ van de praktische richting had gefungeerd. "Hier vonden zij [pas beginnende artsen die clinische kennis ontbeerden] de in die gevallen gebezigde geneesmiddelen opgesomd, hunne werking aanschouwelijk gemaakt, hunne giften bepaald, ja zij hadden zelfs maar hunne formules na te schrijven en ze eveneens toe te dienen, om hun wetenschappelijk geweten gerust te stellen, om morgen hunner lijder met versterkt zelfvertrouwen de op handen zijnde beterschap te voorspellen, op deze wijze werd vaak de grofste empirie in de hand gewerkt, de onverantwoordelijkste routine bevorderd."

De beperkingen eigen aan deze aan routine en overgeleverde handelingspraktijken gekoppelde opvatting van 'ervaring' zijn duidelijk": "Ondervinding is de zekerste standaard, om echte waarde te beoordelen'. Maar welke is nu de waarde van die daadzaken, van de practische lectuur, van de practische geneeswijze? Zou er wel eene wetenschap zijn, die rijker in middelen en zekerder in uitkomst was, dan de Geneeskunde, wanneer alle practisch welgestaafde geneesmiddelen en onfeilbare geneesmiddelen hadden stand gehouden? Niets is onzekerder dan practijk en ondervinding, zoo het slechts practijk, slechts ondervinding, slechts eene indigesta moles van daadzaken is" (De Gids 1837: 15). Diegenen die de geneeskunde op de natuurwetenschappen willen baseren, isoleren 'ervaring' uit de sfeer van de traditie en de overgeleverde handelingspraktijk en betrekken deze op de waarneming van levensprocessen: "Ongelukkig, wie thans nog op de ervaring zijner voorouderen, of bij de zekerheid, die hem omtrent de juiste waardering der ziekelijke veranderingen in hunne Handboeken wordt gegeven, insluimert, en het oog sluit voor het licht, hetgeen de Natuurkundige Wetenschappen in de laatste jaren over de Geneeskunde verspreid hebben" (Arntzenius 1842b: 87). Een opvatting van praktijk als berustend op overgeleverde ervaring wordt niet langer geduld: "Is

doorglaggevende rol van "ervaringskenuis' binnen de geneeskunst (Dirckx 1983: 45). Ook heden ten dage wordt door sommigen een teriggrijpen op Aristotelische categorieen bepleit (Wieland 1975: 88; Pellegrino and Thomasma 1981; Widdershoven-Heerding 1987: 184).

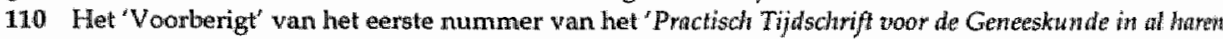
omwang" (1822: 1-IV) vermeldde als taak "zoodanige Beofenaren der Geneeskunde, als [die] door gebrek an geleygenheid, door mindene bekendheid met vreemde talen en buitenlandsche geschriften, slechis zelidzaam aanleiding krijgen ter meer wetenschappelike beoefening van het hun, in meerdere of mindere mate, toevertrouwde wak, bekend tracht te doen worden met de nieuwste en meest practisch - nuttige en wetenswaardige waarnemingen van geleerden en geneesheeren van hoogeren stempell in hum eigen vaderland en andere landen ${ }^{s *}$.

111 Zie ook Toellner (1984: 168-169). 
het iemand genoeg dat hij wete dat nitrum onsteking tegengaat en wil hij het hoe niet weten: noemen wij hem geenen geneeskundigen maar geneesonkundige (...), maar wachten wij ons voor den onkundigen kunstoefenaar ${ }_{j}$ die liever blind wil wezen, terwijl zijne oogen door anderen voor hem geopend worden" (Mulder 1842a: 320). De op de natuurwetenschappen georiënteerde geneeskunde profileert zich als 'empirische' en 'ervarings'-wetenschap (Van Geuns 1842a). Maar 'ervaring' heeft dan een andere betekenis gekregen. Begripsverwarring ligt op de loer.

In een controverse tussen $W$. Koster en J. Evers wordt deze laatste een onjuist gebruik van het begrip 'empirie' en 'ervaring' verweten (zie ook S. 1865): Evers hanteert in de ogen van Koster (1864: 14-15) het begrip 'ervaring' op een manier, "welke aan bakers- en vroedvrouwen-beschouwingen herinnert. Het woord wordt geheel willekeurig alleen voor het waarnemen van de werking der geneesmiddelen aan het ziekbed gebruikt. $\mathrm{Nu}$ is naar die ervaring gestreefd zolang de menschheid bestaat, en het resultaat is, dat de geneeskunde zich in den gebrekkigen toestand bevindt, welke door Evers zelf geconstateerd (...) wordt. (...) De biologische wetenschappen (anatomie, physiologie en pathologie) zijn bij uitstek op ervaring gegrond (...). Het doordringen van den geest der ervarings-wetenschappen bij studie aan het ziekbed heeft nu in den loop der laatste halve eeuw aangetoond, dat de vermeende ervaring van vele geneeskundigen omtrent de behandeling van een aantal ziekten onjuist was." Evers' hanteren van het begrip 'empirie" treft eenzelfde soort verwijt: "Het is eene beschuldiging [aan het adres] van de biologen, dat zij ruwe empirie en ongemotiveerden twijfel hebben bevorderd; het is eene geringschatting der biologische studiën, en de verdediging eener 'ervaring aan het ziekbed', welke volgens $\mathrm{E}$ [vers] duizend maal hooger staat dan 'ruwe empirie', maar die mijns inziens, juist de ruwste empirie is" (Koster 1864: 8). J. Boogaard (1866: 32) spreekt in een soortgelijk verband over de "oude empirie, die uitsluitend op de aan het ziekbed waargenome verschijnselen hare geneesleer wilde doen steunen."

'Waarneming', voorheen één van de trefwoorden om de 'praktische" richting aan te duiden, wordt eén van de sleutelwoorden van een geneeskunde die zich op de natuurwetenschappen wil oriënteren ${ }^{12:}$ " Zonderling genoeg heeft men aan dit woord in de geneeskunde allerlei beteekenis gehecht. (...) Geluk$\mathrm{kig}$ is men in de latere jaren aan hetgeen men waamemen noemt in de geneeskunde, eene zuiverder beteekenis gaan hechten. Men beschouwt de zieken als

11. "Doch er is eene andere zaak (..) waarop het bij de beoordeling van de nieuwere rigting un de wetenschap voomamelijk aankomt: de waarde, welke men hecht aan het waarnemen der verschijnsellen, aan de nawwkeurige ontleding en herleiding tot bekende physische, chemische of physiologische warheden, daanin ligt voornamelijk thet karakteristieke van de tegenwoordige geneeskunde; de algemeene pathologie ontdoet zich meer en meer wan de schoolse vormen, waarin zij voortheen gedrongen was, en vesitigt zich hoofdzakelijk op de physiologie ${ }^{* j}$ (De Gids 1848. 337). 
natuurvoorwerpen, als levende en werkende voorwerpen ${ }^{113}$ (...) Objectieae waarneming noemt men ze ten onregte, als of de subjectieve eene waameming ware. (...) De geneeskunde is min of meer eene nieuwe wetenschap, en die het ontkent, hij kent de eenige ware beteekenis niet, welke aan waarneming mag worden toegekend" (Von Baumhauer 1848: 16-18; 19). S. Rosenstein (1866: 8-9) onderscheidt expliciet de oude ervaring van de nieuwe, en benadrukt de veranderdle inhoud van 'waarneming' daarbij: "Beobachtung aber ist mehr als blosses sehen. (...) Hierbei soll nicht die sinnliche Erscheinung ueberhaupt nur wahrgenommen, sondern im Zusammenhange mit andren Phänomene erfasst. (...). Nur wer so sieht, beobachtet, und nur wer so beobachtet macht Erfahrungen."

De 'ervaring' die de natuurwetenschappen leveren draagt echter niet meer bij aan het bestendigen van routines: "Reeds lang heeft een vrijmoedig scepticisme gestreden tegen de verjaarde regten van hetgeen men gewoon was eraring, ondervinding te noemen - eene reeks van abstractiën, zonder eenig ander gezag, dan dat van den persoon des waarnemers - men begint te onderscheiden tusschen datgene, wat in de boeken staat, en datgene, wat de waarneming der Natuur ons leert; men gelooft niet meer aan de afgeronde ziektebeelden der Handboeken, noch aan de onverstandige Formules der Receptverzamelaars; men gevoelt dat men geenen steun meer heeft aan de ijdele hypothesen en weidschklinkende namen, waarmede men eeuwen lang de bekrompenheid zijner kennis bedekt heeft" ${ }^{\prime \prime}(\mathbb{H}$. 1842a: 117-118). Als de Leidse hoogleraar G. Suringar in 1855 de jongste ontwikkelingen in de geneeskunde overziet, constateert hij dat in alle leervakken ervaringskennis het uitganspunt vormt. Niet alleen in de anatomie, de fysiologie en de pathologie maar ook voor de therapie $^{114}$. Ook het medische handelen dient zich op waarneming en proefneming te baseren. Hoe en in welke mate is dan de vraag: "Minder eenstemmig denkt men over het geneeskundig proefnemen (...). Hoewel toch voorzigtige proefnemingen aan het ziekbed meermalen onmisbaar zijn, (...) zo volgt hieruit geenszins, dat de zoogenaamde natuurkundige methode, in al hare gestrengheid, op de geneeskundige praktijk kan toegepast worden, of dat therapeutische

113 Hier is direct de uit de sociologische literatum bekende omkering in de arts-patient verhouding mee verbonden: "Tot wór korten tijd hechtte men de grootste waarde bij het ziekbed aan de klagter" die de zieken witten (...) [Nu] anderzoekt [men] den lijder, betast hem, hoort de verscheidentheid der geluiden, gat alles zorgvuldig na, wat te zien, te voelen, te ruiken, te hooren is, en neemt eerst in de laatste plaats de kJagten van zieken of omstanders op, die echter voor den geoefenden arts meestal nutteloos zijn" (Von Baumhauer 1848; 16-18).

114. "Moet die praktische blik door oefening, door onbevooroordeelde, vlijtige veelzijdige en weten" schappelijke waarneming verkregen worden, of, met andere woorden, de vrucht van ware natuurstudie zijn, hetzelfde mag gezegd worden van een arder gelijksoortig, voor den praktischen geneesheer even zeer begeenlijk talent, van den medischen takt, of het vernogen, om na bezonnen overleg, met waardigheidl en op de meest geschikte manier te handelen" (Suringar 1855: 386). 
experimenten, in den waren zin van het woord, mogelijk zijn" (Suringar 1855: 387). De pijler der oude 'ervaring' is onder het medisch handelen aan het ziekbed weggevallen. Hoe de natuurwetenschappelijke methode, die door de bestudering van ziekteprocessen centraal te stellen een groot aantal onzekerheden $^{115}$ introduceert, een nieuwe grondslag daarvoor kan leveren is voorshands niet duidelijk. Aan het ziekbed is geen ruimte voor proefneming en experiment. Daar zijn zekerheden ${ }^{116}$ vereist, die een op wetenschappelijke methode georiënteerde geneeskunde niet kan geven. Dat gegeven levert de strohalm waaraan de 'ervaren' richting binnen de geneeskunde zich vastklampt: "Als zuivere wetenschap bekleede de geneeskunde eene plaats, al is het eene betrekkelijk kleine, op het gebied der biologie; als praktische kunst, die dagelijksche en dadelijke toepassing eischt, beware zij hare zelfstandigheid, ontwikkele zij zich onafhankelijk en houde zij steeds het oog op haar doel gerigt" (Evers 1864: 10). Er zijn immers ziektetoestanden "wier herstel in den regel door den geneesheer uit kracht van het weten, dat hij uit zijne ervaring put, moet verkregen worden." Niettemin geeft Evers (1864:26) toe dat de zaken veranderd zijn, dat ervaring niet meer uit het klakkeloos overnemen van handelingspraktijken kan bestaan: " $[\mathrm{N}] \mathrm{u}$ komt bij dat alles nog die groote moeijelijkheid, dat de lessen van het verledene niet altoos vruchten dragen, die geheel genietbaar zijn voor het tegenwoordige geslacht, en dat de ervaring elders verkregen niet altoos hier steek houdt." Maar het pleit is dan al beslist: "De tijden van het geloof aan autoriteit, aan recepten en dogmata, steunende op de traditie der vermeende ervaring van beroemde geneesheren is voorbij" , roept Koster (1864: 6) triomferend.

Het strikte onderscheid tussen theorie en praktijk - gebaseerd op de verschillende aard van de kennis die deze vereisen, die bovendien via verschillende opleidingstradities overgegeven wordt - gaat in de loop van de negentiende eeuw verloren. Daarvoor komt een opvatting van praktijk als toegepaste wetenschap in de plaats. Het meest expliciet wordt dat geformuleerd door L.

115 "Menigmalen hoort men klagten over de onzekerheid, die thans in de fondamentele begrappen der geneeskunde heerscht. Die Klagten zäjn zeker niet ongegrond. Bedriegen wij ons niet, dan ligt evenwel in die onzekertheid het bewijs, dat men zich meer men losmalkt van de oude overgeleverde begrippen, die voorheen met eenen zekeren eerbied als gelonfspunten aangenomen werden" (Van Geuns $1842 \mathrm{a}: 152)$.

116 "Waarom toch anders wilde hij [A.C.G. Suerman] de Geneeskunde, door de hulp dier Natuurkundige Wetenschappen, als eene exacte Wetenschap behandelem, dan om daardoor, onafhankelijk van eemig stelsel. vrij en onbevangen, onder den strijd der meeningen, tot zekerheid, tot eene vroeger niet gekende zekerheid, zoo mogelijk op te klimmen? Of zouden zij zich op zekerheid mogen beroemen, die alieen bezorgd zijn, den toestand van den lijder met het afgeronde beeld eener ziekte, zoo als dat in de Hardboeken geschilderd staat, overeen te brengen, en er in te berusten, wanner zij met den dáx́r geschreven' nam die ziekte kunnen stempelen? Neen, dat is eene zekerheid, welke voor den stelligen zin wan Suerman te oppervlakkig, te onvruchtbaar was" (v,C. 1841:83-84). 
Ali Cohen in het voorwoord van het eerste nummer van het Nieuw practisd tijdschrift voor de geneeskunde in al haren omvang. L. Ali Cohen (1852: 3) wil de kloof dichten die van oudsher tussen de praktische richting en de wetenschap gaapt: "Ook wij hopen hier der Wetenschap bevorderlijk te zijn: minder echter door haar als in 't afgetrokkene te behandelen; dan wel in hare toepassing op het praktische leven." Ali Cohen beseft dat het hier een ingewikkeld punt betreft dat om opheldering vraagt, hij voegt er dan ook onmiddellijk aan toe: "Wij wenschen echter zeer, dat men ons vooral in dit opzigt wél versta (...) dat de wetenschap in de eerste plaats als zoodanig moet worden gehuldigd, will men dat zij in de tweede plaats nuttig zij voor het leven, dat is: dat zij kunne worden toegepast." Toch opteert Ali Cohen (1852: 4-5) voor zijn nieuwe tijdschrift voor een op de praktijk gerichte koers. "En waarom dat? De reden is tweeledig: eensdeels, omdat, - aangezien er bij alle op prijsstelling der wetenschap op zich zelve, voor de maatschappij ontegenzeggelijk ten allen tijde eene allerdringendste behoefte bestaat, niet alleen aan de kennis van de zoo veel mogelijk reeds in toepassing gebragte wetenschap, maar evenzeer ook aan de kennisneming van die gedeelten der wetenschap, waar deze toepassing we] nog op dezen oogenblik niet volledig kan plaats hebben, maar toch blijkbaar op weg daartoe is, - er dus ook noodwendig organen moeten zijn, die zich deze zoogenoemde (d.i. zeer dikwijls hoogst verkeerd opgevatte) 'praktische' rigting tot een eerste leidend beginsel nemen, en anderdeels, omdat ${ }_{\text {, }}$ - daar wetenschap en praktijk niet alleen niet tegenover elkander staan, maar eenzelvig zijn - althans behooren te zijn (...), wij voor ons gaarne ons aandeel, hoe gering het ook zijn moge, willen bijdragen ter bereiking van het gemeenschappelijke doel, dat dan toch in allen gevalle ten laatste een wezenlijk praktisch doel is, - altijd het woord 'praktisch' genomen in zijn ware, hooge betekenis, en niet in den bekrompen en onwetenschappelijken of tegenwetenschappelijken zin, waarin het vroeger, - en ongelukkiglijk ook nu nog hier en daar, - werd opgevat." De betekenisverschuiving van het begrip 'praktijk' die bij Ali Cohen expliciet wordt geformuleerd, kondigt zich al eerder aan. Pruys van der Hoevens 'Gedachten over de studie en het onderwijs der Geneeskunde' (1826: 262) laat een voortdurende worsteling zien met de juiste interpretatie van de verhouding tussen theorie en praktijk: "Onze kunst is daardoor van vele anderen onderscheiden, dat zij haren beoefenaar overbrengt in het praktische, werkdadige leven. Praktijk is hare ware strekking. Tot dit doel moet alle studie der geneeskunst in de eerste plaats zijn ingericht, en hij, die haar eens zal uitoefenen, moet bovenal eene praktische vorming hebben, moet vooral tot praktisch geneesheer worden opgeleid. Niet dat ik daarmede zoude willen te kennen geven, dat men daarom de hulpwetenschappen zou moeten verwaarloozen, ${ }_{r}$ of zich met een vlugtig overzigt van alle andere gedeelten der wetenschap zou kunnen vergenoegen, om maar spoedig, ja hoe eer hoe liever tot de praktijk over- 
tegaan. Zulk eene methode leidt tot niets anders, dan tot de grofste empirie en routine." Aan de basis van de problematische verhoudling tussen theorie en praktijk waar Pruys van der Hoeven mee worstelt, ligt de kloof tussen twee opleidingstradities. Over de tijdschriften (journalen) bedoeld voor jonge medici - zoals het praktisch tijdschrift - merkt Pruys van der Hoeven (1826: 275) op: "[D] ie ze als leerboeken, als handleidingen der praktijk beschouwd, die meent door dezelve de lectuur van onze klassieke auteurs (...) te kunnen missen, heeft nimmer ware praktijk gekend". Pruys van der Hoevens voorstel voor de inrichting van het onderwijs leidt dan ook tot een merkwaardige poging tot verzoening: "Volgens mijn oordeel moet dus het praktisch onderwijs vooral daarheen strekken, om den leerlingen met dien klassieken geest bekend te maken, om hen niet vele, maar de beste schrijvers in handen te geven, om hen niet de nieuwste, maar de meest beproefde geneesmiddelen boven anderen te doen bezigen, om hen niet naar het nieuwe, het vreemde, het onbekende, maar naar het goede, het nuttige, het bruikbare te doen streven" (276). Pruys van der Hoevens taalgebruik verraadt een normatieve uitgangshouding. Het gaat erom bestaande, zekere kennis uit te breiden, niet die primair op haar geldigheid te ondervragen: "Maar daarbij zij voert, en met regt, den naam van geneeskunst, kunst van genezen, niet van proefnemen. Genezen moet haar doel zijn, helpen, weldoen, geene bevrediging van ijdele nieuwsgierigheid. (....) Het proefnemen moet dan het genezen ondergeschikt zijn, het moet op goede gronden, op gezag, op ondervinding, op gezonde beginselen, met de teederste nauwgezetheid geschieden" (Pruys van der Hoeven 1826: 263).

Voor diegenen die de geneeskunde op de natuurwetenschappen willen baseren moet praktijk uiteindelijk toegepaste wetenschap worden" "De pathologische anatomie, op den tegenwoordigen stand van ons weten, [is] de hoeksteen (...) der geneeskundige praktijk; terwijl zonder haar geene vaste diagnose, zonder haar geene rationele behandeling mogelijk is (...). Bij het tegenwoordige standpunt der geneeskundige wetenschappen, is het eene hoofdvereischte de praktische geneeskunde zoo veel mogelijk aan de physiologie aan te sluiten (...) slechts in de voleinding der wetenschap kan de kunst hare voleinding vinden (...) men vindt het in het algemeen nog steeds gemakkelijker zijnen praktischen tact of instinct te volgen dan hetgeen men weet te vergeten, en opnieuw te onderzoeken" (De Gids 1848: 337). Zelfs de chirurgie, die van oudsher gebaseerd was op ervaring die in een meester-leerling verband werd doorgegeven, krijgt het stempel wetenschappelijk opgedrukt. "Wat is kunst an-

$117{ }^{24}$ In de geneeskundige studie is het praktische kennis, die gevorderd wordt in Natuurkundige Weternschappen; prokitiche kenuis in Ontleed-en Zlektekundige; praktische kennis in Therapeutische (...) theoretische wetenschappen heeft men tot heden in de Geneeskunde niet, en het is te hopen, dat zij er nimmer in komen zullen" (Mulder 1842b: 209-10). 
ders dan toegepaste wetenschap", roept M. Polano (1869: 10) uit. "Zelfs de vraag of de geneeskunde een wetenschap of een kunst is, kent de moderne geneeskunde niet meer" (De Gids 1847: 728).

\section{Eenheid van stand}

De artsenwetten van 1865 zouden, door het invoeren van natuurkundige en geneeskundige staatsexamens ${ }^{118}$, een einde maken aan de verschillen in bevoegdheden tussen academische en niet-gegradueerde artsen. Ook aan het tot stand komen van deze wetten gaat een uitgebreide discussie vooraf. Alleen al naar aanleiding van het wetsontwerp van minister Thorbecke uit 1862 verschijnen meer dan 72 adressen, beschouwingen, bedenkingen etc. (Ali Cohen 1862; Van Lieburg 1983a: 450). In de voorafgaande paragrafen is ingegaan op inhoudelijke veranderingen die in de geneeskunde en in de medische opleiding in de jaren veertig en vijftig spelen. Deze ontwikkelingen hollen de verschillen tussen de opleidingen uit. In de jaren vijftig en zestig wordt vanuit de Rotterdamse School bepleit bij de reorganisatie van het Hoger Onderwijs aan de Klinische school een meer wetenschappelijke status te verlenen (Van Lieburg 1978: 62). Sommigen zien dan geen wezenlijke verschillen meer tussen de opleiding aan de universiteiten en die aan de klinische scholen. "Vergelijken wij nu in de eerste plaats de veelzijdigheid der studie, of de verschillende vakken, waarin èn van den student in de medicijnen, èn van den kweekeling aan de clinische school bekwaamheid vereischt wordt, dan zien wij, dat het onderscheid niet zeer groot is; dat men voor beide van de overtuiging uitgegaan is, dat de geneeskunde en heelkunde althans in theorie één zijn; dat beide dezelfde voorbereidende studiën en hulpwetenschappen noodig hebben" (Schneevogt 1842: 28 ).

In de publieke discussie rondom de artsenwetten van 1865 spelen behalve medisch-inhoudelijke aspecten ook overwegingen van geheel andere aard en inzet een rol. Het karakter van het hoger onderwijs in zijn algemeenheid staat ter discussie. Dat laatste punt wordt onder andere door G.J. Mulder opgepakt. Mulder (1865: 17-18) beschuldigt de Tweede Kamer een aanslag op het hoger anderwijs te plegen door staatsexamens in te willen voeren. Een dergelijke controle van buiten af doet de vrijheid die eigen hoort te zijn aan de hogescholen teniet ${ }^{119}$. "Zoo men het Hooger Onderwijs controleert, breekt men het beste af, dat er in de staat leeft. Er zijn bedieningen in den staat die hoog heeten: zij

118. Een minderheid in de commissie van 1842 (Heye 1843) had reeds het invoeren van staatsexamens en onafhankelijke examencomnissies voorgesteld.

119 Zie voor ean algemenere bespreking van deze problematiek hoofdistuk 2. 
alle staan boven controle, of de naam hoog is eene onwaarheid. Naar den Minister van Binnenlandse zaken is nu de naam van Hoogeschool en van Hoogleeraar eene onwaarheid geworden." Men moet de waarde van examens volgens Mulder (1865: 11; 15; 14) niet overdrijven: " $[W]$ at leert mij nu de ondervinding sedert vele jaren? Dat er alleen bij uitzondering eenige overeenkomst is tusschen de deugdelijkheid der geschreven antwoorden en hetgeen de kweekelingen inderdaad zijn (...) Examina zijn voor jonge menschen goed als prikkel, maar zij hebben geene anderen waarde." "[D]enkt men wel aan het nadeel van examens? Is het afrigten niet doodend voor ellke breedere ontwikkeling?" Mulder kan niet anders dan schamperend spreken over de te verwachten effecten van de nieuwe staatsregeling: "[G]eene examinatoren die onderwijs geven, en zeker niet bij voorkeur, die Hooger onderwijs geven, want voor dezen juist de contrôle. Alzoo zullen die contrôleurs zijn of examinatoren, die lager onderwijs geven, dan het Hoogste, of die geen onderwijs geven. Eene derde species is er niet. En dat zou dan verbetering zijn" (Mulder 1865: 12). J. van der Hoeven sluit met zijn 'ernstig woord ter verdediging van het Hooger Onderwijs' aan bij Mulders kritiek. Ook hij benadrukt de vrijheid van hogescholen; die zal op langere termijn van groter belang blijken dan het op de korte termijn nastreven van praktisch nut ${ }^{120}$. Van der Hoeven (1865: 14) kan de wens van de regering om in te grijpen niet plaatsen: "Na de afscheiding van België en de daaropgevolgde jaren van buitengewone krachtsinspanning en van onzekerheid voor de toekomst, was 'bezuiniging' het eenige woord, dat gehoord werd, en sedert dien tijd heeft het Hooger onderwijs bijkans geene andere inmenging der regering gezien, dan die met bezuiniging verbonden was."

Tevens zijn in de discussie direct institutionele belangen in het geding. Koster (1865) is bevreesd dat de extra-universitaire opleidingsweg ${ }^{121}$ die door de staatsregeling open wordt gelaten, een bedreiging vormt voor de universiteiten. Met name het Athenaeum van Amsterdam wordt door de universiteiten als een (te) sterke concurrent ervaren. Koster (1865) probeert de positie van de universiteiten te versterken door het belang van wetenschapsbeoefening als zodanig te benadrukken ${ }^{122}$ : "Aan het duitsche stelsel [o.a. de privaat-

120 Van der Hoeven (1865: 15) haalt ter ondersteuning Agassiv aan: "Lell me say that the community should foster the purely intellectual efforts of scientific men as carefully as they do their elementary schools and their practical institutions, generally considered so much more useful and important to the public." 121. Deze buiten-universitaire opleidingsweg stond open woor personen met een HBS-diploma of nadat een sttaitsexamen op grond van de $\mathrm{MO}$-wet was alfgelegd.

122 "[M] jine (...) overtuiging van de noodzakelijkheid van algemeene beschaving en ruime weten" schappelijke (biologische) studièn voor den geneeskundige, er wan den nadeeligen invloed, welker. de nieuwe geneeskundige staatsregeling daarop zal uitoefenen. (...) Zal er in Nederland een hoogeschool met een medische faculteit, een centrum der geneeskundige wetenschappen, een werkplats ter harer ontwikkeling zijn? Of will men alleen opleidingsscholen voor geneeskundigen, die geschikt zijm om in de maatschappil praktisch werkzaam te zijn?' Die wragen gelidt het hier" (Koster 1865: 4). 
docenten] heeft men de gansche reeks van nieuwe ontdekkingen op biologisch gebied te danken, die meer tot vooruitgang der wetenschap en tot het verkrijgen van zekerheid in de praktijk hebben bijgedragen dan de 'praktischnuttige' rigting, welke ons 't goede dreigt te ontnemen, dat wij nog bezitten" (Koster 1865: 10).

De opleidingskwestie speelt echter ook nog steeds tegen de achtergrond van de noodzaak tot verbetering van de geneeskundige zorg op het platteland. De noodzaak tot verbetering daarvan zou alleen nog maar toenemen. "De onderinvesteringen in de universiteit, het uitblijven van adekwate regelingen voor de vooropleidingen (...) hadden tot gevolg dat het aantal in de praktijk werkzame artsen in de periode 1865 tot 1890 schrikbarend afnam" (Goudsmit 1978: 33). Vanuit het perspectief van C. Winkler (1901: 110) vormt die verbetering van de zorg zelfs het kernpunt van de discussie rondom 1865: "Hier behoefde men niet in de eerste plaats verbeterde regeling der geneeskundige bevoegdheid, maar wel verbeterde geneeskundige hulp ten plattelande ${ }^{123}$." Kosters voorkeur gaat uit naar een situatie waar alle opleidingen door de universiteit worden verzorg $\mathrm{d}^{124}$. Wanneer dat niet mogelijk is dan moeten eenvoudigere opleidingen, buiten de universiteit om, het tekort aan geneeskundige hulp op het platteland ongedaan maken ${ }^{125}$.

De Eerste Kamer zag in de wetten die Thorbecke voorstelde eveneens "een slooping van het universitaire onderwijs in de geneeskundige wetenschappen". Ook daar werd geopperd dat wanneer men eenheid van stand nastreefde, dat via het universitaire onderwijs gerealiseerd moest worden (Verslag der Commissie van Rapporteurs in de Eerste Kamer, Winkler 1901: 111). De Minister antwoordde dat de eisen der nieuwe staatsexamens zeer hoog gesteld waren, zodat deze alleen zouden kunnen worden afgelegd door hen, die de universitaire hulpmiddelen benut hadden (Winkler 1901: 112). Bovendien wees Thor-

123 De transformate die het domein wan de geneeskunde in amper 60 jaar doormatllt is dermate radicaal dat Winkler (1901; 10) weigert te geloven dat de verschillen in bevoegdheid een wezentifk discussiepunt had kunnen zijn: "Toch was de hoofdvaag, die zich in 1865 voordeed, naar mijn meening: niet die der regeling der bevoegdheid, mat een geheel andere (...); namelijk het verbeteren van de zorg op het plattaland. Leuzen (...) alls: ex behoort te zijn eenheid van stand of eenheid van bevoegdheid, hadden niebs daarmede uit te staan (...)."

124 "Ik wees er reeds vroeger op, en in het dezer dagen door den Utrechtschen Senaat aan de Eersike Kumer gezonden adres, wordt in denzelfden geest gesproken, dat de opleiding van het merendeel der geneeskundigen aan de hoogeschool wenschelijk is, ja, dat het misschien mogelijk zou zijn, de bezwarem welke uit de behoeften wan het platteland voortwloeijen, wit den weg te ruimen, niettegenstaande alleen gepromoveerde geneeskundigen het regt tot uitoefening der praktijk verkregen. Wix aan $z$ ulk eene regeling zal toch ieder verstandige, die zich niet door het zinledige woord 'monopolie' laxat bevangen, de voorkeur" moeten geven" (Koster 1865: 24).

125 "Het blijkt (...) dat, bij een verstandige inrigting van de opleiding dier geneeskundigen, hunne geschiktheid voor de praktische geneeskunde niet merkbaar verschilt van de aan een hoogeschool gepromoveerden" (Koster 1865: 12). 
becke de oppositie voortdurend op het tijdelijke karakter van de wetgeving. De wetten van 1865 'regelende de bevoegdheid tot uitoefening der geneeskunst" kwamen tot stand "vooruitlopende op een in de lucht ${ }^{126}$ hangende wijziging van de wet op het Hooger Onderwijs (die tot 1876 zou blijven hangen)" (Winkler 1901: 110). In de aanstaande Hoger Onderwijswet zou alles definitief en zo gewenst anders geregeld worden. Het tegendeel was het geval. De Hoger Onderwijswet van $1876 \mathrm{zou}$, wat de regeling van het medisch onderwijs betreft, geheel in de lijn van de artsenwetten van 1865 liggen.

De artsenwetten van 1865 voorzagen in staatsexamens in de natuur- en geneeskunde, af te nemen door commissies, die buiten de medische faculteiten om de bekwaamheid van de aanstaande beoefenaren der geneeskunst zouden toetsen. Een academische promotie gaf niet langer ook onmiddellijk de bevoegdheid de praktijk uit te oefenen; eerst moest een staatsexamen in de praktische genees-, heel- en verloskunde worden afgelegd. In afwachting van een betere regeling van het hoger onderwijs waren diegenen die een kandidaatsexamen in de geneeskunde hadden afgelegd, wel voorlopig vrijgesteld van het eerste (het z.g. natuurkundig) staatsexamen. Ook doctorand" in de geneeskunde waren, eveneens voorlopig, vrijgesteld van het eerste, theoretisch geneeskundig gedeelte van thet tweede staatsexamen (Winkler 1901: 110-111). Voor de jaarlijks door de minister vast te stellen staatscommissies die de staatsexamens moesten afnemen, werd gerecruteerd onder universitaire docenten, praktisch werkzame artsen en ziekenhuisdirecteuren. Reeds tijdens de eerste gelegenheid waarbij de Rijkscommissie examens afnam, bleek een groot deel der kandidaten niet aan de minimumeisen te voldoen (Kühler 1953: 99-100). De wet van 1865 ondermijnde de positie van de klinische scholen ${ }^{127}$.

Ook voor "s Rijkskweekschool voor Militaire Geneeskundigen ${ }^{128}$ te Utrecht bleven de artsenwetten niet zonder gevolg. De Staatscommissie van 1.848 had in haar streven naar 'eenheid van stand' al gepoogd de afzonderlijke opleilding tot militair geneeskundige af te schaffen (Beukers 1988). De Rijkskweekschool was toen de dans ontsprongen. In een brochure (De gezamenlijke 1851) ter verdediging van de speciale status van thun school wezen de docenten erop, dat de militaire geneeskundigen een speciale stand vormden: "[M]en is nog geen Officier van Gezondheid, wanneer men arts is en de uniform draagt" (Kerst 1851 deel 2: 113 in Beukers 1988). Ook hier zou de standsindeling van

126 F.C. Donders (1867a: 23) spreekt over "de aanstaande regeling van het hooger onderwijs".

127 C.W. Bruinvis (1915: 30) over het einde van de klinische school te Alkmaar: "Den 4 augustus [1865] gaven B en W te kennen, dat de bestande school naar hunne overtuiging niet in staat was om aan de nieuwe examen-eischen te voldoen, en dus stelclen zij voor har met 1 november op te heffen."

128 Deze school was bij K.B. wan 30 maart 1822 opgertht uit een samervoeging van de militairgeneeskundige opleidingsinstituten te Leiden en te Leuven (De Moulin 1978: 32; Haneveld 1978: 83; Langeveld 1988). 
voorheen ondergeschikt worden gemaakt aan de eenheid die het domein van ziekte en gezondheid moest karakteriseren. Donders (1867a: 6) bevat een frontale aanval ${ }^{12 s}$ op een medische kweekschool die los bleef staan van de hogeschool, terwijl door het gereedkomen van een nieuw ziekenhuis in Utrecht ook de praktische vakken naar behoren zouden kunnen worden onderwezen: "Vond men vroeger in een afzonderlijke kweekschool een waarborg, dat in de behoefte aan officieren van gezondheid zou kunnen worden voorzien ${ }^{230}$, de wet had hieraan een eindle gemaakt." In het kamerdebat over deze kwestie kwamen drie posities naar voren. "[T]en eerste, dat de militair-geneeskundige opleiding voor alles medisch-wetenschappelijk, dus universitair behoorde te zijn; ten tweede, dat de militair-geneeskundige opleiding vór alles militair van aard was, zowel wat de speciale militair-geneeskundige vakken als wat de gewenning aan militaire reglementen en krijgstucht betreft, en ten derde; dat de militair-geneeskundige opleiding zich in hoofdzaak diende te richten op de vorming van lager gekwalificeerden voor de kolonieën" (Van Lieburg 1988a: 86). Onderbrenging van de kweekschool aan de hogeschool te Utrecht stuitte echter op bezwaren. Het gebrek aan lijken te Utrecht zou het anatomisch onderwijs bemoeilijken, het militaire hospitaal leverde een onvoldoende verscheidenheid aan ziekten op, en in Utrecht kon het vereiste aantal bevallingen niet worden bijgewoond (Van Lieburg 1988a: 87). Voorts konden de meeste leerlingen van de kweekschool niet voldoen aan de toelatingseisen voor een universiteit (Idenburg (red.) 1927: 110). De Kweekschool voor Militaire Geneeskundigen zou worden ondergebracht bij het Athenaeum te Amsterdam.

De eisen van de staatsexamens en dle daaruit volgende afschaffing van de klinische scholen dwong de toekomstige arts universitair onderwijs te volgen of het Athenaeum van Amsterdam te bezoeken. Want of hij nu voortaan via de universiteit of via staatsexamens zijn bevoegheid wilde verkrijgen, een verblijf aan de universiteit of Athenaeum was noodzakelijk geworden (Winkler 1901: 112). De universiteit was echter alleen toegankelijk voor diegenen die het gymnasium hadden doorlopen. Volgens de wet van 1865 was ontheffing van deze verplichting echter mogelijk. Het ministerie verleende gedurende de periode 1865-1878 aan een groot aantal HBS-ers toegang tot de universiteit (Groen 1985b: 2; 32; zie hoofdstuk 2).

Alhoewel van de staatsexamens een sterk uniformerend effect uitging, liep

129 Donders achtte de investeringen die noodzakelijk zijn om de kweekschool op niveau te brengen onverantwoord hoog. Bovendien zou de wet gebieden ook een vrouwen-en kinderafdeling in te richten. 130 "Vroeger kon men kweekelingen aannemen naar den maatstaf van kennis, dien men zelf bepaalde en die elk jaar door het aantal en het gehalte der aspiranten werd aan de hand gedaan. Men kon hun nu verder opleiden naar een plan, eigenmachtig vastgesteld buiten de wet, de gevorderde bewijzen van kennis en geschiktheid, ook regelen naar opleiding, ze zelf, in verband met de bestaande behoefte aan officieren van gezondheid, naar goedvinden wat uitzetten of inkrimpen" (Donders 1867a: 6). 
het instituut staatsexamens uit op een fiasco. De staatsexamens stonden bloot aan felle kritiek ${ }^{31}$. Om te beginnen werd, zij het zonder officiele wetswijziging, de samenstelling der staatscommissie veranderd (Winkler 1901: 113). Er werden meer universitaire docenten opgenomen in de staatscommissies. De hoger onderwijswet van 1876 lag verder geheel in de lijn van de artsenwetten van 1865. De afzonderlijke doctoraten in geneeskunde, chirurgie en obstetrie werden afgeschaft. De voorlopige vrijstellingen aan candidaten en doctorandi gegeven, werden definitief. Het afnemen der staatsexamens werd opgedragen aan de faculteiten der betrokken universiteiten. Daardoor verdween na korte tijd het verschil tussen het theoretisch geneeskundig staatsexamen en het faculteitsexamen. Er resteerde toen nog éen staatscommissie die belast was met het afnemen van het praktisch artsexamen. Deze commissie, die jaarlijks nieuw werd benoemd, hield beurtelings zitting in Amsterdam, Leiden en Utrecht. Maar ook zij ging spoedig ter ziele. Studenten klaagden: "[D]e rivaliteit der universiteiten sprak. Had de staatscommissie haar zitting te Leiden en dus een groot aantal Leidsche hoogleraren tot leden, dan was slagen voor de studenten in Utrecht of Amsterdam zeer moeilijk" (Winkler 1901: 115). Docenten klaagden: de grote toevloed van studenten bracht met zich mee "week in week uit, soms op andere plaatsen dan waar zij hun werkkring hadden, uit examineren te gaan" (Winkler 1901: 114-115). Het voorstel om de commissie over de vier universiteiten te verdelen, ging dan ook uit van de commissie zelf. Dat zou in 1885 gebeuren. De staatscommissies waren hiermee in feite faculteitscommissies geworden.

Een belangrijk onderdee ${ }^{132}$ in de discussie rond de Hoger Onderwijs-wet van 1876 vormde de toelating van HBS-ers tot de universiteit. Reeds vanaf 1871 waren er stemmen opgegaan (Rosenstein 1871) die het recht op universitaire studie bepleitten voor gediplomeerden van een HBS (Bartels 1963: 132). Rosenstein meende dat het onderwijs in de moderne talen minstens even vormend was als dat in de klassieken. Het feit dat er op de HBS-en meer aandacht gegeven werd aan wiskunde dan op de gymnasia pleitte juist in hun voordeel. Van de ruime aandacht op de HBS-en voor de natuurwetenschappen ging een vormende invloed wit op de waarneming (Rosenstein 1871: 17). Bestudering van de klassieken was voor een geneeskundige allerminst nog noodzakelijk. Immers het "eigenlijke karacteristieke der hedendaagsche natuurwe-

131 Zue o.a. Donders (1875); Penn (1876); Dresselhuys (1876); Evers (1876).

132 Daamaast klonk de zorg door dalt de strenge eisen die sedert 1865 aan de geneeskunsibeoefenaren werden gesteld tot een tekort an artsen zou leiden (Goudsmit 1978: 33). "Bij de thans vigeerende Wet worden wij met eene schaarschte wan geneeskunstoefenaren bedreigd, die zich hier en daar op het plattelarid en wooral bij het leger en de vloot reeds pijnlijk doet gevoelen, en binnen weinige jarten wullen de geneeskunstoefenaren aan hunne patiënten de wet kunnen stellen op eene wijze, die noclu in hun belang is, noch in het belang der matschappiy" (Donders 1875: 12). 
tenschappen, het ondervragen der natuur, het experiment, was hun [de klassieken] geheel vreemd" (Rosenstein 1871: 21). Donders (1875) lanceerde het voorstel om de abituriënten van de HBS-en te laten studeren aan een door het Rijk op te richten geneeskundige school, die volgens hem in Amsterdam zou moeten worden gevestigd (Bartels 1963: 133). De strijd om de gelijkschakeling van toelatingsrechten tot de universteit voor de HBS-en en de gymnasia bereikte een voorlopig hoogtepunt in 1876 bij de behandeling van de aanstaande wet op het Hoger Onderwijs. Na heftige debatten in de Tweede kamer hoefden gediplomeerden van de HBS voortaan enkel een aanvullend examen in Latijn en Grieks af te leggen om tot de universiteit te worden toegelaten; voor de overige vakken bood het HBS-diploma vrijstelling. De 'artsenwet ${ }^{\text {'133 }}$ van 1878 stond vervolgens toe dat HBS-ers, na het afleggen van het eerste natuurkundig examen van de universiteit, de universitaire artsenstudie volgden ${ }^{134}$, zij het dat voor hen in speciale examens, parallel aan de academische examens, was voorzien.

De veranderingen in de medische opleiding doen G.J. Mulder omzien in wrok $^{135}$. Mulder spreekt over de "heilloze Artsen-wet van 1878: eerst geen Latijn en Grieksch meer noodig ${ }^{136}$, toen gelijkstelling van Hoogere Burgerscholen en Gymnasiën voor dlen aanstaanden Geneeskundige: nog één pas en gij hebt de verderfelijke artsenwet" (Mulder 1880: 16). De klassieken, en met name de klassieke vooropleiding op het gymnasium zijn belangrijk omdat zij de mens sieren, de ontwikkelingsgeschiedenis van de mens uit de barbarij tonen en bijdragen tot de ethische ontwikkeling, die vooral voor geneeskundigen zo belangrijk is. De tragiek wil dat die geleerde traditie juist onder druk was komen te staan door de geneeskunde op de natuurwetenschappen te oriënteren. En daarvan was uitgerekend Mulder één van de gangmakers geweest.

Naast de achterhoedegevechten die zich voltrokken diende zich omstreeks 1870 ook een volgend en serieus probleem aan: het uitdijen van het aantal

133 Officieel geheten de 'Wet van 25 december 1878 Statsblad 222, houdende regeling der voorwatardet tot verkrijging der bevoegdheid van arts, tandmeester, apotheker, vroedviouw en apothekersbediende".

134 "Er waren wel 'eenige leden', die er" volgens het Voorlopig Verslag (...) op wezen, dat het wetsontwerp "breekt met het beginsel, dat de klassieke vorming noodzakelijk is voor wetenschappelijke oplediding', mas volgens hen zou de regeling het voordeel opleveren 'dat eene vergelijkende proel zal kumen genomen worden omtrent de gevolgren en vizchten van klassieke en niet-klassieke opleiding" (Bartels 1963: 136).

135 Ook Koster (1886) en Tilanus (1888) doen van zich horen (Van Lieburg 1989 b).

136 "De geschriften der Grieksche en Romeinsche Geneeskundigen leest men heden ten dage ten behoeve der witoefening van de geneeskunde niet meer, en spoedig zal dit ook het geval zijn met de geneeskundige geschriften van den nieuwen tijd, die nog in de Latijnsche taal geschreven worden. ( ${ }_{\text {... }}$ Hett is nawwelihks an twijfel onderhevig dat er eenmaal geneeskcundigen zullen zijn, die de tegenwoordige in geneeskundig weten verne overtreffen, en Grieksch noch Latijn zullen verstaan" (Brücke 1880: 8.). 
leervakken, terwijl het aantal hoogleraren sinds 1815 niet meer was uitgebreid. Reeds in 1872 klonken waarschuwingen tegen verregaande specialisering: "Wanneer ik de taak van den geneesheer zoo breed heb uitgemeten, ik deed het, omdat het mijne overtuiging is, dat die taak zoo breed, zoo ruim moet opgevat worden, wil de geneeskundige zich voor eenzijdigheid vrijwaren en niet in specialisering verdwalen" (Huet 1872: 35). De 'jonge' specialismen ${ }^{137}$ probeerden allen een plaats in het curriculum te verwerven ${ }^{138}$, terwijl de studietijd beperkt was. De problemen die dat opleverde, blijven hier echter verder buiten beschouwing (Schwalbe 1918).

\section{Conclusie}

In de sociologische literatuur vormen de eenheid van stand, de samenvoeging van de geneeskunde en de chirurgie, en het monopolie van de academisch opgeleide arts op de geneeskunstbeoefening belangrijke merkpunten om de professionalisering ${ }^{139}$ van het medisch beroep mee te markeren. Alhoewel Frijhoff (1983a: 405) beweert dat de ordening en opdeling van medische kunstbeoefenaars reeds in de loop van de 17 de en 18 de eeuw geleidelijk aan begint te verschuiven ${ }^{240}$ en dat het professionaliseringsproces reeds in de achttiende eeuw "niet officieel, maar wel feitelijk" zijn beslag zou hebben gekregen, sluit deze studie bij de sociologische traditie aan en wordt de spil van het professionaliseringsproces wederom in het midden van de negentiende eeuw gesitueerd. Eveneens in aansluiting bij de sociologische traditie is ook hier een cruciale rol weggelegd voor de opleiding: "Bij de domeininstitutionalisering ${ }^{141}$

137 Zie voor een overzicht van thet ontstaan van de specialismen in Nederland Lindeboom (1981).

138 serecht zegt de woortreffelinke Turijnsche geleerde Grademigo dat het tijd wordt, dat de verschillende specialiteitten vertegenwoordigd zijn, niet meer naar haar ouderdom, maai maar het belang dat zij heden ten dage thebben voor den praktiserenden geneesheer" (Burger 1905: 20). Zie ook Guye (1886). 139 De bettekenis van begrippen als professie en professionalisering is sterk afhankelijk van du sociale theorie waarin ze gebnuikt worden. Aspecten als thet standaardiseren van de opleiding en de vorming van een zelf-regulerende organisatie met een intern tuchtcollege dat zich baseert op een gedragssodie en een beroepsethiek "komen echter in de meeste theorieèn aan bod (Rüschemeyer 1980: 316).

140 "Het verticale rangstelsel wan corporatieve aard dat de medische sector aan linet begin van onze periode [De Republiek] kent, wordt van binnen uit, door professionele ontwikkelingen, witgehold en brengt een onderlinge herordening van de medische beroepen tot stand. De statusgroep wordt daarbiy als ordeningsbeginsel vervangen door de beroepsgroep (...). Niet de socialle status, maar de sociale functie gat thans een overheersende rol spelen" (Frijhoff 1983a: 384).

141 Mok (1973) onderscheidt domeininstitutionalisering van en daarop volgende fase wan sociale institutionalisering watrin vestigingsstrategieen centraal staan. In dit hoofdstuk is hoofdzakelijk ingegaan: op de institutionalisening van het domein. Vestigingsstrategieën zujn van later dattum: "De geringe frequentie, het incidentele karakter en de veelal koele ontvangst van voorstellen, aangaande de materiéle positie der artsen, illustreert wel onmiskenbaat, hoe weinig aandacht in deze eerste 50 jaren in en door de maatschappij aan de materiele belangen der artsen werd geschonken (...). In de negentiger jaren komt 
gaat het in de eerste plaats om de 'klassieke' requisieten die altijd netjes worden opgesomd bij beschrijvingen van het begrip professionalisering. De belangrijkste zijn opleiding, organisatie en professionele code en daarvan is, durikt mij, alleen de opleiding essentieel. De kern van de zaak in de inmiddels gangbare begripsvorming omtrent professionalisering is deskundigheid"' (Gastelaars 1988: 21).

Alhoewel sociologische studies de uniformering van de opleiding een centrale rol toedichten in het professionaliseringsproces, wordt de functie van de natuurwetenschappen daarin veelal miskend, of sterk vertekend. In zijn klassieke studie over het professionaliseringsproces verbindt $E$. Freidson (1970: 16) de introductie van de natuurwetenschappen en laboratoriumtechnieken in het medisch domein direct aan een verbetering van de therapeutische expertise: "For the first time in history, causes of numerous diseases became known: The way was opened for a replacement of systematic or empirical treatment by causal treatment and prevention. Those accomplishments created a qualitative break with the past, making possible for the first time the predictable and reliable control of a wide spectrum of human ills by virtually any well-trained practitioner of the occupation, not solely by a great clinician." Maar de directe causale koppeling tussen de matuurwetenschappen en het vergroten van therapeutische mogelijkheden is inmiddels door historische studies achterhaald. Tussen de introductie van het onderwijslaboratorium in het medisch onderwijs en het tijdstip waarop laboratoriumtechnieken vruchten beginnen af te werpen voor de therapie liggen zeker vijf decennia (Tuchman 1988: 85).

M.S. Larson (1977: xii) onderkent in haar analyse van de opkomst van de medisch professional dat historische studies het beeld hebben ondermijnd dat "'regular" physicians had, in general, any more competence than their "irregular" competitors". Zij beschouwt de roep om een natuurwetenschappelijke oriëntatie als een onderdeel van het gevecht om macht en invloed "by which producers of special services sought to constitute and control a market for their expertise" (Larson 1977: xvi). Een gestandaardiseerd en op de natuurwetenschappen gebaseerd curriculum zou het mogelijk maken om het universele, objectieve en onzelfzuchtige karakter van de professie te onderstrepen. Door een goed-gedefinieerd, homogeen en superieur produkt aan te bieden kon de professie controle verkrijgen over de markt. De opleiding had vooral "the standardized and centralized production of professional producers" (Larson 1977: 17) tot taak. Maar waarom nu juist de natuurwetenschappen de ideologische functie die zij aan de opleiding toeschrijft kunnen vervullen, blijft ook bij Lar-

die kentering (...). Als teken des tijds opent het tijdschrift in 1896 een rubriek "beroepsbelangen', "een onderwerp', schrijft de Redactie 'dat om goede redenen meer dan vroeger de aandacht trekt" (Gedenkboek 1949: 38). 
son vaag. In sommige passages suggereert zij dat het prestige en de superioriteit van de natuurwetenschappen zelf-evident zijn. Eerder het tegendeel is het geval, wat zij op andere plaatsen ook toegeeft. Aan de ene kant verbindt Larson het professionaliseringsproces met het monopolie van de academisch gevormde arts, aan de andere kant erkent ze dat de introductie van de natuurwetenschappen een breuk betekende binnen de academische traditie zelf. Om het ontstaan van het monopolie van de academisch gevormde arts en de rol van de natuurwetenschappen daarbij te verklaren, valt Larson uiteindelijk terug op de "staat" 142 . "In conclusion, to view professional modernisation as a project of market control underlines the central role of the state in the development of this project, most particularly its function of sponsoring monopolistic education systems" (Larson 1977: 18).

Terwijl Freidson de therapeutische superioriteit die volgt op de bekering van de geneeskunde tot de natuurwetenschappen an de basis legt van het monopolie van de academisch arts - en daarmee vijf cruciale decennia eenvoudig overslaat - is volgens Larson (1977: 14) het doorslaggevend effect van de introductie van de natuurwetenschappen in de opleiding vooral gelegen in thet standaardiserende effect dat daarvan uitgaat in een opkomende markt. In havar ogen is de medische markt uiteindelijk afhankelijk van ideologische bronnen van sociaal krediet (Larson 1977: 23). Maar waarom juist de natuurwetenschappen stabiele criteria konden leveren, of wat de achtergrond vormt van het sociale krediet en de veronderstelde stuperioriteit van een geneeskunde gebaseerd op de natuurwetenschappen blijft duister. Waarom vormden de natuurwetenschappen een solidere basis dan de klassieke opleiding van de Medicinae Doctor?

De superioriteit van een op de natuurwetenschappen gebaseerde geneeskunde is allerminst evident. Diegenen die een meer op de fysiologie of op de natuurwetenschappen georiënteerde geneeskunde bepleiten, moeten zich aanvankelijk juist verdedigen tegen de aanval dat ze de zekerheden en routines van de geneeskunst ondermijnen, wat tot "scepticisme" of "nihilisme"143 in de therapie en het medisch handelen zou leiden ${ }^{\text {I.4 }}$. G.J. Mulder, én van de

142 "Often the resistance of regullar medicine to bacteriology required an intervention of the state aganingt established sectors of the profession, on the one side of popular demand and of public health movements in which laymen often outnumbered physicians. For medicine to appropriate the riew discoveries, the bulk of the profession had to be socialized to the new toolls. This required, in effect, that one or more generations of physicians be formed along new and homogeneous standards of training Until that time, the state's intervention on the side of "regular' medicine should be seen more as a politi" cal response than as a matter of encouraging the best product in a vital market" (Larson 1977: 24).

143. Volgens $\mathrm{O}$. Temkin (1977a: 46) gat de overgang van de traditioneel bekende geneeskunde nazi. een natumrwetenschappelijke geneeskunde gepaard net een periode van therapeutisch nililisme, die bedoeld is als revolutie tegen de heersende farmaceutische aanpak in de interne geneeskunde.

144. "Maar zal die rigting [fysiologie, natumwettenshappehjke geneeskunde] der geneeskunde niet tot nihilisme leiden op het gebied der therapie? Zullen die artsen der toekomst de zieken niet aan hun lot 
Nederlandse voormannen om de geneeskunde als natuurwetenschap op te vatten, antwoordde in 1842 op de vraag of de geneeskundige praktijk reeds naar de toenmalige stand van de natuurwetenschappelijke kennis over de aard der ziekten was ingericht: "Neen, zoo verre is men nog niet, dan in weinige ziekten gekomen. Heeft het dus wel eenige waarde die onderzoekingen voort te zetten en mogen wij ons, moeten wij ons niet scharen bij die soort van practici, die met een zeker medelijden daarover de schouders ophalen? (Mulder 1842a: 321; zie ook Heynsius 1856: 18). Ruim twintig jaar later merkte I. Leonides van Praag (1866: 262-266) nog op: "De utopie eener geneeskunst gegrondvest op physiologisch-anatomisch weten is zeer schoon en stellig onzer aller vurigste wensch, maar die kan vooralsnog niet als maatstaf van ons handelen aan het ziekbed gelden."

Door het proces-karakter van een ziekte te benadrukken, wordt de uitkomst van een ziekte principieel onzeker. Het is niet meer mogelijk de afloop van een ziekte te voorspellen, wanneer de essentiële symptomen zijn vastgesteld. Die onzekerheid leidt onder andere tot beschuldigingen van therapeutisch scepticisme en nihilisme aan het adres van fysiologen. Het belang van de natuurwetenschappen ${ }^{145}$ is in eerste instantie dan ook niet gelegen in het vergroten van het therapeutisch kunnen. De aan de fysiologie ontleende notie van ziekte als een verstoord levensproces levert primair een alternatief organisatiecriterium voor de hiërarchieën die aanvankelijk nog het beroepsveld verdelen. De hiërarchie van kunstbeoefenaars aan het begin van de negentiende eeuw vindt haar legitimatie en bestaansrecht in indelingscriteria waarin (opleidings)tradities of tijdloze parameters een belangrijke rol spelen. De nauwkeurige waarneming en registratie van het individuele ziekteproces biedt een alternatief organisatiecriterium voor het domein van ziekte en gezondheid. Dat legt de grondslag voor professionele autonomie en voor een model van coöperatie - in tegenstelling tot de hiërarchieën die kunstbeoefenaars tot dan toe scheidden. De acceptatie van een grote mate van onzekerheid over het verloop van een ziekte brengt met zich mee dat een nauwkeurige, zelfstandige en continue waarneming van het ziekteproces vereist is. De waarneming van fysiologische processen ligt in het verlengde daarvan ${ }^{145}$ of vormt - didactisch

overlaten? (Heynshus 1866: 29-30). Zie ook H. (1842a: 117-118).

145 Zie voor een soortgellike on wwiklkeling in Duitsland Coleman en Holnes (eds.) (1988) en Huerkamp (1985).

146 "Deze weg is niet gemakkelijk, net elegant; men moet een groot gedeelte van den dag in de hospitalen en an het ziekbed doorbrengen, men noet bloed, etter, slijm, pis, drekstoffen, huiduitwase ming enz. op verschillende wijzen en soms verscheidene malen dagelijks onderzoekem (...): men ziet zich niet zelden in zijne verwachtingen te leur gesteld, ontmoet elk oogenblik leemten in het eigen weten en wordt darenboven ook dikwijls ontmoedigd door de gewaarwarding, over een ziekteproces nog zoo. weinig net zekerheid te kunnen vermelden en zich ewenwel jaren lang te hebben voorgeskeld hetzelwe te hebben doorgrond" (Gobée 1844a: xi). 
gezien - de voorbereiding daarop ${ }^{147}$.

Op wetenschappelijk niveau vormt de nauwkeurige waarneming van ziekteprocessen die fysiologische geneeskundigen voorstaan, een alternatief voor de geleerde traditie, waarin de systematische indeling van ziekten prevaleerde boven de eigenaardigheden van het individuele ziektegeval en ziekteproces. De fysiologie wordt de spil van de moderne geneeskunde: "Immers daar zij de leer van de natuurverschijnselen bij den mensch tot onderwerp heeft, maakt zij met de ontleedkunde, weefselleer, ziel- en ziektekunde ééne wetenschap uit, terwijl zij zich de scheikunde, algemeene natuurkunde, wiskunde, de natuur- en ontleedkunde der dieren en planten als hare hulpwetenschappen toe-

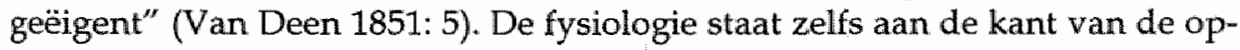
komende hygiënistische beweging: "Het is gemakkelijker ziekten te voorkomen, dan ze te genezen" (Heynsius 1866: 32; Rosenstein 1866: 18). In haar methodologie is de fysiologie al even megalomaan: zowel de praktische ontleedkunde, de microscopie, proefnemingen als ziektekundige opmerkingen en vergelijkingen rekent ze tot haar methodes (Van Deen 1851: 16). Voor fysiologen is ziekte niet meer en niet minder dan een verstoring van het normale levensproces. Daardoor wordt de traditionele verhouding tussen de leervakken op zijn kop gezet. Pathologie en fysiologie vormen nu een eenheid. Noch de anatomie noch de pathologische anatomie kunnen blijven wat deze vroeger waren: "Ofschoon beschrijvende ontleedkunde zeer goed zonder physiologie kan beoefend worden, zal echter de met eenige zucht tot wetenschap bezielde anatoom zich nimmer te vreden stellen met de eenvoudige beschrijving der verschillende werktuigen, maar ook in de verrigting daarvan willen doordringen" (Van Deen 1851: 7).

De zelfstandige waarneming en registratie van processen levert een alternatief dat de kloof tussen onderwijs in een meester-leerling traditie en het academisch onderwijs kan overbruggen. Kenmerkend voor het onderwijs aan 'practici' of 'empirici' was het van generatie op generatie doorgeven van 'ervaring' in een meester-leerling verband. De 'geleerde' vorming aan de universiteiten profileerde zich daarentegen door kennis van de klassieken en systematische classificaties van ziekten. Door de opleiding te centreren rondom de observatie van processen waarvan de afloop principieel onzeker is, wordt die onverzoenlijke tegenstelling in de aard en inhoud van de over te dragen kennis opgeheven. Het praktisch klinisch onderwijs aan de universiteiten wordt - althans in woord en geschrift - een verlengstuk van het praktisch laboratoriumonderwijs in de natuurwetenschappen.

147 "Het waarnemen van verschijnselen, het opsporen wan oorzaken en het opmaken van een beshil, is eene doorgaande bezigheid van Natuurkundigen; daarom alleen is reeds de beofening der Natuur. wetenschappen voor den Geneeskundige van onschatbare waarde" (Mulder 1842a: 320). 


\title{
IV \\ Het onderwijs in de Faculteit der Rechtsgeleerdheid
}

\author{
Inleiding
}

Terwijl in de periode tussen het Organiek Besluit en de Hoger Onderwijswet van 1876 de inhoud, methode en organisatie van de medische opleidingen in het brandpunt van de belangstelling staan, is de rechtsgeleerde opleiding veel minder vaak onderwerp van discussie. Pas tegen het eind van de negentiende eeuw wordt de opleiding tot jurist een op zich zelf staand thema ${ }^{1}$. De diversiteit aan beroepsperspectieven, het feit dat het Organiek Besluit het recht om als advocaat aan rechtbanken en gerechtshoven te praktiseren had voorbehouden aan hen die de graad van doctor in de Romeinse en hedendaagse rechten hadden verworven ${ }^{2}$ (O.B. art. 120), maar vooral het gegeven dat de rechtsgeleerde studie van oudsher de vanzelfsprekende ${ }^{3}$ introductie tot hogere functies en ambten vormde, leidt ertoe dat wanneer rechtsgeleerden zich in de discussie over het hoger onderwijs mengen, zij in eerste instantie geen inhoudelijke of methodische veranderingen in het onderwijs binnen de faculteit op het oog hebben, maar zich veeleer richten op kwesties die de organisatie van het hoger onderwijs in het algemeen betreffen. Kwesties die in het tweede hoofdstuk zijn geinterpreteerd in de context van een transformatie in de maatschappelijke orde, waar selectie op basis van persoonlijke prestaties een steeds belangrijker rol gaat innemen.

1 Een mijlpaal vornt de tweedargse bijeenkomst van de Nederlandse Juristen Vereniging in 1899, die de opleiding tot jurist tot onderwerp heeft. Vanaf dat moment volgt cen riet aflatende reeks van publi. caties met als hoofdonderwerp het juridisch onderwijs: In de jaargang 1899 van Themis wersehijnt eer artikel van J.A. Levy (1899), in het Rechtsgelevd Magazijn van die jaargang een artikel van D. Joseplus Jitta. In Themis van 1900 en 1902 volgen artikelen van Hijmans. Zie voor een geselecteerde literatuurlijat Handelingen der Nedertandse Juristen-Vereniging (1972: 245-255).

2 De lagere rechtspraak was tot aan de Franse tija in hoofdzaak in handen van Jeken (Egmond 1989. 15).

3 Modderman (1875: 14) formuleert dat heel puntig: "De rechten is een vak, dat de meesten toit zich trekt die noch lust noch liefde voor studie hebben, een vak waarin men voonuit kan komen, zonder dat men er in vooruit behoeft te gaan" ${ }^{\prime \prime}$

4 "De professionalisering van het rechterlijk personeel verloopt moeizalam, un die zin dat er eigenujk geen sprake is van een "career open to talent'. Het vervullen van een openbaar ambt is zeer lang iets gebleven dat men zich moest kunnen veroorloven" (Pieterman 1990a: 138). 
Ondanks die relatief geringe aandacht voor de opleiding veranderen in de loop van de negentiende eeuw de opvattingen over de verhouding tussen recht, rechtswetenschap en wetgeving en als afgeleide daarvan het onderwijs binmen de faculteit der rechtsgeleerdheid radicaal. Volgens L.]. van Apeldoorn (1932:140) is er in het 300-jarig bestaan der Amsterdamsche Hoogeschool nooit een "grooter omkeering geweest in de beofening en het onderwijs der rechtswetenschap dan in de dertiger jaren van de vorige eeuw" (zie ook Huizinga 1951 b: 71; Groen 1985a: 25). P.C. Kop spreekt in dit verband over "een diepgaande mentaliteitsverandering", al situeert hij deze, zoals de meeste moderne rechtshistorici, in de laatste decennia van de vorige eeuw of op zijn vroegst in de jaren zeventigs.

Het is niet ongebruikelijk de veranderingen binnen het domein van het recht te plaatsen in de context van een industrialiserende en moderniserende maatschappij (Jaspers 1980). J. Valkhoff (1938: 82) heeft ooit de ontwikkeling van de wietgeving in Nederland tussen 1838 en 1938 met de term "vermaatschappelijking" aangeduid. Hij verstaat daaronder dat het recht "minder statisch" en "meer sociaal" wordt. Met name het aspect van het "socialer' worden van het privaatrecht, "waarbij de collectiviteit meer op de voorgrond komt en de gemeenschapsbelangen meer gaan gelden naast die van de enkeling' is daarbij

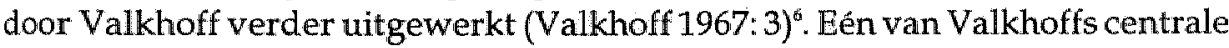
stellingen, namelijk dat het eigendomsrecht" allengs zijn strikt privaatrechtelijke karakter, dat het in het Burgerlijk Wetboek van 1838 nog heeft, verliest en meer en meer deel uit gaat maken van het domein van het publiekrecht - dat overigens pas vanaf de zeventiende eeuw als afzonderlijk leervak bestond (Van den Bergh 1988b: 127; Poortinga 1987: 15-24) - is echter grotendeels onhoudbaar gebleken (Valkhoff 1956; Van den Bergh 1987; Van den Bergh preprint: 10).

Hier worden de veranderingen binnen het onderwijs in de rechtsgeleerdheid geplaatst in het moderniseringsperspectief dat in het eerste hoofdstuk is uiteengezet. Het aspect van globalisering, een vergroting van de schaal waarbinnen

5. "De jaren zeventig van de vorige eetw wormen een periode van omslag. Zo raakt de rechtswetenschap uit de ban van het wetspositivisme" (Van den Brink 1976: 62).

6. In dit vernaatschappelijkingsproces numt Valkhoff een belangrikke plaats in voor de toename van het verkeer. De aunleg van spoorwegen, rond 1840, doet de behoefte aan een onteigeningswet ten behoeve van het algemeen belang voelen. Het feit dat de in 1839 aangelegde spoorweg Amsterdam-Iaarlem pas in in 1842 werd doorgetrokken naar Leiden en in 1847 van Den Haag naar Rotterdam, is volgens Valkhoff te wijten aan het ontbreken van zo'n onteigeningswet. Die zou er op 28 Augustus 1851 komen. De opkomst wan telegraaf en telefoon met hum bowengrondse dradennet, maakte weer op een andere manier de beperkingen van de eigendomswet zichtbaar (Valkhoff 1938: 20-26; zie ook Modderman 1867: 27, 35). 7 Valkhoff illustreert zign these aan talloze voorbeelden. Een charvan betreft het arbeidsrecht. In het Burgerlijk Wetboek van 1838 staat het privaatrechtelijke eigendomsconcept centratl. Doordat eigendont het beslissingsrecht over de in eigendom zijnde zaken impliceert, heeft een fabriekseigenaai praktisch ook beschikkingsmacht over de arbeiders. Het arbeidsrecht zou hier een eimde aan maken (Valkhoff 1938 32). 
sociale verhoudingen op elkaar afgestemd moeten worden, duikt in de discussies naar aanleiding van de invoering van nationale wetboeken regelmatig op. Alhoewel de rechtsongelijkheid en de rechtsverscheidenheid ${ }^{8}$ in de Republiek wellicht niet die omvang hebben gehad als lange tijd is gesuggereerd ${ }^{9}$, worden als voordelen van (het streven naar) codificatie ${ }^{10}$ steeds het scheppen van rechtseenheid en rechtszekerheid genoemd. In de decennia die volgen op het gereed komen van eigen nationale wetboeken ${ }^{11}$ voltrekt zich echter ook een transformatie ten aanzien van de opvattingen over recht in de temporele dimensie. Uiteraard is het besef dat het recht interpretatie en uitleg behoeft van alle tijden. Evenals het besef dat wat recht is in iedere tijd in een andere gedaante verschijnt. Maar het idee dat het recht méer van doen heeft met steeds veranderende en contingente maatschappelijke verhoudingen dan met vastliggende bronnen of algemeen geldende principes, dát idee wordt pas in de loop van de negentiende eeuw geboren: "Meer en meer won (en wint) het inzicht veld, dat het recht geen volledig autonoom verschijnsel is, geen puur abstract-logisch systeem, waarbinnen normen en begrippen een eigen leven leiden, los van ethische voorstellingen, los ook van maatschappelijke belangen en feiten. Langzamerhand begon men te beseffen, dat er tussen dit alles een onverbrekelijke samenhang en een voortdurende wisselwerking bestaat" (Heyman 1973:247-248).

Uiteraard is het in dit bestek niet mogelijk precieze veranderingen binnen elk afzonderlijk leervak aan te orde te stellen ${ }^{12}$. De aandacht gaat vooral uit

8 "De rechtsverscheidenheid bünen het territoir van de Republiek was dus geen toeval, maar een opzettelijk gevolg van de gekozen staatsinrichting. Sterker nog zij was éen der wezenskenmerken van het staatsbastel der Unie" (Lokin \& Zwalve 1986: 251) "De groote tegenstelling tusschen de 19de eeuw en vroegeren tijd ligt niet in het bezit van eigen recht in plaats wan Romeinsch en natuurrecht, maar in het bezit van omlijind recht en rechtszekerheid in stede van vag, betwist onzeker recht, dat de gesteldheid van vroegere euwen kenmerkt" aldus Wan Heynsbergen (1925: 120); zie ook Scholten (1938). A. Jaspers (1980: 10) onschrifft de situatie op het eind van de achttiende eeuw als volgt: "De onzekerheid welk recht wan toepassing was, en het feit dat prowincies en steden hum eigen recht hadden, maakten de rechtsbedeling ondoorzicivig en verwarrend. De reeks van 'Commentaren' en 'Adviesboeken' die door de rechtsgeleerden werden witgegeven om leemten aan te vullen en regels uit te leggen, vergrootten slechit de chens."

9 Gegeven de grote fragmentatie van de rechtsmacht, blijkt echter uit recent historisch onderzoek in de Republiek "een verrassend grote eenheid in de bestraffingsvormen en een aanzienlijke mate wan rechtsgelij]kheid" te hebben bestaan, althans binnen een stalusgroep warbij met name van belang was of de dader over een vaste woonplaats beschikte en te goeder naam en fam belkend stond (Egmond 1989: $14-15 y_{i}$

10 "[C]odificatie is: geschreven recht, waaraan de overheid een aan haar gezag ontleende, uitsluitende gelding toekent; deze exclusiviteit makkt de rechtsoptekening tot een volledige" (Lokin \& Zwalwe 1986: 2) Uiteraard is codificatie geen noodzakelijke voorwaarde voor modernisering. Denk aan het Angelsalksische rechtssysteen.

11 In 1838 worden tegelijk met een nieuw burgerlijk wetboek, het wetboek wan koophandel, het wetboek van burgerlijke rechtsvondering en het wetboek van strafvordering ingevoerd.

12 Voor een integraal overzicht van de veranderingen binnen het wakkenpakket wordt verwezen naar Groen (1985a) en naar Veen, Kop m.m.w. Kwanten (red.) (1987). 
naar het privaatrecht. Het staatsrecht komt slechts zijdelings, het strafrecht in het geheel niet aan orde. De motivatie hiervoor is dat van het privaatrecht het meeste materiaal voorhanden is, terwijl een groot deel van de discussies in de negentiende eeuw die binnen het domein van het recht spelen; direct of indirect het privaatrecht raken. Het enige leervak waar langer en uitvoeriger bij stil gestaan wordt, is het Romeinse recht. Immers, wie zich in de vorige eeuw uitliet over de rechtsgeleerde opleiding kon er niet aan voorbijgaan diens visie op de plaats en functie van het Romeinse recht daarbinnen kenbaar te maken.

\section{Op zoek naar zekerheid}

Het besef dat het recht interpretatie behoeft is zo oud als het recht zelf. Dat de uitleg van dat recht tot controverses onder de rechtsgeleerden kan leiden, is eveneens een inzicht van alle tijden, evenals het idee dat iedere tijd zijn eigen specifieke juridische problemen kent. Ook in de zeventiende en achttiende eeuw valt een besef van de veranderlijkheid en historiciteit in het recht aan te wijzen (Jansen 1988). Toch verandert de benadering van die historiciteit in het recht in de negentiende eeuw radicaal. In de zeventiende en in de achttiende eeuw staat het onderwijs in de 'historia literaria' en in de 'historia juris Roma$\mathrm{ni}^{\prime}$ in het teken van de verklaring en de uitleg van een stelsel van rechtsnormen, dat nog steeds (subsidiair) van kracht was. Het geleerde recht - even afgezien van onderlinge verschillen - heeft de uitleg van de logische opbouw van het overgeleverde Romeinse, kanonieke en leenrecht tot doel. Met die inzet is een oriëntatie op vastliggende bronnen en de analyse van de onderlinge verhouding tussen die bronnen verbonden ${ }^{13}$. Die concentratie op een logisch samenhangend stelsel van rechtsnormen dat de wisselingen van de tijden heeft weten te trotseren en nog steeds geldingskracht bezit, wordt in het achttiende eeuwse natuurrecht overgenomen in het streven naar het ideaal van een stelsel van rechtsprincipes dat voor alle situaties inzetbaar is. Uiteraard roept dat kennisideaal ook op gezette tijden de negatie ervan op: het rechtsgeleerd scepticisme, dat dat ideaal in twijfel trekt. Het scepticisme eigen leidt dat echter niet, en zeker niet in de achttiende eeuw (Lokin \& Zwalve 1986: 24) wanneer het zoeken naar zekerheid hèt kenmerk van wetenschappen en filosofie wordt (Toulmin 1990: 115), tot een positief programma.

Binnen het geleerde recht kan de bestudering van het Romeinse recht bogen op een oude en eerbiedwaardige traditie. Een traditie die gekenmerkt wordt

13 "Prinzipiell wurde die Geltung des Rechts als invariant gesehen, zumindest auf invariant geltende Normen gegründet - und nicht etwa auf Adäquität dank laufender Anpassung" (Luhmann 1987b: 194). 
door richtingenstrijd en schoolvorming ${ }^{24}$. Maar in alle benaderingswijzen historisch dan wel systematisch - klinkt het streven naar de systematische orde van een logisch consistent stelsel van rechtsnormen door. Voor dogmatisch-systematische richtingen vormt die logische benaderingswijze een vanzelfsprekend uitgangspunt ${ }^{15}$. Vanaf het humanisme zijn daarnaast benaderingen binnen de bestudering van het Romeins recht aan te wijzen waarin erkend wordt dat voor het juist verstaan van de tekst van het duizend jaar oude Corpus Juris historisch inzicht onmisbaar is. Het feit dat veel Franse humanisten van protestante gezindte waren, heeft er mede toe bijgedragen dat een bellangrijk deel van de humanistische school zich tegen het einde van de zestiende eeuw vanuit Frankrijk verplaatst heeft naar de Republiek der Verenigde Nederlanden (Van den Bergh 1980: 38). Het gros van de Nederlandse beoefenaren van het Romeinse recht van de zestiende tot het midden van de achttiende eeuw wordt meestal gerekend tot de Hollandse Elegante School. De algemene opvatting luidt dat deze school van juristen een min of meer gelukkige synthese tussen humanistische filologie en praktijk heeft weten te bewerkstelligen (Veen, Kop, m.m.v. Kwanten 1987: 9; Zimmerman 1990: 835), hoewel dat ook anders gezien wordt (Van den Bergh 1980: 39; Lokin \& Zwalve 1986: 256). In de achttiende eeuw mondt dat uit in een historisch georiënteerde, antiquarische richting ${ }^{16}$. Historisch moet in de context van de achttiende eeuw echter niet worden misverstaan 17: "[M]et het leggen van den nadruk op het Romeinsche recht 'wie es eigentlich gewesen', het 'ware' Romeinsche recht dat men

14. "[O]f men nu den mos gallicus tegenover den mos italicus stelt, de 'humanistische" of "elegante' school tegenover den ustus modernus pandectarum of zelfs de 'nieuw humanistische rigting' tegenover een nog nieuwere richting, (...) het komt then slotte overal neer op een tegenstelling, die met de woorden historisch-dogmatisch niet beter, maar ook niet slechter is aangegeven dan met de zojuist genoemde uitdrukkingen" (Feenstra 1953: 8). Zie woor een kort maar helder overzicht Feenstra (1974: 118 e.w.) of Van den Bergh (1980).

15 Van den Bergh (1979:25) beschrijft de methode van de traditionele dogmatiek als walgt: "Deze gaat altijd uit van de afzonderlijke elementen - de rechtsbegrippen. Ze probeert die zo scherp mogelijk te definiëren en door constructie verder wit te bouwen. Rechtswetenschap wordt zo continue reconstructie van een begrippenapparaat."

16 Hoewel ook dat een generalisering is: "Men kar zich intussen afvragen of het hele begrip "elegante. of antiquarische school" niet tot werwarring leidt; ook de Nederlandse juristen die door "antiquarische" geschriften bekend zijn hebben daarnaast soms werken in de usus-modernus-trant nagelaten, zoals bijw. Cornelis van Bijnkershoek. De enige juristen van naam die men misschien inderdaad van het etiquet 'antiquarisch" zou mogen voorzien zijn Gerard Noodt, Anton Schulting en Hendrik Brenkmann" (Feenstra 1974: 122/3).

17 Volgens Van den Bergh (19886: 133) is hetzelfde nog steeds van toepassing op het veel modernere interpolatieonderzoek in het Romeinse recht: "Het hele interpolatieonderzoek wordt geleid door het ken" nisdoel, het klassieke Romeinse recht te reconstrueren als een perfect, rationeel rechtssysteem zonder in-nerlijke tegenspraken. (...) Het Romeins recht 'wie es eigentlich gewesen', dat is een stelsel dat nauwelijks die naam verdient, casüistisch, onsystematisch, opgebouwd uit diverse lagen, ontwikkeld gedurende vele eeuwen onder uiteenlopende constituties, met veel ruimtte voor uiteenlopende juristenopinies, elitair, werellivreend," 
'zuiver historisch' moest beoefenen, bedoelde men veelal niet anders dan het stellen van een klassiek 'systeem' tegenover het traditionele, aan het Corpus Juris van Justianus ontleende "systeem" (Feenstra 1953: 14)" . J. Ankum herleidt de verschillen tussen de Hollandse School en de "Usus modernus Pandectarum, die iets eerder in Duitsland tot bloei kwam, tot het punt dat deze laatste het geldende recht van Romeinse en inheemse oorsprong als één samenhangend systeem behandelde, terwijl de Hollandse school beide componenten apart behandelde (Veen, Kop m.m.v. Kwanten (red.) 1987: 10).

De vrijwel exclusieve positie die de bestudering van het Romeinse recht naast die van het canonieke recht in de zestiende en zeventiende eeuw aan de hogescholen had ingenomen, komt in de loop van de achttiende eeuw onder druk te staan (Feenstra 1974: 120; Jansen 1987a en b). Van de kant van de 'practisijns' ${ }^{\prime \prime}$, de aan de balie werkzame advocaten, wordt geklaagd over het geringe practische nut van de universitaire rechtenstudie. Maar de subsidiaire functie - het geldende inheemse recht was verspreid over vele bronnen en bij ontstentenis van wet bezat de uitleg van het Romeinse recht kracht van wet - maakte dat het Romeinse recht, en daarop georiënteerde lesmethodes als tekstkritiek op het Corpus Iuris en bronnenonderzoek, stevig in het zadel zat. In de tweede helft van de achttiende eeuw wordt de kritiek op de exclusieve positie van het $\mathbb{R}$ omeinse recht in de universitaire opleiding gekoppeld aan het opkomende natuurrecht. In 1777 haalt Willem Schorer, president van de Raad van Vlaanderen, uit tegen. "nuttelooze" en "overboodige" elementen in de universitaire rechtenstudie. Schorer bepleit, in navolging van de Groninger hoogleraar F.A. van der Marck, de subsidiaire functie van het Romeins recht te vervangen door het natuurrecht (Jansen 1987a: 1). Niet dat het Romeinse recht in zijn geheel zou moeten verdwijnen. Zolang het Romeinse recht nog geldigheid bezat, is er in zijn ogen zeker plaats voor de bestudering van relevante delen van het Romeinse recht aan de universiteit (Schorer 1777a: XIV). Met het pamflet 'De eer der Hollandsche natie' dient L.J. Vitringa Schorer van repliek: De kern van zijn betoog komt erop neer dat getuige de meningsverschillen tussen de natuurrechtsgeleerden onderling, het natuurrecht geen zekerheid biedt;

18 Feenstra pleit in zijn inaugurale rede (1953!: 21) voor een zuiver historische beoefening wan het Rontuinse recht: "Men placht in vroeger tij d in dit verband well te spreken van interpretatio duplex; uitleg van een tekst in het kader van het klassieke recht naast uitleg in het kader wan het Justiniaanse recht. De moderne Romanist zou thans niet van interpretatio duplex doch van interpretatio multiplex moeten spreken, ondat hij niet meer, zoals nog de eerste generatie van de 'nieuw humanistische' richting, werkt met een 'Schwarzweissmalerei, die slechits het alternatiel: 'echt wassiek' - 'onecht' 'Justiniaans' kende, mar er bij zijn tekstkritiek van uitgaat dat er reeds vobr \usthinanus aan de klassieke geschriften zeer veel weranderd is op verschillende tijdstippen en in verschillende gedeelten wan het Rijk,"

19 Voor de in de praktijk werkzame en veelal ook daar gevormde advocaten worden de wolgende benamingen aangetroffen: advocatus (erbij geroepenen), causidicus, prolocutor, taalman, practizijn, voorspreker, woordhouder (Hermesdorf 1951; Groen 1985a: 8). 
daarnaast vereist een theoretisch, wetenschappelijk standpunt nu eenmaal een integrale bestudering van het Romeinse recht. Vitringa brengt een aantal argumenten in stelling die rechtstreeks gelieerd waren aan de kern van de geleerde en wetenschappelijke benadering van het recht; argumenten die reeds eerder geformuleerd waren ${ }^{20}$ en later nog talloze malen in andere bewoordingen herhaald zullen worden ${ }^{21}$ : Het recht heeft het karakter van een gesloten, deductief systeem, wiens principes eeuwig en overal gelden. "[H]et geen billijk was voor den Romein is ook billijk voor mijnen medeburger: Dog is zulks dus geene reden om de aanneminge van het Romeinsche recht af te keuren, dan moet het vast staan, dat de leerende jeugd op de hoge scholen ook op deeze stoffen, op deeze gedeeltens der rechtsgeleerdheid haren aandagt vestigen moet, dat deze ook harer overweginge waardig zijn, dewijl dit geheele samenstel door de allervoortreffelijkste ordre aan elkanderen gehecht zijnde, men tot geene waare en volledige kennis van het zelve komen kan, dan tenzij men geraakt is tot een recht verstand ook van die gedeeltens deezer rechtsgeleerdheid, welkers afschaffinge door den tijd, en de veranderinge der omstandigheden daar meede verknogt, veroorzaakt is, als ook om andere wetten, die op onze zeden ontwijffelbaar konnen worden toegepast, op eene duidelijke wijze te verklaaren, en tot beslissinge der dagelijksche voorvallen van het gemeene leven in te roepen. (...) Maar ook hebben deeze verouderde gedeeltens van dit wetboek nog eene andere nuttigheid. Men vind in dezelve de uitnemendste regtsgronden, en regelen van uitlegkunde op eene klare en duidelijke wijze afgemaald, en op de aldaar voorgestelde gevallen toegepast" (Vitringa 1777a: 32-33). Wat voor de rechtsgeleerde theoreticus telt is het systematische karakter van het recht, de eenheid van het geheel met zijn delen, en het herleiden van de rechtsregels tot enige principes. "Wil men de onbillijkheid van het Romeinsche recht betogen, dan moet men (gelijk ik reeds hier boven heb aangemerkt) de onrechtvaardigheid der beginselen waarop het steund, der regelen, die daar in heerschen, en van het gehele samenstel in een helder daglicht stellen" (Vitringa 1.777a: 42). In zijn repliek weet Schorer (1777b: 8) vervolgens niet beter dan zich terug te trekken achter de scheidslijn tussen theorie, de kennis van de grondbeginselen, en de praktijk, die stoelt op ervaring. Alleen de praktisijn is op basis van diens ervaring in staat over zaken de rechtbank betreffende te oordelen: " $[\mathrm{I}] \mathrm{k}$ egter van oordeel ben, dat geene professoren op d"universiteiten, als ziende de behandelingen der zaaken in de regtbanken zelfs niet, over 't nut of het schadelijke der Roomsche regten met zoo veel grond konnen oordeelen, dan zij, die dagelijks de behandeling daar van zien en bijwoonen."

20 Onder andere door D.G. Wan der Keessel, zie Jansen (1987a: 160 e.v.; 206 e.v.).

21 "[D]eze hoogere wetenschappelijke waardle des Romeinschen regts huisvestte ook in de thans geheel. verouderde gedeelten ${ }^{\prime \prime}$ (Tydeman 1819: 58). 
Het natuurrecht, met in haar kielzog het staatsrecht (ius publicum) en het volkenrecht (het ius gentium, later ook wel ius naturale genoemd), weet zich vanaf het einde van de zeventiende eeuw geleidelijk een positie binnen de $\mathrm{Ne}$ derlandse hogescholen te veroveren. Het natuurrecht, dat zich bijvoorbeeld op de onveranderlijke orde van het heelal ${ }^{22}$ of op de onbedorven en onfeillbare rede baseert, zou een grotere zekerheid kunnen bieden dan het overgeleverde Romeinse recht ooit zou kunnen ${ }^{23}$ (Jansen 1987a: 30-34). Het natuurrecht is immers in de essentie van de mens en van de zaken gefundeerd. Daardoor is het niet willekeurig maar noodzakelijk, algemeen en onveranderlijk, en combineert het prescriptieve en descriptieve elementen (Unger 1976: 76). Het natuurrecht, zo omschrijft J. van Reenen (1836: 79) het decennia later nog, is vergelijkbaar met de natuurwetten: "De natuurwetten bestaan, zonder stellige willsverklaring van iemand, uit de natuur en het wezen van het voorwerp, waarop zij betrekking hebben." Het natuurrecht is het samenstel dat omvat "al de regels en voorschriften van gedrag, welke door den mensch, als zoodanig, behooren te worden opgevolgd" (Van Reenen 1836: 79 en 81). Als vanzelfsprekend staat dan ook in de studie van het natuurrecht, het logische en systematische aspect voorop: "Het natuurrecht bestaat, aangezien de rede bestaat. En de rede, waarmee de mensen begiftigd zijn, is evenzeer zeker in morele aangelegenheden als bij wiskundige waarheden. De wiskundige zekerheid bestaat met name hierin, dat geen principes worden aangenomen, als ze niet op zich evident zijn of door ervaring buiten twijfel zijn en dat de waarheden, die uit deze principes worden afgeleid, als het ware uit hun eigen oorzaken op syllogistische wijze in een aaneensluitende reeks en zonder onderbrekende schakel worden bewezen" (Van der Marck, in Jansen 1987a: 85).

In die zin vormde het natuurrecht dan ook geen breuk met de Romeinsrechtelijke traditie. Het deelde met de geleerde beoefenaars van het Romeins recht een oriëntatie op formele logica, op eisen van coherentie en consistentie, binmen het rechtssysteem (Van den Bergh 1980: 45). In het debat tussen het Romeinse recht en het natuurrecht stond de hiërarchie van rechtsbronnen ter discussie (Van den Bergh en Jansen 1988: 354). Ging het Romeins recht terug op vastliggende bronnen, de zekerheid van het natuurrecht is gelegen in onafhankelijk van tijd en plaats geldende principes. Daamaast kon het hoofdwerk van de grondlegger van het natuurrecht, Hugo de Groots De jure belli ac pacis, niet goed gelezen worden zonder een grondige kennis van het Romeinse recht.

22 " [H]et recht der matuur is de verzameling van die wetten der naturur, die de volmakte rechten en verplichtingen van menschdom witmaken ${ }^{\prime *}$ (F.W. Pestel (1785) in Jansen 1987a: 86).

23 "Ook waarschuwt Van der Marck, voor de mare, dat het natuurrectht onzeker zou zijn. Wanneer iemand aan de zekerheid en het bestaan van het natuurnecht will twijfelen, lijkkt hij mij be twijtelen aan de zekerheid of hij zelf een mens is of hij zelf wel bestaat" (Gansen 1987a: 42). 
Voorts werd door natuurrechtsdenkers erkend dat sommige natuurrechtelijke regels ook in het Romeinse recht aangetroffen konden worden. Dat èn het feit dat het natuurrecht met name door de invloed van Kant aan hevige kritiek was onderworpen, maakte dat aan het begin van de negentiende eeuw natururrecht en Romeins recht weer min of meer met elkaar verzoend raakten (Jansen $1987 \mathrm{a}: 245$ ). Het Romeinse recht werd toen weer veelal opgevat als de geschreven neerslag van de eeuwige onveranderlijke menselijke rede, de ratio scripta (Kop 1980). H.C. Cras en J.M. Kemper die toen aan het het Athenaeum van Amsterdam doceerden ${ }^{24}$, verbonden het Romeinse recht expliciet met het natuurrecht $t^{25}$.

In Leiden was het jus publicum Romano-Germanicum in 1682 als leervak 'ingevoerd', voornamelijk ten behoeve van Duitse studenten; Utrecht volgde in 1.708 (Roelevink 1986: 257). Sedert het begin van de 18 de eeuw werden aan de universiteiten wel regelmatig voorlezingen gehouden over het jus hodiernum; maar deze bepaalden zich meestal tot een aanwijzing van de punten, waarin dat van het Romeinse recht afweek (Pijnacker Hordijk 1881: 6; Veen, Kop m.m.v. Kwanten (red.) 1987: 14). De bestudering van het oud-vaderlands recht, het jus patrium, nam, vergeleken bij het Romeinse recht en het natuurrecht, een bescheiden plaats in aan de vaderlandse hogescholen. Dat kreeg pas echt vorm rond het midden van de achttiende eeuw, daarbij enerzijds aansluitend op de algemene belangstelling die er op dat moment voor de vaderlandse oudheden bestond (Roelevink 1986: 258), anderzijds gesteund door de opkomende natuurrechtelijke richting, die de dominantie van het Romeins recht

24 Als uitgangspunt voor zijn colleges gebruikte Cras C. van Ecks. Principia Iuris Civilis uit 1689 (Ankum 1977: 95), een voor studenten geschreven dogmatisch boek, waarin meestal aan het begin wan de behandeling van een Digestentitel een definitie wordt gegeven van de rechtsfiguur die in de titel aan de orde komt, waarna in het vervolg de elementen der definitie verder worden uitgewerkt. Van Ecks Principia was een veel gebruikt leerboek in de achttiende eeuw. D. G. van der Keessel legde Van Ecks Principia onder meer ten grondslag aan zijn colleges in het strafrecht terwijl in $1803 \mathrm{H}$.W. Tydeman in Franeker nog met colleges begon over Van Ecks Principia (Van den Bergh 1986: 47).

25 In 1790 had Cras zich in zijn oratie, na eerst zijn bewondering woor het natuurrecht te hebben uitgesproken, fel gekeerd tegen degenen die meenden, dat het Romeinse recht 'zuiver' en op zichzelf bestudeerd zou moeten worden. "Wie zou er zich niet over verbazen en er bezwaar tegen hebben, dat er nu zelfs geleerden zijn, die - daarmee een mening verdedigend, die de eetwen die aan de tijd en de rom van Hugo de Groot voorafgegaan nauwelijks waardig is - alleen het Romeinse recht prijzen, bewonderen en ophemelen, maar het aan alle mensen en volkeren gemeenschappelijke recht (het natuurrecht) niet alleen verwaarlozen maar zelfs geringschatten; en die menen zoveel lof als ment aan deze (natuurrechts)weterschap toe zwaait ten onrechte aan het Romeinse recht wordt ontnomen; en die er zich ten slotte niet voor schamen om dikwijls binnenkamers, soms zelfs openlijk te verkondigen, dat het Romeinse recht in zijn zuivere vorm behandeld moet worden, ja zelfs, dat hoe minder men van het Natuurrecht weet, als des te verstandiger beoefenaar van het Romeinse recht men moet worden beschouwd" (Crats "Oratio dedicto Ciceronis 'non opinione sed natura ius constitutum esse' $: 8$, in en vertaald door Ankum 1977: 95.). 
aan de hogescholen betwistte (Zwalve 1989: 93) ${ }^{26}$. Het argument daarvoor werd geleverd door de constatering dat het inheemse recht meer dan het Romeinse overeenkwam met het natuurrecht en het inheemse daarom de voorkeur verdiende boven het Romeinse recht (Fischer 1946: 7). Maar ook bij de bestudering van het oud-vaderlandse recht ging het om kennis van beginselen, van de principia van dat recht, en de creatie van een logisch coherent systeem (Jansen 1987a: 137, 155, 284) ${ }^{2}$. Het lokale recht, dat toch de primaire rechtsbron vormde voor de rechtspraktijk, verscheen wel in vele tekstuitgaven maar werd nauwelijks wetenschappelijke aandacht waardig geacht. Het lokale recht was "zoals één onzer achttiende eeuwse hoogleraren schreef, van een maxima angustia, "van een zeer grote bekrompenheid" (Lokin \& Zwalve 1986: 254).

De uitgangspositie aan de hogescholen aan het begin van de negentiende eeuw is daarmee geschetst: de rechtstheorie aan de universiteiten concentreert zich op de verklaring en uiteenzetting van een systeem van rechtsnormen, terwijl de man uit de praktijk gekenmerkt wordt door ervaring in het toepassen van, veelal lokaal geldende, rechtsregels ${ }^{28}$. Natuurlijk was de rechtsgeleerde zich bewust van mogelijke consequenties van zijn handelen voor de praktijk. Vrijmoedige tekstkritiek kon de tekstzekerheid en daarmee de rechtszekerheid bedreigen. Modestia (bescheidenheid) en necessitas emendandi (noodzaak tot tekstcorrectie) waren erkende grondbeginselen van alle tekstkritiek (Van den Bergh 1988b: 126; zie ook Jansen 1988: 138). De nadruk binnen de universiteiten op interne, formeel logische, juridische preciesheid ${ }^{20}$, op rationele systematiek en (in het begin van de achttiende eeuw) zelfs op berekenbaarheid van

26 Dergeligke denkbeelden werden in Nederland gepropageend door enige juristen van Duitse afkomst, onder andere door Marckart, sinds 1747 professor te Harderwijk, malar vooral door F.A. van der Marck en P. Bondam te Gromingen (Fischer 1946; Jansen 1987a).

27 Fischer (1946: 8) citeert in dit verband Marckart uil 1734 "Oude en nieuwe bronnen moeten worden geraadpleegd; ook de hedendaagsche wetten zijn dikwijls niet zoo nieuw als zij wel tijken, want het meeste erwar moet worden afgeleid en werklaard uit de wetten van vroeger eeuwen." "Eew echt jurist moest echter de geschiedenis behandielen met in zijn achterhoofd de regels wan 'het' natuurrecht of ween universele rechtsgeleerdheid, anders werd hij naar de mening van juristen als Weiss [1713-1792] en Van der Marck als praktijkjurist een rechtsverdrabuer" (Jansen 1990a: 124-125).

28 De Franeker hooglenaar E. Wigeri vormt de spreekwoordelijke uitzondering op de regel. "[O]p het gebied van het voor de rechtspraktijk zo belangrijke procesrecht is het onderwijs belabberd geweest. (...) Alleen da Franeker hoogleraar heeft in zijn lessen meer werk gemaakt van het procesrecht. Hij ween i.m zijn mectorale oratie wan 1772 erop dat theorie en praktijk onlosmakelijk met ellkaar verbonden zijn en dat de bestudering wan het praktijkrecht niet schadelijk is voor de theoretische vorming" (Jansen 1991 b: 560 ).

29 "Die Etablierung des Rechts als wissenschaftiche Universitälsdisziplin beinhaltete die Systematisie. rung des Rechtstoffes zu eimem Wissens - bzw. - Regelkanon, der unabhängig won praktischer Ueburig ader kunstfertiger Demonstration über Texte und Institutionen lehr- und lerrbar ust" (Caesar Wolf 1984: 203). 
kansen ${ }^{30}$ (Rehbinder z.j.: 9; Caesar Wolf 1984: 201-2), die M. Weber roemde als hoogtepunt van formele rationaliteit van recht, zorgde echter tevens voor een scheiding tussen theorie en praktijk $k^{31}$ (Lokin en Zwalve 1986: 346; Van Apeldoorn 1932: 131; Jansen 1991b: 564). Tegen deze achtergrond stond de jonge staat der Nederlanden in 1815 na afloop van de Franse bezetting voor de taak eigen, nationale wetboeken uit te vaardigen, en tegelijkertijd het onderwijs in de rechtsgeleerdheid aan de rijksuniversiteiten opnieuw gestalte te geven. De ingeslepen opvattingen over theorie en praktijk, en de verhouding daartussen, kwamen toen op een groot aantal fronten ter discussie te staan.

\section{Codificatie, continuïteit en verandering}

In 1796 werd de eenheid en ondeelbaarheid van de Bataafse Republiek door de verkiezing van een Nationale Vergadering bezegeld. $\mathrm{Na}$ een staatsgreep van democraten op 22 januari $1798 \mathrm{kwam}$ in het voorjaar van 1798 een grondwet tot stand waarin een codificatie van het recht wordt verlangd (De Wit 1978; Lokin \& Zwalve 1986; Huussen 1989). Toch zou het tot 1838 duren alvorens de eerste eigen nationale wetboeken zouden zijn ingevoerd. Tot die tijd gold tussen 1 mei 1809 en 6 januari 1811 het 'Wetboek Napoleon ingerigt voor het Koningrijk Holland' en vanaf die datum de Franse Code Civil. De wenselijkheid van een codificatie op zich was in Nederland, in tegenstelling tot Duitsland ${ }^{32}$, niet echt omstreden (Scholten 1938: 3; Lokin en Zwalve 1986: $274)^{33}$. De lange tijdsduur die het tot stand brengen van een codificatie vergde, is een indicatie voor de omvang van de intellectuele en politieke problemen die daarmee gepaard gingen (zie ook Heyman 1975: 428)

In de eerste plaats vormde codificatie een bedreiging voor de privaatrechts-

30 Berekenbaarheid van kansen is zelfs - gedurende een korte periode - in letterlijke zin op te vatten. Een wan de sporen in het ontstaan wan de statistiek loopt terug naar opvattingen van probabiliteit als mat van zelkerheid in een gerechtelijk bewijs. G.W. Leibniz (1646-1716) "was interested in theorems about jus purum, that is, he wanted to know what kinds of combinations, none complete in themselves; would justify a conclusion of unconditionall right" (Hacking 1975: 88; zie ook Herberger 1981: 312-315) 31 "Men had als het ware twee stelsels wan regtsgeleerdheld, het een, zoo als het in de leerscholen, het ander, gelijk het voor de balie gold (...) Over het algemeen heerschite er, tot op het lavat deri worige eeuw, eene strenge afscheiding tussen practijk en theorie" (De Bosch Kemper 1838a: 2d).

32 Toen kort na het totstandkomen van de codificaties in Pruisen, Frankrijk en Oasterrijk de vraag werd opgeworpen of men in de rest van 'Duitsland' niet ook tot codificatie moest overgaan, had Savigny' in zijn 'Vom Beruf unserer Zeit für' Gesetzgebung und Rechiswissenschaf' (1814) deze gedachte ten. felstie bestreden. Tydeman (1819:38) gaat hierop in.

33 De belangrijkste opponent van het idee van codificatie was W. Bilderdjk (1756-1831) Wan den Bergh art Jinsen 1989a: 349).

34 "In die veertig jaren gebeurden op juridisch gebied belangwekkender dingen dan in dle eeuw die erop volgde en in de twee eeuwen die eraan voorafgingen" (Smidt en Huussen Jr. 1968: xv). 
wetenschap op zich. Het gereedkomen van in de eigen landstaal geschreven, en zoals de Franse revolutie ${ }^{35}$ had beloofd, voor iedereen inzichtelijke wetboeken, droeg de dreiging in zich de rechtswetenschap overbodig te maken (Tydeman 1819: 120) ${ }^{36}$. Van het populariseren van wetskennis - iets dat noodzakelijk werd geacht omdat iedere burger in de toekomst zou worden verondersteld de wet te kennen - werd door menigeen een negatieve uitwerking op de wetenschap gevreesd (Tydeman 1819: 13).

Daarnaast stelde het ontwerpen van een codificatie op zichzelf grote problemen. Het waren met name de criteria van wetenschappelijkheid - volledigheid en logische geslotenheid, gekoppeld aan een oriëntatie op bronnen en rechtsprincipes - die problemen opriepen. De natuurrechtsgeleerde Cras behoorde tot de 'Commissie van Twaalf' die op grond van de staatsregeling van 1798 de opdracht had gekregen een Burgerlijk Wetboek te ontwerpen. Voor Cras, een onversneden aanhanger van het natuurrecht, was het vanzelfsprekend dat die wetboeken in zichzelf gesloten, systematisch en volledig moesten zijn (Kop $1987 \mathrm{e}$ ). Het wetboek vormde een samenstel "van zoodaanige voorstellen, in 't welken een ieders regt in allen gevallen kan beslist worden". Daar het volgens hem onmogelijk was in een wetboek in alle bijzondere gevallen te voorzien moest een wetboek "een zamenstel van zoodanige algemeene regtsstellingen [zijin], uit welker middelijke of onmiddelijke toepassing op voorkomende gevallen een ieder regt zij. Het zijn bijzonders de regters, welken, bij publieke gezag, met deze toepassing op bijzondere gevallen belast zijn; zoo dat hunne uitspraken kragt van wet hebben, eeven als of zoodanige uitspraak woordelijk in het wetboek bevat ware." Daarom was de opname in het wetboek van verdelingen en definities onvermijdelijk. De grondbeginselen van het recht moesten deel uitmaken van het wetboek, de onderlinge verhouding van de rechtsnormen was een natuurlijk gegeven; de jurist legde slechts het organisme daarvan bloot. "[R]egt en onregt is eeven weinig van der menschen wil afhanglijk dan waar of valsch". Immers, "[d]e wetgever is in zijn wetboek de

35 Eên wan de belangrijkste slachtoffers van de Franse revolutie was de rechtsgeleerde elite aan de universitteiten (Kunst 1969:24). Codificatie was eén van de wapens waarmee zij werd bestreden. De revolu thontiren ontkenden het bestaansrecht van het bednif der juristen; hun arbeid werd overbodig en zelfs schadelijk geacht. De juristen, 'les gens du palais', vormden de vijand, die zich plaatste tussen het volk en zijp in de wet neer te leggen recht. De juristen hadden, zo heette het, ter wille van geldbejag of zilchat naar aanzien en roem, een wietenschap gemaakt, die nergens toe diende, dan om het klare inzicht in de toch zoo eenwoudige zaken wan recht te verduisteren (5cholten 1938: 3,5). De gelijkheid onder de burgers vereiste woor eenieder toegankelijke en verstaanbare wetten. De nationale vergadering besloot in haar decreten wan 16, 24 Aug 1790, tol opheffing van de onde hoven en parlementen. Een wet van 22 september 1792 riep alle burgers zonder onderscheid tot het ambt van rechter (Den Tex 1839a: 9).

36. Men wagt weinig minder dan dat, na deszelfs afkondiging, geen regtsgedirigen meer zullem stamd grijpen mog regtsgeleerden nodig zijn, even als of er na een verbeterde zamenstel van geneesikunde gene ziektens ons meer zouden kwellen of alle artsen konden worden weggezonden" (Cras 1798 in Jaspers 1980: 201$)$ 
tolk en uitlegger van het natuurregt; hij verklaard, wat de natuur wil en voorschrijft, ook in bijzondere soorten van gevallen; en die verklaaring maakt een einde aan alle mooglijk verschil des wegen; hij verklaard dus de regtsweetenschap, zo als die in den staat moet gelden" (Cras 1798 in Kop 1987e ; BNC E 141, 142, 150 in: Huussen 1989: 649). De orde der voorwerpen was natuurlijk bepaald. Daarom ook was "een ontwerper van een regtswetboek hier niet minder aan de aard, de eigenschappen en het verband der regtsvoorwerpen gebonden, dan een physicus die de natuurwetten, de leges physicae, in een boek wil verzaamelen. $\mathrm{Hij}$ is dus genoodzaakt dat verband, die deling en onderdeling der regtsvoorwerpen te volgen. (...) Gelijk het verband en de orde der regtsvoorwerpen niet willekeurig is, zo zijn ook de uitspraaken over die voorwerpen niet willekeurig, maar hangen van de aart der zaaken af" (Cras 1798 in Jaspers 1980: 21). "Eén en ander brengt ook mee, dat het wetboek niet mag voorbijgaan aan wetenschappelijke controversen; het beslissen daarvan behoort evenzeer tot de taak van de wetgever. Want doet hij dit niet, dan is er immers weer (of nog) rechtsonzekerheid, die hij had kunnen voorkomen, en is hij dus in zijn voornaamste taak tekort geschoten" (Heyman 1975: 429). Om zo weinig mogelijk aan de interpretatie en uitleg van de rechter over te laten, zou in het wetboek bovendien een uitvoerige handleiding voor de rechtsvinding worden opgenomen. Nadat dit codificatieontwerp onder andere op grond van haar theoretische en dogmatische karakter was afgekeurd, werd in $1807 \mathrm{~J}$. van der Linden ${ }^{37}$, waarschijnlijk door toedoen van Lodewijk Napoleon, opnieuw met die taak belast. Zijn ontwerp, dat eveneens niet ingevoerd zou worden, nu omdat Napoleon Nederland een eigen codificatie ontzegde, had in het geheel niet het systematische en gesloten karakter dat Cras van een codificatie eiste. In de inleiding op zijn ontwerp ging Van der Linden in op het verschil tussen het schrijven van een compendium van het Romeinse recht en het maken van een wetboek: "Uit dien hoofde meen ik, dat definiliën en divisiën over 't algemeen hier niet te pas komen ... Men moet de Regtsgeleerdheid hier niet beschouwen uit het oogpunt eener wetenschap, maar uit dat van verordeningen (...) Het opgeven van algemeene regelen, waarvan

37 P.C. Kop (1987a: 196-197) noemt Van der Linden een van de belangrijkste juristen in de periode van overgang van de ach thiende naar de negentiende eeuw. " $\mathrm{Hij}$ is het volstrekte tegendeel van de academische theoreticus. Hij was en bleef main van de praktijk en wilde dat ook weten. In het universilaire milieu keek men met enige achterdocht naar deze advocaat, die naast de bezigheden voor zijn dagelijkse praktijk kennelijk over de tijd beschikte om zeer veel en zeer inwloedrijke geschriften te schrijwen (...). Overbekend is de zo denigrerende uitlating van Cras: 'De man spreekt nogal op hogen toon, terwiil het mij woorkomt, dat hij niet veel wetenschap bezit, en, daarom zich tegen het wetenschappelijke verklaart' (...) Anderzijds liet ook Van der Linden zich niet onbetuigd. In zijn Regtsgeleerd practicanl en koopwnans handboek (1806) porveert hij achtelloos dat 'geschillen in 't stuk van den Koophandel niet sllechts met het oog van eenen stijven Regtsgeleerden, maar ook met dat van eenen Koopman, die zig met den mercasatielen stijl gemeenzaam gemaakt heeft, doorgezien behooren te worden'" " 
velen eigenlijk slechts op bijzondere onderwerpen slaan, acht ik zelfs in een wetboek gevaarlijk" (in Kop 1987a: 199). Van der Linden, de man uit de praktijk, sloot daarbij aan bij het Franse concept van codificatie, waar men zich bewust beperkte tot hoofdlijnen, de uitwerking overlatend aan wetenschap en rechtspraak (Heyman 1975: 429).

In 1814 wordt de taak een opvolger voor de in 1809 ingevoerde Code Civil te ontwerpen toegedacht aan J.M. Kemper. Ook Kemper heeft geen bezwaren tegen codificatie op zich. Onder verwijzing naar Montesquieu erkent hij wel het bestaan van een algemeen natuurrecht, dat aan alle redelijke wezens gemeen en altijd en overal hetzelfde is, maar hij onderscheidt daarnaast het bijzondere natuurrecht, waarbij de wetgever acht moet geven op tijd en plaats en doel der gemeenschap, waarvoor hij zijn wetten geeft. Want daar de staten onderling verschillend zijn, kunnen zij niet hetzelfde bijzondere natuurrecht hebben (Van Apeldoorn 1932: 140) ${ }^{38}$. Maar hoe de geslotenheid en volledigheid ${ }^{39}$ van de wetboeken te realiseren blijft daarmee ook voor Kemper een onoplosbaar probleem, getuige zijn Ontwerp van $1820^{40}$ en zijn briefwisseling met J.D. Meyer (Heyman 1975). Voor Kemper was de belangrijkste verandering die de Franse revolutie had gebracht de strikte scheiding der machten, en

38 "Het is waar, de gronden van regt zijn eeuwig, en voor zoo verre de vaststellingen der wett op dit regt gegrond zijn, moeten ook deze in zekeren zin oweral dezelfde zijn; doch de toepassing dier beginselen op het gezellig leven hangt van tijden en omstandigheden af, beschaving en startkundige intigting van een volk wijzigen dezelve" (Kemper 1809 in Cohen Jehoram 1968: 61-62).

39. "Een volledig wetboek moet in zich zelve volmaakt zijn, en de volmaaktheid sluit alle denkbeeld van aanvullend gezag reeds van zelf buiten. Het goede, dat men elders vindt, kan en moet wel gebruikt worden, maar het moet worden overgenomen, het moet met al het overige slechts een welgevormd geheel uit maken" (Kemper 1808 in Kop 1987c: 201-209). Op grond daarvan kan het Romeinse recht miet subsidiair aan de wretboeken blijven (Kemper 1835: 332-333).

40 "Dat een Wettook nimmer alle bijzondere gevallen, en derzelver duizendvoudige wijzigingen kan omvatten, is zoo duidelijk, als het menigwuldige malen, dikwijls zonder eenige kenuis van zaken, gezegd is, en het behoeft dus wel geen betoog, dat een Wetboek, zoo dan immer een Wetgever van dit punt kon willen uilgaan, ook bij de meestmogelijke uitgebreidheid, nog altijd onvolkomener zoude zijn dan een Wetboek, thetwellk de algemeene beginselen opgevende, daardoor tevens en in eens alle bijzondlere gevallen regelde, welke onder die beginselen kunnen worden opgenomen. De ontwerpers waren het dus met die van hel Frarische Wetboek volkomen eens, dat men bij elk onderwerp van de algemeene beginsels moest uitgaan, al ware het dan ook alleen, om de largwijligheid en uitgebreidheid te ontwijken, walke van het inslaan des tegenovergesteldan wegs wolstrekt onafocheidbaar is, en welker ondoelmatigheid bij de eerste herziening der Pruisische Wetgeving, niet dan mar al te duidelijk gelleken was" (Kemper 1820 in Cohen Jehoram 1968: 68; zie ook Jaspers 1980: 41-42). Maar Kemper ziet zich vervolgens genoodzalkt om te constateren dat, ook wanneer men kiest voor de Franse aampak, de problemen niet uit de wereld zijn" "[W]aar toch is bijna het geval, hetwelk niet op deszelfs beurt als eene algemeenheid van andere bijzondere gevallen kan gedlacht worden? Waar het beginsel, dat niet bij naauwkeurige ontleding, slechts het gevolg van een hooger beginsel is? En wire kan het ontkennen, dat in vele beginselen uit derzelver aard en algemeenheid zelve, iels zoo onbestemds en onzekers is, dat zij alleen daardoor tot naawwketrige en boven allen twijfel en misverstand verhevene regtsbepalingen ongeschikt zijn" (Kenper 1820 in Cohen Jehoram 1968; 68). Hoever de wetgever in bijzonderheden moet treden, zegt Kemper nergens. 
vooral de scheiding van wetgevende en rechtsprekende macht. De wet behoort een volledige en sluitende instruktie aan de rechter te geven, ook wat regels ter vaststelling van de betekenis van haar voorschriften betreft. "Om 'vergissingen' in de praktijk van de rechtstoepassing zoveel mogelijk te voorkomen, moest de wet de rechtsverhoudingen in hun soorten systematisch vastleggen en de rechter binden aan de wettelijke instructies $m . b . t$. het geldend recht en de toepassing ervan. Voor Meyer en zijn geestverwanten uit de praktijk, voornamelijk uit de wereld van de advokaten, voor wie het recht bron van inkomsten was, ging dit alles veel te ver. (...) Een strikte (burgerlijke) wetgeving zou de 'natuurlijke' ontwikkeling van de 'practijk' belemmeren. Het denkbeeld van een 'volledige wet', zodat 'eenieder met het wetboek in de hand een even bevoegd beoordelaar (zoude) zijn van de gevolgen van iederen aard' werd als praktische onmogelijkheid afgewezen" (Jaspers 1980: 47; zie ook Heyman $1975)^{\text {th }}$. Voor diegenen die in de praktijk werken, en zich wat hun handelen op 'ondervinding' beroepen is volledigheid en geslotenheid van het wetboek geen eis: "Maar bij aldien een wetboek zich geene andere volmaaktheid kan voorstellen, dan de volledigheid van algemeene regelen, waaronder alle voorkomende gevallen kunnen worden beslecht, 200 is het werk der dagelijksche praktijk, van den zoogenoemden usus fori, de toepassing dezer regelen op de meest frequente, en naderhand ook tot de zeldzamere gevallen te maken. (..) In de practijk doet dagelijksche ondervinding, hetgeen men te vergeefs in eene wetgeving zoude zoeken, en de afwisseling van de voorkomende gevallen, vestigt de toepassing der algemeene beginselen, die in het Wetboek kunnen vervat zijn" (Derde brief van D. aan E., Briefwisseling 1819: 165; zie ook Gratama 1809a: 191). In de praktijk telt vooral dat de wetgeving een grote continuiteit bezit (Frets 1829). "Het nut van een juridicieële praktijk voor de burgerlijke maatschappij is juist dáárin gelegen dat zij eene vastheid van gang hebbe, en dat derzelver oefenaars, door het gedurig begaan van de regtbanken, voor vele vormen en begrippen bij dezelve kunnen instaan" (Frets in Jaspers 1980: 62).

Naast de aanvankelijke dreiging die van het codificatiestreven uitging en de directe problemen bij het ontwerpen van de nationale wetboeken, stellen deze aanstaande wetboeken ook de toekomstige verhouding tussen wetgeving en wetenschap ter discussie. Naar aanleiding van een prijsvraagaz vangt Ty.

41 Jaspers omschrijt varder de arguntentatie van Meyers c.s. als volgt: "Een gedetailleerde regeling zow onvoldoende mogelijkheder openlaten om aan specifieke gelijkheidseisen en aan snel wisselende belangen van specifieke groepen tegemoet komen, ondat gewacht moest worden op de ingreep van di wetgever. De rechter zou sneller op basis van algemene regelingen de ontwikkeling kunnen volgen." 42 De vramg luidde: "Heet het vervaardigen van nieuwe wetboeken in de taal des lands eenen voor deighen of nadeeligen inwloed op de wetenschappelijke beoefening van het regt? Zoo deze inwoed voordeelig "is, welke zijn dan die voordeelen? maar zoo deze inwloed nadeelig is, welke zijn dan de beste middelen en de beste rigting van het onderwijs, on deze nadeelen weg te nemen of te verminderen? 
deman (1819:20) zijn karakterisering van wat de wetenschappelijke beoefening van het regt na het gereedkomen van een codificatie nog kan behelzen, aan met "dat men 1. elk stellig voorschrift in een wetboek of elke afzonderlijke wet, in verband beschouwe met het geheel, en dat men het wetenschappelijk stelsel of systema, zoo van den geheelen omvang der stellige wetgeving, als van elk der deelen waarin dezelve gesplitst is, trachte te overzien en steeds voor oogen houdt. 2. Dat men in elk bijzonder gedeelte der wetgeving, de vaste algemeene beginselen, welke hier ten grondslag liggen, trachtte op te sporen; en dezelve gevonden hebbende, de uitlegging der bijzonder beschikkingen van de wet en derzelver toepassing op bijzondere gevallen met dat regtsbeginsel trachte in verband te brengen, en daaruit af te leiden." Deze nadruk op interne consistentie, op coherentie van de samenstellende delen en op de algemeen geldende principes achter de wetten, maakt in de ogen van Tydeman een wetenschappelijke benadering van het financieel of fiscaal recht - die "telkens weer veranderde wetten" (23) vrijwel onmogelijk ${ }^{43}$. De eis van volledigheid en de fixatie op een logisch gesloten stelsel van rechtsnormen, die vanuit een bepaald ideaal van wetenschappelijkheid gesteld worden, vormen $e^{44}$ van de struikelblokken bij het ontwerpen van het Burgelijk Wetboek. Vergelijkbare overwegingen kleuren ook de discussie over de inrichting van het onderwijs in de eerste decennia van de negentiende eeuw. Natuurlijk komt daarbij eveneens de scheiding van theorie en praktijk naar voren.

Het eerste publieke debat over de inrichting van het hoger onderwijs in de negentiende eeuw, grijpt terug op de reeds in de achttiende eeuw fel bediscussieerde verhouding tussen het natuurrecht en het Romeinse recht. De opmerking in de 'Inleiding, bevattende de noodige onderrigtingen tot den aanleg, zoo van de studie der regtsgeleerdheid, als van eene uitgelezene regtsgeleerde boekerije' van J. van der Lindens 'Regtsgeleerd, Practicaal, en Koopmans Handboek', waarin deze verkondigt dat het Romeinse recht beter vór het natuurrecht gedoceerd kan worden (Jansen 1989: 136), maakt tal van reacties los. Eén daarvan komt van de hoogleraar natuurrecht S. Gratama (1809a: 192) die de voorrang en de uitvoerige bestudering van het natuurrecht - "als het $A, B, C$. (...) der geheele wetenschap (...) [dat] al het overige, in tijds-orde en afgescheiden moet voorafgaan" - bepleit ${ }^{45}$. Volgens hem moet het verval van

43 In de toekomst zouden "de nueuwe stellige wetten (...) misschien aanleiding kunnen geven, dal iemand ondernam, een wetenschappelijke behandeling op dezelve aan te wenden; en derzelver volledig" heid en orde, en gronden, en bijzondere betrekkingen the onderzoeken, en aan te wijzen of to toetsen" Tydeman 1819: 23).

44 Politieke aspecten zoals de onafhankelijkheidsverklaring van Belgie in 1830 blijven hier buiter beschouwing.

45 "Het Natuurregt geeft de algemeene beginselen op, en leert die op de deellen toe te passen het vormt de jeugdige verstanden voor regtskunde, en het regtskundig te redekavelen. Het geven 't naturur. 
de rechtenstudie in de Republiek vooral geweten worden aan het feit dat "men de jongelingen aan de Akademien tot de positive of stellige regts-studie toelaat, voor en aleer $\mathrm{zij}$ de gronden der natuurlijke regtsgeleerdheid behoorlijk beoefend hebben" (Gratama 1809b: 115). Volgens Gratama is grondige kennis van het natuurrecht voor de toekornstige rechtsgeleerde onontbeerlijk. "[W]ant grondige kennis wint het hier, gelijk overal, boven onkunde en dwaling; maar behalve dit, hier ligt de eenige en eeuwige grondslag van alle, hoe ook genaamde Regtsgeleerdheid." Gratama is overigens van mening dat door de invoering van het "Wetboek Napoleon ingerigt voor het Koningrijk. Holland", en de afschaffing van het Romeinse recht als subsidiair recht, de opleiding geheel herzien moet worden. De studie van het Romeinse recht acht Gratama weliswaar noodzakelijk voor een grondige kennis van de Hollandse rechtsgeleerdheid, maar het Romeinse recht moet 'rein' of 'zuiver' geleerd worden, dit wil zeggen, zonder wat er in latere tijd aan toegevoegd is (Gratama 1809c: 463; Jansen 1989: 140) ${ }^{46}$. Iemand als Kemper ziet daarentegen niet de minste noodzaak de centrale positie van het Romeinse recht in de opleiding aan te tasten: "Veel in het nieuwe wetboek zal op gronden van het Romeinsche regt rusten, omdat de meesten dier gronden eeuwig billijk en regtvaardig zijn, en al aan het nieuwe kan men oogenblikkelijk de rondheid en duidelijkheid van het oude regt bijzetten door eenvoudig kracht van gewijsde te laten aan alle die voorbeelden en gevallen in het Romeinsche regt welke op dezelfde gronden gebouwd zijn. (...) ook wanneer het Romeinsche regt van alle gezag wordt verstoken, ook dan nog blijft deze beoefening van belang; ook dan mag en moet dezelve als een onderwerp van openbaar onderwijs onderhouden worden (...) als bevattende de grondbeginselen, waarop tot nu toe al de nieuwere stelsels van wetgeving zijn opgehaald, en hetwelk men niet zal kunnen verwaarloozen, zoo men niet naar de oorzaken der meeste vaststellingen van het regt in het duister zal willen rondtasten. (...) Bovendien is het Romeinsche regt de eenige band, waarmede de regtsgeleerdheid onmiddellijk aan de oude letterkunde is verbonden. Neemt dezen band weg, vernietigt de noodzakelijkheid om dat regt te beoefenen, en gij zult tevens de behoefte hebben weggenomen om zich in de scholen der oude letterkunde voor de regtsgeleerdheid voor te bereiden. (...) [W] anneer eenmaal het nieuwe regt eenen wetenschappelijken vorm zal hebben aangenomen,

regt leert is algemeen en overal geldig, schoon het zijne wijziging zijne bepaling en uitbreiding, zijne bjjvoegselen van de burgerlijke wet ontvangen kan, die overal verschillende is, en zijn moet" (Gratama
$1809 \mathrm{a}: 189$ ).

46 "Het Romeinsche regt, van't overtollige ontdaan, dat is te zeggen, ontdan van alles, wat voor den tegenwooidigen tijd en vor de tegenwoordige behoefte overtollig is, of mag schijnen, levert ons, als voortbrengsel wan Regtswetenschap, nuets meer en niets minder dan een stelsel van watu wr-regt ew bififhhend wereenigd" (Gratama 1809c: 475). Zie ook De Wal (1820: 91). 
[moeten] de eerste algemeene beginselen van de burgerlijke regtsgeleerdheid ook op dat regt gebouwd zijn, terwijl dan het Romeinsche regt den grond zoude moeten opleveren niet tot voorlezingen over versleten geschillpunten of onbelangrijke kleine bijzonderheden, maar tot geschied- en oordeelkundige vergelijking der oude en nieuwe wetgeving, waardoor niet alleen de geest der wetten, maar ook de zuivere gronden van alle ware wetgeving zouden kunnen gebouwd worden" (Kemper 1808 in Kemper 1835: 334 e.v.).

De teneur van de discussie over de inrichting van het academisch onderwijs in de eerste decennia van de negentiende eeuw is daarmee aangegeven. Het gaat om de vraag welk stelsel van rechtsbeginselen of rechtsbronnen - het Romeinse recht dan wel het natuurrecht - de meeste aandacht in het academisch onderwijs verdient. "Dat zoo wel elke enkele wet, als ieder zamenstel van wetten, uit deszelfs bronnen moet worden opgehelderd en uitgelegd, wordt door allen erkend. Komt het er evenwel op aan, om te bepalen, wat men voor de bron eener wet te houden hebbe, dan is het oordeel der regtsgeleerden zeer verschillend" constateert G. de Wal (1820: 57), wanneer hij nogmaals de voorrang van het natuurrecht boven het Romeinse recht probeert te beargumenteren ${ }^{47}$. Argumenten zoals Kemper die ontwikkelt om de centrale positie van het Romeins recht te handhaven - de volkomenheid van het recht, de oriëntatie op rechtsbronnen en rechtsbeginselen, de band tussen rechtswetenschap en de klassieken - komen in de loop van de negentiende eeuw in verschillende toonaarden terug (Van Reenen 1810; Van Hall 1824; Heynsbergen 1925: 132; Ankum 1977).

Naast de discussie over het primaat van het natuurrecht of het Romeinse recht in de opleiding, blijft de traditionele dichotomie tussen theorie en praktijk de gedachtenvorming over het onderwijs bepalen. Wanneer men Van der Lindens geschrift 'De ware pleiter' (1827), waarin deze de kennis en vaardigheden bespreekt die een goed advocaat moet bezitten, confronteert met Van Reenens 'Algemeen Overzigt' (1836) komt met name deze dichotomie sterk naar voren. Wat de man van de praktijk kenmerkt is volgens Van der Linden "ondervinding" (6). De jonge advocaat moet in de eerste plaats "Regts-kennis" bezitten. Dat vereist een goed overzicht van het natuurrecht, waardoor hij het rechtvaardige van het onrechtvaardige en het billijke van het onbillijke leert onderscheiden. Vooral echter moet de advocaat het positieve of stellige recht kennen, en daartoe beginnen met de Romeinse rechtsgeleerdheid. Bij dat laatste gaat het vooral om "de algemeene beginzelen en regels van het Regt, de

47 In een bijlage bij zijn eigenlijke inzending gaat De Wal uiltgebreid in op de gevolgen van de afschaffing wan het Romeinse recht als subsidiair recht. Een stiellig recht kan nooit volledig zijn. De leidraad die de rechter moet volgen bij stilzwijgen of onvolledigheid van het stellige recht, is de rede die hem leert wat billijk, wrat eeuwig en onveranderlijk is" (jansen 1989: 144). 
verscheidenheid der handelingen in de menschelijke maatschappij, de verschillende actiën, uit die handelingen voortspruitende" (Van der Linden 1827: 29), kortom om de "prima juris principia" (de eerste beginselen van het recht). Niet meer, want Van der Linden acht een diepere en meer historische kennis van het Romeinsche recht wel nuttig en aangenaam voor de geleerde, maar niet voor de aankomende jongeling: "Maar dat aankomende jongelingen hunnen tijd meer aan die sieraden, dan aan de pit en de kern van het Regt besteed hebben, zie ik met weerzin. Ik vrage hun, of zij van al die wetenschap immer of ooit eene enkele syllabe voor de balie kunnen te pas brengen; en of (...) zij desniettemin in de kennis van het Systema juris Romani [het systeem van het Romeinse recht] zwak en bekrompen waren" (Van der Linden 1827: 30). Neen, men moet lezen en herlezen, en de tekst van de wetboeken zelf bestuderen. Men moet de commentaren raadplegen en de jurisprudentie onderzoeken. Men moet zich verdiepen in de uitlegkunde van het recht en de praktijk kennen. In vergelijking met geschriften van zijn tijdgenoten ligt in Van der Lindens betoog een opvallende nadruk op de noodzaak van intensievere bestudering van het 'moderne' recht (Kop 1987a: 199): "Het is al verder miet slechts de kennis van dat Regt, die den waren Pleiter vormt, maar hij behoort ook in de Praktijk ervaren te zijn. (...) Het Wetboek van Burgerlijke Regtspleging zij dus; zoo wel als het Burgerlijk Wetboek, een hoofdpunt van den waren Pleiters onderzoek en studie" (Van der Linden 1827: 32). Naast het Latijn - "den weg tot alle ware geleerdheid" (33) - vraagt Van der Linden ook aandacht voor het Frans ${ }^{48}$ en andere moderne talen die van nutte zijn bij geschillen over avarij$\mathrm{en}$, assurantiën en maritieme handelingen.

Van Reenens 'Algemeen Overzicht' (1836) ademt daarentegen de geest van de traditionele 'geleerde' beoefening van het recht. Immers de uitleg van de wetten in de wetboeken vereist van de jurist "dezelve met elkanderen in verband te beschouwen en te onderzoeken welke algemeene beginselen uit dat verband voortvloeijen en welke wijzigingen die wetsbeginselen ondergaan in de verschillende omstandigheden, in welke zij moeten worden toegepast. Zoodanige kennis nu kan niet bestaan, zonder wetenschappelijke behandeling van het onderwerp en wetenschappelijke leiding van den geest en van het verstand van hem, die zich het onderwerp goed meester will maken; dezelz[v]e kan niet medegedeeld worden dan door hem, die zelf de wetenschappelijke kunde in groote mate bezit" (Van Reenen 1836: 6). Van Reenen (1836: 6) legt vervolgens onder verwijzing naar Cicero en de klassieken uit wat die wetenschappelijke benadering inhoudt: "Ook zij beschouwden de wetenschap als

48 "[N]adat de Fransche wetgewing hiey te lande is ingevoerd, en onze Nederlandsche verwagt wordende wetgeving op dien leest zal (en ook waarlijk moel) geschoeid wezen, is [dat] van de volstrekste noodzakelijkheid" (Van der Linden 1827: 33). 
eene ordelijke en regelmatige zamenvoeging der onderwerpen tot een vak van kennis behoorende, volgens derzelver algemeene en bijzondere eigenschappen." Het model dat hem daarbij voor ogen staat is het ordeningsmodel dat ook in de natuurlijke historie wordt gehanteerd, dat van het "genus proximum et differentia specifica', dat van geslacht en soort: algemene eigenschappen karakteriseren het geslacht, bijzondere eigenschappen de soorten binnen het geslacht. De nauwkeurige beschrijving van zowel de algemene als de bijzondere eigenschappen leidt tot definities of bepalingen, die het fundament voor de verdere wetenschap leggen: "Zoodanige definitiën en divisiën maken met het regelmatig bewijs derzelve het wezen der wetenschap uit: dat regelmatig bewijs bestaat, of in eenvoudige waarheden, of in de gevolgtrekking, die afgeleid wordt uit de zamenvoeging van dergelijke eenvoudige en zekere stellingen" (Van Reenen 1836: 7). Wetenschap is het op de juiste wijze samenvoegen en verdelen ${ }^{49}$. De wiskunde dient de overige wetenschappen daarbij tot voorbeeld. Het invoeren van nieuwe, in de eigen landstaal geschreven wetboeken, mag niet tot een grotere praktijkgerichtheid van de universitaire studie leiden: "De akademische lessen moeten den jongeling tot eenen stand in de maatschappij opleiden, hem die kundigheden doen verkrijgen, zonder welke hij den door hem gekozen stand niet behoorlijk kan vervullen. Hij moet zich die wetenschap aldaar eigen maken, zonder welke hij zijn vak niet of niet goed zoude kunnen uitoefenen. Hij moet dus aldaar de theorie van de tot zijnen stand behoorende zaken meester worden. Maar moet hij ook verder gaan? Moet hij ook de praktijk daarbij voegen? Moet hij de Akademie verlatende, niet alleen de theorie van zijn vak grondig kennen, maar ook ervarenheid in de toepassing op voorkomende gevallen hebben?" (13). Dat Van Reenen deze retorisch gestelde vraag negatief beantwoordt, zal niet verbazen. Kernargument is daarbij dat theorie en praktijk twee wezenlijk verschillende zaken zijn. Karakteristiek voor praktijk is ervaring, "ondervinding". Theorie en praktijk vormen van oudsher gescheiden domeinenen en behoren dat ook te blijven. "Theorie en Praktijk zijn in alle vakken twee geheel verschillende zaken" (16). Van Reenen spreekt - op basis van een gelijkschakeling van praktijk met ervaring en ondervinding - zijn afkeur uit over modernistische stromingen die uit

49. Er blijt dus niets overig om in de moreele zaken tot eenige zekerheid te komen, dan juist die wetenschappelijke behandeling, welke tot de kennis en beoordeling van denkbeeldige zaken brengt, doon het uitvorschen der eenvoudigste beginselen en wan onbetwijfelbare waarheden - door het zamenvoegen van dezelve en het afleiden van niewwe stellingen wit zamengevoegde waarheden, tot dat uit alle deze algemeene en bijzondere, eenvoudige en zamengestelde waarheden en geheel ontstabt, dat ons den getheelen omvang der zaak duidelijk makkt; zoo doende komt men tot eene volledige kennis van zaken. op welke zonder die bewerking, niemand zoude hebben gedacht: men heeft eindelijk die wetenswap en wetensichappelijke kennis, welke men te vergeefs op eenige andere wijze zot de zoeken te verkrijgen" (Van Reenen 1836: 11). 
het buitenland komen en die ook in Nederland - vooral in de geneeskunde opgeld doen, en die er naar streven studenten reeds aan de Akademies in de praktijk te bekwamen: "De praktijk geeft de ondervinding aan dengenen die theoretische kennis heeft, deze ondervinding kan door geene lessen of overleveringen gegeven worden, zij ontstaat alleen uit de eigene handeling" (17): Zijn conclusie luidt "dat de praktijk niet op scholen of Akademiën verkregen kan worden. Men moet evenals onze voorouders verlangen, dat aldaar grondige, theoretische kennis worde verzameld, maar aldaar geene practici willen maken" $(18)^{50}$.

Natuurlijk verdedigt Van Reenen daarmee het traditionele standpunt. Er klinken geleidelijk - en zeker na 1838 - ook andere geluiden door die de eenheid van theorie en praktijk beklemtonen ${ }^{51}$ en de bovenmatige nadruk ${ }^{52}$ in het juridisch onderwijs op het Romeinse recht ter discussie stellen ${ }^{53}$. De oprichting van Themis en het Weekblad wan het Regt in 1839 gebeurt vanuit de wens de rechtspraktijk te verwetenschappelijken (Lokin 1989: 228). De Bosch Kemper (1838a: 72-73) stelt twee jaar na het zojuist aangehaalde geschrift van Van Reenen: "De practijk moet hare beginselen van de wetenschap ontleenen, maar het is de eerste, die aan de wetenschap zoo wel de stof ter bearbeiding, als het doel harer beoefening aanbiedt. Gelukkig zouden wij zijn, indien het gezegde van Seidensticker in ons Vaderland waarheid mogt behelzen: Practische und theoretische Interpretation stehen in genauen Verbindung mit einander. Die Theorie schöpft gern aus actenmässigen Erfahrungen, die Praxis erhebt sich gern zum höheren, freyeren Gesichtspunct der Theorie. Der Gerichtsgebrauch ist das Resultät von Beyden. Er stammt heraus den akademischen Lehrsälen und den Gerichtsstüben, aus den Bibliotheken und den Actenreposituren!"

Een boekbeoordeling ${ }^{54}$ uit 1828 van Nienhuis' "Handleiding bij akademische

50 Van Reenens (1836: 18) verwawhingen ten anzien van die polytechnische school zijn dan ook navenant: "Al wie door Polytechnische scholen, door collegièn of door welke instellingen ook, nneent jongelingen te kumen vormen in de praktijk, vergist zich en wil het onmogelijke."

51 "Gaarne stemmen wij met den sohrijwer in, waar hij bl. 151 de Praxis als het wezenlijk doel der Reghwetenschap voordraagt, en de theorie als middel beschouwt, (...) am dat doel te bereiken. Regtswetenschap toch is eene echt practische Wetenschap; het weten alleen doet nog niet veel af; zij moet op de zaken an voorvallen wan het gemeene leven worden toegepast" (Boekbeoordeeling van H.R. Stöckhardt, Allgemeine Juristische Fundamentallehre, zugleich als erste Lieferung eines Lehrbuches der Juristische

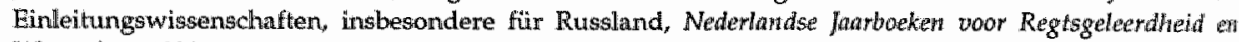
Weigewing, 1839: 140).

52 Op alle Nederlandse hogescholen zün in de jaren twintig leerstoelen voor het Romeinse recht aanwezig (Van Hall 1826: 278). In Leiden wordt twssen 1820 en 183022 un per week gedoceerd over het Romeinse recht tegen 5 : 6 ur over het geldende recht Meijers in Veen, Kop m.m.v. Kwanten (red.) 1.987: 21),

53 De eenzijdige concentratie op het Romeinse recht leidde tot klachten in de Kamer (Zie Staatscourant wan 21 December 1827 , wierde bijvoegsel, opgevoerd in een boekbeoordeling in Bijdrager tot Rechtsgetecritherd en Wetgeving, 1828: 365 ).

54 In Bijdragen tot dwe Regtsgeleerdineid en Wetgeving (1828:448). 
voorlezingen over het hedendaagsch Burgerlijk Regt" (1827) prijst de schrijver voor diens poging een eerste, in Nederduitsch geschreven, handleiding van het hedendaags burgerlijk recht te hebben verzorgd. Maar tevens krijgt het Romeinse recht een veeg uit de pan: "Met regt ook is de schrijver ten uiterste spaarzaam geweest in het aanhalen van Rom. wetsbepalingen. (...) Niets kan onzes insziens de ontwikkeling van het oordeel, het vormen van den regtsgeleerden geest (en daartoe moet toch in zonderheid het Akademisch onderwijs ingerigt zijn) meer nadeelig zijn, dan wanneer de Hoogleeraar de Romeinsche regtsleer, met de hedendaagsche vereenigd, aan zijne Toehoorders wil verklaren, of zijne lessen over het Nederlandsche regt zoo zeer op de Romeinsche leest schoeit, dat de hoorder ook dáár Romeinsche begrippen medebrengt." Van Reenen (1836: 3) waarschuwt daarentegen tegen "de verkeerde meening, die bij velen is ontstaan, dat de oude zoo genaamde geleerde talen en het Romeinsche Regt niet zoo noodzakelijk zijn voor hem, die zich op de studie des Regts toelegt, als vroeger." Hij prefereert de studie van het Romeinse recht boven die van het hedendaagse recht, omdat dat laatste niet die volledigheid en volmaaktheid kent die het Romeinse recht wel bezit (49). Van Reenens (1836: 92) argument om de studie van het Romeinse recht te verkiezen boven de studie van de eigentijdse wetboeken, heeft alles te maken met zijn benadering van het recht als een een logisch gesloten systeem van rechtsnormen: "[N]ieuwe wetboeken zijn niet geschikt om eene wetenschappelijke, eene goede algemeene Regtskennis te verkrijgen, omdat zij voor een bepaald volk geschikt zijn, en dagelijks niet alleen veranderen kunnen, maar ook inderdaad verandéren. (...) Alle volken daarom, die eenige verandering in hunne wetgeving te gemoet zien, doen best, zich in het leggen der gronden van de Regtswetenschap, uitsluitend van het Romeinsche Regt te bedienen. Is de wetenschappelijke leiding daardoor volmaakt; dan is het den jongeling onverschillig, welke wetten hem vervolgens ter nadere bewerking worden voorgelegd." Dat argument voor het centraal stellen van het Romeins recht in de juridische opleiding zou nog lange tijd hoorbaar blijven. De dogmatisch-systematische benadering van het Romeinse recht vindt rond het midden van de eeuw nog een internationaal erkend voorspreker in de persoon van J.E. Goudsmit (1813-1882) ${ }^{55}$. Uit diens inaugurale rede (1859) stamt het veel geciteerde adagium dat het Romeinse recht bestudeerd moet worden 'non quod Romanum sed quod jus': "[H] et Romeinse recht [heeft] zijn overheersende en doordringende invloed te danken aan zijn innerlijke voortreffelijkheid, en bepaaldelijk aan deze zijn eigenschap, dat het voor het grootste gedeelte niet berust op een bekrompen,

55 Zelfs de colleges vam M. Cohn (1848-1911 - vanaf 1882 Conrat geheten - die in 1878 als hoogleraar in het Romeinse recht werd aangesteld te Amsterdam, waren gebaseerd op Dernburgs Pandekten en volgens het ooggetuigeverslag van J.C. van Owen louter dognatisch van karakter (Van Oven 1955/56: 1-2.). 
eigenaardige, specifiek-romeinse volksgeest, maar veeleer de uiting is van een gezonde opvatting van algemeen menselijke betrekkingen" O.E. Goudsnit; Pandecten systeem 1866, in Van den Brink 1973: 34).

\section{Wet en rechter, logica en ontwikkeling}

De decennia rondom het tot stand komen van de codificatie worden beheerst door het zoeken naar een nieuw perspectief op de rechtsgeleerde wetenschap en studie. Weliswaar constateert C.A. den Tex (1839a: 15) dat de "waan van algemeen zoo verstaanbare wetten op te stellen, dat men geene Regtsgeleerde meer zou behoeven, (...) thans wel overal [is] opgeheven"', dat laat onverlet dat de functie van de rechtswetenschap na het invoeren van de nieuwe wetboeken nog allerminst duidelijk is. "Zeker is het intusschen dat zij [de wetboeken] eene omwenteling in het regt, als wetenschap, hebben te weeg gebragt, of liever, dat zij aanleiding geven moeten, om, op de puinhoopen van hetgeen zij onder de voet hebben gehaald, met de bouwstof, welke daarbij is bewaard gebleven, en op den grondslag, dien zij gelegd hebben, eene nieuwe wetenschap te grondvesten" (Van Hall 1851: v).

Het onderwijs in het 'hedendaags burgerlijk recht's, dat twee jaar na het invoeren van het burgerlijk wetboek met het K.B. van 30 juni 1840 , Staatscourant nr. 163) verplicht wordt voorgeschreven aan alle hogescholen, blijft in eerste instantie sterk gekleurd door de Romeinsrechtelijke traditie ${ }^{57}$. Alleen al omdat het onderwijs in het Romeins recht en het modern privaatrecht aan dezelfde persoon blift toevertrouwd ${ }^{\text {ss }}$ (Van Oven 1938: 320). Bovendien gaat het Burgerlijk Wetboek via het Ontwerp Nicolai terug op de Franse Code Civil (Lokin en Zwalve 1986: 283), die zelf al grotendeels op het Romeinse recht is gebaseerd, terwijl het Burgerlijk Wetboek daarenboven een aantal cruciale onderscheidingen, die niet in de Franse Code Civil voorkomen, van het Romeinse recht overneemt" . Asser (1839) schrijft over "de ware beginselen des Romeinschen regts" waartoe de staat der Nederlanden met het invoeren van het Burgerlijk

56 Bij besluit van 30 juni 1840 worden afzonderlijke colleges in het handelsrecht, de burgerlike rechlswordering en strafwordering werplicht gesteld (Groen 1985a: 26).

57 A. C. Holtius die als eerste onderwijs in het handelsrecht verzorgt te Utrecht, hanteert daarbij het uitgangspunt dat alle nieuwe recht onverklaarbaar is zonder de geschiederis van het Romeinse en. Germanane recht (Korthals Altes 1986: 59).

58 In Leiden worden de leerstoelen van het Romeins recht (Goudsmit) en Hedendaags Burgerlijk Recht (Van Boneval Faure) in 1859 gesplitst.

59 Zo gat eigendom over door traditie en niet zoals in Frankrijk door hell ontstaan wan een verbintlenis. die tot eigendomsovergang verplicht. "Deze afwijking noopt tot een geheel andere opbouw" van het wetboek, tot een scherpe scheiding tussen zakenrecht en verbintenissenrecht die in de Code uiterard niet wordt gemaakt" (Lokin en "Zwalve 1986: 284). 
Wetboek is teruggekeerd (Van Tienhoven 1869). Verder blift in het onderwijs de nadruk liggen op het werklaren van de wettelijke norm. Reeds in 1839 verschijnt een uitgave van het nieuwe wetboek, met verwijzingen naar de plaatsen uit het Corpus Iuris waaraan de artikelen meer of minder ontleend zijn.

Enerzijds valt in de decennia na het tot stand komen van de codificatie een blijvende aandacht voor het Romeinse recht en het verklaren van de wettelijke norm te constateren; anderzijds wordt na de politieke omwenteling van 1848 het ideaalbeeld van een rechtssysteem dat zekerheid, 'berekenbaarheid' en voorspelbaarheid waarborgt overgedragen op de wet, resulterend in het legisme (Poortinga 1987: 56-57). De wetenschappelijke oriêntatie wordt verlegd van de systematische samenhang van rechtsbeginselen en bronnen naar de logische samenhang van een systeem van wetten birnen het wetboek. De taak van de jurist is het uitleggen van de wet, opgevat als een in zich zelf gesloten $^{6}{ }^{\circ}$, coherent stelsel: "[A]ltijd moet de bepaling, wier zin men will kennen, met de andere voorschriften der wet in verband worden gebracht, en in den rijkdom harer betrekkingen worden ontvouwd" (Opzoomer 1848a: 221, in Jaspers 1980: 71). Codificatie betekent immers niet dat de staat willekeurig recht kan produceren. In de ogen van Thorbecke bijvoorbeeld, dient de staat de rechtsbeginselen op te sporen die zich in de geschiedenis openbaren, en hieraan in de wetgeving uitdrukking geven (Poortinga 1987: 64; 79). Wetten zijn niet zozeer uitdrukking van de (subjectieve) wil van de wetgever, als wel de historisch geronnen neerslag van algemeen geldige rechtsbeginselen. De rechtswetenschap moet zich blijven concentreren op het opsporen van die beginselen. Ook voor Opzoomer is de wet de emanatie van de volkswil, en haar centrale orgaan is de wetgever. In het legisme, waarvan Opzoomer een belangrijke vertegenwoordiger is, worden vervolgens recht en wet zelfs als vrijwel identiek beschouwd: "Waar een eigen wetgevende macht tot stand is gekomen, (...) daar is het redelijk dat geen ander positief recht gelde, dan hetgeen door haar in woorden, (...) dat is in wetten is uitgesproken" (Opzoomer 1848a: in Jaspers 1980: 74-75). Enkel de wetgevende macht heeft de bevoegdheid nieuw recht te proclameren ${ }^{61}$. Vanuit dat perspectief moet de invloed van de rechter geminimaliseerd worden, anders zou immers de zekerheid die

60) Men moet daarbij niet hangen aan de letter van de wet, maar naar haar bedoeling zoeken. Daarbij kan en mag men echter niet zover gaan, dat "het oogrmerk, dat de wetgever' zocht te bereiken, het in de toekomst liggende doel waarnaar hij streefcle en waartoe de wetsbepaling het middel moext $z \mathrm{ufin}^{\prime \prime}$, beslissend is voor de betekenis, want dan wil men de wet verklaren "uit hetgeen buiten haar ligt" (Op zoomer 1848a: 211 in Jaspers 1980: 71 ).

61 "De langstte rij van overeenstemmende arresten zelfs wan het hoogste rechitterlifke lichaam maakt geen positief recht. De meest besliste harmonie van alle juristen van exkend gezag doet het everimin. Eerst als hun overtuiging ook die der wetgevende macht is geworder, en door deze in woorden, in wetten, is uitgesproken, is het bestaande recht door haar hervormd, verbeterd" (Opzoomer in Kop 1987d: 221). 
in het stelsel van positieve wetten ligt besloten, ontkracht worden ${ }^{62}$. De rechterlijke macht mag in geen geval een "derde hoofdmacht in de staat" worden. Dat laatste houdt direct verband met het doctrinair-liberale gedachtengoed (Heyman 1976: 370; Jaspers 1980: 197; Van den Bergh 1980: 62; 1982: 44). De overwinning op het oude bestel moet zoveel mogelijk in wetten worden vastgelegd; daarbij wordt het stabiele, zekere karakter van die wetten beklemtoond (Van der Hoeven 1989: 86) . $^{63}$.

Het ideaal dat het recht een consistent en coherent geheel vormt, dat is opgetekend in de wet, danwel uit de Romeinse bronnen of uit de natuur met behulp van de rede geconstrueerd kan worden, en dat daarenboven de wetenschappelijke bemoeienis met het recht de verklaring en de uitleg van dat systeem tot doel heeft, staat van verschillende kanten onder druk. Voor De Bosch Kemper is het enerzijds nog vanzelfsprekend dat de geslotenheid van de wetboeken impliceert dat deel en geheel elkaar constitueren ${ }^{64}$. Anderzijds concludeert hij uit de onmogelijkheid om in een wetboek alles te bepalen, dat de "ruimte tusschen de stellige wetgeving en hare toepassing (...) door wetenschappelij]ke uitlegkunde [moet] worden aangevuld" (De Bosch Kemper 1838a: $15)^{65}$. Zijn ankerpunt in de traditie blijkt als hij de bestudering van het Romeinse recht als een uitnemende oefening daarin aanmerkt. Maar in de voorrede van zijn boek over strafvordering stelt De Bosch Kemper (1838b: v) het wetenschappelijke ideaal van volledigheid expliciet ter discussie: "Door velen zal de uitgave van dit boek voorbarig genoemd worden; zij is dit ook, wanneer men de wetenschappelijke volkomenheid als de hoogste verdienste van een regtsgeleerd werk stelt. Weinigen kunnen, en wij het minst, dadelijk bij de invoering van eener nieuwe wetgeving rijpe vruchten leveren. Maar wetenschappelijke volkomenheid is niet het doel; de regtswetenschap bestaat slechts, opdat er regt geschiede; een regtsgeleerd werk heeft dan deszelfs hoogste ver-

62 "Waar de wetgever zich ten doel stielt wastheid en eenheid van het regt door het geven varn welboeken te bevorderen, dam kan hij de gewoonte niet nevens deze laten bestaan en werken, zoo hij zijn doel niet door haar verijdeld will zien" (Diephuis 1844-1855 1: 97 in Jaspers 1980: 69).

63 Te meer daan Pieterman (1990a: 138) wijst op de bindingen wan de rechterlijke macht met de aristocratie.

64 "Elk regtsgeleerde gevoelt, hoe ligt door de verandering of verplaatsing van eenig artikel in eene wel, ook de zin en onvang van een ander niet veranderd of verplaatst artikel wordt gewijzigd" (De Bosch Kemper 1838a: 12 ).

65 De interne spannimgen in De Bosch Kempers geschriften komen ook nam voren in zijn negatieve waardering van het rut van jurisprudentie: "Men doet [door jurisprudentie] dat gedeelte der wetgeving. hetwelk zich woorthurend behoorde te ortwikkelen en met de wetenschap gelijken tred houden, stationair worden, en vergeet daarbij, dat de Jurispndentie, slechts het vitvloeisel der wet zijnde, de beoefening der wet miet moest wegnemen. (...) Door hare uitgebreidheid is zij onvatbaar, om volledig gekend te worden; wie zou toch al die duizenden uitspraken in zijn geheugen kunnen prenten, die in de Repertoires en verzamelingen ons reeds zijn, of door de Gnzetse des Tribumaux en Le Droit nog dagelijks worden aangeboden" (De Bosch Kemper 1838a: 66-68). 
diensten, wanneer door hetzelve de goede en ware toepassing der wet wordt bevorderd, en wanneer er zelfstandige regtsstudie door wordt aangekweekt. Hiertoe behoeft men niet zoo zeer volledige en bijna boven kritiek verhevene werken, welke een tien- of twintigtal jaren na de invoering der wetgeving uitkomen, dan wel zoodanige, welke op een oogenblik dat er in de praktijk de meeste behoefte naar wetenschap gevoeld wordt."

In de Romeinsrechtelijke traditie zelf wordt onder invloed van de historische school de nadruk steeds meer verlegd van de bronnen naar de interne ontwikkelingsgang van het Romeinse recht ${ }^{66}$. Nieuw daarin is vooral dat het onderwerp van rechtsgeleerde studie niet langer meer gevormd wordt door een abstract normenstelsel, maar dat het concrete functioneren van het recht in een maatschappelijke context centraal staat. "Savigny's Systementwurf bringt gegenüber der bisherigen Dogmatikgeschichte eine völlig neue Problemstellung. Sie entsteht dadurch, daß das dogmatische Satz-system nicht mehr nur auf das Normensystem, sondern auch auf davon verschiedene Realsysteme bezogen wird. Daraus erklärt sich dann, daß der 'mos mathematicus' Wolffscher Prägung ohne Modifikationen zur Lösung der neuen Aufgabe nicht mehr ausreicht" (Herberger 1981: 396). Aan de hand van De Bosch Kempers (1863b deel2: 849-851) geschriften is het mogelijk te laten zien, hoe geleidelijk die overgang van natuurrechtsdenken naar ontwikkelingsgeschiedenis zich kan voltrekken: "In de natuur der levensbetrekkingen ligt de eerste aanleiding tot de civiel regtelijke instituten. De magthebbenden handhaven op hun standpunt van ontwikkeling de regelen, die zij meenen dat in de onderscheidene levensbetrekkingen moeten worden nagekomen. Men vervalt echter in eene eenzijdigheid, wanneer men alleen uit de natuur der levensbetrekkingen de regtsinstellingen zoekt te verklaren; nog grooter eenzijdigheid is het, wanneer men de levensbetrekkingen eene absolute onveranderlijke natuur toekent en vergeet, dat de in de wet erkende bestemming des levens eene andere wordt, naar mate de wetgever zelf in ontwikkeling vooruit gaat. De regtsinstellingen ontlenen haar bestaan aan het regtsbegrip zelf; maar ook deze voorstelling ontaardt in eene eenzijdigheid, wanneer men het zóo voorstelt, alsof de regtsinstellingen als planten zich vermenigvuldigen, en dan naar hare genera en species kunnen onderscheiden worden. De empirische wijsbegeerte erkent teregt de regtsinstellingen als vruchten van den menschelijken vooruitgang, maar slechts een meer idealistische wijsbegeerte kan het regt doen volmaken. De ware regtswetenschap tracht de leidende gedachten des wetgevers op te sporen, het historisch en stellig regt te begrijpen en te ordenen, maar tevens uit de ideeën omtrent de bestemming der menschen de 
noodzakelijke uiterlijke voorwaarden voor het leven af te leiden en langs dien weg een volmaakter regt te construeren, opdat ieder in zijne levensbetrekkingen beschermd zou worden in zijne vrijheid om het goede uit eigene overtuiging te verwezenlijken; zij verbindt de kennis van de ontwikkeling van het regt met de ideeën die in de levensbetrekkingen moeten heerschen. Het regt is bij deze beschouwing een beschermingsinstelling voor het persoonlijk leven." E. Poortinga's intellectuele biografie van J.R. Thorbecke (1987:39-81; m.n. 59) laat eenzelfde vloeiende overgang van natuurrecht naar ontwikkelingsdenken zien ${ }^{67 .}$. Het eeuwig natuurrecht is een 'potentia' die in de tijd 'actû' moet worden. Doordat het natuurrecht zich in de tijd realiseert krijgt de historische rechtsontwikkeling een bepaalde zin. (...) We kunnen daarom stellen dat Thorbecke uitgaat van wat ik noem gehistoriseerd natuurrecht."

In plaats van de wet erkent de historische school een andere rechtsbron: de 'Volksgeist' tot uitdrukking komend in het gewoonterecht ${ }^{6 s}$ eigen aan iedere natie en bron van verdere ontwikkeling. "Tot regt begrip van het ware wezen van het tegenwoordige, het levendig verband tusschen hetzelve en het verledene te doen erkennen, dat was het doel dier school. Daartoe trachtte zij in onzen hedendaagschen regtstoestand de Romeinsche bestanddeelen op te sporen, ten einde, door afsnijding der afgestorvene deelen, voor de ontwikkeling der nog levenden te zorgen" (De Greve 1841: 565-576; zie ook Hufeland 1827: 24-25; Tichelaar 1897: 4). Door zich te oriënteren op de ontwikkelingsgeschiedenis van het Romeinse recht pogen Savigny c.s. een historische en een systematische benadering van recht met elkaar te verzoenen ${ }^{69}$ (Van den Bergh 1988b: 131). Volgens M. Herberger (1981: 352-353) wordt daarbij teruggegrepen op Kant, die "die Synonimität von 'dogmatisch' und 'systematisch" in Frage stellte: Man konnte nun auch 'nicht-dogmatisches', also 'historisches' Wissen in ein System bringen. Noch trägt eine historische Lehre dieser Art dem Verständnis Kants nach zwar auch gegenwärtige Zustande vor; sie ist also keineswegs auf die Vergangenheit beschränkt. Trotzdem war dadurch eine wichtige Weichenstellung

67 Uiteindelijk zal ook Thorbecke zijn oriëntatie weer verleggen van vastliggende bronnen en begin: selen naar open open toekomst. "Later is Thorbecke steeds meer de nadruk gaan leggen op het ellement toekomst" (Poortinga 1987: 53).

68 Maar de belangen van de rechtsgeleerden zijn veilig gesteld" "Er "Er vormt zich bij meerdere ontwikke. ling', aldus leert hij, "een bijzondere stand van rechtskundigen, die, zelf bestanddeel des, volks, in dezent $\mathrm{kring}$ wan gedachten de gemeenschap vertegenwoordigt. Het recht leidt dan een tweevoudig leven. in zijne grondtrekken leeft het voort in het gemeenschappelijk bewustziju, de nauwkeuriger ontwikkeling is de bijzondere taak van den stand der rechlisgeleerden" (Savigny in Drucker 1882a: 18).

$69 \mathrm{~F}_{\mathrm{n}}$ de Greve (1841: 565; 576) karakteriseert Von Savigny"s aanpak als "kritisch-systematisch". "Deszells hoofddoel is, en nieuw en scherp onderzoek wan het gansche stelsel des Romeinsche Regts, en de opzettelike bestrjiding en wederlegging van daarin verouderde dwalingen en ingewortelde vooroordeelen: eene kritische strekking derhalve. Maar de daarvoor gekozen vorn is de systematische: eene levendige en overtuigende voorstelling van den imnigen zamenhang der regtsdenkbeelden en regtsmegelen in derzelver ware verwantschap en éenheid." 
für das auf die Vergangenheit bezogene ('geschichtliche') Entwicklungsdenken vorgenommen: 'Historisches" Denken konnte auf die von Kant vorgezeichnete Weise systematisch interpretiert werden und mußte so nicht mehr den Verdikt verfallen, nur sammelnde Vorstufe für die Dogmatik zu sein."

Door de onveranderlijke rechtsbeginselen te benadrukken die aan het Romeinse recht ten grondslag liggen en bij verdere ontwikkeling van de maatschappij steeds een andere uitdrukkingsvorm vinden, staat de historische school in de traditie van het geleerde recht (Kop 1982: 8; Lokin 1989: 237) Aan de andere kant stelt de historische school wel het ontwikkelingsaspect van het recht en het functioneren van het recht in een concrete context expliciet aan de orde ${ }^{p_{1}}$. Bovendien wordt in de verdere ontwikkeling van de historische school de verhoudling tussen historiciteit en dogmatiek inzet van discussie (Herberger 1981: 405). Von Thering verwijt in zijn postuum verschenen 'Entwicklungsgeschichte des römischen Rechts' Savigny en zijn navolgers dat deze zich steeds hebben beperkt tot een beschrijving van het Romeinse recht, zoals dit in verschillende perioden was, zonder dat zij ook hun aandacht wijdden aan de oorzaken, die tot die voortdurende ontwikkeling hebben meegewerkt. Ook in de geschiedenis van het recht wil hij een antwoord op het 'waarom?" gegeven zien. "Dat men tot nu toe daaraan niet had gedacht, wijt hij aan verschillende oorzaken. In de eerste plaats hieraan, dat men de rechtsgeschiedenis steeds heeft beschouwd als hulpwetenschap voor de dogmatiek van het rechit; dat men vervolgens in verband hiermede bij haar dezelfde methode heeft toegepast als bij de dogmatiek, t.w. zich steeds heeft bepaald tot het weergeven der rechtsregelen zonder te letten op de maatschappelijke toestanden, waarin deze hunne toepassing vonden; de rechtsgeschiedenis gaf alleen eene successieve dogmatiek en Von Ihering verwachtte hierin geen verbetering, voordat zoowel in wetenschap als onderwijs de rechtsgeschiedenis eene zelfstandige plaats naast de dogmatiek had gekregen. Maar bovendien schrijft hij het volgen van gemelde methode toe aan den invloed der historische

70 De hustorische school beklemtoonde het 'zuivere' Justiniaanse recht en niet het Romeinse recht zoals dat in de Middeleeuwen was beofend er in Duitsland was doorgedrongen " Met een zin voor systematiek dile hij [Savigny] ongetwijfid aan het door hem zo zeer bestreden natururrecht ontleed had, mak kte hij wan het aldus opgevalte 'zulivere' Romeinse recht een soort gekunsteld samenstel van rechtsregels die miet met elkaar in tegenspraak mochten zujn: terwille van deze "hamonistiek' werden ook de historische achtergronden van het Justiniaanse recht bewust op het tweede plan gebracht" (Feenstra 1974: 124; rie ook Kop 1982: 13)

71 Een fraai voorbeeld van dat hybride karakter eigen aan de Historische School is Modderman (1867). Enerzijds bestaat de taak wan elke jurist "in de eerste plaats in het leren kennen en verstaan van het regt dat hem en de om hem heen levende matschappij beheerscht" (15). Van de andere kant houdt Modderman vast aan een systeem van beginselen dat in het Romeinse recht gelegen is: "Hoe beter het systeem, hoe dieper het inzigt in het wezen der verschillende instituten, des te eenvoudiger zal het geheel worden, des te geringer het getal der grondtypen"s (31). 
school; hij meent, dat wanneer men het recht eenvoudig beschouwt als de onmiddellijke uitdrukking van het nationale rechtsbewustzijn, dat zich onbewust ontwikkelt, men er niet toe komt te vragen, waarom dat recht nu zoo en niet anders is; het antwoord zou steeds hetzelfde $z_{i j n}, \mathrm{n} .1$. het volk heeft het nu eenmaal zoo beschouwd" (Tichelaar 1897: 14).

In de periode na het gereed komen van de nationale wetboeken ${ }^{72}$ wordt, wanneer de waarde van het Romeinse recht voor de rechtsgeleerde opleiding ter sprake komt, ook in Nederland de ontwikkeling van het functioneren van het Romeinse recht in een concrete historische context steeds meer beklemtoond. Intussen krijgt de volkomenheid en de interne consistentie en coherentie van een abstract systeem van rechtsnormen steeds minder aandacht (Feenstra 1984; Kop 1989: 131; 133). Van Tienhoven onderkent in diens inaugurele rede "De waarde van het Romeins recht voor de studie van het privaatrecht' (1869: 8) nog wel de volmaaktheid en interne geslotenheid ${ }^{73}$ van de beginselen van het Romeinse recht, die ook in de codificatie van 1838 terug te vinden zijn. "[D]e Themis Romana heeft haren ouden luister behouden (...) om de beginselen van eeuwige waarheid, die zij in zich draagt, om hare waarachtige innerlijke grootheid". Maar de nadruk komt op het ontwikkelingsaspect te liggen. "[E]venmin wordt de geest van het Romeinsche Recht begrepen, indien men zijne uitspraken voor die toestanden, welke door alle tijden heen dezelfde zullen blijven, voor het laatst gesproken woord van het recht houdt (...) dan streed dit met den geest van een recht, dat op elke bladzijde zijner geschiedenis naar ontwikkeling henen wijst" (Van Tienhoven 1869: 32). Voor het onderwijs betekent dat, dat het vormende moment in het Romeinse recht van een training in logica, naar de demonstratie van het ontwikkelingsproces wordt verlegd: Geen ander recht, dan het Romeinse "gunt ons, zijn ontwikkelingsproces uit eenvoudige beginselen in verschillende phases beter en naauwkeuriger na te gaan" (Van Tienhoven 1869: 30). Goudsmits opvolger te Leiden W.M. $\mathrm{d}^{\prime}$ Ablaing verkondigt in zijn oratie over 'Recht en Rechtswetenschap' (1882: 35) opvattingen die lijnrecht tegen die van Goudsmit en de Duitse Pandektisten ingaan: het Romeinse recht moet niet om zijn abstracte perfectie maar

72. In Hufeland $(1827)$, een vertaling van een oorspronkelijk Duitse rede uit 1814 , vallen dergelinke ideeèn ook al aar te treffen ( $\mathrm{m} n$. pp. 52-53).

73 Op basis hiervan sluit Wan Tienhoven (1869:28-29) een partièle behandeling van het Romeinse recht wit. "Welk nut, zoo zal de bloote practicus vragen, zall mij de kennis geven van het Romeinsche Recht in zijn vollen omvang ook in zijne voor onze tijd afgestorven gedeelten? Alsof niet het geheele veld bearbeid moet worden om de schatten te bemachtigen, in een gedeelte daarvan verborgen! - alsof gij zondter keninis van het geheel tot het juiste begrip der deelen kunt doordringen!' Tichelaar (1897:7) zou dat argument nog eens herhalen: "De verschillende deelen van het recht, ook van het Romeinsche, hangen te naw samen dan dat men bij de behandeling van enkele onderdeelen tot een juist begrip daarvan kan komen, zonder hetwelk het doel (...) 4.w. het Romeinsche recht zijn vormende kracht te doen uitoefenen op den aanstaanden jurist, zeker niet te bereiken is." 
om zijn geschiedenis bestudeerd worden (Feenstra 1984: 62).

Het opleven van de belangstelling voor het oud-vaderlands recht, dat onder invloed van de codificatie-perikelen aan belangstelling had ingeboet (Fischer 1946: 9; Tydeman 1819: 59), en de opkomst van het leervak rechtsvergelijking ${ }^{\text {th }}$ rondom het midden van de negentiende eeuw ${ }^{25}$, vallen eveneens in de context van de historische school en de historisch-filosofische school van Thibaut en Feuerbach te situeren ${ }^{76}$. Enerzijds is er - onder invloed van de codificatie een zich afzetten tegen een eenzijdige aandacht voor het Romeinse recht, vergezeld gaande van een grotere interesse voor een eigen nationale traditie (Smits 1869), maar anderzijds is er het vasthouden aan het openleggen van bronnen, beginselen van inheems recht en het streven naar een ontwikkelingsgeschiedenis in de geest van de historische school (Fockema Andreae 1877; Pijnacker Hordijk 1881; Fischer 1946). De bestudering van het oud-vaderlandse recht staat in het teken van het scheppen van nationale eenheid: "Er is wel veel, zeer veel voorhanden, gedeeltelijk bewerkt, gedeeltelijk onbewerkt, - dan er ontbreekt aan dat alles eénheid - zamenhang tot één groot geheel" (Voorduin 1846: 39). Daarmee werd aangesloten bij het streven naar een ontwikkelingsgeschiedenis van de Germaanse rechtsgeschiedenis" zoals dat in Duitsland op dat moment gestalte kreeg. Wanneer geschiedenis als ontwikkelingsgeschiedenis word topgevat, dan wordt daarmee de mogelijkheid geschapen die ontwikkelingsgeschiedenissen onderling te vergelijken. C.W. Star Numan omschrijft Van Fleusdes colleges in de artesfaculteit die voorbereidden tot de eigenlijke rechtsgeleerde studie aldus: "Men werd er dus van zelf toe gebragt, om het regt uit de geschiederis, de geschiedenis uit het regt te verklaren. En, daar de gemeenschappelijke voorstellingen, welke de menschen, die tot een organisch geheel zijn zamengevloeid, zich aangaande de regeling en inrigtingen hunner maatschappelijke betrekkingen maken, niet alleen in de verschillende leeftijden van ieder Volk

74. Waarwan Von Therings 'Vorgeschichte der Indo-europäer' algeneen als het intellectuele fundament kan wonden beschouwd (Hamaker 1888: 62; Tichelaar 1897: 8).

75 Ook eerder vallen er geluiden voor een opwaardering van het oud-vaderlands recht te horen. Zowel de Statiscommissie van 1828 als die van 1849 beval opname van het oud-vaderlands recht in het vakkenpakket van de rechtsgeleerde faculteit aan. Volgens Pijnacker Hordijk (1881: 7) zou eanzelfde oproep in 1828 van W. Curtus zijn uitgegaan.

76 In 1852 betoogde ). de Wal in een tweetal Leidlste oraties ("Oratio de historica juris institutione in patria nostra, jurisprudentiae romanae finibus handquaquam circumscribenda" " en "Oratio de detrimento, quod neglectum historicum juris nostri studium patriae disciplinaeque adtulit') dat de oludie van de rechtis geschiedenis zich niet mocht beperken tot de oude Romeinsche rechtshistorie. "De Wal gaf te Leiden, onwerplicht, gedurende eenige jaren colleges over het ontistaan van onze rechtsbronnen en over Nederlandsche rechtsantiquiteiten. Sloet en De Geer begonnen met de publicatie van bronnen en het schrijven van artikelen. En zoo kwam de studie van het oudvaderlandsche recht weer op gang" (Fischer $1946: 10$ ). 77 "Dieper onderzoek wan de inheemsche rechtsbronnen zoude wel hebben geleerd, dat deze, mits gezujverd van de Romeinsche inmengselen (...) bij alle verschil in bijzonderheden toch in sommige hoofdbeginselen oveneenstemden" (Pijnacker Hordijk 1881. 39). 
uiteenloopen, maar bij alle Volken, naar de meerdere of mindere ontwikkeling van hun volks-en staatsleven, aanmerkelijk verschillen, terwijl aan den anderen kant nationale verwantschap, dezelfde uiterlijke invloed, onderling verkeer, gelijksoortige verschijnselen opleveren: zoo is eene vergelijkende regtstudie een natuurlijk gevolg van zulk eene beschouwing. Eenheid ontstaat daarin, wanneer men de geschiedenis des regts met de geschiedenis der geheele Menschheid verbindt. Dit alles en het laatste vooral was het kenmerkende van de school van De Rhoer; in dezen geest (...) droeg later Arntzenius de geschiedenis van het Romeinsche regt voor: Door Van Heusde was men voor zulke eene behandeling voorbereid" (Star Numan 1839: 45-46).

In de periode tussen 1850 en 1875 wordt herhaaldelijk aangedrongen op instelling van professoraten in oud-vaderlands recht (Smits 1869; Coninck Liefsting 1869). De Hoger Onderwijswet van 1876 zou het oud-vaderlands recht en zijn geschiedenis als 'leerstoel' (niet als examenvak)) verplicht stellen voor alle juridische faculteiten. De aard en de oriëntatie van de belangstelling voor het oud-vaderlandse recht dragen echter de kiem van de mislukking met zich mee ${ }^{\prime \prime}$. Geleidelijk zou een geheel andere benaderingswijze van rechtsgeschiedenis ontstaan, die zich geheel afwendt van systeem-en stelselbouw: "Voor hen, die het recht beschouwen als eene de maatschappij beheerschende macht van metaphysischen oorsprong, die mitsdien het object der rechtswetenschap voor en boven alles zoeken in kennis en uitlegging van rechtsregelen, is de rechtsgeschiedenis ook alleen en uitsluitend een geschiedenis van rechtsregelen. (...) Een gansch andere is de rechtsgeschiedenis volgens de opvatting van hen, die het recht beschouwen als niets dan éene der zijden der maatschappelijke ordeningen, en voor wie dus de kennis der maatschappij het onafwijsbare prius van ernstige rechtskennis is. (...) In dezen gedachtenkring echter wordt de rechtsgeschiedenis tot eene gansch andere wetenschap, dan zij tot dusverre geweest is. $\mathrm{Zij}$ wordt tot eene geschiedenis der ontwikkeling van het recht in de maatschappelijke ordeningen, in de rechtsgemeenschappen (...) Zij zal zich tevens voortdurend afvragen of het alstoen gesproken recht in overeenstemming was met de matschappelijke eischen van dien tijd" (Hijmans 1902: 267-269) ${ }^{79}$.

78 "Toch is het hem [Pijnacker Hordijk] niet gelukt, er veel belangstelling voon te wekken. De studentenalmanak uit dien thij prijst de rechtsgeschiedenis als "eene schoone studie, die alleminst gemist kan worden" en de colleges erover als zeer "boeiend" mar voegt erbij, dat zij niet druk bezocht werden" (Van Apeldoom 1932 159). Toch was de bellangstelling in Amsterdam nog groter dan in Leiden (Gratama 1900 : 77 w. v). Na het vertrek wan Pijnacker Hordijk werd het onderwijs in het 'oud vaderlandsch recht en zujne geschiedienis" in Amsterdam overgedragen aan een lector, de Amsterdamse archivaris N. de Roever. Zijn. colleges konden in sommige jaren door het geheel ontbreken van toehoorders geen doorgang vinden. Na het overlijden van de Roever in 1893 werd zijn plats niet opgevuld (Van Apeldoorn 1932: 160 ).

79. "Men ging zich niet meer in de eerste plaats interesseeren voor de vraag, hoe het Germaansche recht was geweest, maar men wroeg, thoe het recht, Germaansch of niet Germaansch, zich werkelijk had ontwikkeld" (Fischer 1946: 16). 
Wordt binnen de beoefening van het Romeinse recht en het oud-vaderlands recht geleidelijk de aandacht van een coherent en consistent stelsel van rechtsregels naar het ontwikkelingsaspect van recht verlegd, binnen de kring van diegenen, die zich op het hedendaagse recht concentreren, doet zich iets vergelijkbaars voor. Daar dringt zich na het tot stand komen van de codificatie in de eerste plaats de vraag op wat de taak van de rechtswetenschapper nog is. Die vraag is verbonden met de kwestie waarop de rechter zich kan baseren alls de wet toch onverhoopt onduidelijk of onvolledig mocht blijken. Den Tex, die een aanhanger van het "oude" natuurrecht was (Kop 1982: 28-30; Jansen 1990b: 36 ; 1990c: 826-827), deelde in 1839, op grond van de gebleken onmogelijkheid om een wetboek op te stellen dat in alle mogelijke gevallen zou voorzien, de wetenschap een rol toe ter verklaring, aanvulling, en toepassing der wetboeken. "'Verklaring', want - zegt hij - 'het getal bepalingen dat een wetboek kan opnemen is steeds hoog doch gering in vergelijking met de duizenden gedaanten, in welke de handelingen der menschen in het burgerlijk leven voorkomen; en bijna nimmer zal men voor een gegeven geval een wettelijk voorschrift in het Wetboek aantreffen, hetwelk uitsluitend daarop toepasselijk is'. Aanvulling, want - 'de ervaring heeft overtuigend bewezen, dat volledigheid met geen mogelijkheid te bereiken is'. Toepassing, want - 'de wetgeving heeft de wetenschap noodig als een onontbeerlijke medehelpster, teneinde een système $\mathrm{d}^{\prime}$ application te vormen, dat in verband met de stellige Wetgeving door den tijd den geheelen omvang van het bestaande Recht uitmaakt ${ }^{\prime \prime \prime}$ (Scholten 1938: 22; Kop 1982: 27). Den Tex wil teruggrijpen op de situatie van voor de codificatie, namelijk dat in gevallen waarin het wetboek niet voorziet de rechtsgeleerde kan putten uit bestaande en zekere bronnen en met name uit beginselen die uit de natuur afleidbaar zijn: "Het is dus de wetenschap, die door de verklaring van hetgeen bestaat, door redeneringen ex analogia ${ }_{r}$ enz. behoort te voorzien dárin, waar de bepalingen van het Wetboek zich als onvolledig doen kennen. (...) De Regtswetenschap toch omvat van zelf al wat in de Wetboeken voorkomt, en buitendien nog zoo veel meer, wat daarin niet gevonden wordt. De wetenschap (...) onderzoekt al die zoo verschillende regtsbronnen, stelt ze zamen, rangschikt, brengt tot beginselen terug al wat het Regt en de Wetgeving betreft. (...) Den Regtsgeleerde past het de bepalingen der Wetboeken tot algemeene beginselen terug te brengen, en uit dezelve de bijzondere bepalingen, die de Wetboeken uitmaken, af te leiden en te verklaren; zóó eerst ontstaat er door zijnen arbeid een waarlijk wetenschappelijk geheel" (Den Tex 1839a: 25-31). Dat standpunt, dat erop neer komt dat de jurist kan vertrouwen op natuurrechtelijke beginselen naast de positieve wetgeving, is echter niet meer houdbaar.

Ook J. van Hall (1851: v en vi) is in het voorwoord van zijn 'Handleiding tot de beoefening van het Burgerlijk Regt' op zoek naar een nieuwe taak voor de 
Nederlandse rechtsgeleerde na het tot stand komen van de codificatie. Nog steeds heeft de rechtswetenschapper als eerste taak de samenhang en het systeem van de nieuwe wetboeken te expliceren ${ }^{50}$. Maar aan de andere kant ziet Van Hall (1851: iv) - sterk beïnloed door de historische school - grote nadelen aan het wetboeken-stelsel op zich: "Het regt in zijne ontwikkeling gade te slaan, te beschrijven, door de Wet te verzekeren, van gebreken te zuiveren, is overal en altijd eene taak, de onvermoeide zorgen van den Wetgever waardig; maar bij het Wetboeken-stelsel beoogt men iets anders. Daarbij wordt niet aan verbetering van het bestaande, maar aan het leggen van eenen nieuwen grondslag voor het burgerlij $\mathrm{k}$, of handels- , of strafregt, in zijnen geheelen omvang, gedacht, zoo als men bij eene nieuwe Grondwet eene algeheele hervorming in de grondslagen zelve van het openbare regt bedoelt. (...) Wat mij bij het Wetboeken-stelsel inzonderheid afkeuring waardig voorkomt, is niet het bestaan van geschreven Wetboeken op zich zelve,- ofschoon ik aan afzonderlijke Wetten over onderwerpen, die voor de beschrijving rijp zijn, de voorkeur geven zou,- maar het is de dwaling, waartoe het stelsel aanleiding geeft, als ware nu de taak des Wetgevers afgesponnen en het regt in de burgerlijke zamenleving voor altijd bepaald."

Van Hall opponeert tegen het legistische standpunt dat vertrekt vanuit het ideaal van een gesloten, coherent en consistent, stelsel van geschreven rechtsregels (zie m.n. Kop 1982: 32-33). Idealiter hoeft de rechter de wet alleen maar toe te passen: "De regter moet de wet als wet erkennen en toepassen, hoe hij ook denkt over de doelmatigheid en den zamenhang harer bepalingen, hare beantwoording aan de lessen der staathuishoudkunde enz. (...) Zoo is het voor hem als regter onverschillig, of eene wet uit vroegeren tijd nog voor den onzen past, en mag hij haar niet ter zijde stellen om, noch haar plooyen naar zijne voorstelling van de tegenwoordige toestanden en behoeften" (Diephuis $1885^{2}$ Dl. I: $87-118$ in Fockema Andreae 1938: 70). Wetsexegese is de voornaamste bezigheid van juristen. Zij dienen zich erin te bekwamen de wet zo uit te leggen dat geen geval aan de wet ontsnapt. De discussie concentreert zich dan op het punt welke methoden men bij de uitlegging van de wet mag hante$r^{2}{ }^{81}$. Doet de wil van de welgever terzake of alleen de wetstekst? ${ }^{82}$ Kan de

80 "Het eergte is, dat ik hel Burgerlijk Regt, niet eeniglijk het Burgerilik Wetboek, moet trachten te verklaren; het weede dat het regt, als wetenschap niet gekend kan worden, zonder naawwikeurige en doorgande toetsing aan het Romeinsche Regt, ook in zijne latere geschiedenis. De stelselmatige vorm van de Humllaing is aan het eerste, de doorlopende aanhaling van het Corpus iuris aan het laatste denkbeeld toe the schrijven" (Wan Hall 1851; vi/ wii).

\$1 "Interptetatie betekent hier niet een activiteit waarmee een nieuw element aan het bestaande recht wordt toegevoegd. Dat is ook het grote verschil met de moderne discussies over rechtsvirding: daar wordt bijwoorbeeld de rechterkijke activiteil (...) gezien als een scheppende activiteit" (Kop 1982: 32). 82 Wanneen men wetten opvat als de geschreven neerslag van algemeen geldige rechtsbeginselen dan is de wetgever vooral een niddel en boet de (subjectiewe) will van de wetgever sterk aan betekenis in. 
parlementaire geschiedenis bij de uitlegging der wet behulpzaam zijn? In de ogen van Opzoomer is de taak van de rechter beperkt en in wezen eenvoudig $^{83}$. De rechter wordt geacht de algemene regel op het bijzonder geval toe te passen en de uitspraak vloeide daar logisch en zonder meer uit voort. "Is de wet onvolledig, of zwijgt zij geheel, dan moet hij uitspraak doen volgens het systeem der geheele wet, en die beslissing aannemen, die met logische noodzakelijkheid uit dat stelsel voortvloeit: kan hij ook dezen weg niet betreden, dan moet hij zijn toevlucht nemen tot hetgeen door rede en billijkheid wordt aanbevolen" (Opzoomer 1884: 230). Volledige uitlegging bevat volgens Opzoomer, in navolging van Savigny, vier elementen: het grammaticale element (het verklaren van woorden naar de wetten van de taal); het logische element ("dat in de analyse der gedachte bestaat, in het aanwijzen van de betrekking tusschen hare deelen"); het systematische element (het doen uitkomen van de samenhang van de rechtsregels, van de eenheid van het rechtsstelsel) en het historische element, hetgeen "zum Gegenstand hat den zur Zeit des gegebenen Gesetzes für das vorliegende Rechtsverhältniss durch Rechtsregeln bestimmten Zustand", met andere woorden de reconstructie van het nieuwe wetselement uit reeds bestaande wetgeving (Opzoomer 1884: 215; Jaspers 1980: 72; Kop 1982: 38). "Waren [de wetten] (...) onbevredigend of zelfs ongerijmd, niet de uitlegger, niet de rechter had het zich aan te trekken, doch de wetgever, en deze alleen was in staat er orde op te stellen" (Fockema Andreae 1938: 70). In tegenstelling tot Opzoomer, voor wie de will van de wetgever niet of nauwelijks telt, staat die voor G. Diephuis in de uitlegging der wet voorop. Diephuis schetst de methode waarlangs de wil van de wetgever moet worden opgespoord als volgt: eerst de woorden der wet en hun onderlinge verband, vervolgens het verband en de samenhang met andere bepalingen, waarin "de wetgever zijnen wil heeft uitgedrukt omtrent een ander onderwerp, bij welks regeling men verwachten mag, dat hij door hetzelfde beginsel is gelleid" en ten slotte de "historie". Tot het laatstgenoende "middel" rekent hij in de eerste plaats "de geschiedenis der bepaling, de redactie waarin zij is voorgedragen tesamen met de toelichting, bedenkingen en beraadslaging" (Diephuis 18441855 I: 111 in Jaspers 1980: 72). Bij de analogische redenering moet de rechter zich niet laten leiden door "de aanleiding tot, noch [door] het doel, maar [door] de reden van de wetsbepaling (de ratio legis) het beginsel waarvan zij

Thorbecke wijst daarom de wetshistorische interprettatie af. De Bosch Kemper kan zich daarmee niet verenigen (Poortinga 1987: 72-74).

83 "Thorbecke komt niet op de gedachte dat jurisprudentie zen zelfstandige rechtsbron nasis de wet is. Wetsuritlegging is het winden van de gedachte die reeds in de wet bes'oten ligt; zij draagt zelf niet tot de reclhtsontwikkeling bij. Deze opvatting was niet beperkt tot de negentiende-euwse legisten, mar was in de vorige eeuw veel algemener, ook al namen sommigen exn ruim interpretatiekader aan" (Poortinga $1987: 78 \%$ 
eene uitdrukking en toepassing, de leidende gedachte, waarvan zij cen uitvloeisel is" (in Jaspers 1980: 72). Onvolledigheid moet worden opgelost door samenhang en verband met bekende regels. "Daartoe moet de aard en het doel der handeling naauwkeurig onderzocht; zoo zal men een regel vinden, die, getoetst aan, en waar het te pas komt, gewijzigd naar de in het bekende regt heerschende beginselen, als regt ten aanzien dier handelingen of regtsbetrekkingen mag worden aangenomen" (Diephuis $1885^{2}$ I: 87-118 in Fockema Andreae 1938: 69).

Natuurlijk erkende ook Opzoomer de noodzaak van bijstelling van de wet. Maar primair staat het logische systeem. Het aanbrengen van veranderingen in de wet zou aan een permanente commissie van wetgeving kunnen worden overgelaten, bestaande uit de beste rechtsgeleerden en de meest geoefende praktijkmensen van het land. De taak van de rechter bleek echter allerminst eenvoudig. Door uitspraken te doen nam hij een deel van de wetgevende functie over (Lokin 1989: 235). In de laatste decennia van de vorige eeuw vallen vele pleidooien voor, en natuurlijk sterke weerstand tegen, een vrijere rechtsvinding te beluisteren: "[S]lechts de beginselen in de wet neergelegd, de vrije toepassing aan den rechter overgelaten. De waan als kon men den rechter maken tot eene machine, bij welke aan de eene zijde het wetsartikel wordt ingeschoven en aan de andere zijde het vonnis te voorschijn komt, is gebleken een ijdele waan te zijn" (Drucker 1882a: 38). C. Asser (1892: 14) merkt op dat "bij de groote ontwikkeling der maatschappij en de onophoudelijk veranderde sociale toestanden, [het recht] telkens in veelerlei opzicht dreigt te kort te schieten." "Allerwege begint men te onderzoeken of de beginselen der wet berusten op een wezenlijke en op goede gronden steunende overtuiging omtrent de behoeften der maatschappij, dan wel of zij hunnen oorsprong ontleenen aan traditien, die slechts in het leven worden gehouden door zekeren behoudenden geest, die nog verreweg de meeste regtsgeleerden bezielt. $Z$ ij die op dit gebied het verst gaan spreken van dogma's, die ons van alle zijden beklemmen en benauwen en eene vrije ontwikkeling in de weg staan" (Asser 1892: 11). Assers conclusie luidt dat aan de mannen van de rechtspraktijk meer invloed op de gang van de wetgeving moet worden gegeven. Onder andere Hamaker, Moltzer, Molengraaff, Levy, Treub en Houwing, getuige zijn in 1895 gehouden inaugurale rede 'wet en rechter', stemmen daarmee in. Die pleidooien voor een vrijere rechtsvinding worden verbonden met een veranderde rechtsopvatting (Kop 1982: 55-56). Recht is niet meer primair een afgeleide van een logisch consistent systeem van rechtsbeginselen, maar wordt opgevat als een concreet onderdeel van het maatschappelijk proces. Wetgever, wetenschap en rechter hebben in dat maatschappelijke proces een taak die zich niet logisch dwingend uit een stelsel van normen laat deduceren. Ook de wetenschap kan dat niet. In zijn oratie uit 1882 verwoordt H.L. Drucker (1882a: 6) die kentering 
aldus: "[A] an het recht, dat, onafhankelijk van tijd en plaats, den wetgever als ideaal voor oogen zou moeten zweven gelooft niemand meer. Alle recht is positief, leert men in Duitsland alom, en als reactie tegen het natuurrecht is die stelling volkomen juist." P.A. Tichelaar (1897: 8) is anderhalf decennium later nog explicieter: "De betrekkelijke waarde van elken rechtsregel komt het best aan den dag, wanneer men aantoont, hoe het recht zich voortdurend geleidelijk heeft ontwikkeld in verband met de maatschappelijke krachten."

\section{Recht als onderdeel van een maatschappelijk proces}

De belangrijkste voorsprekers om het recht niet als een afgeleide van een stelsel van abstracte normen en principes, maar als een tot op grote hoogte contingent onderdeel van het maatschappelijk proces te beschouwen stammen uit progressief liberale hoek. Vooral W. Molengraaff, H.L. Drucker en S. Katz proberen met het door hun in 1882 opgerichte Rechtsgeleerd Magazijn het denkbeeld ingang te doen vinden, dat de maatschappij leert in welke richting het recht zich moet ontwikkelen. In zijn inaugurale rede citeert J.P. Moltzer met instemming uit Von Iherings 'Geist des Römischen Rechts', III (Leipzig 1877'): 311-312): "Brechen wir den Bann, mit dem der Irrwahn uns gefangen hält. Jener ganze Cultus des Logischen, der die Jurisprudenz zu einer Mathematik des Rechts hinaufzuschrauben gedenkt, ist eine Verirrung und beruht auf einer Verkennung des Wesens des Rechts. Das Leben ist nicht der Begriffe, sondern die Begriffe des Lebens wegen $\mathrm{da}^{\prime \prime \prime}$. De strekking van W. Molengraaffs inaugurele rede van enkele jaren later is gelijkluidend: "Onder recht versta ik de voor het bestaan en de ontwikkeling der samenleving noodzakelijk geachte regeling der menschelijke verhoudingen, m.a.w. de gedragslijn, die in het dringend belang der samenleving door de mensen in hun onderling verkeer wordt gevolgd. Recht toch is een postulaat, een product der samenleving. (...) Niet alsof aan het ontstaan van elken rechtsregel een bepaald denkproces vooraf zoude moeten gaan en steeds gegaan zijn, alsof er geen rechtsregel in de wereld zou zijn gekomen, die niet vooraf behoorlijk gewikt en gewogen ware. De drang der omstandigheden, de macht der feiten, de ervaring in éen woord zal in het begin der samenleving hare leden veeleer geheel onbewust geschreven hebben, hunne handelingen jegens elkander zóó in te richten (...), met dat gene, wat zij, mis-

84 Niet uilt den regel ontwikkelt zich het recht, maar naar het recht, zooals het bestaat, vormt zich de regel' Er is wellicht uit den geheelen laatsten titel der Digesta geen regel te putten, waarvan wij ons in den tegenwoordigen tijd meer bewrust behooren te zijn en die op meer kernachtige wijze de richting aangeeft, welke, bij de beofening van ons hedendaagsch privaatrecht, op den voorgrond behoort te treden" (Moltzer 1881: 1). Zie over de 'Begriffsjurisprudenz' Loth (1990). 
schien niet dan na hevigen en scherpen strijd, ondervonden, dat in het belang was dier voor allen nuttige gemeenschap. Het recht wordt dus bepaald door de heerschende opvatting van wat noodzakelijk is in "t belang der maatschappij, het is de afspiegeling, het resultaat dier opvatting. (...) Bij deze beschouwing mist het recht elk absoluut, elk bovennatuurlijk karakter. Van onveranderlijke, eeuwig ware grondslagen van recht, die onafhankelijk van tijd en plaats overal gelden, kan geen sprake wezen. Het recht als ervaringsproduct heeft uit zijn aard een zuiver relatief karakter. Als menschelijke opvatting van menschelijke verhoudingen wisselt het met die verhoudingen. Het is afhankelijk van tijd en plaats, afhankelijk van de ontwikkeling en ervaring van het volk, waarvoor het

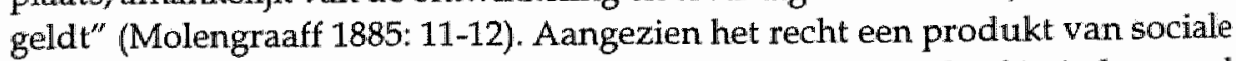
overeenstemming is - het moet door allen worden gevolgd, of in ieder geval kunnen worden afgedwongen - is de gemeenschappelijke overtuiging, het volksrecht, rechtsbron. Echter in tegenstelling tot de rechtsopvatting van de historische school, waarin de wet en de gewoonte ook tot uitdrukking komen in de volksovertuiging, is er nu geen sprake meer van een harmonieus organisch verband: "[N]aarmate bij een bepaald volk, bij een bepaalden stam of eene bepaalde familie de voortschrijdende en uiteenlopende ontwikkeling der individuen gecompliceerder verhoudingen tusschen hare leden onderling in 't leven roept en tegenstrijdige belangen doet ontstaan, het onderling verkeer toeneemt en verdeeling van arbeid plaats vindt, zal eene gemeenschappelijke overtuiging zich steeds zeldzamer voordoen, hetzij omdat niet langer aller rechtsopvatting dezelfde zal blijken, maar ook daarin de strijd der belangen zich zal gaan afspiegelen, hetzij omdat tal van wenschelijke, ja zelfs noodige regels de belangen van slechts enkele groepen onmiddellijk zullen raken" (Molengraaff 1885: 14). Molengraaff verbindt rechtsontwikkeling rechtstreeks met maatschappelijke ontwikkeling. "Het is niet voldoende, dat de wet de sociale ontwikkeling en hervorming op den voet volgt; zij moet er gelijken tred mede houden" (Molengraaff 1885: 19). Zoniet, dan zal het veranderend volksbewustzijn de kracht van de wetboeken ondergraven ${ }^{85}$.

In 1884 maakt H.J. Hamaker de veranderingen binnen de rechtswetenschap onderwerp van zijn inaugurele rede. Hij bepleit een 'historisch-positieve' rechtsopvatting in de plaats te stellen van de tot dusverre geldende 'philosophische'. In de filosofische opvatting is recht "het vast en eeuwig en onveranderlijk beginsel tegenover het tijdelijke, voorbijgaande en veranderlijke, dat der wereld onzer ervaring eigen is" (Hamaker 1884:5). De wetenschap zou zich niet langer, zoals

85 Hanaker (1888: 33) signaleent een zelfde soort probleem: "Hoe licht zal het voorts niet gebeuren. dat de wetgever wetten maakt over onderwerpen, waaromtrent zich eene volksovertuiging nog niet gevormd heeft, of dat hij verouderde, met het recht niet langer overeenstemmende, wetten te lang in stand houdt." 
in de filosofische rechtsopvatting, tot taak moeten stellen de inhoud van het hoogste rechtsgebod of van de rechtsidee te vinden en daaruit de noodzakelijke gevolgen af te leiden. In de historisch positieve opvatting heeft het begrip slechts waarde "voor zooverre het de empirische werkelijkheid, zooals ze nu eenmaal is, met juistheid weergeeft" (Hamaker 1884: 7) ${ }^{86}$. De consequentie is echter dat het recht zijn absoluut karakter verliest en afhankelijk wordt van de contingentie van het maatschappelijk proces ${ }^{87}$. Dat betekent echter niet dat het recht geheel op willekeur berust. Niet de mens maar het leven bepaalt wat recht is. "Dat het recht empirisch opgevat zijne aanspraken op onzen eerbied verliezen zou, daarvoor bestaat alzoo geen vrees. Toch moet het iets prijsgeven, zijne aanspraken namelijk op absolute waarheid en absoluut gezag, aanspraken trouwens die het nooit heeft weten te handhaven" (Hamaker 1884: 17). Recht is niet meer de speurtocht naar vaste beginselen, die in een bepaalde maatschappelijke context een specifieke vorm aannemen, maar wordt verbonden met het direct waarneembare maatschappelijke proces van regelgeving en regelhandhaving. De acceptatie van het contingente karakter daarvan maakt nauwkeurige, empirische bestudering van de maatschappelijke verhoudingen van belang. De geleerde juristen overschatten de logische kant van het recht, aldus W. Modderman in zijn rectorale rede van 1875. "Van jongs af aan worden ons zekere begrippen ingeprent als absolute waarheden, die dit volstrekt niet zijn (...), wij verplaatsen ons van lieverlede in een wereld van abstracte begrippen, totdat wij ons eindelijk zoodanig aan handen en voeten gebonden voelen door de logische noodzakelijkheid van dit begrip, of de logische onmogelijkheid van dat begrip, dat het ons moeilijk, ja onmogelijk wordt ons te bevrijden uit de boeien, waarin wij ons zelven, door onze scholastieke methode geslagen hebben". (Modderman 1875; zie ook Jansen 1990b: 48-49).

In zijn meest extreme uitwerking leidt de empirische wending tot een opvatting van rechtswetenschap als - een naïef - empirische maatschappijwetenschap. De jurist kan recht vinden door de in de maatschappij vigerende normen waar te nemen. "[N]iet (...) de maatschappij en de handelingen der

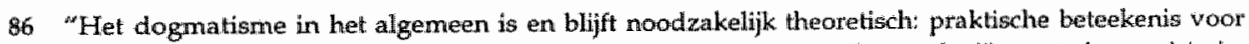
"s menschen leven hier op aarde kan het niet hebben. (..) Komen zijn conclusièn met de empirische verschijnselen overeen, dan leeren zij hem niets, dat hij riet eenvoudiger en beter had kunnen kennen door middel der waameming. Is er strijd tusschen die conclusien en de werkelijkheid, zooals zij zich door de waarneming laat kennen, dan mag hij zich ergeren aan de natuur die zich anders vertoont, dan zif wezenlijk is; of anders is dan ze behoorde te zijn, meer kan hij niet doen" (Hamaker 1884: 13-14).

87 Daar ligt ook het grote verschil met de opvattingen van de historische school: "[D]ie wolstrekte tegernstelling in uitgangspunt, en dientengevolge in het karakter wan de wetenschap en in al hare grondbegrippen (...). De een ziet in het recht den vorm, waarin de maatschappij gegoten, de ander het afgietsel, dat wan de maatschappif genomen wordt. De en beschouwt het als de vooruitgetrokken lijn, die de menschheid in haar voortgang volgt, de andere als het spoor, dat zij al woortgaande achterlaat" (Hamaker $1888 ; 113 \mathrm{j}$ 
menschen door de begrippen, maar omgekeerd, dat deze laatste door onze waarnemingen van de maatschappij en de handelwijzen der menschen zijn voortgebracht" (Hamaker 1888: 57; zie ook Pieterman 1990b). Ook voor J.P. Moltzer (1881) heeft het maatschappelijk proces het primaat boven de rechtsbegrippen Maar hij blijft vasthouden aan het idee dat de rechtswetenschap als "eenig mogelijke taak" heeft "de ordening en samenvatting der in de maatschappij zich voordoende rechtsbetrekkingen, naar de eigen beginselen, die aan elk dier rechtsverhoudingen ten grondslag liggen en de 'samenvattende eenheidsregels' vormen, waarmeê die verschillende rechtsverschijnselen zich tot een stelsel laten groepeeren" (Moltzer 1881: 21). Voor hem is het grote verschil met voorheen er een van methode: De deductieve methode trekt "uit vaststaande begrippen (...) zekere conclusiën" (8). Bij de inductieve methode gaat het om de opsporing van nieuwe rechtsbeginsels die achter nieuwe rechtsverschijnselen in de maatschappij schuilen ${ }^{8}$. Niet langer de logica, maar de contingente historische ontwikkeling levert de primaire invalshoek voor de rechtsgeleerde; "voor de hier bedoelde methode is het recht niet eene met logisch verstand uit vaste praemissen gemaakte gevolgtrekking omtrent de wijze; waarop de menschenmaatschappij het best zou zijn te organiseeren, ter meest volledige bevrediging harer materieele en intellectueele behoeften, maar de naar tijd en plaats verschillende voorwaarden, om de verhoudingen, waarin de zucht tot behoeften bevrediging de menschen tot en vaak tegen elkander brengt, steeds te doen zijn in overeenstemming met dat, wat het in eenig volk heerschend rechtsbewustzijn als absoluut gebod stelt en in die menscheneenheid wil verwezenlijkt zien" (Moltzer 1881: 24).

Door het doorbreken van de verbinding tussen wetenschappelijkheid enerzijds en het logische en systematische karakter van de wetboeken of het recht anderzijds, wordt vanuit de rechtstheorie nieuw licht geworpen op de onderscheiding tussen theorie en praktijk (Modderman 1867; 1875; Jansen 1991b: $65)^{6}$. Theorie en praktijk kunnen niet langer op basis van de tegenstelling tussen kernis van een stelsel van principes, versus ervaring en routine (Modderman 1875: 8), als twee gescheiden domeinen worden behandeld ${ }^{*}$. Daarmee

88 "D] $[\mathrm{D}] \mathrm{an}$ de rechtswetenschap de natum behoort te gaan boven de leer en het rechtsbeginsel, dat in en door het verkeer heeft blijk gegeven wan zijn geldende kracht, zich niet laat verwringen door de kumstmatige banden van een voorafgesteld systeem" (Moltzer 1881:" 8).

$89{ }^{p}[\mathrm{H}]$ oe dikwifls hoort men niet onderscheid maken tusschen het regt der theorie, en het regt der practijk? Wanneer de tegenstelling tusschen wetenschap en leven zoodanig tot in het wezen van het regk doordringt; dan getuigt zij af van eene kranke practijk, of van eene valsche theorie" (Madderman 1867: 33). "Dej] grootsite kanker van ons rechtsleven ligt evenwel in de vervreemding de klove tusschen theorie en practijk der rechtswetenschap" (Drucker 1882a: 34).

90 "De fout schuilt bij de juristen, bij hun levenloos, geestdodend formalisme, hun vasthouden aan systemen begrippen en dogma's, aan traditie en Romeinsch recht waar het niet past, hun onbekendheid met de eischen van het werkelijk leven" (Modderman 1875: 26), 
verschijnt echter ook een groot aantal traditionele strijdpunten in een nieuw licht. Het legistische standpunt, waarin de rol van de rechter bij het tot stand komen van de rechtspraak was geminimaliseerd door op het in principe gesloten en volledige karakter van de wetboeken te wijzen, is, ondanks een aantal felle pleitbezorgers, onder wie N. Land (Kop 1982: 55-56), steeds moeilijker houdbaar ${ }^{\text {t1 }}$. Het besef van de noodzaak van gestage aanpassing van de wetten aan de zich wijzigende maatschappelijke omstandigheden, doet de wens opkomen tot een grotere betrokkenheid van de rechtswetenschap bij het tot stand komen van wetten ( $D^{\prime}$ Ablaing 1882: 6-7; Drucker 1882a). Niet meer als individu dat kan putten uit zekere bronnen, maar als collectief dat beraadslaagt, en betrokken is bij het voorbereiden van nieuwe wetgeving: "De taak der rechtswetenschap is tweeledig: verklaring of liever uitlegging van het geldende recht, en voorbereiding of vorming van nieuw recht door ontwikkeling van het bestaande. (...) [A]an den enkelen jurist zall men niet licht meer de rechtsvorming toestaan; de wetenschap zal wel niet meer als rechtsbron naast de wet worden erkend. Doch aan de andere zijde, bij de uitlegging der wet, eische men met klem voor wetenschap en practijk uitgebreider macht dan hun thans toekomt" (Drucker 1882a: 37) ${ }^{\text {s2. }}$. Dit soort van motieven lag ook ten grondslag aan de oprichting van de Nederlandse Juristen Vereeniging in $1870^{\text {s }}$ (Van Hamel 1870: 476-477; Heyman 1973). Het is veelbetekenend dat één van de eerste vraagstukken die op de jaarlijkse vergadering van de NJV besproken werd, indirect het gesloten karakter van de wetboeken ter discussie stelde, namelijk in de vorm van de vraag of men wetboeken enkel in zijn totaliteit kon wijzigen of dat ook partiële herziening mogelijk en nuttig kon zijn

91 D'Ablaing, die het standpunt huldigt "dat alleen in de wet alle recht vervat moest zijn", moet toegeven, dat "het nutteloos [zonde] zijn te verbloemen, dat het geheele hedendaagse stellig recht meer" en meer onvolkomen blijkt te zijn in verband met de versnelde ontwikkeling van ons magtschappelijk vertheer (D'Ablaing 1882: 29; 6 in Jaspersi 1980: 217).

92 "[D]an is toetsing wan het bestaande en voorbereiding van het toekomstige recht haar levensplicht, ever goed als, ja meer nog dan, dogmatiek en wetsexegese" (Molengraaff 1885: 24).

93 "Door mondelinge wisseling van denkbeelden vleit men zich de zeer witeenloopende meeningen tot meerdere eenheid te brengen. Het doel is daarbij niet wetenschappelijk, maar praktisch. Verbetering in onte wetgeving voor te bereider en te bevorderen, is wat de Vereeniging, naar het denkbeeld van het vororloopig comite, behoort the beoogen (De Vries 1870: 80).

94. Datt probleem had zich ook al bij het ontwerp van het wetboek van 1838 meermalen opgeworpen: "Twee zwarigheden echter hebben toen de afdoening van het ingeleverde verhinderd: de moeijelijkheid, namelijk, welke wellen der Leden van de Staten-Generaal er in verklaarden te winden, orn, betreffende deelen, uitsprak te doen, zonder het gehed te kennen, en de zwarigheid, welke het in had, om over een Wetboek te beslissen, zonder bekend te zijn met den geest, waarin het ontworpen was, en met de grondem, waarop de zamenhang en orde van het geheel rustten" (Kenper 1820 in Cohen Jehoram 1968: 64). Zie ook de kamerdebatten voorafgaand aan de inwoering van het Burgerlijk Wetboek wan 1838 (Handelingen en Bijlagen der Tweede Kamer der Staten Generaal woor het jaar 1842/43; de redevoerinigen wan Star Busman (255), De Backer (257), De Man (258), Kruytwerf Sterling (261), Lutac (262) en Minister van Hall (263). Ook I. van Hall in Rechtsgeleerd Bijblad 1843: 323; Meijers 1938; 49 ). 
(Handelingen Nederlandsche Juristen Vereeniging 1870). Het ideaal van een volmaakt, gesloten en volkomen wetboek wordt ingeruild voor de mogelijkheid van een permanente herziening en bijstelling van de wet: "In de eerste plaats zal het, m.e., noodig zijn voor een wetboek van het verkeersrecht [d.i. burgerlijk recht] de pretentie te laten varen, dat het eene codificatie moet bevatten van het verkeersrecht in zijn geheelen omvang; (...) daarvoor in de plaats het beginsel van zelfstandige codificatie van (...) rechtsinstituten (...) In de tweede en, ik wensch er bij te voegen, de voornaamste plaats zorge men voor gestadige wetshervorming: de wetgever herzie gedurig zijne uitspraken, zorge er onafgebroken voor, dat zij steeds het beeld blijven van de rechtsopvatting van zijn volk" (Molengraaff 1885: 22/23).

Het idee dat recht in direct verband moet worden gezien met maatschappelijke ontwikkeling, brengt een fundamentele verschuiving binnen het denken en spreken over onderwijs met zich mee. Het grote belang dat voorheen in de rechtsgeleerde studie werd gehecht aan formeel-logisch redeneren, wordt geleidelijk verlegd naar de waarneming van een veranderende maatschappij. De Bosch Kemper is één van de eersten ${ }^{\text {\%5 }}$ die zich inzet voor een empirische studie van de maatschappij. "De algemene beschouwing van het menschenrijk moet hare bevestiging vinden in de wetenschap van de werkelijke verschijnselen in de zamenleving" (De Bosch Kemper 1863a: 140). Volledigheid als criterium voor wetenschappelijkheid wordt daarbij expliciet overboord gezet "De menschelijke zamenleving tot eenen voortdurenden voor uitgang bestemd, laat niet toe, dat van haar immer eene volledige wetenschap zal kunnen voorgedragen worden. (...) Wij gelooven dat de tijd tot zoodanige volledige wetenschap nooit komen zal. Naarmate de zamenleving vooruitgaat, zal de wetenschap der zamenleving hare grenzen zien uitbreiden. Geen Wetenschap van de zamenleving wenschen wij daarom voor te dragen, maar slechts eene handleiding voor de encyclopaedische studiën, om tot de kennis der zamenleving te naderen; eene handleiding ter aanwijzing van de plaats, die de wetenschap der zamenleving in de algemeene wetenschap bekleedt, als propaedeutik voor de wetenschap van het recht, als systematisch overzigt van alle de deelen der so-

95 Modderman (1875: 30 ) besluit zijn oratie waarin hij een dogmatische benadering van de rechtswetenschap kritiseerde met een pleidooi voor de beoefening der statathuishoudkunde: "Het recht regelt de betrekkingen die in de samenleving bestaan tusschen de burgers onderling en hunne bezittingen. Zullest wij dat recht met vrucht beofenen, dan dienen wij niet alleen te kennen de theorie dier regelen, maar ook het te regelen object" (zie ook Jansen 1991a: 66).

96 "De mensch is geroepen tot volmaakte kenuis, maar in tijdelijke opvolging en in tijdelijke ontwilkkeling; alle kennis, die hij bezit, moet hij putten uit de verschijnselen die hem omringen; (...) het streven naar eene volkomene encyclopaedische wetenschap [ligt] wel in den aanleg van den mensch, madr het bereiken daarvan is boven zijn vermogen. De menschelijke kennis door het vermogen van den mensch beperkt tot een kennisverkriging in tijdelijke opvolging, is ten twreede beperkt door de uitgebreidheid der verschijnselen, die aan ons geopenbaard worden" (De Bosch Kemper 1860a: 86). 
ciale wetenschap en als hulpmiddel tot eigen onderzoek bij de voorbereiding tot het maatschappelijk leven" (De Bosch Kemper 1860a: 42).

Het leervak encyclopedie van het recht verandert door dit soort van ontwikkelingen in de loop van de negentiende eeuw van karakter. Het Organiek Besluit had binnen elke faculteit het geven van een "kort overzigt (...) van alle deelen dier wetenschap, aanwijzing en opgave van de beste bronnen van elk dier deelen, en eene korte aanwijzing, om de beoefening dezer deelen, of ten minste van de voornaamsten derzelve, over eene akademische loopbaan te verdeelen" verplicht gesteld (art. 60). Encyclopedie van het recht fungeerde als inleiding op de rechtswetenschap, en paste als zodanig binnen het wetenschapsideaal en de rechtsopvatting van het begin van de negentiende eeuw. C. Jansen (1990b) heeft op basis van wat nog resteert aan overgeleverde collegedictaten in Nederlandse universiteitsbibliotheken, de inhoudelijke verschuiving binnen het vak pogen te schetsen. Hij komt tot de conclusie dat de encyclopedie van het recht meer en meer de band met de jur "isprudentia universalis die ze aanvankelijk bezat verliest. Hiervoor in de plaats komt een 'historischorganische' rechtsopvatting ${ }^{\text {g }}$. Uiteindelijk zal de encyclopedie van het recht nog uitsluitend als inleiding fungeren "

Omgekeerd aan de geleidelijke ontmanteling van de encyclopedie van het recht verloopt de opkomst van het leervak staathuishoudkunde en statistiek, benamingen die aan het begin van de negentiende eeuw nog bijna voor synoniem kunnen doorgaan (Jansen 1990a: 112). Het achttiende eeuwse onderwijs in de statistiek was zeer nauw verbonden met het onderwijs in het vaderlandse staatsrecht, het jus publicum en valt daar eigenlijk niet van te scheiden (Jansen 1990a: 116; 120). De ingrijpende wijzigingen in het staatsbestel rondom 1795 maakten die historisch-staatsrechtelijke invalshoek echter zo goed als nutteloos. Toch werd in 1807 de statistiek officieel als leervak aan de univer-

97 "Bij deze belangrijke omkeer in de beofening der regtsencyclopaedie in de laattite jaren, komt telkens meer op den voorgrond de overtwiging: dat de levensbetrekkingen en de regtsbetrekkingen uit elkander moeten verklaard worden, zoowel in het publieke als in het burgerlijke regt, " Het staalsileven en het statsregt zijn onafscheidelijk aan elkandar verbonden, en niet minder heeft zulks plaats in het onderling verkeer der privaatpersonen.(...) Eerst waar de regtiencyclopaedie de voornammste regtsinsttellingen in hare geschiedkundige ontwikkeling zal hebben doen kennen, is we weg geband om tot eene voorstelling te komen, hoe de wet vervuld wordt en het volle leven in de bijzondere levensbetrelkking wordt bewerkt" (De Biosch Kemper 1863b deel 2: 849-856).

98 S.J. Fockema Andreae (1914: 10) spreekt over de "algeneene inleiding (dle oude encyclopaedie)". Vergelijk ook J. Kruseman (1946. 22): "In het midden der vorige eeuw teekende prof. Walter, schrijver van eerve toenmals bekende Juristische Encyclopaedie, protest aan tegen de vereenzelwiging van dezen term met ene inleiding tot de rechtswetenschap, welke meer en meer plaats vond. De door Walter en andere juristen gehuldigde opvating kwam hierop neder, dat de encyclopaedie eene wijggeerige wetenschap was, die ons de plaats der afzonderlijke vakwetenschappen in het gebied der menschelijke kennis behoorde te ontdekken en ons inzicht behoorde te geven in den innerlijken samenhang van de onderdeelen eener weltenschap op den grondslag van het veld van onderzoek, dat door deze wetenschap bestreken wordt." 
siteit van Leiden geinstalleerd ${ }^{9}$. Vervolgens voorzag ook het Organiek Besluit in een leerstoel voor staathuishoudkunde en statistiek ${ }^{100}$, echter alleen voor de universiteit te Leiden. Met als hekkesluiter Groningen bezaten vanaf 1843 alle Nederlandse universiteiten een dergelijke leerstoel. Die statistiek stond voor een belangrijk deel in de traditie van Achenwall, "who regarded statistics as a descriptive narrative about the state with an account of all its resources, institutions, potentialities, and peculiarities" (Hasenberg Butter 1969: 54) ${ }^{\text {ig }}$. Doordat de wet op het Middelbaar Onderwijs van 1863 onderricht in de staathuishoudkunde voorschreef op onder andere de hogere burgerscholen met 3- en 5-jarige cursus (art. 16 en 17), was de toekomst van het leervak staathuishoudkunde aan de universiteit verzekerd. Dit onderwijs aan de HBS-en werd immers grotendeels verzorgd door gepromoveerden in de rechtsgeleerdheid ${ }^{102}$. In 1876 werd Statistiek en Staathuishoudkunde opgenomen in de lijst van aan alle hogescholen binnen de faculteit der rechtsgeleerdheid verplicht te doceren vakken; de 'grondbeginselen der staathuishoudkunde' werden geëxamineerd op het kandidaatsexamen in de rechten, terwijl de 'staathuishoudkunde' en de 'theorie der statistiek' werden geëxamineerd voor het doctoraalexamen in de staatswetenschap. In die emancipatiebeweging van de staathuishoudkunde past het afwijzen van het Latijn als zijnde een ongeschikte taal voor het geven van onderwijs en het schrijven van dissertaties (Vissering 1851: 22) en het streven naar een eigen organisatorisch kader, in casu een staathuishoudkundige faculteit (De vier faculteiten 1859).

Even interessant als de opkomst en de opmars van het leervak is de inhoudelijke transformatie ${ }^{\text {t0a }}$ die het vak rond het midden van de negentiende eeuw doormaakt $^{\text {104 }}$ (Stamhuis 1989). B. Tellegen (1861) presenteert de volkshuishoud-

99 Onder andlere naar aanleiding van een klacht van de Agent van Oeconomie dat statistiek geen leervak vormde aan de hogescholen werd in hel besluit van Koning Lodewijk in 1807 om de Leidse hogseschool te eren met de titel 'Koninklijke Universiteit van Holland' bepaald, dat te Leiden een college over statistiek en staathuishoudkunde zou worden gehouden (Duyveman 1987: 26\%. Zie voor eent becchujping van de geschedenis van de vakken stathuighoudkunde en statist"iek in de negentiende eeuw Stamhuis (1989: m.n. 133-181).

100 Dezze werd tot 1848 bezet door H.W. Tydeman.

101 "Het warem mededeelingen en beschouwingen over den politieken, economischen en socialen loestand wan Nederland, over staalsinichting, bevolking handel, nijverheid, landbouw; visscherij, koloriden" (Vissering 1877: 108).

102 In 1867 waren van de 23 leraren in de stathuishoudkunde, 22 gepromoveerd in de rechten (Duym Werman $1987: 29)$.

103 "In deze twee onderscheiden termen: statistiek des adderlands en wheorie der statistiek, die niet alleen op afwijkende matr op geheel heterogene begrippen doelen, openbaart zich treffend de volslagen evolutie, welke het begrip van de statistiek zelve ondergann heeft in het tijdperk tusschen de afkondiging van het kon. beshuit vain 2 Aug, 1815 en de uitvaardiging van de wet van 28 April 1876 verloopen" (Vussering 1877: 103 ).

104 "De stathwishoudkunde verkeert in een staak van overgang. (...) Vraagt men, waardoor dit komt, dan meen ik inzonderheid op drie oorzaken te mogen wijzen: de invloed der positieve wijsbegeerte, de 
kunde nog in het verlengde van de studie van het natuurrecht, als een zoektocht naar eigenschappen die eigen en algemeen zijn aan de natuur der men$\operatorname{sen}^{15}$. Voor W. van Welderen Rengers (1861) vormt de staathuishoudkunde een aanvulling op de rechtsopvatting van de historische school ${ }^{106}$. Uit het streven van de mens om zijn levensdoeleinden te bereiken komt de maatschappelijke orde tot stand. Op basis van de waarneming van die maatschappelijke orde worden rechtsregels geformuleerd die overeenstemmen met de natuur der mensen. Zo kan de rechtswetenschap gelijke tred houden met de beschaving en de levensopvatting van een volk. Daartoe is studie van die maatschappelijke verhoudingen een vereiste. Zes jaar later schetst $H$. Quack (1868) een geheel ander beeld van de staathuishoudkunde. Deze verschijnt nu als de empirische studie van de maatschappij waarin tegenstrijdige belangen onderkend worden, en die de idee van een absolute staat, die een harmonieuze eenduidige ontwikkeling kent, ter discussie stelt. De (nieuwe) staathuishoudkunde werpt zich op als de wetenschap die de maatschappij die in beweging is onderzoekt ${ }^{107}$. "De maatschappij toch omvat wel al het streven, het leven, het weven, het werken, het door elkander slingeren van al de leden van het volk, maar uit den aard der zaak is dit een veelkleurige rijkdom; het zijn vele belangen, niet éêr georganiseerd belang. (...) [O]mdat de staat telkens in iedere phase inhoud en opgave van de maatschappij ontvangt, kan de staat geen vasten absoluten vorm aannemen" (Quack 1868: 20-21). L. Daston (1987: 295) analyseert die verschuivende benadering aldus: "Eighteenth-century mathematical probability took as its subject matter the judgements and decisions of reasonable men; eighteenth century moral sciences also aimed to reveal the rational grounds for action and belief. Both were individualistic, psychological, and prescriptive in their approach. Nineteenth-century probabilists understood their theory in terms of statistical frequencies; nineteenth-century social scientists sought regularities at the macroscopic level of individual action. For the eighteenth-century thinker, society was law-governed because it was an aggregate of rational individuals;

verwiarring van hypothetische en werkelijke wetenschap, en de toepassing van de denkbeeldan der historische schiool" (Vam Houlten 1863: 401).

105 "Until the nineteenth century ( ${ }_{(\text {. }}$ ) statistical regularity was generally seen as pertaining to the natural history of man, and as indicating divine wisdom and planning" (Porter 1986: 511)"

106 "Zo erkennen will dan nevens den subjectieven regtsgrondenden wil der historische school, een objectheven grond des regts in de zich wedlerkeerig bepalende levensbetrekkingen, welke zich naar humne eigene, orspronkelijk van het regt onafhankelijke wetten ontwikkelen, en die eersit erkend en dan de bepalende regel voor den het regt verwezenlijkende wil moeten worden" (Van Welderen Rengers 1861: 7). 107 "The new interpretation of statistics that emerged during the 1860 s and 1870 was tied to a view of society in which variation was seen as much more vital. Statistical determinism became untenable: precisely when social thinkers who used numbers became unwilling to overlook the diversity of the component individuals in society, and hence denied that regularities in the collective seciety could justify any particular conclusions about its members" (Porter 1986: 150-151). 
for his nineteenth-century counterpart, society was law governed in spite of its irrational individual members. " houdkunde en statistiek gaat deze studie niet verder in ${ }^{109}$.

Voor wie recht opvat als onderdeel van een maatschappelijk proces ${ }^{110}$ is het allerminst evident dat in de rechtsgeleerde studie het Romeinse recht nog een prominente rol moet vervullen ${ }^{11}$ of dat de studie daarmee moet aanvangen. ${ }^{\prime \prime}$ Den jeugdigen jurist worden eene menigte begrippen ingegeven die hij, daar het Romeinsche regt hem van jongs af wordt voorgesteld als de voor alle tijden geldende canon van ons juridisch denken, als logisch noodzakelijk leert vereeren of als logisch onmogelijk leert verwerpen. Verblind door den glans der logische deducties van het Romeinsche regt, beschouwt hij onwillekeurig zijn uitspraken als onfeilbaar, als absolute waarheid, zonder altijd te onderzoeken of de praemissen waarvan het Romeinsche regt uitgaat, niet reeds lang door de veranderde maatschappelijke toestanden zijn veroordeeld. Hij gaat het regt beschouwen als een product van juridische dialektiek; hij raakt er langzamerhand aan gewoon zich te verplaatsen in een wereld van abstracte begrippen, om zich eindelijk aan handen en voeten gebonden te gevoelen door die logische noodzakelijkheid en die logische onmogelijkheid die dikwijls alleen op het gezag van het Romeinsche regt berusten; later valt het zwaar zich los te maken uit eene slavernij, waarin men, door eene ligt verklaarbare overschatting van den logischen kant van het Romeinsche regt, gebragt is" (Modderman 1874: 94-95).

108 Quetelets constructie van de l'homme moyen - de mens waarbij alle te onderscheiden grootheden een gemiddelde waarde hebben - valt als overgang tussen deze beide benaderingen te begrijpen. Quetelets l"honme moyen is in zekere zin vergelijkbaar met Albinus' Hono perfectus: "L'homme que je considère ici est dans la sociéte l'analogue du centre de gravité dans les corps; il est la moyenne autour de la quelle oscillent les élêments sociaux; ce sera, si l'on veut, un etre fictif pour qui toutes les choses se passeront conforménent aux résultats moyens obtenus pour la société. Si l'on cherche à établìr en quelque sorte les bages d'une michanigue sociale, c'est lui qu' on doit considérer sans l'arrêter à examiner les cas partì cuiliers ou les anomalies"' (Quetelet 1832: 4 in Stamhuis 1989:61).

109 Zie Vissering (1866); Van Rees (1858, 1860, 1865); Van Houten (1866); Quack (1868); D' Aulnis (1878, 1897); Pierson (1878, 1879); Quack (1885); Reiger (1891); Treub (1896); Hasenberg Butter (1969). Zie voor een analyse van de veranderingen in de statistiek in het algemeen Hacking (1975); Shapiro (1983); Porter (1986) en kritger, Daston and Heidelberger (eds.) (1987).

110 "[D]e toekomst moet den weg betreden (...) naar nationale regtsontwikkeling in dien zin dat zii haar regels vormt naar, hatr instellingen toetst aan de tegenwoordige maatschappelijke toestanden ent de eischen eener nimumer stilstaande ontwikkeling" (Modderman 1874: 87-88).

111 "Ik zou (...) wenschen dat het zwaartepunt van de studie van het civielregt gelegd werd in de studie van het hedendaagsch priwaatregt: dat den beginnenden jurist vóor alles een systematisch overzigt werd gegeven van alle regtsinstellingen, die in het tegenwoordig leven gevonden worden en zoo als men ze daar aantreft, onverschillig van welken oorsprong zij zijn; dat hem daannevens of daarna de historia interna van alle die instellingen werde ontwikkeld, waarbij tevens op de principiele punten van verschil tusschen Romeinsch en Germaansch regt zou kunnen worden gewezen en de gelegenheid niet zor: ontbreken de verdiensten van het Romeinse regt uit het oogpunt van methode en techniek te ontvouwen" (Modderman 1874: 92-93). 
In de periode voorafgaand aan de Hoger Onderwijswet van 1876 werd van meerdere kanten gepleit voor een inrichting van de kandidaatsstudie waarin de student met overzichten van het burgerlijk recht en een of meer andere doctoraalvakken zou beginnen (Kunst 1969: 27 e.v.). Het lid van de Tweede Kamer Oldenhuis Gratama bepleitte tijdens de behandeling van de hoger Onderwijswet in 1875 krachtig voor het vóropstellen van een overzicht van het geldende recht in de studie. Het Romeinse, Germaanse en canonieke recht diende daarna "het bestaande te doen kennen in zijn" dieperen grond". Het betoog bleeff zonder direct gevolg. In het begin van onze eeuw hoort men nog steeds dezelfde wens: men beginne met het bestaande en late met name de rechtsgeschiedenis pas na het kandidaatsexamen bij de verdieping der studie het inzicht verrijken en historische achtergronden belichten (zie Fockema Andreae e.a. z.j.).

Staat enerzijds het Romeins recht als leervak onder druk, anderzijds passen de pleitbezorgers van het Romeinse recht hun argumentatie aan. Druckers oratie 'Rechtswetenschap en Wetgeving' (1882) is reeds meermalen aangehaald. Na in het eerste deel van zijn inauguratie zijn moderne opvattingen over wet en recht te hebben uiteengezet, gaat hij vervolgens over op het belang van het Romeinse recht voor de studie der rechtsgeleerdheid. Drucker die de leerstoel voor Romeins recht gaat bezetten, laat dan een gematigder toon van zich horen. Hij betreurt het teloor gaan van het stelselmatige in het recht: "Meer en meer wordt de commentarenvorm inheemsch in onze wetenschap (...) voor de practijk zeer verleidelijk, zijn de meeste commentaren voor de wetenschap verderfelijk (...). De echte wetenschappelijke kennis, het systeem, gaat op die wijze verloren: wetskenners worden gevormd, geen juristen. (...) de Romeinsche commentaar hield juist het verband der dingen in het oog (...) dat die commentatoren de ware systematische methode, zoo niet uiterlijk volgden, dan toch volkomen in zich hadden opgenomen" (Drucker 1882a: 19/20). Anderzijds moet Drucker erkennen dat de tijd voorbij is, "dat men het als ratio scripta vereerde, en in complexu voor onzen rechtstoestand geschikt achtte" (Drucker 1882a: 20). Drucker ziet een oplossing door te onderscheiden tussen het familie en het verkeersrecht. "Vooral bij het familierecht is kennis der doode rechtsbepalingen niet voldoende; veeleer moeten deze, ook bij het academisch onderwijs, worden beschouwd, gelijk zij zich practisch in het leven voordeden" (21). Omdat het verkeersrecht echter niet ethisch maar practisch is geldt in dit bereik het Romeinse recht nog steeds ${ }^{112}$. De vormende kracht van het Romeinse recht is gelegen in het bestuderen van de ontwikkelingslogica van het Romeinse

112 "Hier zoude men met Wirdscheid kunnen zeggen: het Romeinsche Recht is de witcirukking van algemeen menschelijke opvattingen van algemeen menschelije verhoudingen. (...) Bovendien bevat het Romeinsche Recht de kierm in zich van verdere ontwikkeling" (Drucker 1882a: 22). 
recht: "Gelukkig dat wij, niet gebonden aan het Romeinsche Recht als positieve wet, naast zijne dogmatische en technische zijde, ook aan zijne geschiedenis de aandacht kunnen wijden, die zij verdient. (...) het Romeinsche Recht (...) in zijne geheele grootsche ontwikkeling na te gaan. Wij zullen dan uit het Romeinsche Recht leeren, wat wij nog mogen overnemen, immers wat de Romeinen zelf zouden hebben behouden, wanneer zij onder onze omstandigheden hadden geleefd" (24). Doordat het Romeinse recht uitmunt "door scherpe, afgeronde begrippen, [en] door eenheid van gedachte" (29) vormt het Romeinse recht de beste aanvang van de rechtenstudie. "Het hier en daar geopperd denkbeeld"13, om de juridische opleiding te doen aanvangen met een systematisch overzicht onzer eigen wetgeving, moge ons ideaal zijn, het kan niet verwezenlijkt worden, zoolang ons recht geen systeem is, zoolang het vastheid van begrippen mist" (30). Drucker lanceert zelfs nog een nieuw ${ }^{114}$ argument dat pleit vóór het Romeinse recht. Hij ontleent dat aan de tendens naar een verdergaande internationalisering van het recht. De gemeenschappelijke band van het Latijn is reeds lang verbroken. "Alleen het Romeinsche Recht kan dien wetenschappelijken band onderhouden, die in onze dagen meer dan ooit noodig is."

J.C. Naber (1885) maakt met zijn inaugurale rede 'De vormende kracht van het Romeinsche recht' de cirkel rond (zie ook Hingst 1885: 250). Aan de hand van casuilstiek, ontleend aan de Digesten voor een aantal juridische leerstukken - onder andere de verkrijgende verjaring, het pandrecht, het bezit, de overeenkomst - laat Naber zien "hoe de Romeinse juristen zich veel meer lieten leiden door de eisen van het dagelijkse rechtsleven dan door levensvreemde constructies en dogma's en hoe zij steeds weer in staat zijn geweest om in vrijmoedige creativiteit en in een subtiel aanpassingsproces van de overgeleverde rechtsinstituten - daarbijgeleid door een antidogmatische geesteshouding - te komen tot een soepel en aan de eigen tijd aangepast verkeersrecht" (Spruit 1986: 138).

De ommezwaai is gemaakt: de vormende waarde van het Romeins recht ligt niet langer meer in het systematische karakter, maar in het feit dat zij een toonbeeld van flexibiliteit vormt!" "Zoo ik $U$ derhalve over de vormende kracht van het Romeinsche recht, vooral voor onzen tijd, wensch te onderhouden, dan is het, omdat ik haar elders dan in het Romeinsche constructiewezen gelegen

113 Het denkbeeld werd onder andere uitgesproken door Modderman (1874: 92); doch afgekeurd in Levy (1879) en in Pijnacker Hordijk (1881: 47), Zie Feenstra (1984).

114 Dat overigens ook reeds door Savigny naar voren was gebracht.

115 Minder expliciet is dat ook reeds de strekking van Modderman (1867: 31; 38/39): "[D]e rijkdom van het regt [is] niet gelegen in het aantal zijner grondregels, maar veeleer in hunne buigzaamheid (....) dat de grandige studie van het RR ook thans nog voor elk degelijk jurist een noodwendig vereischte is, niet ondat het RR het absolute regt is, mat ondat ons regt voor een groot deel op R. bodem is gegroeid; ondat als wij den inhoud niet kennen, wij evenumin de onovertroffen methode van de R. juristen kunnen og prijs stellen en leeren navolgen voor de uillegging en ontwikkeling van ons regt." 
acht. Niet de virtuositeit in het definieeren en construeeren (...); wat zij ons leeren, is juist: zelfstandigheid te betrachten tegenover eene schijnbaar dwingende deductie; ons beter inzicht te handhaven, ook waar het met de eerbiedwaardigste der ons ingeprente constructiën in conflict komt. Ik ga hierin zoo ver, dat ik het waag, de beweering uit te spreken en straks te motiveeren, dat dé voorstanders van strenge, scherpbegrensde constructiën, wel verre van de studie der Romeinsche juristen aan den ingang van den academischen cursus verplichtend te stellen, consequent zouden handelen, door den aanstaanden rechtsgeleerde op strenge straf te verbieden, ooit een blik te werpen in het Justinianeïsche Corpus Juris. Een bloemlezing uit een dozijn Pandektenhandboeken der laatste halve eeuw zou - ware het er om te doen, de jeugd met constructiën en definitiën te voeden - vrij wat beter diensten bewijzen dan de Pandektenfragmenten zelve, waarvan gij zelfs met den besten wil geen bladzijde achtereen kunt lezen, zonder dat uw geloof in de constructie op de bedenkelijkste wijze aan "t wankelen wordt gebracht" (Naber 1885: 8-9) 136 $^{136}$ De historische school heeft aldus Naber slechts half werk geleverd. Naber eindigt zijn rede met aan. te kondigen wat de studenten van zijn onderwijs mogen verwachten: "Geen regelen (...) Geen dogma's (...) wat ik $U$ wel zal trachten te verschaffen is een open oog voor de beweging van het bewegelijke verkeer; het waarnemingsvermogen, waardoor de jurist onderscheidt, hoe de gang van zaken is in de menschen maatschappij" (Naber 1885: 38). "Rechtsstudie is niet anders dan ontwikkeling van het rechtsgevoel met inachtneming der grenzen" (Naber 1889: 19).

Nu het recht als een veranderlijk element in het maatschappelijk proces wordt opgevat, verschijnt het Romeinse recht ook bij Drucker (1889: 10) als het voorbeeld bij uitstek van zo"n geleidelijk aanpassingsproces. "Begrip en dogma de samenvatting van de geldende rechtsvoorschriften - kunnen nooit richtsnoer zijn bij de rechtshervorming (...). Daar is het de vraag: wat eischt het voortschrijdend verkeer? Welke concrete regeling wordt door de maatschappelijke behoefte gevorderd? Heeft de beantwoording van deze vraag geleid tot het vaststellen van nieuwe bepalingen, dan is het de taak der wetenschap te onderzoeken, of de regels en begrippen, uit het vroegere recht afgeleid, nog daarbij passen. Blijkt dit niet het geval te zijn, zoo moeten die regels, desnoods zelfs die begrippen, worden opgegeven en door andere vervangen. De Romeinse juristen waren hiervan doordrongen. (...) Hoe vaak blijkt het recht onmachtig,

116. "Niet het najagen van een onbestaanbaar voor alle tijden geldend natuurrecht, niet het hangen an positiveve rechtsbepalingen, reeds den dag na havar afkondiging bij het verkeer ten achter, niet het zoeken naar denkbeeldige hooggste rechisbeginselen, en vooral niet hel knutselen met begrippen - maar het scheppen wit het valle menschenleven op het voetspoor der onowertroffen meesters, is het doel, waartoe wij de jongeren hebben op te leiden" (Naber 1885: 32). 
gelijken tred te houden met de steeds sneller ontwikkeling der menschelijke samenleving! (...) De oorzaak is, dat de moderne rechtsgeleerden, bevangen in de traditionele regels en begrippen, niet indachtig aan het voorbeeld hunner roemruchtige Romeinsche voorgangers, de eischen der werkelijkheid uit het: oog verliezen, dat bij de meesten hunner het dogma de plaats bekleedt van onbevangen waarneming der feiten." Ook Drucker verwijt de historische school. slechts half werk te hebben geleverd ${ }^{177}$. Wat de opleiding betreft leidt dat tot de conclusie dat "de jurist vrij moet zijn tegenover het dogma, dat hij het leven moet bestudeeren meer dan de teksten (...) Al wat autoriteitsgeloof bevordert, moet in den ban gedaan. Naast het geregeld ordelijk denken, dient het waarnemingsvermogen gescherpt, de onbevangen blik op de werkelijkheid geoefend te worden" (Drucker 1889: 26). Alleen de eindconclusie zal verbazen: "het academisch leerplan geeft, van ons standpunt bezien, geene overwegende aanleiding tot klachten." Het Romeinse recht kan als leervak gehandhaafd blijven. Enkel de praktische richting die het onderwijs bij de Romeinse rechtsgeleerden ook al kende, verdient naast het meer systematisch en theoretisch onderricht navolging.

Het radicale voorstel om het Romeinse recht als leervak te laten vervallen, om plaats te maken voor de beginselen van het hedendaagse recht, het burgerlijk- en handelsrecht, het strafrecht, het procesrecht, het staatsrecht en de staathuishoudkunde, zou worden geformuleerd door A.F. de Savornin Lohman (1899) in diens ingezonden nota ten behoeve van de Nederlandse Juristen Vereniging. Naarmate het nationale recht gecodificeerd is en zich losgemaakt heeft van het Romeinse recht is naar de mening van De Savornin Lohman de directe noodzakelijkheid van de studie van het Romeinse recht verminderd. De studenten lezen de teksten nog slechts in Nederlandse vertaling. De vormende kracht van het Latijn heeft het Romeinse recht niet meer. "Waarom kunnen dan niet het overzicht van de geheele stof, de uiteenzetting der algemeene beginselen, de methode om het onderling verband der rechtsbeginselen te vatten gegeven worden met het oog op ons hedendaagsch, nationaal recht? Hier komt nog iets anders bij. Men is tegenwoordig wel vrij algemeen tot de overtuiging gekomen, dat het recht van eenig volk niet het product is van eenig stelsel, maar ten nauwste verband houdt met de historie en de maatschappelijke ontwikkeling van dat volk. De vroegere door vele juristen gekoesterde meening dat het nationale recht zich vormen moet naar het Romeinsche recht, en als het

$117{ }^{2 f}$ [DJat het recht niet is onveranderlijk, dat het zich schikit naar tijd en plaats en behoefte, dat is immers voor goed vastgesteld door de historische school, dat leerden wij reeds bij onze eerste schneden op het gebied van het recht. De leer is zuiver, maar aan hare toepassing ontbreekt veel. Bij Siavigny er steld; wat de Romeinen niet kenertige bepaling van het Romeinsche Recht als, "logisch noodzakeljk" voorge. begrip" gebrandmerkt" (Drucker 1889. 13) 
ware de definities en de sententies die daarin gegeven worden tot grondslag moet hebben, begint tot het verleden te behooren. (...) Door nog altijd de speciale studie van het R.R. aan alle juridieke studie te laten voorafgaan, wordt telkens weer aan de dwaling voedsel gegeven, dat het recht, het in een volk levende recht, een voortbrengsel is van een systeem; dat de rechtsgeleerde eerst zijne begrippen heeft vast te stellen, om dan daarop het nationale recht te doen steunen. (...) Geen geloof in eene school als grondslag van het recht! Zelfs niet in die van het Romeinse recht" (De Savornin Lohman 1899: 191-192) ${ }^{118}$.

Vanaf het moment dat de rechtswetenschappelijke theorie de oriëntatie op een logisch gesloten en volkomen systeem van rechtsnormen opgaf ontstond ook binnen de faculteit der rechtsgeleerdheid een roep om methodische veranderingen in het onderwijs, in concreto om meer praktisch onderwijs. En ook hier ontstond, net als in de faculteit der geneeeskunde, verwarring over de vraag wat er met dat praktisch onderwijs bedoeld werd. Van oudsher werd praktijk gelijkgesteld met ervaring. Praktisch onderwijs werd dan vooral gezien als stage, als het opdoen van ervaring en ondervinding, en bepleit vanuit in de praktijk werkzame advocaten ${ }^{119}$. Daar' stond dan de traditionele rechtsgeleerde theorie tegenover die de bestudering van de wetenschappelijke beginselen van het recht benadrukte ${ }^{120}$. Van Hall, die in 1848 het Athenaeum van Amsterdam verliet om hoogleraar te worden in het burgerlijk en handelsrecht en de burgerlijke rechtsvordering te Utrecht, was éen van de eersten die gelegenheid gaf tot praktische oefeningen op zijn zogenaamde pleit-college (Heynsbergen 1925: 134). In Amsterdam ijverde nadien onder andere T.M.C. Asser, die in 1862 werd aangesteld als hoogleraar in het hedendaags recht aan het Athenaeum, voor onderwijs met een meer praktische oriëntatie. In zijn 'pleitcolleges' werden zittingen van kantongerecht, rechtbank en hof gesimu-

118 Savormin Lohmans voorstellen werden met 58 tegen 48 stemmen verworpen Pas in het Academisch Statuut van 1921 zou het Romeinsche recht niet meer als afzonderlijk vak vermeld worden. Hiervoor in de plaats kwam de formule: 'Historische ontwikkeling van het recht, bezien in het licht van rechtstelselis, uit welke het Nederlandsche recht zich heeft gevormd' (Smidt 1922).

119 Ln 1828 maakt de Algevneene Konst en Letterbode gewag van een desiderafunt varu het hoogsite belang namelijk "een goed praktisch onderwijs aan de Hoogeschalen zelve. ("..) [W]ie onder de Regtegelewirden herinnert zich niet, indien hij openlijk biechten wil (...) dat (...) hij (....) zich naauwelik ks te redden wist bij eene eenigszins gecompliceerde zaak (...). Indien in elke plaats, waar eene Hoogeschool is, zich ook aen Geregtshof bewond, dan zoude men een' gepractiseerd hebbend Advokat kunnen belasten met dit werk, onder wiens opzigt de jonge lieden de zittingen van het Hof bij konden wonen en later collegialiter bespreken" (Schill 1828: 374).

120 " [D] he betreklkingen [wan de maatschappil]] veranderen dageli]ks: de toestand wan het volk, zoo naar binnen als naar buiten, ondergat zoo veelvuldige wijzigingen, dal de lessen des Hooglecrara, daaromtrent, niet altijd dezelfde kumnen zijn. En de Foogleeraar, die naar den eisch zoodanige lesgen wide geven, zoude geen wetenschappelijk onderwijs geven, maar zich in de plaats moeten stellen wan den wetgever zelwen. Neen; dergelijke bemoeijenissen en verhandelingen behoonen niet tot de Akademische leerstoellen. 2 ij bevatten de toepassing der wetenschappelijke beginselen op de zaken, die behan. deld moeten worden (Van Reenen 1836: 26). 
leerd (Asser 1893: 6; Van Apeldoorn 1932: 158). In Utrecht ging het initiatief daartoe uit van I.A. Fruin, in Leiden van R. van Boneval Faure en C. Asser (Jansen 1990c: 826). In de pleidooien voor meer praktisch onderwijs was heel voorzichtig de wens ingeweven om te breken met de exclusieve plats die de tekst, als basis van kritiek en uitleg, in de rechtsgeleerde traditie innam ${ }^{12 t}$.

Enige decennia later ${ }^{122}$ wordt door diegenen die ijveren voor een andere visie op recht, de connotatie tussen ervaring opdoen en praktisch onderwijs doorbroken. Praktisch onderwijs krijgt expressis verbis de betekenis van een methodische vernieuwing van het onderwijs, voorvloeiend uit veranderde opvattingen over wat een wetenschappelijke benadering van het recht inhoudt. Drucker huldigt het standpunt dat aangezien het academisch examen in de rechtsgeleerdheid in Nederland toegang geeft tot balie en magistratuur, de academische opleiding "eene theoretisch-practische" moet zijn: Dat vereist zowel hel doorbreken van de associatie van praktijk met ervaring en routine als een inhoudelijk andere benadering van het recht: " $\mathrm{Er}$ moet, om met Binding te spreken, worden gebroken met het geloof aan de alleenzaligmakende kracht der dogmatische voordrachten. Niet als ware het doel, den jurist aan de Universiteif die practische routine te verschaffen, die alleen door de dagelijksche behandeling van rechtzaken is te verkrijgen. Waar het op aankomt is, hem eene heldere, levendige voorstelling te geven van zijne bij uitnemendheid practische wetenschap, hem in staat te stellen, met zijne begrippen in het leven te werken" (Drucker 1882a: 41). Drucker wijst in dit verband op het ontstaan en het floreren van de seminaria in Duitsland (zie ook Drucker 1882b; Jansen 1991a: 72). Molengraaff (1885: 31-32) verbindt de wenselijkheid van praktisch onderwijs nog explicieter met een inhoudelijke verandering binnen de rechtswetenschap: " $[\mathrm{I}] \mathrm{k}$ ben ten volle overtuigd, dat de rechtswetenschap eene practische wetenschap is, en dat dit in de eerste plaats gezegd mag worden van het verkeersrecht, resp. het handelsrecht. Dat het recht van het verkeer niet gekend, veelmin begrepen kan worden, indien men het verkeer zelf niet kent en begrijpt, en dat men dit, om het te leeren kennen en begrijpen, gestadig moet gadeslaan en er gedurig voeling mede moet houden, is dunkt mij eene zeer natuurlijke zaak,

121 "Het kont er, voor den onderwijzer, naar mijne overtuiging, inzonderheid op aan, om begrippen en beginselen in humen zamenhang en onderling vexband mede te deelen, en door zijne toehoorders wel te doen verstam. Hij heeft niet zoo zeer den grootsil mogelijken voorraad van wetenschap aan zijn toehoorders rond te deelen, maar hij heeft, door zijne voordragten, hun oordeel te scherpen, hum praktisch verstand, ten behoeve eener geheel practische wetenschap, te verlichten, hen met ém wroord, zooveel mogelijk voor de beofening en toepassing der wetenschap op het leven te wormen. (...) Ik schat (...) de keruis der literatuur niet gering, maar ik zou wenschen haar hare juiste plaats aan te wijzen, omdat ik de regtsgeleerdheid als eene verstandelijke wetenschap en niet als een werk wan het geheugen beschouw (Van Hall 1851: vii en viiin).

122 Asser (1893: 9) ziet de instelling vam het instituut buitengewoon hoogleraar bij de hoger onderwijs wet wan 1877 als een expliciete bekrachtiging wan de eenheid wan theorie en praktijk. 
eene waarheid die niet te miskennen valt. Toch wordt zij nog dikwijls miskend, het meest wel door de methode, die meer juist dan fraail genoemd zou kunnen worden: de methode der artikelpluizerij. (...) Het verleidelijke van dit stelsel ligt daarin, dat het de gemakzucht van den hoogleeraar vleit. Stabiel, onveranderlijk als onze wetboeken, kan ook de eenmaal gepraepareerde stof blijven; hoogstens behoeven literatuur en jurisprudentie een weing te worden bijgehouden. (...) tegen elke eenzijdig en uitsluitend exegetische methode een ernstig protest (...) Het doet ons in één woord alleen het officiëele recht, niet het in het werkelijk leven bestaande kennen."

Tijdens de bijeenkomst van de Nederlandsche Juristen Vereeniging in 1899 staat de kwestie van het praktisch onderwijs op de agenda ${ }^{123}$. Verschillen van inzicht over wat praktijk is en wat onder praktisch onderwijs verstaan kan worden, vertroebelen die discussie. H. Hijmans (1902: 331) merkt drie jaar nadien terecht op, dat grote misverstanden in het gebruik van het woord praktijk tijdens die bijeenkomst speelden: "Zoodra in Nederland iemand over practica spreekt (...) wordt terstond de tegenwerping geuit: "de praktijk kan men alleen uit de praktijk leeren'. Uit de Handelingen der Nederlandsche Juristen-Vereeniging van 1899 blijkt dat de meeste leden, die over de practica spraken, daarbij aan inrichtingen dachten, waar de praktijk bestudeerd werd. Hier is een misverstand aanwezig, dat uit den weg geruimd dient te worden. (...) In het algemeen dan hebben de Duitsche practica niets met de eigenlijke praktijk te maken. Hun doel is de leerlingen te onderrichten in het beslissen van rechtsvragen. (...) Men zou hier van het 'materieele doen' kunnen spreken, in tegenstelling tot het "formeele doen' hetwelk de inhoud der eigenlijke praktijk is." Preadviseur A.P.Th. Eyssell toont zich in zijn preadvies als iemand van de oude stempel. Hij zet zich met name af tegen S.J. Fockema Andreae (1894): "Voor enkele jaren heeft niet de eerste de beste, heeft de hoogleraar Fockema Andreae, (...) het betoog ondernomen, dat de Akademische voorbereiding eene wijziging zou moeten ondergaan door, met groote beperking der overige colleges, de studenten te verpligten tot den arbeid in laboratoria en poliklinieken: de eerste bedoeld als inrigtingen waarin zij zich, onder de leiding hunner hoogleeraren, ongeveer als in de Duitsche Seminare zouden oefenen in historisch en dogmatisch onderzoek; de poliklinieken zouden vervalgens dienen om hunne aandacht te vestigen op regtsvragen, zooals deze zich vertoonen in de regtszaal, in de wetgevende lichamen en misschien ook in de pers" (Eyssel 1899: 36-37). Hoewel ook voor Eyssell de kernvraag ligt in wat er gebeuren moet om de jeugdige

123 Een adres van de Amsterdamse balle aan de Minister van Justitie waarin de jong gepromow eerde ervan wordt beschuldigd, door zonder enige voorbereiding van de sttudeerkamer over te gaan tot de witoefening van de nechtspraktijk, diënten tot slachtoffer te maken van zijn gebrek aan ervaring, is inzet varn discussie op de bjjeenkomst van de NJV in 1899. 
jurist met enige praktische bedrevenheid toe te rusten ${ }^{124}$, ziet hij weinig heil in de voorstellen van Fockema Andreae. Reden hiervoor is dat hij vast blifft houden aan een notie van praktijk als ervaring. "[E]en grondige kennis van de praktijk [kan] alleen (...) worden verkregen door de praktijk zelve en na eenen tijd, veel te lang om als tijdperk van voorbereiding in aanmerking te komen". Hij ziet niet dat Fockema Andreae met zijn pleidooi voor praktisch onderwijs met name een andere opvatting van rechtstheorie op het oog heeft. Collega Preadviseur D. Simons (1899: 92) toont zich een groter voorstander van meer praktisch georiënteerd onderwijs ${ }^{125}$. "[H]et onderwijs in de rechtswetenschap [zall niets aan wetenschappelijke diepte en theoretische grondigheid (...) verliezen, wanneer daarbij het oog voortdurend wordt gericht gehouden op de wijze, waarop de regelen des rechts op de gevallen van het werkelijke leven moeten worden toegepast. Naast hüstorische en dogmatische rechtsstudiën, naast kennis van de systematiek des rechts komt toch ook bij de wetenschappelijke beoefening van het recht nauwkeurige kennis van de bijzondere voorschriften der wet niet in de laatste plaats in aanmerking en die kennis kan eerst in waarheid worden verkregen, wanneer men die voorschriften aanpast aan het werkelijke leven en omgekeerd dat leven met zijne rijke schakeeringen van gevallen aan die voorschriften toetst." Ook Simons (1899:94) wijst in dit verband op de Seminar-oefeningen in Duitsland, ter aanvulling en toepassing van het elders geleerde. Zo ver als Fockema Andreae, die het aantal colleges ten gunste van de zelfstandige bestudering van handboeken en oefeningen in laboratoria en poliklinieken wil terugdringen, wil hij echter niet gaan. "[O]ok ik zou de voorkeur geven aan meer zelfstandige studie, aan de hand van gedrukte werken dan aan de nu vaak machinale studie van geschreven dictaten. Maar de verwijdering van dictaten als hoofdgrondslag van de studie zou daarom nog niet leiden tot zelfstandigen arbeid (...). Bovendien is het niet gemakkelijk voor alle vakken de handboeken aan te wijzen, die aan de eischen van de academische studiën voldoen en eindelijk zal de individualiteit van den

124. "De groote vraag is dus: wat kan gedaan worden om zoo' $n$ jeugdigen jurist met praktische bedreventheid toe te rusten?" (Eyssel 1899: 7).

125 "[H] ier zal moeten worden toegegeven dat de zuiver theoretische studiën, waartoe ons universitair onderwijs als regell leidt, de gevorderde geoefendheid in het hanteeren der bestudeerde rechtsregelen, in de taepassing der verworven rechtskennis niet verschaffen en dat dus ook aan de opleiding van den advocat weel ontbreekt. De conclusie ligt derhalve voor de hand on ook voor den aanstaanden advocaat te vorderen dat zijne theoretische studiën door practische oeleningen aangevuld worden en dat hij door een examen doe blijken dat die oefeningen gunstige uitkomsten hebben gegeven. Inderdaad is die eisch ook gesteld door de heeren Hanssens en Hijmans in hun rapport voor het in 1897 te Brussel gehouden advocaten-congres. Naast het wetenschappelijk onderwijs aan de universiteit verlangen zijeen op de praktijk gericht onderwijs door en tijdens de stage en aan het einde van die stage als voorwaarde voor de toetreding tot de balie de aflegging van "un examen professionel", af te nemen door enkele der voomamste leden van de balie en eenige vertegenwoordigers der rechterlijke macht" (Simons 1899; 88). 
hoogleeraar een belangrijken invloed mogen houden op de richting van het onderwijs."

Ook in zake het praktisch onderwijs komt De Savornin Lohman (1899) weer met de meest verstrekkende voorstellen: Bij hem is het ijveren om meer praktisch onderwijs ingebed in een wens tot radicale herorganisatie van de opleiding. Voor een aantal maatschappelijke functies zouden staatsexamens na het academische examen dienen te worden ingesteld. "Ik stel theorie en praktijk niet scherp tegenover elkaar, en allerminst ben ik van meening dat, om een goed practicus te zijn, men slechts een groote dosis wettenkennis en praktijk behoeft te hebben opgedaan. Geen goed practicus kan eene wetenschappelijke opleiding ontberen, en een rechtsphilosoof, die zich in theorieën verdiept zonder behoorlijk kennis te hebben gemaakt met de algemeene rechtsbeginselen, loopt groot gevaar te vervallen tot inhoudslooze of onpraktische stelselzucht" (De Savornin Lohman 1899: 185). Rechtswetenschap behelst niet langer uitsluitend kennis van een stelsel van rechtsbronnen of rechtsbeginselen, maar is verbonden met de alledaagse werkelijkheid.

Gemeenschappelijk in de argumenten voor meer praktisch onderwijs is de wens de zelfwerkzaamheid van de studenten te vergroten ${ }^{126}$. Daarom moeten de colleges verdwijnen, "geheel verdwijnen!" (Hijmans 1902:328). Practica zullen de student in de eerste plaats moeten leren uit de maatschappelijke verhoudingen het recht te vinden, om daarna inzicht te geven in hoeverre een oordeel al dan niet door dwingende rechtsregelen geleid wordt. "[P] ractica kunnen het uitgangspunt vormen van een algeheele hervorming van het rechtsgeleerd onderwijs" (Hijmans 1902: 332). S.J. Fockema Andreae (1914) zal in zijn pleidooien voor een verandering van onderwijsmethode nog verder gaan. Voor de traditionele voordracht van de leerstof op colleges ziet hij in een tijd waar voor bijna elk vak ruimschoots handboeken voorhanden zijn geen plaats meer. Oefeningen, practica en laboratoria moeten het hoofdbestanddeel van de opleiding uit gaan maken. "Hier zouden de studenten tot zelfstandige werkers moeten worden gevormd. Zelfstandige werkers. Men versta mij wel: ik koester niet de illusie, dat alle juridische studenten tot wetenschappelijke vorschers kunnen worden gevormd: zij kunnen dit zoo min als alle studenten van eenige andere faculteit. Maar zij zullen in het praktische leven telkens voor vragen van recht staan waarover geen enkele schrijver spreekt, en geene enkele rechterlijke uitspraak licht geeft. Zij moeten hebben geleerd dan zelven het antwoord te vinden. Met de mannen 'van videatur Diephuis', zooals mijn leermeester Goudsmit hen spottend placht te noemen, komt men in de praktijk niet ver. De juristen zullen zich bovendien telkens voor groepen van feiten zien

126 "Waar de rechtswetenschap eene wetenschap van de daad is, daar zal het onderwijg in haar hoofdzakelijk moeten zijin een leeren doen" (Hijmans 1902: 329). 
gesteld, waaruit zij de rechtelijke gevolgtrekking hebben te maken. Hierin moeten zij aan de universiteit worden geoefend. Bij ingewikkelde geschillen zullen zij moeten uitvinden, waar nu eigenlijk de vraag zit" (Fockema Andreae 1914: 16). In plaats van een oriëntatie op bronnen en principes waaraan het recht ontspruit, introduceert Fockema Andreae een gerichtheid op de toekomst. Dat zal hèt kenmerk of althans éen van de belangrijkste discussiethema's worden van de rechtsontwikkeling in de twintigste eeuw (Roos 1987: 6).

\section{Conclusie}

In tegenstelling tot het domein der geneeskunde vormde in de periode tussen het Organiek Besluit en de Hoger Onderwijswet van 1876 de universitaire opleiding binnen het veld van de rechtsgeleerdheid geen centraal thema van discussie. Dit verschil tussen de faculteiten der geneeskunde en der rechtsgeleerd heid is deels terug te voeren op het feit dat binnen de geneeskunde sprake was van concurrerende opleidingstypen en -tradities terwijl die concurrentie binnen de rechtsgeleerde wereld nagenoeg ontbrak. Dat hing weer samen met het uiteenlopende beroepsperspectief voor studenten aan beide faculteiten. De duidelijkheid die daarover in de medische faculteit bestond, was in de faculteit der rechtsgeleerdheid afwezig. De studie in de rechtsgeleerdheid had in de negentiende eeuw sterker nog dan in onze eeuw het karakter van een 'general-careerstudy' ${ }^{\prime \prime 2}$. In een wijdlopig artikel gewijd aan de aanstaande hoger onderwijswet in De Gids uit de jaren 1867 en 1868 schetste de staathuishoudkundige S. Vissering in grotendeels stereotype bewoordingen de diversiteit aan verwachtingen en intenties die onder de aanstaande juristen leefden ten aanzien van hun studie. Onder de studenten waren er die niets anders beoogden dan kundige en bruikbare mannen te worden, "rechtsgeleerden in den vollen zin des woords" (Vissering 1867: 413). Er waren er ook die het slechts te doen was "om zich den weg te banen naar eene of andere der vele betrekkingen en bedieningen, tot welke de titel van meester in de rechten den toegang alleen opent of gemakkelijker maakt" (413). De rechtsgeleerde studie fungeerde daarnaast

127 "Maar de juridische faculteit kan daarenboven niet geacht worden enkel tot vorming van eigenlijke rechiggeleerden daar te zijn. Men heeft de regeeringsvormen van onzen tijd weleens le régne des avocats genoemd, en het is zeker watar dat veelal de staatsman, de hooge ambtenaar, de vertegenwoordiger, de gezant zal gekozen worden uit hen, die de volkomenste opleiding genoten, di. die aan het Hoogste Onderwijs deel hebben genomen, en even zeker zullen de zoodamigen, die, niet ter wille van eenig'speciaal vak, mazr om zich in het gemeen een ${ }^{3}$ hoogeren trap wan wetenschappelijke beschaving te verwerven, de akademische lessen bezoeken, in de meeste gevallen leden zijn der juricische faculteit" (Boekbeoordeeling van 'Iets over ons Hooger onderwijs", 's Gravenhage, 1845 en "Brief aan den schrijver van Iets over ons Mooger onderwijs', De Gids 1845; 604). 
als vluchtweg voor diegenen wier krachten voor een andere studie te kort schoten. De rechtsgeleerde faculteit werd tevens bezocht door studenten die een meer algemene vorming nastreefden omdat zij een loopbaan in industrie of politiek ambieerden of zich al rentenierend aan studie en wetenschap wilden wijden. "Maar daar komen er ook, die zich niet veel anders voorstellen, dan het vrolijke studentenleven te genieten, geld en tijd op de aangenaamste wijze door te brengen, en na eenige jaren van genot met fatsoen als meester in de rechten de wereld in te treden, en aldus iets te zijn of te heeten. Daar komen er eindelijk, wie de hoogeschool alleen aantrekt omdat het vrije leven aldaar de meeste ruimte opent voor allerlei losbandigheid. Hun is het vrij onverschillig tot welke faculteit zij behooren; want als hun geld verbrast en hunne jeugd verwoest is, zullen zij weder verdwijnen zonder lets geleerd te hebben of lets geworden te zijn" (413).

De rechtsgeleerde studie behelsde van oudsher een vrij algemene introductie tot hogere ambten en functies. In die context paste geen discussie over de specifieke inrichting van de opleiding. Daar deden vraagstukken als de wenselijkheid van toelatings-, eind- of staatsexamens, voorstellen tot splitsing van het doctoraat in een staatkundige en een rechtsgeleerde richting ${ }^{128}$, of de mogelijkheid tot de promotie op stellingen - in plaats van op een proefschrift, dat overigens soms ook in opdracht werd vervaardigd (Veen 1991: 578) - en het belang van studievrijheid voor de student meer ter zake. In het tweede hoofdstuk is dit type kwesties geïnterpreteerd in de context van een transformatie in de maatschappelijke orde, waar selectie op basis van persoonlijke prestaties een steeds belangrijker rol gaat innemen. In een van de mogelijkheden ${ }^{129}$ die Vissering (1867: 420-422) aangaf om het hoger onderwijs te hervormen, wordt de centrale betekenis die selectie in het hoger onderwijs zou krijgen, kernachtig onder woorden gebracht: "[L]aat ons zorgen dat er beter gestudeerd worde. Die zoogenaamde vrijheid van studie. Is zij niet gebleken voor velen te zijn eene vrijheid om niet te studeeren? Schaffen wij alles af wat gebleken is niet meer dan ledige vorm en ijdele vertooning te zijn. Dat onhoudbare stelsel van testimonia worde opgeruimd; die pompeuse maar niets beteekenende akademische

128 De suggestie on de faculteit der rechtsgeleerdheid om te dopen tot een faculteit van rechto- en administratieve wetenschappen vindt men al in het rapport van de Commissie Roell (1828). Omdat meerderheid in de commissie van mening was dat er in het programma al genoeg vakken voor latere statsdienaren opgenomen wanen, werd het invoeren van een apart leervak in het administratief bestutur verworpen. Een suggestie voor een apart doctorat in de Kameralia stuitte eveneens bij een meerclerheid, die onder andere verwees naar de mislukking daarvan te Halle, op bezwaren. De Commisisie Van Ewijck (1849) komt wederom met het woorstel voor het invoeren van een apart doctoraall in de slaatswetenschappern. De wet op het Hoger Onderwijs van 1876 stelt zo'n apart doctorat in de staatswetenuschappen eindelijk in. Bij gebrek aan belangstelling wordt het in 1921 weer afgevoerd.

129 Waarmee Vissering het overigens niet eens is. Hij zoekt de oplossing in een herinterpretatie van het begrip orijheid. 
graden mogen verdwijnen: de examens zelve daarentegen, waar het op aankomt; worden uitgebreid en zoo noodig verscherpt. (...) één examen bij hunne intrede in de maatschappij. (...) De gelegenheid om onwaardigen, die zich thans op eenen, wie weet hoe kwalijk verdienden, titel beroepen, uit gunst in een gewigtigen post te schuiven, zal, zoo al niet geheel afgesneden, toch zeer ingekort zijn:"

De heroriëntatie op selectie, leerproces en leerprestaties neemt binnen de faculteit der rechtsgeleerheid zijn tijd. Maar het gevoel van onvoldaanheid over de inrichting en de resultaten van de juridische studie wordt geleidelijk aan sterker $^{1300}$. Wanneer de Nederlandse Juristen Vereniging in 1899 een discussie aanzwengelt over de civiele bevoegdheid verbonden aan het juridisch examen, dan is het besef aanwezig dat onderwijs in een moderne maatschappij selectie inhoudt, en dat aan onderwijs noodzakelijkerwijs eisen moeten worden gesteld. Simons (1899: 77-79) formuleert het in diens preadvies voor de jaarlijkse vergadering van de Nederlandse Juristen Vereniging in 1899 als volgt: "De studietijd voor in de rechtswetenschap studeerenden, of laat ik liever zeggen de tijd door hen als student aan de Universiteit doorgebracht, bedraagt voor hen, die zich noch aan te groote snelheid bezondigen noch hunne examenstudiën al te diep en al te grondig opvatten, gemeenlijk tusschen de vier en vijf jaar. Van die vier jaar wordt als regel zeker niet meer dan twee cursussen aan het volgen der colleges gewijd; een jaar voor de candidaats-colleges en een jaar voor de doctorale colleges. Zij die de laatste over twee jaar verdeelen, zijn (...) uitzonderingen. Daarentegen zijn er niet weinigen, die van de noodzakelijkheid van het collegeloopen allerminst overtuigd en niet hechtend aan de viva vox van den magister, hunne kennis geheel door vrije studlie, met den steun van handboeken en dictaten verzamelen, of zich die kennis doen verschaffen door de hulp van repetitoren, wier dikwijls weinig aangename taak daarin bestaat, althans bestaan kan, om ook door weinig voor juridische studiën gevormde hersenen den inhoud en strekking van onze codificatie zoo goed mogelijk te doen opnemen. Over den min of meer gelukkigen uitslag dier aldus gevoerde studiën, waarvan de tijd als regel zeker vrij wat korter is dan de duur van het studentschap,

130 Kruseman (1946) en Eyssell (1897; 133) leggen een direct verband met veranderde eisen voor thet procureurschap. Het Koninklÿk Besluit wan 1 Juni 1879 (Stbl. no. 107) had het procureurschap opengesteld voos eerieder met een promotie in de rechtswetenschappen - zonder stage of statsexamen - terwijl de benoeming tot dit ambt verviel. "Hierdoor vermeenderde het aantal advocaten, tevens procureurs, bij de colleges in aanzienlijke mate, waarbij aan het licht kwam hoe weinig zij van de rechtspraktijk afwisten bij het verlaten der universiteit" (Kruseman 1946: 13). In het Rechtsgeleerd Magazijn van 1883 wordt in de rubriek Diversa de vraag opgeworpen of de wet van 1879 voldoende waarborgen voor een goede: praktijkuitoelening bood. Zie pok Drucker (1882a: 39): "Sommigen beweren, dat de toegang tot de balue, direct of indirect, moest worden bemoeilijkt; dat de eischen voor de advocatie (...) behoorden te worden verzwaard, eene stage moest worden ingevoerd." 
moeten de (...) examina ${ }^{131}$ zekerheid verschaffen. (...) ik [meen] reeds nu zonder vrees voor betwisting te mogen zeggen dat zij als maatstaf voor bekwaamheid weinig zekerheid bieden."

Behalve de grote verscheidenheid aan beroepsperspectieven en de weigerachtigheid selectie in het onderwijs centraal te stellen valt nog een reden aan te wijzen waardoor felle discussie over de inhoud en methode van de rechtsgeleerde opleiding uitbleef. Het streven naar codificatie van het recht - een uitvloeisel van de Bataafse Revolutie - stelde de rechtswetenschap als zodanig voor grote problemen. Het zou tot 1838 duren voordat eigen nationale wetboeken zouden zijn ingevoerd. Voor die lange tijdsduur waren onder andere politieke factoren, zoals de verzelfstandiging van België (1830), verantwoordelijk. Daarnaast speelden echter ook rechtsgeleerde controverses een belangijke rol. De geleerde bestudering van het recht werd in de achttiende eeuw gekenmerkt door een oriëntatie op 'vastliggende' rechtsbronnen (zoals bij de bestudering van het Romeinse recht) of rechtsbeginselen (zoals in het natuurrecht). De wetenschappelijke benadering van het recht stond in het teken van de verklaring en uitleg van een volledig, consistent en coherent systeem van rechtsnormen: een logisch geordend stelsel van definities en principes dat op alle voorkomende gevallen toepasbaar was. Hierbij werd het als een logische vanzelfspekendheid beschouwd dat deel en geheel elkaar constitueren. Wetenschap diende naar volledigheid te streven. De vraag via welke hiërarchie van rechtsbronnen of rechtsbeginselen dat ideaal benaderd zou kunnen worden, riep al in de achttiende eeuw heftige discussie op tussen aanhangers van het rederecht en verdedigers van de romeinsrechtelijke traditie. Die discussie kleurde ook nog in de eerste decennia van de vorige eeuw het debat over de inrichting van het academisch onderwijs.

Na het tot stand komen van eigen nationale wetboeken werd, hoewel het Romeinse recht een prominente plaats in de opleiding behield, de nadruk in het onderwijs geleidelijk verschoven naar de verklaring en uitleg van de nieuwe nationale wetboeken. In de navolgende decennia stonden in discussies in de rechtsgeleerde wereld die wetboeken centraal: Hoe moest de volledigheid daarvan worden begrepen, hoe stak de verhouding tussen wetgever, wet en rechter in elkaar? De discussie over de toegelaten interpretatiewijzen van de rechter

131 "Ik schujif dit woord "examen' niet zonder tegenzin neer, want waarijk ilk gevol er weinig sympathice voor om het overgroot aantal examina, waarin ons land zich reeds mag verheugen, wederom met een te vermeerderen. Maar ik zie geen anderen nitweg" (Simons 1899: 84). De werzwaring van de exameneigen wordt uiteraard doorgevoerd op het moment dat voldoende doctoren in de rechtswetenschap beschikbaar zijn: "Er zijn in ons land voor alle betrekkingen, waarin zij noodig zijn, meer dan voldoende doctoren in de rech tswetenschap beschilbatar. (...) Bestaat er een middel om de gedachte te doen verdwijnen, dat whe voor geen andere wetenschap deugt, nog wel goed genoeg is voor jurist, dat middel moet met beide handen aangegrepen worden" (Simons 1899: 98-99; zie ook Van Bolhuis 1899: 169; Hijmans 1902: 393). 
maakte de inherente beperkingen van het wetboekenstelsel steeds meer manifest. In de tweede helft van de negentiende eeuw maakt de opvatting van recht als een systeem van normen of principes geleidelijk plaats voor een rechtsopvatting, waarin recht begrepen wordt in zijn - veranderende - maatschappelijke context en waarin die veranderlijkheid van de rechtsnorm, en met name de maatschappelijke contingentie daarin, tot uitgangspunt van beschouwing en van de organisatie van het domein van het recht wordt gemaakt ${ }^{132}$. De rechtswetenschap verliest dan haar exclusieve oriëntatie op de analyse van de rechtsnorm, haar intentie die terug te voeren op vastliggende bronnen of deze te herleiden tot algemene en liefst eeuwig geldende rechtsprincipes.

Recht en rechtswetenschap vormen dan niet langer meer een afgeleide van het streven naar een coherent stelsel van normen en rechtsprincipes, maar worden begrepen als een een onderdeel van het contingente maatschappelijke proces waarin regelgeving en regelhandhaving centraal staan en waarin wetgever, rechter en rechtswetenschapper ieder een (niet logisch dwingend ${ }^{323}$ te omschrijven) rol hebben ${ }^{134}$. Er valt een ontwikkeling te constateren "van abstract-logisch naar een meer ethisch-sociologisch gericht civiel-rechtelijk denken. Naast verandering in de inhoud van de rechtsnormen zelf staat dus tegelijk een verandering in de aanpak van juridische problemen" (Heyman 1973: 248). Die veranderde visie klinkt door in de discussies over de inrichting van het onderwijs. De vormende aspecten die aan het Romeinse recht worden toegedicht, verschuiven onder invloed van de Historische school van de oefening in formeel-logisch en abstract denken naar het geven van inzicht in de ontwikkelingsaspecten van het recht. De dogmatisch-systematische aanpak verliest steeds meer terrein, ten gunste van een benaderingswijze waarin de

132 Aan het ideaal dat de wetenschappelijke beoefenaar van het recht ooit gezien had in het bereiken van volkomen zekerheïd in zake beslissingen over recht en onrecht komt dan definitief een einde: "In de zeventiende eeuw ontratat, mede onder invloed van het heersende, door wiskunde en natururwetenschap bepaalde watenschapsideal, het streven de rechtswetenschap te ontwikkelen tot een rekenen rnet begrippen, om zo een mechanische zekerheid in de rechtspleging te bereiken, waaraan men in die tijd van rechtsverscheidenheid en willekeur zo grote behoefte had. Rond het midden van de negentiende eeum bereikt het streven maar dit ideal zijn hoogtepunt, dat tegelijk een keerpunt is. Het geloof dat een abstract begrippenstelsel met mathematische zekerheid rechtvaardige beslissingen kan producwen hebben wiy al lang niet meer" (Van den Bergh 1980: 5; zie ook Van den Bergh 1982; Shapiro 1983: m.n. 29; Toulmin 11990: $55-56)$.

133 "Men beweere niet, dat door zoodanige rechtsbeschouwimg alle rechtseenheid, ja alle rechtszekerheid te loor gaat. Te loor gant alleen datgene, waarwan het bezilt reeds is gekregen; mijn sustenu is juist, dat wiij op vele punten geen rechtseenheid, geen rechtszekerheid bezitten, waar zij door velen ten onrechte voorondersteld wordt. Hot recht is nu eenmal, geen toegepaste mathesis, geen vak, waar slechts logisch denken wordt gevorderd, om allen tot hetzelfde resultat te komen" (Naber 1889: 17-18).

134 "[R]elativering van de eerbied voor de wetgever, toenemende orièntatie op nieuwe noden van een zich in snel tempo industrialiserende malschappij, $(n+1)$ een verandering in wetenschappelijke opvattingen (...): niet alleen de rechtsnorm is meer voorwerp wan onderzoek, maar ook de toepassing ervan, alsmede haar geschiktheid voor het oplossen van concrete problemen." Kop (1987b: 231). 
ontwikkelingsaspecten en uiteindelijk de historische contingenties in het Romeinse recht benadrukt worden ${ }^{135}$. Het observeren van het functioneren van de rechtsnorm in de maatschappelijke praktijk en het beoordelen van de adequaatheid van de rechtsnorm in de actuele situatie krijgen steeds meer nadruk. Onder andere komt dat tot uitdrukking in het toenemende belang dat aan een vak als staathuishoudkunde wordt toegekend, terwijl binnen dat vak weer van een inhoudelijke transformatie sprake is. De faculteit der rechtsgeleerdheid vormt het organisatorisch kader voor de opkomende economische en sociale wetenschappen. Evenals in de medische faculteit wordt met het verschuiven van de opvattingen over de verhouding tussen theorie en praktijk, de roep om praktisch onderwijs luider. 


\section{$\mathrm{V}$ \\ Geleerdheid en Wetenschap}

\section{Inleiding}

In de voorafgaande hoofdstukken zijn veranderingen in de maatschappelijke organisatie van het hoger onderwijs en meer specifiek in de inrichting van het onderwijs in de faculteiten der geneeskunde en rechtsgeleerdheid bezien vanuit een bepaald perspectief op modernisering. Sociale systemen worden op het meest basale niveau beschouwd als opgebouwd uit communicatieve processen, waarvan de (wijze van) voortzetting onzeker is. Collectief beschikbare verwachtingsstructuren maken die maatschappelijke onzekerheid hanteerbaar door bepaalde communicatieve aansluitingen als zinvol te accepteren en andere af te wijzen. Modernisering is vervolgens opgevat als een kwalitatieve omslag in de toegelaten, zinvolle communicatieve bijdragen. Alle drie behandelde maatschappelijke domeinen worden aanvankelijk gedomineerd door hiërarchische indelingen gebaseerd op criteria waarin de ontwikkeling in de tijd geen rol speelt of daaraan een grote mate van voorspelbaarheid en continuiteit wordt toegedicht. Geleidelijk boeten dergelijke hiërarchische indelingen aan kracht in. Maatschappelijke domeinen worden vervolgens gedefinieerd en op elkaar afgestemd door ze direct op een proces te betrekken, waarvan de tijdsafloop principieel onzeker is. In hoofdstuk twee is getoond hoe dat onder andere weerspiegeld wordt in een betekenisverschuiving van de indeling in lager, middelbaar en hoger onderwijs.

Doordat de Nederlandse universiteit in de negentiende eeuw in eerste instantie een onderwijsorganisatie was, zijn de ontwikkelingen van de universiteiten beschreven door discussies over de inrichting van het onderwijs te volgen. In de paragraaf 'materiële en formele vorming' wordt daarop min of meer parafraserend teruggekeken, onder andere door de debatten over de organisatie van het onderwijs in de geneeskunde en in de rechtsgeleerdheid met elkaar te vergelijken. Gemeenschappelijk kenmerk van de veranderingen binnen het onderwijs is het verlaten van de oriëntatie op bestaande en vastliggende bronnen en altijd geldende principes, ten gunste van een opener oriëntatie op de toekomst. De waarneming van de veranderlijke werkelijkheid krijgt zowel binnen het domein van de geneeskunde als in dat van het recht een voorheen ongekend belang. 
Dat verleggen van de aandacht van vastliggende bronnen naar de waarneming van de actuele situatie maakt deel uit van een veelomvattende transformatie van het kennisideaal. Dat is het onderwerp van de paragraaf 'Modernisering en de disciplinaire organisatievorm van wetenschap'. Aanvankelijk staat het kennisideaal in het teken van een streven naar 'geleerdheid', de samenkomst van kennis, beschaving en inzicht in één persoon. Nog in de loop van de negentiende eeuw zal 'wetenschap', het communicatieve proces rondom een beperkt aantal controverses, die persoonsgebonden geleerdheid naar de achtergrond dringen. Mulder (1883: 157) brengt die tijd van overgang in een terugblik op zijn leven bloemrijk onder woorden: "Onze tijd wil van geen isolement meer hooren en eischt de zoogenaamde geleerden midden in de maatschappij. (...) Ik voor mij ben ouder geworden in een tijd van overgang (...) van geleerdheid tot useful knowledge. Ik heb de heeren nog amylum in hun haar zien dragen, $\mathrm{C}_{12} \mathrm{H}_{10} \mathrm{O}_{30}$, wat men later alweder anders geschreven heeft, en van de staarten in de nekken der Mijne Heeren heb ik nog een staartje gezien." In tegenstelling tot de voorafgaande drie hoofdstukken, die vrijwel uitsluitend gebaseerd zijn op historisch materiaal ontleend aan de Nederlandse universiteiten, wordt voor de tweede paragraaf een beroep gedaan op onderzoek naar de ontwikkeling van de Duitse universiteiten. Dit vijfde hoofdstuk wordt afgesloten met een paragraaf die ingaat op de veranderende plaats van de universitaire bibliotheken en kabinetten, die de wijziging van kennisclaim op een specifieke manier demonstreren.

\section{Materiële en formele vorming}

Nederlandse universiteiten zijn in het begin van de negentiende eeuw onderwijsorganisaties. Onderzoek - in de moderne betekenis van het woord - zou pas in de tweede helft van de negentiende eeuw een zelfstandige plaats binnen de universiteiten verwerven. Ideeënuitwisselingen en controversen over het doel en de organisatie van het hoger onderwijs betreffen aanvankelijk uitsluitend het onderwijs. Een vergelijking tussen de domeinen van het recht en de geneeskunde brengt naast verschillen ook een aantal overeerkomsten aan het licht. Zowel in de rechtsgeleerde als in de geneeskundige faculteit wordt in de loop van de negentiende eeuw gepleit voor meer praktisch onderwijs. Daarbij wordt eerst de associatie van praktijk als tegengesteld aan theorie en de associatie van praktijk als synoniem met ervaring" doorbroken, om vervol-

1 Ten aanzien van het anderwijs zelve valt op te merken de strekking, om bij de zuivere theoretische lessen, ook te voegen eene meer praktische opleiding voor de waarneming van den stand of het beroep, waaraan de jonge lieden zich denken te wijden." (Verslag nopens den staat der hooge, middelbare en 
gens een visie van praktisch onderwijs te bepleiten waarin niet langer de nadruk ligt op het verwerven van routines maar op het waarnemen van processen die zich in de actualiteit afspelen.

Opvallend is dat veranderingen binnen het onderwijs eerder worden aangekondigd en bepleit als een verandering van onderwijsmethode of van onderwijsvorm dan als een directe ingreep in het vakkenpakket ${ }^{2}$. De argumenten die bijvoorbeeld Mulder aanhaalt om een onderwijslaboratorium aan de universiteit van Utrecht in te richten zijn hoofdzakelijk didactisch van aard en worden grotendeels ontleend aan de vormende waarde die van de zelfstandige beoefening van de natuurwetenschappen uitgaat: "[K]ennis, in den zin van weten, is het geenszins, wat den geneeskundigen vormt. Zijn waarnemingsvermogen moet tot eene hooge mate ontwikkeld worden, en daartoe dient eene opscherping van zijne zintuigen (...) zou niet reeds daarom alleen u die Natuurstudie eene even onmisbare behoefte toeschijnen voor uwe ontwikkeling als aanstaande geneeskundigen, als gij daartoe het aanleeren van eene taal hebt noodig gehad?"f (Mulder 1842a: 328). Dat deze onderwijskundige innovatie samenhangt met de ontwikkeling van de organische chemie blijft in de argumentatie van Mulder op de achtergrond. Evenals bij G.C.B. Suringar (1855: 248) wanneer deze het nut van de beoefening van de natuurwetenschappen aan de gymnasia bespreekt: "[W]egens haren belangrijken invloed op de formele ontwikkeling van het verstand en de veredeling van het hart" moet aan de natururstudie een belangrijke plaats op de gymnasia worden toegedicht. Ook hier blijft de inhoud van de nieuwe vakken die in het curriculum een plaats vinden, op de achtergrond.

Van de andere kant illustreren de verschuivende ideeën over het belang van het Romeinse recht in het rechtsgeleerde onderwijs dat zodra een heel domein haar oriëntatie verandert, de leerdoelen die met een bepaald vak te realiseren vallen gaandeweg bijgesteld kunnen worden. Het grote belang van het Romeinse recht in het rechtsgeleerde onderwijs dat aanvankelijk geacht wordt gelegen te zijn in de vormende waarde die uitgaat van de helderheid en logica van haar systeem van begrippen wordt, op het moment dat recht primair vanuit zijn dynamische, maatschappelijke context wordt benaderd, gaandeweg

Lagere scholen over het jaar 1829, A!gemeene Konst en Lutterbode, (1831) deel II: 162).

2 Zie voor het samengaan van pedagogische en kennisinhoudelijke ontwikkelingen ook bijv. Kuenzli (1981: 160): "[T/he thesis of a convergence of "Lehre', method and justification is supported and illustrated on the basis of the historic case of Ritter-Pestalozzi".

3 "Het grate voordeel toch, dat aan de beoefening der natuurstudie [boven mathematische studiën], als vormings- en opvoedingsmiddel verbonden is, moet, naar het oordeel van Engelands helderdenkenden wijsgeer [W. Whewell], vooral hierin gezocht worden, dat het begrip van overeenkomst en verschil. waarop alle beschrijvende natuurwetenschappen steunen, in onze ziel opgewekt en gedurig tot grooter juistheid gebracht wordt" (Suringar 1855: 308). 
verlegd. Het Romeinse recht wordt dan een toonbeeld van geleidelijke ontwikkeling en kan de studenten juist met die dynamische aspecten van het recht vertrouwd maken. Eerst was kennis van de bronnen van het Romeinse Recht eigen aan de rechtsgeleerde theorie terwijl de praktijk met ervaring werd geassocieerd. Wanneer echter de visie de overhand krijgt dat theorie en praktijk een eenheid vormen, blijken ook de Romeinen die eenheid van theorie en praktijk al te hebben gerealiseerd. Sterker nog, ook dan kunnen de Romeinen weer als ideaalbeeld voor de studenten fungerent.

Op basis van pedagogische argumenten worden nieuwe onderwijsmethodes en zelfs nieuwe vakgebieden binnen de universiteit geïntroduceerd. Heeft echter - vanaf de tweede helft van de negentiende eeuw - het idee postgevat dat (hoger) onderwijs rond de notie van een individueel leerproces moet worden opgebouwd, dan komt ook een beweging op gang pedagogische van vakinhoudelijke oordelen te onderscheiden. Na het tot stand komen van de eenheid van stand (1865) en het monopolie van de universitaire opleiding tot arts, wordt een volgend discussiethema binnen de geneeskundige faculteit hoe de vele opkomende specialismen op een onderwijskundig verantwoorde wijze in het studieprogramma onder te brengen. Uiteindelijk worden dan de pedagogische argumenten die eertijds aangevoerd werden om veranderingen in het curriculum aan te brengen, ontmaskerd. J. Schwalbe (1918: 51) stelt bijvoorbeeld de zin van het zelfstandig snijden aan de sectietafel weer ter discussie: "Ich bezweifle, daß die Sektionstechnik einen integrierenden Bestand teil des pathologisch-anatomischen Unterrichts bildet, daß sie unentbehrlich ist für die Förderung des pathologisch-anatomischen Verständnisses und Wissens. Bei der vorgenommenen Obduktion lernt der Studierende nicht wesentlich mehr von der pathologischen Veränderungen der Organe, als wenn ihm diese vom Lehrer vorgelegt werden. (...) Die Stellung die die Sezierübungen im Unterricht der pathologischen Anatomie einnehmen, schreibt sich aus der Zeit her, in welcher diese Wissenschaft bei uns unter Virchow sich ihren Platz erobern mußte und wo jedes Mittel, das zur Erreichung des Zieles diente, einen besonderen Wert beanspruchte."

De verwevenheid van vakinhoudelijke, pedagogische en didactische overwegingen komt ook binnen de rechtsgeleerde faculteit naar voren. H. Hijmans (1902: 221) signaleert verbaasd dat de vraagstukken die op de vergadering van de Nederlandsche Juristen Vereeniging (1899) ter discussie stonden onderwijs-

4 " $[\mathrm{I}] \mathrm{n}$ elke eeuw wisselen ook de inzichten, omtrent den grond, wraarom het Romeinsche recht onze aandacht verdient. (...) Ten einde te reageeren tegen het rationalisme van de achttiende eeuw" wierp men zich in de armen van het zuuvere Romeinsche recht, en nawwelifks heeft men dit door nauwgezette geschiedvorscling beter doorgrond of men wendt er zich weder van af en werlangt niets liever, dan het weer aan de geschiedenis terugtegeven" ( $\mathrm{D}^{\prime}$ Ablaing 1882: 32). 
kundige vragen betroffen, die om een specifiek onderwijskundige benadering vroegen, terwijl dat door niemand onderkend werd: "Wij bevinden ons hier op het gebied van het onderwijs en de vragen, die zich voordoen, zijn dus in eerste linie paedagogische vragen en moeten mitsdien volgens paedagogische beginselen behandeld en opgelost worden. Dit is eene zeer eenvoudige waarheid, maar tot dusverre in Nederland niet ingezien. (...) In deze negeering der paedagogie ligt m.i. de hoofdfout van het rechtsgeleerd onderwijs aan onze universiteiten." Hijmans (1902: 344) formuleert vervolgens een aanzet tot een pedagogiek van de juridische wetenschappen ${ }^{5}$ en laat zich daarbij leiden door een drietal maximes ontleend aan $\mathrm{H}$. Schillers "Handbuch der praktischen Paedagogik' (1894): "[D]ass der Unterricht vom Nahen zum Fernen, vom Leichteren zum Schweren, vom Bekannten zum Unbekannten, vom Einfachen zum Zusammengesetzten fortschreite." Wanneer Hijmans vanuit dat perspectief de vraag oppakt of de rechtsgeleerde studie met het Romeinse recht dient aan te vangen, komt hij tot een negatieve conclusie. Volgens hem worden in de discussie drie zaken verward: de historische bronnen van het geldende recht, de wetenschappelijke fundamenten van ons kennen van het recht en pedagogische overwegingen ten aanzien van het onderwijs in de rechten: " $[\mathrm{H}]$ et historische prius is niet uit den aard der zaak het paedagogisch prius. (...) Eerst moet de stof zelf gekend worden, dan eerst is historisch inzicht in haar wording te openen" (Hijmans 1902: 261). In de verdere loop van de studie ziet hij enkel nog plaats voor een beperkte behandeling van het Romeinse recht. Van de traditionele argumenten voor een vooraanstaande plaats van het Romeinse recht in de juridische opleiding laat hij geen spaan heel. "[H]et prachtige rechtssysteem" $^{\prime \prime}$ is lang zo prachtig niet en meer een hedendaagse constructie dan Romeins. Het Romeinse recht als middel tot het aanleren van deductie? De wenselijkheid daarvan vermag Hijmans (1902: 218) niet in te zien. Immers "de rechtswetenschap [is] vóór alles eene wetenschap der levende werkelijkheid, de inductieve methode de in deze wetenschap heerschende." Bovendien leert de student de methode het best "bij de beoefening van het recht, hetwelk hij

5 "[W]] har feitelijk de moderne paedagogie in hoofdzaak op neerkomt [is] op steeds ingrijpender toepassing der inductie (...) hoe ook bij het rechtsgeleerd onderwijs de inductie kan aangewend worden" (Hijmans 1902: 342).

6 Hijmans (1902: 256-262) geeft ook argumenten van buiten de pedagogiek: "1. Het Romeinsche recht bevat een menigte van rechisinstituten, welke in het moderne recht onbekend zijn. 2 . Het moderne rechlt heeft een menigte van rechtsinstituten woortgebracht welke aan het Romeinsche recht vreemd waren. 3. Het Romeinsche recht bevat een massa begrippen in onontwikkelde gedaante, die eerst door dle moderne wetenschap tot volkomenheid gebracht zijn. Om deze drie redenen is het Romeinsche recht dus niet geschikt tot voorbereiding van het tegenwoordig recht (...) Zoolang het Romeinsche recht geldend recht was, was het zeer op zijn plaats de rechtsstudie met eene inleiding in dat recht aan te vangen; waar het Romeinsche recht zijne heerschersrol verloren heeft, is deze inleiding niets dan een atavistisch overblijfsel, dat hoe eerder hoe beter verdwijnen moet." 
zelf naderhand zal hebben toe te passen: dit en niet eenig vreemd of gestorven recht, moet hij naar alle zijden doordenken:" Hijmans erkent slechts drie argumenten om nog - zij het in zeer beperkte mate - aandacht aan het Romeins recht in de opleiding te blijven schenken: Het hedendaagse recht gaat inderdaad op het Romeinse recht terug, de Romeinse juristen blijven om hun genie lezenswaardig en bovendien is het Romeins recht een lichtend voorbeeld door zijn grote aanpassingscapaciteit aan veranderende sociale behoeften. Volgens hem moet de juridische opleiding georganiseerd worden rondom de latere beroepen ${ }^{7}$, die uiteraard niet vast liggen maar in de loop der tijd zullen veranderen. Na een gemeenschappelijk jaar wordt het curriculum gesplitst over drie opleidingsstromen. Kritiek anticiperend, pakt ook hij het thema van eenheid en specialisering op ${ }^{8}$.

Doordat in de negentiende eeuwse discussie over het hoger onderwijs vakinhoudelijke en pedagogische inzichten niet worden onderscheiden, terwijl zowel voor- als tegenstanders van onderwijskundige vernieuwing zich met graagte beroepen op het onderscheid tussen materiële en formele vorming" (De Gelder 1841; Over het onderwijs van de wiskunde 1841; Lamping 1859; Vitringa 1860), en daarbij op de formeel-vormende aspecten van methoden of vakken de nadruk leggen, hebben discussies over het onderwijs veelal een ongrijpbaar karakter. Onderwijshervormers benadrukken de formele vorming die van de natuurwetenschappelijke methode of van de wiskunde uit zou gaan (Harting 1858; Rosenstein 1871). Meer behoudenden wijzen in dat verband op het Latijn. Van het Latijn was veel, zo niet alles te verwachten: "[T]raining van het geordende, logische denken, ontwikkeling van onderscheidings-en combinatievermogen, oefening in accuratesse en volharding en het aankweken van het vermogen zich aan te passen aan een vreemde gedachtengang en uitdrukkingswijze" (Idenburg 1960: 209). Een dode taal, juist omdat het niet onze moedertaal is, zou dwingen tot nauwkeuriger werken en denken ${ }^{10}$. Door

7 Hijmans onderscheidt hierbij een civielrechtelijk, een strafrechtelijk en een staatsrechtelijk clustier wain beroepen.

8 "Ik misken geenszins de eéntheid der rechtswetenschap en daarom verlang ik ook (...) in den tanvang der rechtsgeleerde studie een aan alle studenten gemeenschappelijk onderricht in de grondslagen wan de hoolf dvakken der verschillende groepen. (...) Splitsing, specialisering is steeds onaangenaam, matit hier drijtit de nood. Ontwilkkeling en verdieping der rechtswetenschap is zonder haat ene onmogelijkheid. Wie het laatste begeert moet dus ook met het eerste genoegen nemen" (Hijmans 1902: 293).

9 De term "formele worming" krijgt in de context van het talenonderwijs in de loop van de negentiende eeww een beperktere betekenis dan hij aanvankelijk had: "Aanvankelijk opgewat in de zin van een alzijlige getstelijke on twikkeling (waarbij de keuze van de an de leerling ter bewerking aangeboden "stof" geheel ondergeschikt werd geacht aan het resultaat, d.i. de "vorming', vandaar de qualificatie 'formal"), werd hij later gebruikt in de zin van denkscholing en uiteindelijk in de zin van grammaticale denkscholing" (Wan Dhyvendijk 1955: 139).

10 "De nieuwe talen bevatten niet zoo veel oefening voor den geesit. Minder" veranderingen van den worm der woorden en, wat van zelf "t gevolg hiervan is, minder ingewikkelde konstruktiën, mopen den 
pleitbezorgers van de moderne talen (Rosenstein 1871) wordt dat juist weer ontkend. Volgens Pruys van der Hoeven (1828: 135-136) zijn de klassieken voor de aanstaande arts onontbeerlijk. Niet alleen omdat de terminologie der geneeskunst aan de oude talen is ontleend maar ook omdat een klassieke vorming de dokter zal "behoeden voor dien barbaarschen onzin, welke de schriften der medici zoo dikwijls onverstaanbaar doet zijn. Het zal hem in staat stellen tot die gezonde kritiek, welke in eene kunst zoo vol kwakzalverijen, verdichte, of opgesierde waarnemingen, verzonnen proeven, wonderkuren, hoogdravende theorien, zoo menigmaal door onkundigen, of oningewijden beoefend, ons bovenal te stade komt."

Veelal wordt het blijven vasthouden aan het Latijn geinterpreteerd als uitdrukking van de wens een gemeenschappelijk statuselement van de geleerde stand overeind te houden. Dat is juist, echter slechts één kant van dle medaille. Het opgeven van het Latijn betekent ook het loslaten van een traditie waarin kennis doorgegeven wordt door de overgeleverde boeken te bestuderen en te annoteren ${ }^{11}$. Het Latijn staat voor een bepaalde opvatting van wat kennis is, wat belangrijk en voornaam is. "Latijn en Grieksch (...), het eerste als de taal der Geleerde wereld, de sleutel van alle wetenschappen: en beide te zamen als de beste hulpmiddelen, om tot de bronnen zelve van alle menschelijke kennis en van ware geleerdheid door te dringen" (Over het onderwijs 1840: 163). Het responsiecollege waarbij studenten op vastliggende vragen voorgeschreven antwoorden dienen te geven, is de vertaling van die opvatting in een concrete onderwijspraktijk. Het vervangen van het Latijn door de moedertaal houdt in dat een comtemporaine bijdrage of waarneming belangrijker geworden is dan kennis van de traditie. Het verdwijnen van het Latijn als academische voertaal is niet alleen een verandering van omgangstaal, maar eveneens een breuk in het kennisideaal ${ }^{12}$. In de achttiende eeuw werd nog als het ging om het belang van de klassieken het intrinsieke belang van Griekse en Latijnse schrijvers als primaire bronnen voor alle wetenschappen benadrukt. Dat de klassieke talen een volkomenheid kennen die de moderne ontberen - en die de klassieke talen daarom zoveel geschikter makt - is dan slechts een afgeleide (Van Duyvendijk 1955: 185).

geest veel zeldzanter om elk bijzonder gevall als de toepassing van een taalwet te beschouwen" (Vitringa $1860: 17$ ).

11 "Wie in de achttiende eeuw wetenschappelijk wooruit wenste te komen, moest eruditie nastreven (...). De angewezen methode was de door Hemsterhuis angeprezen adinotandi consuchudo, het annoteren wan teksten bij lezing" (Roelevink 1986: 139).

12. Huizinga (1941: 10) spant - overigens in navolging van de Staatscommissie van 1849 (Idenburg red. 1927: 76) - het paard achter de wagen als hij stelt dat het Latijn "de lenigheid die de Nederlandsche geest noodig had om zich de nieuwere wettenschap eigen te maken een tijdlang ten zeerste [heeft] belem. merd." 
Dat het Latijn niet alleen een statuselement vormde, maar ook refereert aan een bepaald kennisideaal, wordt expliciet geformuleerd in Pruys van der Hoevens artikel 'Over het belang en de voordeelen eener klassieke vorming voor den toekomstigen geneesheer' (1828): "[D]e kennis der oude talen, inzonderheid van het Latijn; eene kennis voor den welopgevoeden medicus even onontbeerlijjk als de natuurkundige wetenschappen. Het Latijn toch was eeuwenlang de algemeene taal der geleerden, waar alle werken van studie in gesclireven, alle wetenschappelijke onderwerpen in behandeld werden" (130). Door het invoeren van de moedertaal als geleerde taal in de nabuurlanden "zijn aldus volken van volken afgezonderd; maar ook tusschen de oude en nieuwe geleerde wereld is eene (...) scheidsmuur opgerigt" (132). De gevolgen van het afschaffen van het Latijn zullen naar Pruys van der Hoevens verwachting desastreus zijn: "Wilde men beweren, dat dit verlies voor den medicus niet zoo groot zou wezen, men zou zijne onkunde zoowel in de Litteratuur, als in den aard onzer wetenschap aan den dag leggen. Immers onze voortreffelijkste schrijvers hebben in 't Latijn geschreven. In het Latijn vindt men de beste waarnemingen (...) de belangrijkste ziektebeschrijvingen, de grootste uitvindingen opgeteekend. (...) ik ben overtuigd dat men door het Latijn wegteschrappen, onze kunst de noodlottigste tiercering zou doen ondergaan.(...) Want de geneeskunde dagteekent niet van de XIXde Eeuw, zij is geene uitvinding van onzen leeftijd, maar verliest zich in ver verwijderde tijdvakken. $\mathrm{Zij}$ behoort tot de empirische wetenschappen en berust als zoodanig op de getuigenissen van meer dan twintig eeuwen (...) [Zij kan] evenmin de ondervinding van het voorgeslacht, als die der tijdgenooten missen. (...) Door het afschaffen der Latijnsche taal bij het onderwijs ontrukt men de leerlingen de beste schrijvers, stopt voor hen de bronnen onzer studie" (133). Voor het domein van de rechtsgeleerdheid formuleert Van Reenen (1836: 44-45) de verwevenheid van het Latijn met een intellectuele traditie, die kennis van de (logische opbouw der) bronnen en kennis van rechtsprincipes hoger waardeert dan kennis van de contingente werkelijkheid. Een leerboek in de Nederlandse taal wordt afgekeurd, want "dan mist de jongeling de kennis van alles, wat bij andere volken gedaan wordt en gedaan is: hij mist het voordeel, dat er bestaan heeft, toen er in eene taal over de verschillende onderwerpen des Regts geschreven werd, door mannen van verschillende volken ${ }_{n}$ die met verschillende in kracht zijnde wetgevingen bekend waren, en in hunne schriften, allen dezelfde leiding en beginselen volgden. (...) ik vraag alleen, wat beter en gemakkelijker zij? Welke bekwaamheid men gemakkelijker kan veronderstellen in een" jongeling: die, om Latijnsche geschriften over éen stelsel wel te behandelen (...); of die, om in verschillende hedendaagsche talen, welker volkomene en grondige kennis, hij dan toch niet gemakkelijk bezitten zal, verschillende stelsels, zoo te behandelen, dat hij de wetenschap zelve volledig leere kennen." 
Hoe snel en hoe rigoureus de transformatie ${ }^{13}$ in de negentiende eeuw zich voltrok, moge blijken uit het gegeven dat de zojuist geciteerde Pruys van der Hoeven nog geen veertig jaar later opmerkt: "Sints 1848 heb ik dat [het verplichte gebruik van het Latijn] kunnen veranderen en er mij wel bij bevonden, ja, zou het Latijn niet terugwenschen. Men spreekt toch zijne landslieden in de landstaal en waarom zou men dan zijne medestudenten en vrienden niet in dezelfde taal toespreken?" (Pruys van der Hoeven 1866: 185; 267). De Perponcher (1816: 100) noemt het Latijn nog "een der onontbeerlijkste grondslagen van alle geleerdheid". Rauwenhoff (1872: 21-22) heeft er enkel nog denigrerende woorden voor over: "Zooals zij hunne namen omzetten in het Latijn, zoo minachtten zij alles wat niet in hun heilige taal was gesteld en in hun academische vormen was gekleed. Wat waren die vormen meestal anders dan een schoolsch formalisme, waaraan hun pedanterie zich te goed deed, maar waaronder zich louter doode veelweeterij verschool."

\section{Modernisering en de disciplinaire organisatievorm van wetenschap}

Rauwenhoff zet zich in 1872 af tegen het Latijn als academische voertaal en het daarbijbehorende kennisideaal. In de periode tussen 1815 en 1876 maakt aan de universiteiten geleerdheid plaats voor wetenschap. Volgens het Organiek Besluit van 1815 is de eerste taak van de hogescholen gelegen in de introductie van de studenten in de geleerde stand. Daarmee wordt een koppeling gelegd tussen hoger onderwijs, geleerdheid en status. Geleerdheid is aan de persoon ${ }^{\text {t4 }}$ van de hoogleraar verbonden en staat zo direct in dienst van het onderwijs. De Commissie van 1828 had expliciet aan de universiteiten de vraag voorgelegd hoe deze de relatie tussen geleerdheid en hoger onderwijs ${ }^{15}$ zagen. Tyde-

13 In 1855 verleent de Minister van Binnenllandse Zaken toestemming aan dle curatoren om promoties in de Nederlandse taal goed te keuren. (Algeneene Konst en Letterbode, 185515 sept, no. 37).

14 Zie ook Van Heusde (1829; 5): "[Z]onderling is het, hoe geheel andere begrippen zich sommigen thans van Hoogescholen vormen, dan anze voorouders hadden. Deze beschouwden dezelfde als zetels van geleerdheid; Hoogleeraren als geleerden, die in Europa uitblonken; sttudenten als jonge menschen, die hier de latste hand aan hunne vorming voor de maatschappij legden: en zoo denkt men wor nog heden in Duitschland over". Het middel tot verbetering van het onderwijs aan de hogescholen moet dan ook niet in "verordeningen en voorschriften" gezocht worden, "maar door op de personen achtteslaan, die ze moeten uitvoeren, deze aantemoedigen door verbetering en verhooging van hunnen stand in de maatschappij, en dit niet alleen door vermeerdering van jaarwedde of voordeelen, maar bijzonder door nienand in hunne orde toegang te verleenen, dan die op eene akademie blijken heeft gegeven van gen beschaald en kundig man te zijn" (63).

15 "Uit welk oogpunt moeten de Hoogescholen in den tegerwwoordigen tijd beschouwd worden? Zjpn zij voormamelijk vereenigingspunten van kennis en wetenschap, werwaarts zij allen zich begeven, die door dorst tot kenuis, daartoe worden genoopt? Of zijn zij voornamelijke hoogere scholen en landsinstellingen, meer bepaldielijk ten doel hebbende de vorming van bekwame Staatsdienaars en Staatsburgers? 
mans antwoord (1828: 35) is heel beslist: "De onbestemde dorst naar kennis en wetenschap, zonder opzigt tot den staat en het belang der Maatschappij is buiten de Regering. (...) De hoogere scholen en landsinstellingen, door de Regering daargesteld, ingerigt en verzorgd - door de Natie bekostigd! - kunnen of mogen geen ander bepaald doel hebben dan de vorming van bekwame staatsdienaars en staatsburgers". Voor B.L.G (1824: 5) behoort het echter vanzelfsprekend ook tot de taak van de hoogleraar op de hoogte te blijven van de stand der wetenschap: "Zoude ook het waarnemen van het onderwijzerschap aan de Hoogescholen blootelijk en alleen daarin bestaan, dat men zoo enige opstelletjes, Dictaten geheeten, voor de jeugd zamenflanste; of zoude er ook toe behooren, dat men voor zich zelven en voor het belang der letteren in het algemeen door bleef studeren, zijne kennis telkens verder poogde uit te breiden, door geschriften deze kennis meer en meer algemeen zocht te maken, kortom niet alleen voor de studenten, maar ook, voor zoo ver zulks doenelijk en noodig is, voor de wetenschap, als wetenschap zelve te leven?".

J. Bake (1828: eerste brief 8) sluit zich hierbij aan: "De hoogste trap van onderwijs vordert van hem, wien dit is toevertrouwd, dat hij of door eigen vlijt en geest zijne wetenschap doe vorderen, of ten minste met de vorderingen, door anderen gemaakt telkens bekend zij, ze beoordeele, en ze ten nutte van zijn onderwijs gebruike". Bake (1828: eerste brief 22-24) gaat nog verder ${ }^{16,}$ " Intusschen, bij de allengs toenemende uitbreiding der belangstelling en de meer en meer noodzakelijke splitsing der wetenschappen zelve, bleven onze Universiteiten $^{17}$, ten minste, op dezelfde voet, als bij hare oprigting, dat wil zeggen, zij ontaardden van de betrekking, die zij toen op den stand der wetenschappen hadden, in eenvoudige leerscholen voor de behoefte van de maatschappij. (...) Men behoort zich niet te vreden te stellen met wetenschappen, waarvan de toepassing tot de tegenwoordige behoefte des levens zigtbaar, en voor een ieder handtastelijk is." Wegens de aan de universiteiten voorhanden, gezonde onderlinge naijver tussen de onderzoekers, is de universiteit meer geschikt voor het doen van onderzoek dan instituten en genootschappen, die "juist daardoor het doel missen, dat alles tot gemeenschappelijk eigendom gevorderd wordt" (28). Onderwijs is in de ogen van Bake de tweede en ondergeschikte taak van de universiteit. Onderwijs staat in dienst van de wetenschap doordat het de hoogleraar op manco's en lacunes in zijn kennis wijst ${ }^{18:}$ " [M]e-

(Commissie 1828, in Tydeman 1828: 35).

16. Voor een goed - err welwillend - lezer blijkt dat al wit het feit dat Bake expliciet 'universilteiten' en mist "hoogescholen" vermeldt in de titel.

17 "[D]e universileiten (...) welke in de eerste plaats een verzameling moeten zijn van bedrevene, en met roem bekende mannen, in ieder vak van wetenschap, zoo wel, als in derzelver ontelbare onderdeelen" (Bake 1828: eerste brief 27).

18 "Hoe menigmaal gebeurt het niet, dat die kundigheid, "t zij door vroegere leiding, 't zij) door be- 
nig punt van onderzoek, hetwelk, zelfs na veel arbeid, in het studeervertrek slechts tot een duister en onontwikkeld resultaat brengt, door de noodzakelijkheid zelve van het medetedeelen, en er over te onderwijzen, eene opheldering en duidelijkheid erlangt, die men te vergeefs uit en voor zijne eigene studie zou verwachten" (Bake 1828: 6). De Senaat van de Hoogeschool te Utrecht maakt in haar reactie op de circulaire van de Commissie 1828 duidelijk ervan uit te gaan dat de hogeschool beide taken moet vervullen: zowel ambtenaren ten behoeve van de staat vormen als fungeren als verenigingspunt van kennis en wetenschap: "Omdat zij vereenigingspunten zijn, zoo veel mogelijk, van alle menschelijke wetenschap, kan iedereen daar bevrediging vinden, voor zijne begeerte tot kennis. Niet die wetenschappen alleen, waarvan de invloed op de behoeften van het maatschappelijk leven onmiddelijk en zigtbaar is, worden aan de Hooge Scholen onderwezen, maar ook die vakken van kennis, waarvan men nog niet kan inzien, welk een invloed zij welligt eenmaal zullen uitoefenen op de behoeften of ten minste op de versiering van de maatschappij" (Inlichtingen 1828: 1).

Overwegend ${ }^{19}$ heerst aan het begin van de vorige eeuw de mening dat de geleerdheid van de hoogleraar in dienst staat van zijn onderwijstaken. In de "Verslagen omtrent de toestand der lage, middelbare en hoge scholen', worden in eerste helft van de negentiende eeuw universiteiten - en meestal spreekt men dan ook over hogescholen - steeds onder de noemer van hoger onderwijs behandeld. Geleidelijk aan wordt wetenschap echter een zelfstandig onderdeel van het universitaire activiteitenpakket ${ }^{20}$. In 1865 noemt De Bosch Kemper onder de noemer van wetenschappelijke inrichtingen in de eerste plaats de universiteiten (De Bosch Kemper 1865: 902). Opzoomer (1873: 43) merkt op dat, na alle discussie die gevoerd is over de juiste indeling van lager, middelbaar

paalde voorliefde woor een of ander gering onderdeel, geen genoegzaam geheel titmaalkt, en miet zelden, zelifs met de grootste verdiensten voor het overige fragmentair is? En wanneer men dil gebrek, zoo als billijk is, voornamelyjk bij het onderwijs als eene groote fout aanziet brengt men zichzelven tot de nuttige noodzakelijkheid orn. het te verbeteren, en arbeidt men op zulk eene wijze niet minder tot ergene beschaving dan tot leering van anderen" (Bake 1828: tweede brief 6 ).

19 Bake (1828: eerste brief 34) die de beoefening wan wetenschap als de belangrijkste activiteit van de universiteiten opvat, houdt er rekening mee dat sommigen hem als een "belagehelijken paradoxist" of "eern gevaarlijken neoloog" zullen "bespitten of verketteren".

20 Het Ontwerp van Wet (1849: 102-104) formuleert de doelern van het hoger onderwijs aldus: "Het hoofdlow" (...) kan geen ander zijn, dan om door grondig onderrigt hare kweekelingen voor maatschappelijke betreklkingen te vormen, en hen in alle rigtingen voor te bereiden tot eigen studie, voortgezelte beotening en toepassing der wetenschap in het maatschappelijk leven (...) Wil echter het hoofddoel der Universiteit bereikt worden, de grondigheid van het onderwijs zill steeds op den voorgrond moeten stan, en deze is niet te werwachten, zoo de onderwijzers, bij den vooruitgang der wetenschap, zelve stationair blijven: (...) Naast het bovengenoemde hoofddoel moel dus noodwendig eene nevenbestemming aan het Hooger onderwijs op de universiteiten worden toegekend, de uitbreiding en bevordering der wetenschap, al ware het alleen omdat het eerste zonder de laatste niet kan bereikt worder." 
en het hoger onderwijs, het hoger onderwijs gekenmerkt wordt door een te onderscheiden en algemeen doel: "wetenschap" (zie ook Heynsius 1875: 11). Maar wetenschap verschilt en wil uitdrukkelijk verschillen van geleerdheid. Wetenschap moet dynamiek vertonen en tevens de dynamiek van een veranderende samenleving bestuderen. "[H]et is toch een hachelijke zaak, zoo op een voetstuk gesteld te worden. Men heeft zijne inzichten en opvattingen, die men telkens opnieuw voordraagt en verdedigt. Slechts zelden ontmoet men bestrijding, (...) Zoo komen wij er onwillekeurig toe, om aan den draad, dien wij eenmaal in de hand hebben genomen, rustig voort te spinnen, en voorbij te zien, dat er op het groote weefgetouw der maatschappij andere draden zijn aangelegd, die veel meer onze aandacht en onze zorg verdienen. Wij worden bevangen in onze professorale meeningen, en bespeuren niet, dat wetenschap en leven onze professorenwijsheid verre vooruit snellen" (Rauwenhoff 1872: 20). De doelen die L.W.E. Rauwenhoff in zijn rede 'De verhouding van de hoogeschool tot de maatschappij" (1872:27) voor de academie formuleert, reflecteren een dynamische opvatting van maatschappelijke en wetenschappelijke ontwikkeling. De academie "moet de belangen van het volk bevorderen" en dat kan zij alleen "door in levende betrekking te blijven met de ontwikkeling in het volksbestaan". "Wat wij, in het belang eener rechte verhouding tusschen Hoogeschool en maatschappij verlangen, zou zijn, dat de wetgever vaststelde al datgene, wat noodig is om het streng wetenschappelijk karakter der studie aan de Academiën te waarborgen. Dat kan niet aan de wisselende meening van den dag of aan de willekeur van regenten of docenten worden overgelaten. Maar daarnevens moest een groote ruimte overblijven voor de zorg der Regeering om het onderwijs altijd in overeenstemming te houden met den vooruitgang in de beschaving. Aan haar moest niet alleen de vrijheid worden gegeven, maar zelfs de verplichting worden opgelegd, om an nieuwe werkelijke behoeften te voldoen door uitbreiding van het academisch personeel of door wijziging in de regeling van het onderwijs" (Rauwenhoff 1872: 31). Het dynamische karakter van de maatschappij vereist dat het onderwijs steeds wordt aangepast. Het dynamische karakter van het onderwijs draagt vervolgens bij aan de dynamiek van wetenschap, vermits onderwijs en onderzoek aan de hogescholen in dezelfde handen zijn: "Een afzonderlijke stand van geleerden, wier eenige werkkring zou liggen binnen de grenzen van hun studeervertrek, zou onvermijdelijk vervallen tot levenlooze knutselarij" (Rauwenholf 1872: 33). Enkele jaren later drukt J. Land de veranderingen die zich aan de Nederlandse universiteiten voltrokken hebben, al uit in de titel van zijn rectorale rede: 'De Oude en de Nieuwe Universiteit". Kenmerkend voor de nieuwe universiteit is dan "de geest des onderzoeks, die alom in de wereld de nieuwe universiteit bezielt" (Land 1.886: 32). 
Huizinga (1951b: 85) heeft het verschil tussen geleerdheid en wetenschap trachten te verwoorden door, Heymans citerend, geleerdheid te schetsen als een levensideaal. "Zij streefde (...) 'nog minstens evenzeer naar schoonheid van vorm en zedelijke inwerking als naar exacte resultaten, vermeide zich liever in algemene beschouwingen dan zich op te sluiten in het minitieuze onderzoek van enkele bijzondere vraagstukken; de koele strengheid der methode had het gemoedelijk enthousiasme nog niet uit de wetenschap verbannen'." Geleerdheid impliceert beschaving, vaderlandsliefde, goed burgerschap, zedelijkheid en kennis. Bovenal is het aan een persoon gebonden ${ }^{23}$; het is de cumulatieve ontwikkeling van een persoon. Daarbij past een encyclopedisch weten ${ }^{22}$, een weet hebben van de orde, de veelheid en de hiërarchie van de wereld en kennis van de principes die die wereld regeren, een 'cognitio ex principiis' (Diemer 1968b). Wetenschap is daarentegen een proces, waarin actoren reageren op elkaars stellingnames. De cumulatieve ontwikkeling van de persoon wordt daarbij ondergeschikt aan het communicatief proces over specifieke thema's en controversen. Kritiek - of misschien algemener het mechanisme van coöperatie en conflict - neemt dan de plaats in van verzamelen en de vervolmaking van de persoon $^{2}$. De nadruk wordt verlegd van bronnen naar de toekomst: "Während die Wissenschaft der Frühmoderne sich als ganz vom Interesse an Strukturerhaltung bestimmt sah, liegt im Forschungsbegriff, der ein semantisches Korrelat der Transformationen der deutschen Universität ist, eine radikale Umorientierung auf den Prozeßaspekt der Wissenschaft und auf die Vorstellung, daß jedes strukturelle Moment der Wissenschaft jederzeit prozessual wieder problematisiert und aufgelöst werden kann und sogar sollte" (Stichweh 1988: 68).

R. Stichweh (1984) heeft, vertrekkend vanuit de systeemtheoretisch georiënteerde sociologie van Niklas Luhmann, het ontstaan van de moderne organisatievorm van wetenschappelijk onderzoek, het disciplinaire systeem, geduid als

21 Geleerdheid was daarmee ook sexe-gebonden. Vrouwelijkheid sloot geleerdheid uit. Pas aan het einde wan de negentiende weuw komt de relatie tussen wrouwen en wetenschap ter discussie te staan (Van Loosbroek et. al. 1988: 7-9).

22 Bij Bolzano (1929/31 [1. 1837], WL I par. 25 s. 112) leidt dat tot een opvatting van wetenschap als lets. "unwandelbares' als de verzameling van alle bekende én nog ontbrekende waarheden: "Ich verstehe also (...) unter einer Wahtheit an sich jeden beliebigen Satz, der etwas so, wie es ist aussagt, wobei ich unbestimmt lasse, ob dieser Satz von irgend jemand wirklich gedacht und ausgesprochen worden sey oder nicht" (Buhl 1968).

23 Het ig echter overhatast hieruit te concludenen dat rollen in het moderniseringspnoces belangrijker zouden worden dari personen: "Dass persönlich adressierte Enwartungen, die mit dem Adressaten 'sterben", und Rollenerwartungen deutlich trenubar sind, ist elin Resultat soziolkultureller Evolution, ist also erst allmählig einsehbar geworden. Man kann dies an der Geschichte der Differenz von Amt und Person ablesen. Aber auch das, was man heute formale Organisation nennt, ist nut dank dieser Trennurg möglich. Dass heisst nicht dass "Persönliches" an Bedeuturig verlöre. Es gibt keinen 'Trend' von Personorientierung zu Rollenorientierung. Die Entwicklung zeichnet sich vielmehr dadurch aus, dass diese Differenz an Bedlevtung gewinnt, auch und gerade im Innenleben formaler Organisationen" (Luhmann 1984: 431;, 
een aflossing van de traditionele ordening van wetenschappen gebaseerd op een - extern aangebrachte - hiërarchie van faculteiten (theologie, recht en geneeskunde) of een hiërarchie van methode (historie, mathematica en filosofie). Die overgang in organisatievorm gaat hand in hand met een inhoudelijke heroriëntatie. Moderne disciplines zijn niet langer verzamelplaatsen van zekere kennis, die het ideaal van geleerdheid vormen: "Frühmoderne Wissenschaft stellt man sich am besten als einen Wissenszusartmenhang vor, der sich aus Bestandteilen zusammensetzt, die aus den heterogensten Quellen überkommen sind. (...) Angesichts eines überkommenen und heterogenen Wissenskorpus, wie ihn die frühmoderne Wissenschaft besaß, ist der eigentliche relevante Erkenntnisakt der Wissenschaft enzyklopädisch-klassifikatorischer Art" (Stichweh 1987a: 450-451). In plaats daarvan formeren disciplines zich rond objectgebieden en daarbij behorende vraagstellingen. Wetenschap wordt dan niet meer gekenmerkt door een overgeleverd corpus van zekere kennis en de ordening van reeds verworven kennis als wel door een communicatief proces dat zich rondom wetenschappelijke controversen ontspint. Dat communicatief proces neemt de ordeningsfunctie over van (extern aangebrachte) hiërarchieën, zoals die van methode of van faculteit. "Die entstehenden naturwissenschaftlichen Disziplinen konstituierten sich über Spezifität im Gegenstandsbezug und Problemstellung und potentielle Universalität im Verfügen über wissenschaftliche

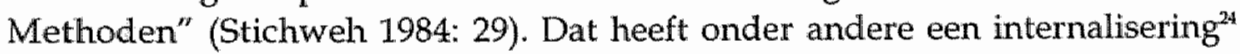
van wetenschappelijke vraagstellingen tot gevolg. Dat betekent niet dat er geen interactie meer kan bestaan tussen maatschappelijke en wetenschappelijke vraagstellingen; maar wel dat een maatschappelijk probleem steeds een belangrijke herformulering moet ondergaan, alvorens het tot onderwerp van wetenschappelijk onderzoek gemaakt kan worden.

Deze heroriëntatie van methode naar disciplinegebonden problemen leidt onder andere tot een breuk in de mathematica ${ }^{25}$, die hier verder buiten beschouwing blijft. Voor ons onderwerp van meer belang is de verandering van de betekenis en de verhouding van filosofie en historie $e^{26}$. Dogmatiek en histo-

24. Bijwoorbeeld in het domein van de mathematica: "[T] mathematics of the 18th century is applied mathematics, i,e. primarily aligned with the natural sciences and subordinate to the description of physical phenomena. (...) What we understand today as pure mathematics, mamely theoretical mathematics in which mathematical theories are developed for their own sake and them applied to particular mathe matical problems for their solution, first existed around the beginning of the 19th century" (Daston 1981: 302).

25 Mathematics (with the possible exception of chemistry) is the one science for which the hypothegis of a break in its eplistemological and ontological conceptions at the turn of the 18 th century can be most easilly verified" 0ahnke and Otte 1981:75).

26 Dat thema vereist op zich een dissertatie. Hier kunnen slechts enkele grove en grote lijner worden wergegeven. Een illustratie van de verschuivende verhouding tussen filosiofie en geschiedenits geeft Poortinga (1987: 54-59) aan de hard van Thorbecke's ideeèn over recht en geschiedenis. 
rie duiden in de zeventiende en achttiende eeuw twee tegenstelde methodes of kenvormen aan, die elk een bepaald type kennis over een object opleveren $^{2}$. Bij Leibniz, Wolff en aanvankelijk ook nog Kant heeft 'historisch' de betekenis var kennis van 'Einzelfakten', die zowel in het verleden als in de tegenwoordige tijd aangetroffen kunnen worden (Herberger 1981: 348). Doordat "historisch' een methode aanduidt is er tot 1780 altijd sprake van de historie van een bepaald onderwerp (Koselleck 1979: 262). Pas daarna is 'Geschichte' als 'Kollektivsingular' beschikbaar, dat gebruikt kan worden zonder een haar toebedeeld subject of object. 'Historie' krijgt dan geleidelijk een andere betekenis. In plaats van methode wordt het onderzoeksobject als zodanig getemporaliseer $d^{2 j}$ (Sitichweh 1984). Als effect daarvan verandert ook de betekenis van de filosofie, de oorspronkelijk methodische tegenvoeter (Herberger 1981: 348).

De inhoudelijke heroriëntatie waarmee de opkomst van de disciplinaire organisatie hand in hand gaat wordt door H.N. Jahnke en M. Otte (1981: 79) het eerst getraceerd ten tijde van de Franse Verlichting: "The conception of science as a language is probably the most influential concept of science developed by the French representatives of the Enlightenment (...) This conception, which was primarily attached to mathematics, and still is of great importance for this science today, contains essentially two aspects: Firstly this conception is to express that preoccupation with the diversity of empirical reality (...). Second$\mathrm{ly}^{23}$, and this is certainly just as important, the conception of science as a language refers to the social-communicative function of science and recognizes that function as an essential element of its development."

De motor achter de opvatting van wetenschap als een communicatief proces is het wetenschappelijk tijdschrift (Stichweh 1987a). De oorsprong van het wetenschappelijk tijdschrift kan in de zeventiende eeuw gesitueerd worden en is onder andere verbonden met het feit dat er te veel boeken kwamen. Het tijdschrift diende toendertijd hoofdzakelijk als samenvatting en als verwijzing

27 "All true history has a capital advantage over every work of fiction' Priestley told his students at Warrington Academy in 1761. "Works of fiction resemble those machines which we contrive to illustrate the principles of philosophy, such as globes and orreries, the use of which extend no turther than the views of human ingenuity: whereas real history resemblest the experiments by the ain punp, condensing angine and electrical machine, which exhibit the operations of nature, and the God of nature himself ${ }^{p s}$ (Schaffer $1983 * 1$ ).

28 "[N]atural science at the begituing of the 19th century was largely transitional, characterised by switch from the concept of nature's absolute immutability (the 18 th century) over to one of nature's evolution (the 19th century). (...) Thus, while previously it had concentrated on the study and grouping. of ruture's objects, it now began to concern itself with the study of processes of changes of the same objects" (Kedrov 1981: 124).

29 Dit heeft ook inhoudelijke consequenties, Bijvoorbeeld in de logica van Condullac (1780): "Condillac will have definitions understood only as indications towards the object in question, and not as a principle or a complete determination of the object from which all properties of the object can be deriwed" (Jahnke and Otte 1981: 80). 
(Solla Price 1963: 63). Die functie zal het tijdschrift vanaf het begin van de negentiende eeuw geleidelijk aan verliezen. "The transformation of the scientific paper into its modern state was not complete until about a century ago. Before that time there was much publication of scientific 'snippets', such as the bare mention of something achieved, or a review of observations that had been made and published elsewhere" (Solla Price 1963: 64). In plaats van een verwijzende functie, gaat het tijdschrift een cruciale rol innemen in het functioneren van wetenschap als proces ${ }^{30}$. Karakteristiek voor het moderne wetenschappelijk tijdschrift is dat het de mogelijkheid biedt, door middel van artikelen, in discussie te treden met andere wetenschappers ${ }^{31}$. Deze verandering in het functioneren van het tijdschrift komt onder andere tot uiting in de opkomst van het gebruik artikelen van andere wetenschappers expliciet te citeren: "[I]t is generally evident from a long run of any scientific periodical that around 1850 there appears the familiar modern pattern of explicit reference to previous work on which rests the distinct, well-knit addition that is the ideal burden of each paper. Before that time, though footnoting is as old as scholarhip itself - compare the very term scholia for the ancient footnote - there is nothing like this attitude toward the accretion of learning" (Solla Price 1963: 65). Vanuit de geleerde traditie wordt het tijdschrift met minachting ${ }^{32}$ bekeken: "Wien toch is het onbekend, dat er onder de geneeskundigen van den huidigen dag vele worden gevonden, die lectuur en studie van Tijdschriften, aan hunne wetenschap gewijd ${ }_{n}(. .$.$) op hoogen prijs stellen, en niet minder velen, die, juist$ omgekeerd, zulks als tijdsverspilling, oppervlakkigheid, zoo niet erger aanmerken, en met niet weinig eigenwaan zich zoo gaarne den naam van Classici, dat is, volgens hen geleerden van den echten stempel, geven, in tegenoverstelling van den beuzelaar, die ook journalen leest, alzoo met zijnen tijd tracht mede te gaan, van den journaalgeleerde. (...) Het Boek der Wetenschap, zelfs langs de randen beschreven, wordt dagelijks uitgeveegd, opgeklad; er wordt bijgevoegd en afgenomen, afgenomen en bijgevoegd, zoodat het uiteindelijk onleesbaar is geworden; een monsterachtig raadsel daargesteld, een register met vele woorden zonder zamenhang, en met zinsneden, ontdaan van allen grond en logica!" (Schreuder 1843: 464; 468). Vrijwel tegelijkertijd met de opkomst van

30 " ${ }^{x}$ Der Uebergang zu periodischen Publikationen bildet einen weiteren wichtigen Aspekt der Verzeitlichung in der Umbruchphase der Wissenschaften zwischen 1795 und 1825. Irnerhalb der Medizin läßß sich dies ebenso wie in der Chemie nachweisen" (Lepenies 1976: 103).

31 Een dergelijke ontwikkeling valt ook binnen het domein van het recht te constateren: "Gedurende de $17 \mathrm{e}$ en $18 \mathrm{e}$ eeuw is de rechtsgeleerdheid echter bijna geheel verstoken gebleven van specifiek juridische tijdschriften. (...) Met de 'Bijdragen' wan Den Tex en Van Hall (1826), in 1838 omgedoopt tot 'Jaarboeken' en met het 'Weekblad van het regt' (1838) begint in ons land het reguliere juridische tijdschriftwezen" (Van den Bergh en Jansen 1988: 341).

32 "Het is bekend, dat daarvoor bij onze Geleerden eene zekere minachting bestaat, en dat men op die journalgalgeerdheid" gaarne uit de hoogte nederziet" (Van Geuns 1842a: 207). 
het wetenschappelijk tijdschrift in zijn moderne vorm gaat een ander instituut ter ziele: de geleerde prijsvraag ${ }^{33}$ (Van Berkel 1985: 110-111). Aan de prijsvraag ontbrak het dynamische en communicatieve aspect dat het tijdschrift juist wel bood. Eveneens raakt de wetenschappelijke reis in discrediet ${ }^{34}$. De betekenis van de ontdekking van nog onbekende soorten (Lepenies 1976: 55) en de bestudering van zeldzame boeken in verafgelegen collecties neemt af.

\section{Verzamelen en classificeren; kabinet en bibliotheek}

Stichweh ${ }^{35}$ karakteriseert de kennisclaim van vroeg-moderne natuurwetenschap als encyclopedisch en classificatorisch van aard. Het doel van kennis was het vatten van de orde ${ }^{36}$ in de natuur ${ }^{37}$ (Hoppe 1978: 124; Mayr 1982: 102; Vernon Pratt 1985: 421; Frängsmyr et al. 1990). "Eeuwen lang was het den natuuronderzoekers genoeg, de voorwerpen, welke de natuur aanbiedt, te kennen en te rangschikken, en hoe menigeen is er nog die daarin het hoogste genot voor zijnen geest zoekt" (Ramaer 1848: 8). De encyclopedie ${ }^{38}$ drukt het geloof uit dat "the whole of knowledge could be digested and codified into a

33 "Hetgeen men weet, staat reeds geschreven of gedrukt; zoo niet, het is een zedelijke pligt, ook dat mede te deelen, wanneer het van belang is. Vragen derhalve naar hetgeen men weet, en een antwoord daarop, vermeerdert de som der wetenschap met niets, of men moest, zoo als veel het geval is, een anderen vorm willen; maar niets is moejjelijker voor te schrijven dan vorm" (Boekbespreking van "Onderzoek en Phantasie' door J. Geel, Leiden, De Gids 1838. 523).

34 "Tegenover de schelklinkende magtspreuken, dat het reizen de menschenkenmis in het groot, de kennis van natiën en volken, de taalkennis, de geleerdheid, de wetenschap, de vrijheid van vooroordeelen bevordert, stelt de Hoogleeraar de natuurlijke naive stelling: dat de grond wan het reizen verveling te huis is; dat de ingebeelde voordeelen bij de ondervinding bedriegen, indien men reist, zoo als er gewoonlijk gereisd wordt, en zoo als het reizen het liefste en het uitlokkendste is" (Boekbespreking van 'Onderzoek en Phantasie' door J. Geel, De Gid's 1838: 524).

35 Ent met hem vele anderen. Zie bijvoorbeeld Hoppe (1978); Stemerding (1987; 1991).

36 "[T] do justice to the fact that the systembuilders were seeking to discover the order of nature, their concern would have to be put differently. They could not be said to intend primarily the classification of discovered species, but rather the discovery, through study of discovered species, of the structure of the system to which those species belonged (Vernon Pratt 1985:426/427).

37 Ther spelen ook physicontheologische motieven in door: "[N]ature was considered the perfect product of the creator or, as interpreted by Seneca and the pantheists, as being one and the same with God" (Vernon Pratt 1985: 426).

38 Het Organiek Besluit schreef in alle faculteiten als inleidend onderwijs onderricht in de encyclopedie voor. "Während die theologischen und juristischen Fakultäten die Enzyklopädie der von ihnen gelehrten Disziplinen stets unterrichtet haben, gibt es meines Wissens im neunzehnten Jahrhundert in Holland nur zwei Dozenten, die einige Jahre einen Auftrag für die medizinische Enzyklopädie bekommen haben; der erste war Jacab Vosmaer (1783-1824), der an der Utrechter Universität 1818 den Antrag bekam: Senuiotica, Therapia generalis, Encyclopaedia medica und Historia medicinae (...) und der bekannte Medizinhistoriker Abraham Hartog Israëls (1822-1883) hat als Lektor am Amsterdamer A thenaeum nebst der Hygiene auch die Enzyklopädie, Hodegetik (Wegweisung) und Geschichte der Medizin während einiger Jahre doziert ${ }^{2 \pi}$ (Lindeboom 1985: 43). 
few volumes, and that knowledge either stood still or made so little progress that the revision of one comprehensive work could easily cope with the results ${ }^{\prime \prime}$ (Collison 1964: 2) ${ }^{39}$. De beste illustratie van het verzamelende en classificerende denken vormt uiteraard het domein van de natuurlijke historie

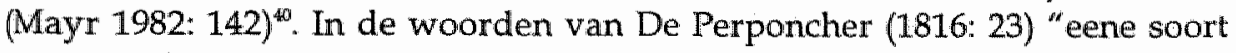
van Reisbeschrijving, door alle de Rijken der Natuur, voordgezet, en alle de geslachten haarer voordbrengselen ten voorwerp hebbende." Waar het uiteindelijk om gaat is al die afzonderlijke onderdelen in één groot verband te plaatsen: "Want even zoo als er eene groote, onafmeetbaare keeten van hoogere en laagere geesten bestaat; even zoo bestaat er ook, in de lichaamlijke wereld, eene even groote keten van stofrijke voordbrengselen, tot beoffening, onderwijs en vorming der eerstgemelden geschikt" (De Perponcher 1816: 41). "Das eigentliche Ziel der botanischen Forschung wie der Naturwissenschaft überhaupt bestand in einer theoretischen Verknüpfung der durch die Collectores ermittelten Einzelkenntnisse. Wie für die Naturwissenschaft insgesamt galt, Scientia Naturalis est divisio ac denominatio illa corporum Naturalium, so stellte Linné auch bezüglich der Botanik fest: "Fundamentum Botanices consistit in Plantorum Divisione et Denominatione systemica, Generica et Specifica" " (Hoppe 1978: 129). Met Carl Linnaeus (1707-1778) bereikt het classificatiedenken in die zin haar hoogtepunt dat voor hem classificeren nog gelijk stond met het vatten van de essentie van de soorten. De logica van de classificatie - die een logica van steeds verdergaande opsplitsing ("downward classification") is - weerspiegelt de logica van de natuur (Mayr 1982: 101; 150). Uiteraard stellen zich problemen bij het aangeven van de grenzen tussen de soorten ${ }^{\text {4l }}$ en het vinden van het juiste ordeningscriterium ${ }^{42}$ hetgeen onder andere leidt tot een controverse tussen Linnaeus en Buffon, die in plaats van Linnaeus' essen-

39. In het begin van de negentiende eetw valt een hausse in thet nitbrengen van encyclopedieèn te constateren (Collison 1964: 174).

40) Wooykaas (1988: 138) tekent de sfeer alsvolgt: "Het tafereel der Natuurlijke Historie van mineralen, planten en dieren schonk vermaak aan het oog en bevredigde de neiging tot verzamelen eru beschrijven die zo typerend is woor de 18-eeuwers." De achttiende eeuwse natuturlijke historie verschill overigens Yan het Baconaanse voorbeeld. "[T] he significant thing is that "natural history' as Bacon conceives it chearly bellongs to the bottom of the pysamid and not the top. It is a means to an end. No such thing is the, howewer of system-building. Its practitioners were concerned, in Linnaeusis words, to arrange and to designate', and their science as they conceived it had no other object" (Vernon Pratt 1985. 425).

41 "De enorme toename van helt aantal planten en dieren dat vanuit verne plaatsen bijeen werd get bracht in tuinen, herbaria en kabinetten confronteerde naturalisten met de klemmende vraag hoe allerled nieuwe en reeds bekende soorten onderscheichen en benoemd noesten worden. Niet zozeer dit probleem was nieun in de achtiende eeuw, maar wooral de schaal waarop het zich voordeed" (Stemerding 1987 ; 74 .

42 Von Ba uhin bis Lüné konkurrieren in der Bolanik 25 verschiedene Klassifikationsverfahren miteinander, $z$ wischen 1647 und 1775 existierten 27 verschiedene Systeme in der Mineralogie" (Lepenies $1976:$ 53). Zile ook Hooykas (1946). 
tialistische aanpakeen meer pragmatische voorstaat (Broberg 1990; Stemerding 1991). Het principe van de 'downward classification' houdt echter lange tijd stand, ook in de classificatie van G. Cuvier die de interne anatomie van de vertebraten aan de basis van zijn systeem legt (Mayr 1982: 183) ${ }^{43}$. In de zoektocht naar het juiste - het natuurlijke - classificatiecriterium wordt echter geleidelijk het principe van 'downward classification' losgelaten in ruil voor 'upward or composittional classification' dat soorten indeelt op basis van classificatiecriteria die voortkomen uit de onderlinge vergelijking van individuen (Mayr 1982: 192). Daarmee wordt het classificatiedenken langzaam losgeweekt van het essentialistische gedachtengoed: "However, simply replacing downward by upward classification was not sufficient to produce a natural classification. There had to be some organizing principle, some basic concept that would serve as a guideline for the taxonomist" (Mayr 1982: 199). Dat zou uiteindelijk in 1859 geleverd worden door C. Darwin, na wie 'natuurlijk' zou gaan betekenen 'of common descent" (Mayr 1982: 200). De logische orde zal uiteindelijk plaatsmaken voor een temporele. Dat zal radicale effecten teweeg brengen: soorten kunnen dan niet langer worden opgevat als logische klassen met intrinsieke eigenschappen maar moeten gezien worden als populaties met noodzakerlijkerwijze variatie in de individuen die daar deel van uitmaken - die een reproductievermogen bezitten, in relatie ${ }^{44}$ tot andere populaties. Soorten worden afstammingsrelaties in de tijd ${ }^{45}$. Maar daarmee verandert ook de verhouding tussen individu (specimen) en soort. In een 'essentialistische' benadering van soorten, kan ieder specimen optreden als representatief voor zijn soort. De bekende problemen die daarbij ontstonden wanneer anderen een gekozen specimen niet zo typisch vonden als wenselijk en het door een ander wilden vervangen, konden daarna rigoureus opgelost worden: "The crucial decision made by systematists was to disentangle two different functions for specimens, that of typifying their species and that of designating them rigidly (Hull 1982a: 6).

De overgang van logica naar temporele orde die Darwin in 1859 expliciet in de taxonomie aanbrengt, is in een groot aantal domeinen terug te vinden. In de hoofdstukken drie en vier is een temporalisering in de domeinen van de geneeskunde en het recht beschreven. Het idee van een tijdsvolgorde en aanzet-

43 "Again the emphasis is on classification from the top down by a process of division and there still is a search for the essence, the true nature of each group" (Mayr 1982: 183).

44 " $[\mathrm{A}]$ relation expressed both behaviorally (noninterbreeding) and ecologically (not fatally competing) "(Mayr 1982: 172).

45 'The identity or continuity of species is not to be found in any 'broad spectrum of similarities' but in the ancestor-descendant relation" (Hull 1982b: 288). Zie ook Suringar (1858: 28): "II]n welken zamenhang die opvolgende vormen tot elkander stonden, hoe de tegenwoordige in verband staan met die welke hen voorafigingen, laat zich zelfs niet vermoeden." 
ten tot evolutionaire stand punten dienen zich op tal van plaatsen aan. Aanvankelijk zijn dergelijke ideeën nog sterk geketend aan essentialistische denkbeelden en ingebed in een ontwikkelingsdenken ${ }^{46}$. Precies aan te geven waar zo'n overgang het eerst plaatsvindt, is onmogelij $\mathrm{k}^{47}$. Het meest voor de hand ligt in dit verband te wijzen op ontdekkingen in domeinen als de kosmologie, de geologie $^{\sharp 8}$ of de archeologie. In het domein van de natuurlijke historie zelf geven tal van ontdekkingen aanleiding tot speculaties over het ontstaan ${ }^{49}$ en het weer verdwijnen van soorten. I. Bulhof (1988: 25) wijst op drie ontdekkingen in het domein van de natuurlijke historie. Namelijk het groeiend besef dat de wereld veel langer bestond dan men tot dan toe op grond van bijbelse gegevens had aangenomen ${ }^{50}$. De ontdekking dat in andere werelddelen heel veel soorten bestonden, die niet pasten in het tableau van de soorten zoals door Linnaeus in de achttiende eeuw was opgesteld (de overgangen tussen de soorten bleken aanmerkelijk vloeiender te zijn dan men gedacht had). En ten slotte de ontdekking door paleontologen van fossiele diere- en planteresten, die leken tot zulke vreemde wezens behoord te hebben, dat zij absoluut nergens bij vielen in te delen. Volgens R. Richards (1987: 21) zijn vooral de debatten gedurende de zeventiende en achttiende eeuw over de oorsprong van bruut menselijk gedrag van belang. "These debates formed the immediate environment for the emergence of evolutionary theories at the turn of the eighteenth century." Van der Woud (1990: 77) benadrukt op zijn beurt het schokeffect dat van een aantal natuurrampen, zoals de hevige aardbevingen in 1783 en 1786 te Italië en de aardverschuiving van 1755 die Lissabon verwoestte, uitging. "Deze natuurrampen hadden in de zeventiende en de zestiende eeuw geen precedenten gehad, hun verschijning in de achttiende eeuw, plus de berichten van de ontdekkingsreizigers over werkende vulkanen overal ter wereld, moeten het gevoel van sommigen hebben versterkt op een geologische tijdbom te leven."

46. letts dat Lowejoy (1936) demonstreert aan de hand van de temporalisering van 'The great chain of being" - de seala naturae.

47 "It is mistaken, though cognitively satisfying, to explain the origin of an important idea by appeal to one or two sources. Creative thought in science, as in other disciplines, usually emerges from a context of interwoven beliefs, suspicions, and observations" (Richards 1987: 48).

48 Zie Van der Woud (1990: 64-101).

49 "Sommige geleerden wisten al dat, om de ongerijmdheden van de fossiele natuur tegemaet te kunnen treden in plaats wan hen te negeren, een overschrijding van de oude paradigmata noodzakellijk was. Petus Camper is waarschijnlijk de eerste Nederlandse geleerde die dit onder ogen heeft gezien. Hij stelde vast dat de fossielen een grotere ouderdom van de aarde aangaven dan op grond van de bijbel werd gemeend, en dat ze wezen op levensvormen die aan de schepping voorafgingen, maar hij heeft deze condusies niet in de openbaarheid willen brengen" (Van der Woud 1990: 71).

50 "Wooral door het Duitse oudheidkundige onderzoek moest het tijdstip waarop wolgens internationale consensus de geschiedenis der mensheid begon, aanzienlijk worden vervroegd. Het belangrijkste argument daarvoor was de ontdekking in 1774 van menselijke beenderen naast resten van uitgestorven zoogdieren, samen in dezelfde ongestoorde fossiele aardlaag" (Van der Woud 1990:44). 
Bij de overgang van een hiërarchische, logische orde naar een temporele ordening vervult een op ontwikkeling en teleologie geënte geschiedsopvatting een belangrijke rol. "Die Naturgeschichte verfügt über keinen temporalisierten Begriff der Entwicklung (...) Die Kette der Lebewesen vermittelte ein hierarchsches Bild, das mit anderen hierarchischen Vorstellungen zusammenpaßtet (Lepenies 1976: 45, 47) ) $^{\text {51 }}$. Vanuit een substantialistisch of essentialistisch oogpunt werd de soort vastgesteld op basis van wezenlijke eigenschappen. Daarmee lag ook de ontwikkeling in de tijd vast. Dat leidde tot heftige controversen over de verklaring van sterk afwijkende vormen, monstruositeiten ${ }^{52}$. Preformationisten ${ }^{53}$ waren van mening dat het onbevruchte $\mathrm{ei}^{\text {st }}$ (Ovisten) of de spermatozoën (Animalculisten) het gepreformeerde individu bevatten. Epi-

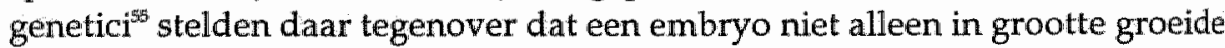
maar ook kon veranderen (Rider 1983: 70). In de tweede helft van de achttiende eeuw zou de epigenetische denkworm steeds belangrijker worden (McLaughlin \& Rheinberger 1989: 2). Geleidelijk wordt de idee van de historiciteit en daarbinnen weer het belang van het contingente in het proces steeds sterker.

Met de verandering van kennisideaal correspondeert een verschuivende functie van kabinet en bibliotheek. Het Organiek Besluit schreef aan elke hogeschool de aanwezigheid voor van kabinetten van anatomische, fysiologische en pathologische preparaten en voorwerpen, van heel- en vroedkundige instrumenten, van natuurkundige instrumenten en modellen van werktuigen, van chemische instrumenten, en van natuurlijke historie en mineralogie (Huizinga 1951b: 79). Het kabinet was een verzameling of een verzamelplaats; het had niets van een werkplaats ${ }^{56}$. Ten behoeve van een demonstratie konden delen van de verzameling of instrumenten uit het kabinet worden gelicht. "Toen men laboratoriën begon in te richten, werd nog niet ingezien, dat deze

51 Waarbij op het hoogtepunt van de systematiserende naturbeschouwing het systeem belangrijker werd geacht dan de natuurgetrouwe weergave van de rijkdom aan soorten (Lepenies 1976: 66).

52 "On the "typological" or "essentiallistic" view of species, collecting was relatively easy. An occasional mutilation or monster to one side, any specimen could equally well serve as a representative of its species" (Hull 1982a: 4).

53 " [A] one to one correspondence of particles in the germ to parts of the body, so that each homogeneous tissue was represented by at least one particle, which when multiplied produced the tissue" (McLaughlin \& Rheinberger 1989: 1).

54 Sommigen namen zelfs het extreme standpunt in dat in ieder ei alle eieren van alle toekomstige generaties opgesloten zaten.

55 "[A] causal sufficiency of the germ to produce the body under given circumstances through a sort of chain reaction, whereby it was not necessary that the representatives of the parts in the germ be somehow similar" (McLaughlin \& Rheinberger 1989: 1).

56. In een beschrijving van de huisvesting van de Groningse universiteit anno 1815 merkt Huizinga (195lb: 74) op dat de vroegere senaatskamer toer dienst deed als verzamelplaats van fysische instrumenten en tevens fungeerde als vergaderkamer voor de curatoren. 
voor praktisch onderwijs der jongelieden en voor het doen van onderzoekingen door den professor en zijne assistenten moesten bestemd zijn. Zij werden slechts gebruikt als plaatsen, waar de voorwerpen en werktuigen, die de professor voor zijn collegie noodig had, door den amanuensis werden gereed gezet. De professor kwam, gaf zijn collegie taliter qualiter..., en ging na afloop weer heen" (P. Harting aan P.F. Hubrecht 9 Jan. 1880. Hs. Univ. Bibl. Gron. $400 \mathrm{a}$, no.3. in Huizinga 1951b: 103).

Het vanaf 1814 jaarlijks uitgebrachte 'Verslag nopens den staat van de hooge, middelbare en lagere scholen' maakt regelmatig gewag van uitbreiding van de kabinetten en de verzamelingen. De schakel tussen het kabinet en het onderzoekslaboratorium wordt gevormd door het onderwijslaboratorium. Het Verslag over het jaar 1843 (Algemeene Konst en Letterbode, 1845 deell II: 123) maakt voorzichtig melding van het feit dat de "te Utrecht voor eenig jaren zoo zeer opgewekte belangstelling in de scheikunde (...) nog steeds [schijnt] toe te neemen, zoodat men al meer en meer ondervindt, dat het laboratorium chemicum te klein wordt voor het aantal kweekelingen”. Ook in Groningen ontstaat de wens een dergelijk laboratorium in te richten. De Verslagen over de jaren 1856 en 1857 spreken over de laboratoria nog steeds uitsluitend in termen van "een gelegenheid tot oefening en waarneming" voor de studenten (Algemeene Konst en Letterbode, 1858, 11 dec no. 50: 195).

De overgang van onderwijs-naar onderzoekslaboratoria verloopt vloeiend. Als argumenten voor het instellen van een fysiologisch-pathologisch laboratorium $^{57}$ voerde Van Geuns in een Memorandum (1854/5) aan Burgemeester en Wethouders van Amsterdam aan: "Het physiologisch-pathologisch laboratorium is een wezenlijke vereischte: 1e. voor het onderwijs, $2 \mathrm{e}$. voor de wetenschappelijke beoefening van de natuurkunde van den mensch, zoowell in zieken als gezonden toestand, 3e. voor de geregtelijke geneeskunde, $4 \mathrm{e}$. het zal voor de Geneeskundigen bij de uitoefening van de praktijk nuttige inlichtingen kunnen verstrekken, $5 \mathrm{e}$. het kan tot gewichtige onderzoekingen in het belang der Maatschappij gebezigd worden" (in Hellinga en Groen 1953: 102).

Van meet af aan hebben de biologische laboratoria een dubbelfunctie vervuld. Ze waren er niet alleen voor het onderwijs, maar stonden vanzelfspre-

57 De instructies van het in 1856 ingerichte pathologisch-fysiologisch laborationium wainvan Heynsus dinecteur zou worden, luidden: "Art 1. Het laboratorium is bestemd voor physiologische en pathologische onderzoekingen en proefnemingen; het zal te dien einde beschikbaar worden gestelid:

le woor de hoogleraren in de genees- en nutururkundige leervakken aan het Athenaeum en de Klinische Schuol.

2e voor de studenten in de geneeskunde aan het Athenaeum en de leerlingen der Klinische School (...) Art. 2. De directeur zal belast zjjn met de leiding van de oefeningen en onderzoekingen der studenten en leerlingen; hij zal daarbij zorgen dat de oefeningen zich zoveel mogelijk aansiuiten anan het onderwijs der hoogleraten, en wel bepaaldelijk aan de lessen in de physiologie en pathologie" (Hellinga en Groen 1953: 89 ). 
kend ook de hoogleraar ter beschikking voor eigen onderzoek (Visser 1986: 256). Het onderwijs moet immers gelijke tred houden met de wetenschap: "Geen nieuwe ontdekking in de wetenschap, of zij moet daar getoetst, gene nieuwe belangrijke proeven, of zij moeten daar herhaald, geen nieuw systeem, of het moet daar ontleed worden" (Heye 1843: 56-57). Nog geruime tijd zouden de laboratoria echter primair vanuit het oogpunt van hun onderwijsfunctie worden bezien. P. van Geer (1887b: 110) ontleent aan de onderwijjsfunctie van de laboratoria zelfs argumenten die pleiten tegen uitbreiding ervan. "Waar vroeger éne bescheiden werkplaats voldoende werd geoordeeld, wordt thans de arbeid verdeeld over verscheidene laboratoria, op kostbare schaal ingericht, die slechts met groote subsidiën kunnen onderhouden worden. Is de uitkomst evenredig aan deze uitbreiding? Door velen, die hierover bij ervaring kunnen oordeelen, wordt de vraag ontkennend beantwoord. Wel wordt de arbeid meer machinaal, daardoor gemakkelijker, ook bij minder begaafdheid en scherpzinnigheid te verrichten, maar de oefening des geestes wordt niet in gelijke verhouding bevorderd. 'Even als de natuur met geringe hulpmiddelen groote uitkomsten te verkrijgen' was de leus van Thorbecke en op grond daarvan hield hij de koorden der beurs bij alle aanvragen om subsidiën voor wetenschappelijke instellingen gesloten." Vanuit een pedagogisch perspectief zijn er volgens Van Geer (1887b: 111) argumenten om de ontwikkeling binnen de laboratoria voor de proefondervindelijke wetenschappen, die over een steeds geavanceerder instrumentarium wensen te beschikken, met enige reserve te bezien. Dat een uitgebreid instrumentarium "in den tegenwoordigen tijd, bij de hooge eischen der proefondervindelijke wetenschappen onvermijdelijk zij, kan men niet ontkennen, maar evenmin dat de scherpzinnige student meer leert uit het juiste gebruik van eenvoudige hulpmiddelen, dan uit de ruime keus van samengestelde instrumenten en kostbare stoffen, die alleen in groote laboratoria zijn te vinden." Echter nog voor de eeuwwende zou J. Moll (1899) uitspreken dat "de eerste en voornaamste plicht van een hoogleraar, is het verrichten van oorspronkelijk wetenschappelijk onderzoek en het naar zijn vermogen bevorderen daarvan bij anderen. Het onderwijs, hoe gewichtig ook, komt toch, naar mijne opvatting, eerst in de tweede plaats in aanmerking". (...) Maar toch geloof ik niet te ver te gaan, als ik zeg dat voor de hoogere autoriteiten, bij den bouw van nieuwe laboratoria, de belangen en behoeften van het onderwijs zeer op de voorgrond staan. En waar deze inzichten worden toegepast, zonder dat men de belangen van het wetenschappelijk onderzoek uitsluit - en zó geschiedt het inderdaad - daar meen ik ook, dat men zich op een juist en zeer praktisch standpunt plaatst" (Moll 1899: 3; 6).

58 Bij benoemingen van hoogleraren dienen volgens Moll de wetenschappelijke capaciteiten dan ook van doorslaggevende betekenis te zijn. 
Met de transformatie van het kabinet in het onderwijslaboratorium verschuiven ook de opvattingen over de functie van het experiment in het onderwijs. In de achttiende eeuw had het experiment voornamelijk de demonstratie $^{\text {so }}$ van een effect ten doel, ofwel de produktie van een fenomeen dat onder 'natuurlijke' omstandigheden niet voorkwam ${ }^{\circ}$. In de negentiende eeuw verandert de functie van het experiment "from mere illustration to an exposition of how experimental procedure was executed, especially in making measurements $\mathrm{s}^{6 \mathrm{i}}$. Either by a closer observation of the experiment or by becoming directly involved in its execution (as they probably did when thermometers and barometers were used or when a phenomenon such as capillarity was discussed), students were drawn more deeply into learning physics, and into learning by doing" (Olesko 1989b: 107). Het doel van het experiment in het onderwijs is niet meer zozeer de demonstratie van een effect als wel de nauwkeurige meting van het verloop van een proces. In tegenstelling tot voorheen worden dan met name die domeinen voor onderzoek interessant waar het mogelijk is herhaalbare fenomenen te produceren ${ }^{62}$ (Becher 1984: 187).

Een vergelijkbare overgang als die van kabinet naar laboratorium doet zich ook voor ten aanzien van de bibliotheek ${ }^{63}$. In het begin van de negentiende

59 "The demonstration experiment derives from the period known as the Scientific Revolution, which extended from the early sixteenth century well into the the eighteenth century" (Rider 1983: 9). Zie ono Hooykaas (1988: 107). Het demonstratie-experiment maakte ook een belangrijk onderdeel uit van de woordrachten in wettenschappelijke genootschappen die op vele plaatsen in Nederland vooral in de tweede helft van de achttiende eeuw wanen opgericht (Snelders 1983).

60 T.S. Kuhn (1981, 36) over de experimentele methode in de zestiende en zeventiende eeuw: "Rather" they wished to see how nature would behave under previously unobserved, often previously nonexis tent, circumstances. Their typical products were the vast natural or experimental histories in which were amassed the miscellaneous data that many of them thought prerequisite to the construction of scientific theory." Of M. Heidelberger (1981); "Experiments are artifices of man by whict he makes nature speak where she is silent".

61 M. Heidelberger (1981: 15) analyseert deze transformatie in kennitideal an de hand van de ac. ceptative van de Wet varn Ohm: "We can conclude that the acceptance of Ohm's law went hand in hand with a gradual tedefinition of the concept of scientific knowledge and cogrition."

62 "De moderne wetenschap is experimenteel; zij gaat ervan uit, dat men kennis van natuurlijke processen en wan raturlijke dingen kan verkrijgen door die na te bootsen en door die te beinvloeder. Zij neent dusi aan, dat men, in principe althans, natuurlijke processen kunstmatig kan herhalen en dat mem

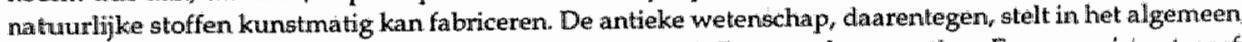
dat natuurligke processen en producten wezenlijk verschillen wan kunstmatige. Een experiment gext volgens haar hoogstensi een model van een natururlik proces of het doet het natuurlijke gewelld aan, zodat het resulltaat niet veel zegt over wat er in de vrije natuux gebeurt. 'Physica' (kennis van het nathurilike), die een deel der flosofie is, staat tegenover "mechanica" (kenis van het kunstmatige en de kunst de natuur te overwinmen door 'list', mechanè). In de moderne opvatting daarentegen staat de mechanica niet tegenower de fysica, maar is zij de kern ervan" (Hooylkatas 1988: 56).

63 "Ontegenzeggelijk kan men in de geschiedenis van het bibliotheekwezen van een cesuur spreken tussen de achttiende en de negentiende eeuw" (Grosheide et all. 1986: 152). "Universiteitsbibliotheken van relatief geringe omvang, grote privebibliotheken en coöperatief boekenbezit binnen genootschappen bepalen zo ke zamen het vroeg 19 e euwse beeld. Honderd jaar later was het onderhouden en opbouwen 
eeuw wordt de bibliotheek nog vooral beschouwd als een verzamelplaats voor kostbare en zeldzame werken, 'rare boeken"st. Een bibliotheek bevatte geen algemeen gangbare publikaties, noch leerboeken voor studenten (Grosheide 1986: 135). Uiteraard speelt daarin mee dat boeken toendertijd kostbaar waren. Pas na 1850 hebben grote veranderingen in het produktieproces ervoor gezorgd dat boeken massaprodukten werden ${ }^{65}$ (Mathijssen 1987: 7, 39). De voorschriften met betrekking tot het gebruik van de bibliotheek sloten aan bij de idee van de bibliotheek als verzameling. De bibliotheek was slechts zelden, en dan enkel voor hoogleraren en niet voor studenten geopend. "Deze omstandigheid doet vermoeden dat het aantal bezoekers niet groot zal zijn geweest: de bij de collectievorming gehanteerde formule bracht dat in feite ook mee" (Grosheide 1986: 103). In Groningen hadden de professoren elk een eigen sleutel der bibliotheek. Enkel zij, benevens de curatoren en de rector der Latijnse school, (en later nog de praeceptoren), mochten boeken mee naar huis nemen, waartoe zij ze zelf inschreven in een register (Huizinga 1951b: 171-174). De leeskamer was wel voor studenten toegankelijk, zij het dat deze tot 1823 slechts zes uur per week geopend was. Op verzoek van de senaat werd in 1823 de openstelling in het belang van de studenten uitgebreid tot alle werkdagen: 's maandags, 's woensdags, en 's zaterdags van negen tot een, 's donderdags en 's vrijdags van twee tot vier. Pas in 1852 zou de senaat ook studenten het recht op uitlening verlenen.

Uit de in 1986 verschenen monografie gewijd aan de universiteitsbibliotheek van Utrecht (Grosheide et al. 1986) komt een zelfde beeld naar voren. Ook daar konden in de tweede helft van de achttiende eeuw de bezoekers slechts enkele uren per week in de bibliotheek terecht. Al lijken daar de studenten de belangrijkste categorie onder de bezoekers te hebben gevormd (Grosheide et al. 1986: 138). " [I]n de eerste helft van de negentiende eeuw groeide de (...) hogeschoolbibliotheek uit tot een instelling die veel meer dan voorheen van belang was voor het wetenschappelijk onderzoek" (Grosheide et al. 1986: 153). Dat komt onder andere tot uiting in een groter aantal bezoekers, een grotere collectie, de uitwiseling van dissertaties en academische geschriften in internationaal verband, nieuwe catalogi etc. Maar het meest in het oog springend is

van een adequate boeken-en tijdschuiftencollectie tot een geinstitutionaliseerde tak van de universiteiten geèvolugerd. De universitaire bibliotheken makten toen een integraal onderdeel van de onderwoijs- ar onderzoekswoorzieningen uit (Homburg 1987: 53).

64 In 1777 wrerd dat, in een unstructie voor de bibliothecaris expliciet onder woorden gebracht (Grosheïde et al. $1986: 86)$.

65 De belangrijkste veranderingen in het productieproces zijn de owergang van uit lompen geprodu. ceerd handgeschept papier op machinal vervaardigd papier uit gemalen hout, het gebruik van een ijzeren in plants van een houten boekdrukpers en rond 1850 de invoering wan de rotatie- of snelpers. Op het gebied van de techniek van de illustraties worden de dure kopergravures en de goedkopere, maar aan sterke slijtage onderhevige, houtsneden vervangen door litho(steen)-gravures. 
ook hier de geleidelijke verruiming van de openingstijden. In 1842 werd de uitleen aan studenten, in de praktijk reeds lang gebruikelijk, officieel toegestaan (Haneveld 1985: 78). Dit ging gepaard met een verandering in het collectieprofiel. In plaats van zeldzame en kostbare werken werd nu recente vakliteratuur aangeschaft ${ }^{\text {th }}$. Ook de wijze waarop die aanschaf plaats vond, veranderde. Wat in de bibliotheek aanwezig moest $z \mathrm{jjn}$, werd voortaan door de faculteiten zelf bepaald. Natuurlijk stuitten dergelijke veranderingen binnen het bibliotheekwezen ook op verzet (Homburg 1987). In de Algemeene Konst en Letterbode uit 1858 pleitte J.Bake, hoogleraar in de klassieke letteren, er voor om na het aftreden van de toenmalige directeur van de Leidse bibliotheek, Geel, opnieuw een klassiek filoloog tot bibliothecaris te benoemen (Grosheide et al. 1986: 208).

Echter geleidelijk groeit, met het uiteenvallen van het ideaal van geleerdheid als het persoonlijk deelachtig zijn aan een bestand van zekere kennis, het besef dat moderne wetenschap specialisten nodig heeft. Dan wordt ook het idee van een onderlinge taakverdeling tussen de universiteiten geboren. "Men eische niet, dat iedere universiteit een volledige vertegenwoordiging der wetenschap zij. Want dan zou de verdeeling van den arbeid, welke op het gebied der kennis met den dag toeneemt, allerwege door een even groote splitsing van leerstoelen gevolgd moeten worden. (...) Het doel moest zijn de drie universiteiten des lands elkander te doen aanvullen, zoodat zij te zamen een zoo volledig mogelijk geheel uitmaken. Doch welke continuäteit van gedragslijn is er bij gestadige wisseling van ministeries en bij vlottende kamermeerderheden te verwachten? Daarom ware het wenschelijk, dat aan de tot één lichaam verbonden rijksuniversiteiten zelfbeheer werd geschonken. Dan zou, om een voorbeeld te noemen, de zaak aldus kunnen worden geregeld, dat wie na de voltooling van zijne algemeene studies specialiteit in geologie wilde worden te Groningen terecht kon (...) Dat elke uitgaaf voor hooger onderwijs in Den Haag vooraf bedisteld moet worden is een belemmering, waardoor veel goeds wordt tegengehouden. Ook pleit voor decentralisatie, dat, daar de staatstaak zich voortdurend uitbreidt, de regeerders spoedig niet meer tegen haar zullen zijn opgewassen. (...) Wijs beleid zou het wezen de universiteiten zoo spoedig mogelijk onafhankelijk te maken van eene elken afzonderlijken begrootingspost uitpluizende en bevittende kamermeerderheid (...) Wanneer er zelfregering aan de

66 Het Verslag omtrent den staat der hooge-middelbare en lagere scholen over 1856-1857 vermeldt: "Bij den aankoop van venschillende boekwerken voor de bibliotheek te Leiden theeft men zich vooral beijwerd zoodanige te kiezen, die het meest geschikt waren om in het algemeen den gang der wetenschap te doen kennen." En in hetzelfde Verslag wordt melding gemaikt van een schenking van de hoogleraren van het Ansterdamse Athenaeum, bij gelegenhied van het 225-jarig bestaan van die instel. ling "bestemd orn daarvoor boeken aan te koopen, die mere bepaaldelijk geschiki waren om den situdemben bij hunne studien van nut te zijn" (Algemeene Konst en Letterbode 1858: 194; 195). 
universiteiten wordt verleend, zal er met hetzelfde geld meer gedaan worden dan thans" (Van der Wijck 1898: 101-102). De toon voor de discussie in het hoger onderwijs voor de twintigste eeuw is daarmee gezet. In een wat moderner jargon gestoken bepleiten de voorstanders van zelforganisatie in het hoger onderwijs anno nu niets anders (Wachelder 1989c). 


\section{VI \\ Voorheen en Thans}

\section{Inleiding}

Wanneer de negentiende eeuw ten einde loopt verschijnen geschriften met titels als 'Voorheen en Thans' (Oud-Student: 1878), of 'Toen en Nu' (Asser: 1893). Die titels geven uitdrukking aan het gevoel dat ergens een breuk heeft plaatsgevonden. In de voorafgaande hoofdstukken is een aantal veranderingen die gedurende de negentiende eeuw in de organisatie en de inrichting van het onderwijs aan de Nederlandse universiteiten zijn opgetreden vanuit een bepaald perspectief op modernisering in hun onderlinge samenhang geinterpreteerd. Dit hoofdstuk is gewijd aan de vraag of op grond van die interpretatie van het ontstaan van de moderne universiteit conclusies kunnen worden getrokken voor de universiteit anno 1991. Daardoor draagt dit hoofdstuk een meer speculatief en versnipperd karakter dan de voorafgaande.

De aanzet tot deze studie was de wens meer zicht te krijgen op het functioneren van de universiteit in haar maatschappelijke context. De aanleiding daarvoor vormde de 'Basisfilosofie" ' waarmee de Rijksuniversiteit Limburg in 1976 van start gegaan is. De 'Basisfilosofie' is een voorbeeld van een overkoepelende universitaire "missie'. In de eerste paragraaf van dit hoofdstuk wordt ingegaan op het nut en de functie van dergelijke programmatische geschriften. Het eerste perspectief daarop wordt aangereikt door de organisatiesociologische en onderwijskundige literatuur over dat onderwerp. Vervolgens zal worden onderzocht tot welke conclusies de analyse van de in de voorafgaande

1 Niet alleen Nederlands jongste maar ook Nederlands oudste universiteit kent een clergelijk geschrift: "The toundation of Leiden"s university in 1575 was primarily a political decision during the Eighty Yers' War of independence against Spain. Its main purpose was the creation of an intellectual strongholld where students were trained for positions promoting the citizens welfare. This meant that the training of practical abilities was accentuated, as can be seen in the hypotyposis a proposal for curricula in different faculties made in 1575 by the professor of theology. Gulielmus Feugueraeus" (Beukeri 19896: 139). In de jaren zeventig wan deze eeuw waren "Basisfilosofieën" schijnbaar populair: In april 1975 verscheen ook een 'Basisfilosofie academische ziekenhuizen' van de minísteries van Onderwijs en Volksgezondtueid (Goudsmit 1978: 137; Van der Maesen 1986: 42),

2. All was de 'Basisfilosofie' in eerste instantie slechls bedoeld voor de op te richten Medische Faculteit Maastricht, een groot aantal desiderata met betrekking tot de inrichting van het onderwijs zijn respectiewelink door de faculteiten Rechtsgeleerdheid, Gezondheidswetenschappen, Economie en Algemene Wetenschappen overgenomen. 
hoofdstukken gepresenteerde historische gevalstudie aanleiding geeft, met name wat betreft de verhouding tussen veranderingen in het onderwijs op het niveau van de maatschappelijke organisatie en op het meer inhoudelijk en methodisch niveau binnen faculteiten.

In de tweede paragraaf wordt de 'Basisfilosofie' geplaatst in de context van de discussie over het medisch onderwijs. De drie elementen die in de negentiende eeuw bij de hervorming van het medisch onderwijs centraal stonden en met elkaar verweven waren - de verhouding tussen theorie en praktijk, een roep om methodische onderwijsvernieuwingen en een veranderde opvatting van ziekte met de daarbij behorende consequenties voor de zorgverlening zijn ook in de 'Basisfilosofie' present. Daarmee sluit de 'Basisfilosofie' aan bij de traditie en vormt ze een programmatisch geschrift van de oude soort. Een dergelijk programma, dat een groot aantal verschillende thema's en ontwikkelingen vanuit één perspectief en met een bepaalde inzet wil begrijpen, is noodzakelijkerwijs gevoelig voor kritiek. De discussie over de "Basisfilosofie" heeft zich de afgelopen decennia ten dele afgespeeld op een zelfde niveau van algemeenheid als het oorspronkelijke geschrift. Aanvankelijk spitste dat debat zich toe op de vraag in hoeverre de gegeven analyse van de verhouding tussen gezondheidszorg, wetenschap, medische opleiding en maatschappij adequaat was. Vervolgens werd het zwaartepunt verlegd naar de vraag of die analyse in het licht van continu veranderende maatschappelijke en technische omstandigheden en wetenschappelijke inzichten nog wel bij de tijd bleef. Wanneer de 'Basisfilosofie' meer in detail bekeken wordt, vormt deze vanzelfsprekend een willig slachtoffer voor specialisten in de onderwijskunde, de filosofie van de geneeskunde of de medische sociologie. In deze studie wordt de 'Basisfilosofie' allereerst gesitueerd in het denken over de gezondheidszorg van haar tijd, de woelige late jaren zestig en vroege jaren zeventig. Vervolgens wordt de 'Basisfilosofie' geplaatst tegen de achtergrond van de geschiedenis van de medische opleiding. In de paragraaf' Het Maastrichtse systeem' worden daaruit conclusies getrokken over de huidige status quo van de 'missie' van de Rijkstuniversiteit Limburg. Daarbij komt ook de overname en de verdere ontwikkeling van de' Basisfilosofie' in de faculteit der rechtsgeleerdheid ter sprake.

In de vierde paragraaf komen consequenties van het in dit boek geformuleerde perspectief op modernisering voor het hoger onderwijsbeleid in het algemeen aan de orde. Dat leidt tot een stellingname met betrekking tot de wenselijkheid van een verdergaande individualisering van het onderwijs. Dat the-

3 Zie bijwoorbeeld R. Reneman in de Obserwant (nummer" 30, 26 april 1990: 5): "Belangrijker is dalt er sindsdien geweldige ontwikkelingen zijn geweest in moleculair-biologische richting, dat kan niemand ontkennen. In het jaar 2000 wordt de huisarts daarmee geconfronteerd. (...) Daar moeten we de studenter. op voorbereiden." 
ma wordt besproken in relatie tot internationalisering, een van de modewoorden in het hoger onderwijsbeleid van deze tijd. Eén van de conclusies van dit hoofdstuk is dat het streven naar internationalisering in het hoger onderwijs conflicteert met het streven naar het behoud of zelfs het vergroten van de autonomie van de afzonderlijke universitaire instellingen.

\section{Een universitaire missie}

"The University's Statement of Goals - An idea whose time has arrived" zo kondigt B.D. McKelvie (1986) juichend aan. Iedere complexe organisatie wordt volgens McKelvie geconfronteerd met één en hetzelfde probleem, namelijk "how to improve the efficiency of their efforts to attain goals" (McKelvie 1986: 151). De universiteit verschilt van andere organisaties doordat ze zoveel verschillende doelen kent, die inconsistent kunnen zijn of onderling kunnen conflicteren. Daarenboven bemoeilijkt de universitaire bestuursstructuur de identificatie van die doelen. Daarom vraagt volgens McKelvie (1986: 152) het vaststellen van die doelen ${ }^{4}$ alle aandacht: "Establishing the mission and goals of the institution is the first step toward the effective use of resources. As a next step, every college (and university) should develop a strategy that will successfully guide the institutions toward those goals". Drie niveaus worden daarbij onderscheiden: mission, waarmee een "institution's educational philosophy", het lange termijn kader, aangeduid wordt; goals, die richting moeten geven aan institutionele groei, en objectives, korte termijn doelen. Vooral het niveau van de 'goals' is volgens McKelvie van belang. Dat moet consistent zijn met de 'missie"; op basis daarvan kunnen prioriteiten aangegeven worden. Helder geformuleerde' goals' maken een coherente instellingspolitiek mogelijk, geven richting aan voor de toekomst, dragen zorg voor legitimering, leveren evaluatiecriteria ten behoeve van overheden en mogelijkheden tot profilering.

Dat optimisme over de zinvolheid van het formuleren van doelen in een organisatie als een universiteit leeft zeker niet algemeen. Dat hangt in de eerste plaats samen met het uiteenlopen van ideeën over organisaties op zich. W.R. Scott (1981:217-223) onderscheid teen "rational system definition' ("an organization is a collectivity oriented to the pursuit of relatively specific goals and exhibiting a rela tively highly formalized social structure"), van een 'natural system definition' ("an organization is a collectivity whose participants are little affec-

4. Al hecht McKelvie veel belang aan 'goals', over de wijze waarop die 'goals' opgespoord, dan wel wastgesteld moeten worden toont zij zich een stuk pessimistischer. Bovendien beperkt het ontbreken van geprononceerde hiêrarchische verhoudingen binnen de universitit de mogelijkheden tot een "management by objectives". "Outcome oriented planning" ligt daar meer voor de hand. 
ted by the formal structure or official goals but who share a common interest in the survival of the system and who engage in collective activities, informally structured, to secure this end"), en een "open systems definition' ("an organization is a coalition of shifting interest groups that develop goals by negotiation; the structure of the coalition, its activities, and its outcomes are strongly in fluenced by environmental factors"). Het belang dat men aan het expliciet formuleren van doelen van organisaties toekent is uiteraard sterk afhankelijk van de ideeën die men over organisaties heeft. Voor theoretici die een organisatie opvatten als een 'rationeel systeem' staan nagestreefde doelen voorop, terwijl diegenen die een organisatie als een 'natuurlijk systeem' benaderen vooral het collectieve karakter van een organisatie zullen benadrukken. "[R]ational system perspective stresses those features of organizations that distinguish them from other types of social groups, while the natural system theorists remind us that these distinguishing characteristics are not their only characteristics" (Gouldner 1959: 406). Wie een "open systeem" opvatting van organisaties hanteert, zal steeds willen benadrukken dat een organisatie een eigen leven leidt dat weinig te maken hoeft te hebben met de 'goals' van de organisatie als geheel.

Zijn er al verschillen van inzicht over de eigen aard van organisaties in het algemeen, over de specifieke aard van de universitaire organisatie lopen de meningen minstens even sterk uiteen. Wijst McKelvie zelf erop hoe moeilijk het is binnen een universiteit 'goals' op te stellen of te traceren, een review-artikel van H.P. Tuckman en C.F. Chang (1988) stemt nog somberder over de mogelijkheden van het hanteren van het "goal'-concept. $Z$ ij onderscheiden doelen voor studenten ${ }^{5}$, doelen voor faculteitsleden ${ }^{6}$, doelen op het beheersni-

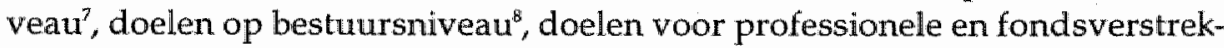
kende organisaties, doelen voor de maatschappij", doelen voor ministeries van

5 To facilitate cognitive leatning, to promote emotional and moral development, to achieve practical competence, to attuin direcl satisfaction and enjoyment, to awoid negative outcomes (Tuckman and Chang 1988: 613).

6 To facilitate cognitive learning for self to increase emoltional and moral self-development, to contributue to student learning, to contribute to the creation of new knowledge, to achieve profiessionall recogsnition and prestige, to achieve economic success, to realize non-kwork related satisfaction and erjoymeni (Tuckman and Chang 1988: 614).

57 To achieve self-cognitive learning, to pursue emotional and moral self-development, to contribute to stuclent and faculty learming, to insure the perpetuation and growth of the institution, to insure efficient management of the institution, to achieve professional recognition and prestige, to achieve economic success, to realize non-work related satisfaction and enjoyment (Tuckman and Chang 1988: 615).

8 To insure survival and growth of the institution, to insure efficient management of the institution, lo represent alumini or state interests, to encourage preservation and dissemination of the human culiture, 10 encourage discovery and dissemination of new knowledge (Tuckman and Chang 1988: 615-616).

9 To preserve and disseminate cultural heritage, to encourage discovery and dissemination of nem knowledge, to encourage discovery, recognition, traiming, and placement of talent, to adwance the social welfare, to assist society in achieving positive and avoiding negative outcomes (Tuckman and Chang $1988: 616 \times 617)$ 
Onderwijs en Wetenschappen ${ }^{10}$, doelen voor filantropische instellingen ${ }^{11}$ en doelen voor particuliere en industriële fondsverstrekkers ${ }^{12}$. Over het tot stand komen van preferenties en de keuze voor specifieke doelen is (nog) niet veel bekend. Het hoger onderwijs wordt daarmee tot een slagveld van conflicterende belangen en doelen, die niet op het niveau van de "missie vochten $^{13}$. De universiteit krijgt het uiterlijk van een 'organized anarchy' (Scott 1981: 272) of zoals Cohen, March en Olsen (1972) het noemen een 'garbage can": "Opportunities for choice in higher education can easily become complex 'garbage cans' into which a striking variety of problems, solutions, and participants may be dumped. Debate over the hiring of a football coach can become connected to concerns about the essence of a liberal education, the relations of the school to ethnic minorities, or the philosophy of Kant" (Cohen and March 1976: 175).

Een vergelijkbare verwevenheid van vraagstukken kenmerkt ook de veranderingen die zich gedurende de negentiende eeuw aan de Nederlandse universiteiten hebben voltrokken. Achteraf is het mogelijk deze te interpreteren als verbonden met schaalvergroting en globalisering, waarbij hiërarchische concepten in de verwachtingsstructuren worden teruggedrongen door procestermen. Dat geeft - terugziend - het beeld van een samenhangende transformatie. In dat transformatieproces zelf zijn er echter nauwelijks echte keuzepunten of verstrekkende dichotomieën aan te geven. Veeleer is ex sprake van een doorlopende discussie met in elkaar grijpende puzzelstukjes waarbij het voorbeeld op het deksel langzaam maar zeker verandert. Zowel de afzonderlijke delen, de relaties daartussen, als het totaalbeeld zijn aan verandering onderhevig. Het gebruik van het Latijn in de domeinen van de geneeskunde en het recht is gekoppeld aan de toerekening van het gymnasium tot het hoger onderwijs. In het vraagstuk van de cursusduur - één jaar of een half jaar - wordt indirect het kennisideaal - de encyclopedische presentatie van een vakgebied versus onderwijs voortbouwend op reeds elders verkregen inzichten - ter discussie gesteld. In de standpunten over het aantal bedden dat het nosocomium,

10 To promote equality of opportunity, to provide student financial aid to the needy, to promote and encourage research, to finance inmovation, to assure efficient use of funds, to protect the right of citizens in the educational process, to train citizens to meet state needs, to coordinate the sources of postsecondary education, to protect the diversity of university offerings (Tuckman and Chang 1988: 618). 11. To upgrade the quality of instruction, to insure equal access to education, to direct students and factily towards felds in short supply, to direct research towards fields of concern to the sociall welfare, to improve the quality of campus facilities (Tuckman and Chang 1988: 619).

12 To upgrade the level of human resources available to industry, to create and disseminate new knowiledge, to provide greater awareness of the economic system (Tuckman and Chang 1988: 619).

13 "In more differentiated and loosely coupled systems such as universities, power diffenences among suburits may be teflectled not so much in direct attempts to redefine the gonls of the larger system bul in efforts to lay elain to a disproportionate share of the organization's resounces's (Scott 1981: 270). 
respectievelijk het academisch ziekenhuis moet hebben, worden opvattingen over het klinisch onderwijs en de ontwikkeling van de maatschappelijke organisatie van de zorgverlening weerspiegeld. De organisatie van de examens heeft effecten op de maatschappelijke bevoegdheid, beïnvloedt de organisatie van de studie en heeft implicaties voor het alledaagse leven van de student. De op pedagogische gronden verdedigde hervorming van het geneeskundeonderwijs, de introductie van het onderwijslaboratorium, de uitbreiding van het klinisch onderwijs, vallen slechts te begrijpen in het kader van een transformatie van het kennisideaal en veranderingen in de opvatting van ziekte etc. De samenhang tussen dergelijke veranderingen wordt pas later geduid, terwiil daarover veelal verschillende visies bestaan.

De discussies over de inrichting van het hoger onderwijs hebben nergens het uiterlijk van een helder debat over een aantal welgeformuleerde alternatieven. Zij worden veeleer gekenmerkt door het door elkaar heen lopen van uiteenlopende invalshoeken en ideeën waarbij zonder moeite van het ene naar het andere abstractieniveau gesprongen wordt. Waarbij uiteindelijk blijkt dat niet eens zozeer de argumenten, als wel de weging van die argumenten in de loop der tijd verschuift. Terwijl de geconstateerde contingentie in bepaalde domeinen van het recht aanvankelijk aanleiding geeft deze uit te sluiten van een wetenschappelijke behandeling aan de universiteit, leidt die ervaring van contingentie later tot een radicale heroriëntatie van de rechtsgeleerde opleiding.

Vanuit dat perspectief wordt het praktisch nut van de hierboven ingevoerde - en veel gehanteerde - driedeling in 'mission', 'goals' en 'objectives' uiterst beperkt. Het beeld van een 'missie' op basis waarvan 'goals' en 'objectives' geformuleerd kunnen worden, voldoet in tijden van verandering of transformatie - en dat zijn de enige periodes die politiek gezien relevant zijn - niet. Er kunnen geen institutionele niveaus worden afgescheiden die zich met de "mission" bezig houden. Ook anno 1991 worden de (bestuurders van) universiteiten geconfronteerd met voorstellen die zowel op het niveau van de 'objectives', als op dat van de 'goals' als op dat van de 'mission' implicaties hebben. En ook hier verandert de 'missie' geleidelijk met verschuivingen in de "objectives'.

Wanneer de'onbestuurbaarheid' van een universitaire organisatie wordt toegegeven, wanneer vastgesteld wordt dat veranderingen in de koers van een universiteit niet in eerste instantie op het niveau van de 'missie' maar op het niveau van de 'goals' en de 'objectives' plaatsgrijpen, dan hoeft dat niet tot de conclusie te leiden dat het niveau van de 'missie' geheel naar de achtergrond kan verdwijnen. De 'missie' vervult immers wel degelijk een aantal belangrijke functies. Ze is belangrijk in de presentatie van de universiteit naar buiten. Ze levert intern een referentiekader waar politieke beslissingen in een gedemocratiseerde universiteit aan getoetst kunnen worden. Het uit pragmatische, of uit korte termijn politiek, laten verwateren van de 'missie' leidt op langere termijn 
onherroepelijk tot breuken en discontinuïteiten binnen de universitaire politiek, die niet alleen in de externe profilering een slechte indruk maken, maar intern kapitaalsvernietiging, frustraties en desinteresse met zich meebrengen.

De conclusie uit de constatering dat in een universiteit belangrijke veranderingen via het niveau van de "objectives' en de 'goals' tot stand worden gebracht moet veeleer luiden dat juist meer aandacht moet worden geschonken aan de vraag naar de implicaties van veranderingen in de 'objectives' voor het niveau van de 'missie'. Maar dat veronderstelt een beeld van een 'missie' als een organisch iets, dat hoewel het enerzijds als referentiekader fungeert, permanent verandert. Het betekent ook dat in de universitaire politiek steeds de interactie tussen "objectives", 'goals' en "mission' in het oog gehouden moet worden. De effecten van het beschikbaar komen van nieuwe technieken en onderwijsmethoden op de 'werkvloer' voor het niveau van de 'missie', verdienen dan meer aandacht.

De misplaatste nadruk op het top-down hanteren van het 'missie'-concept hangt samen met een overschatting van de maakbaarheid van de universitaire organisatie. Meer in zijn algemeenheid is die overschatting eigen aan de grondstructuren van de moderne samenleving. Koselleck $(1979: 34 ; 61-62)$ formuleert de veranderingen die in de tijdsbeleving bij het ontstaan van de moderne samenleving optreden als volgt: "Der Fortschritt öffnet nunmehr eine Zukunft, die den überkommenen prognostizierbaren, naturalen Zeit- und Erfahrungsraum überschreitet und der dadurch - im Zug seiner Dynamik neue, transnaturale und langfristige Prognosen provoziert. (...) Die Machbarkeit der Geschichte entthronte die alte Historie, denn in einem Staate wie dem unsrigen, auf Sieg gegründet, gibt es keine Vergangenheit. (...) Weil sich die Zukunft der modernen Geschichte ins Unbekannte öffnet, wird sie planbar, und mußs sie geplant werden. Und mit jedem neuen Plan wird eine neue Unerfahrbarkeit eingeführt. Die Eigenart der 'Geschichte' wächst mit ihrer Machbarkeit. (...) Nicht mehr aus der Vergangenheit, nur aus der selbst zu schaffenden Zukunft läßt sich Rat erhoffen." De verwachtingsstructuren in een moderne samenleving worden niet meer gedomineerd door hiërarchische indelingen maar door procestermen, die een principiële onzekerheid in de tijdsontwikkeling veronderstellen. Maar de onzekerheid die met de notie van proces gegeven is maakt ook de eenzijdigheid van 'plannings-', 'beleids-" en 'interventiéconcepten duidelijk. Alle refereren aan het langs institutionele weg, 'van boven af", ingrijpen in maatschappelijke domeinen, die geformeerd zijn rondom processen waarvan de afloop onzeker is. Niet alleen ligt de nadruk op ingrijpen van bovenaf, meestal ligt de nadruk ook nog op intentioneel ingrijpen van boven af. In afwijking daarvan stellen Hardy, Langley, Mintzberg en Rose (1984) voor strategische planning te begrijpen als een (evaluatieve) terugblik: "Some have suggested that few universities have strategies and that they had 
better develop them following the methods generally accepted in business (e.g. Dube \& Brown 1983; Doyle \& Lynch 1979). Others have noted that when universities do formulate strategies, they consistently fail to implement them satisfactorily because of a deplorable lack of administrative power, leadership skill, or courage in the face of opposition (e.g. Hosmer 1978; Ladd 1970; Lutz 1982: 653-69). We, on the other hand, believe that the conventional view of strategy as a plan, or a set of explicit intentions preceding and controlling actions - is too narrow to permit a satisfactory understanding of strategy formation in the university setting. (...) An alternate view of strategy focusses not on a priori articulation of intention, but on the existence of consistency in the actions and/or decisions emerging from an organization. Specifically, we define strategies as realized patterns in streams of decisions or actions."

Een vergelijkbare overtuiging had $\mathrm{H}$. Simon (1978: 120) al. eerder het kennisdoel van de sociale wetenschappen als zodanig drastisch doen inperken. "In general, the emphasis on prediction in macrosocial models is a misplaced emphasis. Neither do we have the knowledge of socio-economic mechanisms that would make such prediction possible, nor is it prediction that we need for policy purposes. Our concern is not to forecast the future but: (a) to understand the consequences of alternative possible futures, and (b) to understand which of these possible futures is associated with particular strategies or policy measures." Van de sociale wetenschappen mogen geen overspannen verwachtingen worden gekoesterd. Ze kunnen hooguit bijdragen aan een beter inzicht in de sociale werkelijkheid. Rosenbrock (1979: 915) ziet dat ook als taak voor de pedagogiek" ${ }^{14}$ "Die pädagogische Reflexion der Hochschule ist stets mit dem. Anspruch verbunden, die Wechselwirkungen zwischen der Hochschule und dem gesellschaftlichen Leben so zu erhellen, dass aus der Einsicht in den Erziehungsauftrag der Hochschule, praktische, wirksame Konzepte für die Gestaltung des Hochschulunterrichts selbst folgen und die Erziehungswirklichkeit prägen." Vanuit dat (bescheiden) perspectief wordt in de navolgende paragraaf ingezoomd op eén specifieke universitaire 'missie': de 'Basisfilosofie' (1972) van de Rijksuniversiteit Limburg.

14 In het verlengde hiervan vat K.E. Schorr (1979: 884-885) de pedagogiek op als "Theorie des Erziehungssystems, die selbst Teil dieses Systems ist, das sie behandelt, so dass sie, wenn sie sich selbsit verändert, auch irgendwie ihren Gegenstand veränclert und umgekehrt: wenn ihr Gegenstand sich andert, selbst unter Verändlerungsadruck gerät (ohne immanent ideengeschichtlich gezwungen zu seint)." Of anders geformuleerd: "Die Pädagogik produziert laufend Aussagen im System für das System und nimmt diese Form von Selbstreferenz in der Produktion vorweg, ohne deshalb Aussagen zu formulieren, die sich mit der Form dieser Produktion befassen. Die pädagogische Theorie hat Anschlusswert für das Erziehungssystem selbst und weiss dies" (Schorr 1979: 890). 


\section{De 'Basisfilosofie' van de Rijksuniversiteit Limburg}

De oorsprong van de 'Basisfilosofie" valt te situeren in een tijdsgewricht waarin op ruime schaal binnen de samenleving het idee - of misschen beter de utopie - leefde van een radicale maatschappelijke hervorming. Ook de wetenschapsbeoefening, en het institutionele kader daarvan, de universiteiten, zouden daarbij drastisch moeten veranderen. Wetenschapswinkels vormden één van de bressen in de universitaire muren, van waaruit die wetenschappelijke en maatschappelijke hervormingen verder zouden kunnen worden aangezwengeld (Wachelder 1991a). In diezelfde context zwol binnen het domein van de gezondheidszorg de kritiek op het functioneren van de medisch expert aan. Eén van de aangrijpingspunten daarbij was de verregaande professionalisering van de gezondheidszorg. Deze werd verantwoordelijk gesteld voor de ongewenste transformatie van het lijden van de individuele patiënt tot een biomedisch 'geval'. Er werd geconstateerd dat de mogelijkheden van het laboratoriumonderzoek een eigen dynamiek ontwikkelden, die de medische consumptie opdreef etc. Voor het eerst sinds het ontstaan van de natuurwetenschappelijke geneeskunde in de negentiende eeuw werd met nadruk gewezen op de contraproductieve facetten die met de universitaire, biomedisch georiënteerde geneeskunde verbonden zijn (Illich 1978; Achterhuis 1979). Voorbij een bepaald punt, zo formuleerde $H$. Achterhuis het in navolging van I. Illich, maakt de geneeskunde mensen ziek en onmondig in plaats van gezond en kritisch. Internationaal gezien leidde dat onder andere tot een streven naar 'primary health' van de kant van de World Health Organization. Binnen de Nederlandse artsenstand was al in de jaren zestig, met name door huisartsen er bij voortduring op gewezen dat de medische opleiding niet meer aan de eisen van de eerste lijns geneeskunde voldeed (Goudsmit 1978: 111). Op het eind van de jaren zestig kwam de opleiding tot arts zoals die aan de Nederlandse universiteiten was vormgegeven hevig onder vuur te liggen.

Dat vormt een deel ${ }^{\text {t5 }}$ van de context waarbinnen de "Basisfilosofie" voor de nieuw op te richten Medische Faculteit Maastricht gestalte krijgt. De 'Basisfilosofie" drukt de wens uit de extramurale gezondheidszorg te stimuleren. In plaats van een strikt biomedisch ziektemodel wordt voorgesteld in het onderwijs en onderzoek meer plaats in te ruimen voor het lijden van de individuele patiënt in zijn eigen psycho-sociale omgeving. De inzet is daarbij via onderwijs en onderzoek de gezondheidszorg zodanig te beinvloeden, dat een verschuiving van intra- naar extramurale zorg zou optreden. Van de arts van de toe- 
komst zouden andere kennis en een andere attitude gevergd (moeten) worden. Dat leidt tot het besluit de opleiding tot arts in Maastricht fundamenteel anders op te zetten dan aan de andere medische faculteiten in Nederland. De onderwijskundige ideeën die in het kader van de 'Basisfilosofie' zijn ontwikkeld, staan in dienst van de wens via de medische opleiding de gevestigde structuren in de gezonalheidszorg - en met name de invloed van de biomedische vakken daarbinnen - te doorbreken. Het in Frankrijk op 16 juni 1968 onder verantwoordelijkheid wan het "Comité de synthèse des étudiants en médecine de Paris' verschenen 'Livre blanc de la reforme' neemt een vergelijkbare positie in. Het 'Livre blanc' stelt: "Traditioneel onderwijs veronderstelt een traditionele structuur. Wanneer diskussie en samenwerking op wetenschappelijke basis centraal staan, dan impliceert dit een fundamenteel-demokratische organisatiestruktuur van de fakulteit. De studenten moeten zich ontwikkelen van passieve consumenten van een buiten hen om samengesteld studiepakket tot aktieve participanten, die volgens de aanwijzingen van de deskundigen en specialisten de studiestof reflexief verwerken" (in Goudsmit 1978: 152-153). De grote zelfwerkzaamheid van de student die hier geproclameerd wordt is ook een van de kernpunten van het Maastrichtse onderwijssysteem.

Doordat de "Basisfilosofie" via de organisatie van onderwijs en onderzoek wil bijdragen aan een verandering van de gezondheidszorg, vormt ze tevens een reactie op de ontwikkeling van de medische opleiding ${ }^{16}$ in Nederland ${ }^{17}$. Elk van de trefwoorden waarmee dat onderwijssysteem ${ }^{28}$ vaak gekarakteriseerd wordt-probleemoriëntatie, zelfwerkzaamheid, vaardigheidstraining, attitudevorming en voortgangsevaluatie - kan gesitueerd worden tegen de achtergrond van de geschiedenis van het denken en spreken over de medische opleiding in Nederland. In hoofdstuk drie is getoond hoe de overgang naar eenheid van stand vergezeld gaat van een heroriëntatie van het onderwijs op de hogescholen. Als dan op de hogescholen praktisch onderwijs wordt geïntrod uceerd, gebeurt dat in het kader van de training van de waarnemingsvermogens van de arts. De facto krijgen echter via dat praktisch onderwijs de laboratoriumwetenschappen binnen de geneeskundeopleiding een plaats. Door iets nietuws te introduceren, namelijk zelfstandige observatie en registratie van ziekte- en levensprocessen, weten de zich op de natuurwetenschappen oriënterende geneeskundigen een nieuw ziekteconcept te introduceren, en aldus de

16 Voor deze paragrat is dankbaar gebruik gemaakit van bronnenonderzoek verricht door Annette Boenink. Eventule onjuistheden zujn de werantwoordelijkheid van de auteur. Zie voor een overzicht vari de geschiedenis van de medische opleiding gedurende de twintigste eeuw Goudsmit (1978).

17 Een aantal van de ideeën tot onderwijsherworming uit de "Basisfilosofie" komen via. H.A. Tiddens wit Noord-Amerika.

18 Zie Tiddens, Willighagen en Wijnen (1975); Schmidt en Bouhuijs (1980); Van der Maesen (1986: 34 35). 
bestaande kloof tussen theorie, de geleerde boeken en kennis van ziektesystemen, en praktijk, ervaring, te overbruggen. Praktisch onderwijs betekent in die nieuwe context niet meer primair het opdoen van ervaring, of het volgen van een meester, maar staat in eerste instantie voor laboratoriumonderwijs in natururwetenschappelijke basisvakken. Daaruit groeit in Nederland de situatie dat de natururwetenschappelijke basisvakken niet alleen in de ontwikkeling van het medisch onderzoek en de zorg, maar ook in de medische opleiding een dominante rol gaan vervullen. Geleidelijk krijgt de opleiding de vorm van een introductie in natuurwetenschappelijke en biomedische basisvakken, gevolgd door klinische vakken ${ }^{19}$, en biedt uiteindelijk pas de gelegenheid tot toepassing van het geleerde in de praktijk.

Deze opbouw van de studie, waarbij in de beginfase de nadruk ligt op de natuurwetenschappen en waarbinnen relatief weinig aandacht bestaat voor praktische oefening van vaardigheden, wordt al in het begin van de twintigste eeuw onderwerp van kritiek. De praktische oefening van de arts wordt daarbij opnieuw inzet van debat, waarbij de tegenstelling tussen een wetenschappelijke en een praktijkoriëntatie - uiteraard in een veranderde wetenschappelijke, technische en maatschappelijke context - weer oplaait. In 1906 wordt door het Hoofdbestuur van de Nederlandsche Maatschappij tot Bevordering der Geneeskunst een Blijvende (!) Commissie ingesteld 'voor het Praktische en het Aanvullende Geneeskundig Onderwijs'. Er wordt geconstateerd dat wegens de identificatie van praktisch onderwijs met laboratoriumonderwijs in de biomedische basisvakken de jong afgestudeerde arts vaak "onbeholpen in de praktijk" staat (Rapport 1909). Wanneer dat praktisch natuurkundig onderwijs voor een groot deel naar het gymnasium ${ }^{20}$ zou kunnen worden overgebracht, dan zou op de universiteit meer ruimte komen voor klinisch onderwijs en praktische oefening. De commissie stelt voor de geneeskundeopleiding te herzien: "[Z]ij bedoelt niet een opleiding tot wetenschappelijk onderzoek, maar een wetenschappelijke opleiding tot de klinische studie, en dat is het juist wat het meerendeel der aanstaande artsen noodig heeft" (Rapport 1909: 365). Maar ook het tegenovergestelde geluid valt te horen. "In een tijd dat natuurkunde, scheikunde en physiologie een steeds grooter invloed hebben gekregen op onze onderzoekingsmethoden, ons geneeskundig inzicht en ons handelen, den studietijd, die al te kort genomen is, nog meer te willen bekorten, is een stap achteruit" (Borst 1909: 1634-1635). In overeenstemming hiermee is de mening

19 Waarvan het aanttal door de steeds verdergaande specialisering in de loop der tijd sterk toeneemt. 20 Als achterhoedegevecht laait dan nog eens de discussie over de verschuivende verhouding tussen het middelbaar en het hoger onderwijs op (zie hoofdstuk twee), die in 1917 haar hoogtepunt vindt in het debat rondom de Wet Limburg, die HBS-ers, het recht verleent om te promoveren aarh een universiteit (zie $\mathrm{m} . \mathrm{n}$. de jaargang 1917 van het $N T v G$ ), 
van L. de Jager (1910b: 1729-1730), die door de gelijkstelling van praktijk met ervaring uit de vorige eeuw over te nemen, praktische oefening in feite onmogelijk acht. "[D]e praktische ervaring noodig voor de gewone praktijk wordt nu eenmaal alleen verkregen door de praktijk. (...) De vraag is niet of de jonge arts de noodige praktische bekwaamheid bezit, maar of hij in staat is zich die zelfstandig te verwerven. (...) Aan dien eisch nu voldoet onze universitaire op leiding volkomen." Over het voorstel van een commissie van de NMG om de jonge arts een jaartje op eigen kosten praktijk te laten doen (een min of meer verplicht "volontairschap") zegt hij dat een poosje zelfstandig praktiseeren natuurlijk nuttig is, maar "ik zie niet in, welk verschil het maakt (...), of de patiënten van een ander of van den jongen arts zelf aan dezen overgeleverd zijin (De Jager 1910b: 1730). De kwestie van de regeling van het praktisch onderwijs wordt een slepende zaak. In 1914 klaagt een lid $^{21}$ van de 'Blijvende commissie voor de praktische vorming' tijdens de algemene vergadering van de NMG dat die commissie nu al wel haast twintig jaar "haar lijden voortsleept". Want "men heeft elk rapport principieel, vierkant bestreden" (Handelingen 1914: 1211).

Vanaf 1916 wordt in het NTvG de kwestie van het medisch onderwijs regelmatig aangesneden door $G$. van Rijnberk, de beherend redacteur van dat blad, veelal aan de hand van besprekingen van in het buiteniand verschenen publikaties. In 1916 vestigt hij de aandacht op een aantal opstellen in het Journal of the American Medical Association. De geest die uit deze opstellen spreekt is én en dezelfde: de natuurwetenschappen vormen de basis en het fundament voor het geneeskundeonderwijs. Volgens E.P. Lyon valt in de fysiologie niet aan te geven wat van praktisch nut is en wat niet. "[A]lles wat goede physiologie is, is goede geneeskunde" (in Van Rijnberk 1916: 598). "[H]et stellen van een nuttigheidseisch bij het praeclinische onderwijs is dan ook geheel uit den booze" (Van Rijnberk 1916: 806). L. Barker verdedigt de universiteiten "tegen de aantijging dat de wetenschappelijke standaard steeds hooger wordt opgevoerd, zoodat het er meer op lijkt, dat daar professoren, dan dat er artsen gekweekt worden (...). De universiteiten moeten dus een zoodanig onderwijss geven, dat niet alle leerlingen praktisch dokter worden, maar dat diegene onder de jongere geslachten welke daartoe den aanleg zullen blijken te bezitten, een prikkel ontvangen om zich te wijden aan wetenschap en onderwijs, om later hun leeraren te kunnen vervangen" (Van Rijnberk 1916: 707). Bovendien moet men dit onderwijs geven alsof zijn gehoor uitsluitend uit "besten" be-

21 A.A. Hijmans wan den Bergh.

22 "De kennis wan de physiologie van het kikkerhart is tot in bijzonderheden voor den arts van belang, ook al is een kikker een koudibloedig dier en al weet men zeer goed, dat men die kennis riet onmiddellijk op het menschenhart mag overdragen". 
stond en niet, zoals zijn voorganger deed "zo dat de domsten het nog net konden volgen en de besten er toch ook nog wat aan hadden". Immers, "[h]oe meer van den arts als student aan geestelijke inspanning geëischt wordt, hoe langer dit bij hem nawerkt, hoe langer hij den voortgang van zijn vak zal kunnen volgen" (Van Rijnberk 1916: 807). Wel bestaat er in ons land volgens Van Rijnberk "een bepaald overdreven geloof in het nut van veel college geven" ${ }^{\prime \prime 2}$. In 1918 bespreekt Van Rijnberk de onderwijskundige inzichten van Schwalbe, redacteur van het Deutsche Klinische Wochenschrift, van Pearce en een groot aantal andere Amerikanen. Naast de oriëntatie op de natuurwetenschappen die ook hij wil behouden pleit Schwalbe voor uitbreiding van praktische oefening in de toegepaste geneeskunde (Van Rijnberk 1918: 1528). Voorts wil hij de wijsbegeerte als verplicht vak zien ingevoerd. Een aantal colleges in de klinische vakken - algemene en bijzondere pathologie - kunnen vervallen: "Een goed boek hierover, thuis rustig doorgewerkt, is veel nuttiger dan tijdroovende en uit den aard der zaak droge theoretische colleges over deze onderwerpen" (Van Rijnberk 1918: 1588). Praktisch onderwijs in de oude zin - het zelfstandig verrichten van laboratoriumproeven en lijkopeningen - kan drastisch worden gereduceerd ${ }^{24}$. In de natuurwetenschappelijke propaedeuse kan eveneens gesnoeid worden. De geneeskundige propaedeuse is immers niet bedoeld om geleerden, bijv. fysici, te kweken, doch kan volstaan "met het later voor de praktijk benoodigde te verschaffen" (Van Rijnberk 1918: 1588). Pearce's uitgangspunt vormt de maxime "do it yourself". Hij wil "dat de studenten hun tijd zooveel mogelijk in de cliniek zelve doorbrengen, om daar, onder toezicht van hoogleeraren en assistenten, betrekkelijk onafhankelijk een aantal zieken geheel te bestudeeren, met alle methoden der hedendaagsche diagnostiek. (...) Als een bijzonder goede instelling noemt hij cursussen aan de universiteit van Pensylvanië gehouden, waarbij kleine groepen studenten, gedurende een geheel jaar, bepaalde organen bestudeeren, alle ziekten ervan, voorzoover gevallen er van te krijgen waren, van alle zijden, onderzoeken, met alle in zwang zijnde methoden, niet alleen voor practische, maar ook voor wetenschappelijke doeleinden, daarbij tevens de physiologie en de pharmacologie dier organen proefondervindelijk geheel doorwerken. Pearce noemt dergelijke cursussen: cursussen in geneeskundigen samenhang - courses in medical correlation" (Van Rijnberk 1918: 1657). Ook uit de preklinische vakken wil Pearce - zijn motto "do it yourself" indachtig - colleges vrijwel geheel

23 De vele colleges in bijvoorbeeld Amsterdam "zotaden witerst nadeelig werken, indien de studenten, naar men mij stellig verzekert, zelf niet het kwaad neutraliseenden door als tiegel, terminste kén college elken morger te verzuimen."

24 Zie voor de argumenten van Schwalbe de paragraal "materiële en formele worming" im hoofstuk vijf. 
verbannen ${ }^{25}$. Eến inleidend college en een informeel responsiecollege ter bespreking van gerezen moeilijkheden per week zouden volstaan. De rest van de tijd zou moeten worden doorgebracht in laboratorium en kliniek. F.P. Mall klaagt over de onmogelijkheid het onderwijs aan te laten sluiten bij individuele voorkeuren van de student. C.M. Jackson, gaat nog verder: "Vertel een student nooit iets, dat hij uit zichzelf kan opmerken; maak nooit een gevolgtrekking, waartoe hij zelf kan geraken, los nooit een vraagstuk voor hem op, waarvan hij zelf de oplossing kan bedenken, en vooral, doe nooit iets voor hem, dat hij zelf kan doen" (in Van Rijnberk 1918: 1797).

Langzamerhand wordt in het denken over de medische opleiding de associatie van praktisch onderwijs en zelfwerkzaamheid van de student losgeweekt van hun identificatie met de laboratoriumwetenschappen ${ }^{26}$. Het besef groeit dat praktisch onderwijs en zelfwerkzaamheid iets is, dat zich ook buiten het fysiologisch laboratorium en het academisch ziekenhuis kan afspelen ${ }^{27}$. Dat gaat vergezeld met pleidooien voor meer aandacht voor 'eenvoudige', alledaagse kwalen ${ }^{28}$. Vervolgens wordt meer aandacht geeist voor psycho-sociale vakken. In plaats van wijsbegeerte, zoals Schwalbe voorstelde, wenst I. Idenburg bij de jonge arts "meer kennis van zuigelingsziekten, praktische hygiëne, diaetethische kookkunst, orthopaedie en massage" (Idenburg 1919: 846). Op 25 september 1918 aanvaardt J.M. Baart de la Faille het eerste hoogleraarschap in de sociale geneeskunde in ons land met het uitspreken van een rede getiteld 'De sociale geneeskunde als vak van wetenschap en als vak van onderwijs' (Baart de la Faille 1918; Van Eyk 1920a: 2509; Baart de la Faille 1920). Bij de opening van de algemene ledenvergadering van de NMG in 1921 spreekt C. Nijhoff (1921) de waarschuwing uit dat laboratoriumonderzoek nooit een vervanging kan vormen voor het nauwgezet bestuderen van de

25. "Wanneer $z a l_{\text {, }}$ ook in ons land, het ideaal werwezenlijkt worden, dat bij het onderwijs in alle geneeskundige vakken, de hoogleararen zoo min mogelijk praten en de studenten zooveel mogelijk doen?" (Van Rijnberk 1919a: 822). "Vermindering van het theoretische $e x$ cafthdra-onderwijs en uitbreiding der practische cefeningen, schijnt wel over de geheele wereld de leus van alle hervormingsgezinden in aske hooger onderwije in geneeskunde te zijn" (Van Rijnberk 1919a: 1162).

26 "[O] veral gist het in de academische wereld. Overa], komen de wernieuwde eischen der practij]k, in botsing met de oude overgeleverde regelen. Vernieuwing, venonging verandering vermeerdlering, verbetering: overal toept men er om (Van Rijnberk 1919a: 1391).

27 "Mijn meening is, dat deze praktische kenuis beter verkregen wordt in de praktijk dan in de zienkenhuizen; alsdan zullen onze jonge collega's eens zien, welk verschil er bestaat in allerlei opzichtern. tusschen ziekenhuis en gewone praktijk. Laat ik maar noemen zooals men in de praktijk aantreft, dem omgang met patiënten en familieleden, de localisatie, de voedselverstrekking, de gebrekkige hulpmid. delen in werpleging en verplegingsartikelen, de reinheid en nog vele andere zaken" (Idenburg 1919: 846). 28 "Bij het instrueeren van deze jonge menschen moest ik al dadelijk ontwaren dat hun kerunis omtrent lichte ongesteldheden, zooals zoovele in de praktijk voorkomen, bijv. bronchitis, angina, acute gastritis, enteritis en wormen bij kinderen, influenza, acute exanthemen (mazelen, roodvonk, roode hond) en wele andere, niet bijster groot was; waar hebben zij het moetex leeren? Op het ziekenhuis hebben zij deze ongesteldheden nimmer waargenomen" (Idenburg 1919: 847). 
patiënt als individu. Dat zou er toe leiden dat "de diphterie met serum maar de patiënt met minachting wordt behandeld". En hij vraagt zich vervolgens af: "Wat helpt het de maatschappij of er al aan de zieken het een en ander wordt gedokterd, zoolang de maatschappij zelf zooveel ziekten verwekt, die de beste medicus niet kan cureeren? (...) Moet de geneeskunde als geheel niet een natuurlijke ontwikkeling doormaken en van geneeskunde van het individu niet worden tot geneeskunde van massa?" (Nijhoff 1921: 298). Hiertoe zou volgens Nijhoff in ieder geval het onderwijs in de sociale geneeskunde uitgebreid en verbeterd moeten worden. In 1921 stelt de blijvende commissie voor sociaal-hygiënische aangelegenheden van de NMG een onderzoek in naar het onderwijs in de gezondheidsleer (Goudsmit 1978: 47-48). Van Rijnberk had in 1918 al over de plaats van de psychologie in het medisch onderwijs geschreven ${ }^{29}$. In 1919 had Van Rijnberk in het NTvG ook de aandacht gevraagd voor andere onderwijssystemen dan het in Nederland gebruikelijke.

Zo bespreekt hij aan de hand van de ideeën van G. Newman de onderwijssituatie in Engeland, waar de meester-leerling relatie een belangrijk element in het klinisch onderwijs vormt ${ }^{30}$. Newman betreurt de echtscheiding tussen fysiologie en pathologie, interne geneeskunde en heelkunde: "'Er moesten maatregelen getroffen worden voor een veel inniger verband van het physiologische instituut der universiteit met de laboratoria der pharmacologie en pathologie, en zelfs met het ziekenhuis. Men zou dit inniger verband kunnen bereiken, door toegepaste physiologie en clinisch onderwijs in elkander te laten grijpen."' (Newman in Van Rijnberk 1919a: 747). Co-assistenten zouden zich niet moeten beperken tot het academisch ziekenhuis maar uit moeten zwermen over perifere ziekenhuizen in grote èn kleine steden (Van Rünberk 1919a: 824). Dat zou een zegen zijn voor de studenten, voor de staf van de niet-academische ziekenhuizen maar ook voor de zieken: "Voor die in de academische ziekenhuizen, omdat het den onophoudelijken stroom der co's in andere beddingen en naar meer bedden zou leiden. Voor die in de niet academische ziekenhuizen, omdat, de studenten de nieuwste en beste snufjes die zij op college geleerd zouden hebben, overal zouden willen invoeren" (Van Rijnberk 1919a:

29 Van Rijnberk schrijft Bleuler parafraserend: "De moderne geneeskunde echter is uitsluitend natumrwetemschappelijk (en materialistisch); zij meet en weegt. (...) Bleuler wil, dat de arts alleneerst den zieke en niet alleen de ziekte zie, dat hih in elk geval met het individueele rekening houde, ten in geen gewal wergete, dat het zieke object een psychisch subject is". (Van Rijniberk 1918: 1865).

30 "s]]et zwaartepunt wan het clinisch onderwijs in Engeland [ligt] in de werkzaamheden der studenten op de ziekenzalen: de colleges treden daarbij geheel op de achtergrond. Newman schrijft er nog vam: "Onze) methode is niet die van een groot gehoor; hangend an de gezagvolle, de wetgevende lippen van de professor, het is een zwerm leerlingen, al doende dienend onder een meester". Voor ons Nederlanders, wier onderwijs hoofdzakelijk classicaal, naat Duitsche trant is ingericht, zou de zuiver individwalistische inrichting, zooals Newman die in Engeland prijst, niet geschikt zijn. Tach schijnt er mij veel aantrekkelijks in" (Van Rijnberk 1919a: 823). 
824). De overwegende nadruk op de natuurwetenschappen binnen de geneeskunde opleiding stuit op steeds grotere kritiek. De open brief van de kandidaat in de geneeskunde J. Mulder in het NTVG (1923) eindigt met de oproep: "Laat men toch inzien, dat men geen a.s. physici, chemici, botanici, anatomen of physiologen als toehoorder heeft, doch a.s. artsen die willen leeren handelen aan ziekbed of operatietafel. Laat men toch vooral den student niet overschatten in zijn kunnen en zijn voorbereiding zoo eenvoudig en zoo degelijk mogelijk inrichten" (in Van Rijnberk 1923: 2668). De nadruk op de natuurwetenschappen in de kandidaatsfase, de strikte scheiding tussen de verschillende vakken, de ongebreidelde groei van de klinische vakken en de onbekendheid met de praktijk zijn probleemvelden die zich allengs uitkristalliseren ${ }^{31}$.

Het gebrek aan praktische vaardigheden van de aanstaande arts blijft een regelmatig wederkerend geluid. Een in Nederland studerende Zuid-Afrikaanse student merkt op: "Een student die, zooals het nu staat, de universiteit verlaat, weet bijna niet hoe hij een absces moet openen! En dat behoeft toch niet. Het hangt dikwijls bijna geheel van den assistent af. Gewoonlijk heeft die zelf pas de universiteit afgeloopen, en is maar al te blij, als er iets te doen valt, om zoodoende zelf wat te leeren. En de student mag toezien!" (in Van Rijnberk 1919a: 825). Volgens Van Rijnberk zou al veel verbeteren als de clinische hoogleraren hun studenten ook aan niet-academische ziekenhwizen "toevertrouwden", in plaats van al het onderwijs in eigen hand te willen houden. S.A. Prins klaagt in 1932 over het feit dat studenten geen gelegenheid krijgen om bv. subcutane injecties te geven of verbanden aan te leggen - iets dat hij wel vaak heeft zien doen door verpleegsters! Praktische oefening in het hechten van wonden is een grote uitzondering, aldus Prins en hetzelfde geldt voor b.v. catheteriseren. Hij stelt voor, co-assistenten zelfstandig zaalvisite te laten lopen, uiteraard onder controle van de arts van dienst.

In 1935 vragen de Ministers van Onderwijs, Kunsten en Wetenschappen en van Sociale Zaken advies aan de NMG omtrent het Medisch Hooger Onderwijs. Zij vinden dat "zoowel om practische als om bezuinigingsoverwegingen, het vraagstuk der artsopleiding opnieuw weer aan de orde dient te worden gesteld". De Ministers doen zelf al enkele suggesties, o.a.: "kan groepeering

31 Ook de enorme groei van het aantal klinische specialismen stelt de opleiding voor problemen: "Zoo wordt het artsexamen een worst, waarin men steeds meer stopt, totdat zij barst" (Van Rijnberk 19196: 1862). Van Rijnberk (19196: 1861-1862) trekt daaruit de conclusie dat de eenheid van bevoegdheid van de geneesheer een onding is en afgeschaft moet worden. "Er is tegenover de steeds grootere specialisering in de geneeskunst slechts een maatregel te nemen: het artsexamen niet te verzwaren, doch belangrijk te ontlasten en het te beperken tot een kern van hoofdvakken, welke betrekiking hebben op de meest dagelijks in de practijk voorkomende ziektegevallen en waaronder nog een soort band bestalt, zoodat de eenheid van het vak niet verloren gaat (Van Rijnberk 1919b: 1861-1862). Daarnaast moet de groejende instroom van studenten en de bilgevolg daarvan sterk oplopende studentenaantallen gesignaleerd worden (Bruinsma 1911). 
en inhoud der eigenlijke medische vakken worden gewijzigd, zóó dat a. de mensch van den aanvang af in het centrum van het onderwijs wordt gesteld en b. de aanstaande artsen zoo spoedig mogelijk aan het ziekbed worden gebracht?" Tevens willen de ministers de mening horen van praktiserende geneeskundigen over hun opleiding. De Sociaal-Hygiënische Commissie van de NMG krijgt de opdracht een advies over dit vraagstuk uit te brengen. Als middel daartoe organiseert zij een enquête onder 100 praktiserende artsen, speciaal geselecteerd om hun persoon en wegens de bij hen te verwachten belangstelling voor het vraagstuk. De vaardigheden van de arts vormen nog steeds een probleem: "Te veel co-assistenten mogen te weinig zelf doen" of "Menige leek weet van EHBO en ziekenverpleging op dien leeftijd meer dan de medische student". Eén van de reacties op de vraag of de student eerder aan het ziekbed moet worden toegelaten luidt aldus: "Bij een grondig contact tussen arts en student is hier alles voor en niets tegen. De praktijk in de Universiteitsziekenhuizen is echter zó, dat de co-assistent grotendeels aan zichzelf wordt overgelaten, wordt opgescheept met laboratoriumwerk" ${ }^{\prime \prime}$. Voorstanders van het vroeg toelaten van de student aan het ziekbed wijzen erop dat de leerstof meer perspectief krijgt en dus sneller opgenomen wordt. Bovendien leert de student met zieken omgaan. "Desnoods verrichte hij niet anders dan Verplegingsdiensten", zo besluit één van de artsen zijn pleidooi. Hierbij past de nadruk op wat we tegenwoordig de 'attitude'-aspecten van het medisch beroep zouden noemen. "De persoon van de student wordt verwaarloosd", "de jonge arts staat nagenoeg geheel vreemd tegenover de sociale zijde van het vak", "de medische praktijk bestaat voor $75 \%$ uit savoir-vivre en savoir-faire en voor de rest uit medisch weten, kunnen en kennen." Tegenstanders echter menen dat dit zou leiden tot "waanwijsheid en dilettantisme", dat voor de omgang met zieken "meer mensenkennis en levenswijsheid nodig is dan een jonge student bezit" maar vooral: "dan komt er van de histologie, physiologie en vooral de physiologische chemie nog minder terecht, omdat een furunkel behandelen voor de jongens veel interessanter is." In haar conclusies probeert de commissie de gouden weg van het midden te bewandelen: "De gezonde mensch kome zoo spoedig mogelijk in het middelpunt van het onderwijs te staan." Maar: "De student worde niet aan het ziekbed toegelaten voor hij voldoende anatomie en physiologie kent".

In 1925 verschijnt een studie van Abraham Flexner, waarin deze het medisch onderwijs aan een aantal Europese universiteiten met elkaar vergelijkt. Ook dit boek wordt door Van Rijnberk in het NTvG besproken. In zijn studie onderscheidt Flexner een natuurlijk en een logisch onderwijsstelsel. Nederland is een voorbeeld van een land waar de logische methode wordt gehanteerd. Dat houdt in dat de student door een systematisch geordend curriculum wordt geleid, waarbij volgens Flexner selectief en progressief gebruik wordt gemaakt 
van het perceptie- en het onderscheidingsvermogen van de student " [T] The relatively simple before the relatively more complex". Eerst fysica en chemie, dan de biochemische basisvakken. Alvorens de aard van de afwijking in te kunnen schatten moet het de student bekend zijn hoe de 'normale' toestand er uit ziet. Dus anatomie en fysiologie voor de pathologie ${ }^{32}$. Daartegenover staat de natuurlijke onderwijsmethode: de student leert, in navolging van een leermeester(s), hoe hij bij bepaalde symptomen handelen moet. Het onderscheid tussen de normale toestand en de pathologische groeit daarbij langzaam, maar zeker. In het natuurlijke onderwijsstelsel daarentegen plaatst men "den leerling-arts tegenover de zieken, zonder dat hij iets van ziekte of gezondheid afweet, en brengt hem allengs de eigenschappen van het gezonde, de eigenaardigheden van het zieke lichaam bij" (Van Rijnberk 1925: 1516). De studenten hebben daarbij een grote vrijheid en bepalen zelf wanneer zij examens doen. Studenten worden als volwassenen behandeld, niet als kinderen. Het onderscheid tussen de twee onderwijsstels is volgens Flexner te vergelijken met het leren van een vreemde taal versus het leren van de moedertaal. Flexners voorkeur gaat duidelijk uit naar de logische methode, ook al erkent hij dat daar bezwaren aan kleven. "[O]ver-organization of school material, at any level defeats its own purpose (...). Therefore it is sound to proceed from the known to the unknown, from the simple to the complex, it is equally important not to eliminate struggle with the complex and the unknown" (Flexner 1925: 11). Voor Flexner wegen dergelijke motivationele aspecten echter niet het $z$ waarst ${ }^{33}$. "The argument in behalf of mingling clinical and pre-clinical subjects in order to interest the student is assuredly not convincing. Interest is indeed at every stage a powerful educational factor; but mature young men, at the stage of college graduations or there abouts, may fairly be expected to put forth effort in anatomy and physiology, without being at every step amused or misled, as premature playing with clinical problems is bound to mislead them" (Flexner 1925: 112). Flexner is er van overtuigd - en Van Rijnberk sluil zich hier van harte bij aan - dat het logische stelsel, waarbij het vak metho-

32 "Thus chemistay and physics are studied before physiology, the relatively simple before the relativen. ly mone complex. (...) A similar question as to sound pedagogical order or arrangement arises as between the preclinical and the clinical subjects. Unguestionably the student, at the least the really able student, entering the clinic without previous knowledge of anatomy, physiology, or pathology, may learn in time to disentangle normal from abnormal (...). But sound pedagogy suggests that the student on approaching the patient should already be in possession of the alphabet in terms of which he must express. himself. on, to revert to the terminology already employed, the picture of normality (...) (Flexmer 1925: 109-110). 33 Flexner (1925: 117) vat zijn standpunt als volgt samen: "There is a dutch on each side of the road (.m). It is, therefore, entirely sound to establish in the curriculum a general order which, on the whole, assures logical progression. If at the same time the student's entire time is not requisitioned, he can still undulge in blunders or vagaries enough to teach him the folly of illogicality on the one hand, or the wholesomeness of heterodoxy on the other - both being important lessons, for him as for his teachers." 
disch geleerd wordt op geordende, schoolse, wetenschappelijke wijze veruit devoorkeur verdient. "[N]iemand zal (...) ontkennen, dat het logischer, practischer, doelmatiger en zuiniger is, telkens eerst afzonderlijk te leeren wat men later kan toepassen en dan pas tot de toepassing over te gaan" (Van Rijnberk 1925: 1518). Het Nederlandse geneeskundig onderwijs kan Flexner echter in het geheel niet bekoren. De "volledige echtscheiding tusschen theorie en praktijk" wijst hij af (Van Rijnberk 1925: 1756). Na het kandidaats wordt de student twee jaren "overkropt met college-onderwijs", daarna mag hij anderhalf jaar als co-assistent op zaal, maar het "tempo is te snel en de organisatie te schraal om te voldoen aan de hedendaagsche eischen van onderzoek en oefening!" (Van Rijnberk 1925: 1756).

De in de 'Basisfilosofie' verwoorde intentie zich af te wenden van een strikt biomedisch ziektemodel in combinatie met de keuze voor een praktijkgeoriënteerd onderwijssysteem laat zich naadloos inpassen in de bovenstaande capita selecta uit de geschiedenis van het medisch onderwijs. Het belangrijkste kenmerk van het Maastrichtse onderwijssysteem, probleemoriëntatie, in de studiegids voor geneeskunde uit 1982 omschreven als "de afzonderlijke vakken [zijn] als uitgangspunt van de studie verlaten (...). Het leerproces van de studenten wordt vrijwel uitsluitend in gang gezet door zorgvuldig uitgeschreven concrete praktijkproblemen, meestal ontleend aan het veld van de beroepsuitoefening", speelt leentje buur bij de boven geschetste 'natuurlijke' onderwijsmethode. Als voordelen van de in Maastricht gehanteerde manier van werken worden onder andere genoemd het leren integreren van de inbreng vanuit de verschillende vakgebieden, de oefening in medisch denken en het leren zich op efficiënte wijze toegang te verschaffen tot nieuwe kennis. Tegelijkertijd wordt daarbij de nadruk gelegd op zelfwerkzaamheid van de student die voor een groot deel het eigen leerproces moet organiseren, zonder dat de docenten via colleges kant-en-klare dictaten en oplossingen voor problemen geven. De speciale aandacht voor vaardigheden en attitude in het Maastrichtse onderwijssysteem, zijn reeds eerder gesignaleerd als reactie op de eenzijdige nadruk op de natuurwetenschappen binnen de geneeskundige opleiding.

\section{Het Maastrichtse systeem}

Het in de 'Basisfilosofie' geformuleerde programma vormt een conglomeraat van ideeën waarbij veranderende opvattingen over ziekte en gezondheid, het streven naar veranderingen in de gezondheidszorg en het streven naar een andere inrichting van de opleiding tot arts met elkaar verweven zijn. De intenties van de 'Basisfilosofie' op het gebied van medische zorgverlening zijn echter 
inmiddels goeddeels verlaten ${ }^{34}$. Wel is vastgehouden aan de probleemgeorie teerde onderwijsvorm, hoewel ook deze is afgezwakt: vooral het aspect vo het werken in taakgerichte groepen krijgt steeds meer nadruk. In het curric lum van de medische faculteit ${ }^{35}$ van de Rijksuniversiteit Limburg heeft ged rende de afgelopen jaren in Flexners (1925!) terminologie een verschuiving va de meer natuurlijke methode naar een meer logisch, systematisch curriculus plaatsgevonden. Samengaand met het verleggen van het accent in de beginj; ren van de patiëntencasus naar de basisdisciplines. Als voordelen van de $p_{i}$ tiëntencasus worden de relevantie voor de klinische praktijk, verhoogde st diemotivatie en de multidisciplinaire benadering genoemd. Als nadeel dat "d overvloed aan keuze-mogelijkheden die besloten liggen in een complexe $p_{i}$ tiëntencasus, (...) in de eerste jaren als verwarrend en storend [wordt] ervaren (Nota de Rode Draad III 1987: 8). De Rode Draad II formuleerde drie principe die aan de curriculumherziening ten grondslag zouden moeten liggen : a) va laag naar hoog integratie niveau, b) van basale kennis naar patiëntgericht problemen en c) van normaal functioneren naar de pathologie. Maar tegelijkes tijd moest probleemsturing gehandhaafd blijven en multidisciplinariteit-zeke binnen het blok, maar niet perse binnen elk probleem - als uitgangspunt wol den gehanteerd. Wel zouden problemen niet meer uitsluitend op patiēnten be trekking hoeven te hebben, maar eveneens binnen (en tussen) disciplines mc gen worden geformuleerd. Reacties vanuit de faculteit wezen op het gevaa van thet ontstaan van monodisciplinaire blokken. In de Rode Draad I] probeerde men zowel de kool als de geit te sparen door onder andere $\mathrm{d}$ volgende drie uitgangspunten te formuleren: a) het vernieuwde curriculum i gebaseerd op de principes van probleemgestuurd onderwijs, b) het curriculun vormt een logisch samenhangend inzichtelijk opgebouwd geheel, waaraal relevante disciplines uit de onderscheiden clusters hun bijdragen kunnes leveren en c) blokken zijn multidisciplinair.

In de posities die worden ingenomen ten aanzien van de medische opleiding zijn een aantal 'natuurlijke' bondgenootschappen aan te wijzen. De natuurwe tenschappen scharen zich als vanzelf aan de zijde van diegenen die een logiscl curriculum bepleiten; aan de andere kant is er een cluster dat pleit voor mee: nadruk op de sociale wetenschappen, meer aandacht voor sociale vaardighe den en praktijkoefening. Deze dichotomie is voor een deel verankerd in he ontstaan van de moderne universitaire opleidling tot arts. De nadruk op de natuurwetenschappen hangt samen met een verandering van het ziekteconcep:

34 Zie voor de geschiedenis van de "Basisfilosofie' in de context van de ontwikkeling van de Medische Faculteit en de regionale gezondheidszorgsituatie Van der Maesen (1986).

35 De ontwikkeling van het curriculum van de medische faculteit is uitstekend gedocumenteerd dool de onderwijscommissie FdG in 'Nota de Rode Draad III'. 
rond het midden van de vorige eeuw. De vernieuwing in de geneeskunde die dan optreedt, impliceert het op de achtergrond raken van de oriëntatie op de klassieken in de universitaire opleiding, maar tegelijkertijd het zich afkeren van een opleidingstraditie die gebaseerd is op het in een meester-leerling relatie overdragen van ervaring. Maar dat is slechts éen kant van de medaille. Immers de hervorming in de geneeskunde, die zich formeerde rond een aan de fysiologie ontleend ziekteconcept, beoogde niet een uitsluitende oriëntatie op de natuurwetenschappen. Centraal stond de waarneming van ziekteprocessen - aanvankelijk op alle niveaus. Tussen fysiologen en hygiënisten - sociale geneeskundigen - bestond geen controverse maar een nauwe band: beide groepen richtten zich op de studie van ziekteprocessen, zij het ieder op een ander niveau. $H$. ten Have (1986: 21) heeft op de nauwe verbondenheid gewezen die in de eerste decennia van de vorige eeuw bestond tussen hygiënisten en de artsen die het medisch denken en handelen op de natuurwetenschappen wilden baseren ('fysicalisten'). Beide stromingen hadden gemeenschappelijke vijanden in de geleerde traditie enerzijds en de 'practici' die hun handelen op ervaring baseerden anderzijds. Fysiologie en hygiënisme hadden een gemeenschappelijk fundament. De tegenstelling tussen beide is van latere oorsprong, is meer methodologisch van aard en lijkt op controverses tussen methodologisch individualistische en collectivistische posities in de sociale wetenschappen. In hoeverre een heroriëntatie op historisch geënte verklaringen en de niet lineaire dynamica deze methodologische tweedeling zal opheffen, zal de toekomst moeten leren (Tennekes 1990).

De dichotomie tussen de moderne wetenschappelijk opleiding tot arts en het aanleren van praktische vaardigheden is nog fundamenteler. Het is al eerder opgemerkt dat het monopolie van de universitaire opleiding tot stand is gekomen door de afwijzing van de overdracht van ervaringskennis in een meesterleerling relatie. Het aanleren van onbekende, onbeargumenteerde - maar noodzakelijke - vaardigheden druist in tegen het verlangen naar een rationele therapie. Deze dichotomie is slechts op te lossen door "vaardigheden' zelf tot onderwerp van wetenschappelijk onderzoek te verheffen: Hoe hebben de vaardigheden van de arts zich in de loop der tijd ontwikkeld? Waarom zijn ze nu beter of anders dan een eeuw geleden? etc. Zonder die wetenschappelijke rugdekking en legitimatie zal vaardighedenonderwijs aan een universiteit altijd een buitenbeentje blijven ${ }^{36}$. Dat de opleiding tot arts echter niet buiten dat vaardighedenonderwijs kan, heeft de discussie over de medische opleiding in deze eeuw genoegzaam bewezen.

In vijftien jaar tijd is de 'Basisfilosofie' van de medische faculteit, van een 
programma voor een heroriëntatie van de gezondheidszorg veranderd in een "missie" die vooral gekarakteriseerd wordt door een didactische werkvorm. Geleidelijk aan is in die didactische werkvorm de nadruk verlegd van praktijkoriëntatie naar probleemoriëntatie. Voor de specifieke aanpak van de studie kunnen dan ook nog vrijwel uitsluitend onderwijstechnische argumenten worden aangevoerd (Van der Maesen 1986: 89). In het licht van de interpretatie van het ontstaan van de moderne universiteit, waarbij diffuse verbanden zijin aan te wijzen tussen 'pedagogische' en vakinhoudelijke vernieuwingen of tussen organisatorische en inhoudelijke verschuivingen, is het isoleren en reduceren van een 'missie' tot een didactische werkvorm echter een uiterst dubieuze ontwikkeling, die inhoudelijke veranderingen binnen vakgebieden kan belemmeren. Zeker wanneer de oorsprong van die werkvorm zo duidelijk verweven is met inhoudelijke discussies binnen het domein van de geneeskunde.

Natuurlijk zijn daar ook argumenten tegenover te stellen. Het is mogelijk te wijzen op een steeds verdergaande differentiatie. Het is mogelijk te wijzen op de splitsing binnen de pedagogie in een meer beschouwende, historiserende richting en een onderwijstechnische richting die zich daar juist van afwendt en zich concentreert op het verkrijgen van 'hardere' kennis van leerprocessen. Het is vervolgens mogelijk te wijzen op onderwijstechnisch onderzoek dat het Maastrichtse onderwijssysteem gunstig bij ander onderwijs doet afsteken. Echter de oorspronkelijke samenhang van in de 'Basisfilosofie' verwoorde intenties op het gebied van gezondheidszorg, onderzoek en onderwijs, de verwevenheid van een probleemgestuurde aanpak met specifieke problemen en discussiepunten in de geschiedenis van het medisch onderwijs, en de in de vorige hoofdstukken geconstateerde nauwe verbinding tussen inhoudelijke en "pedagogische' veranderingen maakt dat ik de reductie van een universitaire 'missie" tot een didactische werkworm zeer ongelukkig acht.

De schiere onmogelijkheid om in het denken en spreken over de universitaire opleiding, inhoud, vorm en methode van onderwijs te scheiden, komt ook naar voren bij de faculteiten die in navolging van de medische faculteit in Maastricht hebben getracht hun onderwijs in een andere vorm te gieten (COhen en Crombag 1978; Offermans 1979). In de rechtsgeleerde faculteit, waartoe ik mij hier zal beperken, heeft men met de afwijkende inrichting van het onderwijs nooit een verandering in de organisatie van het rechtsstelsel nagestreefd (Wolleswinkel 1989: 22). Maastricht wilde wel een antwoord zijn op "de gapende kloof tussen theorie en praktijk" (Beurskens en Verheij 1989: 37). Omdat praktijkproblemen zich niet storen aan grenzen tussen vakgebieden ${ }^{3 z}$

37 "Een betere aansluiting op de praktijk was een belangrijk, maar zeker niet het enige argument voor thematisch onderwijs. We hoopten zes jaar geleden ook tot een evenwichtiger verdeling van de aandactht (uilgedrukt in studiebelastingsuren en formatieplaatsen) over de verschillende vakgebieden te komen. 
werd een thematische aanpak voorgesteld ${ }^{38}$. M.J. Cohen en H. Crombag (1978: 359) formuleerden dat als volgt: "Doortrekking van de Maastrichter medische studie naar de juridische betekent doortrekking van de thema- of integratiegedachte: Algehele afschaffing van een systematische bestudering van vakken als burgerlijk recht, staats- en adminstratief recht en strafrecht; in plaats daarvan uitsluitend integratievakken." Maar ook aan een oriëntatie op thematisch, probleemgestuurd onderwijs, met een nadruk op praktijkproblemen, vaardigheden en zelfwerkzaamheid gaat een standpuntbepaling ten aanzien van de verhouding tussen recht en maatschappij vooraf. Zoals het prioriteren van problemen uit de werkelijkheid boven de systematische ordening van vakgebieden (Wolleswinkel 1989: 22). En de overtuiging dat niet "de kennis (...) de grootste prioriteit [heeft], maar het vermogen om het probleem juist te stellen en de vaardigheid om de problemen te kunnen oplossen" (Cohen en Crombag 1978: 356). Een thematische aanpak, die niet uitsluitend op de oude vakindeling terug wil vallen en toch een specifiek juridische aanpak wil zijn, moet zich oriënteren op centrale juridische begrippen die "niet zonder meer voorhanden, maar (...) deels uitgebouwd, deels geconcipieerd worden. (...) Vanuit de thema's moet een kader van algemene rechtsbegrippen worden gevormd, een soort algemene rechtsleer nieuwe stijl. Dat is niet een didactische nieuwigheid alleen, het is vooral een wetenschapsordenende vernieuwing" (Van Maarseveen 1981: 778). Het zal dan ook niet verbazen dat de probleemgeoriënteerde aanpak binnen de Maastrichtse rechtenfaculteit óók te situeren valt tegen de achtergrond van een cluster van opvattingen over rechtsvinding en het tot stand komen van de rechterlijke beslissing (zie ook Crombag 1972). In Crombag. Wijkerslooth en Cohen (1977) wordt de rechterlijke beslissing als een specifiek soort van probleemoplossen benaderd. Het rechterlijk beslissen heeft vanuit die optiek meer met cognitieve, complexiteitsreducerende (zoek-)strategieën dan met interne juridische systematiek te maken. Centraal in deze psychologische theorie staat de 'schematische anticipatie". "[P]robleemoplossen is slechts mogelijk wanneer de oplosser bij de aanvang van het oplossingsproces beschikt over een vrijwel onmiddellijk geconcipieerd idee van de oplossing van het totale probleem of van de verschillende deelproblemen" (Crombag et al. 1977: 19). Dat vanuit dat perspectief een grote aantrekkingskracht uitgaat wan een probleemgeoriënteerde didactiek ligt voor de hand.

Met name wilden we meer aandacht voor nieuwe functionele vakken ( ...) meer aandacht voor de interna*

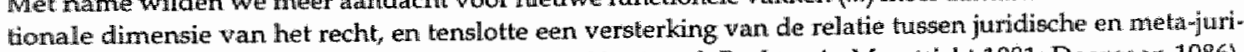
dische disciplines" (Beurskens en Verheil 1989: 39; zie ook Rechten in Maastricht 1981; Doorgaan 1986). 38 Woor het onderwijs heeft dit betekend dat men eerst in de juridische wakken geschoold werd en daama op de praktijkthema"s afging. (...) In elk geval wil men deze onderwijisgang in Maastricht over de gehele lijw en blijvend onkeren. Men verlangt thematisch onderwijs en dat gaat de weg van uit de warkelijkheid naar de juridische begrippen toe" (Nan Maarseveen 1981; 778) 
In de geschiedenis van het denken en spreken over het rechtsgeleerde onderwijs is het pleiten voor meer praktisch gericht onderwijs en een grotere zelfstant digheid van de rechtenstudent onder meer verbonden met een benadrukken van de maatschappelijke ontwikkeling van het recht, ten koste van de logische en systematische opbouw van het rechtssysteem. Praktisch onderwijs werd onder andere nodig geacht omdat juristen zich telkens voor nieuwe en andere groepen van feiten gesteld zien, waaruit zij een rechtelijke gevolgtrekking hebben te maken. Daarin moesten zij aan de universiteit worden geoefend. Daarbil zouden zij zelf moeten uitvinden, waar nu eigenlijk de vraag zat (Fockema Andreae 1914: 16) ${ }^{39}$. Hijmans (1902: 328) bijvoorbeeld trok daaruit de conclusie dat de colleges moesten verdwijnen, "geheel verdwijnen!" In moderne pleidooien voor meer praktisch onderwijs en het vergroten van de zelfwerkzaamheid van de student komen vergelijkbare motieven naar voren: "Doordat et steeds meer kennis komt wordt het gedeelte dat een jurist ervan kan verwerken relatief steeds kleiner. Hierbij komt de snelle veroudering waaraan die kennis onderhevig is. De afgestudeerde komt dus in de praktijk met niet meer dan partiële kennis die bovendien gedeeltelijk al niet meer bruikbaar is" (Lammers-Verdegaal 1982: 288; Cfr. Moust, Bakker en Nuy (1989).

Spruit (1988: 20-21) legt een directe lijn tussen praktijkoriëntatie in het onderwijs en het verminderen van het logische en systematische karakter van het rechtssysteem: "Inmiddels is de erkenning gegroeid dat de wet maar in zeer indirecte mate greep kan hebben op het haarvatenstelsel van het recht en dat de rechter niet zozeer reproductief, op basis van een systematisch-dogmatische en strikt logische redenering, maar veeleer creatief en onder inschakeling van zijn juridisch Fingerspitzengefühl, menselijke intuitie en maatschappelijk invoelingsvermogen, recht zal moeten vinden op grondslag van de wet en binnen het systeem van de wet. In het kielzog van deze sterkere neiging tot een vrijere rechtsvinding met als doel in concrete gevallen het rechtvaardigheidsgehalte van iedere uitspraak te verhogen en, meer in het algemeen, als uitvloeisel van anti-autoritaire en antidogmatische maatschappelijke bewegingen die sedert het einde van de jaren " 60 ook in Nederland gewicht kregen, heeft zich ook aan de juridische faculteiten in alle deeldisciplines van het recht veel sterker de tendens ontwikkeld om het casuistische element te beklemtonen. Het Maastrichtse onderwijsmodel met zijn overaccentuering van een soms enigszins efemere casuïstiek ten koste van de aandacht voor historisch bepaal-

39 Cr. Moust, Bakker en Nuy (1989; 60): "Kennis veroudert immers snel, maatschappelijke en juridischw problemen doen zich voortdurend in steeds andere gedaanten voor. Studenten moeten gedurende lhum studie vorbereid worden op deze ontwikkelingen in de samenleving, niet alleen door hun probleemoplossingsmethodieken aan te reiken, maar cok door hen in stat te stellen een attitude te verwerven, waakbil informatie niet geconsumeerd, maar aktief verwerkt, getransformeerd of creatief bewerkt wordt." 
de systematische structuren en gedurende vele honderden jaren gegroeide dogmatische samenhangen, is daarvan wellicht het springlevende voorbeeld."

Het zal dan ook niet verbazen dat in discussies over het onderwijs in de rechtsgeleerde faculteit van de RL de verhouding tussen praktijkoriëntatie en systematiek een belangrijk thema is geweest ${ }^{30}$. Net als in de medische faculteit valt te constateren dat geleidelijk aan een duidelijker scheiding is aangebracht tussen een didlactische werkvorm, probleemoriëntatie en het werken in taakgerichte groepen enerzijds, en een thematische benadering anderzijds ${ }^{41}$ (Cohen 1989: 14; Beurskens en Verheij 1989: 36). Waarbij de curriculumherziening ook hier meer structuur in de thema's heeft aangebracht: "[T] hematisch onderwijs, maar met een open oog voor het belang van inzicht in de structuur en interne samenhang van elk der klassieke vakgebieden" (Beurskens en Verheij 1989: 46).

\section{Individualisering en internationalisering}

De transformatie die de maatschappij en de universiteit gedurende de negentiende eeuw doormaken heeft tot effect dat in de organisatie en onderlinge afstemming van maatschappelijke domeinen hiërarchieën naar de achtergrond verschuiven. In plaats daarvan treden bij de inrichting van maatschappelijke domeinen procestermen op de voorgrond, waarbij expliciet rekening gehouden wordt met de onvoorspelbaarheid daarvan. In de negentiende eeuw komt in de maatschappelijke organisatie van het onderwijs het individuele leerproces centraal te staan. Aan selectie wordt dan een voorheen ongekend centrale rol toebedeeld (Luhmann 1987a: 187). De carrière, waarvan onderwijs de aanvang vormt, neemt de rol over die status voorheen vervulde (Luhmann 1987a: 188). In tegenstelling tot het status-concept verwijst het carrière-concept echter duidelijk naar een afwikkeling in de tijd ${ }^{42}$. Dat verklaart dat in een traditionele

40 Tijdens de Grote Onderwijsdiscussie van 1986 en 1987 beplestte een niet onbelangrijke groep een temukeer naar een wakgerichte opzet. "Heel kort gezegd stelde deze groep, dat we de betekenis van de onderschevidingen tussen de klassieke vakgebieden onderschat, en de mate watin die onderscheidingen verwagd waren overschat hadden. We zouden te weinig aandacht besteden aan de structuur en systematiek van elk der klasisieke vakgebieden afzonderlijk, waardoor de studenten te weinig inzichll kregen in de systematiek van het positieve recht. De integratie zou vooral verwarring opleveren (Beurshens en Vertinej 1989"46).

41 Zie Doorgain (1986:4)" De opstellers van de Nota Rechten in Maastricht (1981) geven blijk van een witgesproken wook keur woor een 'consequent thematische aampak wan het onderwijs'. In de daarvoor aangedragen argumentatis wordt het thematische karakter van het onderwijs overigeng niet al te duidelijk onderscheiden van de andere, in deze nota afzonderlijk te behardelen uitgangspunten wan het

onderwijs, met name niet van de probleemsturing."
42 "Der Karnerebegrift hat demgegenuber den Vorteil, neutral zu sein in der Frage, ob und wie weit Lebenslagen durch eigene Leistung oder durch. Fremdbeurteilung und Fremdselektion oder sogar dunch gerellschafthiche Veränderungen grolen Stils (Kriege, Technologieungtellungen, politische Krisen, wirt- 
opvatting van onderwijs selectie uitsluitend als een storend element kan worden gezien, terwijl selectie de spil vormt van de moderne onderwijsinrichting ${ }^{43}$.

In het eerste hoofdstuk is het moderniseringsproces in zijn effecten ontleed naar een ruimtelijke en een temporele dimensie. Vanuit dat perspectief kan intemationalisering, eén van de modewoorden van het hoger onderwijs anno $1991^{44}$, gezien worden als een verdergaande stap in het moderniseringsproces; namelijk als een verdere vergroting van de schaal waarover verwachtingsstructuren op elkaar afgestemd worden. Vanuit dat perspectief vallen echter vraagtekens te plaatsen bij de huidige implementatie van het internationaliseringsstreven in het hoger onderwijsbeleid. Op dit moment ligt het zwaartepunt daarbij in het opzetten van internationale uitwisselingsprogramma's voor studenten via het creëren van netwerken tussen een beperkt aantal universiteiten. Door hun planmatige en gereguleerde karakter hebben deze studentuitwisselingen een met massatoerisme vergelijkbaar effect, namelijk het scheppen van enclaves in den vreemde. Wie daarentegen internationalisering als een verdergaande ruimtelijke afstemming van verwachtingsstructuren opvat, zal juist benadrukken dat internationalisering een doorgaande individualisering van onderwijs- en met name selectiemethoden in het hoger onderwijs vereist. Zonder een uitbouw van de in onze tijd nog zeer omstreden mogelijkheden tot verregaande individualisering van leer-en examenmogelijkheden (modularisering, vouchers, etc.), die de kaders van bestaande onderwijstypen en curricula doorsnijdt, is de complexiteit die een daadwerkelijke internationalisering van het hoger onderwijs met zich meebrengt, niet te beheersen. Internationalisering in het hoger onderwijs zal met zich mee brengen dat in nog sterkere mate dan voorheen het individuele leerproces en selectie op basis van individuele leerresultaten, het uitgangspunt voor de organisatie van onderwijs gaan vormen: "Zal men eenmaal den moed hebben, den student naar eigen lust en aanleg te laten kiezen uit hetgeen hier te leeren valt, waarbij het trouwens aan raad en hulp niet mag ontbreken (...) ?" zo sprak Land (1886: 29) reeds meer dan een eeuw geleden.

Wat de selectiemogelijkheden betreft lijkt het aan de Rijksuniversiteit Lim-

schaftliche Konjunkturen etc.) bestimmt sind" (Luhmann 1987a: 188-189).

43 "Dennoch ist es ein nener Gedanke, die Grundstruktur der Hochschule nicht mehr in einer übergrei" fenden Wissenschaftsidlee, sondern in der Behandiung des Problems der Selekton zu suchen" (Luhmann 1987a: 220).

44 Ook hier geen nieuws onder de zon; zie (Wan Rijnberk 1919a: 501-504); "Internationaliseering der examens: binnen en buitenlandse studiereizen van studenten. (...) Het zal wel niet zoo spoedig verwezenlijkt zijn, dat onze studenten als regel in hun studietijd éen of meer jaren naar het buitenland gaan, om aan een uitheemsche universiteit te gaan studeeren. Maar er zou al veel bereikt zijn, als men op bescheidener schaal verkrijgen kon, dat onze studenten binnen ons eigen land niet te hokvast aan die universiteit kleefden, waar zij, om wrelke reden dan ook, hun studie hebben aangevangen." 
burg ingevoerde systeem van voortgangstoetsing grote mogelijkheden te bieden tot uitbouw als een individueel toetsinstrument. De voortgangstoets is een toets die het kennisdomein van de hele opleiding omvat en waarvan de vragen een afspiegeling vormen van het eindniveau van de opleiding. Op gezette tijden onderwerpen alle studenten zich aan zo'n toets. Omdat de toetsen zijn samengesteld uit vragen die uit hetzelfde domein afkomstig zijn (het einddoel van de opleiding), worden de toetsen die successievelijk worden afgenomen geacht equivalent te zijn. Op die wijze ontstaat inzicht in de kennisgroei van de student (Van Berkel et al. 1990: 189; Wijnen en Van der Vleuten 1985). Het door A. de Groot (1972) voorgestelde alternatief (het expeditiemodel) voor het bestaande (veldloop)model van toetsing ${ }^{45}$, voldoet overigens niet aan die eis tot verdergaande individualisering. Uitgangspunt voor het expeditiemodel, waarbij zowel student als docent gezamenlijk verantwoordelijk zijn voor de goede afloop, is een eenmaal afgegeven geschiktheidsverklaring aan de student. Tegenover een inspanningsverplichting van de zijde van de student staat een prestatieverplichting van de docent: het laten slagen van de student. Niet alleen wordt daarmee de onzekerheid over het resultaat van het leerproces van studenten, waar selectie juist een antwoord op moet geven, tot op zekere hoogte ontkent $t^{46}$, een expeditiemodel kan enkel functioneren bij een grote uniformiteit van leerpaden.

Verdergaande individualisering van het toetssysteem kan bovendien aan de gebruikelijke ${ }^{47}$ bezwaren tegen examens - namelijk dat de studie gedomi-

45. "Het veldloopmodel is het stelsel dat wij kennen: de docent levert slechts een inspanning, terwijl huj niet veantwoordelijk gesteld kan worden voor hel resultaat. Vanuit de student bezien ziel dat stelsel er alls wolgt uit. De studie is een veldloop met horden, over iedere horde kum je altijd weer struikelen, je moet je geschiktheid telkens opnieuw bewijzen" (Cohen 1979: 19).

46 "[H] ilet is onmogelijk on volstrekt betrouwbare uitspraken te doen over de vratag of een bepaalde student well of miet in staat geacht moet worden een bepaalde studie te voltooien. Zulke uitspraken. bewatten altijd onzekerheidsmarges. Met andere woorden, bestaat altijd een zelker risiko dat de verwachting omtrent jemands geschiktheid later onjuist blijkt te zlin" (Cohen 1979: 19y).

7 Zie bijw. Mulder (1923) in Van Rijnberk (1923): "Crelukkig is de student slim! Hij heeft al zo' n beetje emwaring van academische examens en nood maakt vindingrijk. Hij ziet in, dat hij er niet komt, als hij doorgaat met in dikke boeken te lezen en polloodschrappen te zetten. Hij weel ook (studenter praten weel met elkaar over af te leggen en afgelegde examens) dat de professor veel vraagt over hetgeen hij gewrown is te behandelen. De "breede" opzet van de studie wordt beschowwd als de oefening in heit leeren wan hett studeeren, het dictaat wordt voor den dag gehtald, ontbrekende dictaten worden tegen hoge prijzen gekocht, ower het bezwaar, dat zo'n gekocht ding waak opgeschreven is, zonder dat de toehoorder behoorlijk zorg heeft gedragen voor een voldoende gelijktijdige verbinding van de lobug temporalis en schriffentrum met de transcorticale begripscentra, wordt heengestapt, een repititorium dient als an nvulling. Eventueel loopt hij, als de beurs het toelaat, naar een repetitor en gewoonlijk weet de student op het examen net genoeg, on een goed figuur te slaan. Wel blijkt af en toe overtuigend, dat hij de verschillilende leervakken in afzonderlijke, streng geilsoleerde hersengedeelten heeft opgestapeld." Of Van Rijmberk (1919b: 1514): "Voor de zeer goeden is het examen dus een vorm. Voor de gemiddelden een dwang om, na eenigen tijd inpompen, voor eenigen tijd een hoeveelheid parate kennis bij elkaar te dwin-
gen, waarwan zij spoedig weer bevrijd zijn. Zonder examen zouden de zeer goeden even goed zijn en 
neerd wordt door het streven naar goede examenresultaten (Luhmann 1987a 218) - tegemoet komen. De behoefte aan een individualisering van het toets systeem signaleerde Van Rijnberk trouwens reeds in 1919. "Waar het heen moet is, naar mijn meening, naar een trapsgewijze regeling der studie, waarbij niemand verder kan komen, dan zijn eigen kennis en vaardigheid hem toestaat, waarbij automatisch de vooruitgang van elke student bepaald wordt" (Van Rijnberk 1919b: 1515) ${ }^{\text {s. }}$. Wanneer internationalisering en een individualisering van het toetsinstrument begrepen worden als samenhangende facetten van een verdergaand moderniseringsproces in het onderwijs, dan zal het niet verbazen dat met die doorgaande individualisering van het toetsinstrument een vergroting van de maatschappelijke onzekerheid zowel voor de student als voor de docent aan de orde is: "Die 'harten' Studiengänge würden schärfere Fremdselektion mit höherer Sicherheit des Berufszugangs kombinieren. (...) Die "weichen' Studiengänge würden sich durch allgemeinere Bildungsziele, vielseitigere, aber unbestimmtere Chancen, mehr Selbstselektion als Fremdselektion und mehr Zukunftsunsicherheit auszeichnen" (Luhmann 1987a: 218).

Maar internationalisering en de bijbehorende verdergaande individualisering van het hoger onderwijs maakt onherroepelijk de traditionele binding van een universiteit met één locatie (Leiden, Utrecht, Maastricht) obsoleet. Het brengt een verregaande integratie van het universitair bestel met zich mee, in eerste instantie op nationale schaal". Computer ondersteund onderwijs, is via moderne communicatietechnieken ook als lange afstandsonderwijs op te vatten. Ook hier stelde Land reeds in 1886 voor het Nederlandse hoger onderwijs als éen stelsel op te vatten: "De souvereine provinciën hebben ons afgeslotene en op elkander naijverige hoogescholen, elke met haren aanhang nagelaten; behoeft die toestand gehandhaafd te worden, de eene met de andere gelijk en gelijkvormig geschaafd, de kweekelingen zijn geheele akademieleven lang aan een enkele vastgehouden; bij ontstentenis van een titularis een tijdelijke hulp van elders onmogelijk gemaakt? Boven de plaatselijke traditie, die de schelding en zooveel anders nog dat zijn tijd overleeft, zou willen bestendigen, staat immers de nationale eenheid en het belang der wetenschap. (...) Wat ver-

de gemiddelden zouden uit zich zelf precies zoo veel leeren, als zij nu zes maanden na de examens nog onthouden kunnen. Alleen voor de zér slechten werken de examens als een breidel van tijdelijkert arand."

48 Bij practica zou men "de studenten aran den tand moeten voelen en van de uitkomst van deze kentamenachtige, ongedwongen gesprekken, aanteekening houden in het grootboek. Dit zou telkerts slechts weinig tijd kosten, en het onberekenbare nut hebben, de studenten gestadig voeling te doen houden tusschen de theoretische studie en de practische oefeningen" (Van Rijnberk 1919b: 1516).

49 [T]e meer waar Leiden, A.nsterdam en Utrecht zoo dicht bij elkarider liggen en in normale tijdent zulke goede spoorweg-verbindingen bezitten dat een student in zijne unwersiteitsstad zou kurunem blijven wonen en tevens enkele speciale colleges in de andere universiteitsstad zou kunnen volgen (Kruseman 1946: 7). 
biedt ons eigenlijk, bij al hetgeen wij anders doen dan onze vaderen, van die huishouding een geheel te maken" (Land 1886: 33-34). Vanuit die optiek verschijnt de al bijna een eeuw voortsukkelende taak- of vroeger rolverdeling tussen de diverse universiteiten niet alleen als een bezuinigingsoperatie, maar ook als een hernieuwde confrontatie tussen een onderwijsorganisatie die zich wil baseren op het individuele leerproces en een die vast wil houden aan traditioneel gegroeide indelingen en hiërarchieën. 


\section{Samenvatting}

In de periode tussen de eerste en de tweede Hoger Onderwijswet (1815-1876) grepen aan de Nederlandse universiteiten een aantal verstrekkende veranderingen plaats. Het Latijn verloor zijn status als academische voertaal, terwiil nieuwe onderwijsvormen, meer praktisch onderwijs vooral, hun intrede aan de vaderlandse universiteiten deden. In de achttiende eeuw had iedere serieuze toetsing aan de universiteiten vrijwel ontbroken; in de negentiende eeuw kwamen examens juist in het middelpunt van de belangstelling te staan. Ook het idee van een vaste en voorgeschreven studievolgorde voor de academische lessen kreeg toen gestalte, in schril contrast met de totale studievrijheid die studenten in de voorafgaande eeuw hadden genoten. De hoogleraren kregen naast hun taak onderwijs te verzorgen, expliciet de opdracht onderzoek te verrichten. Dat transformatieproces van het hoger onderwijs wierp een groot aantal problemen op, dat door direkt betrokkenen in inaugurale redes, tijdschriften en inleidingen van handboeken werd gesignaleerd. Die problemen vormen het uitgangspunt voor dit boek. Controverses over de wenselijkheid van veranderingen in de maatschappelijke organisatie van het hoger onderwijs worden hier geconfronteerd met discussies over de inrichting en de inhoud van het onderwijs in de faculteiten der geneeskunde en der rechtsgeleerdheid.

De problemen en thema's die in deze debatten naar voren komen, worden hier geduid vanuit een model van maatschappelijke modernisering. Het maatschappijtheoretisch kader van waaruit deze studie vertrekt wordt gevormd door Niklas Luhmanns theorie van zelforganiserende systemen. Deze theorie beschouwt sociale systemen als zelfreferentiële processen, opgebouwd uit communicaties. Die afzonderlijke communicaties worden samengehouden door structuren, opgevat als verwachtingsverwachtingen. In afwijking van de systeemtheoretische traditie worden structuren hier niet langer gezien als min of meer stabiele relaties tussen een aantal elementen van het geheel. Verwachtingsverwachtingen selecteren zinvolle aansluitingsmogelijkheden voor communicaties, en sluiten andere uit. Daarmee verliezen structuren hun statische karakter. Structuren veranderen en die veranderingen komen tot uiting in betekenisverschuivingen. Veranderingen in de betekenis van algemeen gangbare begrippen als theorie, praktijk of ervaring, worden dan opgevat als uitdrukking van maatschappelijke veranderingen.

Gedurende de bestudeerde periode verschoof de betekenis van een aantal termen die bij de maatschappelijke organisatie van het hoger onderwijs en bij 
de inrichting van het onderwijs in de faculteiten der geneeskunde en der rechtsgeleerdheid een cruciale rol speelden. Wat de maatschappelijke organisatie van het hoger onderwijs betreft kwam het indelingscriterium zèlf ter discussie te staan. De vraag werd opgeworpen wat nu het eigene van het hoger onderwijs uitmaakte, wat het hoger onderwijs onderscheidde van lager en middelbaar onderwijs. Gedurende de achttiende eeuw was de organisatie en inrichting van het onderwijs in ons land op een hiërarchisch standenonderscheid gebaseerd. Hoger onderwijs leidde op tot een geleerde stand in de maatschappij. Daarbij hoorde een bepaald vormings- en kennisideaal. Aan het einde van de negentiende eeuw was het onderwijssysteem zoals wij dat heden ten dage kennen - althans in zijn contouren - een feit. De grote lokale autonomie die gedurende de Republiek de organisatie van het onderwijs had gekenmerkt, had toen plaats gemaakt voor een centraal afgestemde organisatie. Maar nog belangrijker: de organisatie van dat onderwijs kende niet langer een standsmatige opbouw, maar werd afgeleid van de idee van een leerproces. 'Hoger' in de onderwijscontext verkreeg geleidelijk de betekenis van een aanduiding in kennisniveau en verloor zijn verwijzing naar speciale vakken, naar een bepaalde benadering van onderwerpen, of bijzondere kennis. Terwijl een standsgewijze onderwijsorganisatie onderwijsty pen primair differentieert in termen van eindonderwijs behorend bij een stand, staat in een onderwijsstelsel dat zich op het individuele leerproces oriënteert het doorstroom- en selectiekarakter voorop. Daarmee hangt zowel een 'pedagogisering' van het onderwijs als een centrale rol voor examens - selectie op basis van individuele leerprestaties - samen. De zekerheid die het standsbesef bood werd geëlimineerd; de mogelijkheden tot verticale mobiliteit werden vergroot. Daarmee werd - in moderne termen gesproken - de weg geopend tot een democratisering van het onderwijs.

Zoals in de loop van de negentiende eeuw de betekenis van het bijvoeglijk naamwoord 'hoger' in de onderwijscontext verschoof, zo veranderde ook de betekenis van termen als 'ervaring', 'routine' en 'praktijk', die een belangrijke rol vervalden in de demarcatie van de positie van de 'geleerde' doctor ten opzichte van diens niet-academische concurrenten. De universitaire opleiding tot Medicinae Doctor introduceerde van oudsher de student vooral in een statusgroep. Die statusgroep vormde echter niet langer het primaire onderscheidingsteken voor de (natuur)wetenschappelijk gevormde artsen uit het tweede deel van de eeuw. Daarvoor waren inmiddels de academische opleiding zelf, de inhoud van de medische wetenschap en de verhouding tussen theorie en praktijk te radicaal veranderd. De uniformering van bevoegdheden en examenvereisten die de wetten van 1865 en 1878 met zich meebrachten, wordt in deze studie dan ook niet zozeer begrepen als een overwinning van de academisch opgeleide arts over zijn niet-academische concurrenten. De hervormers die een geneeskunde op natuurwetenschappelijke grondslag bepleitten, verdedigden 
niet zozeer een academische elite, maar reikten veeleer een alternatief organisatiecriterium aan; zowel voor de maatschappelijke organisatie van de zorgverlening als voor de opleiding van de aanstaande arts en voor de beoefening, van de geneeskundige wetenschap als zodanig. In plaats van te wijzen op de zekerheden van de overgeleverde kennis, benadrukten de hervormers het proces-karakter van ziekte. Met de nauwkeurige waarneming en registratie van het individuele ziekteproces werd het fundament gelegd voor professionele autonomie en voor een model van coöperatie - in tegenstelling tot de hiërarchieèn die de geneeskunstbeoefenaars tot dan toe scheidden. De acceptatie van een grote mate van onzekerheid over het verloop van een ziekte, bracht ook met zich mee dat een nauwkeurige, zelfstandige en continue waarneming van het ziekteproces vereist was. De waarneming van fysiologische processen lag in het verlengde daarvan, of vormde - didactisch gezien - de voorbereiding daarop. Het praktisch klinisch onderwijs aan de universiteiten werd - althans in woord en geschrift - een verlengstuk van het praktisch laboratoriumonderwijs in de natuurwetenschappen. Daarmee werd een alternatief geformuleerd dat de kloof tussen onderwijs in een meester-leerling traditie en het klassieke academisch onderwijs kon overbruggen.

Voor het onderwijs aan de rechtsgeleerde faculteit gold aan het begin van de negentiende eeuw eens te meer dat het studenten primair in een statusgroep introduceerde. De rechtsgeleerde studie behelsde van oudsher een vrij algemene introductie tot hogere ambten en functies. Maar ook hier groeide in de loop van de negentiende eeuw allengs een gevoel van onvoldaanheid over de inrichting en de resultaten van de juridische studie. Toen de Nederlandse Juristen Vereniging in 1899 een discussie aanzwengelde over de civiele bevoegdheid verbonden aan het academisch eindexamen, was definitief het besef gevestigd dat onderwijs in een moderne maatschappij selectie inhoudt. Ook de inhoud en de inrichting van de rechtenopleiding maakten rigourenze wijzigingen door. Ten tijde van het Organiek Besluit (1815) werden discussies over de inrichting van het rechtsgeleerde onderwijs nog gevoerd in termen die ook de bestudering van het geleerde recht in de achttiende eeuw beheersten. De wetenschappelijke benadering van het recht stond in het teken van de verklaring en uitleg van een volledig, consistent en coherent systeem van rechtsnormen: een logisch geordend stelsel van definities en principes dat op alle voorkomende gevallen toepasbaar was. Wetenschap diende naar volledigheid te streven. Wetenschappelijk onderwijs in het recht diende studenten met de logica van het recht bekend te maken. Na het tot stand komen van eigen nationale wetboeken (1838) werd, hoewel het Romeinse recht een prominente plaats in de opleiding behield, de nadruk in het onderwijs geleidelijk verschoven naar de verklaring en uitleg van de nieuwe nationale wetboeken. De discussie over de toegelaten interpretatiewijzen van de rechter maakte de inherente beperkin- 
gen van het wetboekenstelsel steeds meer manifest. In de tweede helft van de negentiende eeuw kwam een opvatting van recht naar voren waarin meer de nadruk werd gelegd op de maatschappelijke context van het recht. De rechtswetenschap verloor haar exclusieve oriëntatie op de analyse van de rechtsnorm, en haar intentie die terug te voeren op vastliggende bronnen, of deze te herleiden tot algemene en liefst eeuwig geldende rechtsprincipes. Recht en rechtswetenschap werden vervolgens begrepen als een onderdeel van een contingent maatschappelijk proces waarin regelgeving en regelhandhaving centraal staan, en waarin wetgever, rechter en rechtswetenschapper ieder een (niet logisch dwingend te omschrijven) rol hebben. Die veranderde visie klonk door in de discussies over de inrichting van het onderwijs. De vormende functie die aan het Romeinse recht werd toegedicht verschoof van de oefening in formeellogisch denken naar het geven van inzicht in de ontwikkelingsaspecten van het recht. Het observeren van het functioneren van de rechtsnorm in de maatschappelijke praktijk en het beoordelen van de adequaatheid van de rechtsnorm in de actuele situatie kreeg meer nadruk. Evenals in de medische faculteit werd met het verschuiven van de opvattingen over de verhouding tussen theorie en praktijk, de roep om praktisch onderwijs luider.

Zoals al aangegeven, zijn de veranderingen in de maatschappelijke organisatie van het onderwijs en de veranderingen in de faculteiten der geneeskunde en der rechtsgeleerdheid hier bezien vanuit een perspectief op modernisering, dat gebaseerd is op Luhmanns sociale theorie. Modernisering betreft enerzijds een vergroting van de schaal waarbinnen sociale verhoudingen op elkaar afgestemd worden, globalisering. Het streven naar codificatie wordt steeds in een adem met het scheppen van rechtseenheid en rechtszekerheid genoemd. De organisatie van het onderwijs en de organisatie van de medische zorg verliezen in de loop van de negentiende eeuw hun lokale karakter. In de bestudeerde domeinen valt daarnaast waar te nemen dat (extern aangebrachte) hiërarchische indelingen, waarbij de tijdsfactor geen rol speelt, of de ontwikkeling in de tijd in grote mate voorspelbaar wordt geacht, ondergeschikt worden aan indelingen gebaseerd op procestermen die een open toekomst suggereren en een eigen dynamiek ontwikkelen: functionele differentiatie. Een verrassingsbewustzijn ontstaat, en maatschappelijke domeinen worden zo ingericht dat in veel grotere mate dan voorheen, de bereidheid ontstaat verwachtingen (collectief) bij te stellen wanneer deze teleurgesteld worden. Aldus maakt temporalisering een dominantie van cognitieve over normatieve verwachtingsverwachtingen mogelijk: rationalisering.

Deze studie draagt daarmee een alternatief aan voor de zienswijze dat Nederland in de negentiende eeuw een vaststaand 'Duits model' heeft overgenomen. Zonder de vele contacten tussen Duitse en Nederlandse wetenschappers te ontkennen en zonder de parallellen tussen de Duitse en Nederlandse ont- 
wikkeling te negeren, wordt in dit boek de ontwikkeling van de Nederlandse universiteiten geplaatst in de context van een moderniserende maatschappiij. Dan pas kunnen de toename van de eisen die bij de academische examens gesteld worden, de veranderingen in het kennisideaal en in de organisatievorm van wetenschap, in hun onderlinge verband worden begrepen. De invoering van democratie, het ontstaan van een disciplinaire organisatievorm van onderzoek, en de invoering van selectie op basis van individuele leerprestaties, hangen samen met het gaan fungeren van proces-termen als leidend beginsel voor de inrichting van verwachtingsverwachtingen. Kenmerkende organisatievormen, zoals de eenheid van onderwijs en onderzoek, die steevast met het 'Duitse model' worden verbonden, worden dan ondergeschikt aan dat moderniseringsproces.

Voor het debat over de inrichting van het hoger onderwijs in onze tijd levert deze studie een aantal handreikingen. Opvallend in het transformatieproces van de universiteit in negentiende-eeuws Nederland, is de verstrengeling van veranderingen in onderwijsinhoud en didactische vernieuwingen. Ook het document dat in 1972 de oprichting van de Rijksuniversiteit Limburg (aanvankelijk Medische Faculteit Maastricht) vergezelde, de 'Basisfilosofie', wordt door een dergelijke verwevenheid gekarakteriseerd. De geleidelijke reductie van het ambitieuze programma van die 'Basisfilosofie' tot een pleidooi voor een bepaalde didactische werkvorm, en de generalisatie van de in de 'Basisfilosofie' neergelegde ideeën buiten de faculteit der geneeskunde, hebben die verwevenheid van onderwijsinhoud en -vorm ondergraven. Op basis van de in dit boek beschreven ontwikkeling van de negentiende eeuwse universiteit is dat bedenkelijk. De herinterpretatie van de ontwikkeling van de Nederlandse universiteiten in de negentiende eeuw voert tot de conclusie, dat de verdere ontwikkeling van de universiteiten in de 21 e eeuw meer gediend is met de ontwikkeling van alternatieve selectieinstrumenten, dan met het vasthouden aan organisatorische karakteristieken die hun oorspronkelijke functie hebben verloren. Zo zal, wanneer het Nederlandse hoger onderwijs in de komende decennia daadwerkelijk wil internationaliseren, eerder een individualisering van selectiemethodes en diploma's vereist zijn, dan dat de eenheid van onderwijs en onderzoek bewaard moet blijven. 


\section{Summary}

In the period between the first and the second national act on higher education (1815-1876) a number of far-reaching changes occurred in the Dutch universities. Latin definitively lost its status as lingua franca, while new ways of teaching, especially practical teaching, were introduced. Whereas academical examinations were almost inexistent in the eighteenth century, the interest in examinations grew in the nineteenth century. The idea of a regular and prescribed sequence of academic lessons - a curriculum - also took shape at that time. It contrasted greatly to the absolute freedom of learning students had enjoyed in the previous century. In addition to their regular teaching, professors were now also expected to do research. For the people involved in this transformation of the system of higher education a host of problems - discussed in inaugural addresses, journals, prefaces of textbooks etc. - loomed; they are the primary sources of this study. In this book controversies concerning the desirability of changing the organization of higher education in general confront discussions about the content and arrangement of education in the medical faculty and the faculty of law.

The problems and themes which were mentioned in those debates are interpreted here in terms of a modernization model which starts from Niklas Luhmann's theory of self-organizing, autopoietic, systems. In this theory social systems are conceived as self-referential processes which have communications as their elements. Those communications are bound together by structures which are viewed as expectations of expectations. In contrast to traditional systems theory, structures are no longer taken as more or less stable relationships between a number of elements of the whole system. Expectations of expectations select meaningful connections for communication, excluding others. Structures thus loose their static character. Structures change and those changes are expressed as changes of meaning. Shifts of meaning of currently used terms such as "theory", "practice" or "experience", can then be apprehended as an expression of social changes.

In the period studied here, the meaning of a number of terms which played a prominent part in the organization of higher education and in the arrangement of medical and legal studies shifted. As far as the organization of higher learning is concerned, the criterion of arrangement of education became an item of discussion itself. The question arose in which sense higher education was different - and could thus be distinguished - from primary ('lower' in 
Dutch) and secondary ("middle') education. In the eighteenth century the arrangement of higher education was based on social ranking. Higher education brought up for a 'learned estate'. This situation was confirmed by the operative ideals of knowledge and educational formation. At the end of the nineteenth century the modern educational system was established, at least in its: fundaments. The local autonomy which characterized the organization of education during the Republiek (1579-1795) made room for a much more elaborated and centralized organization. Even more important, differences of social standing became less relevant to the organization of higher education and the learning process became central. The term 'higher', in the context of education, gradually acquired the meaning of a level of knowledge and the term lost its reference to special subjects, a special treatment of subjects, or a particular type of knowledge. When the organization of education is based on a hierarcty of estates, the types of schools are basically distinguished in terms of the different destinations of their students. But when the learning process becomes the central axis for organization, the flow of students from one type to another and consequently, selection, become more important. Pedagogics and examinations - a selection according to individual performance - now appeared on the scene. The certainty of being raised and educated in the standards of one's station in life disappeared; the possibility of vertical social mobility increased. Put in modern terms, the possibility of a democratization of education emerged.

Not only the meaning of the epithet 'higher' shifted in the nineteenth century; the meaning of such terms as "experience", "theory" and "practice" which were an important factor in the demarcation of the learned Medicinae Doctors from their non-academic competitors - changed as well. Whereas the academic training of a Medicinae Doctor introduced the student into a status group, the status group was no longer the distinguishing mark for the scientifically trained physician. In this book the unification of competences and examination demanded by the medical acts of 1865 and 1878 are not first and foremost interpreted as a victory of the academic physicians over their nonacademic competitors. The academic training itself, the content of medical science and the relationship between theory and practice changed dramatically. The reformers who argued for a science-based medicine did not primarily defend an academic elite; they rather tried to establish a new organizational criterion for the organization of health care, the training of practioners and the cultivation of medical science. Instead of relying on the certainties of traditional wisdom, the reformers stressed the process character of a disease. Careful observation and registration of the course of a disease in individual patients laid the foundations of professional autonomy and of a model of cooperation - in contradistinction to the hierarchies which divided practioners until then. Tolerance of more uncertainty with respect to the course of a 
disease made more careful, independent and continuous observation and registration imperative. The observation of physiological processes matched with this idea of a disease and constituted the best training - didactically speaking - for prospective physicians. Practical clinical training - at least through the spoken and the written word - became an annex to the practical laboratory training in the teaching laboratory. Thus the gulf between traditional academical teaching and training by apprenticeship was bridged.

Academic teaching introduced students into a status group even more strikingly in the faculty of law. Studying law had for a long time past been viewed as the via regia to higher offices and functions. Gradually the arrangement of legal studies also came under attack. 1899, the year in which the Dutch association of lawyers (NJB) devoted its annual meeting to the problems of the civil competence of the final academic examination, is a landmark in their respect: it had become clear to everyone by then that university instruction cannot do without rigorous examinations. The content and arrangement of legal education changed drastically as well. At the time of the Organiek Besluit (1815), the terms and notions which dominated eighteenth-century legal thought also absorbed the debates about the arrangement of legal studies. The learned approach to law aimed to explain and expound a complete, consistent and coherent system of norms: a logically composed system of definitions and principles which could be applied to all cases in occurring circumstances. The task of academic instruction was to make students familiar with the logical construction of law. After the promulgation of national codes in the Netherlands (1838), the emphasis of academic teaching shifted towards the explanation of the new national codes - although Roman law remained the most important subject for a long time. Discussions of the acceptable interpretations of the codes soon exposed the inherent limitations of the new system of codes. In the latter part of the century an idea of law took shape in which the social context of law came to the fore. Legal studies abandoned their exclusive orientation toward legal norms and their intention to trace back legal norms to firmly established sources or to reduce them to a set of general, eternally valid, first principles. Law and the academic study of law came to be understood as part of a contingent social process in which regulations, legislation and jurisdiction were considered on a par and in which the role of neither legislators nor judges nor jurists could be prescribed in a logically compelling way. This change of opinion understandably influenced the discussions about legal education. The educational value attributed to Roman law shifted from the training in abstract logical thinking to providing sound judgement in the development of law through the ages. More attention was now being paid to the concrete operation of legal norms in society and to the appreciation of the adequacy of legal norms in the situation at stake. The relationship between theory 
and practice changed, and consequently more practical teaching methods were urged for.

Changes in the organization of higher education in general and in the faculties of medicine and law in particular are interpreted in this book from the viewpoint of modernization theory, which is formulated with the help of $\mathbb{N}$. Luhmanns social theory. Modernization concerns on one hand, the enlarged dimensions in which social relationships are attuned to one another: globalization. Thus, for instance, the aim at codification was always mentioned in the same breath with the creation of unity and legal security. In the nineteenth century, the organization of education and medical practice lost its local orientation. Moreover, one observes that in the domains studied here, (external) hierarchical divisions in which the factor time played no part or development over time was taken to be predictable became of minor importance. These divisions were replaced by terms indicating an open-ended process. This required an awareness of surprise, which took some time to emerge. Now the preparedness of a (collective) adaptation of expectations in case of disappointment could be institutionalized. Temporalization made the dominance of cognitive over normative expectations of expectations possible: rationalization. The emphasis on process which became characteristic for all social domains generated a formerly unknown dynamics: functional differentiation.

This book offers an alternative to the received interpretation that in the nineteenth century a fixed 'German model' was adopted in the Netherlands. This is not to deny the many contacts between Dutch and German scholars - a number of parallels between the changes in the organization of higher education in the Netherlands and Germany are stressed. But those changes are now interpreted from the perspective of a modernising society. This allows us to interconnect the increase in qualifications required at academical examinations, changes in the idea of knowledge, and the shift in the organization of research. The rise of a democratic political system, the rise of the system of scientific disciplines and the introduction of selection based on individual performance, are expressions of the dominance of process terms in the expectations of expectations. Characteristical organizational features, such as the unity of research and teaching, which are usually associated with the 'German model', become subordinated to that modernization model.

A number of extrapolations can be made from this study to current debates about the organization of higher education. Remarkable in the transformation process of Dutch universities in the previous century was the simultaneity of changes in the content of learning and didactic innovations. A similar interwovenness characterized the document which accompanied the foundation of the University of Limburg (at the outset the Medical Faculty of Maastricht) in 1972, the 'Basisfilosofie'. The gradual reduction of the ambitious 'Basisfilosofie' 
fie program to a plea for one specific didactic method (Problem Oriented Learning) and the generalization of the 'Basisfilosofie' to the whole university have destroyed this blend of content and form. In the long run the curtailing in didactic methods might hinder the innovation of the intellectual content. The reinterpration of the German model leads to the conclusion that the further development of the universities in the twenty-first century requires the creation of new forms of examinations rather than the continued adherence to organizational characteristics which by now have lost their function. Thus, for instance, if the declared aim of Dutch universities to an internationalization of their programmes has to become reality in decades to come, an individualization of examinations and certificates will be required, whereas the unity of research and teaching might well be abandoned. 


\section{Bibliografie}

Ablaing, W.M. d', 1882, Recht en Rechtswetenschap. Rede bij de aanvaarding van het hoogleeraarsambt aan de Rijksuniversilteit te Leiden, op den 31sten Mei 1882 gehouden, De Erven F. Bohn, Haarlem.

Abrams, Ph., 1982, Historical sociology, Open Books, West Compton House, Near Shepton Mallet, Somerset, England.

Achterhuis, $\mathrm{H}_{*}$, 1979, De markt wan welzijn en geluk. Een kritiek van de andragogie, Amboboeken, Baarn.

Alberti, H., 1847, 'Staatsexamina', Uittreksel uit eene Verhandeling ... van Dr. H. Alberti, Rector des Gymnasiums zu Schleiz, Algemeene Konst en Letterbode, (1847) deel I, 291-298.

Albury, W.R., 1977, Experiment and explanation in the physiology of Bichat and Magendie, Studies in History of Biology, 1 (1977), 47-131.

Andel, M.A. wan, 1981 [1941'], Chirurgijns, Vrije Mesters, Beunhazen en Kuakzalvers. De chirurgijnsgilden en de praktijk der heelkunde (1400-1800), Martinus Nijhoff, "s Gravenhage.

Ankum, J.A., 1977, Van Cras tot Conrat, De beoefening, van het Romeinse recht door de hoogleraren aan het Athenaeum lllustre en aan de Universiteit van Amsterdam in de negentiende eeuw, In: Van den Brink, Moorman van Kappen, Van der Linden, en Van Holk (red.), 1977, pp. 93-112.

Anrich, E. (Hrsg.), 1956, Die Idee der deutschen Universität. Die füff Grundschriften aus der Zeit ihrer Neubegründung durch klassischen Idealismus und rowantischen Realismus, Wissenschaftliche Buchgesellschaft, Darmstadt.

Apeldoorn, L.J. van, 1932, De Rechtsgeleerdheid, In: Gedenkboek, 1932, pp. 127-162.

Arntzenius, D.J.A., 1842a, Uitvoerbaarheid eener hervorming in het Onderwijs en de toelating onzer Geneeskundigen, Bijdragen tot Genceskundige Stantsregeling, 1 (1842), 226-259.

Arntzenins, D.J.A., 18426 , Noodzakelijkheid eener hervorming in het Onderwijs en de toelating onzer Geneeskundigen, Bijdragen tot Geneeskundige Staatsregeling, 1 (1842), 79-124.

Arntzenius, D.J.A., 1842c, Over het Staats-Examen van Medicinae Doctoren in verband met de hun verleende wetenschappelijke regten, Bijdragen tot Geneeskundige Staatsregeling, 2 (1842), 90-106

Arntzenius, D.J.A., 1845, Statistieke opgaven omtrent de geneeskundige bevolking van Nederland. Bijdragen tot Geneeskundige Stantsregeling, 3 (1845), 22-67.

Asser, 1839, Burgerlijk Wetbock vergeleken met het Rameinsche en Fransche regt onder toezigt wan Mr. S.P. Lipman, Amsterdam.

Asser, $C ., 1892$, Wetenschap en wetgeving. Rede bij de aanvaarding van het hoogleeraarsambt aan de Rijksuniversiteit te Leiden op 19 october 1892 uitgesproken, S.C. van Doesburgh, Leiden.

Asser, T.M.C., 1893, Toen en Nu. Afscheidsrede uitgesproken op Zaterdag 21 October 1893 in de aula der universiteit te Amsterdam, De Erven F. Bohn, Haarlem.

Aulnis de Bourouill, J. d', 1878, Het Katheder-sactalisme. Redevoering bij de aanvaarding van het hoogleeraarsambt aan de Rijks-universiteit te Utrecht op den 23sten Maart 1878 uitge- 
sproken, J.L. Beijers, Utrecht.

Aulnis de Bourouill, J. d", 1897, Sociale economie, De Gids, (1897) I, 281-290.

Baar, P.P. de, 1982, 'Zij schaaft het ruwe volk, bestraalt ze met haar gunst'. De opkomst van de wetenschap in een tolerante handelsstad, Folia Ciwitatis, 9 januari 1982, no. 19, 411.

Baart de la Faille, J., 1842, Eenige opmerkingen betreffende de rapporten over de Geneeskundige Stantsregeling ingediend door de commissie, benoemd bij zijner Majesteits beshuit wan den 20 november 1841, J. Oomkens Akademiedrukker, Groningen.

Baart de la Faille, J.M. 1918, De sociale geneeskunde als wak van wetenschap en als wakk wan onderwijs. Rede uitgesproken bij de aanvaarding van het hoogleeraarsambt aan de Rijksuniversiteit te Utrecht op den 25 september 1918, A. Oosthoek, Utrecht.

Baart de la Faille, J.M. 1920, Sociale Geneeskunde als onderwijsvak, Nederlandsch Tijdschrift voor Geneeskunde, 64 (1920) IIB, 2161-2164.

Baecker, D., J. Markowitz, R. Stichweh, H. Tyrell, H. Willke (Hrsg), 1987, Theorie als Passion. Niklas Luhmann zum 60. Geburtstag, Suhrkamp, Frankfurt am Main.

Bake, J., 1828, Over Universiteiten en Hooger Ondenwijs. Eerste-zevende Brief, H. W. Hazenberg junior, Leiden.

Bartels, A., 1963, Een Eeww Middelban Onderwijs 1863-1963, J.B. Wolters, Groningen.

Basisfilosofie, Basisfilosofie Achtste Medische Faculteit, 1972, Medisch Contact, 27 (1972), 1-6.

Baudelaire, Ch., 1954, La peintre de la vie moderne, Librairie Gallimard, Paris.

Baumhauer, E.J.G. von, 1848, Over de noodzakelijkheid die er bestant, om klinisch onderwijs op eene ruime schaal te geven, en de behoefte, die daaruit voortoloeit, om groote verzamelplantsen voor zieken op te rigten. Inwijdingsrede, bij het aanvaarden van het hoogleeraramambt aan de Utrechtsche Hoogeschool, uitgesproken 22 junij 1848, C. Campagne, Tiel.

Becher, T., 1984, The cultural view, In: Clark (ed.), 1984, pp. 165-196.

Bemmelen, J.A. van, 1825, Redevoering over den weldadigen invloed van het openbanr anderwijs op de uitbreiding en volmaking wan alle de onderscheidene wakken der geneeskinde. Gehouden te Haarlem, den 5. april 1825 in de Luthersche kerk bij de opening van de genees- heel-, verlos- en artsenijmengkundige school, Wed. A. Loosjes Pz., Haarlem.

Ben-David, J., 1984 [1971'], The Scientist's role in society. a comparative study, University of Chicago Press, Chicago/London.

Berger, J., 1987, Autopoiesis: Wie 'systemisch' ist die Theorie sozialer Systeme? In: Haferkamp of Schmid (Hrsg.), 1987a, pp. 129-152.

Bergh, G.C.J.J. van den, 1979, Recht en Taal. Praeadvies t.b.v. Jaarlijkse Algemene Vergadering Koninklijke Notariële Broederschap vrijdag 21 september 1979 , Kluwer, Deventer.

Bergh, G.C.J.J. van den, 1980, Geleerd recht. Een geschiedenis wan de Europese rechtswetenschap in oogelvhucht, Kluwer, Deventer.

Bergh, G.C.J.J. van den, 1982, Wet en Gewoonte. Historische grondslagen won een dogmatisch geschil, Kluwer, Deventer.

Bergh, G.C.J.J. van den, 1986, Cornelis van Eck 1662-1732, een dichter jurist, In: Van den Bergh, Spruit, en vid. Vpugt (red.), 1986, pp. 36-54.

Bergh, G.C.J.J. van den, 1987, Schijnbewegingen. Hercodificatie en eigendomsdefinitie in historisch perspectief, Recht en Kritiek, 13 (1987), 327-341.

Bergh, G.C.J.J. van den, 1988a, Kennis en Macht. Verkenningen van een rechtshistoricus rond het thema overheid en wetenschappen, In: Le Pair, Benschop en Broeder (red.), 1988, pp. 1552.

Bergh, G.C.J.J. van den, 1988b, De jurist, de rechtswetenschap en de rechtsgeschiedenis, In: Kamstra, Kunmewan ew Maris (red.), 1988, pp. 125-142.

Bergh, G.C.J.J. van den, preprint, Het rechtssociologische/criminologische forum vergeleken met het rechiswetenschappelijk forum.

Bergh, G.C.J.J. van den en C.J.H. Jansen, 1988 , De wording van het juridisch tijdschrift. Drie 
Nederlandse pogingen uit de Franse tijd, Tijdschrift voor Rechtsgeschiederis, 56 (1988), 341 354.

Bergh, G.C.J.J. van den en C.J.H. Jansen, 1989a, De Weegschaal. Een tegendraads tijdschrift uit de $19 \mathrm{e}$ eeuw, Rech en Kritiek, 15 (1989), 345-362.

Bergh, G.C.J.]. wan den en C.J.H. Jansen, $1989 b_{n}$ Het tijdischrift als tijdspiegel. Een verkenring. van anderhalve eeuw Themis en Rechtsgeleerd Magazijn, RM Themis, (1989), 247-266.

Bergh, G.C.J.J. van den, J.E. Spruit; M. van de Vrugt (red.), 1986, Rechtsgeleerd Utrecht. Levensschetsen van elf hoogleraren wit driehonderdviffig jaar Faculteit der Rechtsgeleerdheid in Utrecht, De Walburg Pers, Zutphen-Linschoten.

Berkel, A. van, 1886 , Utrechtsch hoogeschool veertien jaren na het begin en veertien jaren voor het einde der negentiende eenw 1814-1886, A. Rössing, Amsterdam.

Berkel, H.J.M. E. de Graaff, J. Sprooten en H.G. Schmidt, 1990, De eerste ervaringen met een geindividualiseerde toets bestaande uit 600 vragen, Tijdschrift voor Onderwijsresearch, 15 (1990), 189-191.

Berkel, K. van, 1985, In het voetspoor wan Stevin - geschiedenis van de natuurwetenschap in Nederland 1580-1940, Boom, Meppel/Amsterdam.

Besouw, F. van, P, den Boer, F.W.N. Hugenholtz en Th. van Tijn (red.), 1987, Balans en Perspectief. Visies op de geschiedutetenschap in Nederland, Wolters-Noordhoff/Forsten, Groningen.

Bess, J.L. (ed.), 1984, College and university arganization. Insights from the behavioral sciences, New York University Press, New York and London.

Beukers, Hi, 1983, De beginjaren van de microscopie aan de Geneeskundige Faculteilten the Utrecht en te Leiden. Tsch.Gesch.Gnk.Natuurw.Wisk.Techn., 6 (1983), 65-81.

Betukers, H., 1984, Groel en Ontwikkeling, De Leidse faculteit der geneeskunde in het derde kwart der negentiende eeuw. In: Otterspeer (red.), 1984, pp. 76-102.

Beukers, H., 1986a, Een nieuwe werkplaats in de geneeskunde: de opkomst van laboratoriat in de geneeskundige faculteiten, Tsch.Gesch.Gnk.Natuunw.Wisk.Techn., 9 (1986), 266-277.

Beukers, H., 1986b, Aan bed geleerd - 350 jaar medisch klinisch ondenwijs, Vouwblad De Lakenhal Stedelijk Museum Leiden, Leiden.

Beukers, H., 1988, Bloei en Kritiek. Het onderwijs onder de inspecteurs Beckers en Snabilié, In: De Moulin (red.), 1988, pp. 35-48.

Beukers, H., 1989a, De Heelkunde bij Kamper, In: Schuller tot Peursum-Meijer en Koops (red.), 1989, pp. 45-52.

Beukers, H. , 1989b, Clinical Teaching in Leiden from Its Beginning until the End of the Eighteenth Century, Clio Medica, 21 (1987-1988), 139-152.

Beturskens W.J.J. en Verheij, 1989, Thematisch onderwijs, In: Ervaringen, 1989, pp. 35-58.

Bierman, A.I., 1988, Van arsenijmengkunde naar artsenijbereidkunde. Ontwikkelingen wan de Nederlandse farmacie in de negentiende exuzo, Rodopi, Amsterdam.

Bijsterveldt, Q. van (red.), 1988, Over tijd. Verkenningen van de temporele organisatie van onze. samenleving, Acco, Amersfoort/Leuven.

Billroth. Th. 1876, Uber das Lehren und Lernen der Medicinischen Wissenschaften an den Uni* versitäten der Deutschen Nation Nebst Algemeiner Bemerkungen über Universitäten. Eine Culturhistorische Studie, Carl Gerold's Sohn, Wien.

Binneveld, J.M.W., en M.J. van Lieburg, 1986, Amsterdamse en Rotterdamse ziekenhuizen in de negentiende eeuw. Stedelijke rivaliteit als factor in de geschiedenis van de gezondheidszorg, In: Blans en Van Herwaarden (red.), 1986, pp. 150-169.

Blaas, P.B.M., 1988, Anachronisme en historisch besef. Momenten wit de ontwikkeling van het Eutopees historisch bewustzijn, Nijgh \& Van Ditmar, Den Haag.

Blaas, P.B.M. en J. van Herwaarden (red.), 1986, Stedelijke naijoer. De betekenis van interstedtelijke conflicten in de geschiedenis. Enige beschouwingen en case-studies, VUGA, 's Gravenhage. B.L.G., 1824, Iets over onze noordelijke Hoogescholen, J. Oomkens, Groningen. 
Blom, T., 1988, De zelforganisatie van de sociale werkelijkheid - Een introductie op Niklas Luhmanns "Soziale Systeme', Kennis en Methode, 12 (1988), 236-255.

Boehm, L., 1983, Wilhelm won Humboldt and the university: idea and implemantation, CREInformation; no. 61 (1983), Research at the university

Boekholt, P.Th.F.M. en E.P. de Booy, 1987, Geschiederis van de school in Nederland. Vanaf de middeleeuwen tot aan de hwidige Hij, Van Gorcum, Assen/Maastricht.

Boesman, Th. 1942, De examens iw de chirurgijnsgilden, Kemink, Utrecht.

Bolhuis, G.H. van, 1899, Praeadvies voor NJV, Handelingen der Nederlandsche Juristen Vereentging, (1899) I, 153-183.

Bolkestein, $G_{.,}$1914, De voorgeschiedenis van het Middelbaar Onderwijs 1796-1863, Uitgaven van de Vereeniging van Leeraren bij het Middelbaar Onderwijs, Amersfoort.

Boogaard, J.A., 1866, De anatomisch-physiologische rigting in de hedendagsche geneeskunde, wit de geschiedenis verklaard en gegtwaardigd. Redevoering ter aanvaarding van het buitengewoon hoogleeraarambt aan de Leidsche hoogeschool den 21sten maart 1866 uitgesproken, Jacs. Hazemberg, Corns Zoon, Leiden.

Boogman, J.C., 1978, Rondom 1848. De politieke ontwikkeling wan Nederland 1840-1858, Unieboek, Bussum.

Boon, L. 1989, Wetenschapstheorie en historisme. In: Boon en de Vries (red.), 1989, pp. 108117.

Boon, L. P. Gottschal, J.A. Harbers, R. Otten en G.H. de Vries, 1989, Disciplines, kundes en de kwaliteit van wetenschap, z.p.

Boon, L. en G. de Vries (eds.), 1989, Wetenschapstheorie: de empirische wending, WoltersNoordhoff, Groningen.

Borst, I., 1909, Verslag der Commissie in zake geneeskundige opleiding, Nederlandsch Tijdschrift voor Geneeskunde, 53 (1909) 1, 1633-1636.

Bosch Kemper, J. de, 1838a, Gedachten over de Beoefening en Toepassing der aanstaande Nederlandsche Wetgeving - voomamelijk in Betrekking tot de tegenwoordige regtsgeleerdheid, Ten Brink \& De Vries, Amsterdam.

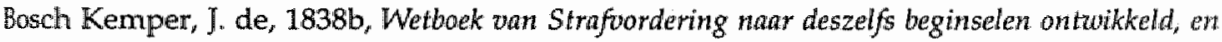
in werband gebragt met de algeneene regtsgeleerdheid 4 delen; Müller, Amsterdam.

Bosch Kemper, J, de, $1860 \mathrm{a}_{,}$Handleiding tot de wetenschap der zamenleving, Müller, Amsterdam. Bosch Kemper, J. de, 1860b, De wetenschap der zamenleving. Müller, Amsterdam.

Bosch Kemper, J. de, 1863a, Handleiding tot de kennis van de wetenschap der zamenleving en wan het Nederlandsche statsregt, Müller; Amsterdam.

Bosch Kemper, J. de, 1863b, De Wetenschap der Zamenleving, Müller, Amsterdam.

Bosch Kemper, J. de, 1865, Handleiding tot de kennis waw het Nederlandsche Statsregt en Stantsbestuut, vermeerderde uitgave, Bijgewerkt tot op de wetgeving op 10 augustus 1865, Miiller, Amsterdam.

Bottenburg, M. van, 1990, Hoe recent is modern? Over de herkomst van 'modern', 'modiemiteit' en 'modernisering', en het gebruik ervan in de sociologie, Amsterdams Sociologisch Tijdschrift, 17 (1990), 101-118.

Bourdieu, P., 1989, La noblesse d'etat - grandes écoles et esprit d'etat, Les Bditions de minuit, Paris.

Brands, M.C., 1965, Historisme als ideologie. Het 'anti-normatieve' en 'onpolitieke' element in de Duitse geschiedwetenschap, Van Gorcum \& Comp. N.V.-Dr. H.J. Prakke \& H.M.G. Prakke, Assen.

Breuer, S. und H. Treiber (Hrsg.), 1984, Zur Rechtssoziologie Max Webers, Interpretation. Kritik, Weiterentwicklung, West Deutscher Verlag, Opladen.

Brief, 1845, Brief aan den schrijuer van het Iets over ons hooger anderwijs, H.W. Hazenberg \& 
Comp. Leiden.

Briefwisseling, $1819\left[1814 / 1815^{1}\right]$, Briefwissting van eenige Regtsgeleerden, over de annstamide Nederlandsche Wetgewing, H.W. Hazenberg Junior, Leiden.

Brill, W.C., 1864, Over de toekomst van de hoogeschool bij de uitbreiding oan het middelbar ondenwijs in deze dagen. Redevoering gehouden den 21 september 1864 ter opening zijner lessen, E.J. Brill, Leiden.

Brink, H. van den, 1973, Typen van rechtshistorie, In: Van Herwaarden (red.), 1973, pp. 33-46.

Brink, H. van den, 1976, Rechtsgeschiedenis bij wijze van inleiding, Kluwer, Deventer.

Brink, H. van den, M. Moorman van Kappen, H. van der Linden en L.E. van Holk (red.). 1977, Samenwinninge. Tien opstellen over rechtsgeschiedenis geschreven ter gelegenheid wan het tienjarig bestann van het interuniversitair Nederlands Centrum voor Rech tshistorische Docunentatie, Tjeenk Willink, Zwolle.

Broberg, G., 1990, The broken circle, In: Frängsmyr, Heilbron and Rider (eds.) 1990, pp. 45-71.

Broers, H. J. 1842, Over de uitoefening der verloskunde en het verloskundig onderwijs in ons vaderland, Bijdragen tat Geneeskundige Staatsregeting, 2 (1842), $23-39$.

Broman, Th., 1989, University reform in medical thought at the end of the eighteenth century, In: Olesko (ed.) Osiris second series vol. 5, (1989), 36-53.

Brookman, F.H., 1979, The making of a science policy. A historical study of the institutional and conceptual background to Dutch science policy in a West-European perspective, diss. Amsterdam, Academische Pers BV, Amsterdam.

Brouwer $_{r}$ A.M., 1912, De moderne richting, eene historisch-dogmatische studie, Ten Hoet, Nijmegen.

Brown, R. (ed.), 1973, Knowledge, education and cultural change. Papers in the sociology of education, Tavistock publications, Londion.

Brücke, E./Mulder G.J., 1880, Over de noodzakelijkheid van gymnasiale opleiding voor geneeskunstoefenaren. Rectorale redevoering gehouden 11 october 1879 [uit het Duitsch vertaald door M. van Westrienen], met eene voor-en narede van G.J. Mulder, H.A. Kramers \& Zoon, Rotterdam.

Brugmans, 1.J., 1960, Standen en klassen in Nederland gedurende de negentiende eeuw, In: Geurts en Messing (red.), 1977, pp. 110-128.

Bruin, A.A. de, 1985, Het ontstan van de schoolstrijd - Onderzoek naat de wortels van de schoolstrijd in de Noordelijke Nederlanden gedurende de eerste helft van de 19de eeuw; een cultuurhistorische studie, Ton Bolland, Barneveld.

Bruinsma, G.W., 1911, Toenemend aantal geneeskundigen in Nederland, Nedeplandsch Tijdschrift voor Genteskunde, 55 (1911) 1, 937-942

Bruinvis, C.W., 1915, De geneeskundige schoal te Alkmaar 1827-1865, N.V. Boek- en Handelsdrukkerij woorheen Herms. Coster \& Zoon, Alkmaar.

Buckley, W., 1968, Society as a complex adaptive system, In: Buckley (ed.), 1968, pp. 490-511.

Buckley, W. (ed.), 1968, Modern systems research for the behavioral scientists. A sourcebook, Aldine, Chicago.

Buddingh, D, 1842, Over Industrie- en Handel-akademiën, en verdere inrigtingen van onderwijs ter betordering van nijverheid en handel in Europa, naar anueiding wan het Koninklijk beshit wan 8 januarij 1842, No. 75, M.H. Schonekat, Amsterdam/B. Bruins, Delft.

Buhl, G., 1968, Der Wissenschaftsbegriff bei Bolzano, In: Diemer (Hrsg.), 1968a, pp. 63-70.

Bulhof, 1.N., 1988, Darwins Origin of Spectes: Betoverende wetenschap. Een onderzoek natar de relatie tussen literatuwr en vetenschap. Ambo, Baarn.

Burger, D. Jr., 1849, Iets over het hooger onderwijs, P.N. van Kampen, Amsterdam.

Burger, $H_{\text {, }}$ 1905, De Keel- Neus- Oorheelkunde als studievak voor den anstonanden arts. Intreerede uitgesproken bij de aanvaarding van het ambt van buitengewoon Hoogleeraar aan de Universiteit van Amsterdam den 2den October 1905, J.H. de Bussy, Amsterdam. 
Burger, H., 1910, Onderwijsbelangen, Nederlandsch Tyjdsduriff voor Geneeskunde, 54 (1910) I, $1-7 ; 77-85 ; 137-143 ; 201-207 ; 265-278$

Burger, H.C., 1923, Het onderwijs in de natuurkunde aan de studenten in de geneeskunde, Physica Nederlandsch Tijdschrift voor Natuwrkunde, 3 (1923), 1-10.

Butttner, J., 1990, Leitgedanken in der Geschichte der klinischen Chemie, Medizinhistoriscles Jourmal. Internationale Vierteljahresschrift für Wissenschaftsgeschichte, 25 (1990), 268-285.

C พ., 1841, Herinnering aan A.C.G. Suerman als arts en klinisch leeraar, Archief voor Geneeskunde, 1 (1841), 74-93.

Caesar Wolf, B., 1984, Der Deutsche Richter am 'Kreuzweg' zwischen Professionalisiertung und Deprofessionalisierung, In: Brewer und Treiber (Hrsg.), 1984, pp. 199-222.

Camijn, A.J.W., 1987, De industrialisatie van Nederland, 1814-1914, Veen, Utrecht/Antwerpen. Cannegieter, D., 1954, Honderdrijftig jaar gezondheidswet, Van Gorcum \& Comp N.V.-G.A. Hak Dr. H.J. Prakke, Assen.

Chapman, J.W. (ed.), 1983, The Western university on trial, University of California Press, Berkeley/Los Angeles/London.

Clark, B.R (ed.), 1984, Perspectives on higher education, eight disciplinary and conparative tietus, University of California Press, Berkeley, Los Angeles, London.

Cohen, L. All, 1852, Over doel en middelen van de Geneeskundige Journalistiek, ook hier te lande. Een woord ter inleiding voor den jaargang 1852, Nieuw practisch tijdschrift voor de geneeskunde in al haren omoung, 311 (1852), 1-9.

Cohen, L. Ali, 1862, Korte beoordeling van de voornaamste bedenkingen, die tot dus ver zijn in het midden gebragt tegen de op 20 junij j.l. door de regering bij de Tweede Kamer der Staten Generaal ingediende vier ontwerpen van wet betreffende de geneeskundige aangelegenheden, Nederlandsch Tijdschrift voor Geneeskunde, II 6 (1862), 675-693.

Cohen, M.J., 1979, Over inspanning en resultaat in het onderwijs, Ars Aequi, 28 (1979), 18-20.

Cohen, M.J., 1989, Vijf jaar probleemgestuurd juridisch onderwijs, In: Ervaringen, 1989, pp. 5-20.

Cohen, M.J: en H.F.M. Crombag, 1978, De nieuwe medische faculteit in Maastricht en de juridische opleiding, NJB, 13 mei 1978 afl. 19, 355-360.

Cohen, M.J. \& W.E. Elzinga, 1989, Vaardigheden in het juridisch onderwijs, In: Eroaringen, 1989, pp. 71-87.

Cohen, M.D., J.G. March and J.P. Olsen, 1972, A garbage can model of organizational choice, Adn. Sci. Q. 17 (1972), 1-25.

Cohen, M. \& J. March, 1976, Decisions, Presidents and Status, In: March and Olsen (eds.), 1976, pp. $174-205$.

Cohen Jehoram, H., 1968, Over Codificatie. Van voor Portalis tot na Meviers, Kluwer, Deventer. Coleman, J.S, 1971 [1968], Modernization. Political Aspects, In: International Encyclopeditu of the Social Sciences, vol. 10 (ed.) D.L. Sills, The Macmillan Company \& The Free Press, New York, Collier-Macmillan Publishers, London.

Coleman, W., 1988, Prussian Pedagogy: Purkyne at Breslau, 1823-1839, In: Colemann and Holmes (eds.), 1988, pp. 15-64.

Coleman, W. and F.L. Holmes, 1988, Introduction, In: Coleman and Holmes (eds.), 1988, PP. $1-14$.

Coleman, W. and F.L. Holmes (eds.), 1988, The Investigative Enterprise- Experimental Physiology in Nineteenth-Century Medicine, University of California Press, Berkeley/Los Angeles/London.

Collison, R., 1964, Encyclopaedias: their History throughout the Ages, Hafner Publishing Company, New York \& London.

Coninck Liefsting's, F.B., 1869, De algemeene beginselen van het bezitrecht en de Nederlandsche Bezilactiën, Steenhoff, Leiden. 
Cooth, C. van, 1842, Akademisch onderwijs en praktische vorming, Bijdragen tot Genteskundige Stautsregeling, 2 (1842), 53-89.

Comps, J.H.A.E. 1953, Een provinciale school woor apothekers in Maastricht. Tevens bijdrage tof de geschiedenis van de pharmacie in de Franse tijd, Sociaal Historisch Centrum voor Limburg Maastricht.

Coster, D. I., 1868, Modene Plantkunde, De Gids, (1868) III, 204-216.

Cousin, V., 1838, De l'Instruction publique en Hollande. Journal d'un voyage fait dans ce pays dans le mois de septembre 1836, Sociête Belge de librairie, etc. Hauman, Cattoir et Compie., Bruxelles.

Cranefield, P.F, 1957, The Organic Physics of 1847 and the Biophysiscs of Today, Journal of the History of Medicine and allied sciences, 12 (1957), 407-423.

Cremer, J.T., 1870, Openbare Brief awn Z. Ex. den Minister van Binnenlandse Zaken, opgenomen in Het Vaderland,'s Gravenhage.

Crombag, H.F.M., 1972, Preadvies voor de Nederlandse Juristen-Vereniging, Handelingen der Nederlandse Juristen-Vereniging (De juridische Opleiding), (1972) I, 13-65.

Crombag, H.F.M. J.L. de Wijkerslooth en MJ. Cohen, 1977, Een theorie over rechterlijke beslissingen, H.D. Tjeenk Willink, Groningen.

Cunningham A. \& N. Jardine (eds.), 1990, Romavticism and the sciences, Cambridge Uniwersity Press, Cambridge/New York/Port Chester/Melbourne/Sydney.

Cyert, R.M. and J.G. March, 1963, A behavioral theory of the firm, Prentice hall, Englewood Cliffs, New Jersey.

Czermak, J., 1851, Reisebilder aus Holland In Briefen an. Hrn. Prof. Purkyne, Vierteljahrschrift für die praktische Heilkunde, 8 (1851), 1-10.

Dahrendorf, $\mathbb{R}$, 1958, Zu einer Theorie des sozialen Konflikts, Hamburger Jahrbuch für Wirtschafts- und Gesellschaftspolitik, 3 (1958), 76-92.

Dasberg, L. en J.W.G. Jansing, 1977, Het socioculturele leven in Nederland 1844-1875, In: Algemene Geschiedenis van Nederland deel 12, pp. 210-232.

Dassen, 1845, Gedachten over Geneeskundig Onderwijs en Wetgeving, Bijdragen lot Geneeskundige Staatsregeling, 3 (1845), 1-21.

Daston, L.J., 1981, Mathematics and the moral sciences: the rise and fall of the probability of judgements, 1785-1840, In: Jahnke et al, 1981, pp. 287-309.

Daston, L.J., 1987, Rational individuals versus laws of society: From probability to statistics, In: Krüger, Daston and Heidelberger (eds.), 1987, pp. 295-304.

Davids, K., J. Lucassen en J. Luiten vam Zanden, 1988, De Nederiandse geschiedenis als affoijking van het algemeen ntenselijk patroon - Een anzet tot een programma van samenwerking, Internationaal Instituut voor Sociale Geschiedenis, Amsterdam.

De gezamenlijke Officieren van Gezondheid, leeraren aan 's Rijks Kweekschool woor Milltaire Geneeskundigen te Utrecht, 1851, De Kweekschool voor Militaire geneeskundigen. Betoog. strekkende ter beantwoording der voorstellen tot hare opheffing, welke van verschillende zijde zijn gedon, en ter aawwijzing der noodzakelijkheid wan hare instandhouding voor Nederland, J.G. van Terven \& Zoom, Utrecht.

De vier Faculteiten, 1859, Tijdschrift voor Stanthuishoudkunde en Statistiek, 18 (1859), 407427.

Deen, I. van, 1851, Over den omoang der physiologische wetenschap en de warneming als het eenige middel om haar te beofenen. Inwijdingsrede bij het aanvaarden van het hoogleeraarsambit aan de Groninger Hoogeschool. Uitgesproken den 12 november 1851.

Dekker, J.J., 1981, De betekenis van "Montaillou" voor historisch-pedagogische theorievorming: de inquisitie tussen opvoeding en onderzoek, In: Papousek (red.), 1981, pp. 73-84.

Dekker, IJ., 1987, Geschiedenis van opvoeding en onderwijs: bijdrauge tot onderzoek en 
bijdrage tot praktisch inzicht; Pedagogisch Tijdschrift, 12 (1987), 74-80.

Dekker, J.J. en L.F. Groenendijk, 1991, The Republic of God or the Republic of Children? Childhood and Child-rearing after the Reformation: an appraisal of Simon Schama"s thesis about the uniqueness of the Dutch case, Oxford Review of Education, (1991), in print:

Dekkers, O., 1986, Onder dokters handen. Drie euwen artsen in Bunschoten, Spakenburg, Eemdijk/Bunschoten.

Delprat, C.C, 1924, Het ontstaan der Nederlandsche Maatschappij ter Bevordering der Geneeskunst en haar rol bij de herziening der geneeskundige staatsregeling van 1818, Overgedrukt wit het Gedenkboek der Nederlandsche Maatschappij tot Bevordering der Geneeskanst witgegeven ter gelegenheid van haar vijfenzeventig jarig bestan.

Derde Rapport, 1911, Derde Rapport der blijvende commissie voor het praktische en het aanvullende geneeskundig onderwijs, benoemd door het hoofdbestuur der Nederlandsche Maatschappij tot Bevordering der Geneeskunst, ingevolge het besluit der algemeene vergadering van dinsdag 10 juli 1906, Nederlandsch Tijdschrift voor Geneeskunde, 55 (1911) I. 1364-1370.

Diederiks, H.A., 1974, Klassen en klassenbewustzijn, Mededelingenblad/Orgaan van de Nederlandse vereniging tot beoefening van van de sociale geschiedenis, 46 (1974), 109-118.

Diemer, A. (Hrsg.), 1968a, Beiträge zur Entwicklung der Wissenschaftstheorie im 19. Jahthundert. Vorträge und Diskussionen im Dezember 1965 und 1966 in Düsseldorf, Anton Hain, Meisenheim am Glan.

Diemer, A. 1968b, Die Begründung des Wissenschaftscharakters der Wissenschaft im 19. Jahurhundert - Die Wissenschaftstheorie $z$ wischen klassischer und moderner Wissenschaftskonzeption, In: Diewer (Hrsg.), 1968a, pp. 3-62.

Diemer, A. (Hrsg.), 1978, Konzeption und Begriff der Forschung in den Wissenschaften des 19. Jahwhunderts. Referate und Diskussionen des 10. wissenschaftstheoretischen Kolloquiums 1975, Anton Hain, Meisenheim am Glan.

Diephuis, G. 1844-1855 [1885²], Het Nederlandsch Burgerlijk Regt, Wolters, Groningen.

Diephuis, G., 1862, Redevoering over de wetenschap des regts in betrekking tot de wetgeving 22 september 1859, In: Annales Academici 1858/1859, Leyden.

Dirckx. J.H., 19832. The language of medicine. Its evolution, structure, and dynamics, Praeger Publishers, New York.

Doctor L., [ps، van A.F.H. de Lespinasse], 1842, Humor en ernst in gedachten en opmerkingen nopens de rapporten over de geneeskundige statsregeling in 1841-1842, M. Ballot, Deventer.

Dodde, N.L., 1983, Het Nederlandse ondenoijs verandert. Ontwikkelingen sinds 1800, Coutinho, Muiderberg.

Doesschate, G. ten, 1961, J.L.C. Schroeder van der Kolk als physioloog, Het Utrechts universiteitsmuseum Trans 8, Utrecht.

Doesschate, $G$. ten, 1963, De Utrechtsche Uniwersiteit en de geneeskunde 1636-1900, B. de Graal, Nieuwkoop.

Donders, F.C., 1848, De harmonie van het dierlike leven. De openbaring van wetten. Inwijdingsrede, bij het aanvaarden van het hoogleraarsambt aan de Utrechtsche hoogeschool, Uitgesproken 28 januarij 1848 , C. van der" Post, Utrecht.

Donders, F.C., 1865, Mijn open brief aan de leden van de Tweede Kamer der Staten-Genernal betrekkelijk de wetsontwerpen, regelende het geneeskundig staats-toezigt, enz. legen de anunallers verdedigd, W.F. Dannenfelser, Utrecht.

Donders, F.C., 1867a, De kweekschool voor militaire geneeskundigen, in verband beschouwd met de Stantsbegrooting voor het dienstjaar 1867 en met de regeling van het hooger onderwijs, W.F. Dannenfelser, Utrecht.

Donders, F.C., 1867b, Nog eens: de kweekschool voor militaire geneeskundigen. Antwoord op somwrige bedenkingen, W.F. Dannenfelser, Utrecht. 
Donders, F, C, 1872 , Levensschets van Gustaaf Eduard Voorhelm Schneevogt, Jaarboek der Koninklijke Akademie van Wetenschappen, Amsterdam (1872), 50-99.

Donders, F.C., 1875, Over de regeling vast het medisch ondenwijs in verband met die van het hooger onderwij in het algemeen. Openingstede op de zes en twintigste algemeene vergadering der Nederlandsche Maatschappij tot Bevordering der Geneeskunst, den 23sten Juni 1875, uitgesproken, W.F. Dannenfelser, Utrecht.

Doorgaan, 1986, Doorgaan maar beter. Nota mar annleiding van vier jaat enoaringen met het Maastrichtse juridisch onderiois, interne uitgave $\mathbb{R L}$, Maastricht.

Doorman, M., 1989a, Steeds mooier. Over vooruitgang in de kunst, De Gids, 152 (1989), 99. 106.

Doorman, M, 1989b, Het vooruitgangsbegrip. Onuitgegeven document, Rijksuniversiteit Limburg, Maastricht.

Doyle, P. \& J.E. Lynch, 1979, A strategic model for university planning Journal of Operational Research, 30 (1979), 603-609.

Draaisina, D., 1990, Het verborgen radenwerk. Over tijd, machines en bewustzijn, Ambo, Baarn.

Dresselhuys, G., 1876, De Regeling van het medisch anderwijs ten opzichte van eenige punten in de rede van prof. Donders, gehouden Juni 1875, praktisch toegelicht, met bijschrift, W. Thieme \& Cle, Zutphen.

Driessen, P.; 1820, De nieuwe hulpmiddelen, ter beoefening der natuurkundige wetenschappen, bi deze hoogeschool daargesteld, ten algemeenen nutte der ingezetenen aan te wenden, openlijk te Groningen gehouden, den 8 october 1818 toen hij het bestuur der Hoogeschool nederleide, uit het Latijn vertaald en met eenige bijgevoegde aantekeningen uitgegeven door Johannes Ernestus Winter, Predikant te Zuidhorn etic., J. Oomkens Akademiedrukker, Groningen.

Drucker, H.L., 1882a, Rechtswetenschap en Wetgeving. Rede bij de aanvaarding van het hoogleeraarsambt aan de Rijksuniversiteit te Groningen op den 28sten september 1882, De Erven F. Bohn, Haarlem.

Drucker, H.L., 1882b, Boekbeschouwing van o.a. J.P. Moltzer, Door het recht tot den regel, Rechtsgeleerd Magazijn, 1 (1882), 209-220.

Drucker, H.L., 1889, Begrip en Dogma in de rechtswetenschap. Rede bij de aanvaarding van het hoogleeraarsambt aan de Rijksuniversiteit te Leiden op den 28 sten october 1889 uitgesprom ken, De Erwen F. Bohn, Haarlem.

Dube, C.S. If \& A.W. Brown, 1983, Strategic assessment - A rational response to university cutbacks, Long Range Planming, 16 (1983) no. 2, 105-113.

Dux, G., 1989, Die Zeit in der Geschichte, Suhrkamp, Frankfurt am Main.

Duyvendijk, A.J., 1955, De motivering van de klassieke vorming. Een historisch-paedagogische studie over rwee eeuwen, Wolters, Groningen.

Duyverman, J.P., 1987, Rondom 'Staathuishoudkunde', In: Knoester (red.), 1987, pp. 25-37.

Eeghen, I.H. van, 1974 [1965"], De gilden. Theorie en Praktijk, De Haan, Bussum.

Een eeutw middelbatr onderwijswet herdacht, 1963, Wolters, Groningen.

Egmond, F., 1989, Fragmentatie, rechtsverscheidenheid en rechtsongelijkheid in de Noordelijke Nederlanden tijdens de zeventiende en achttiende eeuw, In: Faber (red.), 1989, pp. 9. 23.

Eisenstadt, S.N., 1964, Social Change, differentiation and evolution, Anerican Sociological Review, 29 (1964), 375-386.

Eisenstadt, S.N., 1974, Studies of Modernization and Sociological Theory, History and Theory, $13(1974), 225-252$

Ekker, A.H.A., 1854, Brief over Latijnsche scholen en Gymnasiën, K. van Hulst, Kampen.

Ellwein, T., 1985, Die deutsche Universität. Vom Mittelalter bis zur Gegenwart, Athenäum, Königstein/Ts.

Elshout, A.M., 1952, Het Leidse kabinet der anatomie uit de achttiende eeuw. De betekenis van e.en 
wetenschappelijke collectie als cultumhistorisch momument, diss. Leiden, Universitaire Pers Leiden, Leiden.

Elster, J, 1989, Nuts and Bolts for the Social Sciences, Cambridge University Press, Cambridge/New York/Melbourne/Sydney.

Ende, A. van den, 1846, Geschiedkundige Söhets oan Nêerlands schoolwetgeving met canteekewïngen en bijlagen, J. de Lange, Deventer.

Engelhardt, H.T. jr. and S.F. Spicker, 1975, Evalwation and Explanation in the biomedical sciences, proceedings of the first trans-disciplinary symposium on philosophy and medicine held at Galveston, may 9-11, 1974, Reidel, Dordrecht-Holland/Bositon-U.S.A.

Engelhardt, D. von, 1978, Die Konzeption der Forschung in der Medizin des 19. Jahrhundert, In: Diemer (Hirs.), 1978, pp. 58-103.

Ervaringen, 1989, Eroaringen met probleengestuurd onderwijs. Opstellen tew bethowe van de conferentie van 15 januari 1988, 1e lustrum van de Faculteit der Rechtsgeleerdheid, Rijksuniversiteit Limburg, Kluwer, Deventer.

Evers, J,C.G., 1848, De verbetering van ons geneeskundig onderwijs, De Gids, (1848) II, 615632.

Evers, J.C.G., 1864, De waarde der ervaring aan het ziekbed voor de beofening der geneeskunde, Redevoering ter aanvaarding vam het hoogleeraarsambt aan de hoogeschool te Leiden den 23sten September uitgesproken, Gebroeders Van der Hoek, Leiden.

Evers, I., 1876, Het hooger onderwijs en de aanstaande medici. Overgedrukt uit Het Vaderland van $7,8,9$ en 11 februari 1876 , s.l.

Eyk, H.H. van, 1920a, De wetenschappelijke oplleiding van sociaal-geneeskundigen, Nederlandsch Tijdschrift voor Geneeskunde, 64 (1920) IIB, $2507-2511$.

Eyk, H.H. wan, 1920b, Sociale Geneeskunde als onderwijswak, Nederlandsch Tijdschrift voor Geneeskunde, 64 (1920) IIB, 2053-2056.

Eyssell, A.P.Th., 1897, De procureurswet, de lex Hartogh en de toekomst der Balie, Themis, $58(1897), 133-168$.

Eyssell, A.P.Th., 1899, Praeadvies voor NJV, Handelingen der Nederlandsche Juristen Vereeniging, (1899) 1, 153-183.

Faber, Sj. (red.), 1989, Nieutw licht op oude justitie. Misdand en straf ten tijde van de Republiek, Coutinho, Muiderberg.

Feenstra, R., 1953, Interpretatio multiplex. Een beschouwing over de zgn. Crisis van het Romeinse recht. Rede uitgesproken bij de aanvaarding van het ambt van hoogleraar aan de Rijksuniversiteit te Leiden op vrijdag 20 maart 1953, Tjeenk-Willink, Zwolle.

Feenstra, R., 1974, Romeins recht en Europese rechtswetenschap, In: Spryit (red.), 1974, pp. $101-137$.

Feenstra, $R, 1984$, De beoefening van de rechtsgeschiedenis aan de Leidse Universiteit van rond 1875 tot rond 1925, In: Otterspeer (red.), 1984, pp. 55-75.

Feith, P.R. 1868, Rechtsgeleerdheid, Letterkundig Overzigt, De Gids, (1868) III, 143-158.

Fischer, H.W.F.D., 1946, Oude en niewwe opuattingen omtrent de studie van het oudvaderlandsche recht. Rede uitgesproken bij de aanvaarding van het ambt van hoogleeraar aan de Rijksuniversiteit te Leiden op vrijdag 28 juni 1946, Universitaire Pers Leiden, Leiden.

Flexner, A., 1912, Medical Eduation in Europe. A Report to the Carnegie Foundation for the advancement of teaching, with an introduction by H.S. Pritchett, Bulletin number six, New York cily.

Flexner, A., 1925, Medical Education. A comparative study, The Macmillan Company, New York.

Fliedner, T, 1831, Collektenreise nach Holland und England, nebst einer ausfuhtichen Darstelluwg des Kirchen-, Schul-, Armen- und Gefangmiswesens beider Länder mit vergleichender Hinweisurg auf Dewtschland, vorzighlich Preussen, G.D. Bädeker, Essen. 
Floud J. and A. H. Halsey, 1958, The Sociology of Education. A Trend Report and Biblio graphy, Current Sociology/La Sociologie Contemporaine, 7 (1958), 165-235.

Fockema Andreae, I.P., 1938, De methode wan interpretatie van het B.W. van 1838 tot heden, In: Scholten en Meijers (red,), 1938, pp. 65-96

Fockema Andreae, S.J., 1877, Gronden voor de beoefening der Germaansche rechtsgeschiedenis. Rede bij de aanvaarding wan het hoogleeraarsambt aan de Rijks-universiteit te Leiden, den 28sten november 1877 uitgesproken, S.C. van Daesburgh, Leiden.

Fockema Andreae, S.J, 1894, Het rechtsgeleerd bedrijf in Nederland. Rede uitgesproken bij de viering van den 319 den verjaardag der Leidsche Hoogeschool door den Rector Magnificus, Eu. Brill, Leiden.

Fockema Andreae, S.J., 1914, De opleiding onzer juristen, Rechtsgeleerd Magazijn, 33 (1914), $1-24$.

Fockema Andreae S. J. e.a., z.j. (Opdracht 1915), Rapport betreffende de universitaire opleiding der jwristen, uitgebracht aan het provincial Utrechtsch genoorschap van kunsten en wetenschappen.

Fockema Andreae, S.J., 1957, Een mensenlewen in Nederland. Driekwart eeuw ontwikkeling von operbaar bestuur, onderwijs en onderneming, N. Samsom N.V., Alphen aan de Rijn.

Foppen, J.W., 1989, Gistend beleid. Veertig jaar universitaire onderwijspolitiek, VUGA, "s-Gravenhage.

Fortgens, H.W., 1958, Schola Latina. Uit het verleden van ons voorbereidend hoger onderwijs, W.E.J. Tjeenk Willink, Zwolle.

Foucault, M. 1974 [1966], Die Ordnung der Dinge, Suhrkamp Verlag. Frankfurt am Main, vertaling wan Les mots et les choses: une archéologie des sciences humaines, Gallimard, Paris.

Foucault, M., 1986 [1963'], De Geboarte van de Kliniek (een archeologie van de medische blik), SUN, Nijmegen, vertaling van La naissance de la clinique: une archéologie du regard médical, Paris.

Fournier, M. 1983, Hoofdlijnen van de microscopie in de negentiende eeuw, Tsch.Gesdi,* Gnk.Natuwn.Wisk.Techn, 6 (1983), 59-107.

Frängsmyr, T., J.L. Heilbron and R.E. Rider (eds.), 1990, The quantifying spirit in the 18th century, University of California Press, Berkeley, Los Angeles, Oxford.

Freidson, E., 1970, Frofession of medicine, a study in the sociology of applied knowledge, Harper \& Row, New York.

Freidson, E., 1986, Professional powsers. A study of the institutionalization of formal knowledge, University of Chicago Presis, Chicago and London.

[Frets, Fr.], 1819, Een der Advijsen over de beide ingekomen verhandelingen, In: Tydemam, 1819, pp. 100 e.w.

Frets, 1829, Over het verval van de juridicièele praktijk, Bijdragen tot de Regtsgeleerdheid en de Wetgewing, 4 (1829), 210 e.v.

Frijhoff, W.Th.M., 1981, La société Néerlandaise et ses gradués, une recherche sérielle sur le statut des intellectuels à partir des registres universitaires, 1575-1814, Holland University Press B.V. Ansterdam en Maarssen.

Frijhoff, W.Th.M., $1983 \mathrm{a}$, Non satis dignitatis, Over de maatschappelijke status van geneeskundigen tüdens de Republiek, Tijdschrift voor Geschiedenis, 96 (1983), 379-406.

Frijhoff, W. Th.M., 1983b, Van onderwijs naar opvoedend onderwijs. Ontwikkelingslijnen van opvoeding en onderwijs in Noord-Nederland in de achttiende eeuw, In: Werkgroep Achttiende Eeuw, Onderwijs en Opvoeding in de achttiende eeuw, 1983, pp. 3-41.

Frijhoff, W.Th.M., 1986, Hoger onderwijs als inzet van stedelijke naijver in de vroegmoderne tijd, In: Blaas en Van Herwaarden (red.), 1986, pp. 82-128.

Frijhoff, W.Th.M., 1987a, Keuzepatronen van de universiteit in historisch perspectief, EURotterdam, Rotterdam. 
Frïhaff, W.Th.M., 1987b, Opleiding en wetenschappelijke belangstelling van het Nederlandse regentenpatriciaat tijdens de Republiek: Uitgangspunten, kenmerken, ontwikkelingen, Bulletin Werkgroep Elites, no. 8, december 1987, 6-20.

Gastelaars, M. 1988, Het verschijnsel professionalisering en de sociologische literatuur, Tijdschrift voor Agologie (TvA), 17 (1988), 17-28.

Gedenkboek, 1932, Gedenkboek van het Athenneum en de Umiversiteit van Amsteriam 1632-1932, Stadsdrukkerij, Amsterdam.

Gedenkboek, 1934, Gedenkboek Maatschappij tot Nut onn 't Algemeen, Amsterdam Centraal Station Kamer 57/59, Amsterdam.

Gedenkboek, 1949, Gedenkboek der Koninklijke Nederiandsche Maatschappij tot bevordering der Geneeskunst. Ter gelegenheid van haar honderd-jarig bestan 7-8-9 jwi 1949, 1848-1949, J. H. de Bussy, Amsterdam.

Geer, B.J.L. de, 1869, De regeling van het hooger onderwijs in Nederland in 1814, Niewwe Bijdragen tot Regtsgeleerdheid en Wetenschap, 19 (1869), 212-272.

Geer, P. van, 1887a, Ons hooger onderwijs (eerste artikel), Vragen des Tijds, (1887) 1, 315-346.

Geer, P. van, $1887 \mathrm{~b}$, Ons hooger onderwijs II. De Universiteit, Vrogen des Tijds (1887) II, 96 130.

Geer, P. van, 1887c, Ons hooger" onderwijs III. Vier Universiteiten, Vragen des Tijds, (1887) $\mathbb{I}_{x}$ 2011-234.

Geerling, J, G.A. Lindeboom, A. Querido, J. Roos en L. Schalm (red.), 1981, Nederlandsche Internisten Vereniging 1931-1981, Bohn, Scheltema \& Holkema, Utrecht.

Gelder, J.J. de, 1841, De vormende strekking van het classieke en wiskundige ondenwijs, H.W. Hazenberg \& Comp., Leyden.

Gelfand, T., 1980, Professionalising modern medicine. Paris surgeons and medical science and institutions in the 18th century, Greenwood Press, Westport, Connecticut/London, England.

Gemert, G.A. van, J. Schuller tot Peursum-Meijer en A.]. Vanderjagt (red.), 1989, 'Om niet aan onwetendheid en barbarij te bezwijken" Groningse geleerden 1614-1889, Verloren, Hilversum.

Geneeskundige Statsicommissie, 1850, Advies omtrent het onderwijs in de geneeskunst en in de artsenijbereidkunst, 's Gravenhage.

Geschriften, 1842, Geschriften over geneeskundige wetgeving, Boekbeoordeling van Ontwerp van verbetering der geneeskundige wetgeving', Leyden, H.W. Hazenberg en Co. en G. Salomon, Gedachten en wenken, rakende de geneeskundige wetten en het geneeskundig onderwijs in het koningrijk der Nederlanden. Archief voor Geneeskunde, 2 (1842), 107-115.

Geuns, J. van, $1842 \mathrm{a}$, Het tegenwoordige standpunt der geneeskundige wetenschap, in betrekking tot het onderwijs, Bijdragen tot Geneeskundige Staatsregeling. 1 (1842), 134:155; 203-225.

Geuns, J. van, 1842b, Boekbespreking van "Wenschen en Wenken voor de Geneeskundige Wetgeving in ons Vaderland, $S_{,} E$, van Nooten, Schoonhoven, 1842 , Bijdragen tot Genteskurdige Stantsregeling, 2 (1842), 107-122.

Geuns, J. van, $1842 \mathrm{c}$, Boekbespreking van 'Stukken, betreffende de herziening der geneeskundige wetten en verordeningen in 1841-1842, 's Gravenhage, 1842, Bijdragen tot Geneeskundige Staatsregeling, 2 (1842), 146-192.

Geuns, ]. van, $1842 \mathrm{~d}$, Blik op onze tegenwoordige staatsregeling, Bijdragen tot Geneeskundige Stantsregeling, 1 (1842), 1-15; 57-73.

Geuns, J. van, 1845, Bibliographie, Bijdragen tot Geneeskundige Staatsregeling, 3 (1845), $247-431$.

Geuns, J. van, 1847, De geneeskundle als eene zelfstandige natuurwetenschap. Inwijdingsrede bij de aanvaarding van de betrekking van buitengewoon hoogleraar in de geregtelijke geneeskunde en de algemeene ziektekunde aan de doorluchtige Amsterdamsche School, gehouden den 28sten january 1847, Stadsdrukkerij, Amsterdam.

Geuns, J. van, 1849, Voorwoord, In: Hoefle 1849. 
Geuns $_{i}$ ]. van, 1850 , Over het begrip ziekte als eenheid, Tijdschrift voor de wiso en naturkkundge wetenschappen uitgegeven door de eerste klasse van het Koninklijk Nederlandsche Institumt wan wetenschappen, letterkinde en schoone kunsten, (1850) derde deel, 77-98; 181-202.

Geurts, P.A.M. en F.A.M. Messing, 1977, Economische ontwikkeling en socinle emancipatie. 18 opstellen over economische en sociale geschiedenis, 2 delen, Martinus Nijhoff, Den Haag.

Geyer, R.F. \& J van der Zouwen (edis.), 1978, Sociocybemetics. An actororiented social systemis approach vol 1 and 2, Martinus Nijhoff, Leiden/Boston/London.

Geyer, R.F. \& J. van der Zouwen (eds.), 1986, Saciocybernetic Paradoxes. Observation, controt and evolution of self-steering systems, Sage, London.

Giele; J. en G.] wan Oenen, 1974, De sociale structuur van de Nederlandse samenleving rond 1850, Mededelingenblad/Orgaan van de Nederlandse Vereniging tot beofening van de sociale geschiedenis, 45 (1974), 2-32.

Giele, I. en G.J. van Oenen, 1975, Wel diskussie, geen vooruitgang. Een antwoord op 'Klassen en klassenbewustzijn' van Herman A. Diederiks, Tijdschrift voor Sociale Geschiedenis, 1 (1975), 147-150.

Giele, JJ. en G.J. van Oenen, 1976, Theorie en Praktijk van het onderzoek naar de sociale structuur, Tijdschrift voor Saciale Geschiedenis, 2 (1976), 167-186.

Giesen, B., preprint, Code und Situation, vers. 2.

Glastra van Loon, J.F., 1956, Norm en handeling: bijdrage tot een kentheoretische fundering der sociale wetenschappen, diss. Leiden, 1957, De erven F. Bohn, Haarlem.

Gobée, C., 1844a, Voorrede, Kliniek. Tijdschrift woor wetenschappelijke geneeskunde, $\mathbb{1}(1.844), \mathrm{V}$. XII.

Gobée, $C$, 1844b, Over het verband der scheikunde met de practische geneeskunde, Kliniek. Tijdschrift voor wetenschoppelijke geneeskunde, 1 (1844), 73-131; 169-181.

Gobée, $C ., 1849$, Blik op het tegenwoordig stand punt der geneeskunde, Kliniek. Tijdschrift voor wetenschappelijke geneeskunde, 4. (1849), 1-71; 323-370.

Goei, L. de (red.), 1989, Ontregeld zenuwleven. Historische opvattingen over de relatie tussen vrouwen en waanzin, Nederlands Centrum Geestelijke Volksgezondheid, Utrecht.

Goudsmit, I., 1978, Anderhalve eeuw dokteren aan de arts. Geschiedenis van de medische opleiding in Nederland, SUA, Amsterdam.

Gouldner, A.W., 1956, Some observations on Systematic Theory, 1945-55. Sociology in the United States of America, Unesco, Paris.

Gouldner, A.W., 1959, Organizational analysis, In: Merton, Broom and Cottrell Jr. (eds.), 1959, pp. 400.428.

Graaff, H. de, 1988, What's up professional? Een overzicht van recente Engelstalige literatuur over professionalisering, Tijdschrift voor Agologie (ToA), 17 (1988), 100-117.

Gratama, S., 1809a, Wat is Akademische Regtsstudie, en hoe hoort die bij ons, na de Afschaffing des Romeinschen Regts, als Regt, te worden ingerigt, Regtsgeleerd Magaziju, (1809), 171-207.

Gratama, S., $1809 \mathrm{~b}$ "Berigt omtrent een paar magtspreuken van zekeren Recensent, die tot verantwoording geroepen wordt, Regtsgeleerd Magazin, (1809), 114-130.

Gratama, S., 1809c, Nog iets over het Romeinsche Regt, Regtsgeleerd Magazijn, (1809), 461-476.

Gratama, S., 1900, Het onderwijs in het oud-vaderlandsche recht en zijne geschiedenis onder de wet tot regeling van het hooger onderwijs van 28 april 1876 (Staatsblad no. 102), Regtsgeleerd Magazijn, 19 (1900), 97-123.

Greve, F. de, 1841, Boekbeoordeling van 'F.C. von Savigny 'System des heutigen Römischen Rechts', Band I-III, Berlin, 1840', Nederlandsche Jaarboekew voor Regtsgeleerdheid en Wetgeving. 3 (184.1), 564-599.

Groen, M., 1985a, Het wetenschappelijk onderwijs in Nederland van 1815-1980. Een onder- 
wijskundig overzicht, Deel 4: Rechtsgeleerdheid, EUT" Report 85-WM-004, Eindhoven.

Groen, M. 1985b, Het Wetenschappelijk onderwijs in Nederland van 1815-1980, Een onderwijskundig overzicht, Deel 5 Geneeskunde, Technische Hogeschool Eindhoven, EUT report 85-WM-005, Eindhoven.

Groen, M., 1985c, Het wetenschappelijk onderwijs in Nederland van 1815-1980. Een onderwijskundig overzicht, Deel 6: Maatschappelijke bevoegdheid; de wetgeving. EUT Repont 85WM-006, Eindhoven.

Groenhuysen, M.S 1988 , Rechtswetenschapen geschiedenis, Tijdschrift woor Geschiedenis, 101 (1988), 557-574.

Groot, A.D. de, 1972, Selectie woor en in het hoger ondenwijs. Een probleentanalyse, Staatsuitgeve. rij, "s Gravenhage.

Groot, D. de, 1898, Het lager onderwijs, In: Ritter (red.), 1898, pp. 119-138.

Groshans G.Ph.F. 1853, Historisch verslag over de geneeskundige school te Rotterdam, uitgebragt in eene openbare redevoering bij de plegtige wiering van haar vijfentwintig jarig bestaan, uitgesproken in de Waalsche kerk den 8sten september 1853, M. Wijt \& Zonen, Rotterdam.

Grosheide, D., A.D.A. Mouna en P.N.G. Pesch, 1986, Vier eetwen unizersiteitsbibliotheek, Utrecht deel I De eerste drie eewwen, Utrecht.

Groustra, F.N., 1985, Haemodynamica en ademhaling, In: De Moulin (red.), 1985, pp. 33-44.

Groustra, F.N., 1988, Het preklinisch onderwijs in zijn natuurwetenschappelijke aspecten, In: De Moulin (red.), 1988, pp. 49-65.

Grundman, H., 1964², Vom Lrsprung der Universität im Mittelalter, Wissenschaftliche Buchgesellschaft, Darmstadt.

Guye A.A.G, 1886, De beteekenis der oorheelkunde in de geneeskundige wetenschap. Rede uitgesproken bij de aanwaarding van het buitengewoon hoogleeraarsambt aan de Universiteit van Amsterdam op den 4den october 1886, De Roever Kröber-Bakels, Amsterdam.

$\mathrm{H}_{i}, 1842 \mathrm{a}$, Over de gebreken der Duitsche geneeskunde, en over de noodzakelijkheid eener bepaalde wetenschappelijke rigting daarin, boekbespreking van Roser und Wünderlich, Archif für physiologische Heilkunde, Jahrgang 1. Heft 1, Archief voor Geneeskunde, 2 (1842), 116-118.

H., 1842b, Bibliographie, Bijdragen tot Geneeskumdige Staatsregeling, 1 (1842), 44-56.

Hacking, I, 1984 [paperback] [1975'], The Emergence of Probability. A philosophical study of early ideas about probability and statistical inference, Cambridge University Press, Cambridge London etc.

Hacking, I., 1987, Was there a probabilistic Revolution 1800-1930, In: Krüger, Daston and Heidelberger (eds.), 1987, pp. 45-55.

Halerkamp $H$. \& M. Schmid (Hrsg.), 1987a, Sinn, Kommunikation und soziale Differenzierung. Beiträge zu Luhmanns Theorie sozialer Systeme, Suhrkamp, Frankfurt am Main.

Halerkamp, H \& M. Schmid, 1987b, Einleitung, In: Haferkamp \& Schmid (Hrsg.), 1987a, pp. $7-21$.

Hall, J. van, 1824, Oratio de meritis Belgarum in excolendo historico jutis Romani studio habita a.d. xii Aprilis Anwi 1824 quam in illustri Athenaeo Anstelaeda mensium, juris civilis, cum Rontani, cum hodierni professionemauspicaretur, Amstelaedami ex typographica civitatis publica 1824.

Hall, J. van, 1826, Academische literatuur, Bijdragen tot Rechtsgeleerdheid en Wetgeving, 1 (1826).

Hall, J. van, 1851, Handleiding tot de beoffening wan het burgerlijk regt in Nederland, Johannes Müller, Amsterdam.

Hamaker, H.J. 1884, Dogmatische en empirische rechtsbeschouwing. Redevoering, uitgesproken op den jaardag der Universiteit, den 26sten Maart 1884, In: Molengraaff en Star Busman (red.), 1913, pp. 1-18.

Hamaker, H.J., 1888, Het recht en de maatschappij, Martinus Nijhoff 's Gravenhage, In: 
Molengraaff en Star Busman (red), 1913, Pp. 19-133.

Hamel, G.A. van, 1870, De Duitsche Juristendag, De Gids, (1870) I, 209-253; 466-485.

Hamers-wan Duynen, S.W., 1978, Hieronymus Dowid Gaubius (1705-1780) zijn corresponden met António Nunes Ribeiro Sanches en andere tijdgentoten, diss. Amsterdam, Van Gorcu Assen/Amsterdam.

Hammerstein, N. 1972, Jus und Historie - Ein Beitrag zur Geschichte des historischen Denkens, Deutschen Universitaten im späten 17, und in 18. Jahrhundert, Vandenhoeck \&upred Göttirigen.

Handelingen, 1914, Handelingen van de 65ste Algemeene Vergadering van de Nedterlam sche Maatschappij tot Bevordering der Geneeskunst, Nederlandsch Tijdschrift woor Genes kunde, 58 (1914) IIB, 1197-1404.

Haneveld, G.T., 1978, Bijdrage tot de geschiedenis der pathologische amatomie. Utrecht in de eer. helft van de negentiende eeuw, Ronald Meesters, Amsterdam.

Haneveld, G.T., 1985, Veranderingen in de pathologie 1840-1870, In: De Moulin (red.), 198 pp. 71-81.

Haneveld, G.T., 1988, Het dagelijks leven der Studenten. Het klinisch onderwijs, In: 1 Moulin (red.), 1988, pp. 67-80.

Hardy, C., A. Langley, H. Mintzberg \& J. Rose, 1984, Strategy formation in the universi setting, In: Bess (ed.), 1984, pp. 169-210.

Haren Noman, D. wan, 1886, Het ziektebegrip in de leet de Huidziekten. Rede uitgesproken de aanvaarding van het buitengewoon hoogleeraarsambt aan de Universiteit van Amste dam op den 4 den februari, Utrechtsche Drukkerij, Utrecht.

Harney, K., D. Jütting und B. Koring (Hrsg.), 1987, Professionalisierung der Enwachsenen B: dung. Fallstudien, Materialen, Forschungsstrategien, Lang, Frankfurt am Main/Bern.

Harting. $P_{n}, 1844$, Over de belangrijkheid van mikroskopische onderzoekingen voor de geneeskana Uitgesproken bij gelegenheid der opening van eenen cursus over mikroskopische histol gie, Van Paddenburg \& Comp., Utrecht.

Harting, P., 1848, De Heer Jac Moleschott privaat Docent te Heidelberg in zijne verhouding tege over de Geneeskundige Faculteiten in Nederland, Van Paddenburg \& Comp., Utrecht.

Harting, P., 1858, Gedachten over het Hooger Onderwijs in ons Vaderland, H.C.A. Campagn Tiel.

Hasenberg Butter, 1, 1969, Academic Economics in Holland 1800-1870, Martinus Niphoff, TH Hague.

Have, H. ten, 1986, Gezondheidszorg en samenleving, over de idee van geneeskunde sociale wetenschap, Scripta medico-philosophica, 1 (1986) no. 1, 10-28.

Heederik, G.J., 1973, Van kasboekregister tot burgerlijke stand. Medisch-denografische aspecten w de registratie van fivwelijken, geboorte en sterfte, Boom, Meppel.

Hegeman, J.G., 1981, Darwin en onze voorouders. Nederlandse reacties op de evolutiele van 1860-1875. Een terreinverkenning, In: Snelders en Van Berkel (red.), 1981, pp. 212-24.

Heidelberger, M, 1981, Some patterns of change in the Baconian Sciences of the early 191 century Germany, In: Jahnke \& Otte (eds.), 1981, pp. 3-18.

Heilbron, D., 1797. Adres en vertoog ter verbetering van het genees-en heelkundige in ons Geme nebest, den 27 April 1796 aan de Nationale Vergadering overgegeven en thans met eenif bijvoegsels vermeerderd, I. van Cleef, Den Haag.

Heim, H.J. van der, 1862 , Eerte aanteekening op het ontwerp van wet tot regeling wan het midde baar ondenwijs, W.P. van Stockum, 's Gravenhage.

Hellinga, $G, 1928$, De voormalige Amsterdamsche clinische school en het Binnengasthu 1828-1 september-1867, Nederlandsch Tijdschrift voor Geneeskunde, 72 (1928), 4220-4269.

Hellinga, G., 1930, Geschiedenis van het St. Pieters- of Binnengasthuis, Stadsdrukkerij, Amste dam. 
Hellinga, G. en J. Groen, 1953, Bijdrage tot de geschiedenis van het Onderwijs in de Algemene Ziektekunde en van de Stichting van het laboratorium voor Algemene Pathologie aan de Universiteit van Amsiterdam, Geneeskundige Bladen uit kliniek en laboratoriuw woor de praktijk; 45 (1953), 64-106.

Henle, F.G.J., 1840a, Pathologische Untersuchungen, August Hirschwald, Berlin.

Henle, F.G.J., 1840b, Ueber Verlauf und Periodicität der Krankheit, In: Henle, 1840a, pp. 166 205.

Herberger, M., 1981, Dogmatik. Zur Geschichte von Begriff und Methode in Medizin and Jurisprudenz, Vittorio Klosterman, Frankfurt am Main.

Herder, J.G., 1955 [1799], Metakritik zur Kritik der Reinem Vernunft, Berlin (Ost).

Herderscheê, J., 1904, De Modern-godsdienstige richting in Nederland, Van Holkema \& Warendorf, Amsterdam.

Hermesdorf, B.H.D, 1951, Licht en schaduw in de advocatuut der lage landen. Historische studie, Brill, Leiden.

Herwaarden, J. wan (red.), 1973, Lof der historie, Opstellen over geschiedenis en maatschappij, Universitaire Pers Rotterdam, Rotterdam.

Heusde, Ph.W. van, 1829, Brieven over den aard en de strekking wan hooger onderwijs, J. Altheer, Utrecht.

Heye, J.P., 1841, Naschrift van de redactie, Archief voor Geneeskinde, 1 (1841), 37-39.

Heye, J.P., 1842, Over geneeskundige staatsregeling, Archief voor Geneeskunde, 2 (1842), 445492.

Heye, J.P., 1843, Over geneeskundige staatsregeling, Archief voor Geneeskunde, 3 (1843), 1-64. Heye, J.P., 1844, Over het wijsgerig wetenschappelijk beginsel der geneeskunde, Ardhief voor Geneeskunde, 4 (1844), 274-312.

Heye, J.P., 1845, Journalistiek. Een woord aan alle geneeskundigen, Archief voor Geneeskunde, 5 (1845), 210-222.

Heylighen, F. \& F. Demeyere (eds.), 1990, Self-Steering and Cognition in Complex Systems, Gordon and Breach, London.

Heyman, H.W., 1973, De juristen-vereniging en de aanzet tot vermaatschappelijking wan het privaatrecht, In: Van Henwarden (red.), 1973, pp. 243-286.

Heyman, H.W., 1975, Kempers strijd tegen de Code Civil. Kanttekeningen bij een vertrouwd beeld, RM Themis, (1975), 420-443.

Heyman, H.W., 1976, Ars longa, vita Brevis. Diephuis en Opzoomer, Ars Aequi, 25 (1976), $364-373$.

Heynsbergen, P. van, 1925, Geschiedenis der rechtsuetenschap in Nederland. Beknopt overzicht der geschiedenis onzer rechtswetenschap tot 1900, Meulenhoff, Amsterdam.

Heynsius, A., 1856, De werkkring van het physiologisch-pathologisch laboratoritum an de doorhuchtige en klinische scholen te Amsterdam. Amsterdam.

Heynsius, A., 1866, Redevoering over het tegenwoordig standpunt der physiologie en haar verbond met de geneeskunde, uitgesproken ter aanvaarding van het hoogleraarsambt aan de hoogeschool te Leiden den 7 maart 1866, C.G. van der Post, Amisterdam.

Heynsius, A., 1870, Het natuurkundig examen (polgens art. 4 der wet van 1 juni 1865) en het ontwerp van wet op het hooger onderwijs, S.C. van Doesburgh, Leiden.

Heynsius, A., 1875, Feestrede bij het derde eeuwfeest der Leidsche Hoogeschool. Den "sten februari in de Pieterskerk gehouden, A.H. Adriani, Leiden.

Hijmans, H., 1900, De opleiding van den jurist, Themis, 61 (1900), 1-32.

Hijmans, H., 1902, De opleiding van den jurist. Themis, 63 (1902), 217-293; 323-401.

Hingst, S.J., 1885, Prof J. C. Naber, 'De vormende kracht van het Romeinsche Recht, Rechtsge. leerde Bijdragen en Bijblad, Afd. A. : Burgerlijk recht I, 1 (1885), 250. 
Hoefle, MA., 1849, De sctuikunde en het mikroskoop aan het ziekbed. Eene Bijdrage tot de genteskundige herkeniningsleer, voor den Nederlandschen lezer bewerkt door Dr. Henry Riehm met een woord tot inleiding wan den hoogleeraar J. van Geuns, Utrecht/Amsterdam.

Hoenderdaal, G.J., 1984, Het modernisme in Leiden, In: Otterspeer (red.), 1984, pp. 10-25.

Hoeven, J. van der, 1859, Over de opvolging en ontwikkeling der dierlijke bewerktuiging op de oppervlakte onzer planeet in de verschillende tijdperken van haar bestaan, Album dier Natuur, (1859). 33-48.

Hoeven, J. van der, 1865 , Een ernstig woord ter verdediging van het hooger onderwijs. (Naan aanleiding van de Regeling der woorwaarden tot verkrijging der bevoegdheid van Geneeskundige enz. in het wetsontwerp door de tweede kamer der Staten Generaal op 27 maart 1.1, aangenamen.), A.C. Kruseman, Haarlem.

Hoeven, J. van der, 1989, De drie dimensies van het bestuursrecht. Ontstaan en vorning vaw het Nederlandse bestuursrecht, VAR-reeks 100, Samsom H.D. Tjeenk Willink, Alphen aan de Rijn.

Hofstede de Groot, P., 1849, Is bezuiniging op het onderwifs, vooral door opheffing eener Hooge. school, aan te raden, C.M. van Bolhuis Hoitsema, Groningen.

Holthoon, F.L. van (red.), 1985, De Nederlandse samenleving sinds 1815. Wording en samenhang, Van Gorcum, Assen-Maastricht.

Homburg, E., 1987, Over het boekenbezit van Gerrit Jan Mulder, Aan de hand van teen veilingcatalogus, Tsch.Gesch.Gnk Natuurw. Wisk.Techn, 10 (1987), 45-56.

Hooykaas, R., 1946, Rede en Erouring in de natuurwetenschap der XVIIIe eeuw. Rede uitgespro. ken bij de aanvaarding van het ambt van Buitengewoon hoogleraar in de Faculteit der Wis- en Natururkunde aan de VU te Amsterdam op vrijdag 1 februari 1946, s.l., s.n.

Hooykaas, R., 1988, Wetenschap in dienst van het Gemenebest, In: Le Pair, Benschop en Broeder (red.), 1988, pp. 53-155.

Hoppe, B., 1978, Umbildungen der Forschung in der Biologie im 19. Jahrhundert, In: Dienter (Hrsg.), 1978., pp. 104-188.

Hosmer, L.T., 1978, Academic strategy, University of Michigan, Ann Arbor, Michigan.

Houck, A.J., 1840, De ware verhouding tusschen Hooger-, Middelbar- en Lager Onderwijs bschou wd als middel ter wookoming wan eenen algemeenen heerschenden geest van jongelieden ubt den Burgerstand om zich boven den stand humner ouders te verheffen, J. de Lange, Deventer.

Houten, S. van, 1863, Kritiek der practische staathuishoudkunde, De Gids (1863) 1, 401-434. Houten, S. van, 1866, De staathuishoudkunde als wetenschap en kunst, De Gids, (1866) III, $185-209$.

Houtzager, H. L., 1979, Medicyns, vroedwy/s en chirurgyns. Schets van de gezondheidszorg in Deff en beschrijing wan het Theatrum Anatomicum aldan in de $16 \mathrm{e}$ en $17 \mathrm{e}$ eetw. Rodopi. Amsterdlam.

Houwaart, ES., 1988, Lokalisme in de epidemiologie', 1850-1880 Samenvatting van lezing in hat kader van het wetenschapshistorisch colloquim van het Instituut voor Geschiedenis der Natuitrwetertschappen, dd. 6 april 1988.

Hubrecht, P.F., 1880, De ordenwijswetten in Nederland en hare uitwoering. Administratieze werzit meling oan alles wat darop betrekking heeft uitgegeven met magtiging van zijne Excellentiv den Minister van Bimenlandsche Zaken, Stemberg, 's Gravenhage.

Huerkamp, C., 1985, Der Aufstieg der Aurzte im 19. Jahrhundert. Vom gelehrien Stand zwn professionellen Experten: das Beispiel Preufens, Kritische Studien zur Geschichtswissenschaft Band 68 , Van den Hoeck und Ruprecht, Göttingen.

Huet, G.D.L., 1872, Over de noodzakelijkheid on de genteskunde als natuurwetenschap op te vatten. Redevoering ter aanvaarding van het gewoon hoogleraarsambt aan de Hoogeschool te Leiden, den 12den November 1872 uitgesproken, W.T. Werst, Leiden.

Hufeland, G., 1827 [oorspr. 1814], Verhandeling over den eigenanrdigen geest van het Romeinsdie 
regt - In het algemeen, en met betrekking tot de hedendangsche wetgeving en regtsgeleethidi, Uit thet Hoogduitsch vertaald en met eenige aanmerkingen en ophelderingen voorzien door Mr. C.C.C. Warmolts, Scheltsberg, Leeuwarden.

Huizinga, I. 1941, De wetenschappen in het algemeen en die der afdeeling letterkunde, In: Viif maal viffentwintig jaar wetenschap in Nederland, 1941, pp. 1-22.

Huizinga, J., 1951a, Universiteit, Wetenschap en Kunst, Verzamelde Werken deel VII, H.D. Tjeenk Willink \& Zoon, Haarlem.

Huizinga, I., 1951b, Geschiedenis der universiteit gedurende de derde eeuw van hatar bestaan 1814-1914, In: Huizinga 1951a, pp. 36-339, [oorspr. Academia Groningana MDCXIVMCMXIV, Gedenkboek ter gelegenheid van het derde eeuwfeest der Universiteit te Groningen, ütgegeven in opdracht van den academischen senaat, Eerste gedeelte, P. Noordhoff, Groningen, 1914].

Huizinga, J., 1951c, Universitas, In: Huizinga 1951a, pp. 31-35 [oorspr. Minerva, Algemeen Nederlandsch Studenten-weekblad, 45 e jrg, no.5, 23 October 1919, 58-59, E.J. Brill. Leiden]. Hull, D.L., 1982a, Exemplars and scientific change, PSA 1982 vol. 2, East Lansing MI, Plilosophy of Science Association, 73-92.

Hull, D.L., 1982b, The Naked Meme, In: Plotkin (ed.), 1982, pp. 273-327.

Humboldt, W. von, 1984a3 [1956] Schriften zur Anthropologie und Bildungslehre, Klett-Cotta/Ullstein, Frankfurt am Main/Berlin/Wien.

Humboldt, W. von, 1984b [1809], Der Litauische Schulplan, In: Humboldt 1984a, pp. 76-82.

Humboldt, W. von, 1984c [1810], Über die innere und äussere Organisation der höheren wissenschaftichen Anstalten in Berlin, In: Humboldt 1984a, pp. 82-90.

Huussen, A.H., 1989, De betekenis van codificatiegedachte en -praktijk voor de natievorming, BMGN, 104 (1989), 638-653.

Idenburg, I.C., 1919, Een kleine aanvulling voor het arts-examen, Nederlandsch Tijdschrift voor Geneeskunde, 63 (1919) I, 846-847.

Idenburg, P.J. (red.), 1927, Van Athenaew tot Universiteit. Geschiedents van het Athenaeum Mustre in de negentiende eeuw, Uitgegeven door de Curatoren van de Universiteit van Amsterdam, Stadsdrukkerij, Amsterdam.

Idenburg, Ph.J., 1960, Schets wain het Nederlandse Schoolwezen, Wolters-Noordhoff, Groningen. Idenburg, Ph.J., 1963, Thorbecke"s middelbaar onderwijs wet 1863-1963, In. Een eeuw middelbar onderwijswet herdacht, 1963, pp. 1-20.

Iets, 1842, Iets over de hoogescholen, H. Lagerwey, Dordrecht.

lets, 1845, Iets over ons hooger onderwijs, 1845, P.C. Dill, "s Gravenhage.

IJsselmuiden, van P.C., 1988, Binnenlandse Zaken en het ontstaan van de moderne buteaucratie in Nederland 1813-1940, J.H. Kok, Kampen.

Illich, I., 1978, Grenzen ain de geneeskunde: hel medisch bedriff, een bedreiging voor de gezondheid, Het Wereldvenster, Baarn.

Impey, O. and A. Macgregor (eds)., 1985, The Origins of Museums. The cabinet of curicsities in sixtew th and seventeenth century Europe, Clarendon Press, Oxford.

In het spoor van de Liefde, 1986, In het spoor wan de Liefde. Japans-Nederlandse ontmoetingen sinds 1600, De Batalsche Leeuw, Amsterdam/Museum voor Volkenkunde, Rotterdam.

Inlichtingen, 1828, Inlichtingen of Consideratien van de Akademischen Senaat der Hooge School te Uitrecht over de punten wan overweging, woor de Commissie, bijeengeroepen doar Zr. Mts besluit wan 13 April 1828, no 100.

lacyna, L.S., 1988, Models of Clinical Instruction: The Nineteenth Century Critique of the Edinburgh Method, In: Program, Papers, and Abstracts for the Joint Conference Manchester, England, 11-15 July 1988, BSHS/HSS, p. 504.

lacyna, L.S., 1990, Romantic thought and the origins of cell theory, In: Cunningham and Jardine (eds.), 1990, pp. 161-168. 
Jager, L. de, 1910a, De voorbereiding voor de studie der geneeskunde, Nederlandsd Tijdsd voor Ceneeskunde, 54 (1910) $1_{\alpha} 444-449$.

Jager, L. de ${ }_{s} 1910 \mathrm{~b}_{s}$ De geneeskundige oplleiding, Nederlandsch Tijdschrift voor Geneeskunde. (1910) $1,1729-1730$.

Jager, L. de, 191Dc, De praktische opleiding, Nederlandsch Tijdschrift woor Geneeskunde, (1910) I, 2072-2074.

Jahnke, H.N. and M. Otte (eds.), 1981, Epistemological and Social Problems of the Sciences in Early Nineteen th Century, D. Reidel Publishing Company, Dordrecht Holland/Boston US London England.

Jahnke, H.N. and M. Otte, 1981, Science as a language In: Jahnke et al., 1981, pp. 75-89

Jahnke H., M. Otte and B. Schminnes, 1981, Introduction, In: Jahtike et al., 1981, pp. xi-Jansen, C.J.H., 1987a, Natuurrecht of Romeins Recht. Een studie over het leven van F.A. van Marck (1719-1800) in het licht wan de apvattingen wan zijn tijd. E.J. Brill/Universitaire I Leiden, Leiden.

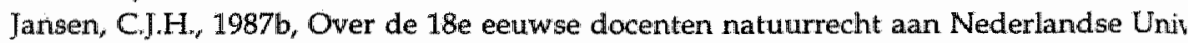
siteiten en de door hun gebruikte leerboeken, Tijdschrift voor Redhtsgeschiedenis, 55 (19) 103-116.

Jansen, C.J.H., 1988, Groeiend historisch bewustzijn bij de $18 \mathrm{e}$ eeuwse juristen en de invkt daarvan op de positie van het Romeinse recht, Recht en Kritiek, 14 (1988), 126-133.

Jansen, C.J.H., 1989, Natuurrecht of Romeins recht. Enkele twisten uit de eerste decennia i de 19e eeuw over de inrichting van het academische onderwijs, Tijdschrift woor Rechts schiedenis, 57 (1989), 135-146.

Jansen, C.J.H., 1990a, Het achttiende-eeuwse onderwijs in de statistiek aan de juridis faculteiten van de Republiek der Verenigde Nederlanden, Tijdschrift woor Rechtsgeschiede: 58 (1.990), 111-128.

Jansen, C.J.H., 1990b, Van Kemper tot Hamaker. Een onderzoek naar de encyclopedie van het te in de negentiende eeuw, W.E.J. Tjeenk Willink, Zwolle.

Jansen, C.J.H., 1990c, Het oudste inleidingsboek in Nederland. De encyclopaedia juris prud tiae (1839) van C.A. den Tex, Ars Aequi, 39 (1990), 823-828

Jansen, C.I. $H_{4}, 1991 \mathrm{a}$, Begriffsjurisprudenz, deductie of inductie: variaties op een mc ontleend aan $\mathrm{R}$. von thering (1818-1892), RM Themis, 1991, 63-77.

Jansen, C.J.H., 1991b, De verhouding tussen wetenschap en praktijk in de juridische op ding van de $18 \mathrm{e}$ en 19e eeuw, NJB, 28 maart 1991, 564-570.

Janssen, H.H., 1963, Van middelbaar onderwijswet 1863 naar Mammoetwet 1963, In: I eeutw middelbwar ondenwijswet herdacht, Groningen, 1963, pp. 34 e.v.

Jarausch, K. $\mathrm{H}_{\text {. }}$ 1983, The transfornation of higher Leaming, 1860-1930, expansion, diversificati social opening and professionalization in England, Gernany, Russia, and the United States, Kl Cotta, Stuttgart.

Jarausch, KH., 1986, The Old 'New History of Education': A German Reconsiderati Mistory of Education Quarterly, 26 (1986), 225-241.

Jaspers, A.Ph.C.M., 1980, Rechtspreken int de Maatschappij. Een onderzoek naar opvatingen o plaats en funktie van de rechtspraak in het Nederlandse ekonomische, sociale en politieke bestel : het einde van de achttiende tot het begin van de twintigste eeuw, Universitaire Pers Leiden-[ Haag, W.E.J. Tjeenk-Willink, Zwolle.

Jitta, D. Josephus, 1899, De toelating tot de rechtspraktijk en de magistratuur, Rechtsgele Magaziju, 18 (1899), 422-435.

Jobling, R., 1973, A traditional theme in general sociology and its relevance for the study universities, In: Brown (ed,), 1973, pp. 203-218.

Jong, J. de, 1986 , Een deftig bestaan. Het dagelijkse leven wan regenten in de 17 de en 18 de eet $\mathbb{K}_{\text {Kosmos, }}$ Utrecht/Antwerpen. 
Kathoven, C.W.H. van en A.H. van der Boon Mesch, 1848, Over den gebrekkigen stant van de geneeskundige intigting voor zieke armen te Leiden. Verslag aan den stedelijken raad, P. Engels, Leiden.

Kampman, J.G., 1989, De Groningse student vó́r 1815, In: Kingma et al. (red.), 1989, pp. $41-$ 55.

Kamstra, O.W.M., F.B.M. Kunneman en C.W. Maris, 1988, Nederlandse rechtswetenschap. Tussen distantie en betrokkenheid: paradigma's in de twintigste eeww, W.E.J. Tjeenk Willink, Zwolle..

Kan, J.B., 1865, Ons hooger onderwijs. Grieven en Wenschen, H.C.A. Thieme, Nijmegen.

Karsemeyer, J., 1963, De wet Thorbecke op het M.O. in de praktijk, In: Een eeuto middelbaar onderwijswet herdacht, Groningen, 1963, pp. 21-33.

Kedrov, B., 1981, European Natural Science (The beginning of the 19th century), In: Jahnke \& Otte (eds.), 1981, pp. 123-140.

Kemper, J.M., 1808, Het gezag des Romeinsen regts hier te lande en den wenschelijken invlaed, welke de invoering wan een nieuw wetboek op dat gezag en de beofening daarvan zou moeten hebben.

Kemper, J.M., 1809, Crimineel Wetboek voor het Koningrijk Holland. Met eene Inleiding en Aanmerkingen, Amsterdam, 1809, voorrede pp. X-XIII, In: Cohen Jehoram, 1968, pp. 61-62. Kemper J.M., 1816, Redevoering bij de inhuldiging der herstelde Leydsche Umiversiteit en de invoering der nieuwe inrigting amtrent het hooger onderwijs, Uitgesproken in de St. Pleterskerk te Leyden den 6 den november 1815, Johannes van der Hey, Amsterdam.

Kemper, J.M., 1820, Ophelderende Memorie omtrent de beginselen welke men gemeend heeft, bij de bearbeiding des overgegevenen ontwerps van het Burgerlijk Wetboek voor het Koningrijk der Nederlanden ten grond te moeten leggen (algemeen gedeelte) [Ontwerp 1820], In: Cohen Jehoram, 1968, pp. 63-71.

Kemper, J.M., 1835, Verhandelingen, redevoeringen en statkundige geschriften, 3 delen, Johannes van der Hey, Amsterdam.

Kerst, J.F., 1851, Handleiding der bijzondere natuurkunde oan den zieken mensch en der heelkundige behandelingswijze der ziekten, J.G. van Terven \& Zoon, Utrecht.

Kieh, W.F.P., 1852, Over Staats-Geneeskunde en Geneeskundige Staatsinstellingen, vooral in betrekking tot de ontwerpen van wet voorgesteld door de Staats-commissie benoemd bij Konimklijke Besluiten van 25 julij en 4 augustus 1848, No 64 en 50, de Erven Doorman, 's Gravenhage. Kingma, J., W.R.H. Koops en J.R.H. Smit (red.), 1989, Universitair leven in Groningen 16141989, Universiteitsmuseum/Universiteitsbibliotheek, Groningen.

Kirsch, G. , P. Nijkamp and K. Zimmerman (eds.), 1988, The Formulation of Time Preferences in a Multidisciplinary Perspective - Their Consequences for Individual Behaviour and Collective Decision-Making, Avebury, WZB-Publications, Hants England.

Kiss, G., 1990, Grundzüge und Entwicklung der Luhmennschen Systemtheorie, Ferdinand Enke Verlag, Stuttgart.

Klikspaan [ps. I. Kneppelhout], 1982, Studententypen: december 1839-mety 1841, Veen, UtrechtAntwerpen. Facsimile van de uitgave Hazenberg, Leiden, 1841.

Klir, G. J., 1989, Principles of Uncertainty in Systems Science, In: Proceedings of the first european congress on system science, CES 1, Lausanne, 3-6 October 1989, pp. 5-16.

Knecht-van Eekelen, A. de, 1985, Een fysiologische geneeskunde, In: De Moulin (red.), 1985, pp. $20-32$.

Knippenberg H. en B. Nauta, 1989, Naar eenheid van tijd in Nederland 1835-1909, Tijd'schrift waor Sociale Geschiedenis, 15 (1989), 325-346.

Knippenberg, H. en B. de Pater, 1988, De eenwording vam Nederland, schaatvergroting en integratie sinds 1800, SUN, Nijmegen. 
Knoester, A. (red.), 1987, Lessen uit het verleden. 125 joar vereniging voor de Stanathuishoudkunde, H.E. Stenfert Kroese, Leiden/Antwerpen.

Koehler, P.J „1989, Het localisatieconcept in de neurologie jan Brown-Séquard, Rodopi, Amsterdam/Atlanta.

Koelliker, A., 1899, Erinnerungen aus meinem Leben, Wilhelm Engelmann, Leipzig.

König, R, 1970 [1935], Vom Wesen der deutschen Universität, Wissenschaftliche Buchgesellschaft, Darmistadt.

Kop, P.C., 1980, Beschouwingen over het zgn. "vulgaire' Romeinse recht, Universitaire Pers Leiden, W.E.J. Tjeenk Willink, Den Haag etc.

Kop, P.C, 1982, Legisme en priwatrechtswetenschap. Legisme in de Nederlandse Privatredhtswetenschap in de negentiende eeww, Kluwer, Deventer.

Kop, P.C., 1987a, Johannes van der Linden (1756-1835), In: Veen, Kop m.m.v. Kuranten (red.), 1987, Pp. 196-200.

Kop, P.C., 1987b, Hendrik Jacobus Hamaker (1844-1911), In: Veen, Kop m.m.v. Kwanten (red.), 1987, pp. $231-235$.

Kop, P.C., 1987c, Joan Melchior Kemper (1776-1824), In: Veen, Kop m.m.v. Kwanten (red.), 1987, Pp. 201-208.

Kop, P.C., 1987d, Cornelis Willem Opzoomer (1821-1892), In: Veen, Kop m.m.v. Kwanten (red.), 1987, pp. 218-224.

Kop, P.C., 1987e, Hendrik Constantijn Cras (1739-1810), In: Veent, Kop m.m.v. Kwanten (red.), 1987, pp. 190-195.

Kop, P.C., 1989, Savigny en de wetenschap van het privaatrecht in Nederland in de negentiende eeuw, Tijdschrift voor Rechtsgeschiedenis, 57 (1989), 117-134.

Korst, J.K. van der, 1988, Om liff en lewen. Gezondheidszorg en geneeskunst in Nederiand circa 1200-1960, Bohn, Scheltema \& Holkema, Utrecht/Antwerpen.

Korthals Altes, A., 1986, Adriaan Catharinus Holtius 1786-1861, In: Van den Bergh, Sprutten v.d. Vrugt (red.), 1986, pp. 56-69.

Koselleck, R. (Hrsg.), 1978, Historische Semantik und Begriffsgeschichte, Klett-Cotta, Stuttgart.

Koselleck, R., 1979, Vergangene Zukunft - Zur Semantik geschichtlicher Zeiten, Suhrkamp. Frankfurt am Main.

Kossmann, E.H., 1984", De lage landen 1780-1940. Anderhalve eeuw Nederland en België, Elsevier, Amsterdam/Brussell.

Koster, W., 1864, Het hooger ondenwijs en de geneeskunde. Een beschouwing naar aanleiding der redevoering awn prof. Evers te Leiden, W.F. Dannenfelser, Utrecht.

Koster, $W, 1865$, De grieven der hoogesdhool tegen de ontwerpen van wet op de geveeskundige stantsregeling, welke aan de goedkeuring der Eerste Kamer zullen worden ondenworpen, Kemink en Zoon, Utrecht.

Koster, W. 1870, Het ontwerp van wet tot regeling van het hooger onderwijs, De Gids, (1870) I, 1-32.

Koster, W., 1882, De opleiding der artsen en de vermindering der Staatsuitgaven voor het Hooger Onderuijs, C.H.E. Breijer, Utrecht.

Koster, W., 1886, Latijn en Grieksch wenschelijk voar de opleiding onzer geneeskundigen?. Nederlandsch Tijdschrift ooor Geneeskunde, II 22 (1886), 173-182.

Krafft, F. \& C.I. Scriba (eds.), 1989. XVIIth International Congress of History of Science: Science and Political Order, Abstracts, Hamburg-Munich.

Kredov, B.M, 1981, European Natural Science (The beginning of the nineteenth century), In: Jahnke et al. 1981, pp. 123-140.

Kroon, Th. Jhz $z_{\star}$ 1863, Boekbespreking van Studiën over krankzinnigheid en gemoedslijden. Een leerboek voor de kennis der krankzinuigheid en de geneeskundige verpleging van krankzinnigen, door Dr. Heinrich Neumann, De Gids, (1863) II, 142-163. 
Krüger, L, 1987, The slow rise of probabilism: philosophical arguments in the nineteenth century, In: Krüger, Daston and Heidelberger (eds.), 1987, pp. 59-89.

Kritiger, L., L.J. Daston and Michael Heidelberger, 1987, The probabilistic Revolution. Volume I. Ideas in History, Bradford, The MTT press, Cambridge, Massachusetts, London, England:

Kruithof, B., 1990, Zonde en deugd in domineesland. Nederlandse protestanten en problemen van opvoeding. zeventiende tot twintigste eeww, Wolters-Noordhoff, Groningen.

Krul, W.E., 1985, De Nederlandse gymnasia in de negentiende eeuw, In: Wes (red.), 1985, pp. 36-59.

Kruseman, J., 1946, De academische opleiding der juristen, Overzicht van het tijdvak 18761946, RM Themis, (1945/1946), 5-85.

Kruy't, H.R., 1931, Hooge School en Maatschappij, H.J. Paris, Amsterdam.

Kühler, K.P., 1953, Jan van Geuns, Zijn betekenis voor de geneeskundige wetenschap en het geneeskundig ondenwijs, academisch proefschrift, Leiden.

Küinzler, J., 1989, Medien und Gesellschaft - Die Medienkonzepté von Talcott Parsons, Jügen Habermas und Niklas Luhmonn, Ferdinand Enke Verlag, Stuttgart.

Kuenzli, R., 1981, Teaching Method and Justification of Knowledge: C. Ritter-J.H. Pestalozzi, In." Jahnke et al. (eds.), 1981, pp. 159-181.

Kuhn, T.S., 1981 [1976'], Mathematical versus experimental traditions in the development of physical science, In: Snelders en Van Berkel (red.), 1981, pp. 26-54.

Kuile, Th.E. ter, 1906, De umiversitaire medische studie, Scheltema \& Holkema's Boekhandel, Amsterdam.

Kunneman, F.B.M., 1986, Ower het inleiden tot de rechtswetemschap. De wenselijkheid en mogelijkheid van een encyclopedische inleidingstheorie, Eburon, Delft.

Kunneman, F.B.M., 1988, Object en methode van rechtswetenschap en juridisch onderwijs, In: Kamstra, Kunneman en Maris (red.), 1988, pp. 173-191.

Kunst, A.J.M., 1969, Opmerkingen over het juridisch ondenwijs tussen de tweede en de twintigste. eeww, Tjeenk Willink, Zwolle.

Labrie, A., 1986, 'Bildung' en politiek 1770-1830. De "Bildungsphilosophie" van Wilhelm ton Humboldt bezien in haar politieke en sociale context, Amsterdamse Historische Reeks 9, Historisch Seminarium van de Universiteit van Amsterdam.

Ladd, D.R., 1970, Change in educational policy. Self-studies in selected colleges and universities: a general report, McGraw Hill, New York.

Lakke, A.J., 1908, Philip Willem van Heusde 1778-1839, Dissertatie, Brill, Leiden.

Lamwel, H.-U., 1989, Krankheit, Gesundheit. Das Elend der romantischen Medizin, Medizinhistorisches Joumal - Internationale Vietteljahresschrift fur Wissenschaftsgeschichte, 24 (1989), 79-98.

Lammers-Verdegaal, A.M.W., 1982, De plaats van zelfwerkzaamheid in de rechtenstudie, Ars Aequi, $31(1982), 288-292$.

Lamping, J.A. 1859, De voorbereiding tot het hooger onderwijs, boekbespreking naar aanleiding van P. Harting, Gedachten over het Hooger Onderwijs in ons Vaderland, De Gids, (1859) I, 1-51.

Land J.P.N., 1886, De oude en de nieuwe universiteit. Redevoering uitgesproken op den 311 den verjaardag der universiteit te Leiden op 8 februari 1886, EJ. Brill, Leiden.

Landes, D. S., 1983, Revolution in time. Clocks and the making of the Modern World. The Belknap press of Harvard University Press, Cambridge, Massachusetts and London, England.

Landeszentrale für politische Bildung des Landes Nordrhein-Westfalen (Hrsg.), 1975, Der Mertsch in den Konfliktfeldern der Gegenwart, Köln.

Langeveld, A.P.M., 1988, Van applicatiecursus tot kweekschool. De beginjaren van de militair-geneeskundige opleiding in Nederland, In: De Moulin (red.), 1988, pp. 17-34.

Langman, L., 1986, "The family: a 'sociocybernetic' approach to theory and policy , In: Geyer 
and Van der Zourwen (eds.), 1986, pp. 26-43.

Larson, M.S, 1977. The rise of professionalistn. A sociological analysis, University of Califo: press, Berkeley/Los Angeles/London.

Lawrence, $C ., 1988$, Alexander Munro primus and the Edinburgh manner of anatomy, letin of the History of Medicine, 62 (1988), 193-214.

Lawrence, S.C., 1988, Entrepreneurs and private enterprise: the development of med lecturing in London, 1775 -1820, Bulletin of the History of Medicine, 62 (1988), 171-192.

Leersum, E.C. van, 1918, Is het wenschelijk, dat de 'kennis der geneesmiddelen' (phan cognosie) van den rooster der candidaats- en tweede natuurkundig examens verdwijg Nederlandsch Tijdschrift voor Geneeskunde, 62 (1918) II, 1671-1675.

Lenders, $I_{1}, 1988$, De burger en de volksschool. Culturele en mentale achtergronden van een on wijsvernieuwing. Nederland 1780-1850, SUN, Nijmegen.

Lenoir, T., 1982, The strategy of life. Teleology and Mechanics in Nineteenth Century Gem Biology, Reidel, Dordrecht.

Lenoir, T., 1988, Science for the clinic: Science policy and the formation of Carl Ludwi institute in Leipzig, In: Coleman and Holmes (eds.), 1988, pp. 139-178.

Lenoir ${ }_{t} T_{*}, 1988$, Practice, Reason, Context: The dialogue between theory and experime Science in Context, 2 (1988), 3-22.

Leonides van Praag, I, 1866, Onze richting in ons handelen aan het ziekbed, Nederland Tijdschrift voor Geneeskunde, II 2 (1866), 263-266.

Le Pair, C., H. Benschop en J.J. Broeder (red.), 1988, De wetenschappen in relatie tot de overh in het werleden en nu, STW/FOM, Utrecht.

Lepenies, W. 1976, Das Ende der Naturgeschichte. Wandel kultureller Selbstoerständlichkeiten den Wissenschaften des 18. und 19. Jahrhunderts, Hanser Verlag, München/Wien.

Lerner, D., 1968 [1958]. The passing of traditional society: Modernizing the Middle East, The F: Press, Glencoe Ill.

Lerner, D., 1972 [1968], Modernization. Social aspects, In: International Encyclopedia of Social Sciences, vol. 10 (ed.) D.L. Sills, The Macmillan Company \& The Free Press, Nt York, Collier-Macmillan Publishers, London.

Lesch, J.E., 1984, Science and medicine in France. The emergence of experimental physiology, $\mathrm{H}_{i}$ vard University Press, Cambridge, Massachusetts/London, England.

Lesch, J.E., 1988, The Paris Academy of Medicine and experimental science, 1820-1848, Coleman and Holmes (eds.) 1988, pp. 100-138.

Lesch, J.E., 1990, Systematics and the geometrical spirit, In: Frängswyr, Heilbron and Rit (eds.), 1990, pp. 73-111.

Levy, I.A, 1879, Savigny en de historische rechtsbeoefening, Nieuwe Büdragen tot Rechts leerdheid en Wetgeving, (1879), 285 e.v.

Levy, J.A., 1899, De vorming van den rechtsgeleerde - met bijlagen, Themis, 60 (1899), 488-7\%

Lieburg, M.J. van, 1973, Gerrit Jan Mulder docent der Clinische School te Rotterdam, In: Vi Herwarden (red.), 1973, pp. 213-240.

Lieburg, M.J. van, 1978, Het medisch onderwijs te Rotterdam 1467-1967, Rodopi Amsterdan Lieburg, M.J. van, 1983a, De tweede geneeskundige stand (1818-1865), Een bijdrage tot . geschiedenis wan het medisch beroep in Nederland, Tijdschrift voor Geschiedenis, 96 (198: 433-453.

Lieburg, M.J. van, 1983b, De microscopie in het onderwijs van de klinische scholen in Nede land (1824-1865), Tsch.Gesch.Gnk.Natuuro. Wisk.Techn., 6 (1983), 82-98.

Lieburg, M.J. van, $1983 \mathrm{c}$, Geneeskunde en medische professie in het genootschapswezen wa Nederland in de eerste helft van de negentiende eeuw, De Negentiende Eeww, 7 (1983), 12 145. 
Lieburg. M.J. van, 1985, De Nederlandse medische tijdschriften en de wetenschappelijke geneeskunde 1840-1870, In: De Moulin (red.), 1985, pp. $1-19$.

Lieburg, MJ. van, 1986a, Het Coolsingelziekenhuis te Rotterdam 1839-1900. De ontwoikkeling van een stedelijk ziekenthuis in de $19 e$ eeuw, Rodopi, Amsterdam.

Lieburg, M.J. van, 1986b, De ontwikkeling van het klinisch-diagnostisch laboratorium in Nederland tot omstreeks 1925, Tsch.Gesch.Gnk.Natuurw.Wisk.Techniek, 9 (1986), 278-318.

Lieburg, M.J. van, 1987, De medische promoties aan de Nederlandse universiteiten (1815-1899), Batavia Academica, 5 (1987), 1-17.

Lieburg, M.J. van, 1988a, De academisering van de militair-geneeskundige opleiding in Nederland (1860-1880), In: De Moulin (red.), 1988, pp. 81-94.

Lieburg, M.I. van, 1988b, "Beworderlijk voor de kunst en nutig voor de mantschappit' De geschiedenis van het Genootschap ter bevordering van Heel-en verloskunde (1857-1929) en van het Amsterdans Geneeskundig Genootschap (1925-1988), Rodopi, Amsterdam.

Lieburg, M.J. van, 1989a, Woord en Boek in de Geschiedenis van de Geneeskunde. Een beschowwing over de toegankelijkheid van medische kennis, Rodopi, Amsterdam/Atlanta G.A.

Lieburg, M.J. van, 1989b, Municipall Hospitals and Clinical teaching in The Netherlands during the 19th century, Clio Medica, 21 (1987-1988), 125-138.

Lieburg, M.J. van \& H. Marland, 1989a, Elisabeth en Neeltje van Putten: twee 18-e eeuwse grensgangers tussen de beroepsvelden van vroedvrouw en vroedmeester, Tsch.Gesch.Gnk.Naturuw. Wisk.Techn. 12 (1989), 181-197.

Lieburg, M.J. van \& H. Marland, 1989b, Midwife regulation, education, and practice in the Netherlands during the nineteenth century, Medical History, 33 (1989), 296-317.

Lindeboom, G.A., 1972, De geschiedenis van de medische weterischap in Nederland, Fibula-van Dishoeck, Bussum.

Lindeboom, G.A., 1981, Schets van de geschiedenis van de Nederlandse Internisten Vereeniging, In: Geerling et al. (red.), 1981, pp. 68-103.

Lindeboom, G.A., 1985, Historisches zum Begriff 'Enzyklopädie' - Die Wissenschaftskunde von Johann Joachim Eschenburg (1743-1820), In: Toellner und Van Lieburg (Hrsg.), 1985, pp. 42-53.

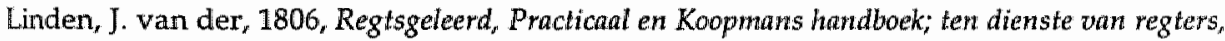
practizijns, kooplieden, en allen, die een algemeen overzicht van regtskennis verlangen, Johannes Allart, Amsterdam.

Linden, J. van der, 1827, De ware pleiter, P. den Hengst en Zoon, Amsterdam.

Lokin, J.H.A., 1989, Van tweeën een. Drie tijdschriften herdacht, RM Themis, (1989), 223-245.

Lokin, J.H.A.\& W.J. Zwalve, 1986, Hoofdstukken wit de Europese Codificatiegeschiedenis, WolttersNoordhoff/Forsten.

'Loo. LF. van, 1987 [1981'], 'Den arme gegeven...' Een beschrijuing van amoede, armenzorg en saciale zekerheid in Nederland, 1784-1965, Boom, Meppel/Amsterdam.

Loos, D. de, 1898, Het middelbaar onderwijs, In: Ritter (red.), 1898, pp. 107-118.

Loosibroek T. van, UI. Jansz, A. de Wildt, M. de Baar, F. de Haan, F. Dieteren, 1988, Redactioneel, In: Loosbroek T. van, U. Jansz, A. de Wildt, M. de Baar, F. de Haan, F. Dieterem, (red.) 1988, pp. $7-10$.

Loosbroek T. van, U. Jansz, A. de Wildt, M. de Baar, F. de Haan, F. Dieteren (red.), 1988, Geleerde vrouwen. Negende Jaarboek voor Vrouwengeschiedenis, SUN, Nijmegen.

Loth, M.A., 1990, De geest van Begriffsjurisprudenz, RM Themis, (1990), 3-12.

Lovejoy, A.O., 1936, The great chain of being, Harvard U.P., Cambridge Mass.

Lucassen, J., 1987, De sociale ontwikkeling van Nederland gedurende de laatste twee eeuwen: het historisch onderzoek sinds circa 1970, In: Van Besauw, Den Boer, Hugenholtz en Th. van Tijn (red.), 1987, pp. 119-146.

Lucassen, J. en Th. van Tijn, 1976a, Nogmaals sociale stratificatie, Tijdschrift voor Sociale Ge- 
schiederis, $2(1976), 74-91$.

Lucassen, J. en Th, wan Tijn, 1976b, Naschrift, Tijdschrift voor Sociale Geschiedenis, 2 (1976), I1 189.

Luhmaann, N., 1975, Konfliktpotentiale in sozialen Systeme, In: Landeszentrale fur prolitisi Bildung des Landes Nordrhein-Westfalen (Hrsg.), 1975, pp. 67-73.

Luhmann, N., 1978, Temporalization of complexity, In: Geyer and Van der Zouwen (eds.) w 2, 1978, pp. 95-111.

Luhmann, N., 1981a, Gesellschaftsstruktur und Semantik. Studien zur Wissenssoziologie der n dernen Cesellschaft, Band 1, Suhrkamp, Frankfurt am Main.

Luhmann, N., 1981b, Ausdifferenzierung dies Rechts, Suhrkamp, Frankfurt am Main.

Luhmann, N., 1982, The Differentiation of Society, Columbia University Press, New York,

Luhmann, N., 1984, Sozidle Systeme-Grundriss einer allgemeinen Theorie, Suhrkamp, Frankf am Main.

Luhmann, N., 1986a, Die soziologische Beobactitung des Rechts, Alfred Metzner, Frankfurt a Main.

Luhmann, N., 1986b; The autopoiesis of social systems, In: Geyer and Van der Zouwen (eds 1986, pp. 172-192.

Luhmann, N., 2987a, Soziologische Aufklärung 4, Beiträge zur funktionalen Differenzienung a Gesellschaft, Westdeutscher Verlag, Opladen.

Luhmann, N., 1987b [1980'], Rechtssoziologie Band 1/2, Westdeutscher Verlag, Opladen.

Luhmann, N., 1990, Die Wissenschaft der Gesellschaft, Suhrkamp, Frankfurt am Main.

Luhmann, N. \& P. Fuchs, 1989, Reden und Schweigen, Suhrkamp, Frankfurt am Main.

Luhmann, N., K.E. Schorr, 1979, Das Technologiedefizit und die Pädagogik, Zeitschrift $f$ Pädagogik, 25 (1979), 345-365.

Lunsingh Scheurleer, Th. H., 1985, Early dutch cabinets of curiosities, In: Impey and MacGreg (eds.), 1985, pp. 115-120.

Lutz, F.W., Tightening up loose coupling in organizations of higher education, Administrathi Science Quarterly, 27 (1982), 653-69.

Luyendijk-EIshout, A.M., 1989, Het hysterie-begrip in de 18de eeww, In: De Goei (red.), 198! pp. $30-41$.

Maarseveen, $H$. van, 1981, Rechten in Maastricht, $N J B, 29$ augustus 1981 no. 29, 777-779.

Maesen, L.J.G. van der, 1986, De jongste Medische Faculteit ter vernieuwing der gezondheidszor te Manstricht, Folia 19, Stichting Onderzoek Maatschappelijke Strategie Ontwikkelin. Amsterdam.

Man, I.C. de, 1902, De geneeskundige school te Middelburg, hare lectoren en leeringen, 1825-186t D.G. Kröber Jr., Middelburg.

March J.G. and J.P. Olsen (eds), 1987', Ambigwity and choice in organizations, Universitetsforla get, Bergen Norway.

Mathijssen, M.T.C., 1987, Het literaire leven in de negentiende eeuw, Martinus Nijhoff, Leiden

Matthijssen, M.A.J.M., 1982, De elite en de mythe. Een sociologische analyse van strijd on ondes wijswerandering, Van Loghum Slaterus, Deventer.

Maulitz, R.C., 1987, Morbid appearances: The anatomy of pathology in the early nineteenth century Cambridge University Press, Cambridge/New York.

Mayntz, R., B. Rosewilz, U.Sehimank, R. Stichweh, 1988, Differenzierung und Verselbständigung Zur Entwicklung gesellschaftlicher Teilsysteme, Campus, Frankfurt/New York.

Mays, E., 1982, The grow h of biological thought. Diversity, evolution, and inheritance, The Belknat Press of Harvard University Press, Cambridge, Massachusetts London, England.

McClelland, Ch.E., 1980, State, Society and University in Germany, 1700-1914, Cambridge U.P. Cambridge. 
Mclelland, ChE., 1986, Structural change and social reproduction in German universities 1870-1920, History of Education, 15 (1986), 177-193.

McKelvie, B.D., 1986, The University's Statement of Goals - an idea whose time has arrived, Higher Education, 15 (1986), 151-163.

McLaughlin P. \& H.-J. Rheinberger, 1989, Repräsentationsmodelle des Körpers im Keim Representations of the Body in the Germ: Theories of Generation in the 19th Century, Poster session, In: Krafft and Scriba (eds.), Hamburg 1989.

Meijers, E.M., 1938, Wijzigingen en aanvullingen van het Burgerlijk Wetboek na 1838 , In: Scholten en Meijers (red.) 1938, pp. 33-63.

Menze, C., 1975, Die Bildungsreform Wilhelm von Humboldts, In. Das Bildungsproblem in der Geschichte des europäischen Erziehungsidenken, Band XIII, Hermann Schroedel Verlag, Hannover/Dortmund/Darmstadt/Berlin.

Merton, R.K. L. Broom and L.S. Cottrell Jr. (eds.), 1959, Sociology Today. Problems and prospects, Basic Books Inc., New York.

Merquirior, J.G., 1988 [1985'], De filosofie man Michel Fowcaul, Aula Het Spectrum, Utrecht, vertaling van Foucault, Fontana, London.

Metz $z_{s}$ K.H., 1987, Paupers and numbers: The statistical argument for social reform in Britain during the period of industrialization, In: Krïger, Daston and Heidelberger (eds.), 1987, pp. $337-350$.

Metzger, W.. 1955, Academic freedom in the age of the university, Columbia University Press, New York.

Meulen, R.H.J. ter, 1988, J.N. Ramaer (1817-1887) en de fysiologische psychiatrie, Tijdschifit woor Psychiatrie, 30 (1988), 127-138.

Meulen, R.H.J. ter en I. Widdershoven-Heerding, 1985, Het fysiologisch ziektebegrip in de vroege Nederlandse psychiatrie, In: De Moulin (red $), 1985$, pp. 110-120.

Mijnhardt, W.W. en A.J. Wichers (red.), 1984, On het Algemeen Volksgeluk. Twee euwen particulier initiatief 1784-1984. Gedenkboek ter gelegenheid van het tweehonderdjarig bestaan van de Maatschappij Tot Nut van 't Algemeen, Maatschappij tot Nut van 't Algemeen, Edam.

Milders, C.F.A. en W. van Tilburg (red), 1988, Systeemdenken en Psychiatrie, een kritische oriëntatie, Van Gorcum, Assen/Maastricht.

Mills ${ }_{f}$ C.W., 1959, The sociological imagination, Oxford University Press, London/Oxford/New York.

Ministerie van Onderwijs en Wetenschappen, 1968, De Universiteit, doelstellingen, structwrer. Miquel, 1842, Gedachten over het onderwijs in de Botanie, woor Genees-en Artsenijkundigen, Bijdragen tot Geneeskundige Staatsregeling, 2 (1842), 16-22.

Modderman, W., 1867, Het Romeinsche reg" en de hedendagsche regtsgeleerdheid, Redevoering ter aanvaarding van het hoogleeraarsambt aan de hoogeschool te Groningen den 6. Junij 1867, J.B. Wolters, Groningen.

Modderman, W., 1874, De receptie van het Romeinsche recht, J.B. Wolters, Groningen.

Modderman, W., 1875, Practijk en Theorie der Rechtsweterschap, Redevoering den 14 october 1875 uitgesproken bij de overdracht van het rectoraat der hoogeschool te Groningen, J. B. Wolters, Groningen.

Mok, A.L., 1973, Beroepen in actie. Bijdrage tot een beroepensociologia, Boom, Meppel.

Molengraaff, W.L.P.A., 1885, Het verkeersrecht in wetgeving en wetertschap. Rede bij de aanvaarding van het hoogleeraarsambt aan de Rijksuniversiteit te Utrecht, op den 17den April 1885, De Erven F. Bohn, Haarlem.

Molengraaff, W.L.P.A. en C.W. Star Busman (red.), 1913, Verspreide geschriften van Mr. H.J. Hamaker in leven Hoogleeraar te Utrecht, De Erven $\mathbb{F}$. Bohn, Haarlem.

Moleschott, J., 1848, Die medicinischen Lehranstalten an den Hochschulen Niederlands, Archiv fïr physiologische Heilkunde, 7 (1848), 472-479. 
Moleschott, ], 1989 [1864 $]$, De eenheid des levens. Redevoering bij de heropening der $\mathrm{p}$ siologische lessen aan de hoogeschool te Turijn, $K$. var Hulst, Kampen, In: Peeters (19i pp. $87-116$.

Moll, JW., 1899, Onze laboratoria en de wetenschap, Rede, bij de opening van het Botani Laboratorium der Rijks-Universiteit te Groningen, Stoomdrukkerij, Firma Robijns \& ( "s Hertogenbosch.

Moltzer, J.P., 1881, Door het recht tot den regel. Rede uitgesproken bij de aanvaarding van hoogleeraarsambt in de rechtswetenschap aan de universiteit van Amsterdam, Frede Muller \& Co, Amsterdam.

Mooy, JI.A., 1987a, De werell der waarden. Essays over cultutur en samenleving, Meulenhr Amsterdam.

Mooy, I.I.A, 1987b, De veerkracht van het burgerlijk cultuurideaal, In: Mooy, 1987a, pp. 89-1

Morrell, J.B., 1972, The chemist-breeders: The research schools of Justus Liebig and Thom Thomson, Ambix, 19 (1972), 1-46.

Mortier, F., 1985/6, Zelfadaptatie en Nomering van de relaties tot het menselijk licham. E theoretische benadering en een studie van de disciplinaire en somatische waarden in de $18 d e$ eeun Franse medisch-predagogische filosofie, diss. Gent.

Moulin, D. de, 1978, Die Medizin zur Zeit der Regierung des Königs Wilhelm I in d Niederlanden (1813-1840). Janus: archives internationales pourl'histoire de la médecine et po la geographie medicale, 65 (1978), 21-44.

Moulin, D. de (red.), 1985, Kracht en Stof. De introductie van moderne natuunvetenschappelij denkwijzen in de geneeskunde, zoals bijkt wit de Nederlandse medische vakbladen, 1840-187 Rodopi, Amsterdam.

Moulin, D. de, 1988, Samenvatting en conclusies, In: De Moulin (red.), 1988, pp. 120-124.

Moulin, D. dle (red.), 1988, 's Rijkskweekschool woor Militaire geneeskundigen te Lutrecht (1822-186' Verslag van een symposium gehouden te Nijmegen op 26 september 1987 onder redactie van 1 de Moulin. Met een lijst van kwekelingen, samengesteld door M.I. van Lieburg, Rodopi, Amste dam.

Moust, J.H.C., R.E. Bakker en H.J.P. Nuy, $1989^{*}$ De rol van de docent in probleemgestuur onderwijs, in: Eroaringen, 1989, pp. 59-70.

Mulder, G.I., 1841, Toespraak bij het openen der geneeskundige lessen. In: Mulder (red.), 184 pp. 1-17.

Mulder, G.J., 1842a, Over de waarde der natuurkundige wetenschappen voor de geneeskund uitgesproken bij de opening der scheikundige lessen aan de Utrechtsche Hoogeschool 184 In: Mulder (red.), 1842, pp. 303-336.

Mulder, $G$.J., 1842b, De beginselen van hooger onderwijs voor Geneeskundigen wervat in ht rapport der geneeskundige staatscommissie, Bijdragen tot Geveeskundige Stantsregeling, (1842), 193-220.

Mulder, G.J., 1842c, A pothekersstand, Bijdragen tot Geneeskundige Stantsregeling, 1 (1842), $74-7$ 128-133.

Mulder, G.J. (red.), 1842, Scheikundige onderzokingen gedan in het laboratorium der Utrechtsch Hoogeschoal, uitgegeven door G.J. Mulder, eerste deel, H.A. Kramers, Rotterdam.

Mulder, G.J., 1846, De vraag van Liebig aan de zedelijkheid en de wetenschap getoetsi Scheikundige onderzoekingen gedaan in het laboratorium der Utrechtse school, 3 (1846), $357-487$

Mulder, G.J., 1865, Het geneeskundig Hooger Onderwijs in Nederland in 1865, H.A. Kramers Rotterdam.

Mulder, G. J, 1876, Getnigenis in zake hooger onderwijs, H.A. Kramers \& Zoon, Rotterdam.

Mulder, G.J., 1879, De geneeskunst-aefenaren narar de Nederlandsche uetten met $1 e-3 e$ verwolg Oc 1878-november 1879, Rotterdam, H.A. Kramers \& Zoon.

Mulder, G.J., 1880, Voorrede, In: Brücke/Mulder, 1880. 
Mulder; G.J, 1883, Levensschets van G.J. Mulder. Door hem zelven geschrewen en door drie zijner vrienden uitgegeven, Van der Post, Utrecht.

Muiller, D.K. 1987, The process of systematisation: the case of German secondary education, In: Müller et al. (eds.), 1987, pp. 15-52.

Miiller, D.K., F. Ringer and B. Simon (eds.), 1987, The rise of the modern educational system: Structural change and social reproduction 1870-1920, Cambridge University Press, Cambridge, London etc., Editions de la maison des sciences de l'homme, Paris.

Müller, P.N., 1864, Beter Onderwijs, De Gids, (1864) III, 463-485.

Naber, J.C., 1885, De vormende kracht van het Romeinsche Recht. Rede uitgesproken bij de aanvaarding van het hoogleeraarsambt in de rechtsgeleerdheid te Utrecht, 21 september 1885 , J.L. Beijers, Utrecht.

Naber, J.C., 1889, De verhouding van het Romeinsche recht tot het hedendaagsche. Toespraak gehouden bij het openen der colleges in het Romeinsche recht 28 october 1889, J.L. Beijers, Utrecht.

Naber, S.A., 1863, Gymnasilaal onderwijs en paedagogiek, De Gids, (1863) I, 1-18.

Naber, S.A., 1864, Gymnasiaal onderwijs en paedagogiek II, De Gids, (1864) II, 238-253.

Naber, S.A., 1867, Boekbespreking van J. Pijnappel, Gz.., Ons Onderwijs, 1867, J. ten Cate, Een woord over het middelbaar onderwijs, 1867, De Gids, (1867) II, 547-551.

Naber, S.A., 1868, Hooger onderwijs en paedagogiek, De Gids, (1868) II, 393-430.

Napjus, J. en G.A. Lindeboom, 1985, De hoogleraren in de geneeskunde aan de Hogeschool en het Athenaeum te Franeker, Rodopi, Amsterdam.

Nederlandsche Maatschappij tot Bevordering der Geneeskunst 1849-1924, 1924, Gedenkboek der Nederlandsche Matschappij tot Bevordering der Geneeskunst, Bij haar viff en zeventig jarig bestant den leden aangeboden 8 juli 1924.

Niethammer, F.I., 1808, Der Streit des Philanthropinismus und Humanismus in der Theorie der Erziehungs-Unterrichts unserer Zeit, Fromman, Jena.

Nijhoff, C.C., 1921, Enkele opmerkingen over de vorming en de opleiding der geneeskundigen aan onze universiteit, Nederlandsch Tijdschrift voor Geneeskunde, 65 (1921) Ila, 293-301.

Nijhoff, C.C., 1923, Hoe zijn wij gekomen aan den titel van arts, Nederlandsch Tijdschrift voor Geneeskunde, 67 (1923) IIB, 1610-1611.

Nipperdey, Th., 1986, Nachdenken über die deutsche Geschichte 1800-1866, Beck, München.

Nipperdey, Th., 1990, Wo aber Einheit ist, wächst das Spaltende auch, Frankfurter Allgemeine Zeitung, Montag 29 Oktober 1990 Nr. 252, s. 35.

Nisbet, R., 1986, The making of modern society, Wheatsheaf books, Brighton Sussex.

Noordam, N.F., 1979, Historische pedagogiek van Nederland. Een inleiding, Intro, Nijkerk.

Noordman, I., 1981, Onderwijsdemokratisering in de patriottentijd. Vatebenders plan voor een radikale vernieuwing van het Nederlandse onderwijs, Comenius, 1 (1981), 521-550.

North, J.D. and J.J. Roche (eds.), 1985, The light of nature. Essays in the history and philosophy of science presented to A.C. Crombie, Martinus Nijhoff, Dordrecht.

Nota de Rode Drand III, 1987, Nota van de onderwijscommissie Faculteit der Geneeskunde Rijksuniversiteit Limburg, Maastricht.

Nowotny H. 1988, From the future to the extended present. In: Kirsch, Nijkamp and Zimmermann (eds.), 1988, pp. 17-32.

Nutton, $V, 1983$, The seeds of disease: an explanation of contagion and infection from the Greeks to the Renaissance, Medical History, 27 (1983), 1-34.

Oelkers, J. und H.-E. Tenorth (Hrsg.), 1987, Paidagogik, Erziehungswissenschaft und Systentheorie, Beltz Verlag, Weinheim und Basel.

Offermans, J.P.G.M, Schets van een juridische studierichting in Maastricht, Ars Aequi, 28 (1979), 599-602. 
Offringa, C, 1983, Ars Veterinaria: ambacht, professie, beroep. Sociologische theori historische praktijk, Tijdschrift voor Geschiedenis, 96 (1983), 407-432.

Ogawa, T. (ed.), 1978, History of the professionalization of medicine. Procadings of th International Sympositum an the Comparalive History of Medicine-East and West, October 1978, Susono-shil, Shizuoka, Japan.

Olesko, KM, 1988a, "The pedagogical imperative - Shaping Scentific Knowledge foi struction, 1800-1900, In: Program, Papers, and Abstracts for the Joint Conference Mancht England, 11-15 july 1988, BSHS/MSS, pp. 93-100.

Oles $1 k 0, K M$, $1988 \mathrm{~b}$, Commentary: On institutes, investigations, and scientific training Coleman and Holmes (eds.), 1988, pp. 295-332.

Olesko, K.M., 1989a, Introduction, In: Olesko (ed.), 1989, pp. 7-14.

Olesko, K.M, 1989b, Physics instruction in Prussian Secondary Schools before 1859. In: O second series volume 5, Olesko (ed.), 1989, pp. 94-120.

Olesko, K. (ed.), 1989, Osiris second series volume 5, Science in germany - The intersectio institutional and intellectual issues.

O'Malley, M., 1990, Keeping watch - a history of American time, Viking Penguin, Harmor worth/New York.

Ontijd, G.C., 1843, Proeve eener Geneeskundige Staatsregeling of Bedenkingen en aummerkin betreffende de rapporten over de Geneeskundige Statsregeling, K. Fuhri, "s Gravenhage.

Ontwerp van Wet op het Hooger Onderwijs, 1849, Ontwerp van Wet op het Hooger Onden met bijgevoegd rapport en memorie zan toelichting aan den Koning ingediend door de Statsc missie benoewd bij Konikiijk Besluit oan 15 januarij 1849, Algemeene Landsdrukkerij, "s Grav hage.

Ontwerp van Wet op de examens, 1849, Ontwerp van Wet op de examens ter witoefening geneeskunst en der artsenijbereidkunst met memorie an toelichting. (Extract uit het Rapport Commissie benoend bij Kaninkijke Besluiten van 25 july en 4 augustus 1848 n's 64 en 50 Graverhage.

Opmerkingen en Gedachten over de inrigting van het Hooger Onderwijs, 1849, C. van der Post Utrecht.

Opzoomer, C.W., 1848a, Aanteekeningen op de wet, houdende algemeene bepalingen der wetgezn van het Koningrijk, Leyden [1884", Belinfante, 's Gravenhage].

Opzoomer, C.W., 1848b, De belangen van het hooger ondenwijs. Memorie asn zijne Majesteit korting, Naar aonleiding wan het ministerielle rapport van 13 november 1848, J.B. Gebhard Comp., Leyden en Aunsterdam.

Opzoomer, $\mathrm{CW}, 1849$, De hervorming onzer hoogeschalen. Rapport, toetsontwerp, en memorie v toelichting, J.I-I. Gebhard en Comp., Leyden en Amsterdam.

Opzoomer, C.W., 1873, Onze achterlijkheid in de kunst der wetgeving aangetoond vooral in. attikelen der grondwet die aan het onderwijs gewijd zijn, J.B. Gebhard en Comp. Amsterdat

Otterspeer, W. (red.), 1984, Een Universiteit herleeft. Wetenschapsbeofening ann de Leidse Li versiteit vanaf de tweede helft van de negentiende eeuw, E.J. Brill, Universitaire Pers Leide Leiden.

Oud-Student, Een, 1860, De Delftsche Akademie. In het bijzonder met betrekking tot de opleidi vart Civiel-Ingenieurs hier te lande, W.E.J. Tjeenk Willink, Zwolle.

Oud-Student, Een [ps. P. Harting], 1878, Voorheen en thans 1828-1878. Herinneringen, Opme kingen en Wenken, J. Greven, Utrecht.

Oven, J.C. van, 1938, Romeinsch recht en Nederlandsch burgerlijk recht na 1838 , In: Scholtt en Mejjers (red.), 1938, pp. 327-346.

Oven, J.C. van, 1955/56, Dogmatische en historische rechtswetenschap, Ars ,Aequi, 5 (1955/56 1-8. 
Over het onderwijs, 1840, Over het onderwijs van nieuwere talen en wetenschappen op de latijnsche scholen. Bijlage tot de levensschets van F.A. Bosse, Algemeene Konst en Letterbode, (1840) deel II, 114-171.

Over het onderwijs, 1841 , Over het onderwijs van de wiskunde op de latijnsche scholen, vervolg der Bijlage tot de levensschets van F.A. Bosse, Algemeene Konst en Letterbode, (1841), $102-105 ; 122-126 ; 136-139$.

Over Universiteiten en Hooger Onderwijs, 1828, H.W. Hazenberg Junior.

Overbeek de Mejer, G. van, 1877, Het regt van het onderivijs in gezondheidsleer aan de Hoogeschool. Rede bij de aanvaarding van het hoogleeraarsambt aan's Rijks universiteit te Utrecht, 14 december 1877, P. F. Dekema, Utrecht.

Papousek, D.A. (red.), 1981, Montaillou in Groningen: verslag van een interdisciplinaire studiedag. Vakgroep Culturele Antropologie, Groningen.

Parsons, T., 1951, The social system, The Free Press, Glencoe Illinois.

Parsons, T., 1964, Evolutionary Universals in Society, American Sociological Review, 29 (1964), 339-357.

Parsons T. and G.M. Platt, 1973, The American university, Harvard U.P., Cambridge Massachusetts.

Peeters, V.J.B.M. (red.), 1989, Jacobus Moleschott. De eenheid des levens, Geschiedenis van de wijsbegeerte in Nederland deel 18 , Ambo, Baarn.

Peeze, M., 1986, 'Japonsche rocken' De kimono in Nederland, In: In het spoor wan de liefde, 1986, pp. 83-87.

Peirce, Ch. S., 1958, Values in a universe of chance. Selected writings of Charles $S$. Peirce (18391914), Stanford U.P., Stanford California.

Pekelharing, C.A., 1918, Toespraak gehouden bij zijn afscheid van het onderwijs aan de universiteit, Nederlandsch Tijdschrift voor Geneeskunde, 62 (1918) 1, 1680-1692.

Pellegrino E.D. and D.C. Thomasma, 1981, A philosophical Basis of Medical Practice, Oxford University Press, New York.

Penn, J. 1876, Hooger ondenwijs en examens der geneeskundigen, Joh. Geradts \& Comp., Hilversum.

Perponcher, W.E. de, 1816, Aan de op's Rijks hooge schoolen studeerende jeugd, Van Schoonhoven, Utrecht.

Pickstone, J.V., 1978, The Professionalization of medicine in England and Europe: the State, the Market and Industrial Society, In, Ogawa (ed.), 1978, pp. 33-57.

Pickstone, J.V., 1981, Bureaucracy, liberalism and the body in post-revolutionary France: Bichat's physiology and the Paris school of medicine, Hist. Sct., xix (1981), 115-142.

Pierson, N.G., 1878, Het Kathedersocialisme, De Gids, (1878) III, 250-280.

Pterson, N.G., 1879, Werkkring en methode der staathuishoudkunde, De Gids, (1879) III, 377411.

Pleterman, $\mathrm{R}, 1990 \mathrm{a}$, De plaats van de rechter in Nederland 1813-1920. Politiek-juridische ideeenstrijd over de scheiding van de machten in de staat, Gouda-Quint BV, Arnhem.

Pieterman, R., 1990b, Rechtswetenschap en sociologie tijdens het leven van Hendrik Jacob Hamaker 1844-1911, Recht der Werkelijkheid, 11 (1990), $15-46$.

Pijnacker Hordijk, C., 1881, De tnak van den beoefenaar der Nederlandsche rechtsgeschiedenis, Redewoering bij de aanvaarding van het hoogleeraarsambt aan de Rijksuniversiteit te Utrecht, op den 7den October 1881, J.L. Beijers, Utrecht.

Pitlo, A., 1956, De geschiedenis der notariele wetenschap, Noord-Hollandse Uitgeversmij, Amsterdam.

Ploeg, $\mathrm{R}$. van der \& $\mathrm{R}$. Zinkstok, 1986, Wij zijn allen werklieden - De opkomst van de moderne arbeidsmoraal in Nederland in de negentiende eeww, Ambo, Baarn.

Plotkin (ed.), H.C., 1982, Learning, development and culture. Essays in evolutionary epistewology. 
John Wiley \& Sons, New York.

Poel, H. wan der, 1988, Een geschiedenis van tijdsbesef en tijdrekeningen, In: Van Bijsterweldt (red.), 1988, pp. 10-34.

Polano, M., 1869, Over het karakter der moderne chirurgie, Redevoering ter aanvaarding van het hoogleeraarsambt aan de hoogeschool te Leiden den 8sten october 1869 uitgesproken, Jacs. Hazenberg, Corns. Zoon, Leiden.

Pols, I, 1988, Psychiatrische diagnostiek en de Algemene Systeem Theorie, In: Milders en Van Tilburg (red.), 1988, pp. 39-49.

Poortinga, E, 1987, De scheiding tussen publiek-ew privaatrecht bij Johan Rudolph Thorbecke (17981872): theorie en toepassing, Ars Aequil Libri, Nijmegen.

Porter, T.M., 1986, The rise of statistical thinking 1820-1900, Princeton University Press, Princeton New Jersey.

Porter, T.M., 1987, Lawless society: Social science and the reinterpetation of statistics in Germany 1850-1880, In: Krüger, Daston and Heidelberger (eds.), 1987, pp. 351-375.

Prahl, H.W., 1978, Sozialgeschichte des Hochschtwwesens, Kösel, München.

Prigogine, I. \& I. Stengers, 1988, Entre le temps et l'éternité, Fayard, Paris.

Pruys van der Hoeven, C., 1826, Gedachten over de studie en het onderwijs der geneeskunde, Geneeskundige Bijdragen, 1 (1826), 261-279.

Pruys van der Hoeven, C, 1828, Over het belang en de voordeelen eener klassieke vorming voor den toekomstigen geneesheer, Geneeskundige Bijdragen, 2 (1828), 127-147.

Pruys van der Hoeven, C., 1866, Academieleven, Van der Post, Utrecht.

Przeworski, A., 1979, Some problems in the study of the transition to democracy, Working papers of the Latin American Program of the Woadrow Wilson International Center for Scholars. number 61 , Chicago.

Punt, $\mathrm{H}_{.}$, 1983, Bernard Siegfried Albinus (1697-1770) on 'Human Nature': Anatomical and plysiological ideas in Eighteenth-century Leiden, B.M. Israel, Amsterdam.

Quack, H.P.G., 1868, Stat en Maatschappij. Inwijdingsrede den 23sten October 1868, uitgesproken bij de aanvaarding wan het Hoogleeraarsambt te Utrecht, s.l, s.n.

Quack, H.P.G., 1885, Sociale Politiek. Rede bij de aanvaarding van het Hoogleeraars-ambt te Amsterdam, 29 september 1885, s.l, s.n.

Quetelet ${ }_{r}$ L.A.J. 1832, Recherches sur la loi de la croissance de l'homme, Nouv. Mém. de l'Acad. Roy, VII, 1-32.

Ramaer, J.N., 1844, Over het begrip van specifieke geneesmiddelen, Archief woor Genceskunde, 4. (1844) $1-77$.

Ramaer ; IN, 1845, Geneeskundige stand en controle, Bijdragen tot Genteeskundige Staatsregeling, $3(1845), 91-119$.

Ramaer, J.N., 1848, De wetenschap der natuur, haar doel en de wijze haar te beoefenen, De Gids, (1848) II, 1-34.

Ramaer, J.N., 1851, De geneeskunde als stellige wetenschap, Tijdschrift der Nederlandsche waatschappij Lot bevordering der geneeskunst, 2 (1851) Tweede deel, 1-30.

Ramaer, J.N., 1857, Brieven over de behandeling der krankzinnigen vór hunne plaatsing in de gestichten, Nederlandsch Tijdschrift poor Geneeskunde, II 1 (1857), 113.

Rapport, 1909, Rapport cler blijwende commissie voor het praktische en het aanvullende geneeskundig onderwijs, benoemd door het hoofdbestuur der Nederlandsche Maatschappij tot Bevordering der Geneeskunst, ingevolge het besluit der algemeene vergadering van 10 juli 1906. Nederlandsch Tijdschrift voor Geneeskunde, 53 (1909) I, 357-384.

Rauwenhoff, L.W.E., 1872, De verhouding van de hoogeschool tot de maatschappij. Rede uitgesproken bij het nederleggen van het rectoraat der Leidsche Hoogeschool, den viii Februari. S.C. van Doesburg, Leiden.

Rechten in Maastricht, 1981, Rijksuniversiteit Limburg, Maastricht. 
Rectior, Een oude, 1834, Beschouwing van den tegenwoordigen toestand der Latijnsche scholen, Algeneene Konst en Letterbode, (1834) deel II, 130-133; 147-151.

Reenen, J. van, 1810, Oratio de iuris Romani studio etiam nostris temporibus non intermitterdo, Amsterdam.

Reenen, J.H. van, 1836, Algemeen overzigt der akademische werkzaawheden van den toekomenden meester in de regten, A.D. Schinkel, 's Gravenhage.

Rees, O. van, 1858, Redevoering over de Staathuishoudkundige Geschiedenis van Nederland, Bij gelegenheid van de aanvaarding zijner betrekking als buitengewoon hoogleeraar in de Faculteit der Regtsgeleerdheid aan de Hoogeschool te Groningen, op den 24 April 1858, Willem Thieme, Zutphen.

Rees, $O$ van, 1860, Redevoering over de wetenschap der statistiek, uitgesproken bij de aanvaarding: van het hoogleeraarsambt in de staatswetenschappen aan de Utrechtsche hoogeschool, op 14 december 1860, C. van der Post Jr., Utrecht.

Rees, O. van, 1865-68, Geschiedenis der staathwishoudkunde in Nederland tot het einde derachttiende eeuw, Kemink, Utrecht.

Regtien, T., 1969, Universiteit in opstand. Europese achtergronden en de Nederlandse situatie, Van Gennep, Ansterdam.

Rehbinder, M., z.j., Max Weber und die Rechtswissenschaft.

Reiger, W.A., 1891, De economie en de feiten. Rede ter aanvaarding van het hoogleeraarsambt in de rechtsgeleerdheid aan de Rijks-Universiteit te Groningen op maandag den 14 september 1891, J.B. Huber, Groningen.

Reij de Grenoble, J. 1827, Du perfectionnement des études légales, dons l'etat actuel de la sacieté. Paris, 1827.

Reil, J.C., 1804, Pepinieren zum Unterricht ärzticher Routiniers als Bedüfnisse des Strats nach seiner Lage wie sie ist, Curt, Halle.

$\mathbb{R e y}, \mathbb{R} ., 1990$, Point de vue physiologique et point de vue pathologique dans l'oeuvre de Bichat, Livre des Résumeés/Abstract Book XXXIle Congrès International d'histoire de la Médecine 2.09-7.09.1990 Antwerpen/Brussel.

Richards, R., 1987, Darwin and the emergence of evolutionary theories of mind and behaviour, University of Chicago Press, Chicago \& London.

Ridder-Symoens, H. de, 1978, Universiteitsgeschiedenis als bron voor sociale geschiedenis, Tijdschrift uoor Sociale Geschiedenis, 4 (1978), 87-115.

Rider, R.E., 1983, The show of science, Friends of the Bancroft library, University of California, Berkeley.

Riediel, H. 1860, Het toekomend middelbarr onderwijs, Groningen.

Rijnberk, $G$. van, 1916, Een en ander over hooger onderwijs in de geneeskunde, Nedexiandsch Tijdschrift voor Geneeskunde, 60 (1916) II, 593-598; 705-709; 805-808; 903-905; 1365-1368; 1453 $1456 ; 2133-2138$.

Rijnberk, G. van, 1918, Hervorming van de opleiding van den geneesheer, Nederlandsch Tijdschrift voor Geneeskunde, 62 (1918) Il, 1527-1530; 1587-1589; 1655-1659; 1731-1732; 1795$1798 ; 1864-1867$.

Rjinberk, G. van, 1919a, Nieuwe banen voor de geneeskundige opleiding, Nederlandsch Tijdschrift voor Geneeskunde, 63 (1919) I, 501-504; 649-653; 746-749;821-825; 1005-1007; 1161 $1165 ;$; $1389-1391$.

Rijnberk, G. van, 1919b, Examens, diploma's en bevoegdheden, Nederlandsch Tijdschrift voor Geneeskunde, 63 (1919) II, 1513-1516; 1613-1615; 1861-1864; 1933-1936.

Rijnberk, G. van, 1923-24, Onderwijsvraagstukken, Nederlandsch Tijdschrift voor Geneeskunde, 67 (1923) II, 2390-2393; 2546-2549; 2662-2670; 68 (1924) 1, 774-776; 894-898.

Rijnberk, G. van, 1925, De geneeskundige opleiding in Europa, Nederiandsch Tijdschrift voor Geneeskunde, 69 (1925) II, 1216-1219; 1312-1316; 1408-1410;1516-1519; 1644-1647;1752-1756; 
$1860-1861 ; 1968-1971 ; 2068-2069$.

Ringer, F., 1969, The decline of the german Mandarins - the german academic community. 1890-1933, Harvard University Press, Cambridge, Massachusetts.

Ringer, F., 1979, Education and society in modern Europe, Indiana University Press, Bloomington \& London.

Ringer, F., 1982, Bestimmung und Messung von Segmentierung. Eine Teilantwort an Peter Lundgreen, Geschichte und Gesellschaft, 8 (1982), 280-285.

Ringer, F, 1987, Introduction, In: Miller et al. (eds.), 1987, pp. 1-12.

Ringer, F. 1990, The intellectual field, intellectual history, and the sociology of knowledge, Theory and Society, 19 (1990), $269-334$.

Risse, G.B., 1989, Clinical Instruction in Hospitals: The Boerhaavian Tradition in Leyden, Edinburgh, Vienna and Pavia, Clio Medica, 21 (1987-1988), 1-19.

Ritter, P.H. (red.), 1898, Eene halve Eeuw 1848-1898. Historisch Gedenkboek. Uitgegeven door Het Nieuws van den Dag bij de inhuldiging van Koningin Wilhelmina. Tweede deel Wetenschap, kunst en godsdienst, J.L. Beyers \& J. Funke, Amsterdam.

Ritter, I. (Hirsg.), 1972, Historisches Wörterbuch der Philosophie, Schwabe \& Co. Verlag, Basel/Sttuttgart.

Roelants, J.M.A., 1842, Iets over het gebruik der Latijnsche taal bij het geneeskundig onderwijs aan de hoogescholen, Bijdragen tot geneeskundige Staatsregeling, $2(1842), 40-46$.

[Roelevink $J_{,}, 1986$, Gedicteerd verleden. Het onderwijs in de algemene geschiedenis ann de universiteit te Ltrecht, 1735-1839, APA-Hollland Universiteits Pers, Amsterdam-Maarssen.

Roelevink, I., 1987, 'Invalides, Onwillige en Combattanten'. Aanstaande regenten op de achttiende-eeuwse universiteit, Bulletin werkgroep elites, december 1987 no. 8, 21-34.

Roessingh, K.H., 1922, Het moderniswe in Nederland, De Erven F. Bohn, Haarlem.

Roos, N.H.M., 1987, De Nederlandse privaatrechtsleer in drannatisch perspectief, Wolters-Noordhoff, Groningen.

Rosenbrock, G., 1979, Bildung und Ausbildung. Ansätze zur pädagogische Theorie der Universität im 19. Jahrhundert, Zeitschrift für Pädngogik, 25 (1979), 905-917.

Rosenstein, S., 1866, Ueber die Beziehungen zwischen Wissenschaft und Praxis in der Medicin mit Rüksicht auf die Aufgabe der Klinik. Antrittsrede gehalten an der Universität zu Groningen am 8. Februar 1866, P. Noordhoff, Groningen.

Rosenstein, S.S., 1871, Gymnasia en Hoogere Burgerscholen als intichtingen tot voorbereiding voor het academisch onderwijs. Rede uitgesproken bij gelegenheid der overdracht van het rectoraat der Hoogeschool te Groningen, P. Noordhoff, Groningen.

Rossum, W. van, E.K. Hicks en J.C.M. van Eyndhowen (red.), 1987, Onderzoek nan Wetenschap, Technologie en Samenleving, SISWO Amsterdam.

Rostow, W.W., 1956, The Take-Off into self-sustained growth, The Economic foumal, 66 (1956), 25-48.

Rostow, W.W., 1960, The stages of economic growih: A non-communist manifesto, Cambridge University Press, London.

Rothschuh, K.E., 1968, Physiologie. Der Wandel ihrer Konzepte, Probleme und Methoden, Kanl Alber, Freiburg/München.

Rothschuh, K.E., 1974, Hyrtl contra Brücke. Ein Gelehrtenstreit in 19. Jahrhundert und seine Hüntergrunde, Clio Medica, 9 (1974), 81-92.

Rovers, I.A.C., 1875, Wie was Philip Willem van Heusde? Eene vraag ten behoeve van belangstellende jonge menschen beantwoord. Met een voorrede van M.A.N. Rovers, J.L. Beijers, Utrecht.

Roxborough, I., 1988, Modernization theory revisited. A review article, Comparative Studies in Sodiety and History, 30 (1988), 753-761.

Rudy, W., 1984, The universities of Europe, 1100-1914: a history, Fairleigh Dickinson University Press, Rutherford (N.J.)/Associated University Presses, London/Cranbury N.J. 
Ruëgg, W., 1983, a Conversation about the humanities, In: Chapman (ed.), 1984, pp. 118-130. Rüschemeyer, D., 1965, Doctors and lawyers, Canadian review of sociology and anthropology, 1 (1965), 17-30.

Rüschemeyer, D., 1980, Professionalisierung. Theoretische Probleme für die vergleichende Geschichtsforschung, Geschichte und Gesellschaft, 6 (1980), 311-325.

Rüschemeyer, D., 1984, Theoretical generalization and historical particularity in the compatrative sociology of Reinhard Bendix, In: Skocpol (ed.), 1984, pp. 129-169.

S., 1865, Boekbespreking van 1. De waarde der ervaring aan het zlekbed voor de beoefening der geneeskunde, J.Evers 2. Het hooger onderwijs en de geneeeskunde, Eene beschouwing naar aanleiding van de redevoering van prof. Evers te Leiden door W. Koster, Utrecht, Dannenfelser, 1864 3. De moderne rigting in de geneeskunde, door Dr. LH. Verweli, Schoonhoven, Van Nooten, 1864, De Gids, (1865) $\mathbb{I}_{r}$, 343-359.

Salomon, G., 1842, Gedachten en wenken rakende de geneeskundige wetten en het geneeskundig. onderwijs in het Koningrijk der Nederlanden, C.C. van der Hoek, Leiden.

Savornin Lohman, A.F. de, 1899, Nota, Handelingen der Nederlandsche Juristen Vereeniging, "s Gravenhage 1899, deel 1, Pp. 184-198.

Schaepman, H.J.A.M., 1883, 'Bijna.' een antwoord aan Dr. W. Koster, Wed. J.R. van Rossum, Utrecht.

Schaffer, S., 1983, Natural philosophy and public spectacle in the eighteenth century . Hist. Scie., xxi (1983), 1-43.

Schama, S., 1970, Schools and politics in the Netherlands, 1796-1814, The Historical Journal, $13(1970), 589-610$.

Schelsky, $\mathrm{H}_{.,} 1971$ [1962'], Einsamkeit und Freiheit. Idee und Gestall der deutschen Universität und intrer Reforment, 2. um einen 'Nachtrag 1970' enweiterte Auflage, Bertelsmann Universitätsverlag, Düsseldorf.

Schepers, R., 1989, De opkomst van het medisch beroep in België. De evolutie wan de wetgeving en de beroepsorganisaties in de 19e eeuw, Radopi, Amsterdam/Atlanta.

Scheurkogel, I., 1981, Nieuwe universiteitsgeschiedenis en late middeleeuwen, Tijdschrift voor Geschiedenis, 94 (1981), 194-204.

Schill, P.S., 1828, lets over het onderwijs, Algemeene Konst en Letterbode, (1828) 374.

Schilling, H., 1982, Die Geschichte der nördlichen Niederlande und die Modernisierungstheorie, Geschichte und Gesellschaft, 8 (1982), 475-517.

Schmid, M., 1982, Theorien sozialen Wandels, Westdeutscher Verlag, Opladen.

Schmid, M., 1987, Autopoiesis und soziales System: Eine Standortbestimmung, In: Haferkamp und Schmid (Hrsg.), 1987, pp. 25-50.

Schmidt, H.G. en P.A.J. Bouhuijs, 1980, Onderwijs in taakgerichte groepen, Spectrum, Utrecht/Antwerpen.

Schmidt, S.J., 1989, Die Selbstorganisation des Sozialsystems Literatur im 18. Jahwhundert, Sulurkamp, Frankfurt am Main.

Schmitz, R., 1984, Der Arzneimittelbegriff der Renaissance, In: Schmitz und Keil (Hrsg.), (1984), pp. 1-22.

Schmitz, R. und G. Keil (Hrsg.), 1984, Humanismus und Medizin, Acta humaniora, Chemie Verlag, Weinheim.

Schneevogt, G.E.V., 1842, Over de afzonderlijke uitoefening der Genees-en Heekunde, Bijdragen tot Geneeskundige Staatsregeling, 1 (1842), 26-43.

Scholten, P., 1938, De codificatie-gedachte vóor honderd jaar en thans, In: Scholten en Meijers (red.), 1938 , pp. $1-31$

Scholten, P. en E.M. Meijers (red.), 1938, Gedenkboek Burgerlijk Wetboek 1838-1938, TjeenkWillink, Zwolle.

Schorer, W., $1777 \mathrm{a}$, Vertoog over de ongerymdhetd wan het samenstel onzer hedendaagsche regis- 
geleerdheid en praktyk, Pieter Gilissen, Middelburg/Amsterdam.

Schorer, W, 1777b; de jonge practisijn ontmoskerd, Pieter Gilissen, Amsterdam/Middelburg. Schorr, K.E., 1979, Wissenschaftstheorie und Reflexion im Erziehungssystem, Zeitschrift für Pädagogik, 25 (1979), 883-891.

Schrant, J.M., 1862, Over de empirisuthe ontwikkeling van het ziektebegrip. Redevoering ter aanvaarding van het hoogleeraarsambt aan de hoogeschool van Leiden den 17 den october 1862 uitgesproken, J.W. van Leeuwen, Leiden.

Schreeuwer, Jan de (Ps. B.H. Lalofs), 1828, Gedachten van Jan de Schreeutuer over het hooger ondenwijs: Eene kleine bijdrage en weêrklank tot en op het veelvuldig geschrijf over dat ondenwerp in de nieuwspapieren wan onzen tijd, Oomkens, Groningen.

Schieuder, H.A., 1839, Een blik op oude en jonge geneeskundigen, Wenken en meningen om trent geneeskundige stantsregeling en algemene geneeskunde, 2 (1839), 11-33.

Schreuder, H.A., 1843, Een blik op geneeskundige jouralistiek, Archief voor Geneeskunde, 3 (1843), 463-475.

Schriewer, ]. and K. Harney, 1987, On 'systems' of education and their comparability: methodological comments and theoretical alternatives, In: Müller et al. (eds.), 1987, pp. 197-209.

Schubring, G. (Hrsg.), 1991, 'Einsamkeit und Freiheit' neu besichtigt-Unizersitätsreformen und Disziplinebildung in Preußen als Modell für Wissenschaftspolitik im Eu ropa des 19. Jahrhunderts, Franz Steiner Verlag, Stuttgart.

Schubring ${ }_{n}$ G. \& E. Hültenschmidt, Vorwort, In: Schubring (Hrsg.), 1991, pp. 9-23.

Schull, P.S., 1828, lets over het Onderwijs, Algemeene Konst en Letterbode, (1828), 358-361; 371 375.

Schuller tot Peursum-Meijer, J. en W.R.H. Koops (red.), 1989, Petrus Camper (1722-1789) Onderzoeker wan Nature, Universiteitsmuseum, Groningen.

Schupbach, W., 1982, The paradox of Rembrandt's Anatomy of Dr. Tulp., Medical History Supplement 2, London.

Schuttevâer, $\mathrm{H}_{0}, 1974$, De ontwikkeling van het recht en van de juridische studierichtingen, Gouda Quint, Arnhem.

Schuurman, A.J., 1989, Materiële cultuur en levensstijl - Een onderzoek naar de taal der dingen op het nederiandse platteland in de 19 eeuw: de Zaanstreek, Oost-Groningen, Oost-Brabant, dissertatie Landbouwuniversiteit Wageningen en HES Uitgevers B.V., Utrecht.

Schwalbe, I., 1918, Zur Neuordnung des medizinischen Studiums, Thieme, Leipzig.

Schwartz, B., 1981, Vertical classification - A study in structuralism and the sociology of knowledge. The university of Chicago press, Chicago and London.

Scott, W. R., 1981, Organizations. Rational, natural and open systems, Stanford University, PrenticeHall Inc., Englewood Cliffs.

Senat, 1828, De Senaat der Akademie te Leyden gebruik makende van de vergunning, on zijn gevoelen te mogen mededeelen op de punten van overweging woor de Commissie, bijeen geroepen door Z.M. Besluit van 13 April 1828 no. 100 geeft zich de eer de navolgende bedenkingen aan de Conmmissie voor te dragen.

Shapiro, B.J., 1983, Probability and certainty it seventeenth-Century England. A study of the relationships between natural science, religion, history, law, and literature, Princeton University Press, Princeton New Jersey.

Shortt $t_{s}$ S.E.D., 1983, Physicians, science, and status: issues in the professionalization of angloanerican medicine in the nineteenth century, Medical History, 27 (1983), 51-68.

Siegenbeek, M., 1828, Lets over Hoogescholen de onderwijzers en het onderwijs op dezelve, briefswijze voorgesteld, $\mathrm{S}$, en J. Luchtmans, Leiden.

Sikkel, A., 1899, lets wit de geschiedenis van Nederland's Geneeskundige Staatsregeling, Feestrede uitgesproken ter gelegenheid wan het wijftigjarig bestan wan de afdeeling's Gravenhage en Onstre- 
ken van de Nederlandsche Maatschappij tot bevordering der Geneeskumst, op 4 januari 1899, De Swart en Zoon, "s Gravenhage.

Silverman, D., 1968, Formal organizations or industrial sociology: towards a social action analysis of organizations, Sociology 2 (1968), 221-238.

Simon, H.A., 1978, Simulation of large scale systems by aggregation, In: Geyer en Van der Zowwen (eds.), 1978, pp. 113-122.

Simons, D., 1899, Praeadvies voor NJV, Handelingen der Nederlandsche Juristen Vereeniging, "s Gravenhage 1899, deel $I_{s}$ pp. 74-152.

Skocpol, Th., 1984, Sociology's historical imagination, In: Skocpol (ed.), 1984, pp. 1-21.

Skocpol, Th. (ed.), 1984, Vision and method in historical sociology, Cambridge University Press, Cambridge/London/New York/New Rochelle/Sydney/Melbourne.

Smidt ${ }_{r}$ H.J., 1922, Het academisch statuut (Koninklijk Besluit oan 15 juni 1921, staatsblad no. 800) met aanteekeningen, Samsom, Alphen aan de Rijn.

Smidt, J.Th. de, 1966, Codificatieperikelen. Rede uitgesproken bij de aanvaarding van het ambt van gewoon hoogleraar in het oudvaderlands recht aan de Rijksuniversiteit te Leiden op vrijdag 17 juni 1966, E.E. Kluwer, Deventer.

Smidt, J.Th. de en A.H. Huussen jr., 1968, Bronnen van de Nederlandse Codificatie sinds 1798, Kemink, Utrecht.

Smidt, J. Th. de, 1977, Oude en nieuwe opvattingen omtrent de wetenschapsbeoefening van het oud-vaderlandsche recht, In: Van den Brink, Moorman van Kappen, Vander Linden en Van Holk (red.), 1977, pp. 1-9.

Smit, F.R.H. 1989, De Groningse Universiteit 1614-1989, In: Kingma, Koops en Smit (red), 1989. pp. $13-40$.

Smith, A.D., 1973, The concept of social change. A critique of the functionalist theory of social change, Routledge \& Kegan Paul, London and Boston.

Smits, J.J. 1869, Nederland en de beoefening der Germaansche rechtsgeschiedenis, Niewwe Bijdragen voor Regtsgeleerdheid en Wetgeoing, 19 (1869), 105-129.

Snelders, H.A.M., 1981, Romantiek en 'Naturphilosophie' en de anorganische natuurwetenschappen 1797-1840: een inleidend overzicht, In: Snelders en Van Berkel (red.), 1981, pp. 168192.

Snelders, H.A.M., 1983, De natuurwetenschappen in de lokale wetenschappelijke genootschappen uit de eerste helft van de negentiende eeuw, De Negentiende Eeuw, 7 (1983), 102-122.

Snelders, H.A.M, 1986. Chemische laboratoria in de negentiende eeuw, Tsch.Gesch.Gnk.Natuurw.Wisk. Tectn, 9 (1986), 204-215.

Snelders, H.A.M. en K. van Berkel (red.), 1981, Natuurwetenschappen zan Renaissance tot Darwin. Thema's uit de wetenschapsgeschedenis, Martinus Nijhoff, Den Haag.

Solla Price, D. de, 1963, Little Science, Big Science, Columbia University Press, New York and London.

Spaapen, J.B., C.A.M. van Suyt, A.A.M. Prins en S.S. Blume, 1988, Evaluatic van 6 jaar voor waardelijke financiering. De moenzame relatie tussen beleid en onderzoek, Vakgroep Wetenschapsdynamica, s.ll, s.n.

Spiegel, L.P. van der, 1777, Gedagten over het samenstel onzer hedendagsche burgerlyke reglsgeleerdheid, Jacobus Huysman, Goes.

Spoormans, H. 1988, 'Met uitshiting van voorregt" Het ontstaan van de liberale democratie in Nederlond, SUA, Amsterdam.

Spruit, J.E. (red.), 1974, Coniectamea Neerlandica iwris Romani. Inleidende opstellen over het Romeins recht, Tjeenk Willink, Zwolle.

Spruit, J.E., 1986, Jean Charles Naber 1858-1950, Historische notities omtrent een singulier personage, In: Van den Bergh, Spruit en v.d. Vrugt (red.), 1986, pp. 132-177. 
Spruit, J.E, 1988, Romeins Recht. Terugblik en Uitzicht, Nieuwenhoflezing I, Kluwer, Deven Staatscommissie, benoemd bij Koninklijk Besluit wan 15 janwary 1849, 1852, Vrijmoeu gedachten over het hooger onderwijs naar aanleiding van het on tweerp van wet op het hooger ont wijs, S.E. van Nooten, Schoonhoven.

Stamhuis, 1.H., 1989, 'Cijfers en Aequaties' en 'Kennis der Staatskrachten' Statistiek in Nederl in de negentiende eeww, Rodopi, Amsterdam-Atlanta.

Star Numan, C, 1839, Ter nagedachtenis van Ph. W. van Heusde. Bij de opening zijner lesse en 7 september 1839, J.B. Wolters, Groningen.

Stemerding, D., 1987, Planten, dieren en formules. Achttiende eeuwse classificaties bekel in het licht van Latour's antropologie van de wetenschap. In: Van Rossum, Hicks en Van Ey hover (red.). 1987.

Stemerding, D., 1991, Plants, animals and formulae - Natural history in the light of Latour's scie in action and Foucault's the order of things, WMW-publikatie 4, Faculteit Wijsbegeerte Maatschappijwetenschappen, Universiteit Twente.

Steyn Parvé, D. J, 1863, De wet tot regeling van het Middelban Onderwijs opgehelderd door aunteekening, G.I. Thieme \& D.A. Thieme, Arnhem.

Steyn Parve, D.J., 1878, Organisation de l'instruction priwaire, secondaire el superieure darts royaume des Pays-Bas, ouvrage publié sous les auspices de la commission royale Neerlandaise pe l'exposition universelle de 1878, A.W. Sijthoff, Leide.

Stichweh, R. 1984, Zur Entstehung des modernen Systems wissenschaflicher Disziplinen - Phy in Deutschland 1740-1890, Suhrkamp Verlag, Frankfurt am Main.

Stichweh, R., 1987a $a_{n}$ Die Autopoiesis der Wissenschaft, In: Baecker, Markowitz, Stichweh, Tyr Willke (Hrsg.), 1987, pp. 447-481.

Stichweh, R., 1987b, Akademische Freiheit, Professionalisierung der Hochschullehre und Polit In: Oelkers und Tenorth (Hrsg.), 1987, pp. 125-145.

Stichweh, R., $1987 \mathrm{c}$, Professionen und Disziplinen - Formen der Differenzierung zwe Systeme beruflichen Handelns in modernen Gesellschaften, In: Harney, Jütting und Kori: (Hrsg.), 1987, pp. 210-275.

Stichweh, R. 1988, Differenzierung des Wissenschaftssystems, In: Mayntz et al., 1988, pp. 45-11 Stoeder, W., 1974, Geschiedlenis der Pharmacie in Nederland. In opdract van de Nederlandsc Matschappij ter bevordering der pharmacie, Schie-pers, Schiedam.

Stone, L. (ed.), 1975a, The University in Society, volume 1: Oxford and Cambridge from the 14 to the early 19 th century, Princeton University Press, Princeton New Jersey/Oxford Universi Press, London.

Stone, L. (ed.), 1975b, The University in Society, volume 2: Europe, Scolland and the United Stat from the 16 th to the 20 th century. Princeton University Press, Princeton New Jersey/Oxfor University Press, London.

Stone, L., 1975c, The size and composition of the Oxford student body 1580-1909, In: Sto (ed.), 1975a, pp. 3-110.

Straub, M., 1895, De vorming van den geneeskundige, rede bij de aanvaarding van het buitel gewoon Hoogleeraarsambit aan de Gemeentelijke Universiteit van Amsterdam, De Erve F. Bohn, Haarlem.

Student, Een, 1849, Een woord over het fooger onderwijs, J.H. Gebhard \& Co, Leyden en An sterdam.

Stuurman, 5., 1983, Verzuiling, kapitalisme en patriarchaat. Aspecten van de ontwikkeling wan. moderne stant in Nederland, SUN, Nijmegen.

Stuurman, S., 1986, Moderniteit en politieke theorie - Rede uitgesproken bij de openbare aar vaarding van het ambt van gewoon hoogleraar in de politicologie, in het bijzonder $d$ geschiedenis van de politieke theorieën, aan de Universiteit van Amsterdam, op maanda 
de 28ste april 1986, SUN, Nijmegen.

Stuurman, S., 1987. De Nederlandse staat tussen verzuiling en moderniteit, In: Van Besourd, Den Boer, Hugenholtz en Van Tijn (red), 1987, pp. 263-283.

Suerman, B.F., 1848, Redevoering bij gelegenheid der overdragt van het Rectoralat der Utrechtsche hoogeschool, den 27 maart 1848 uitgespraken, over de verbetering van het geneeskundig hooger onderwijs, als den voornaamsten grond, waarop de in ons vaderland in te voeren geneeskundige uetgeving behoort te rusten. Uit het Latijn vertaald en door aanteekeningen toegelicht, $\mathrm{C}$. van der Post Jr., Utrecht.

Suerman, B.F., 1857, De geneeskundige wetsontwerpen door de regering aangeboden anan de statengeneraal, C. van der Post Jr, Utrecht.

Suringar, G.C.B., 1831, Inwijdings-rede over het verband tusschen de geschiedents der geneeskunde en die der beschaving, gehouden den zesden juny 1831, Stadsdrukkerij, Amsterdam.

Suringar, G.C.B., 1855, De opvoeding der zintuigen. Eene bijdrage tot de leev van het onderwijs inzonderheid van de Natuur-en Geneeskundige wetenschappen, J.H. Gebhard \& Comp., Amsterdam.

Suringar, W.F.R., 1858, De beteekenis der planten-geographie en de geest van haar onderzoek. Redevoering ter aanvaarding van het buitengewoon hoogleeraarsambt aan de hoogeschool te Leiden, den 14den November 1857, G.T.N. Suringat, Leeuwarden.

Swaan de, A., 1989, Zorg en de Staat Welzijn, onderwijs en gezondheidszorg in Europa en de Verenigde Staten in de nieuwe tijd', Bert Bakker, Amsterdam.

Talma, S., 1905, Over de secretie der zieke nier, Nederlandsch Tijdsclurift voor Geneeskunde, II 41 (1905) IIB, 1229-1243.

Tellegen, B.D.H., 1861, Volkshuishoudkunde en Regtswetenschap. Inwijdingsrede uitgesproken bij de aanvaarding zijner betrekking als hoogleeraar in de faculteit der Regtsgeleerdheid aan de Hoogeschool te Groningen, op den 20 December 1860, RJ. Schierbeek, Groningen.

Temkin, O., 1928, Die Krankheitsaufassung von Hippokrates und Sydenham in ihren "Epidemien', Archiv für Geschichte der Medizin, 20 (1928), 327-352.

Temkin, O., 1977a, The meaning of medicine in historical perspective. In: Temkin, 1977b, pp. $41-49$.

Temkin, O., 1977b, The double face of Janus and other essays in the history of medicine, The John Hopkins University Press, Baltimore and London.

Tennekes, H. (red.), 1990, De vlinder van Lorenz. De verrassende dynamica van chaos, Aramith, Bloemendaal.

Terpstra, W., 1838, Brieven over den voormatigen en tegenwoordigen toestand det Latijnsche Scholen in het Koningrijk der Nederlanden, 5 . en J. Luchtmans, Leiden.

Tex, C.A. den, 1839a, Over Wetenschap en Wetgeving in derzelver noodwendig verband, Nederlandsche Jaarboeken voor Regtsgeleerdheid en Wetgeving, 1 (1839), 1-34.

$\mathrm{Tex}_{r}$ C.A. den, 1839b, Boekbeoordeling van' Allgemeine Juristische Fundamentallehre, zugleich als erste Lieferung eines Lehrbuches des Juristische Einleitungs-Wissenschaften, insbesondere für Russland', Von Dr. Heinr. Rob. Stöckhardt. St. Petersburg, 1837, Nederlandsche Jaarboeken voor Regtsgeleertheid en Wetgeving, 1 (1839), 137-144.

Thijssen, H.F., 1828, Redevoering over de geschiedenis en de strekking der klinische geneeskunde. gehouden ter aanvaarding wan het hoogleeraarambt in de klinische geneeskunde en ter opening der genees- heel-en verloskundige school te Amsterdam, den derden september 1828, Stadsdrukkerij, Amsterdam.

Thompson, E.P., 1967, Time, work-discipline, and industrial capitalism, Past and Present, 38 (1967), 56-97.

Thorbecke, J.R., 1824, Ueber das Wesen und den organtschen Charakter der Geschichte. Ein Schreiben an K.F. Eichhorn in Göttingen, Göttingen.

Thorbecke, J.R., 1844, Over het hedendaagsche Staatsburgerschap, In: Thorbecke, 1978, pp. 266278. 
Thorbecke, JR, 1978, Historische Schetsen, In: De Wit (red.), 1978, pp. 177-373.

Tuchelaar, P.A., 1897, Het Romeinsche recht en de historische school. Rede bij de aanvaarding $v$, het hoogleeraarsambt aan de Rijksumiversiteit te Leiden op den 6 den october 1897. De Erv F. Bohin, Haarlem.

Tiddens, H.A., R.G.J. Willighagen en W.H.F.W. Wijnen, 1975, Medisch onderwijs in ontwi keling, Medisch Contact, 30 (1975), 1077-1085.

Tienhoven, $\mathrm{G}$ van, 1869, De waarde wan het Romeins recht voor de studie van het hedendaagsc privuatrecht. Redevoering ter aanvaarding van het hoogleeraarsambt in de rechtsgeleerdhe aan het Athenaeum llustre te Amsterdam, Martinus Nijhoff,'s Gravenhage.

Tijn, Th, van, 1974, Voorlopige notities over het ontstaan van het moderne klassebewustzi in Nederland, Meadelingenblad/Organn van de Nederlandse Vereniging tot beoffening pan sociale geschiedenis, 45 (1974), $33-48$.

Tijn, Th, van, 1977, Het Sociale leven in Nederland, 1844-1875, In: Algemene Geschiedenis d Nederlanden, deel 12, pp. 131-166.

Tilanus, J.W.R, 1888, De voorbereiding tot de studie der geneeskunde en de nationaliteit i de chirurgie, Nederlandsch Tijdsdinft voor Geneeskunde, II 24 (1888), 61-69.

Tilly, Ch., 1981, As sociology meets history, Academic Press, Orlando/SanDiego/San Fransii co/New York/London/Toronto/Montreal/Sydney/Tokyo/Sao Paulo.

Tipps, D.C., 1973, Modernization theory and the comparative study of societies: A critici perspective, Comparative Studies in Society and History, 15 (1973), 199-226.

Toellner, $\mathbb{R}, 1984$, Zur Begriff der Autorität in der Medizin der Renaissance, In: Schmitz un Keil (Hrsg.), (1984), pp. 159-179.

Toellner, R. und M.J. van Lieburg (Hrsg.), 1985, Deutsch-Niederländische Beziehungen in de Medizin des 18. jahrhunderts. Vorträge des Deutsch-Niederländischen Medizinhistoriker Treffen 1982, Rodopi, Amsterdam.

Toulmin, S., 1975, Concepts of function and mechanism in medicine and medical scieno (hommage a Claude Bernard), In: Engelhardt jr. and Spicker (eds.), 1975, pp. 51-66.

Toulmin, S., 1990, Kosmopolis, Kok Agora, Kampen/Pelckmans, Kapellen, (vert. van Cosmopolis The hidden agenda of modernity, The Free Press, New York, 1990).

Treub, M.W.F., 1896, De ontwikkeling der staathuishoudkunde tot sociale economie, Rede uitge sproken bij de aanvaarding van het hoogleeraarsambt in de staathuishoudkunde en dx statistiek aan de gemeentelijke universiteit te Amsterdam op den 23sten november 1896 Scheltema en Holkema's Boekhandel, Amsterdam.

Treub, M.W.F., 1894, Rechter en Wetgever, Weekblad voor Notaris-ambi en Registratie, (1894) No. 1271,1272 en 1287

Tsouyopoulos, N., 1990, Doctors contra clysters and feudalism: the consequences of a Romantic revolution, In: Cunningham G Jardine, 1990, pp. 101-118.

Tuchman, A.M., 1988, From the lecture to the laboratory: The institutionalization of scientific medicine at the university of Heidelberg, In: Coleman and Holmes (eds.), 1988, pp 65-100.

Tuckman, H.P. and C.F. Chang, 1988, Conflict, Congruence, and Generic University Goals, Journal of Higher Education, 59 (1988), 611-633.

Tümpel, Ch. met bijdragen van A. Tümpel, 1986, Renbrawdt, H.W.J. Becht, Amsterdam.

Turner, R.S., 1971, The Growth of Professiorial Research in Prussia, 1818-1848 - Causes and Context, Historical Studies in the Physical Sciences, 3 (1971), 137-182.

Turner, R.S., 1975, University Reformers and professional scholarship in Germany 1760-1806, In: Stone (ed.), 1975b, pp. 495-531.

Turner, R.S., 1989, Commentary, In: Olesko (ed.) Osiris second series volume 5, 1989, pp. 296-304. Tweede Rapport, 1910, Tweede Rapport der Blijvende Commis[s]le voor het Praktische en het Aanvullende Geneeskundig Onderwijs, benoemd door het hoofdbestuur der Nederlandsche Maatschappij tot Bevordering der Geneeskunst, ingevolge het Besluit der Algemeene 
Vergadering van dinsdag 19 juli 1906, Nederlandsch Tijdschrift woor Geneeskunde, 54 (1910) I, $809-818$.

Tydeman, H.W., 1819, Verhandel ing over de wetenschappelijke bewefening wan het regt in Nederland, na het uitourdigen wan nieuwe wetboeken in de taal des lands, Met eenige bijlagen, H.W. Hazenberg junior, Leyden.

Tydeman, H.W., 1828, Consideratien van Prof. H.W. Tydeman, te Leiden over de punten wan overweging betrekkelijk het acadewisch onderwijs, Leyden.

Ultee, W.C., 1983, Het aanzien van beroepen, op andere plaatsen en vooral in andere tijden. Een analyse van een aantal recente historische studies, Tijdschrift voor Sociale Geschiedenis, 9 (1983), 28-48.

Unger, R.M., 1976, Law in modern society. Toward a criticism of social theory, The Free Press, New York/London.

Valk, J.M.M. de (red.), 1989, Philip Willem van Heusde. Wijsbegeerte van het gezond verstand. Geschiedenis van de Wijsbegeerte in Nederland deel 16, Ambo, Baarn.

Valkhoff, J.W., 1938, Een eeuw rechtsontwikkeling. De vermaatschappelijking van het Nederlandse privaatrecht sind's de codificatie (1838-1938), De Arbeiderspers, Amsterdam.

Valkhoff, J.W., 1956, Boekbespreking van 'Raymond Derine, Grenzen van hel eigendomsrecht in de negentiende eeuw. Bijdrage tot de geschiedenis van het modlerne privaatrecht, $R M$ Thentis, (1956), 626-632.

Valkhoff, J.W., 1967, Vermaatschappelijkt vermogensrecht in het wieuwe B.W. Afscheidscollege gegeven op zaterdag 24 juni 1967, Tjeenk Willink, Zwolle.

Vatebender, G.C.C., 1802a, Mengelwerk in ongebonden en gebonden silil, bevattende verhandelingen over de cultuur der duinen, - de belooningen van verdiensten, en - de spelling der Nederduitsche tad; Benewens eenige oorspronglijke dichtstukjes en overzettingev, $M$. van Graauwenhaan, Delft.

Vatebender, G.C.C., 1802b, Over de verschillende wijzen, bij vroegere en latere volken gebruikelijk, om verdiensten te beloonen, en het misbruik derzelve. In: Vatebender, $1802 \mathrm{a}, 32 \mathrm{pp}$.

Veen, T.J., 1976, Recht en nut, Studiën over en naar aanleiding van Uirik Huber (1636-1694), W.E.I. Tjeenk Willink, Zwolle.

Veen, T.J., 1991, Studiosus sine studio sus est: visitatie van een juridische faculteit, Nederlands Juristen Blad, 28 maart 1991, pp. 572-580.

Veen, T.J., P.C. Kop m.m.v. C.H.N. Kwanten (red.), 1987, Zestig juristen. Bijdragen tot een beeld van de geschiedentis der Nederlandse rechtswetenschap, W.E.J. Tjeenk Willink, Zwolle.

Veld, Th.W.R., 1987, Volksonderwijs en leerplicht. Een historisch sociologisch onderzoek naur het ontstaan van de Nederlandse leerplicht 1860-1900, Eburon, Delft.

Verkade, W., 1935, Overzicht der staatkundige denkbeelden van Johan Rudolph Thorbecke (1798-1872), Van Loghum Slaterus, Arnhem.

Vernon Pratt, 1985, System-building in the eighteenth century, In: North and Roche (eds.d, 1985, PP. 421-431.

Verrijn Stuart, C.A., Schets ener geschiedenis van de Vereniging voor de staathuishoudkunde en de statistiek, In: Knoester (red.), 1987, pp. 9-18.

Verschaffel, B., 1985, Tonen, wijzen, tekst. Over historisch realisme en Historische intelligibiliteit, diss. Leuven.

Verschaffel, B., 1988/89, 'Postmoderniteit. Over de dood van de kunst en de alomtegenwoordigheid van de schoonheid", In: De glans der dingen, Gent, pp. 43-60.

Verwey, G., 1987, Localisme, actueel of achterhaald?, Scripta medico-philosophica, 2 (1987) no. 4, 5-21.

Verwey, L.H., 1866, De geneeskundige wetgeving in 1865 tot stand gebragt door Mr. J.R. Thorbecke, Minister wan Binnenlandsche Zaken, verklaard, toegelicht en opgehelderd, $\mathrm{H}$. Nijgh, Rotterdam.

Verzameling, 1836, Verzameling van Wetten, Besluiten en Reglementen, betrekkelijk de burgerlijke geneeskundige dienst in het Koningrijk der Nederlanden, J.P. Beekman, Hz,. 's Gravenhage. 
Viff matal wiffentwintig jaar wetenschap in Nederland, 1941, Viff maal viffentuintig jaut wetenschap in Nederland, Redevoeringen gehowden in de vereenigde vergadering der Nederlandsche Akadewite wan Wetertschappen op 7 april 1941, door de beide voorzitters, ter herdenking van hare oprichting op 6 april 1816.

Vijuer, $G$. van de, 1988/9, Dielgerichtheid in cybernetica, connectionisme en cognisivisme. Tussen twee epistemische opties: Naturatisme en Constnctivisme, diss, Gent.

Virilio, P., 1989 [1984], Het horizon-negatief, Duizend \& Een, Amsterdam. Essay over dromoscopie, vertaling van L'horizon negatif.

Visser, R.P.W., 1986, De ontwikkeling van de universitaire biologische laboratoria, TschGesch.Gnk.Natuuno.Wisk. Techn., 9 (1986), 255-265.

Vissering, 5, 1850, Over Vrijheid, het grondbeginsel der staa thuishoudkurde. Redevoering uitgesproken den 23sten Maart 1850, bij de aanvaarding van het Hoogleeraaarsambt in de Rechtsgeleercle Faculteit aan de Hoogeschool te Leiden, In: Vissering; 1889b, pp. 142-170.

Vissering, S., 1851, Populaire staathuishoudkunde, De Gids, (1851) I, 1-24.

Vissering, S., 1866, De staathuishoudkunde als wetenschap en kunst, De Gids, (1866) III, 185-209.

Vissering, S., 1867-1868, Hooger Onderwijs, De Gids, (1867) III, 42-65; 181-210; 389-434; (1867) IV, 111-129; (1868) II, 282-306; 404-435.

Vissering, S., 1877, De Statistiek aan de Hoogeschool. Toespraak bij de opening van den Akademischen cursus 1877/78, In: Vissering, 1886b, deel II, pp. 102-120

Vissering, S., 1886a, De Vereeniging voor de Statistiek in Nederland en het Statistisch Instituut, In: Vissering, $1886 \mathrm{~b}$, deel II, pp. 120-141

Vissering, 5. 1886b, Verzamelde Geschriften, Eerste en Tweede Bundel, E.J. Brill, Leiden.

Vitringa, A.I., 1860, Tegenwoordige toestand en plan tot hervorning van het middelbaar owderwijs, D.A. Thieme, Arnhem.

Vitringa, L. J. [onder ps. Eene jonge practizijn], 1777a, De eer der Hollandsche tatie, en van hare wetgevers, rechters en rechtsgeleerden, met eene zeedige, dog noar den aard der belediginge geschikte vrymoedigheid verdedigd, tegens het Vertoog over de ongerymdheid van het zamtenstel onser hedendaagsche regtsgeleerdheid en practijk van Mr. Willem Schorer, 's Gravenhage.

Vitringa, L.J., $1777 \mathrm{~b}$, De valschelijk ontmaskerde jonge Practisyn, 's Gravenhage.

Vhigt van der, $W_{*}, 1898$, De geestelijke wetenschappen, In: Ritter (red.), 1898, pp. 1-70.

Voorduin J.C., 1846, Gedachten over eene geschiedkundige beoefening onzer oud-vaderlandsche regten, hare hooge waarde en klaarblijkelijk nut, Nederlandsche Jaarboeken voor Regtsgeleerdheid en Wetgeving, 8 (1846), 32-70.

Vos, J.F., 1973/4, Onderwijspolitiek in Nederland: Democratie versus restauratie. De onderwijs democratiseringsbeweging omstreeks de Bataafse revolutie, Tijdschrift voor Opvoedkunde, $19(1973 / 4), 188-210$.

Vries, Az. G. de, 1870, Praeadvies over de vraag: "welke hoofdbezwaren staan aan de herzlening onzer wetboeken in de weg, en hoe die op te lossen, ten einde te bevorderen, dat die wetboeken steeds beantwoorden aan de veranderende eischen der samenleving, en ten allen tijde de juiste uitdrukking zijn der meest algemeene opvatting van het recht door de bevoegde beoordeelaars in ons vaderland", Handelingen Nederlandsche Ju risten-Vereeniging. 1 (1870) I, 80-110.

Vries, H. de, 1987, De transformatie van de Nederlandse Universiteit van 1815 tot 1940: een onderzoeksproject, Batavia Academica, 5 (1987), 31-41.

Young, M.F.D., 1973, Curricula and the Social Organization of Knowledge, In: Brown (ed,), 1973 , pp. 339-362.

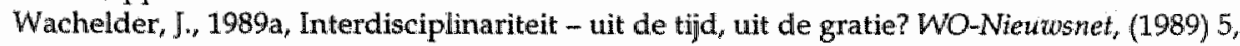
$38-47$.

Wachelder $]_{*}, 1989 \mathrm{~b}$, Autopoiesis and the modernisation of the western world. In: Proceedings of the first european congress on system science, CES 1, Lausanne, 3-6 October 1989, pp. 367-374. 
Wachelder, $J ., 1989 c_{n}$ Zelforganisatie: Modegril of reëel alternatief? Tijdschrift voor Hoger Onderwoijs, 7 (1989), 38-43.

Wachelder $\mathrm{J}_{.,}$1990a, Self-Reference in Social Studies of Science, In: Heylighen \& Deweyere (eds.). 1990 , pp. 403-413.

Wachelder, J., 1990b, Een Modelziekenhuis. Boekbespreking van M.J. van Lieburg, Het Coolsingelziekenhuis te Rotterdam, Rodopi, 1986, In: Tijdschrift voar Geschiedentis, 103 (1990), 129.130.

Wachelder, J., 1991a, Professionals aan de Winkel, In: Weerdenburg en Pènnings (red.), 1991, pp. 105-113.

Wachelder, J., 1991b, Umgestaltung des niederländischen akademischen Unterrichts im 19. Jahrhundert nach einem deutschen Modell'? Das Modell: Modernisierung, In: Schubring (Hrsg.), 1991, pp. 227-254.

Wal, G. de, 1820, Over den invloed van wetboeken in de taal des lands op de wetenschappelijke beoefening van het regt. Met twee bijuoegsels, Wybe Wouters, Groningen.

Warnkoenig, De l'enseignement du droit dans les Universites des Pays-bas, Themis I, 382 e.v. Weber, M., $1972^{3}$ [1921 $]$, Wirtschaft und Gesellschaft, J.C.B. Mohr, Tübingen.

Weber, M., 1980a [1921'], Gesammelte politische Schriften, Mit einem Geleitwort von Theodor Heuss herausgegeben von Johannes Winckelmann, J.C.B. Mohr (Paul Siebeck), Tübingen. Weber, M., 1980b, Wahlrecht und Demokratie in Deutschland, In: Weber, 1980a, Pp. 245-291. Weerdenburg, $\mathrm{J}$ en F. Pennings (red.), 1991, Wetenschapswinkels in de jaren negentig, Studium Generale, Rijksuniversiteit Utrecht, Utrecht.

Wehler, H.-U., 1975, Modemisierungstheorie und Geschichte, Vandenhoeck \& Ruprecht, Göttingen. Weick, K.E., 1969, The social psychology of organizing, Addison-Wesley, Reading Massachusetts. Weick, K.E., 1976, Educational organizations as loosely coupled systems, Administrative Science Quarterly, 21 (1976), 1-19.

Welderen Rengers, W.J. wan, 1861, Beschouwingen over het verband tusschen het burgerlijk regt en de staathuishoudkunde. Academisch proefschrift, P.W. van de Weyer, Utrecht.

Wels, C.B., 1979, Stemmenen Kiezen, 1795-1914, Tijdschrift woor Geschiedenis, 92 (1979), 313-332 Wenken en Meningen, 1838, Wenken en Meningen omtrent geneeskundige stautsregeling en algemeene geneeskunde, 1e deel aantekeningen, berigten.

Werkgroep Achttiende Eeuw, 1983, Onderwijs en Opvoeding in de achttiende eeuw. Enseignement E Education dams les Pays-bas au xviiie siècle, APA-Holland University Press, Amsterdam \& Maarssen.

Wes, M.A. (red.), 1985, Van Parthenon tot Magadenhuis. Maet het gymnasium blijwen?, Synopsis, De Arbeiderspers, Amsterdam.

Widdershowen-Weerding, $I_{2}, 1987$, Medicine as a form of practical understanding, Theoretical Medicine, 8 (1987), 179-185.

Wiegersma, S., 1989, De innovatie van het hoger onderwijs, Wolters Noordhoff, Groningen.

Wieland, W., 1975, Diagnose. Überlegungen zur Medizin theorie, Walter de Gruyter, Berlin/New York.

Wieringen, A.M.C. van, 1975, De identiteit van het hoger bepoepsonderwijs. Een onderzoek natur de taak en plaats wan het hoger beroepsonderwijs in het Nederlandse schoolwezen, diss. Til. burg/Amsterdam.

Wiggen, G. I. van, 1987, In meer eerbare banen. De ontwikkeling van het landheelkundig beroep in Nederland wan 1865-1940, Rodopi, Amsterdam.

Wijck van der, B.H.C.K., 1898, Het hooger onderwijs, In: Ritter (red, ), 1898, pp. 83-106.

Wijhe J.W. van, 1889 , Het lichaam van den mensch als getuigenis van zijne afkomst. Redevoering, uitgesproken bij de aanvaarding van het hoogleeraarsambt aan de Rijksuniversiteit te Groningen, op den 24 sten september $1889, \mathrm{~J}$.B. Wolters, Groningen.

Wijnen, W.H.F.W. en C.P.M. van der Vleuten, 1985, Toetsing: hordenloop of voortgangscon- 
trole? Universiteit en Hogeschool, 31 (1985), $270-279$.

Wijsenbeek-Olthuis, Th.F., 1987 , Achter de gevels van Delft. Bezit en bestaan vart rijk en arm im een periode van achteruitgang (1700-1800), Verloren, Hiversum.

Willeumier, CM. J., 1887, De Gemeente-universiteit te Amsterdam. Vragen des Tijds, (1887) II, $335-352$.

Willink, B., 1988, Burgerlijk scièntisme en wetenschappelijk toponderzoek. Sociale grondslagen van nationale blociperioden in de negentiende eeutuse bêtawetevischappen, diss. Amsterdam.

Windelband, W., $1909 \mathrm{a}^{*}$, Die philosophie im deutschen Geistesleben des XIX Jahrhunderts. Fünf Vorlesungen won W. Windelband, J.C.B. Mohr (Paul Siebeck), Tübingen.

Windelband, W, 1909b, Das ästhetisch-philosophische Bildungssystem, In: Windelband, 1909a.

Wingelaar, K, 1989, Studeren in Utrecht in de negentiende eeuw, Ltrechtse Historische Cahiers, $10(1989) 1 / 2$.

Winkler, C, 1901, Het Hooger Onderwijs in de Geneeskunde in Nederland, De Gids, (1901) II, $103-135$.

Wit, C.H.E. de, 1965, De strijd tussen aristocratie en democratie in Nederland 1780-1848. Kritisch onderzok wan een historisch beeld en herwardering van een periode, Winants, Heerlen.

Wit, C.H.E. de, 1978, Het ontstaan van het moderne Nederland 1780-1848 en zijn geschiedschrijoing, H.J.J. Lindelauf, Oirsbeek.

Wit, C.H.E de (red.), 1980a, Thorbecke en de wording van de Nederlandse natie, Socialistische Uitgeverij Nijmegen, Nijmegen.

Wit, C.H.E. de, 1980b, Thorbecke, Staatsman en historicus, In: De Wit (red.), 1980a, pp. 5-176.

Wittrock, B. and A. Elzinga (eds.), 1983, The University Research System, The public policies of the home of scientists, Studies in Higher Education in Sureden, no. 5, Stockholm.

Woestijne, J. van de, 1982, 'Aan Amsterdam wordt toegestaan een universiteit in te rigten'. Een stilstaande kikkerpoel komt tot leven, Folia Civitatis, 9 januari 1982 no. 19, 42-48.

Wolfe, D.E. 1961, Sydenham and Locke on the limits of anatomy, Bulletin of the History of Medicine, 35 (1961), 193-220.

Walleswinkel, R, Studeren in een probleemgestuurd curriculum, In: Ervaringen, 1989, pp. $21-34$.

Woud, A. van der, 1987, Het lege land. De ruintelijke orde van Nederiand 1798-1848, Meulenhoff Informatief, Amsterdam.

Woud, A. van der, 1990, De Balaafse hut. Verschnivingen in het beeld wan de geschiedenis (17501850), Meulenhoff, Amsterdam.

Young, M.F.D., 1973, Curricula and the social organization of knowledge, In: Brown (ed.), 1973, Pp. $339-362$.

Zaaljer, T. 1866, Het getwigt ener doelmatige on tleedkundige teclmiek. Redevoering ter aanvaarding van het buitengewoon hoogleeraarsambt aan de hogeschool te Leiden den 10den maart 1866 witgesproken, Jacs. Hazenberg, Corns. Zoon, Leiden.

Zaaijer, T., 1891, 1866-1891 - Toespraak tot mijne leeringen, gehouden den 12den Maart 1891, S.C. Van Doesburgh, Leiden.

Zanten, L, van, 1887, De Universeele Tijd, Vragen des Tjjds, (1887), 275-286.

Zapf. W., 1979, Einleitung, In: Zapf (Hrsg.), 1979, pp. 11-32.

Zapf, W. (Hrsg) 1979. Theorien des sozialen Wandels, Athenäum/Hain/Scriptor/Hanstein, Meisenheim.

Zimmerman, R., 1990, Das römisch-höllandische Recht und seine Bedleutung für Europa, Juristenteitung, 45 (1990), 825-838.

Zwalve, W.J., 1989, Het recht en de verlichting. De juridlische hoogleraar Frederik Adolf van der Manck (1719-1800), In: Van Gemert, Schuller tot Peursum-Meijer en Vanderjagt(red.), 1989, pp. 83-100. 


\section{Curriculum vitae}

Joseph Caspar Marie Wachelder werd op 3 april 1958 te Schaesberg geboren. Hij genoot voorbereidend wetenschappelijk onderwijs aan het R.K. Gymnasium Rolduc te Kerkrade van augustus 1970 tot juli 1976 en studeerde aansluitend theoretische natuurkunde aan de Katholieke Universiteit te Nijmegen tot 14 januari 1982. Daarna werkte hij achtereenvolgens bij het universiteitsbureau en de vakgroep Wijsbegeerte van de Rijksuniversiteit Limburg (RL) te Maastricht. Sedert 1 januari 1991 is hij verbonden als universitair docent aan de vakgroep geschiedenis van de Faculteit der Algemene Wetenschappen van de RL. 